$$
\text { UNIVERSIDADE DE SÃO PAULO }
$$

FACULDADE DE FILOSOFIA, LETRAS E CIÊNCIAS HUMANAS

DEPARTAMENTO DE LETRAS CLÁSSICAS E VERNÁCULAS PROGRAMA DE PÓS-GRADUAÇÃO EM LETRAS CLÁSSICAS

RAFAEL DE CARVALHO MATIELLO BRUNHARA

ELEGIA GREGA ARCAICA, OCASIÃO DE PERFORMANCE E TRADIÇÃO ÉPICA: O CASO DE TIRTEU

Versão Revisada. O exemplar original encontra-se no CAPH (Centro de Apoio à Pesquisa Histórica) da FFLCH-USP.

São Paulo 
UNIVERSIDADE DE SÃO PAULO

FACULDADE DE FILOSOFIA, LETRAS E CIÊNCIAS HUMANAS

DEPARTAMENTO DE LETRAS CLÁSSICAS E VERNÁCULAS

PROGRAMA DE PÓS-GRADUAÇÃO EM LETRAS CLÁSSICAS

\title{
ELEGIA GREGA ARCAICA, OCASIÃO DE PERFORMANCE E TRADIÇÃO ÉPICA: O CASO DE TIRTEU
}

\author{
Rafael de Carvalho Matiello Brunhara
}

Orientadora: Profa. Dra. Paula da Cunha Corrêa

Dissertação apresentada ao Programa de Pós graduação em Letras Classicas do departamento de Letras Clássicas e Vernáculas da Faculdade de Filosofia, Letras e Ciências Humanas da Universidade de São Paulo para a obtenção do título de Mestre em Letras.

Versão Revisada. O exemplar original encontra-se no CAPH (Centro de Apoio à Pesquisa Histórica) da FFLCH-USP.

São Paulo 
Dedico este trabalho à memória de meu pai, Oswaldo Matiello Brunhara

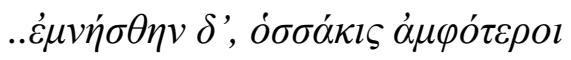
$\eta " \lambda l o v$ \&่v $\lambda \dot{\varepsilon} \sigma \chi \eta \kappa \alpha \tau \varepsilon \delta \dot{v} \sigma \alpha \mu \varepsilon v .$. 


\section{AGRADECIMENTOS}

À FAPESP, pela bolsa de auxílio à pesquisa que tornou possível este trabalho.

À minha orientadora, Profa. Dra. Paula da Cunha Corrêa, por ser uma mestra atenciosa e paciente. Devo a minha formação como pesquisador de Letras Clássicas a ela, que desde a minha iniciação científica acompanha os meus passos e até hoje tanto me ensina. Agradeço também ao Prof. Dr. Teodoro Assunção e à Profa. Dra. Giuliana Ragusa pelas arguições realizadas durante o exame de qualificação. Por ter contado com tais leitores, ressalto que qualquer falha ou inconsistência que ainda permanecer nesse trabalho deve-se apenas a mim.

Sou grato aos meus professores de graduação e pós-graduação, responsáveis por ampliar os meus horizontes intelectuais e fomentar a minha paixão pelas Letras Clássicas: Adriane da Silva Duarte, Adriano Machado Ribeiro, Alexandre Hasegawa, André Malta Campos, Breno Sebastiani, Christian Werner, Daniel Rossi Nunes Lopes, Elaine Sartorelli, Giuliana Ragusa, Jaa Torrano, João Angelo Oliva Neto, Paula da Cunha Corrêa e Paulo Martins.

Ao Buri, à Fy, ao Daniel, ao Neves, ao Victor Miguel : há poucas palavras capazes de resumir tantos anos de amizade tão legítima.

Aos amigos da pós em Letras Clássicas, pelos diálogos constantes e pelo coleguismo.

Aos “companheiros délficos" de 2011, pelas gratas e saudosas amizades.

À minha família: à minha mãe, Lourdes, por todos os dias encontrar forças; ao meu irmão Gustavo pelo bom humor de sempre; à minha querida avó, Joana.

E à Aline, por tantas coisas, mas sobretudo por me fazer crer na mais importante. 


\title{
RESUMO
}

Consoante aos estudos recentes sobre a lírica grega arcaica, hoje podemos aduzir a ocasião de performance como um elemento central para a definição de um gênero poético. A partir dessa concepção mais ampla de gênero, este trabalho visa à tradução e estudo dos fragmentos elegíacos de Tirteu, tendo em vista o caráter estritamente político de suas elegias narrativas e marciais e seus vínculos temáticos com a tradição épica, de modo que possamos ensejar uma reflexão outra sobre a função e estatuto dessa poesia em suas determinadas ocasiões de performance.

PALAVRAS-CHAVE: Tirteu, elegia grega arcaica, tradição épica grega, ocasião de performance, simpósio.

\begin{abstract}
According to modern studies on archaic greek lyric, occasion of performance was a main feature to the definition of a poetic genre. Thus, this work seeks to translate and analyze the elegiac fragments of Tyrtaeus, considering the strictly political aspect of his martial and narrative elegies and its thematic resemblances with epic tradition, in order to raise a different comprehension on the function and meaning of this poetry, given it's occasions.
\end{abstract}

KEYWORDS: Tyrtaeus, archaic greek elegy, greek epic tradition, occasion of performance, symposium. 


\section{SUMÁRIO}

NOTA LIMINAR

\section{INTRODUCÃO - TIRTEU E A ELEGIA GREGA ARCAICA}

1.1. A elegia grega arcaica 13

1.2. A elegia e sua ocasião de performance 23

1.3. Os poemas de Tirteu 34

1.4. A fortuna crítica de Tirteu 41

1.5. Homero e Tirteu 43

1.6. Poéticas de Guerra 48

\section{I-AS ELEGIAS EXORTATIVAS E O SIMPÓSIO}

CAPÍTULO 1. O FRAGMENTO 10 W E A EXORTAÇÃO MARCIAL 52

1.1. O fragmento $10 \mathrm{~W}$ e um exemplo de évápreıa 61

1.2. A bela morte e o penoso exílio (vv.1-14) 63

1.3. O papel do poeta e a exortação marcial (vv.15-18) 74

1.4. aioxpòs Өá vatos e valores éticos e estéticos no fragmento $10 \mathrm{~W}$ (vv.29-30) 76

CAPÍTULO 2. O FRAGMENTO 11 W E O MODO DE GUERRA 82

2.1. Os filhos de Héracles vão à guerra (vv.1-2) 85

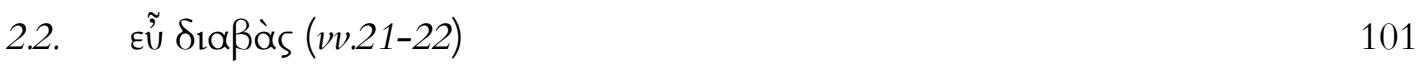

2.3. Uma lição de guerra e uma cena de batalha 103

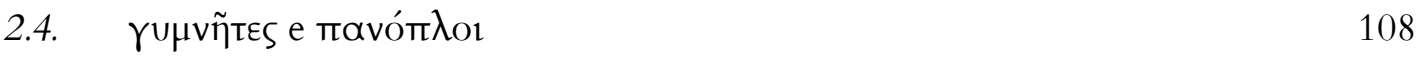

CAPÍTULO 3. O FRAGMENTO 12 W: SIMPÓSIO E ópetń 
3.1. As fontes e a fortuna crítica 116

3.2. A glória do canto e a maior virtude (vv.1-12) 121

3.3. O homem bom na guerra (vv.15-22) 133

3.4. O herói tirtaico e suas recompensas (vv. 27-43) 142

II - AS ELEGIAS NARRATIVAS E O FESTIVAL PÚBLICO

CAPÍTULO 1. A POÉTICA DA EUNOMIA 147

$\begin{array}{ll}\text { 1.1. A Eunomia e a miragem espartana } & 147\end{array}$

1.2. A Eunomia de Tirteu 156

1.3. O fragmento $2 \mathrm{~W} \quad 159$

1.4. Estratégias comunicativas no fragmento $2 \mathrm{~W}$

$\begin{array}{ll}\text { 1.5. O fragmento } 4 W & 169\end{array}$

1.6. Ocasião de Performance e estrutura do fragmento $4 \mathrm{~W}$ de Tirteu 191

$\begin{array}{ll}\text { 1.7. O fragmento } 5 \mathrm{~W} & 194\end{array}$

$\begin{array}{lll}\text { 1.8. } & \text { A conquista da Messênia } & 198\end{array}$

1.9. Elegia e Historiografia? A primeira guerra da Messênia 204

1.10. Os fragmentos 6-7 W 209

1.11. O simile homérico e o simile tirtaico (fr.6.1 W e fr. $13 \mathrm{~W})$

1.12. A punição dos Messênios (fr. 6.2-3 W e fr.7W) 217

\section{III - EXCURSO: AS ELEGIAS FRAGMENTÁRIAS}

1.1 O papiro de Berlim e os fragmentos 18-23W 222

1.2 O papiro de Oxirrinco 3316 e o fragmento $23 a W$

$1.3 \quad$ O fragmento $19 \mathrm{~W}$ : uma elegia exortativa? 230 
CONSIDERAÇÕES FINAIS

REFERÊNCIAS BIBLIOGRÁFICAS

$\underline{A N E X O}$

TEXTO GREGO E TRADUÇÃO DOS FRAGMENTOS DE TIRTEU

260 


\section{NOTA LIMINAR}

Este trabalho consiste precipuamente de tradução e comentários dos fragmentos elegíacos supérstites atribuídos ao poeta elegíaco grego arcaico Tirteu (c.640 a.C), segundo a edição estabelecida por Martin West, Iambi et Elegi Graeci Ante Alexandri Cantati (1991). Desde a Antiguidade, a obra de Tirteu é classificada em pelo menos dois grupos: A Eunomia, uma obra de conteúdo histórico e cívicoreligioso, e as Exortações, elegias marciais que indicam uma visão de mundo heroica, similar àquela encontrada na tradição épica.

Os comentários aos poemas seguem uma divisão pautada pelos debates em voga sobre a ocasião de performance da elegia grega arcaica: a primeira parte, As elegias exortativas e o simpósio, compreende a leitura dos fragmentos 10, 11 e 12 W - a parte mais conservada da poesia de Tirteu. Na segunda parte, As elegias narrativas e o festival público, são analisados os fragmentos 1 a $7 \mathrm{~W}$, que teriam feito parte da Eunomia. Uma terceira parte, um excurso denominado As elegias fragmentárias, faz uma breve análise de um grupo de elegias (18 a 23 a W) conservadas em fontes de transmissão direta e cujo estado lacunar não permite uma classificação precisa. Cabe lembrar que essa divisão é apenas preliminar e antes de tudo metodológica, uma vez que se pauta em hipóteses que ainda serão discutidas e avaliadas no decurso deste trabalho.

Antes de proceder ao comentário das elegias de Tirteu, pretende-se ora considerar introdutoriamente alguns aspectos gerais da elegia grega arcaica e de sua ocasião de performance, assim como o modo com que Tirteu foi recebido pela tradição crítica - sobretudo no que concerne à sua relação com a epopeia homérica.

Todas as traduções apresentadas nesse trabalho são de minha autoria, exceto quando indicado em notas. Observo que são realizadas traduções próprias de obras já traduzidas em língua portuguesa. Justifico a minha opção por tal procedimento 
movido pela necessidade de uniformização ou de evidenciar aspectos, vocábulos ou expressões não realçadas em outras traduções e que eram importantes aos meus comentários. A tradução dos poemas é em verso livre e branco.

As edições dos textos gregos utilizados são listadas abaixo.

Obras: dicionários e edições utilizadas para a tradução de Tirteu, testemunhos, outros poetas elegíacos arcaicos, Álcman, Píndaro e demais fragmentos mélicos

Bailly BAILLY.Dictionnaire grec-français. Paris:Hachette, 2000.

Bergk $\quad$ BERGK, T. Poetae Lyric Graeci - II. Leipzig: Teubner, 1882.

Chantraine CHANTRAINE, P. Dictionaire étymologique de la langue grecque. Paris: Klincksieck, 1999.

Davies DAVIES, M. (ed.). Poetarum Melicorum Graecorum Fragmenta. Oxford: Clarendon Press, 1991.

G-P GENTILI,B.,PRATO,C. (ed.). Poetae Elegiaci: Testimonia et Fragmenti. Leipzig: Teubner. 1988.

LSJ LIDDEL,H.G; SCOTT, R., JONES,S. Greek-English Lexicon with a revised supplement. Oxford: Clarendon Press. 1996.

PMG PAGE, D.L. (ed.). Poetae Melici Graeci. Oxford: Oxford University Press, 1962.

Sn-M SNELL, B., MAEHLER, H. (eds.) Pindarus - pars altera: fragmenta. Leipzig: Teubner. 1964.

Prato PRATO, C. (ed. e estudo). Tirteo. Introduzione, texto critico, testimonianze e commento. Roma: Edizioni dell' Ateneo.

W WEST, M.L. (ed). Iambi et Elegi Graeci ante Alexandrum Cantati. Oxford: Oxford University Press. 1992. v.2.

Abreviações de periódicos seguem o padrão do Anée Philologique. 
Para as traduções de Aristóteles, Ateneu, Diógenes Laércio, Estrabão, Eurípides, Hesíodo, Homero, Horácio, Pausânias, Quintiliano, Platão, Plutarco e Xenofonte as edições utilizadas foram as seguintes:

ARISTOTLE. Athenian Constitution, Eudemian Ethics,Virtues and Vices. Trad. H.Rackham. Cambridge: Harvard University Press, 1935.

ATHENAEUS. The Deipnosophists I. Books 1 - 3.106e. Trad. C.B.Gulick. Cambridge: Harvard University Press. 1927. . The Deipnosophists VI. Books 13-14.653b. Trad. C.B.Gulick.

Cambridge: Harvard University Press. 2009.

DIOGENES LAERTIUS. Lives of Eminent Philosophers - I. Books 1-5. Trad. R.D.Hicks. Cambridge: Cambridge University Press, 1925.

GRAY, V. (ed. e estudo). Xenophon, On Government. Cambridge: Cambridge University Press, 2007.

HERODOTUS. The Persian Wars III, Books V-VII. Trad. A.D.Goodley, Cambridge: Harvard University Press, 1999.

HESIOD. Theogony, Works and Days, Testimonia. Trad. G. Most. Cambridge: Harvard University Press, 2007.

HOMER. The Iliad - I. Books I-XII. Trad. A.T.Murray. Cambridge: Harvard University Press. 1975. . The Iliad - II. Books XIII-XXIV. Trad. A.T.Murray. Cambridge: Harvard University Press. 1975. . The Odyssey - I. Books I-XII. Trad. A.T.Murray. Cambridge: Harvard University Press. 1975. . The Odyssey - II. Books XIV-XXIV. Trad. A.T.Murray. Cambridge: Harvard University Press. 1975.

HORACE. Satires, Epistles and Ars Poetica. Trad. R. Fairclough. Cambridge: Harvard University Press. 1929. NAUCK, J.A. Tragicorum Graecorum Fragmenta. Leipzig: Teubner, 1892. 
PLATO. Laws - I. Books 1 - 6. Trad. G.S.Bury. Cambridge: Harvard University Press. 1926.

PLUTARCH. Lives - I, Theseus and Romulus, Lycurgus and Numa, Solon and Publicola. Trad. B.Perrin. Cambridge: Harvard University Press.1967. QUINTILIAN. The Orator's Education - IV. Books 9-10. Trad. D.A.Russell. Cambridge: Harvard University Press. 2002.

SPIRO, F. (ed.), PAUSANIAS. Graecia Descriptio. Leipzig: Teubner. 1903.

STEVENS, P.T. Euripides: Edited with Introduction and Commentary. Oxford: Clarendon Press, 1971.

STRABO. Geography - IV. Books 8-9. Trad. H.L.Jones. Cambridge: Cambridge University Press, 1927. 


\section{INTRODUÇÃO \\ TIRTEU E A ELEGIA GREGA ARCAICA}

A elegia grega arcaica é um gênero de difícil delimitação. Concepções não só modernas, como também antigas, datadas a partir do período clássico (séc. V. a. C), exigem uma depuração de conceitos, o estranhamento de um nome que, se hoje nos diz algo, à época dos gregos arcaicos pode ter sido assimilado de outra maneira.

\section{A elegia grega arcaica}

Em síntese, três termos concorrem para o estabelecimento atual da noção de

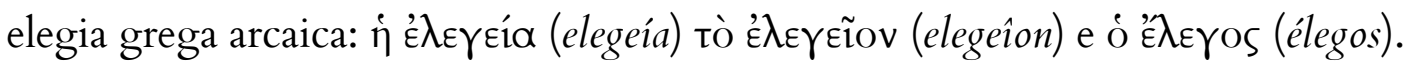

Por abranger um espectro múltiplo de temas - desde reflexões éticofilosóficas, narrativas míticas a exortações militares, do qual apenas exclui-se a narrativa erótico-pornográfica, a didática de cunho direto e factual e a filosofia natural (West, 1974, p. 18) - o único critério seguro para definir essa noção é o métrico. Trata-se do dístico elegíaco, formado pela conjunção do hexâmetro datílico e do chamado "pentâmetro", uma unidade métrica composta por dois hemistíquios com dois pés dátilos e meio cada (sendo que o primeiro hemistíquio pode admitir espondeus), formando um "meio hexâmetro", ou como é tradicionalmente chamado, hemiepes.

Contudo, a palavra grega que designa esse critério métrico e que melhor corresponde à elegia grega arcaica no sentido que temos hoje, $\mathfrak{i}$ Ė $\lambda \varepsilon \gamma \varepsilon \dot{c} \alpha$, é tardia, ocorrendo pela primeira vez em Aristóteles, Constituição de Atenas, 5.2:

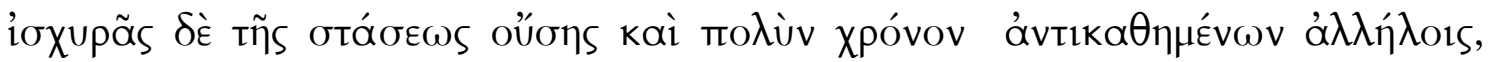

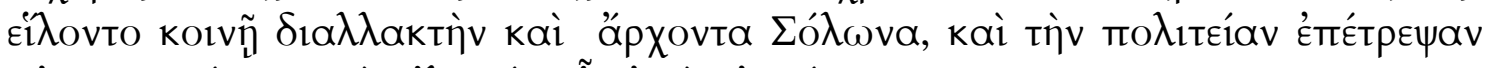

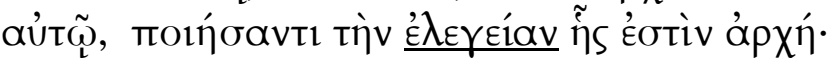

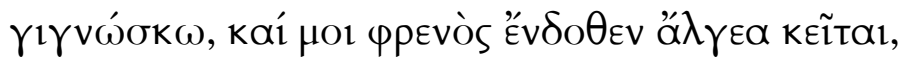

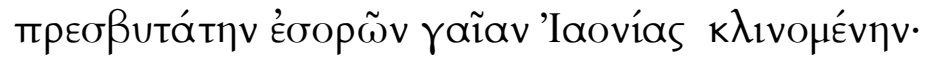


Quando as revoltas civis eram intensas e uns assentavam-se contra os outros durante muito tempo, escolheram em comum [acordo], como mediador e arconte, Sólon, e legaram a administração [da cidade] a ele, que fez a elegia cujo começo é:

Sei, e no fundo do meu peito jaz a dor, contemplando a mais antiga terra jônia em declínio"

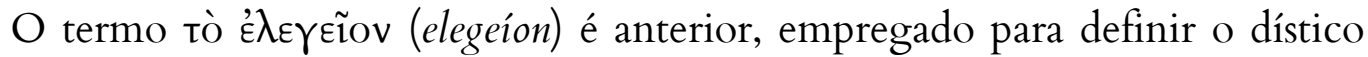
elegíaco ou o "pentâmetro" que o compõe. O plural, tò ̇̉ $\lambda \varepsilon \gamma \varepsilon i ́ \alpha$, designa extensões de versos em dísticos, a obra completa de um poeta ou inscrições tumulares. É dessa maneira que gramáticos posteriores entenderam a diferença entre $\dot{\eta}$ Ė $\lambda \varepsilon \gamma$ Eía (elegeía)

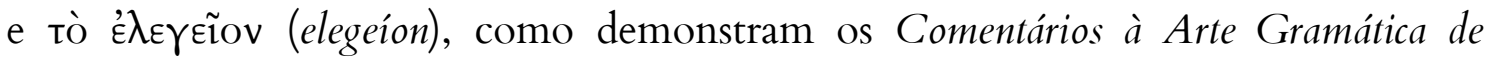
Dionísio Trácio (p. 173.13):

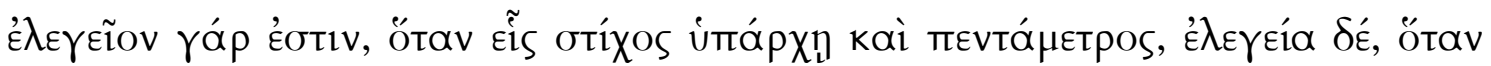

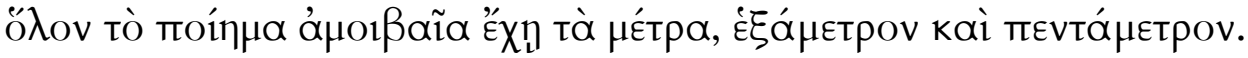

Pois é é $\lambda \varepsilon \gamma \varepsilon \tilde{o} o v$ [=dístico elegíaco] sempre que há um verso no início e então um pentâmetro, e é é $\lambda_{\varepsilon} \gamma \varepsilon$ cía [=elegia] sempre quando o poema tem metros em alternância, hexâmetro e pentâmetro.

Mas o termo mais problemático, e também o primeiro encontrado na literatura grega supérstite, é é $\lambda \varepsilon \gamma o \varsigma$, que era utilizado para denominar a canção de lamento acompanhada pelo aulo. Sua conexão com a elegia recebeu formulação mais conhecida na Arte Poética de Horácio (v.75: versibus impariter iunctis querimonia primum, "primeiro, o lamento era em versos desiguais unidos"), mas já encontrava antecedentes em Dídimoe Proclo².

\footnotetext{
${ }^{1}$ Dídimo (63 a.C - 10 d.C) seria pouco anterior a Horácio. O Etimológico de Órion (58.7) cita seu

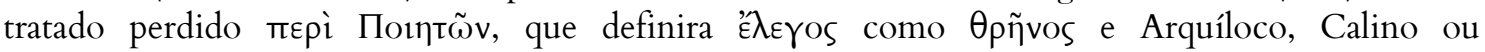
Mimnermo como os seus possíveis eúpetaí.

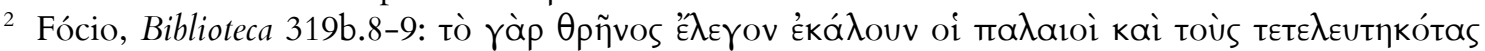

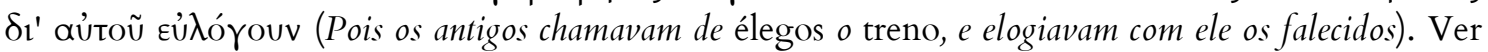
Gentili, “Epigramma ed Elegia”, Fondation Entretiens Hardt XIV, 1967, p. 51.
} 
É nesse sentido que Pausânias (Descrição da Grécia, 10. 7. 4-5) teria entendido

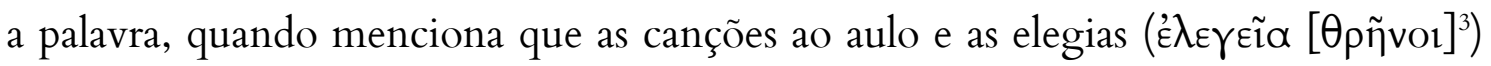
foram extintas dos jogos olímpicos por serem "extremamente melancólicas"

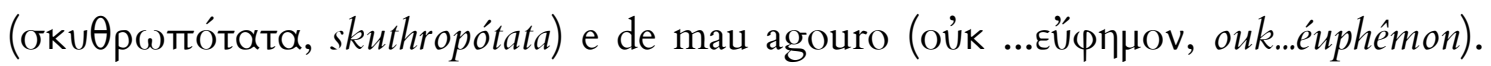
$\mathrm{O}$ autor recorre a um epigrama do auleta Equêmbroto da Arcádia - vencedor do concurso aulódico de 586 a.C. - para confirmar a sua hipótese:

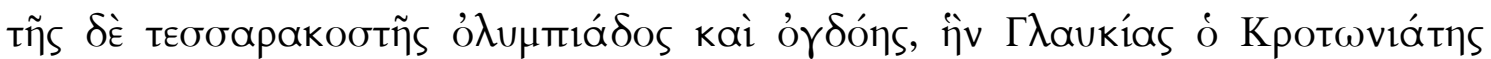

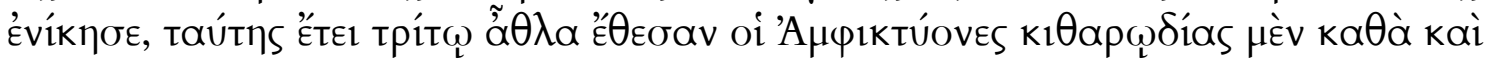

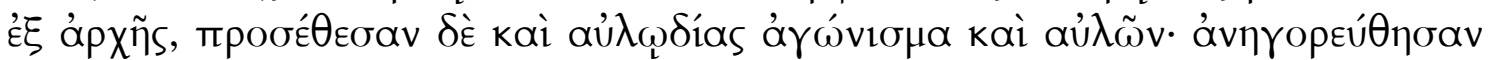

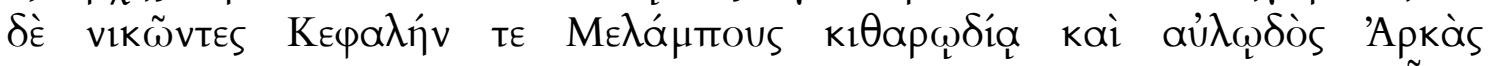
'Ex

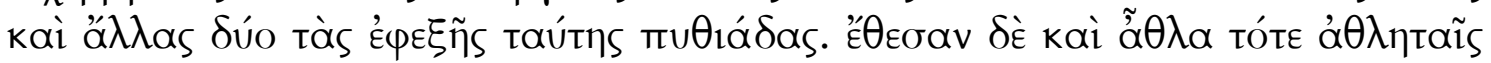

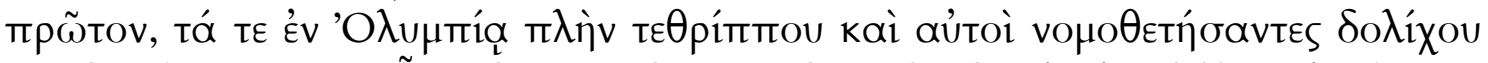

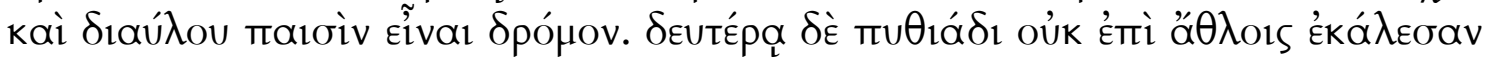

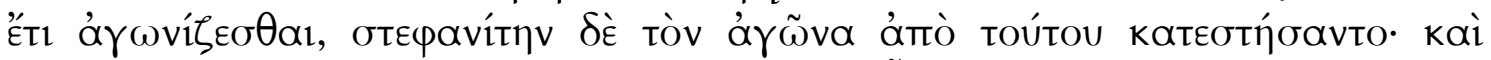

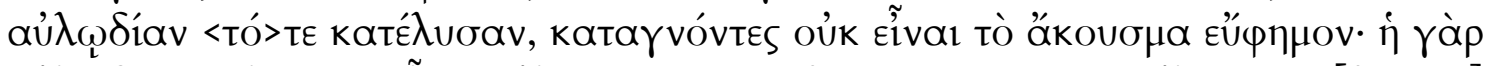

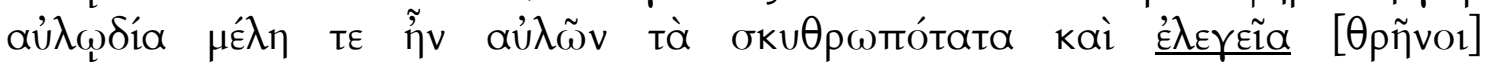

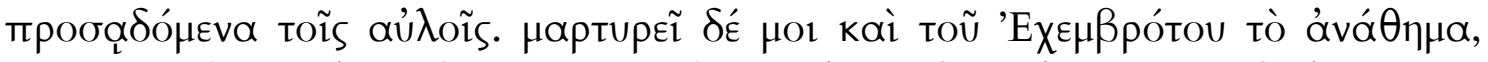

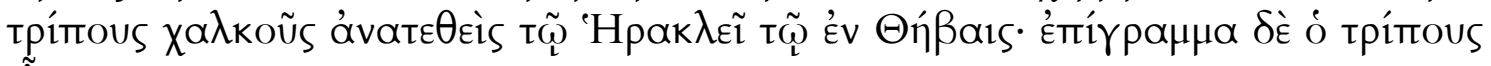
Eix $\chi$ Ev.

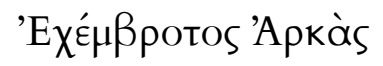

$\theta \tilde{\eta} \kappa \varepsilon \tau \tilde{\omega}{ }^{~ ' H \rho \alpha \kappa} \lambda \varepsilon \tilde{\imath}$

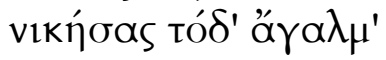

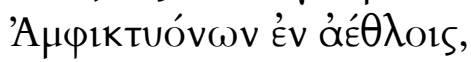

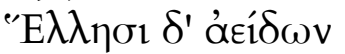

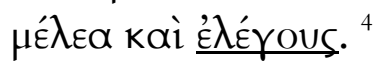

No terceiro ano da quadragésima oitava olimpíada, a que Gláucias de Crotona venceu, os Anfictiões estabeleceram concursos de citaródia desde o começo, e além disso, também acrescentaram competições de aulos e de aulodia. Foram proclamados vencedores Melampo da Cefalênia na citaródia, o auleta Equêmbroto de Arcádia, e Sacadas de Argos na competição de aulos. Este Sacadas também conquistou as outras duas Pitíadas depois dessa. Nessa época também estabeleceram pela primeira vez prêmios para os atletas nos jogos em Olímpia (exceto a corrida de quadrigas)

\footnotetext{
${ }^{3} \mathrm{O}$ texto de Pausânias traz a palavra $\theta$ pĩvor (thrênoi, "treno"), mas a maioria dos editores a exclui considerando-a uma glosa acrescentada ao texto original (ver Gerber, D. 1997, p. 95)

${ }^{4}$ West assim estabelece o texto e supõe se tratar de um poema composto em metros eólicos e não em dísticos elegíacos, como Spiro (1903) em sua edição de Pausânias.
} 
além de ter instituído eles próprios a corrida de longo percurso e trajeto duplo para crianças. Na Pitíada seguinte, não chamaram mais para competir por prêmios. Depois dela, estabeleceram a coroação como prêmio das competições e revogaram a aulodia, pois julgaram que o som não era de bom agouro. Pois a aulodia e as canções dos aulos eram extremamente melancólicas, e elegias [os trenos] eram cantadas com os aulos. Meu testemunho é o ex-voto de Equêmbroto, uma trípode de bronze dedicada à Héracles em Tebas. A trípode continha a inscrição:

Equêmbroto da Arcádia

dedicou à Héracles

esta dádiva ao vencer

nos jogos dos Anfictiões,

cantando aos gregos

canções e lamentos.

Ao analisar as ocorrências de cada termo, West (1974, p. 4) conclui que Ė $\lambda \varepsilon \gamma \varepsilon \tilde{i} o v$, por ter na base de sua definição o elemento métrico, poderia apenas ter

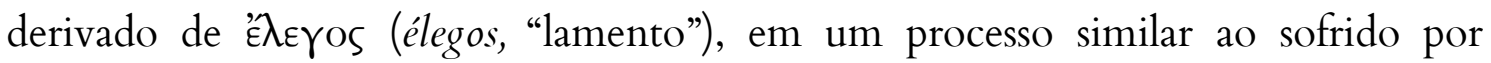

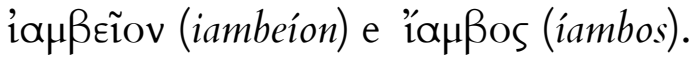

A asserção coloca um problema, já observado por West (1974, p.7): como situar ' $̇ \lambda \varepsilon \gamma o \varsigma$ na base do termo elegia, uma vez que no corpus sobrevivente de poemas elegíacos arcaicos não há peça significativa que seja representante de um lamento?

West soluciona a questão estabelecendo que os versos em metro elegíaco não eram antes do século $\mathrm{V}$ a.C. conhecidos por qualquer termo específico senão pelo genérico Émı, que poderia designar simplesmente versos, visto que para West a ocasião e função dessa poesia é múltipla.

Mas E. L. Bowie rejeita esta hipótese em seu artigo "Early Greek Elegy, Symposium and Public Festival" (1986, p. 27), observando em primeiro lugar que a poesia elegíaca teria, sim, uma ocasião privilegiada (o simpósio, ver abaixo, p. 23) e que o uso de émin para designá-la era raro, empregado apenas na última década do século V por Heródoto para referir-se aos versos de Sólon (5.113.2), talvez porque o próprio poeta já se referisse a eles assim (fr.1. $2 \mathrm{~W}$ ).

Ele conclui que é̉eros poderia ser, pelo menos até meados de 420 a.C, um termo apropriado para a elegia grega arcaica tal como a entendemos hoje, sem 
relação necessária com o lamento. Seu sentido geral seria de "canção geralmente acompanhada pelo aulo e entoada principalmente no simpósio" ou simplesmente “canção acompanhada pelo aulo". Com o surgimento de $\varepsilon^{\lambda} \varepsilon \hat{\gamma} \varepsilon \tilde{\imath} o v$ no final do século $\mathrm{V}$, este passa a ser utilizado irrestritamente em detrimento de '̉ $\lambda \varepsilon \gamma o \zeta$, que já havia adquirido então o sentido de canção lutuosa e não mais serviria para classificar inequivocamente o tipo de poesia composta em dísticos elegíacos. ${ }^{5}$

Essa leitura de Bowie ainda é prevalecente hoje em dia ${ }^{6}$, mas uma teoria proposta por Denys Page em 1936, no artigo “The Elegiacs in Euripides' Andromache" (p. 206 -230) voltou a ser aceita e debatida mais avidamente, revivida em grande medida graças à descoberta de novos fragmentos de Simônides a respeito da Batalha de Plateia.

O estudioso argumentava sobre a existência de uma escola dórica de poesia, que compunha lamentos em versos elegíacos e da qual Equêmbroto da Arcádia e Sacadas de Argos seriam os únicos representantes que nos chegaram. Os versos 103116 da Andrômaca de Eurípides aludiriam a essa tradição dórica da prática da elegia lutuosa:

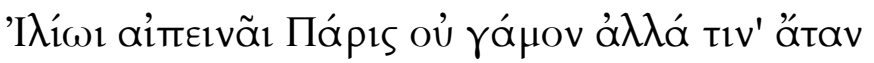

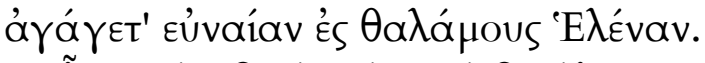

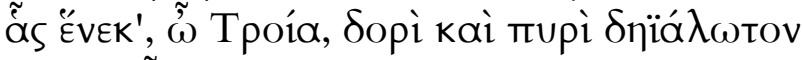

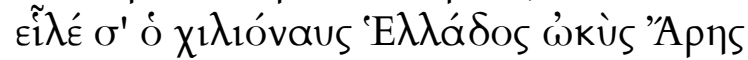

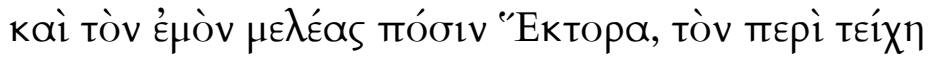

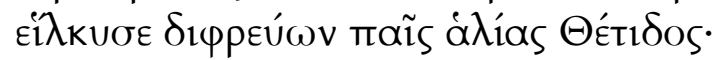

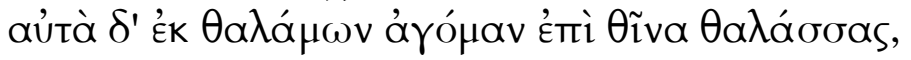

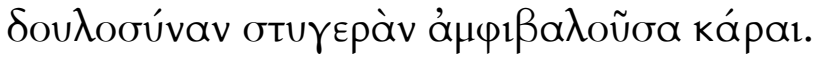

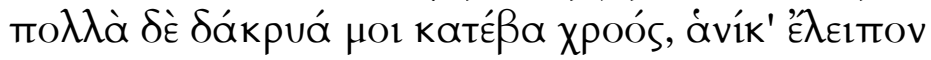

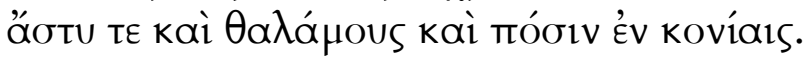

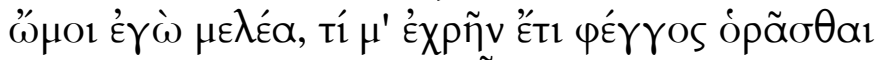

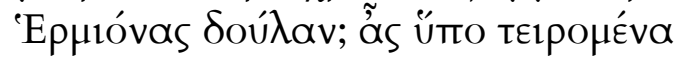

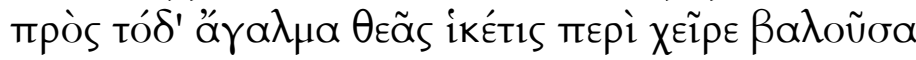

\footnotetext{
${ }^{5}$ Como se observa em Eurípides, que usa 'é $\lambda \varepsilon \gamma o s$ não para designar um gênero, mas somente $o$

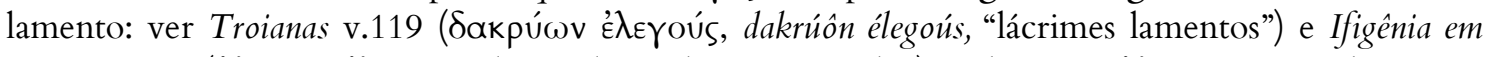

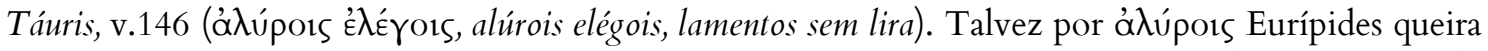
referir-se a cantos acompanhados pelo aulo, e esse é o entendimento de Aristóteles (Retórica, 1408 a).

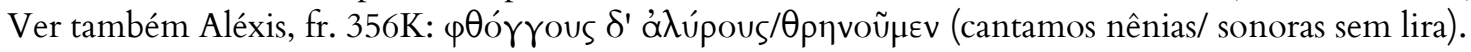
${ }^{6}$ Ver Gerber, 1997, p. 96 e Aloni, 2009, p.169.
} 


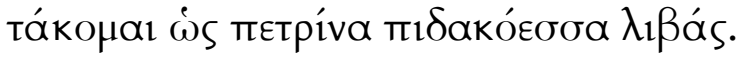

À íngreme Ílion Páris não trouxe núpcias, mas ruína, ao levar Helena ao seu tálamo como esposa.

Por causa dela, ó Troia, por ferro e fogo prisioneira, tomou-te o ágil Ares de mil naus gregas

e - pobre de mim! - ao meu marido Heitor, ao redor dos muros

o filho da marinha Tétis arrastou em seu carro;

eu mesma, do tálamo fui levada às margens do mar,

com a escravidão odiosa a cingir-me a fronte.

Do rosto verti copioso pranto, quando deixei cidade, leito e marido na poeira.

Ai, pobre de mim! Porque eu devia ainda ver a luz do sol, como escrava de Hermíone? Oprimida por ela,

abracei essa estátua da Deusa, como suplicante,

e esvaio em lágrimas, qual fonte manando das pedras.

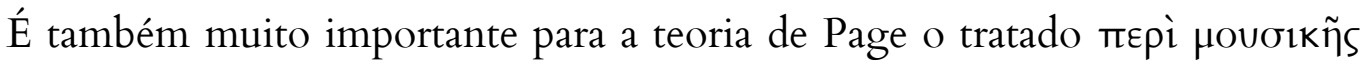
de Plutarco ${ }^{7}$, que atesta a existência de um nomo chamado é $\lambda \in \gamma$ 's, que teria se desenvolvido no Peloponeso, e que provavelmente fora nomeado por Clonas de Tégea, um poeta épico e elegíaco ${ }^{8}$. Embora, como note Bowie (1986, p.24) e Gentili (1967, p. 52), Plutarco não faça qualquer relação explícita entre é $\lambda \varepsilon \gamma o \zeta$ e lamento e nem admita que os dísticos elegíacos eram o metro exclusivo do nomo

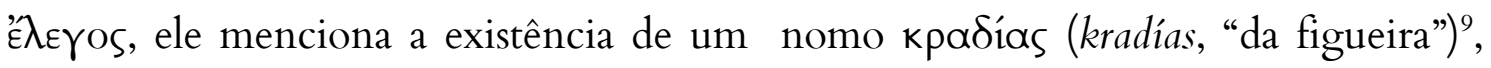
um nomo que, pelo contexto em que seria entoado - a procissão dos phármakoi poderia ser efetivamente dotado de um caráter lamentoso.

Muitos estudiosos demonstraram ceticismo às hipóteses de Page ${ }^{10}$, mas as objeções mais fortes foram levantadas por Bruno Gentilli, em "Epigramma ed Elegia” em L'Épigramme Grecque, Fondation Hardt Entretiens XIV (1967, pp.52 64). O principal argumento destes críticos é que não há evidências substanciais no corpus elegíaco sobrevivente para comprovar a existência de tal escola. Esta é

\footnotetext{
${ }^{7}$ Para debates acerca da autoria desse texto a Plutarco, ver Rocha Júnior, O Perì Mousikês de Plutarco: tradução, introdução e notas, p. 15- 30, 2007.

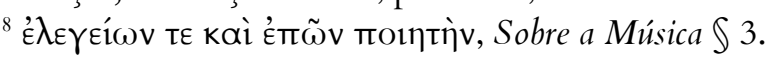

${ }^{9}$ E outro nomo antigo é o chamado Crádias, o qual Hipônax diz que Mimnermo tocou no aulo. Pois na origem os auledos cantavam elegias musicadas (Trad. de Roosevelt Araújo da Rocha Júnior, 2007).

${ }^{10}$ Ver, por exemplo, Friedlander e Hoffleit, Epigrammata 1948, p.66; Bowie, 1986, pp.23 -25, Fowler, 1987, The Nature of Early Greek Lyric: Three Preliminary Studies, p. 87.
} 
também a opinião de Fowler (1987, p. 87) que julga ser improvável que o nome de um gênero eminentemente jônico fosse dado a partir de uma obscura tradição dórica.

E. L. Bowie, em "Ancestors of Historiography in Greek Elegiac and Iambic Poetry?" em The Historian Craft in the age of Herodotus (2001, p. 53), discorda da teoria de Page e acredita que os dísticos elegíacos da Andrômaca seriam uma alusão a uma elegia narrativa composta por Sacadas de Argos, denominada Queda de Troia e referida por Ateneu (Banquete dos Eruditos, 13.610 c). A teoria é interessante - uma vez que há pressupostos para crer que a primeira performance da Andrômaca tenha se dado em $\operatorname{Argos}^{11}$ - mas é de tão difícil comprovação quanto a de Page.

A. E. Harvey, em seu artigo "The Classification of Greek Lyric” (1955, p. 170) adere à hipótese de Page, afirmando que tanto o gênero trenódico quanto a elegia apresentam conselhos, reflexões e exortações. Para o estudioso, a elegia não lutuosa teria desenvolvido outros temas a partir da lutuosa, mantendo, no entanto, o tom reflexivo e exortatório que caracterizaria ambas. Mesmo assim, como Harvey não oferece nenhum novo argumento, o problema da teoria de Page se mantém.

Recentemente, Cristopher A. Faraone procurou reforçar a teoria de Page em The Stanzaic Architecture of Early Greek Elegy (2008, p.137), oferecendo alguns possíveis candidatos. O autor afirma que "os dísticos elegíacos peloponésios cantados em estrofes foram utilizados por mulheres para inúmeros propósitos rituais, incluindo lamentos e hinos". Faraone relembra o Hino ao Banho de Palas de Calímaco, uma elegia também composta em dialeto dórico ${ }^{12}$ e que constituiria uma imitação em literatura erudita dos cantos peloponésios em dísticos elegíacos.

Alguns estudiosos anteriores a Faraone ${ }^{13}$ já haviam visto influências desta possível escola de elegias trenódicas ao analisarem a narrativa de Tirésias presente no Hino (vv.70-136). Na passagem, a mãe de Tirésias, Cariclo, se queixa da crueldade

\footnotetext{
${ }^{11}$ Ver Stevens, P.T. Euripides Andromache, Edited with an Introduction and Commentary, p. 20.

${ }^{12}$ E não em jônico, como esperado. Ver pp. 153-154.

${ }^{13}$ Heinze,em 1919, foi o primeiro a propor uma conexão do quinto hino de Calímaco e a tradição elegíaca do lamento (“Ovids elegische erzähung”, 95.1 em Bulloch, A, p. 33, 1985.).
} 
de Atena e lamenta a sorte do filho, que perdera a visão por contemplar, ainda que involuntariamente, a deusa nua.

Mas um olhar mais atento à passagem, como mostra Anthony W. Bulloch em Callimachus Fifth Hymn (1985, pp.33-34), revela que o lamento não é o enfoque da elegia (restringindo-se a apenas dez versos, 85-95), e tampouco a narrativa se assemelharia a uma canção fúnebre: o poema apresenta uma conclusão positiva com a intervenção de Atena nos versos finais (vv.120-136), oferecendo dádivas compensatórias à cegueira de Tirésias. Assim, embora o Hino ao Banho de Palas pudesse de fato ter sido influenciado por tradições rituais do Peloponeso, nada nele indica que tais tradições seriam trenódicas.

A outra evidência de Faraone seria uma inscrição em um monumento funerário coletivo (poluandrion) datado do século VI a.C e encontrado em Ambrácia, o "Poliândrio de Ambrácia". O monumento contém dez versos em dístico elegíaco, chamando a atenção por ser proveniente de um período em que a maioria dos epitáfios não ultrapassava quatro versos ${ }^{14}$ :

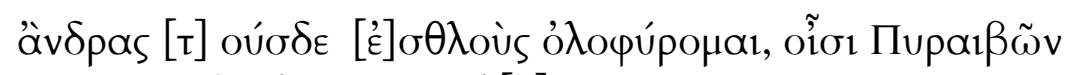

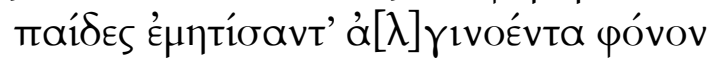

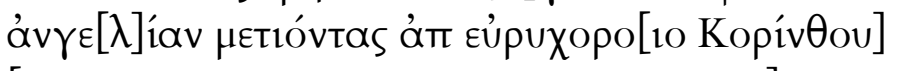

$\left[\begin{array}{lllllll}. & . & . & . & . & . & .\end{array}\right]$

$\left[\begin{array}{llllllll}. & . & . & . & . & . & . & .\end{array}\right]$

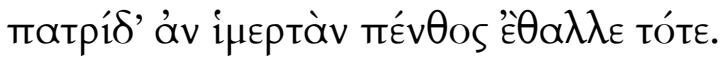

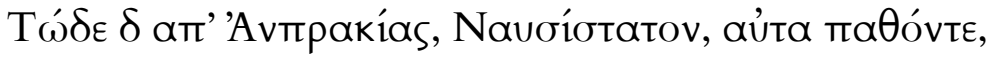

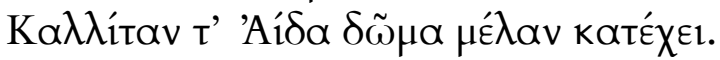

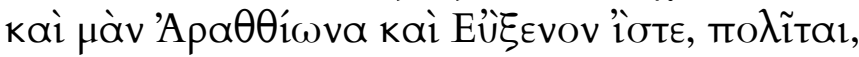

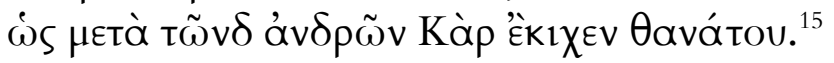

Por estes valentes varões eu choro, a quem os filhos

De Pirebo tramaram uma d[o]lorosa morte, enquanto seguiam uma embaixada da espaç[osa Corinto] $\left[\begin{array}{llllllll}\cdot & \cdot & . & . & . & . & . & \\ {[.} & . & . & . & . & . & . & .\end{array}\right]$

\footnotetext{
${ }^{14}$ Ver West, 1974, p.2: “Antes das Guerras Pérsicas, é raro encontrar um epigrama mais longo do que quatro versos".

${ }^{15}$ Utilizo a edição revisada do texto, conforme apresentada em D’Alessio, 1995, Sull' Epigrama dal Polyandrion di Ambracia, p.26.
} 
e então o luto florescia na encantadora pátria.

Ambos de Ambrácia, ambos padeceram do mesmo destino, Nausístrato

e Cálite; retêm-nos a negra casa do Hades.

E sim, sabei, cidadãos, que em companhia desses varões,

a Sina da morte pegou Arácion e Euxeno.

O epitáfio aos embaixadores de Ambrácia reúne características que estimularam os estudiosos ${ }^{16}$ a reavaliarem a conexão entre lamento e elegia, e, portanto, a revalidar a hipótese de uma escola de elegia trenódica no Peloponeso.

Dentre elas, poder-se-ia elencar: o dialeto dórico, próprio da região de Ambrácia; o uso de um formulário comum à elegia grega arcaica, como em Kà $\rho$

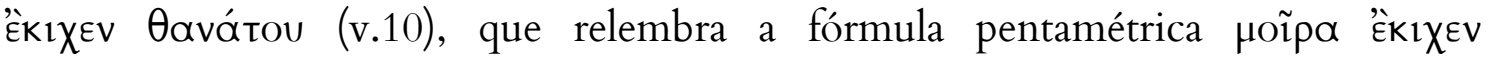

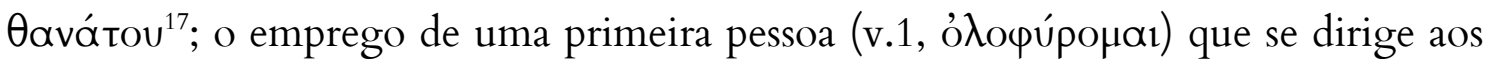
cidadãos de Ambrácia (v.9, по $\lambda \tilde{\imath} \tau \alpha \mathfrak{l})$, um expediente mais utilizado na elegia ${ }^{18}$ do que no epigrama funerário arcaico, que emprega com mais frequência a segunda pessoa ${ }^{19}$.

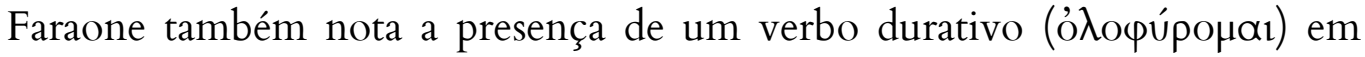

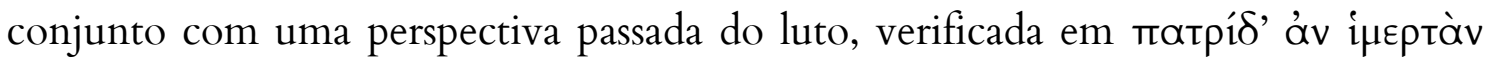

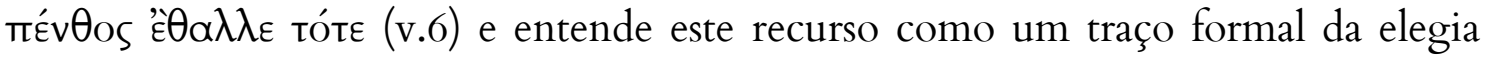
trenódica (p.135), não só porque evoca o lamento de Andrômaca ${ }^{20}$, mas também o fragmento $13 \mathrm{~W}$ de Arquíloco, que alterna referências passadas de um desastre no mar (vv.3-4) com o luto atual na cidade (v.1, vv.4 -5):

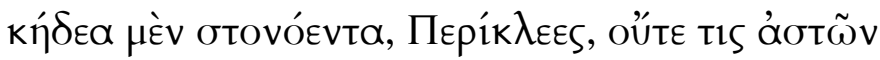

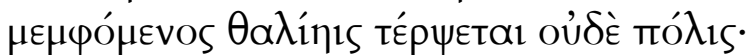

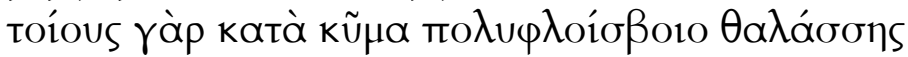

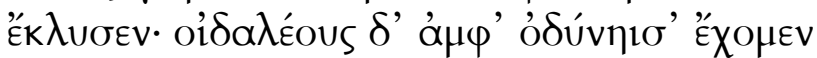
пveúfovas (...)

\footnotetext{
${ }^{16}$ Ver Cassio, A.C. 1994, apud Faraone, 2008, pp. 133, 135.

17 Ver Tirteu 7.2 W, p.216, 218.

${ }^{18}$ Ver, por exemplo, Tirteu fr.10.15W; Sólon fr. 4.5-6W.

${ }^{19}$ Ver West, 1974, p.2: “O poeta suprime a sua personalidade; verbos em primeira pessoa regularmente têm o objeto inscrito ou o indivíduo morto como seu sujeito, enquanto aqueles em segunda pessoa dirigem-se a quem quer que leia a inscrição"

${ }^{20}$ Ver a profusão de verbos no passado, quando Andrômaca relembra a tomada de Troia (vv.103-115) e o presente tákoнa1, no verso 116. Ver Faraone, p. 135.
} 
Nosso gemente luto, Péricles, nenhum dos cidadãos censurando se alegrará em festas, e nem a cidade.

Pois tais homens as ondas do mar políssono engolfaram: e temos os pulmões túrgidos de dores. (...)

Mas o que Faraone julga como conclusivo é o fato de que tanto o epitáfio do Poliândrio de Ambrácia quanto os primeiros dez versos do lamento de Andrômaca se adequam à sua teoria de que a elegia grega era constituída por estrofes de cinco dísticos, e o uso do dialeto dórico em ambos fornece um argumento para a proposição de Page de que Eurípides estaria refletindo na Andrômaca uma antiga tradição trenódica do Peloponeso.

Gregory Nagy em “Ancient Greek Elegy” (2009, p. 23) tenta buscar na épica homérica antecedentes para a elegia trenódica, que ele define como um canto lutuoso monódico e profissionalizado, entoado exclusivamente por homens, e que é respondido por um coro, não profissional e principiado por homem ou mulher.

Esse processo seria verificado no contexto da Ilíada, que utiliza $\theta \rho \tilde{v} v o \varsigma$ (thrênos, "treno" ou "canto fúnebre") sempre em um sentido mais técnico significando o lamento profissional - e reserva o termo yóos (góos, "lamento") para o canto responsivo amador que vem em sua sequência, geralmente acompanhado pela fórmula érì $\delta \grave{~ o t ~ o t \varepsilon v a ́ X o v t o ~ \gamma u v a i ̃ k e s ~(" e ~ e m ~ s e g u i d a, ~ a s ~ m u l h e r e s ~}$ pranteavam”). Os versos 720 - 723 do Canto 24 da Ilíada são um exemplo claro dessa dinâmica ${ }^{21}$ :

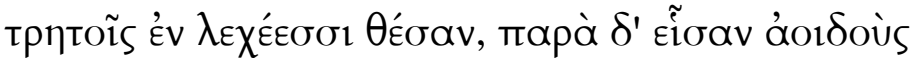

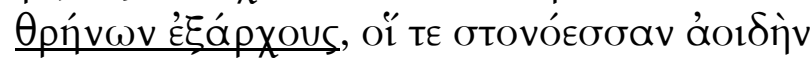

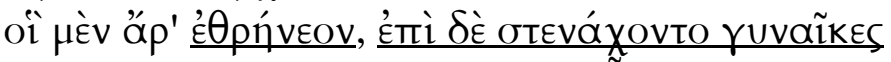

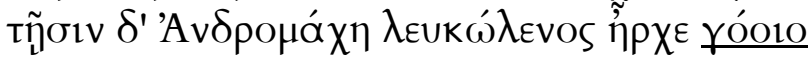

em leito cordado puseram-no, e ao lado assentaram os cantores

regentes dos trenos. Uma gemente canção

eles entoavam, e as mulheres pranteavam em resposta.

E entre elas Andrômaca de níveos braços começava o lamento.

\footnotetext{
${ }^{21}$ Além do yóos de Andrômaca (24.725-745) outros exemplos citados por Nagy são: Ilíada 19.282302 (Briseida); 24.748-759 (Hécuba); 24.763-775 (Helena).
} 
Nagy (2009, p.12) entende que esse "pranto em resposta" seria a representação dada pela épica a um róos em dístico elegíaco, visto que é característico do épos subsumir outras formas métricas ao seu próprio metro ${ }^{22}$. Para Nagy, a fundação da elegia como gênero adviria com a profissionalização desse róos, que passaria a ser entoado principalmente por homens nos simpósios, em uma ocasião deslocada de seu ambiente original (o funeral) e em um contexto de cantos monódicos, não mais corais - o que possibilitaria a abundância de temas que constitui a elegia grega arcaica, e também a sua reelaboração em outro espaço de performance, como o festival público.

Nesse sentido, embora o lamento possa continuar a fazer parte do horizonte desta espécie de elegia (como mostra Arquíloco $13 \mathrm{~W}$ ), torna-se um lamento estilizado (Ver Nagy, 2009, p.36), que leva em consideração o seu próprio ambiente simpótico $^{23}$. Independente de seguirmos ou não a hipótese de Nagy, é notável que a sua leitura tente conciliar a proposta de uma elegia trenódica com um aspecto definidor do gênero: a ocasião de performance, isto é, o ambiente de destinação e produção de um poema - que, no caso da elegia, resumir-se-ia ao simpósio.

\section{A elegia e sua ocasião de performance}

Em meados da década de 60, no artigo "The poetry of Archilochos", Kenneth Dover sugeriu, dada certa coincidência de éthos entre composições elegíacas e jâmbicas de Arquíloco, que o único traço comum para a definição genérica de seus poemas seria a ocasião para a qual foram compostos (1964, p.189). Desde então, consoante aos trabalhos que se seguiram a esse estudo e ao de Martin L. West sobre a elegia grega arcaica e clássica em Studies in Greek Elegy and Iambus

\footnotetext{
${ }^{22}$ Ver Richard Martin, The Language of Heroes, 1989, p. 12-42

${ }^{23}$ Nagy conclui que há uma relação do fragmento $13 \mathrm{~W}$ com o simpósio a partir da presença de

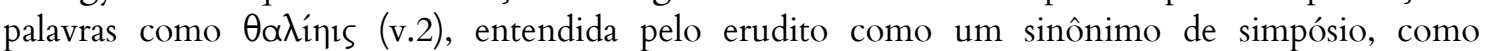
poderiam demonstrar por exemplo, também os versos 983-988 da Teognideia e os versos 56 e 454 do Hino Homérico a Hermes. O verbo '€̇ $\theta \alpha \lambda \lambda_{\varepsilon}$ no Poliândrio de Ambrácia(v.5) seria, ainda, para Nagy (p.38) uma maneira encontrada pelo poeta de manter na inscrição epigráfica o referente simpótico.
} 
(1974, pp. 10 - 13), acredita-se que para a interpretação de um gênero poético na Grécia do período arcaico (séc. VII a.C- V a.C) é necessário pensar também na ocasião de performance de um poema, além de seu metro e linguagem.

Os estudos dos últimos anos assinalam que quase toda a lírica monódica do período arcaico - incluindo sob esta categoria a poesia elegíaca - tivera o simpósio ${ }^{24}$ como seu espaço de performance original. Ewen Bowie, em "Early Greek Elegy, Symposium and Public Festival" (1986, pp.19-21), por exemplo, demonstra que as evidências que se pode depreender de fragmentos supérstites atestam tão somente o simpósio como ambiente propício à prática de elegias breves.

O erudito menciona os versos 237-243 do corpus de elegias atribuído a Teógnis, a Teognideia. O poeta anuncia ao seu eromenos Cirno que seus versos são alados dons de Musas que o farão transpor os limites do tempo e do espaço, pois seu nome será eternamente celebrado por toda a terra grega. E o local dessa celebração remete propriamente ao simpósio - banquetes e festins integrados por belos jovens com aulos, instrumento da elegia:

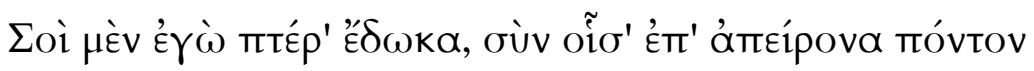

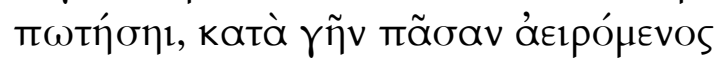

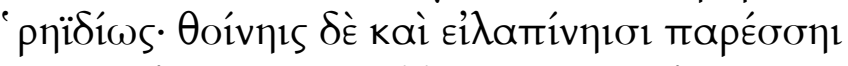

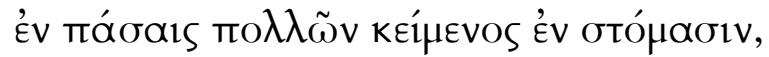

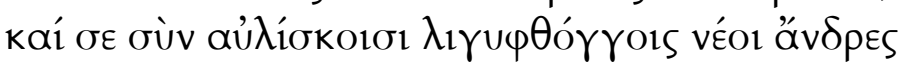

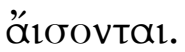

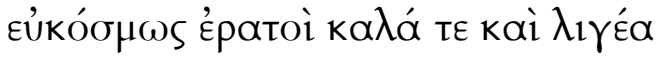

Eu te dei asas, com as quais sobre o infindo mar voarás, e por toda a terra, elevando-se facilmente; em todos os banquetes e festins estarás presente, reclinado sobre os lábios de muitos, e com aulos, flautins harmoniosos, rapazes atraentes com beleza e harmonia em ordem te celebrarão.

\footnotetext{
${ }^{24}$ Entendo o simpósio (бuнтóorov, symposion) como uma festividade altamente ritualizada, com regras específicas, que se dava após o banquete propriamente dito (( $\delta \varepsilon \tilde{i} \pi v o v$, deipnon) e privilegiava o ato de beber. Era composto por pequenos grupos de homens aristocratas e dominado, ao mesmo tempo, por um forte sentimento de coesão e competição (Ver Wecowski 2002, pp. 337-361, sobretudo 337-338).
} 
Todavia, quanto ao contexto de apresentação das elegias de cunho militar exortatório, cujos autores mais significativos são Calino de Éfeso e Tirteu de Esparta $^{25}$, algumas questões são continuamente levantadas.

Segundo West (1974, p. 10), as elegias exortativas de Tirteu eram entoadas em um momento precedente à batalha, na qual "os guerreiros são exortados a ter coragem e a conquistar glória”, mas não há qualquer alusão direta a essa ocasião nos fragmentos que nos foram transmitidos. West recorre a dois testemunhos para o estabelecimento de uma ocasião de performance para a elegia marcial. O primeiro é datado do século IV a.C. Trata-se do opúsculo Contra Leócrates (\$ 107), de Licurgo. Nele, o orador menciona que em sua época era um nomos espartano a récita de poemas de Tirteu na tenda do rei :

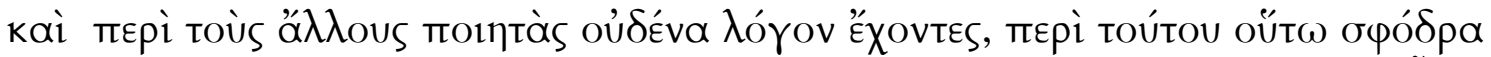

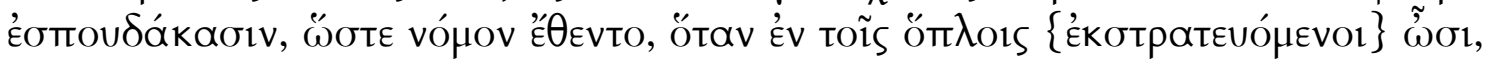

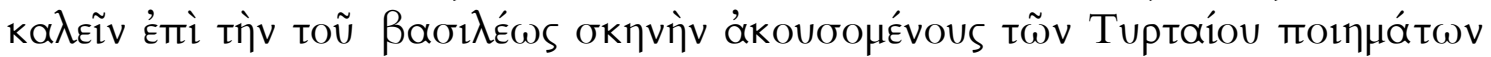

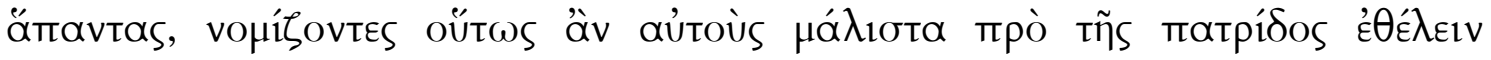

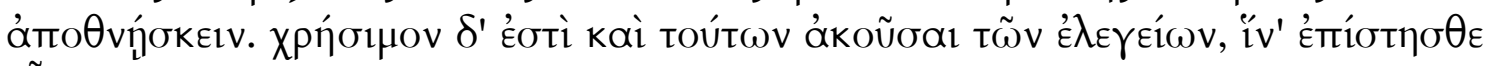

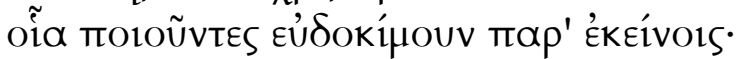

Embora não tivessem em conta alguma os outros poetas, por ele [scil. Tirteu] tiveram um interesse tão veemente que outorgaram uma lei (nomos) que, quando estivessem em armas, \{fazendo uma expedição militar\}, convocava todos à tenda do rei para ouvirem os poemas de Tirteu, presumindo que assim eles desejariam ao máximo morrer pela terra pátria. É-vos útil ouvir destes dísticos elegíacos, de modo a vos persuadires quanto ao tipo de poesia que era apreciada entre eles [scil. Espartanos] (...)

Contudo, a citação de Licurgo é anacrônica para a análise das ocasiões de performance de elegias no período arcaico, por relatar um procedimento bem posterior à época em que se estima a atividade poética de Tirteu. Um testemunho do historiógrafo Filocoro de Atenas (Fr. Gr. Hist. 328 F 216) encontrado no Banquete dos Eruditos de Ateneu (XIV, 630 ss.) é então aduzido por West para

\footnotetext{
${ }^{25}$ Outras elegias incluídas neste grupo podem ter sido o fragmento $3 \mathrm{~W}$ de Arquíloco e o $14 \mathrm{~W}$ de Mimnermo (Ver West, 1974, p.10).
} 
corroborar que a prática espartana já retrocedia ao sétimo século. Filocoro afirma que o hábito de entoar os poemas de Tirteu nas expedições espartanas surgira logo após a vitória sobre os messênios, o que teria se dado em meados do século VII a.C :

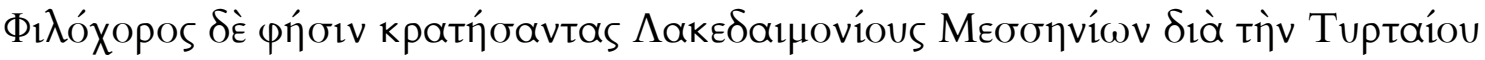

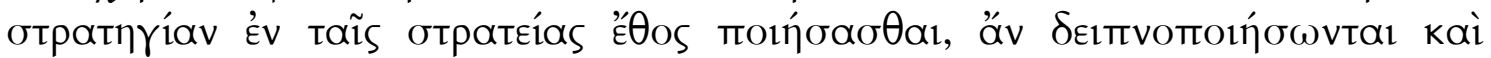

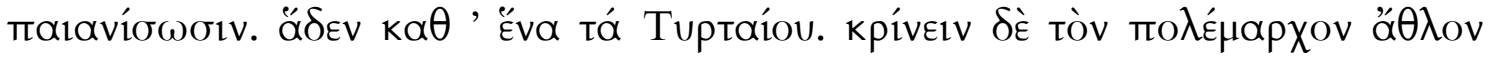

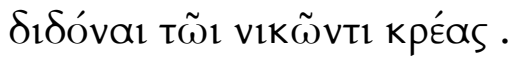

"E Filocoro diz que os lacedemônios, depois de vencerem os messênios pela liderança de Tirteu, estabeleceram um hábito em suas campanhas militares: sempre depois de jantarem e entoarem o peã, cantariam um por um os poemas de Tirteu. $\mathrm{O}$ polemarca julgaria e daria carne ao vencedor como prêmio".

De modo geral, os testemunhos recolhidos por West informam que a performance das elegias de Tirteu se dava quando os soldados estavam em campanha. Por outro lado, nada nas fontes parece sugerir que a elegia exortativa marcial seria apresentada em uma ocasião precedente à batalha.

A única elegia marcial que pode trazer alguma referência a um ambiente de performance específico é o mais longo fragmento de Calino de Éfeso (1 W), que em seus quatro primeiros versos traz:

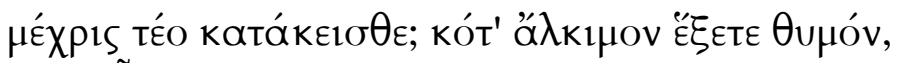

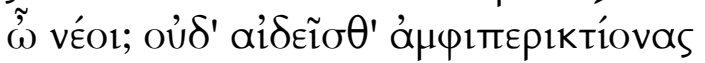

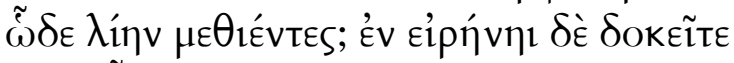

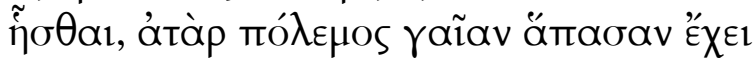

Até quando ficais acomodados? Quando tereis um ânimo valente, jovens? Não tendes vergonha de seus convizinhos, assim folgados em excesso? Em paz pareceis vos assentar, mas a guerra ocupa toda a terra.

Os termos utilizados pelo poeta elegíaco parecem remeter precisamente ao simpósio. No primeiro verso, emprega-se o verbo кaтóкєıна (katákeimai). Este verbo é utilizado como uma sinédoque para um estado de ociosidade e inação, mas seu sentido primeiro denota simplesmente o ato de acomodar ou reclinar-se, que é o 
mesmo verbo empregado para designar a postura dos convivas no simpósio. Adkins (1977, p. 69) observa que o termo ocorre na Ilíada e na Odisseia e utilizado apenas literalmente, com o sentido de "estar deitado" ${ }^{26}$.

Dentre os textos de que temos notícia, essa sinédoque é atestada pela primeira vez somente em Xenofonte ${ }^{27}$, como mostra Gennaro Tedeschi em "L' Elegia Parenetica-Guerriera a il Simpósio” (1978, p.95). Segundo o autor, katákєıนaı é um termo técnico empregado para designar o ato de sentar-se reclinado em

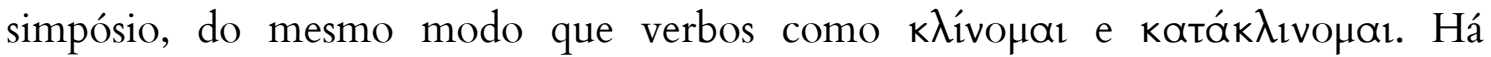
exemplos desse uso nos versos 515-516 da Teognideia:

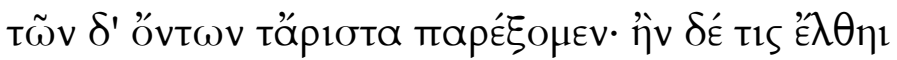

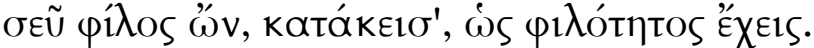

Oferecerei o que há de melhor: se algum amigo teu chegar, acomoda-o, conforme a estima.

Bowie em "Miles ludens? The problem of martial exhortation in early greek elegy" (1990, p.223) acredita que o sentido literal é o mais adequado, pois a acusação de ociosidade feita pelo poeta à sua audiência não condiz com um ambiente precedente à batalha, em que os esforços já estariam concentrados na atividade bélica, o que seria até mesmo impróprio como uma exortação à luta. Por conseguinte, seria preciso supor antes um contexto de relaxamento, e tal contexto, dadas as fontes e testemunhos oferecidos, provavelmente seria o simpósio. $\mu \varepsilon \theta_{\imath \in ́ v t \varepsilon S}$

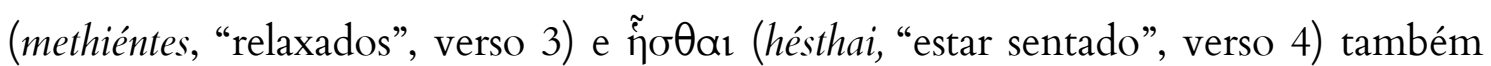
não são termos estranhos a uma ocasião simposial: ambos contêm a mesma literalidade de $\kappa \alpha \tau \alpha ́ \kappa \varepsilon ı \sigma \theta \varepsilon$ e prolongam a ideia apresentada por este verbo.

\footnotetext{
${ }^{26}$ Adkins encontra sete ocorrências na Ilíada e na Odisseia: Il.17.677; 24.10; Od.11.45, 10.532, 19.439 e três no Hino Homérico a Hermes: H.Merc. 254, 324, 358. Curiosamente, três ocorrências da palavra na Odisseia $(7.188,18.409$ e 18.419) - as duas primeiras usadas em um contexto de banquete - não são registradas pelo estudioso.

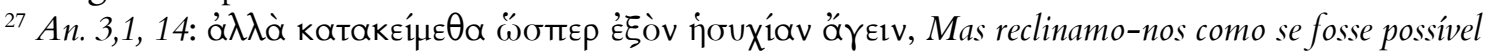
estar tranquilos)
} 
Embora não tenha encontrado muita adesão entre os estudiosos ${ }^{28}$, a ideia de que poderiam existir elegias marciais destinadas ao simpósio não é nova, e segue, em princípio, hipóteses já lançadas por Richard Reitzenstein em Epigramm und Skolion, no fim do século XIX (1893, p. 50), e também Cecil M. Bowra em Early Greek Elegists (1938, p. 14). West (1974, p. 11) não dá um veredito a respeito da ocasião de performance da elegia marcial, mas reconhece a possibilidade do simpósio ser um cenário propício para poesias de caráter exortativo, referindo-se a uma passagem da Teognideia (vv. 825-830) que apresenta uma situação similar à de Calino $1 \mathrm{~W}$ :

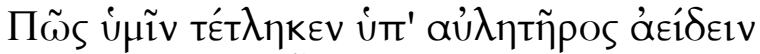

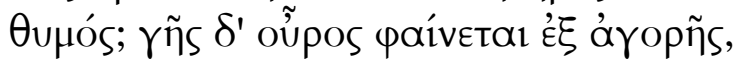

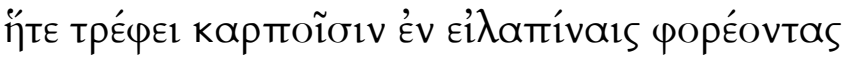

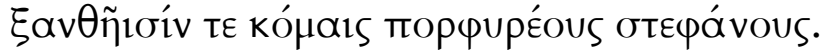

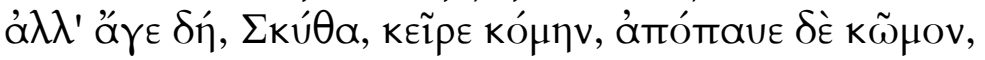

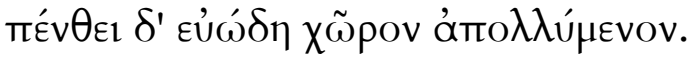

Como vosso ânimo suporta o cantar do auleta?

O limite da terra revela-se da ágora, que nutre com frutos os que portam nos festins coroas púrpuras nos cabelos louros.

Eia, Cita, vamos! Corta teu cabelo, cessa o cortejo, lamenta o lugar pefumado que te arruína.

Mas qual seria a função no contexto de simpósio de uma poesia que tem como um dos seus temas centrais a exortação à coragem militar? Bowie (1990, p.228) recorre à Teognideia para demonstrar que o tema podia ser utilizado no ambiente simpótico, mesmo quando hostilidades não estivessem à vista (885-890):

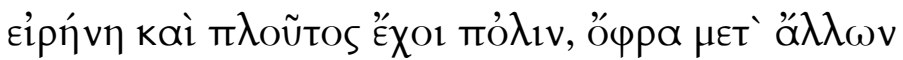

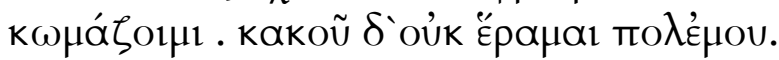

Que paz e riqueza mantenham a cidade, para que eu festeje com os outros: não gosto da guerra má !

\footnotetext{
${ }^{28}$ Verdenius (1969, p.02) argumenta, com Fränkel (1975, p.153), que o poema não ocorreria necessariamente em um simpósio e como argumento cita passagens da Ilíada (2.797, 4.371, 5.78283). Ver também Campbell (1982, p.163).
} 


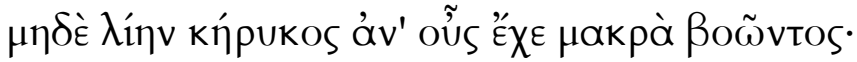

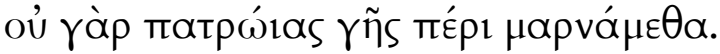

Não dê muito ouvidos aos brados do arauto: nós não lutamos pela terra pátria.

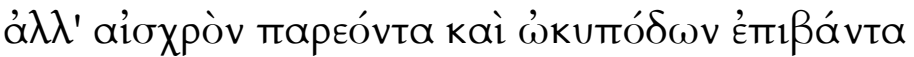

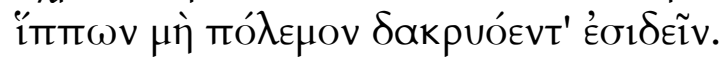

É torpe quem se apresenta e marcha com celerípedes corcéis para não encarar a guerra lácrima.

Os exemplos da Teognideia apresentam três atitudes contrastantes diante da guerra, que demonstram como essa tópica poderia ser trabalhada na ocasião do simpósio. ${ }^{29}$ Bowie conclui assim que não seria estranho pensar na elegia marcial sendo apresentada nos simpósios de qualquer cidade grega, uma vez que a guerra também dizia respeito ao simposiasta - ao mesmo tempo um cidadão e um soldado.

Consideradas tais hipóteses, resta pensar em que medida elas seriam aplicáveis às elegias exortativas de Tirteu, tendo em vista que muitos estudiosos, amparados por testemunhos antigos ${ }^{30}$, atribuem à sua poesia um papel único em determinado contexto histórico: o de estimular soldados para a imediata ação bélica nos confrontos entre Esparta e Messênia de meados do século VII.

Vale notar que esses juízos têm como fundamento uma concepção de Esparta que tende a ignorar as similaridades entre ela e as demais póleis gregas, ao mesmo tempo em que descartam certa "consciência genérica" da elegia exortativa de Tirteu, evidenciada, por exemplo, no uso quase absoluto do dialeto jônico: se as elegias de

\footnotetext{
${ }^{29}$ Ver Vetta (1980, p. XXIX, n.33)

${ }^{30} \mathrm{~A}$ maioria dos testemunhos antigos coloca Tirteu como um ex-professor ateniense que se tornou

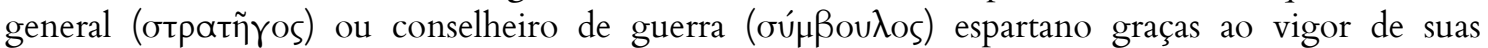
exortações bélicas (Ver, por exemplo, Ath.14.630a, Paus. 4.15.6, Diod. Sic. 8.27-1-2, e sobretudo Hor. Art. poet. v. 402 (mares animos...exacuit). Dos estudiosos contemporâneos, ver: West (1974, p. 10), ao colocar a ocasião de performance da poesia de Tirteu como antecedente à batalha, e Bowra (1938, p.41): "Tyrtaeus is the very voice of the Spartan ruling class, the interpreter of its ideals and its instructor on the art of war"
} 
Tirteu visavam de fato infundir coragem e exortar soldados ao valor marcial, é estranho pensar que foram compostas em outro dialeto que não fosse o local.

Elizabeth Irwin, em Solon and Early Greek Poetry: The Politics of Exhortation (2005, p. 30) já alerta que não se pode descartar o aspecto pan-helênico da elegia exortativa marcial, uma forma convencional que segue determinações genéricas e detém amplo sentido no universo de diversas póleis gregas. Um indício desse panhelenismo pode ser verificado quando se compara as exortações de Tirteu ao fragmento marcial de Calino acima citado: ambos os poetas compuseram elegias da mesma jaez, apesar de muito distantes geograficamente e próximos cronologicamente para supor que um poderia ter sido influenciado pelo outro.

Antonio Aloni em "Elegy: forms, function and communication" (2009, p.171) divide as elegias simpóticas de acordo com o tempo, o espaço e a estrutura sociopolítica de onde foram compostas. Segundo o autor, os simpósios espartanos não se restringiam às ovooítıa (sussítia, "refeições comunais") ${ }^{31}$, mas constituíam-se também como um espaço para performances mélicas e citaródicas de poetas espartanos como Álcman ou Terpandro. De fato, a tradição registra Terpandro como o primeiro poeta a cantar em âmbito simposial, a quem Píndaro atribui a invenção dos okódı (skólia, "canções de mesa") ${ }^{32}$ e do ßápßıtos (bárbitos), um instrumento de corda próprio para a monodia (fr.125 Sn-M.) ${ }^{33}$ :

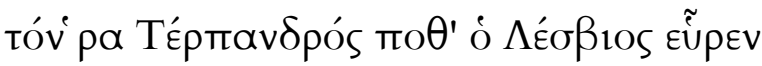

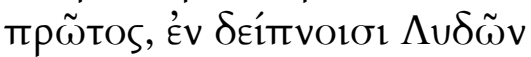

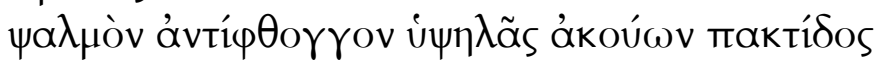

a ele (sc. bárbitos) um dia Terpandro,o Lésbio, descobriu primeiro, nos banquetes dos Lídios o vibrante som concorde de sublime harpa (péctis) ouvindo...

\footnotetext{
${ }^{31}$ Questão que trataremos também na Parte 2 - Capítulo 1 deste trabalho, A Poética da Eunomia ("A Eunomia e a miragem espartana"), p.147-156

${ }^{32}$ Plut. Mus, 28: "Mas, se como Píndaro diz, Terpandro também foi o inventor das melodias escólias

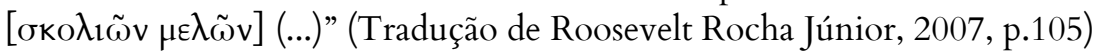

${ }^{33}$ Píndaro, fr. 125 Sn-M.; Ver Vetta, 1992, p. 184.
} 
Luana Quatroccelli no artigo "Sparta Convivialità" (2004, p.15) recorda um testemunho do epicurista do século II a.C. Filodemo de Gádara, que menciona o poder psicagógico da música de Terpandro, entoada nas sussítia espartanas como uma maneira de conter o povo em um período de rebeliões civis (De Mus. 1. Fr.30) :

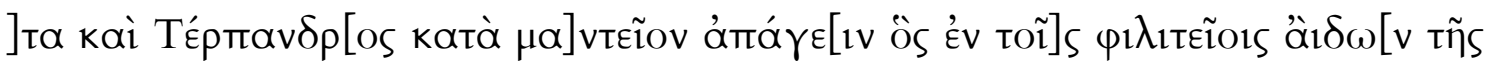

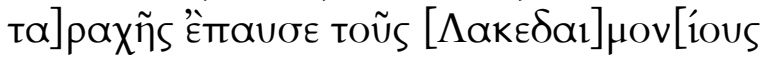

]...e Terpand[ro, conforme] a designaç[ão or]acular, cantando nos banquetes comunais (philitêiois) ${ }^{34} \mathrm{fez}$ os Lacedemônios cessarem o tumulto .

Analisando tais evidências, a hipótese de Massimo Vetta, em "Il Simposio: la Monodia e il Jambo" em Lo Spazio Letterario della Grecia Antica (1992, p. 184) é de que Terpandro compôs nomos citaródicos que tinham como espaço de performance original um simpósio que em nada diferia dos simpósios aristocráticos conhecidos em outras póleis gregas, mas que depois foram reintroduzidos no circuito de reperformances das sussítia, que marcaram a Esparta mais fechada e conservadora do século VI a.C.

O fragmento 19 Davies de Álcman - poeta quase contemporâneo de Tirteu - também revela-nos que esse simpósio seria uma reunião bem diferente das refeições comunais espartanas ${ }^{35}$ :

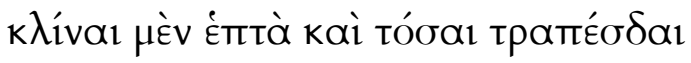

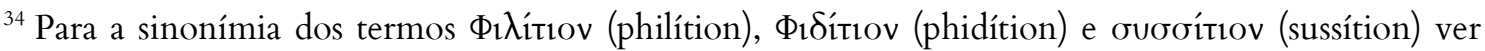
Irwin,2005, p. 32, n.40.

${ }^{35}$ Os versos de Álcman remetem à prática da poesia metasimposial que se ocupa de descrever metodicamente o ambiente simpótico e suas práticas. O fr. 1W de Xenófanes é um dos exemplos mais bem acabados, embora não seja o único: "Agora, limpo é o chão, e as mãos de todos, /e as taças: um cinge-nos trançadas coroas,/e outro estende-nos olente bálsamo em um prato: la cratera está repleta de alegria./Pronto outro vinho, melifluo nas jarras,/Odor de rosas, que afirma jamais acabar;/No meio propaga-se santo perfume de incenso; lé fresca a água, é doce, é pura./Ao lado pães dourados, majestosa mesa/cheia de queijos, de mel pingue; /o altar no meio está todo coberto de rosas; /Canto dança e festival envolvem a casa./Devem primeiro hinear ao Deus os homens alegres /Com afamados mitos e puras palavras/Após libar e rogar pelo poder de fazer o justo /(isto em verdade é mais fácil, não a insolência); /deve-se beber o quanto suportas, e poder/voltar para casa sem auxílio, a menos que muito idoso,/e louvar aquele homem que ao beber revela nobres palavras,/para que haja memória e esforço pela virtude; le não devem expor os combates de Titãs, de Gigantes,/de Centauros, fiç̧ões dos antigos, /ou ardentes sedições, nelas não há o que preste - Imas ter dos Deuses sempre a boa providência".
} 


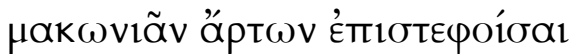

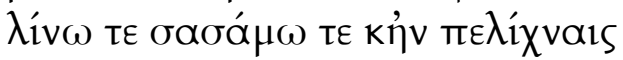

$\pi \varepsilon ́ \delta \varepsilon \sigma \tau 1$ хрибоко́ $\lambda \lambda \alpha$.

assentos sete e tantas mesas

repletas de bolos de papoula,

linhaça e sésamo; e nos canecos,

está presente o khrysokólla ${ }^{36}$

Outros fragmentos de Álcman ainda exploram imagens próprias do mundo simposial: o fr. 95a-b Davies retrata o ambiente convivial espartano e a sua terminologia; o fr. 98 Davies refere o procedimento de entoar peãs em simpósios e, por fim, o fr. 17 Davies (vv. 3-8), de rara temática privada, parece demarcar uma distinção entre dois grupos; um é o $\delta a \tilde{\mu} o \zeta$, no qual o poeta se insere, que "gosta de refeições simples", e outro, que aprecia iguarias sofisticadas (um dos sentidos

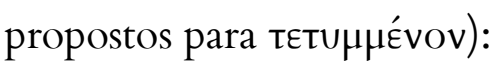

$[\ldots]$

á $\lambda \lambda^{\prime}$ '

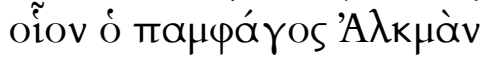

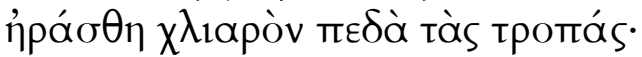

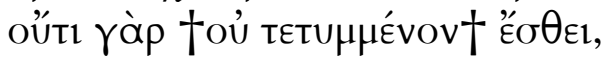

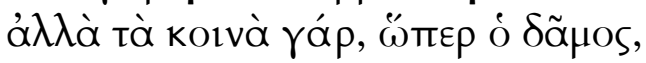

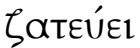

[...]

Por enquanto ainda fria, mas logo cheia

Da sopa de ervilhas que o onívoro Álcman

Ama quente após o solstício:

Pois confeitos ele não come,

Mas coisas comuns, tal qual o povo

- ele busca.

A conclusão de Aloni (2009, p.173) é a de que Tirteu emergiria nesse contexto não só como o mais famoso poeta elegíaco espartano, mas também, talvez,

\footnotetext{
${ }^{36} \mathrm{O}$ fragmento foi conservado por Ateneu $(3.110 \mathrm{f}-111 \mathrm{a})$, interessado na menção feita por Álcman à

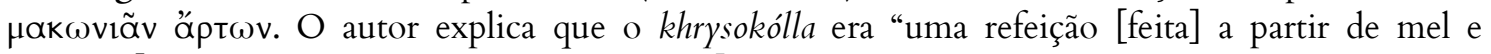

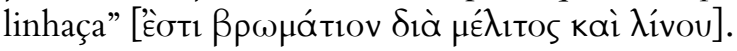


como o único. A elegia teria sido o meio escolhido por ele para representar e dar dimensão heroica a uma nova forma de combate, o hoplítico, já bem delineada no mundo jônico.

Esse argumento levanta alguns problemas, se considerarmos os testemunhos que falam de uma tradição de poetas elegíacos atuantes em Esparta no período arcaico, embora não fossem naturais de lá. ${ }^{37}$ Além disso, pode-se perguntar: por que Tirteu optaria também pelo dístico elegíaco em seus fragmentos políticos, que a priori não se ocupam da exortação ao combate? E em que medida suas elegias representam de fato uma nova forma de combate $^{38}$ ? A associação da elegia com o mundo jônico seria suficiente para conferir estatura heroica e delimitar essa nova forma de combate?

Vetta (1992, p.186) supõe que a grande fama das elegias de Tirteu se dera por causa de uma seleção operada nas sussítia nas primeiras décadas do século VI a.C. Poderíamos então imaginar que Tirteu teria passado pelo mesmo processo que Terpandro: assim como os cantos simposiais dele permaneceram vivos em reperformances realizadas nas sussítia principalmente por conta de seu valor político, os poemas de Tirteu se mantiveram em circulação por serem exemplares de uma moral cívica e guerreira que se desenvolvia em Esparta na época, e é com esse papel que Tirteu seria recebido pela tradição ${ }^{39}$.

Pesadas essas avaliações, parece mais plausível concordar com Douglas Gerber em "Elegy" (1997, p.92), e supor que as elegias marciais de Tirteu podiam ter as suas primeiras performances visando tanto a tenda real, em um contexto de relaxamento similar ao do simpósio (como se depreende das citações de Licurgo e Filocoro) quanto o simpósio aristocrático, e aquelas que se provassem mais populares eram entoadas indistintamente em ambos os locais.

\footnotetext{
${ }^{37}$ Ver Plut. De Mus. $\$ 3,8,9$.

${ }^{38}$ Ver Comentários ao fr.11 W (pp82-113.).

${ }^{39}$ Plat. Leg. 629a, 660e-661b (ver pp.116-119 deste trabalho). Cabe acrescentar que Platão é o autor mais antigo que temos notícia a registrar a obra de Tirteu, em um contexto que lhe era importante salientar as diferenças entre os simpósios atenienses e espartanos.
} 
Mas além do simpósio, Bowie (1986, pp.27-34) admite ainda uma segunda circunstância de performance para a elegia: o autor propôs a existência de longas elegias destinadas à performance pública em grandes festivais, teoria que em grande medida foi confirmada com a descoberta dos novos fragmentos de Simônides de Céos. Essas elegias públicas compartilhariam algumas características em comum, como a predileção por narrativas míticas e/ou históricas, a prevalência de valores cívicos que dizem respeito a toda uma comunidade e a preocupação em demarcar datas e eventos cronológicos, o que poderia antecipar os procedimentos da prosa historiográfica do período clássico.

Assumindo essas posições de Bowie, verifica-se nos poemas de Tirteu um instrumento profícuo para o estudo da elegia grega arcaica, uma vez que seus poemas poderiam ter sido compostos para ambas as ocasiões de performance aqui sugeridas, quais sejam, o simpósio aristocrático e o festival público. Que poemas seriam esses e de que maneira podemos organizar os fragmentos supérstites de Tirteu?

\section{Os poemas de Tirteu}

Conforme a Suda, a obra de Tirteu era classificada em três modalidades

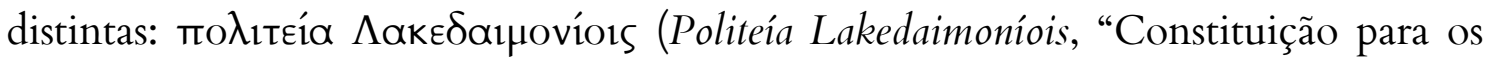

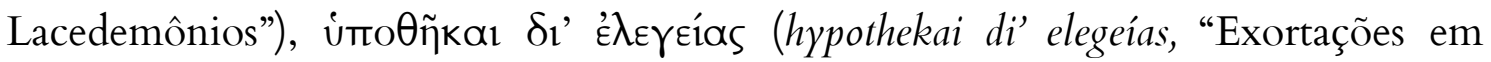

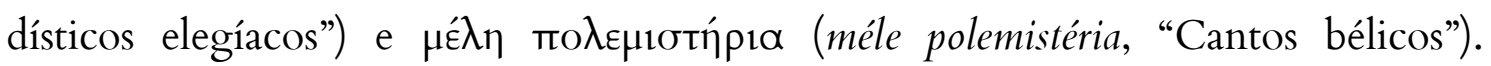

Naturalmente, tal divisão não se encontra em testemunhos mais antigos, que

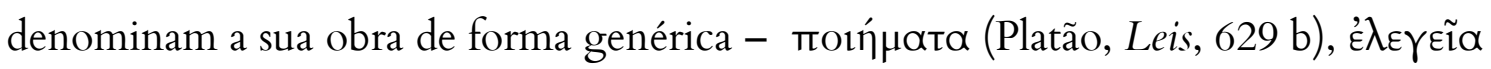
(Licurgo, Contra Leócrates 106) e éñ (Máximo de Tiro, 35.5) - tampouco são títulos originais, conferidos pelo poeta, que apenas em uma ocasião denomina a sua obra, com o amplo termo $\lambda$ ó os $(12.1 \mathrm{~W})$. Nesse caso, os títulos podem ter surgido de uma necessidade de distinguir os poemas tirtaicos por sua métrica (ن்rro $\theta \tilde{\eta} k \alpha \mathfrak{l} \delta \mathfrak{l}$ '

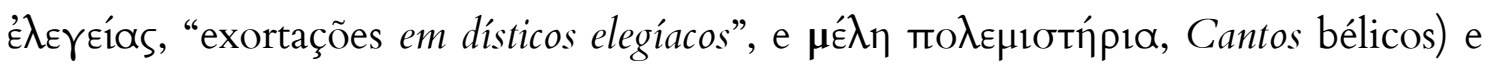




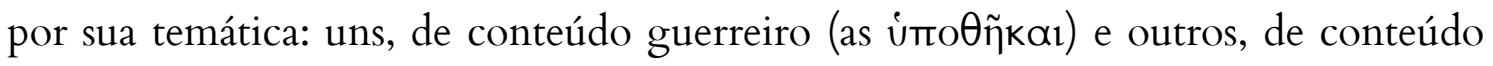

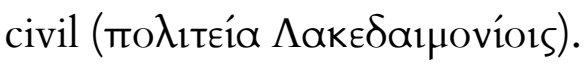

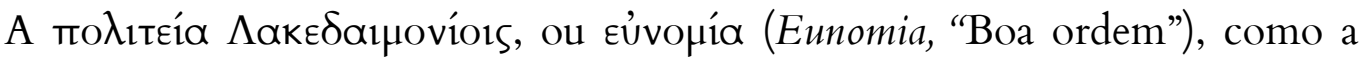
chamaram Aristóteles (Pol.1307a) e Estrabão (Str. 8.4.10), seria supostamente um poema narrativo que visava o festival público como ocasião de performance. Bowie (1986, p. 29 - 30) reconhece em alguns fragmentos tirtaicos elementos próprios da elegia narrativa pública, e é seguido pela grande maioria dos estudiosos que dedicaram páginas à poesia de Tirteu, como D’ Alessio (2009), Faraone (2008), Irwin (2005) e Stehle (1997). Teriam feito parte deste poema os fragmentos 1 a 4 e possivelmente os fragmentos 5 a $7 \mathrm{~W}$.

O fragmento $1 \mathrm{~W}$ é um testemunho da Política de Aristóteles que informa qual seria o tom da Eunomia: um poema admonitório, composto para conter os ânimos civis e assim evitar uma sedição em Esparta; o fragmento $2 \mathrm{~W}$ narraria o regresso dos descendentes de Heracles para a Lacedemônia; o fragmento $4 \mathrm{~W}$ oferece um oráculo que traria prescrições destinadas a todo o povo de Esparta; o fragmento $5 \mathrm{~W}$ colocaria ênfase na datação da guerra, e os fragmentos 6 e 7 W, em seus acontecimentos e resultados.

As Exortações (fr. 10, 11 e $12 \mathrm{~W}$ ) constituem a parte mais preservada da poesia de Tirteu. O vínculo com a tradição épica não se dá aqui apenas em nível formal (o hexâmetro dactílico que integra o dístico elegíaco), mas também em nível temático. São elegias que prescrevem um imaginário heroico que condena a fuga (como aioxpós, aiskhrós, "feia e vergonhosa", "torpe") e glorificam o guerreiro que

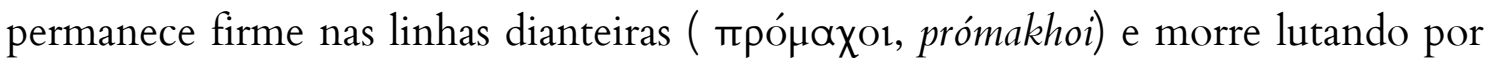
sua pátria, de modo mais ou menos similar ao figurado na tradição legada pela poesia épica, notadamente pela Ilíada.

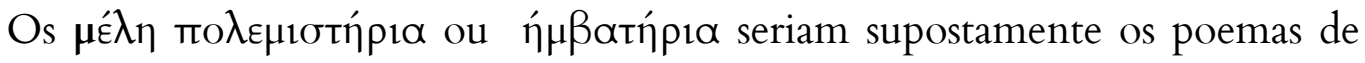
Tirteu compostos em verso anapéstico, hoje perdidos, mas mencionados por Ateneu (Banquete dos Eruditos XIV, 630), Pausânias (Descrição da Grécia, 4.15.6) e provavelmente Tucídides (História da Guerra do Peloponeso, 5.70). Pausânias registra 
a existência de poemas mélicos em metro anapéstico de Tirteu, e traça um paralelo entre eles e as composições elegíacas:

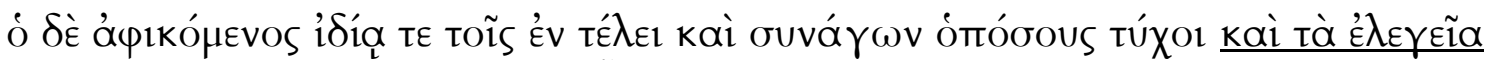

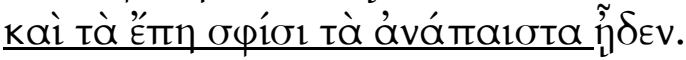

Quando ele (sc. Tirteu) chegou, cantou em particular para eles (sc. nobres) os seus versos elegíacos e anapésticos, e para quantos ele viesse a encontrar.

Ateneu, por sua vez, informa a tradição dos cantos de marcha na Lacedemônia, e nota que os cantos de Tirteu foram entoados nesse contexto para auxiliar a marcha dos combatentes:

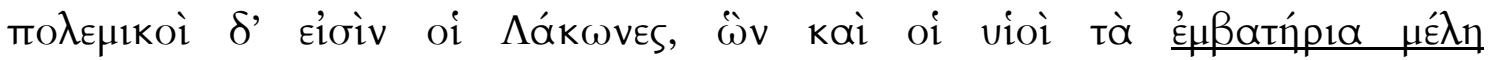

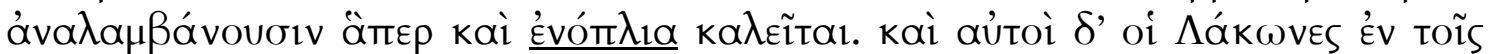

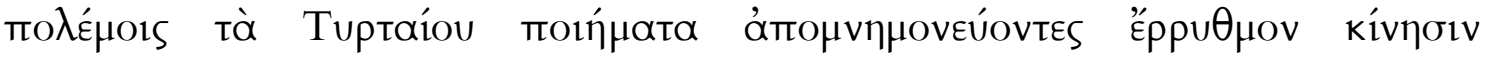
по10ũvtaı.

Os lacônios são belicosos, e até mesmo os seus filhos encarregam-se dos cantos de marcha, que são chamados precisamente de enóplios. Os próprios lacônios, recitando de cor os poemas de Tirteu nas guerras, fazem o seu movimento em ritmo.

Tucídides menciona essa mesma tradição em Esparta como mais um índice para a oposição que traça entre espartanos e atenienses. Contudo, o historiógrafo apenas cita o uso do aulo durante estas marchas, sem fazer referência ao nome de Tirteu:

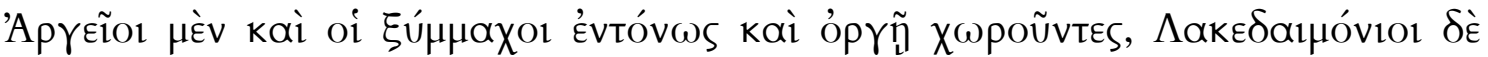

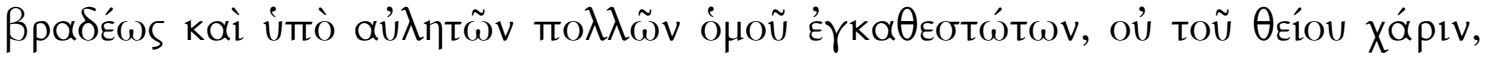

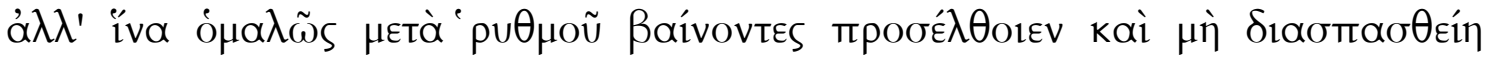
aỦToĩ

Ao passo que os argivos e seus aliados marchavam em fúria e energicamente, os lacedemônios marchavam lentamente e sob o som de diversos auletas, não por rito sacro, mas a fim de que procedessem uniformemente, caminhando com o ritmo, e as suas fileiras não se desalinhassem, o que é usual que grandes exércitos façam ao atacarem. 
Díon Crisóstomo (Oração 35, 10) refere-se a um દ̇ßßatípiov lacônico (PMG 856-857) e seu escoliasta o atribui a Tirteu. Embora considerado espúrio, o fragmento consta na edição de West (1992) como os fragmentos 15 e 16:

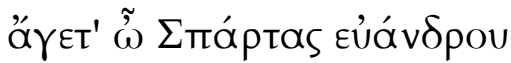

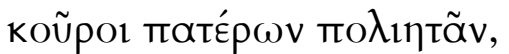

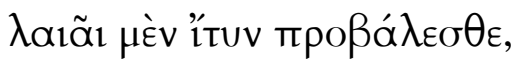

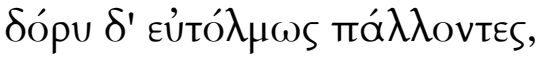

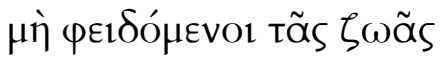

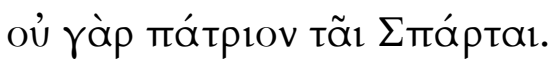

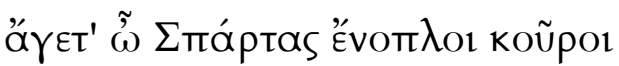

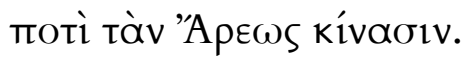

Vamos, valentes d' Esparta, moços de pais livres!

À esquerda, anteponde o escudo, e atirai a lança com coragem, não poupando a vida: esse não é o costume de Esparta.

Vamos, moços de Esparta em armas, para a marcha de Ares.

Hoje é comum considerar estes fragmentos como exemplos de poemas populares de Esparta, e a sua atribuição a Tirteu é incerta. Entretanto, as semelhanças com as elegias exortativas são inegáveis: note-se a menção aos koũpo1 (15.2W, 16.1 W), que ecoa o chamado aos véor no fragmento 10. $15 \mathrm{~W}$; o apelo para que se enfrente o inimigo portando escudo $(15.3 \mathrm{~W})$ é evocativo do fragmento

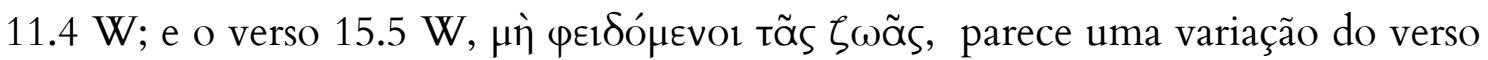

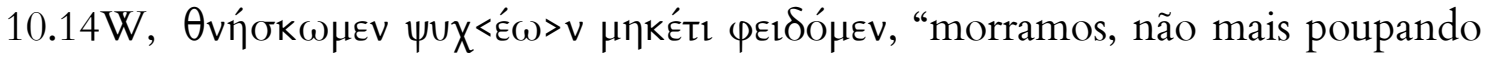
a vida”.

Outro fragmento na edição de West que não pertence a Tirteu é o $24 \mathrm{~W}$, proveniente de uma inscrição encontrada na cidade de Tirreu e provavelmente datada do final do século III a.C, período em que a região teria sido atacada pelos Etólios. Este fragmento cita Tirteu nominalmente, e sua autoria é atribuída ao epigramista helenístico Damágeto por Paul Friedländer, em “A new epigram of 
Damagetus" (1942, p. 71- 83), graças a similaridades vocabulares entre a inscrição e os epigramas desse autor da Antologia Grega.

De qualquer maneira, ainda que não constituam alguma citação direta a Tirteu, a inscrição demonstra a persistência de sua obra no período helenístico:

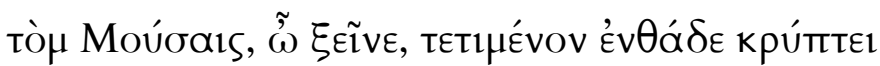

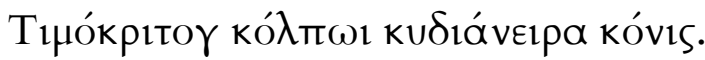

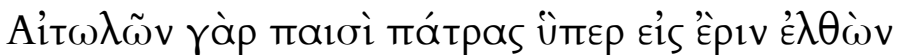

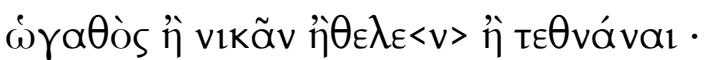

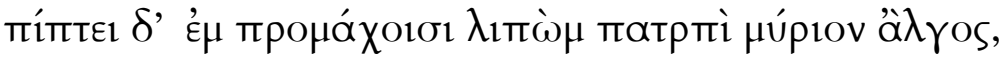

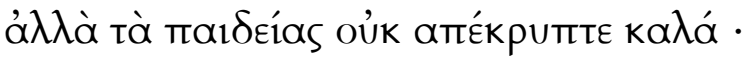

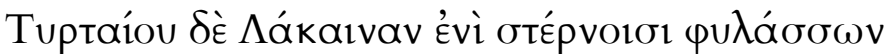

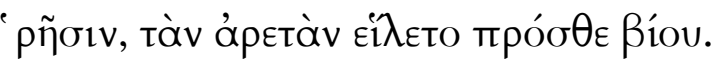

Estrangeiro, aqui a poeira glorificadora de homens eclipsa

em seu seio Timócrito, honrado pelas Musas.

Quando foi à luta pela pátria contra os filhos dos Etólios,

o valente escolheu: era vencer ou morrer.

Cai na vanguarda, abandonando o pai em dor infinita,

mas a bela educação não se eclipsou:

guardando no peito o lacônio verbo

de Tirteu, escolheu virtude em vez da vida.

Os fragmentos 8 e $9 \mathrm{~W}$ são testemunhos que também citam o nome de Tirteu. O fragmento $8 \mathrm{~W}$ tem como fonte a Geografia de Estrabão, e relata eventos das duas Guerras Messênicas. O testemunho informa que o próprio Tirteu teria mencionado que fora um general durante esta guerra, uma informação que poderia ter sido extraída de seus poemas (8.4.10): 


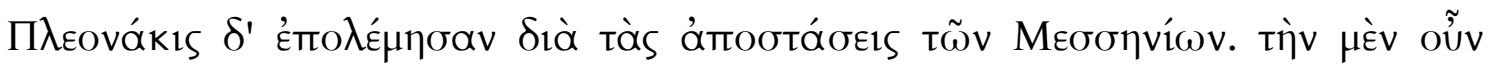

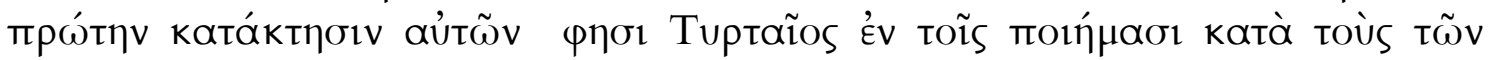

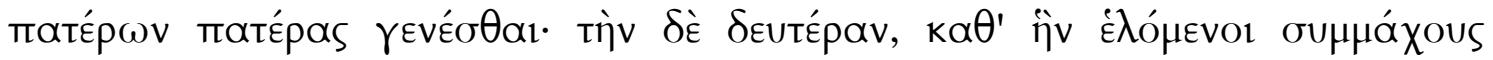

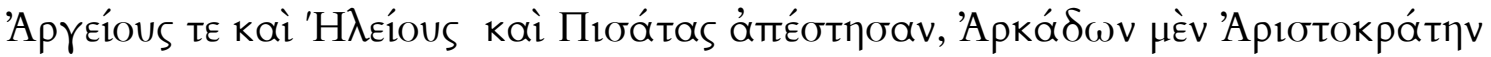

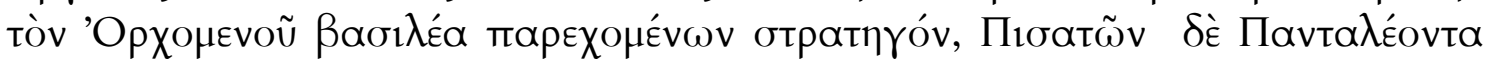

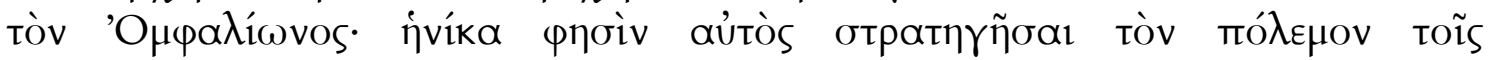
$\Lambda \alpha \kappa \varepsilon \delta \alpha \mu$ ovíois

Amiúde fizeram guerra por causa das insurreições dos Messênios. Tirteu diz em seus poemas que a primeira conquista deles ocorreu no tempo dos pais dos pais (Fr. 5.6.) A segunda, no tempo em que se revoltaram, tendo escolhido aliados Argivos, Eleios e Pisanos. Os árcades ofereceram Aristócrates, rei dos Orcômenos, como general e os Pisanos [ofereceram] Pantaleão de Onfalion, enquanto pelos espartanos [Tirteu] diz que ele próprio foi o general.

O fragmento 9 é uma citação da Ética a Nicômaco (1116 a), seguida por uma passagem dos Comentários a Aristóteles de Eustrácio (20, 165.1). Na Ética, Aristóteles define como belo e viril o comportamento dos homens que lutam na vanguarda do combate:

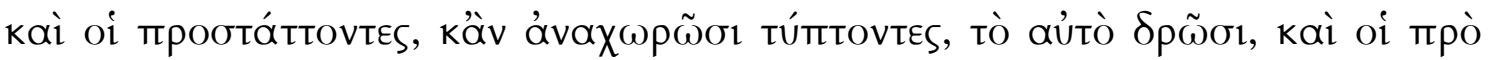

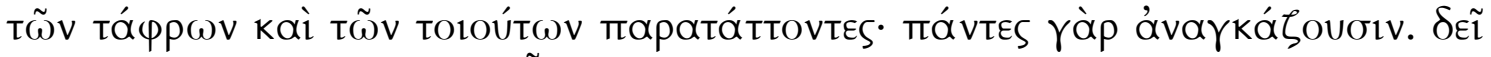

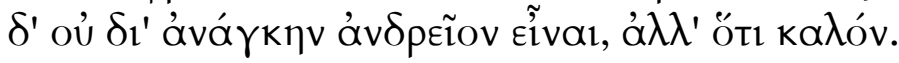

Aqueles que vão à frente e golpeiam os outros caso retrocedam, fazem o mesmo (e também aqueles que se põem diante de trincheiras e de outras coisas do tipo) porque são obrigados. Mas deve-se ser viril não por obrigação, e sim porque é belo.

Eustrácio exemplifica o comentário informando que tal era o comportamento dos espartanos durante a Guerra Messênica, conforme narram os poemas de Tirteu. Provavelmente o escoliasta tinha em mente poemas exortativos como 10, 11 e 12 W, que exploram como principal argumento a exortação para lutar nas primeiras linhas do combate:

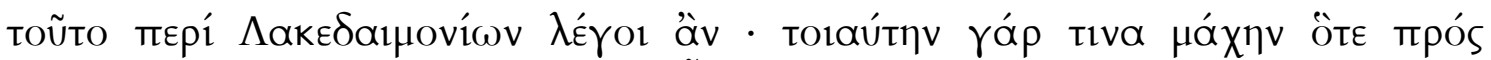

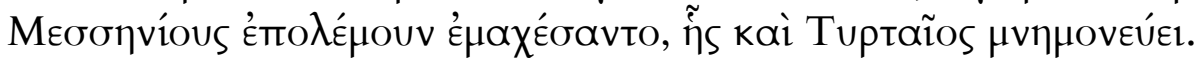


Poder-se-ia falar isso dos espartanos: Pois lutaram de tal modo quando travavam uma guerra contra os Messênios, aquela que Tirteu menciona.

O fragmento $13 \mathrm{~W}$ foi recolhido por Galeno em Sobre as Doutrinas de Hipócrates e Platão: ao tratar das doutrinas de Crisipo que sugerem a existência de duas faculdades da alma, racional e irracional, o autor apresenta um verso "estranho"

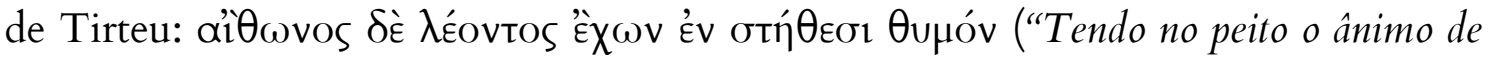
árdego leão").

O fragmento $14 \mathrm{~W}$ está presente nos Paradoxos Estoicos de Plutarco. O verso

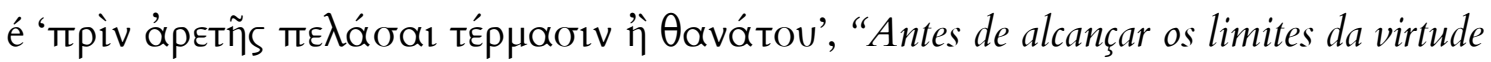
ou da morte". O metricista Querobosco é quem registra o fragmento $17 \mathrm{~W}$ para mostrar uma peculiaridade métrica de Tirteu: em um verso hexamétrico em que

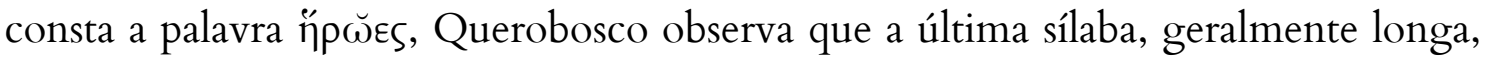
é escandida como breve.

Por fim, restam os fragmentos $18-23 \mathrm{~W}$ e 23 a W que diferentemente dos demais fragmentos que compõem o corpus de elegias tirtaicas, provêm de fontes de transmissão direta. Os fragmentos $18-23 \mathrm{~W}$ pertencem a um papiro oriundo do período ptolomaico, de meados do século III a.C, que apresenta duas colunas de texto (West, 1974, p.187). A edição de West distingue seis fragmentos nas duas colunas, que não necessariamente pertenciam a um mesmo poema. A primeira coluna, praticamente ilegível, compõe os fragmentos classificados como 18, 20 e $22 \mathrm{~W}$. Integram a segunda coluna os fragmentos 19, 21 e $23 \mathrm{~W}$.

O fragmento 23 a W corresponde ao Papiro de Oxirrinco 3316, descoberto em 1980. Data provavelmente do século III a.C., e seria uma elegia exortativa com referências a um momento particular da Segunda Guerra da Messênia, a aliança entre Argivos e Arcádios já mencionada no fragmento $8 \mathrm{~W}$. 


\section{A Fortuna Crítica de Tirteu}

As primeiras hipóteses modernas acerca da poesia de Tirteu datam do século XIX, e se embebem do espírito que caracterizou a obra magna de Friedrich Wolf, Prolegomena ad Homerum (1795). Ao propor que Homero teria composto oralmente rapsódias que seriam reunidas apenas no século VI a.C. como um canto uno, Wolf deu origem à linha de estudos que seria denominada analítica. Esta escola, por muito tempo vigente, propôs a existência de um núcleo principal original nas epopeias homéricas que teria sido tardiamente preenchido por interpolações e camadas que quebram ou se somam à continuidade narrativa do núcleo original.

O ceticismo a respeito da unidade da poesia homérica estendeu-se a outros autores do período arcaico, e dentre estes Tirteu - gerando o que alguns chamaram, analogamente, de "Questão Tirtaica" ${ }^{40}$. De fato, em 1816, Francke (apud Prato, 1968, p.08) preconizaria, à maneira dos estudos analíticos, que Tirteu fizera uma longa elegia de cunho patriótico, que sofrera séries de intervenções ao longo dos séculos e teria sido desmembrada no que hoje são os fragmentos 10 e $11 \mathrm{~W}$. O fragmento $12 \mathrm{~W}$ e a Eunomia (fr. 1 - $4 \mathrm{~W})^{41}$ seriam também composições autênticas.

Em 1826, Thiersch (apud Prato, 1968, p.08) tencionou demonstrar que a poesia de Tirteu era espúria e o poeta nunca existira: segundo o autor, os fragmentos de sua obra seriam composições que acompanhavam diferentes etapas da Segunda Guerra da Messênia e fruto de diversos autores: era a visão romântica de um "anônimo gênio espartano".

Foi Bach, em 1831, que encerrou a questão ao argumentar não ser lícito comparar Homero com uma figura historicamente comprovada pela tradição como Tirteu. Apenas no fim do século a historicidade da poesia de Tirteu volta a ser duramente questionada, com base na tradição da própria Guerra Messênia. A. W. Verrall, em seu artigo de 1896 "Tyrtaeus and Graeco-roman tradition” (pp.269-277)

\footnotetext{
${ }^{40}$ Ver, por exemplo, Hugh Parry na resenha a Carlo Prato, Tirteo (1970, p. 498).

${ }^{41}$ Tratadas na época como uma coletânea de poemas cívicos (Ver Prato, C., 1968, p.09).
} 
acreditava ser a poesia de Tirteu e sua figura uma hábil composição ateniense, datada de tempos de uma hipotética terceira rebelião da Messênia. Calcado em uma citação do orador Licurgo ${ }^{42}$ e na escassez de fontes sobre as antigas Guerras Messênias (apenas um relato romanceado de Pausânias ${ }^{43}$ ) Verrall afirmou que, se o poeta tivesse existido, seria após as Guerras Pérsicas, duzentos anos depois da data normalmente atribuída a ele.

Schwartz publica, três anos depois no artigo "Tyrtaeos" (1899, pp.429-468), uma proposta ainda mais radical: ele defende que as Guerras Messênias jamais teriam existido. O exagero das fontes helenísticas que trataram destas guerras - o poeta épico Riano de Creta e o historiógrafo Míron de Priene - e a sua data tardia impediam uma apreensão clara de sua historicidade, e, portanto, também da historicidade de Tirteu, cuja poesia estaria intrinsecamente ligada a estas guerras. Para comprovar que Tirteu era uma construção ateniense do séc. V, Schwartz já apresentava hipóteses que seriam retomadas por Fränkel no século seguinte, como a presença da argumentação silogística no fragmento $12 \mathrm{~W}$, típica dos oradores do quinto século, e não do período arcaico em que o poeta teria vivido.

Wilamowitz (apud Jäger, 1966, p. 105) foi quem por fim argumentou contra essas teses, assumindo tanto a autenticidade das Guerras Messênias como a historicidade de Tirteu. O filólogo alemão entende, contudo, que alguns poemas de Tirteu, como o $11 \mathrm{~W}$, sofreram intervenções pontuais de outros poetas, do mesmo modo que ocorrera com a poesia de Teógnis, cuja fama como poeta moralista fizera com que muitos poemas com este teor fossem acrescentados à sua coleção. Depois deste estudo, a poesia de Tirteu passa a interessar também aos historiadores, que, seguindo à autoridade e peso do estudo de Wilamowitz, passam a ver em seus fragmentos a única testemunha crível da Guerra Messênia, das técnicas de combate desempenhadas em seu decurso e, especialmente, uma valiosa fonte para a história do desenvolvimento da pólis arcaica e da história espartana.

\footnotetext{
${ }^{42}$ Contra Leocrates, 106 ss.

${ }^{43}$ Descrição da Grécia, 4. 4 - 29
} 


\section{Homero e Tirteu}

Quando se observa a Ilíada em conjunto com o que restou da obra poética de Tirteu, certas comparações são inevitáveis. É uma tarefa difícil encontrar algum verso, dístico, vocábulo ou epíteto que não pareça evocar algum trecho da poesia homérica. Na Antiguidade latina, este vínculo já não era ignorado, sendo notória a passagem de Horácio em sua Arte Poética ${ }^{44}$. Desde então, o aspecto que reúne ambos os poetas é a exortação militar (Arte Poética, 402-3: "mares animus in martia bella/versibus exacuit"), com uma evidente superioridade técnica do poeta épico assinalada. ${ }^{45}$

Nos dias atuais, esta relação foi diversamente analisada, mas sempre colocou Tirteu como dependente direto do substrato homérico; a opinião de Carlo Prato, em sua edição dos fragmentos de Tirteu, resume o juízo prevalecente ao afirmar que "O método de trabalho de Tirteu é extremamente simples e claro; consiste da combinação de vocábulos e expressões derivadas do épos, em um esforço contínuo de modernização do velho formulário e de adaptação às exigências de sua arte" $(1968$, p.50*). Imbricada na afirmação de Prato, podemos entrever a tese que dominou meados do século XX e se convencionou chamar de "Escola Snell Fränkel”.

Talvez a obra mais influente nesse sentido tenha sido a de Bruno Snell, Tyrtaios und die sprache des epos (1969). As teses de Snell-Fränkel escoram-se em uma percepção evolutiva dos gêneros, que apresenta épica, lírica e drama em sucessão cronológica. Deste modo, a elegia exortativa marcial seria vista como a ponte entre Homero e a literatura do período clássico. Esta sucessão entre os gêneros seria, para Snell, o reflexo de uma importante etapa do desenvolvimento do espírito

\footnotetext{
${ }^{44}$ vv. 401ss: "[...]post hos insignis Homerus/ Tyrtaeusque mares animos in Martia bella/ versibus exacuit" ("Depois disso o insigne Homero/ e Tirteu, que às guerras de Marte os ânimos viris/ com versos incitaram") Ver Quint. Inst. X. 32 ("Quid? Horatius frustra Tyrtaeum Homero subiungit?"; Quê? Horácio erra ao justapor Tirteu e Homero?")

${ }^{45}$ Ver Quint. Inst. XII. 11, 27: neque enim, si quis Achillis gloriam in bellicis consequi non potest, Aiacis aut Diomedis laudem aspernabitur, nec qui Homeri non fuerunt, Tyrtaei. (e ainda, se algum homem não pode alcançar a glória de Aquiles na guerra, não desdenhará de elogio [como o] de Ajax ou Diomedes; e nem, os que não foram Homeros, [não desdenharão de serem] Tirteus")
} 
humano: a emergência da individualidade em um mundo eminentemente impessoal.

Nesse contexto, Tirteu surge como um poeta que, embora usuário do repositório épico, inova em relação a ele em três aspectos: (a) nos sentidos de termos que denotam os órgãos anímicos do homem, especialmente o Oupós (thumós, "ânimo") Conforme sua tese, esmiuçada em A Descoberta do Espírito, o Oupós consistiria em um órgão que repousa no peito à espera de um estímulo externo. Nesse caso é que Tirteu se distinguiria de Homero, pois em seus versos o $\theta$ urós é um órgão

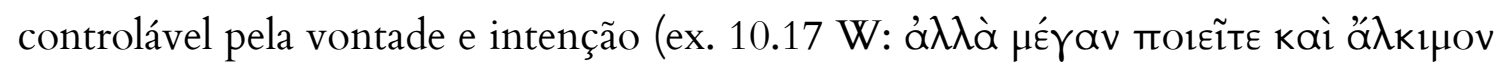

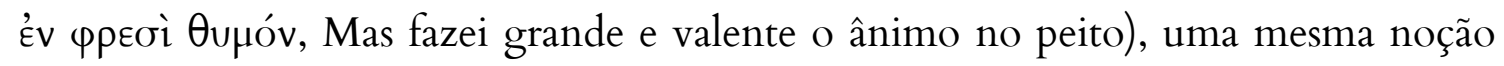
que já estaria presente em alguns fragmentos de Safo (Ver fr.1 V) e Arquíloco (Ver fr.128 W). Não é escopo do presente trabalho deter-se nessa questão; diversos estudiosos já se debruçaram sobre isso, mostrando que Homero entendia o $\theta$ upós de maneira não muito distinta de Tirteu e outros líricos (Ver Corrêa, 2009, p.33-40); (b) No tratamento da ápєtí (areté), a virtude ou excelência humana. Snell é adepto das proposições de Werner Jäger, descritas em "Tyrtaeus on True Arete” (1966, p. 103 - 142). Enquanto na poesia de Homero encontramos diversas atividades que são consideradas ápєtaí, no fragmento $12 \mathrm{~W}$ Tirteu consideraria apenas uma única e verdadeira excelência, a bravura impetuosa ( $\theta$ oũpıs à $\lambda_{k}$, thoúris alké) que faz com que o soldado se mantenha em seu posto sem fugir.

Tal leitura se deve a uma interpretação, a nosso ver, equivocada do verso 13 ,

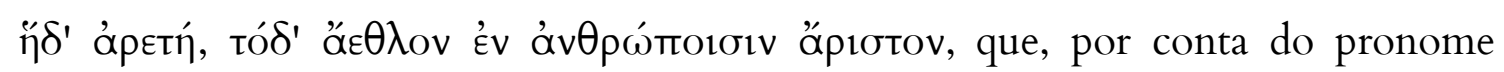

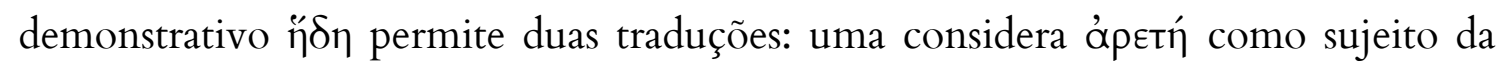
oração e tem $\dddot{\delta} \delta \eta$ como predicado; "Essa [é] a virtude, esse [é] o prêmio, entre homens o melhor" ${ }^{46}$ A outra possibilidade é considerar todo o sintagma $\dddot{\eta} \delta \delta^{\prime}$ ápetí como

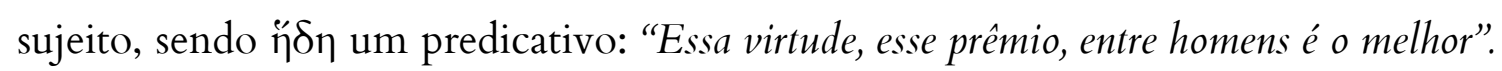
Snell opta pela primeira tradução. Um dos argumentos em seu favor é que o

\footnotetext{
${ }^{46}$ Ver, por exemplo, a tradução de Prato (1968, p. 130): "Questa (è) la (vera) areté" e a tradução portuguesa de Artur Parreira, sobre Jäger, Paideia, p.122: "Isto é arete, este é o título mais alto e mais glorioso..."
} 
paralelismo entre os pronomes $\dddot{\delta} \delta \eta$ e tó $\delta \varepsilon$ na frase sugere que ambas poderiam ser traduzidas da mesma maneira. ${ }^{47}$

Entretanto, o contexto favorece a segunda possibilidade. No verso 2,

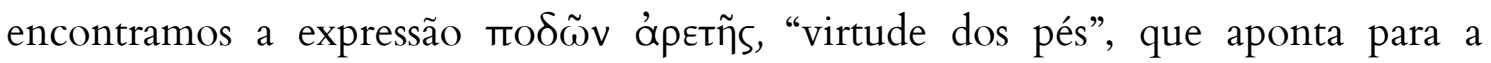
existência de outras que Tirteu rejeita na sua elegia em nome da bravura impetuosa.

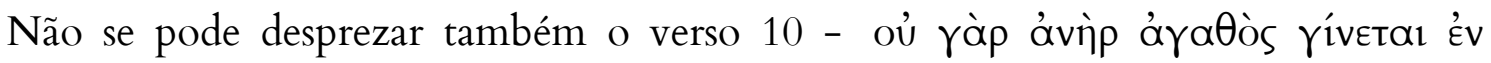
$\pi о \lambda \varepsilon ́ \mu \omega \imath$ ("pois um varão não se torna valoroso na guerra") - onde o adjunto દ́v

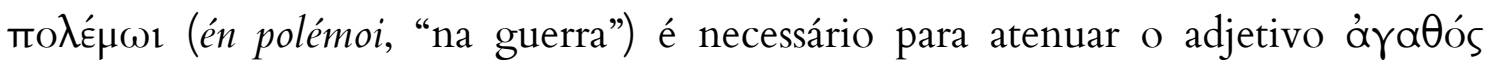
(ágathós, "bom, valente, valoroso") e ainda é jogado para o fim do verso, um expediente comum na poesia grega arcaica e frequentemente empregado por Tirteu para realçar algum vocábulo ou expressão.

Considerando essas hipóteses, não haveria motivos para acreditar que Tirteu oferece a visão de uma ápєtí diferente daquela apresentada por Homero. O fato é que a tese de uma ópєtí absoluta incorre na terceira e última inovação vista por Snell na poesia de Tirteu: (c) a noção de patriotismo. Segundo esse estudioso, enquanto Homero não retrata o patriotismo e apenas mostra os guerreiros em defesa de seu próprio círculo familiar, Tirteu, nas palavras de Jäger, "transformou o ideal homérico da ápєtń do campeão singular na ápєtń do patriota” (1966, p. 103); “o ideal homérico da ópetí heroica transforma-se no heroísmo do amor a pátria” $\left(1995^{\star}\right.$, p.120).

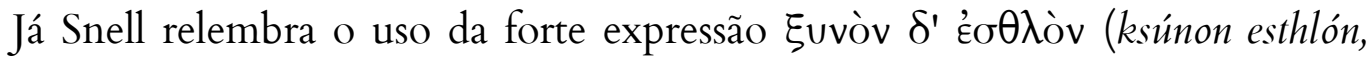
"bem comum", 12.15 W), para concluir que, na elegia exortativa, o valor marcial estaria fortemente atrelado ao bem da comunidade - a terra pátria (matpís, patrís,

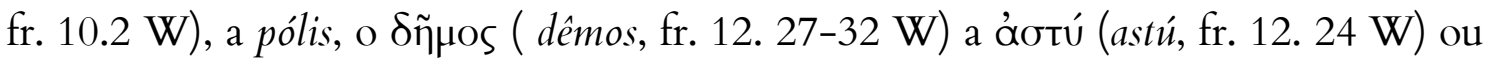

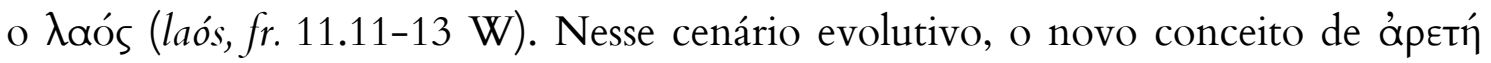
heroica da pólis advém, segundo Jäger, da adaptação da ideia de glória heroica para o ambiente da pólis. Agora é a cidade que mantém o k $\lambda$ Éos (kléos, "glória") outrora individual: é ela que confere a imortalidade que subtrai o homem da transitoriedade de sua condição humana e o insere e preserva no espaço duradouro da comunidade,

\footnotetext{
${ }^{47}$ Ver análise ao Fr.12 W, pp.113-146.
} 
além de ser glorificada pelo sacrifício do herói. Esta última tese, porém, não parece se sustentar à leitura de algumas passagens da Ilíada.

O que se nota é que conceitos de defesa da família e patriotismo são colocados em um mesmo plano, e muitas vezes são equacionados ${ }^{48}$, mas as proporções com que aparecem dependem da necessidade e do contexto narrativo exigidos em cada passagem, e de conformações que são próprias de cada gênero.

$\mathrm{Na}$ Ilíada, são os troianos que estão em posição equivalente à dos interlocutores de Tirteu, e por isso, vemos amiúde heróis como Heitor e Glauco exortarem os seus camaradas a defenderem a pátria. Heitor exorta Polidamante, "Apenas um augúrio tem valor! Lutar pela pátria” (Il.12.243); Glauco, por sua vez, reprova os troianos com as palavras $(17.156-159)$ :

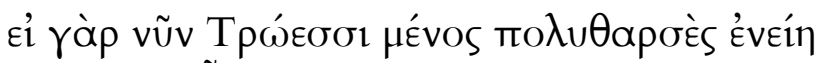

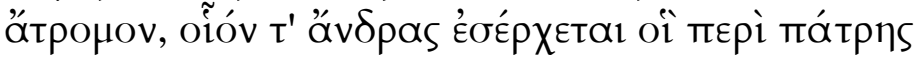

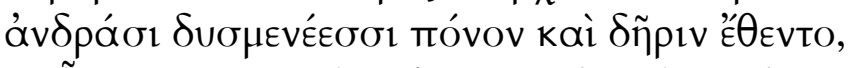

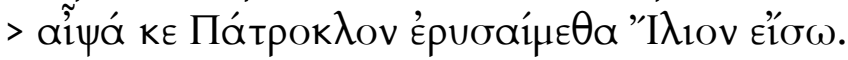

Ah, se agora entre os Trôas houvesse uma força muito audaz, imperturbável, do tipo que advém aos homens que pela pátria impõem o combate e a labuta contra homens inimigos, na hora arrastaríamos Pátroclo p'ra dentro de Ilíon!

O próprio Heitor é visto por outros seus compatriotas como o bastião troiano, sua queda como que significando a queda da própria cidade; é nesses termos que Príamo se expressa (Il.24.499-501) e esse é o motivo do nome do filho de Heitor, Astíanax $(I l .6 .403)^{49}$. Embora menos comum, a preocupação com o גaós também aparece entre os heróis do lado grego: não é visando o bem comum do

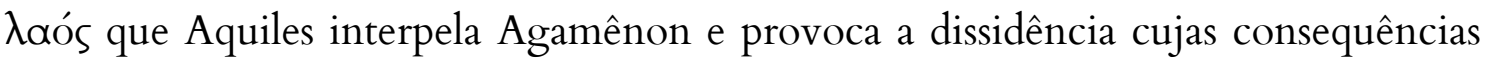
nortearão toda a primeira metade da trama da Ilíada?

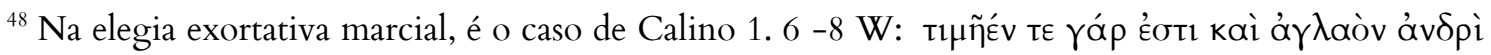

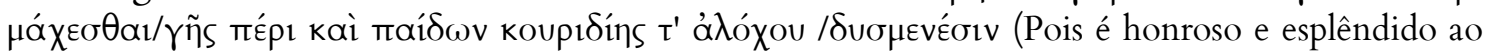
varão lutar/ pela terra, filhos e esposa legítima/ contra os inimigos)

${ }^{49}$ Ver Greenhalgh, 1972, "Patriotism in the Homeric World”, pp.528 - 537.
} 
Em seu recente comentário à Ilíada, The Making of Iliad, Disquisition and Analytical Commentary, Martin L. West considera que "Homero" seria um poeta letrado da metade do século VII a.C (aproximadamente 680-640 a.C.), e que a Ilíada fora o resultado de um longo período de elaboração que contou com a ajuda da escrita. Nesse processo, o poeta acrescentava a um núcleo original novos cantos e episódios, além de trechos reelaborados, que poderiam ou não ser influência de outros poetas e tradições do período.

Nesse cenário proposto por ele, Homero situa-se no mesmo século e na mesma época em que certamente os dois poetas de elegias bélicas que nos restaram já estavam em plena atividade (Calino, aproximadamente 650 a.C; Tirteu, por volta de 640 a.C.), embora certamente não fossem os primeiros, visto que a distância geográfica que separa ambos - Calino na Jônia, e Tirteu em Esparta - indica que a esta época a elegia marcial já estava bem propagada na Grécia.

O postulado de West não é novo, e retoma, em suma, antigos estudos analíticos. No que concerne a relação entre Homero e os elegistas marciais, West parece reavaliar as teorias de Von Dietrich Mülder, filólogo alemão do início do século XX, que em seu trabalho Homer und die altonionische Elegie (1906) havia sido o primeiro a sugerir a precedência dos poetas elegíacos jônicos em relação a Homero.

O autor justificava a sua hipótese ao verificar que, na composição geral do poema - preparações para a batalha, advertências de Nestor e outros - tudo está de acordo com a época de Tirteu, isto é, com a própria época do poeta que compôs a Ilíada; mas, nas cenas de batalha, o poeta remete aos tempos heroicos, descrevendo os combates de campeões singulares como na tradição épica. Um argumento de Mülder que parece ter se tornado pelo menos questionável nos dias atuais é a ideia de que a representação da guerra na Ilíada difere em larga medida daquela representada por Tirteu. Se na elegia marcial não há o retrato do herói singular,

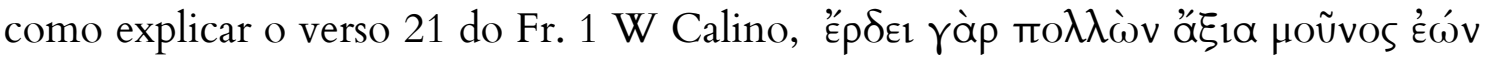
("embora só, faz feitos dignos de muitos"), que poderia muito bem aludir a um guerreiro de investidura tipicamente épica? E o que dizer do fragmento $12 \mathrm{~W}$ de 
Tirteu, que não se detém na descrição de um grupo de soldados, firmemente posicionados em seus lugares, mas em vez disso concentra-se em um único

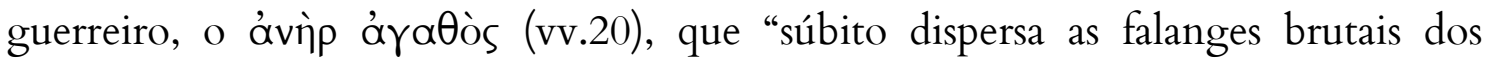
inimigos" (v.21) e "rápido detém o fluxo da guerra" (vv.22) $)^{50}$ ?

O que parece mais plausível é considerar que Homero e Tirteu retratam um mesmo universo guerreiro, com mudanças que se devem à estrutura e à função de cada poema.

\section{Poéticas de Guerra}

Nos capítulos seguintes pretende-se analisar os fragmentos e os testemunhos acerca das elegias exortativas de Tirteu (Fr. 10-12 W) e o poema intitulado Eunomia (Fr. $1-4 \mathrm{~W})$, assim como de outros fragmentos que poderiam ser incluídos sob este nome (Fr. $5-7 \mathrm{~W})$.

O cerne da questão está no debate da ocasião de performance para a qual estes versos teriam sido compostos. Seguindo a hipótese influente de Bowie (1986, pp.29-33) hoje é possível alocar o corpus elegíaco em duas circunstâncias distintas com base na extensão de cada poema: uma particular, voltada para as heterias aristocráticas do simpósio, e outra pública, com longas elegias narrativas direcionadas aos festivais cívico-religiosos.

Quanto ao primeiro grupo, a atribuição do simpósio como circunstância de performance ideal para as elegias de Tirteu suscita novas reflexões sobre o estatuto e as funções da poesia de Tirteu: qual é o sentido da confluência de temas da elegia exortativa militar e da tradição épica no contexto do simpósio? O vínculo intertextual entre ambas as tradições pode ser relacionado às discussões acerca do gênero elegíaco, conforme praticado na Grécia do século VII a.C. ? Elizabeth Irwin

\footnotetext{
${ }^{50}$ Vale indicar, contudo, que no tempo em que Mülder escreveu sua obra o debate sobre a autenticidade do poema $12 \mathrm{~W}$ (e mesmo sobre a autenticidade do próprio Tirteu!) era intenso. Wilamowitz (1900, apud Luginbill 2002) julgava-o espúrio por seu estilo destoante das demais. Depois de Jäger, em 1960, poucos helenistas se aventuraram a negar a autoria de Tirteu para o poema (Ver Tarditi, G. Parenesi e Arete nel corpus tirtaico, 1982).
} 
em Solon and Early Greek Poetry, the Politics of Exhortation (2005, pp. 35-62) encontra o elo entre a ocasião de performance da elegia marcial e a poesia épica nas cenas de banquete da Ilíada, nas quais são revelados os privilégios e as honras dos heróis. A elegia marcial, sendo apresentada no simpósio, poderia aludir implicitamente a estes banquetes militares e assim identificar sua audiência simposiasta a heróis de estatura épica. Como resultado, a elegia forma e justifica a identidade deste grupo social - exclusivamente aristocrático - diante da polis.

A partir desta perspectiva, a análise dos fragmentos 10-12 W assume dois pressupostos correlatos: (1) O simpósio aristocrático é a ocasião de performance original da elegia exortativa marcial. Este simpósio poderia apresentar em sua forma peculiaridades que são típicas da região de Esparta ou de um contexto militar específico, mas não difere funcionalmente dos simpósios de outras poleis gregas. Por conseguinte, (2): a linguagem da elegia grega arcaica veiculada em espaço simpótico exibe um componente aristocrático. Nas exortações marciais de Tirteu este componente revela-se como a atribuição e ficcionalização de papeis heroicos, expediente que elabora, face ao universo da polis, uma identidade destacada para a aristocracia.

Quanto à Eunomia, acreditou-se por muito tempo que fosse um poema narrativo destinado à comunidade e entoado apenas no espaço do festival público. Sua temática civil favorece essa hipótese - o poema trataria possivelmente da colonização da região do Peloponeso (Fr. 2 W), da revolta que acometeu Esparta com o término da Segunda Guerra da Messênia e do primeiro conflito contra os Messênios (Fr. 5-7 W). Wolfgang Rösler em "Mnemosyne in the Symposion" (1990, p. 233-234) revisitou a evidência e verificou pontos de contato entre estes poemas e o ambiente do simpósio, sendo seguido por uma revisão de Bowie sobre a sua hipótese (2001, p. 45-47) no que concerne à Eunomia. Atualmente a discussão permanece em aberto, sobretudo por causa da escassez dos fragmentos que restaram. Stehle em Performance and Gender in Ancient Greece (1997, p.51) considera-a um exemplar de poesia da comunidade, enquanto D'Alessio em "Defining Local Identities in Greek Lyric Poetry" (2009, p. 151) chama-a de "elegia coral" e 
identifica, não só neste poema, mas em todo o corpus tirtaico, uma ideologia comunal adequada às sussitia, reuniões espartanas afins aos simpósios de outras póleis.

Ao longo deste estudo, em vez de conjeturar uma ocasião de performance definitiva para cada poema, pretende-se ter como horizonte os seguintes questionamentos: Há marcas textuais que distinguem uma poética circunscrita aos eventos públicos e outra, própria do ambiente simpótico? Se sim, haveria pontos de contato entre elas? Pode-se dizer que as elegias de Tirteu revelam tais marcas? 
I. As Elegias Exortativas e o Simpósio 


\section{Capítulo 1}

\section{O fragmento $10 \mathrm{~W}$ e a exortação marcial}

Deve-se a sobrevivência do fragmento $10 \mathrm{~W}$ (6-7 G-P) ao ateniense Licurgo, que o introduz em sua obra katà $\Lambda \varepsilon \omega$ kpátous (katá Leokrátous, "Contra Leócrates") No discurso, composto no ano de 330 a.C., o orador acusa certo Leócrates de traição à cidade de Atenas por este ter se dirigido a Rodes, violando um decreto ateniense que proibira seus cidadãos de abandonarem a cidade após a Batalha de Queroneia. Notório pela grande quantidade de citações a poetas e relatos históricos, o opúsculo detém-se em exemplos de vívido patriotismo e em certo momento ocupa-se da figura de Tirteu. Segundo ele, a Atenas de seus ancestrais era tão valorosa que até mesmo os reis de Esparta, célebres por sua bravura, acataram o oráculo que lhes prescrevera obter um líder ateniense $(\mathbb{S} 105-106)^{51}$. O fragmento de Tirteu é citado nesse contexto, como exemplo de poesia - único tipo apreciado em Esparta, segundo Licurgo - capaz de mover os ânimos dos guerreiros espartanos e fazê-los desejar morrer por sua pátria $(\mathbb{S} 107)^{52}$ :

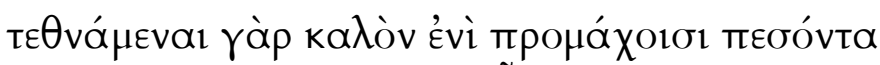

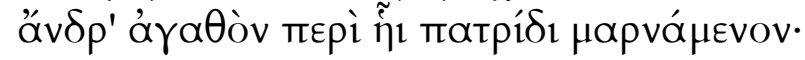

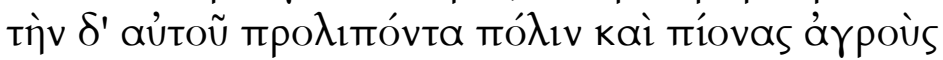

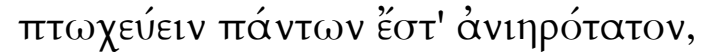

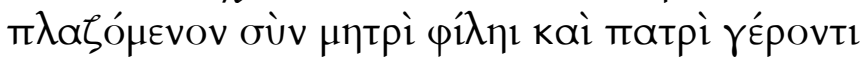

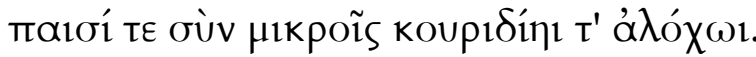

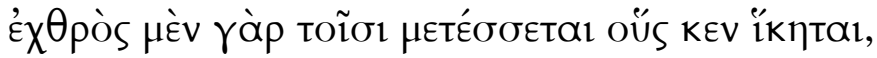

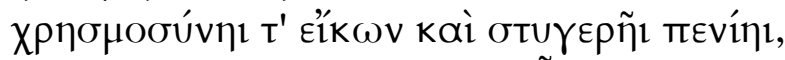

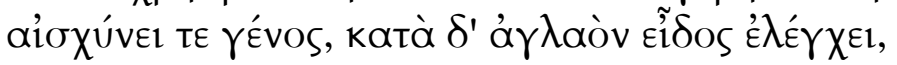

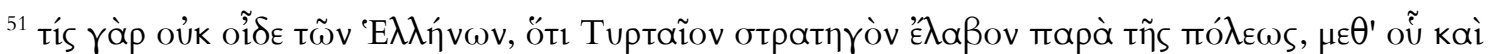

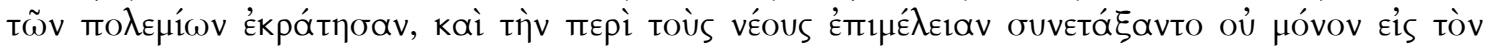

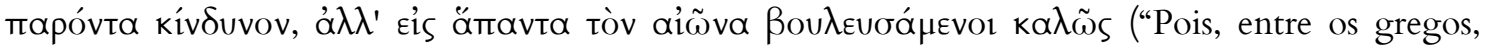
quem não sabe que [os espartanos] tomaram Tirteu como general para a sua cidade? Por meio dele, inclusive, venceram a guerra e também organizaram uma educação para os jovens, não somente para a ameaça presente, mas bem a planejaram para todo o sempre").

${ }^{52}$ Ver a Introdução, "Tirteu e a Elegia Grega Arcaica" para citação, tradução e uma consideração desta fonte no que tange à ocasião de performance da elegia grega arcaica.
} 


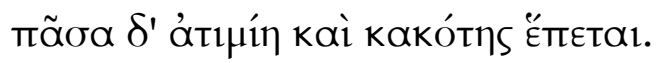

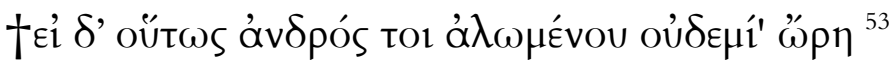

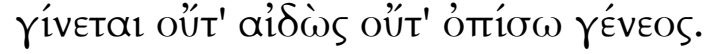

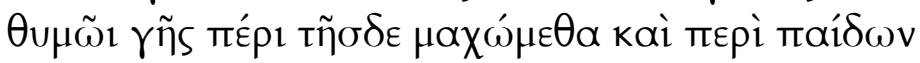

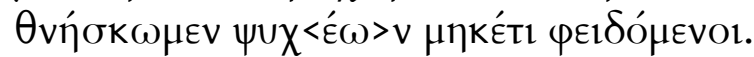

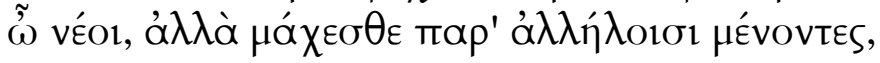

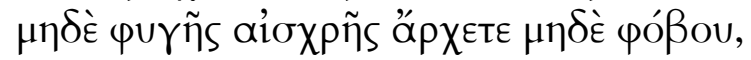

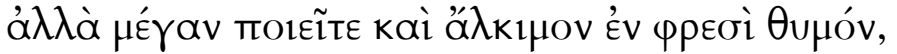

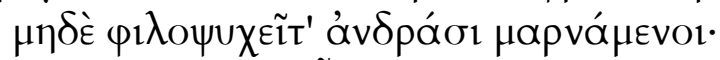

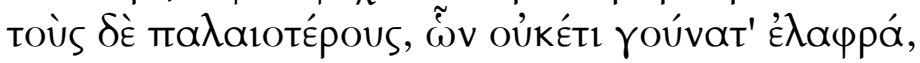

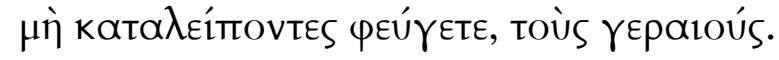

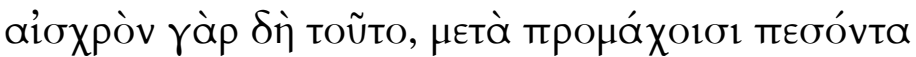

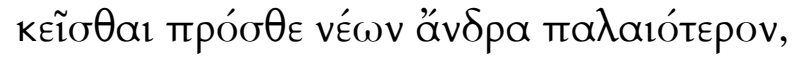

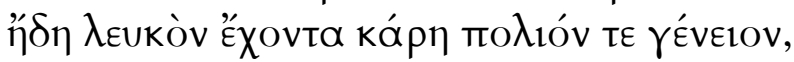

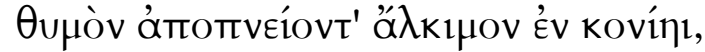

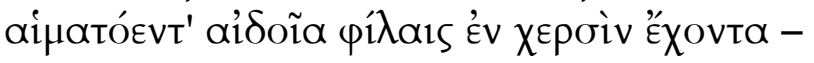

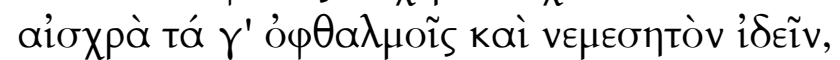

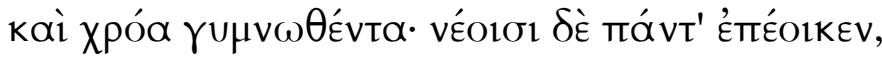

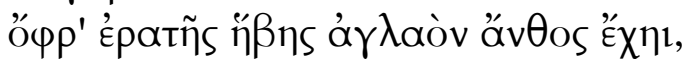

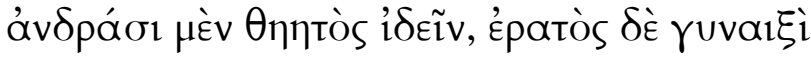

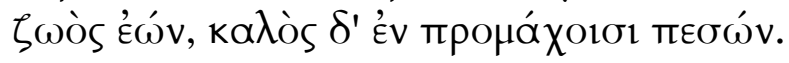

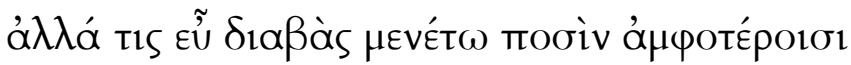

бтпрıхӨ

Belo, sim, é morrer, na vanguarda caindo

um varão valoroso em luta pela pátria.

Mas mendigar, deixando sua cidade e férteis

campos, de tudo é o mais penoso,

vagando com a cara mãe e o velho pai,

filhos pequenos e esposa legítima.

Será odioso entre aqueles a quem chegar,

pois cede à carência e à pobreza horrível,

envergonha a linhagem, vexa a forma esplêndida

${ }^{53}$ Neste verso, adotamos a correção proposta por Francke (1816). 
e toda a desonra e vileza o seguem.

Se é assim, se ao varão errante não vêm préstimo ou respeito algum, nem à descendência, com ânimo, por esta terra lutemos, e pelos filhos morramos, não mais poupando a vida! Ó jovens, eia, lutai, mantendo-se lado a lado, não inicieis a torpe fuga ou o pavor mas fazei grande e valente o ânimo no peito; não amai a vida, em luta com varões ! E não fujais, aos mais velhos abandonando, aos anciãos, que não têm mais joelhos ágeis.

Pois, sim, isto é torpe: na vanguarda caindo, jazer ante aos jovens um varão mais velho, já de cabeça branca e barba grisalha, expirando o valente fôlego na poeira, os ensanguentados genitais nas próprias mãos que espetáculo torpe, que visão revoltante! e o corpo despido: Mas tudo convém aos jovens enquanto tiverem a flor brilhante da linda juventude: é admirado por homens, por mulheres amado, quando vivo; e belo, se na vanguarda cai.

Mas que cada um fique bem firme, ambos os pés fixos ao chão, mordendo os lábios com os dentes! 
Há uma divergência quanto à composição dessa elegia. Embora os 32 versos do poema sejam citados por Licurgo de maneira contínua, como se fossem um só poema, a tese mais difundida entre os estudiosos é de que se trata de duas elegias distintas justapostas: a primeira, do verso 1 ao 14, e a segunda, do verso 15 ao 32 . O texto de Licurgo em nada auxilia a dirimir esta questão, uma vez que ele denomina os versos de Tirteu apenas como é $\lambda \varepsilon \gamma \varepsilon \tilde{\imath} \alpha$, “dísticos elegíacos”, podendo eles pertencerem a um único poema ou diversos.

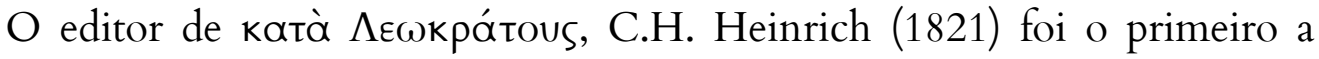
aventar a hipótese da elegia separada, sendo seguido por Wilamowitz (1900) e por alentada análise de F. Jacoby (1921, apud Prato, 1968, p.82).

Wilamowitz questiona a autenticidade dos versos 15-32, uma vez que a palavra (1900, p.111 apud De Falco e Coimbra, 1941, p. 165) ${ }^{54}$. O erudito também lança suspeitas sobre os versos 1-14, que, segundo ele, descrevem uma guerra defensiva contrária à situação dos Espartanos durante a Guerra Messênia.

O argumento de Jacoby para a cisão está em uma possível mudança de interlocutores: enquanto nos primeiros versos predomina uma exortação na qual o próprio poeta se associa aos demais, como demonstram os subjuntivos exortativos

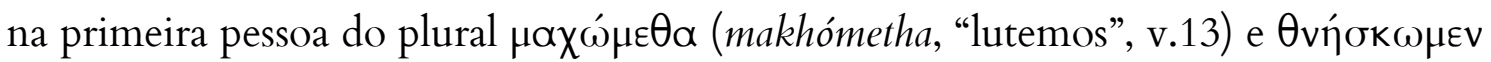
(thnéskhomen, "morramos", v.14), a partir do verso 15 o poeta se afasta e o

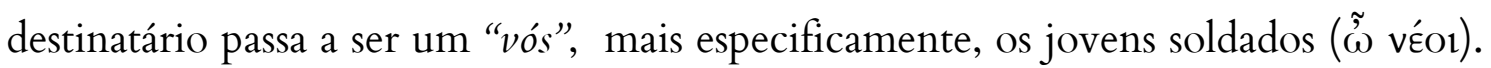
O uso de verbos na segunda pessoa do plural, como, por exemplo, $\mu a ́ \chi \chi \varepsilon \sigma \theta \varepsilon$ (mákhesthe, "lutai”, v.15), assinalariam esta exortação mais destacada.

Sitzler (1921, apud Prato, op.cit.) ofereceu argumentos contra esta hipótese ao observar que, na Ilíada, um mesmo passo às vezes alterna ordens na primeira e na segunda pessoa do plural, ou as traz em sucessão, de maneira a indicar ações

\footnotetext{
${ }^{54}$ Eurípides, Alceste, v.703; Hécuba, 315; Heraclidas 518, 533.
} 
distintas $^{55}$. Assim, por exemplo, as palavras de Ares no Canto V da Ilíada (vv.464-

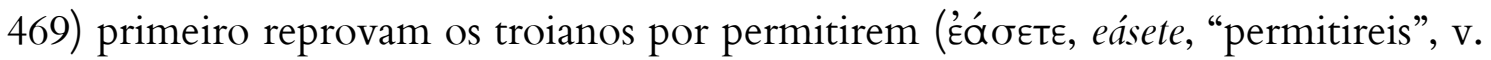
465) o morticínio provocado pelos Aqueus e, depois, sugerem enfaticamente o resgate de Eneias, que havia sido ferido por Diomedes, usando a primeira pessoa do

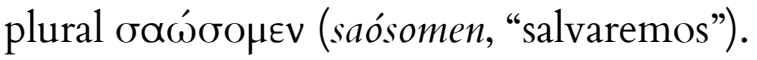

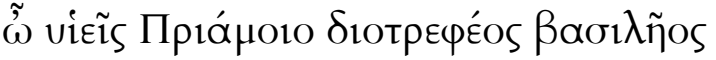

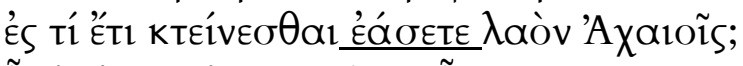

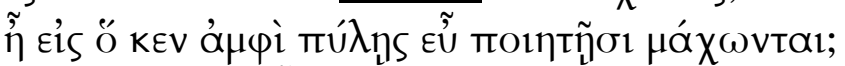

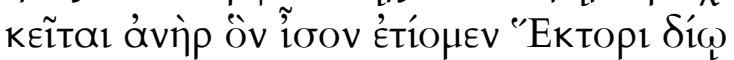
Aiveías viòs $\mu \varepsilon \gamma \alpha \lambda$ ńtopos 'A $\gamma x$ í́ao. ó $\lambda \lambda \lambda^{\prime}$ ớ

Ó filhos de Príamo, rei nutrido por Zeus, até quando permitireis que a tropa seja dizimada pelos Aqueus?

Quando estiverem lutando ao redor das portas bem lavradas? Está caído o varão, que igual ao divino Heitor louvávamos, Enéias, o filho de Anquises de grande coração. Eia, vamos! Salvemos o bom companheiro do embate!

Quanto a essa sugestão, Prato $(1968$, p.83) rejeita-a alegando que Tirteu não exorta para duas ações distintas, mas para a mesma ação, evidente no uso dos verbos $\mu \alpha \chi \omega ́ \mu \varepsilon \theta \alpha$ (vv.13) e $\mu \alpha ́ \chi \varepsilon \sigma \theta \varepsilon$ (vv.15). Embora muitos dos exemplos propostos por Sitzler sejam discutíveis, uma vez que nem todos constituem exortações de fato, concordaremos com outra leitura, proposta por Schmid (1929, apud De Falco e Coimbra, 1941, p.165), Jäger (1966, p. 107), Verdenius (1969, p.346) e, mais recentemente, Faraone (2008, pp.45-51) que leem os versos de Tirteu como pertencentes a um único poema.

Schmid (apud De Falco e Coimbra, 1941, p.165) enxerga no poema uma composição tripartite: para ele, os catorze primeiros versos têm como interlocutores homens já não tão jovens, com esposa, filhos pequenos e pais idosos (entre os quais o poeta se reconhece), ao passo que os versos restantes dirigem a exortação a rapazes na flor da idade. Ambos os grupos seriam reunidos na exortação final do poema (vv.

\footnotetext{
${ }^{55}$ Os exemplos trazidos pelo estudioso são: Il 5.464 ss., 6.67 ss., 13.95 ss., 15.496 ss..
} 
31-32), conferindo unidade à elegia. Apesar de este não ser um recurso estranho às elegias de Tirteu ${ }^{56}$, não nos parece haver tal segmentação neste poema; nesse caso, estaremos mais de acordo com a proposta de Verdenius (1969, p.346): em vez de uma mudança nos interlocutores, o que ocorre é uma mudança de tom. Segundo Verdenius, a primeira parte (vv. 01-14) apresenta um tom mais reflexivo, e a exortação propriamente dita se daria apenas a partir da segunda metade da elegia (vv. 15-32). O uso da primeira pessoa do plural, então, consistiria em uma estratégia retórica; diz Verdenius (1969, p.347) : “a primeira pessoa do plural é frequentemente utilizada como ficção para fins pedagógicos; o narrador expressa sua identificação com um grupo ao simular que pertence a ele. É o que professores fazem sempre. Por que Tirteu não poderia ter feito o mesmo?”.

Christopher A. Faraone, ao analisar a estrutura da elegia grega arcaica em The stanzaic archicteture of early greek elegy (2008, pp.45-51) observa que esta alternância entre reflexão e exortação não seria apenas um recurso empregado por Tirteu, mas antes constituiria um padrão composicional de toda a elegia grega arcaica.

O autor sugere que a elegia grega arcaica é organizada por uma estrutura estrófica, na qual cada estrofe corresponde a cinco dísticos elegíacos. Faraone (2008, p.41) observa que um dos recursos comuns da elegia marcial é a alternância de estrofes que contém reflexões com estrofes propriamente exortativas. Os trinta primeiros versos do fragmento $10 \mathrm{~W}$ demonstram esta alternância: a primeira estrofe (vv. 1-10) oferece uma reflexão, na qual se colocam duas situações opostas: lutar e morrer pela terra pátria (vv. 1-2) ou fugir (vv.3-10). Os versos descrevem, de maneira geral e hipotética, as consequências para um guerreiro que abandona o conflito. Já no segundo grupo de cinco dísticos (vv.11-20), o poeta passa para a exortação direta de seus interlocutores, distribuindo sete ordens ao longo dos dez

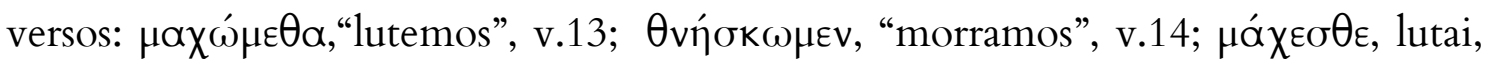

\footnotetext{
${ }^{56}$ Ver o fragmento $11 \mathrm{~W}$, no qual os 34 primeiros versos dirigem-se à linhagem do invencível

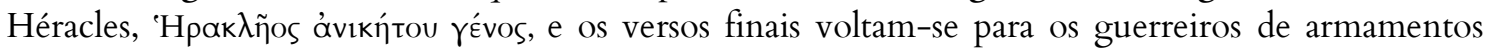

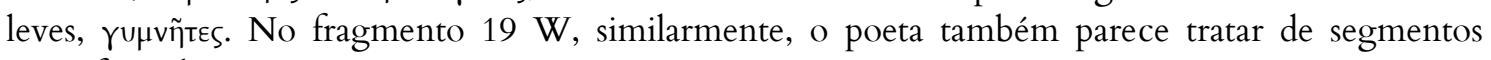
específicos do exército.
} 


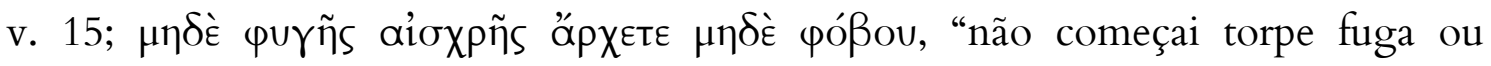

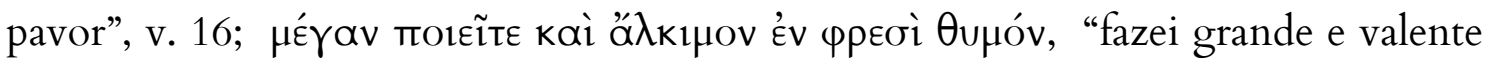

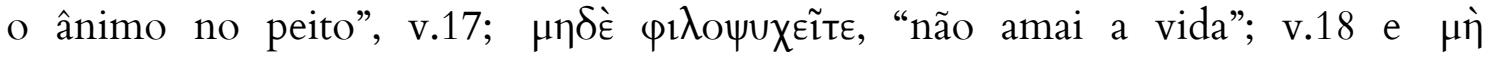

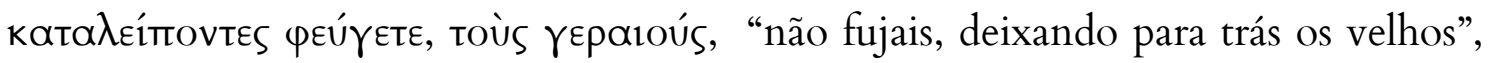
v.20. Nos versos 21-30, o poeta volta às reflexões de cunho geral para demonstrar, novamente, dois quadros distintos: por um lado, o horror que é a visão de um guerreiro veterano que tomba na linha de frente, e, por outro, a conveniência desta mesma situação para um jovem.

Faraone ainda observa que as três estrofes são interrelacionadas de modo a sugerir uma unidade coesa entre elas, uma vez que, no início de cada nova estrofe, Tirteu retoma um tema que era central na estrofe anterior. Assim, diante das consequências da fuga descritas na primeira estrofe, o poeta conclui, na estrofe seguinte, que a melhor alternativa é lutar (vv.11-14):

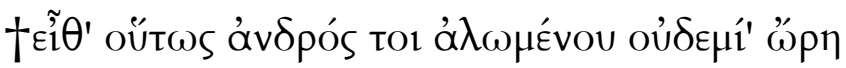

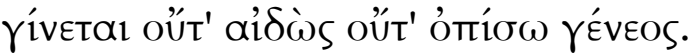

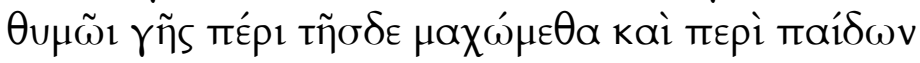

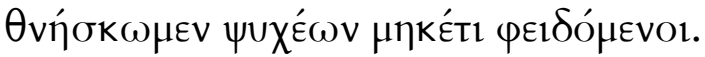

Se é assim, se ao varão errante não vêm préstimo ou respeito algum, nem a descendência, com ânimo por esta terra lutemos, e pelos filhos morramos, não mais poupando a vida!

Enquanto os versos 21 a 30 dão a explicação para a exortação empreendida ao fim da estrofe anterior (vv.19-22):

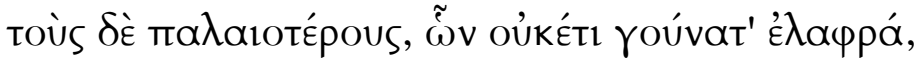

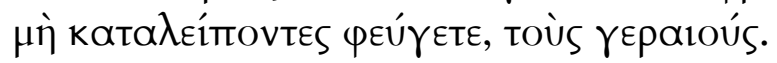

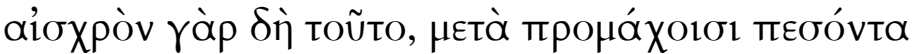

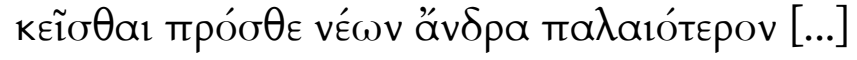

E não fujais, aos mais velhos abandonando, aos anciãos, que não têm mais joelhos ágeis .

Pois, sim, isto é torpe: na vanguarda caindo, jazer ante aos jovens um varão mais velho (...) 
A análise de Faraone é extremamente acurada ao notar as semelhanças entre cada grupo de dez versos no fragmento de Tirteu, mas não consegue incluir em seu esquema de composição estrófica o dístico final (vv.31-32):

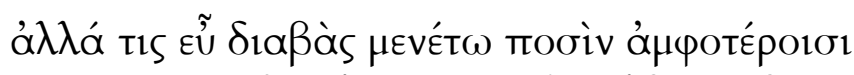

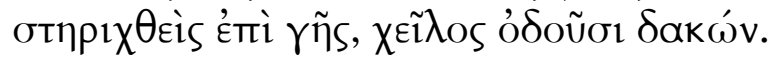

Mas que cada um fique bem firme, ambos os pés fixos ao chão, mordendo os lábios com os dentes!

Esses versos geraram suspeitas já entre os primeiros editores das elegias de Tirteu. Brunck (1772 apud Faraone 2008, p.51), verificando que este dístico é idêntico aos vv. 21-22 do fragmento $11 \mathrm{~W}$, o desconsidera, julgando que se tratava de alguma interpolação feita por um copista. Francke (1816, p. 153 apud Bach, 1831, p.105) o segue, e tenta reunir os fr. $10 \mathrm{~W}$ e o $11 \mathrm{~W}$ em um mesmo poema. Bach (1831, p. 105) rejeita a sua hipótese, já observando a qualidade destes versos ${ }^{57} \mathrm{e}$ perguntando-se porque Tirteu não poderia repeti-lo em outro poema.

Para Faraone (2008, p. 51) o último dístico encerra o poema "de maneira desajeitada", caso se leve em conta "a estrutura estrófica delineada acima". O autor então sugere que o poema continuava após o verso 32, formando uma elegia com, no mínimo, quatro estrofes - e que, portanto, Licurgo não citaria duas elegias justapostas, mas apenas uma, incompleta. A proposta de Faraone é adequada no sentido de resolver a questão longamente discutida sobre cisão da elegia no verso 15 , ao identificar similitudes e continuidades ao longo dos versos 1-30; Entretanto, parece-nos criar outro problema quando sugere, ex silentio, a incompletude da elegia.

A nosso ver, o emprego de uma breve exortação após uma sequência de meditação (como são os vv. 21-30) imprime no poema um fecho sentencioso que resume e contribui para a unidade da elegia marcial. O impacto desta exortação final

${ }^{57}$ Ver o Capítulo 2: o fragmento 11 e o modo de guerra, pp.101-102, para uma análise detalhada deste dístico. 
é evidenciado no uso de à $\lambda \lambda \alpha$ - "partícula usualmente empregada em comandos e exortações para marcar um encerramento ou um último apelo" (Denniston, 1954, p. 14). Esta conclusão impactante, na qual versos meditativos são seguidos por um dístico de exortação, ocorre também em outro fragmento de Tirteu (12. 35 - 44 $\mathrm{W})$ :

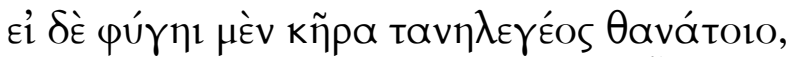

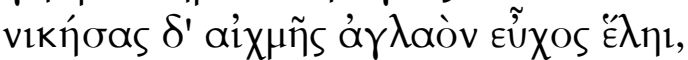

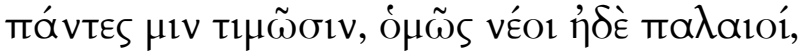

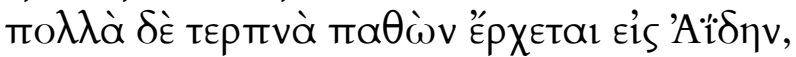

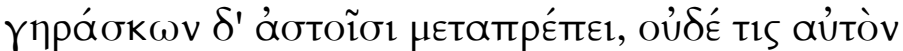

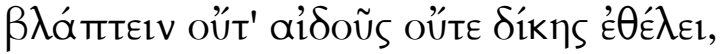

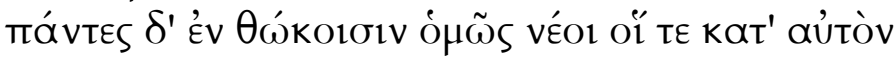

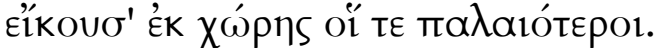

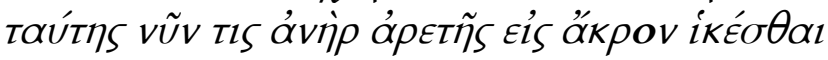

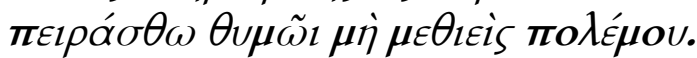

Mas se escapa à sina da morte de longo luto,

e, ao vencer, conquista o triunfo ilustre da lança, todos o honram, igualmente jovens e velhos e depois de viver muitas alegrias, vai ao Hades. Envelhecendo, distingue-se entre os cidadãos, e ninguém quer faltar-lhe com respeito e justiça; todos, jovens e seus coetâneos, cedem-lhe lugar em conselho, e também os mais velhos.

\section{Tente hoje cada varão ao ápice dessa virtude chegar, com coragem, sem descuidar da guerra!}

Jäger (1966, p. 107) e Verdenius (1969, p. 345) sugerem que esta elegia é indiretamente citada por Platão, em um passo das Leis (630 b), anterior, portanto, ao ката̀ $\Lambda \varepsilon \omega$ kpátous de Licurgo. O Estrangeiro Ateniense tenta comprovar a sua hipótese de que o melhor homem dispõe da combinação de quatro virtudes cardeais:

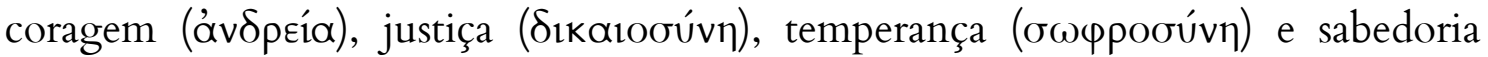

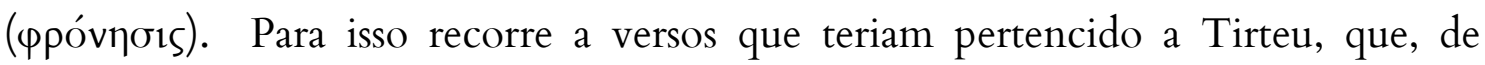
acordo com ele, falou de homens que possuíam apenas bravura e careciam das demais virtudes: 


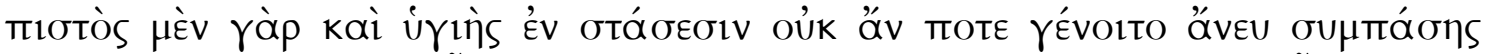

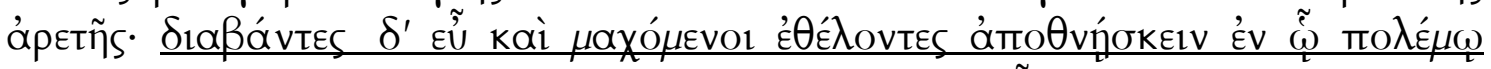

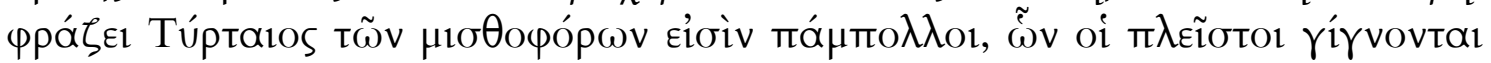

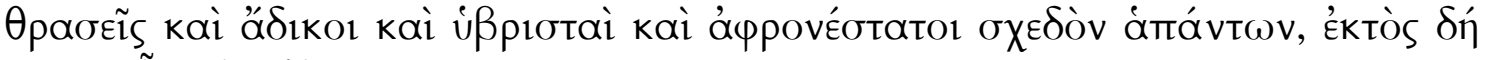

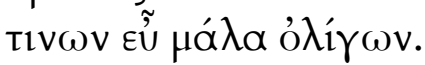

Pois [um homem] jamais seria leal e íntegro nas guerras civis sem uma virtude total. $\mathrm{Na}$ guerra a qual Tirteu se refere, havia uma grande quantidade de mercenários firmemente plantados e tencionando morrer em combate. Desses a maioria era insolente, injusta, descomedida e, ouso dizer, os mais insensatos de todos os homens, exceto uma minoria bem pequena.

Nesse sentido, seguiremos a sugestão de que se trata de um único poema, provavelmente completo, e que sua coesão pode ser verificada a partir de imagens e argumentos que se reiteram ao longo de todo o poema. Cabe, portanto, analisar que imagens seriam essas e de que maneira o poeta procede em sua elaboração.

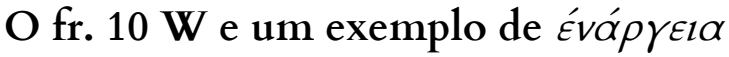

Além de uma mudança de tom como propõe Verdenius, lançaremos a hipótese de que o fr.10 W engendra duas imagens em sucessão, cada uma visando realçar e explicar a mesma situação vista por dois pontos de vista diferentes. A primeira imagem (vv.3 - 10) concebe as consequências hipotéticas para o varão fora do combate: o guerreiro que evitou a guerra, se não morre em combate, é condenado a um destino ainda pior aos olhos do poeta: vagar em completa miséria e destituído de todos os seus privilégios. Com essa imagem, o poeta justifica a asserção feita nos

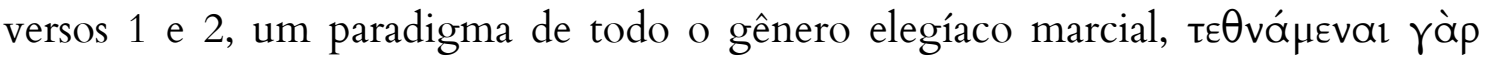

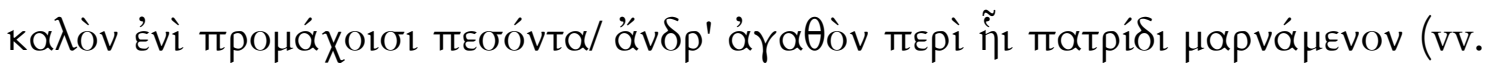
$1-2)$.

O poeta conclui a imagem no verso 10 e dirige as primeiras exortações nos versos 11 a 14. Contrapondo-se à imagem do guerreiro errante, o poeta conclui que a melhor alternativa é adentrar o combate, e ratifica assim a validade universal do preceito exposto no vv.1-2 (o que justificaria também o uso da primeira pessoa do plural). 
As exortações que se seguem (vv. 15 - 20) ainda levam em conta a oposição entre fugir ou lutar, mas já pressupõem um jovem guerreiro dentro do campo de batalha. Uma vez lá, a exortação geral dos versos 14-15, "viver e morrer pela pátria e pelos filhos", se desenvolve em outras exortações que prescrevem como deve ser a conduta deste jovem no combate (vv.13-20).

Assim, a segunda imagem elaborada pelo poeta também será do ponto de vista de dentro do combate, e versará agora sobre as consequências da fuga vistas sob essa ótica.

Novamente é um julgamento ético e moral que desencadeia a construção da

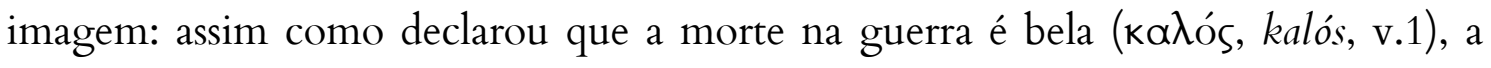
fuga, por sua vez, é feia e vergonhosa (aioxpós, aiskhrós, v.21). O poeta então justifica essa última declaração com outra imagem, a do guerreiro veterano que morre de forma aviltante no lugar dos jovens (vv.21-27). Os últimos versos (vv.2729) retomam a afirmação geral do primeiro e acrescentam a ela um tom

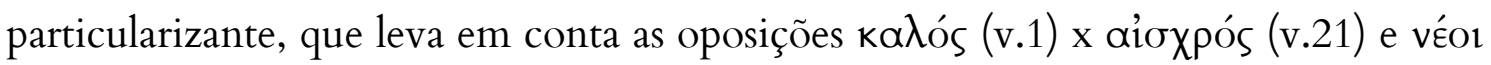

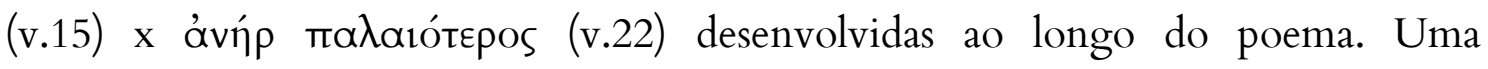
exortação final, demarcada por á $\lambda \lambda$ á, encerra o poema.

Como observam Prato (1968, p. 53*) e Maria Noussia em "Lo Stilo Semplice di Tirteo?" (2010, p.17), a poesia exortativa de Tirteu tem como característica elaborar exortações inspiradas por uma visão de mundo heroica. Como se trata de uma visão de mundo já transmitida e conhecida pela tradição, o poeta não precisa explicar os conceitos éticos nos quais essas exortações se fundam, mas procura justificá-las, acessando conhecimentos que já são compartilhados por toda a sua audiência por meio de descrições imagéticas. Noussia (2010, p. 19) identifica esse

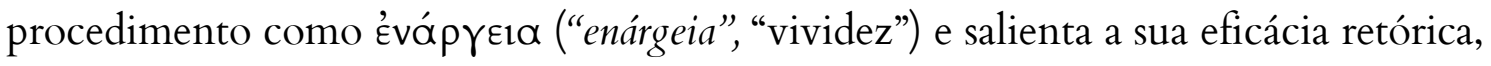
cujo resultado é a identificação e a criação de um elo emocional entre autor e público. 
Vale acrescentar que uma poesia que dá tamanha dimensão a enárgeia - cuja principal característica é por diante dos olhos da audiência um retrato distante ${ }^{58}$ encontra-se em casa no simpósio, que tem como uma de suas características a atribuição de papéis ou de situações apenas imaginadas pelos seus participantes ${ }^{59}$. E, como se tentará demonstrar nos comentários abaixo, o fr. $10 \mathrm{~W}$ deixa entrever um contexto eminentemente simposial, no qual Tirteu desenha imagens de guerra repletas de detalhes realísticos e circunstanciais com o intuito de atribuir à sua audiência papéis heroicos similares àqueles retratados pela tradição épica.

\section{A bela morte e o penoso exílio (vv. 1 - 14)}

O primeiro dístico introduz uma tópica que forma um argumento recorrente na elegia exortativa marcial, embora não seja exclusiva dela: Tirteu afirma a primazia do dever cívico e a beleza da morte em combate, dando a vida pela terra pátria e pela família. Muitos estudiosos tencionam estabelecer uma característica distintiva entre a épica e a elegia marcial ${ }^{60}$ vendo nesses versos um desenvolvimento da noção de patriotismo. Como tentamos demonstrar ${ }^{61}$, essas diferenças não parecem tão substanciais a ponto de representar uma mudança histórica ou um novo estágio no desenvolvimento do pensamento político grego. Ainda que a anterioridade da poesia de Homero esteja garantida, pode se atribuir as diferenças entre um e outro ao gênero: enquanto a poesia épica, dada a sua extensão, pode desenvolver diversas perspectivas acerca da guerra, Tirteu coloca na forma mais breve da elegia apenas os argumentos que deseja ressaltar.

Não é, portanto, um traço primaz da elegia exortativa marcial, mas um lugar comum que já se encontra em muitos passos da poesia grega arcaica. O primeiro

\footnotetext{
${ }^{58}$ Ver Bowie, 1990, p. 222.

${ }^{59}$ Ver Bowie, 1986, p. 17.

${ }^{60}$ Bowra, 1960 (p.52); Snell, 1982 (p. 172-173), Krischer, 1979, pp.385-389 (apud Irwin, 2005, p. 46); Raaflaub, 1993, pp. 41- 42.

${ }^{61}$ Ver Introdução, "Homero e Tirteu", pp.43-48.
} 
exemplo é na Ilíada, quando Heitor exorta seus compatriotas com um sentimento similar àquele expresso nos versos de Tirteu (Il. 15. 494 - 497):

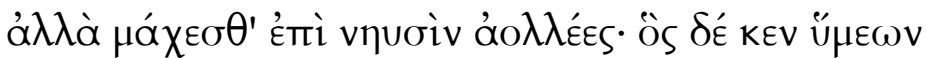

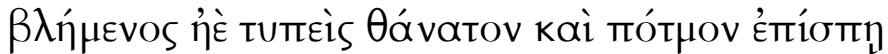

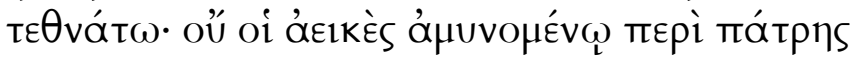
$\tau \varepsilon \theta$ vá $\mu \varepsilon v(.$.

Eia! Combatei, juntos nos navios! Caso algum de vós Seja golpeado ou ferido e encontre a morte e a sina, Que morra! Não é vergonha p'ra quem defende a pátria Ser morto!

Calino de Éfeso (fr.1, v.11-15 W) também registra essa tópica, sob uma perspectiva muito explorada na poesia elegíaca ${ }^{62}$, a da inevitabilidade da morte.

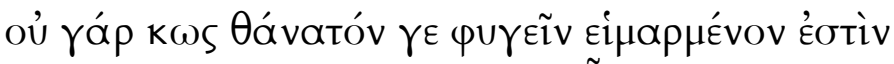

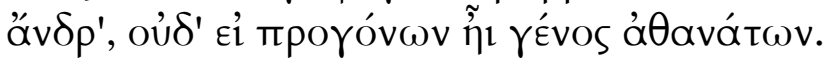

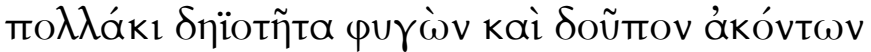
ह̌p

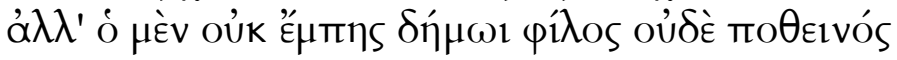

Pois não há como um varão fugir à morte assinalada, Mesmo que seja da estirpe de ancestres imortais; muitas vezes quem foge à luta e ao estridor de dardos retorna, mas a hora fatal da morte o pega em casa. Esse não é caro ao povo, nem dele se tem saudade;

A tópica também é explorada nos fragmentos de Simônides que nos chegaram sob o título de $\theta$ p̃̃vor (thrênoi, trenos), mas enquanto lá a fatalidade do destino serve como ensejo para o elogio do morto, na elegia exortativa constitui um argumento para a exortação ao combate. O fragmento 525 PMG de Simônides já ressalta a impossibilidade de um guerreiro subtrair-se à morte com a fuga:

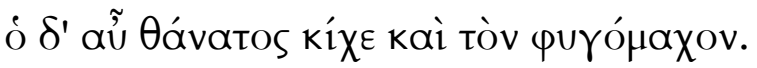

${ }^{62}$ Ver, por exemplo, Simônides, fr. 8 W; Mimnermo fr. 2. 5-7 W. 
e a morte alcança até mesmo o desertor.

A primeira palavra do poema, ıєӨvá $\mu \varepsilon v a ı$, pode ser lida de duas maneiras diferentes e excludentes entre si. A leitura mais aceita é a de W. J. Verdenius, em Tyrtaeus 6-7 D: A Commentary (1969, p.338). O autor entende o verbo, situado em início de oração, como um enfático para "morrer", e encontra usos similares em Homero (ver acima, Il. 15, 496-497) e no Ájax de Sófocles (vv.479-480). Ele nota a presença do particípio presente $\mu \alpha \rho v \alpha ́ \mu \varepsilon v o v$ (v.2) que força a entender que o poeta está empregando o perfeito para exprimir a intensidade de uma ação. O sentido seria: "é belo morrer lutando pela pátria".

A outra leitura é proposta de Carlo Prato em seu comentário a Tirteu (1968, p. 87). Para esse estudioso, trata-se do perfeito em sua utilização habitual, a de indicar o estado presente de uma ação passada, e poderíamos denotar isso por causa

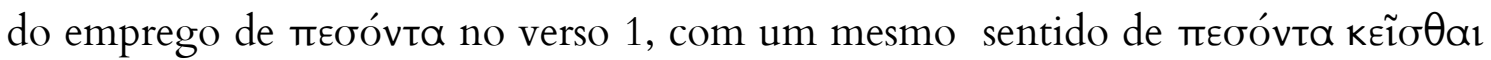
(“jazer caído”, 10. 21-22W), no mesmo fragmento. A leitura correta para Prato seria, então: "Estar morto, caído na vanguarda, é belo". Cada estudioso cita o particípio que favorece mais a sua leitura e ignora o outro. Qual seria, então, a leitura mais adequada?

Não é difícil pensar que Tirteu tenha considerado as duas possibilidades para

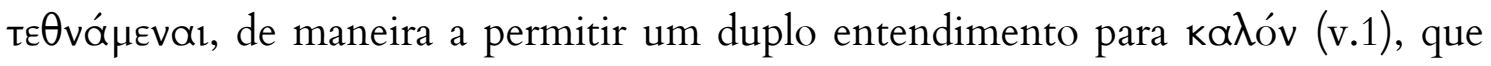
pode ser tanto ético (se considerarmos a hipótese de Verdenius, "é belo morrer... lutando pela pátria") quanto estético ( a hipótese de Prato, "é belo estar morto caído nas primeiras linhas”), já que ambos os sentidos para o adjetivo serão reiterados ao longo do poema, como veremos.

A noção de bela morte não é exclusiva de Tirteu e da poesia épica, mas recebeu ampla difusão: encontramo-la em um fragmento de Alceu (fr. 400 Voigt: tò

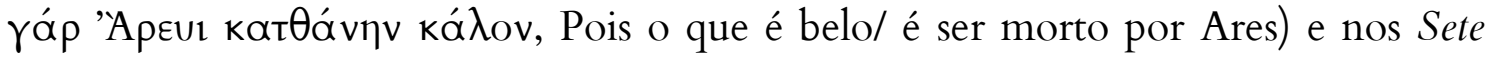

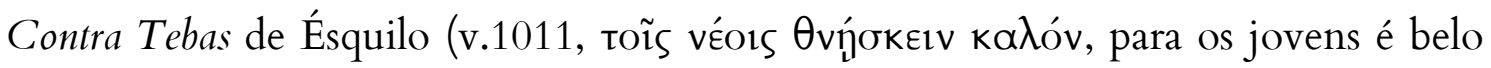
morrer). Horácio veio a empregar a noção e ampliá-la na Ode 3.2, v.13: Dulce et decorum est pro patria mori. Se Horácio compôs este verso influenciado pelo de 
Tirteu, como sugere Locksley I. Lindo, em “Tyrtaeus and Horace Odes 3.2 ” (1971, pp.258-260), é curioso notar que ele provavelmente teria lido ka $\lambda$ óv com o mesmo sentido ético/estético assinalado em Tirteu, ao se valer de um vocábulo latino que evoca ambivalência similar: decorum, cujo significado pode ser tanto estético ("belo", "elegante" ${ }^{63}$ ), como ético ("nobre" ou "adequado" ${ }^{64}$ )

Na epopeia homérica, прона́xor (v.1) é o termo empregado para denominar os guerreiros mais valorosos, o herói que luta sozinho na vanguarda. ${ }^{65}$ Não há porque pensar que Tirteu fizesse aqui uma alusão explícita à falange hoplítica ${ }^{66}$, mas é muito provável que estes трона́xor fossem compostos preferencialmente de jovens combatentes, como mostrarão os versos $21-22$.

O sujeito de $\tau є \theta v a ́ \mu \varepsilon v a ̊$ será introduzido no início do verso 2 em posição

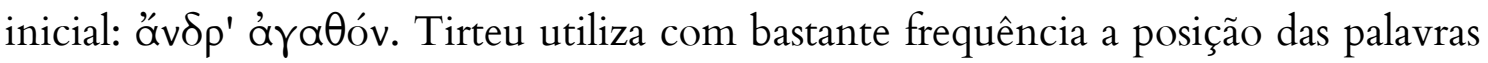
no verso para gerar efeito estético, colocando as palavras de maior destaque nas posições mais importantes do verso, o início e o fim, e é o que ocorre aqui.

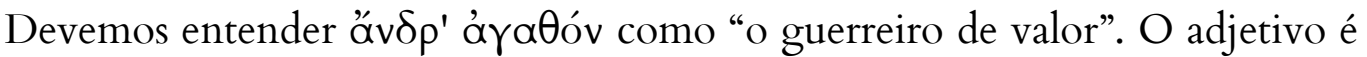
considerado um termo chave da ética homérica e está associado na Ilíada à noção de eficácia, como demonstra A.W.H. Adkins em Merit and Responsibility, a Study on Greek Values (1960, p.31-32) ${ }^{67}$. E tanto nas elegias de Tirteu quanto na Ilíada, essa eficácia está diretamente associada à capacidade militar: no fragmento $12 \mathrm{~W}$, Tirteu

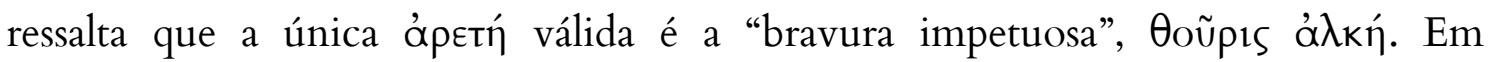
Homero, mostra Verdenius (1969, p. 339), ocorre a mesma concepção: quando Aquiles chama Heitor de àpıotos em Ilíada 21.279, não está em jogo nenhuma qualificação moral: apenas o valor de Heitor como o melhor guerreiro de Troia.

Do mesmo modo, é o valor na guerra que é considerado no fragmento,

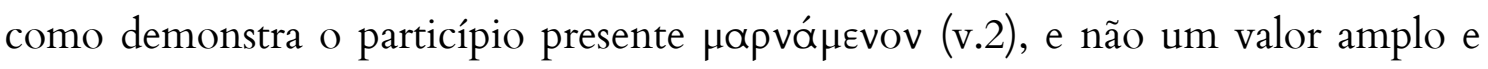
abstrato, como sugeriu Bowra (1938, p. 64).

\footnotetext{
${ }^{63}$ Ver Virg. Eneida, 11.480 (oculos decoros).

${ }^{64}$ Ver Hor. Odes Odes 1.10.3-4 (decorae...palaestrae), Odes 4.1.35-36 (decoro...silentio).

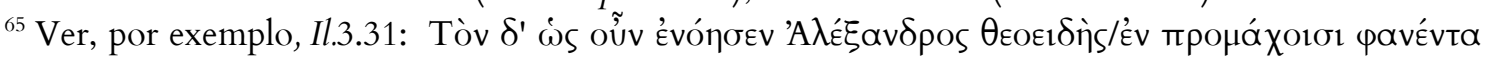
(quando deiforme Alexandre viu-o/aparecendo na vanguarda).

${ }^{66}$ Ver os comentários ao fr. $11 \mathrm{~W}$, pp. 82-112.

${ }^{67}$ Ver os comentários ao fr.12W, pp.113-145.
} 
Os versos 3-10 opõem o tom sentencioso e heroico do dístico anterior com um cenário negativo para o derrotado que sobrevive ao combate. A oposição é um dos procedimentos mais utilizados por Tirteu, e revela um método de argumentação e pensamento típicos da elegia grega arcaica. ${ }^{68}$

Há divergências entre os estudiosos sobre como o guerreiro se abstém do combate: para Schwartz (apud Prato, p. 88), trata-se do exílio voluntário, um desertor que almeja fugir das obrigações militares e dos riscos da guerra. Essa também é a opinião de Prato (1968, p. 89) e Jäger (1966, p.110), mas Verdenius (1969, p.339) prefere ver nesses versos o exílio forçado, a consequência para aquele que é derrotado em combate e reduzido à escravidão. $\mathrm{O}$ autor argumenta em favor dessa hipótese evocando o fragmento 5. 7-8 W de Tirteu, que relata a situação dos Messênios derrotados, que tiveram de abandonar as suas "férteis lavouras" ( $\pi$ íova

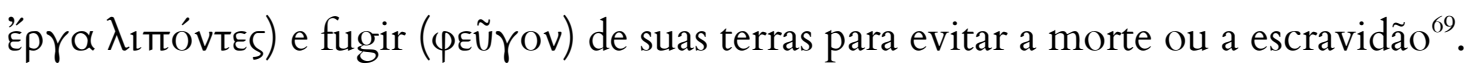

O fragmento 4. 23-25 W de Sólon retrata a escravidão como o desfecho para os muitos males que assolam a cidade, dentre eles a guerra:

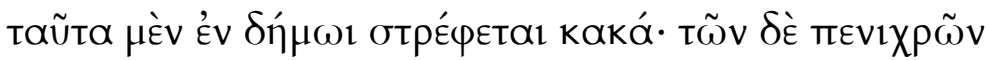

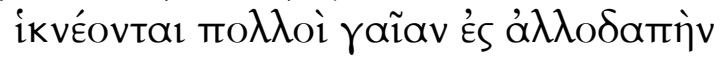

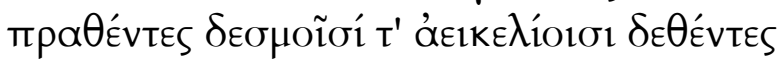

revolvem no povo esses males; dentre os pobres muitos chegam à terra alheia, vendidos e agrilhoados com vexatórios grilhões.

Luana Quatrocelli, em “Tirteo e La Retorica de Elite” (2008,p.12) aduz um dado histórico: a autora informa que o confisco de bens e o assassinato eram dois elementos frequentes que compunham a violência contra as elites em situações de revolta civil (otáors). Nesse sentido, talvez o quadro de Tirteu para o guerreiro exilado (vv. 3-10) seja direcionado não para um soldado qualquer, mas

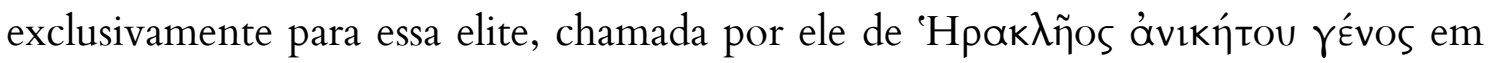

\footnotetext{
${ }^{68}$ Ver, por exemplo, Sólon fr.4W, vv. 19ss, Teognideia 949-954.

${ }^{69}$ Ver os comentários ao fr. 5W, na Parte II deste trabalho (pp. 194-198).
} 
outro poema (fr.11.1 W). A única alternativa à escravidão desenhada por Tirteu é o

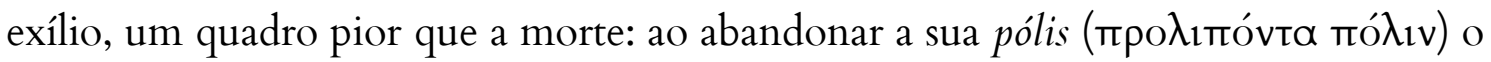
guerreiro perde os seus direitos como também a sua riqueza, sinalizada aqui por Tíovas àrpoùs (píonas agroús, "campos férteis”).

A similaridade entre os termos níovas àrpoùs (píonas agroús, "campos

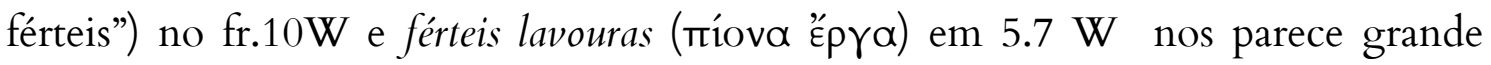
demais para descartar a possibilidade de que Tirteu não estivesse espelhando propositalmente as imagens dos dois poemas.

Mas a menção aos campos férteis se insere também em um registro mais amplo da poesia grega e especialmente da epopeia homérica; trata-se de um conceito que define a glória conquistada na guerra e a тици́ por termos que são essencialmente materiais (Ver Adkins, 1977, pp.70-71). Assim, ao mesmo tempo em que são um sinal de status, a opulência conquistada representa em termos materiais o valor guerreiro. Talvez o exemplo melhor elaborado dessa equação entre status e valor na guerra esteja no discurso de Sarpédon para Glauco, no canto 12 da Ilíada. Lá, o herói dirige-se ao seu interlocutor afirmando que as honrarias que eles recebem de seu povo os identificam também como os melhores guerreiros dentre os seus:

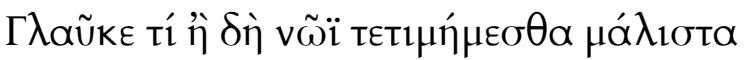

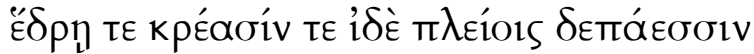

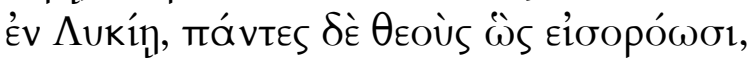

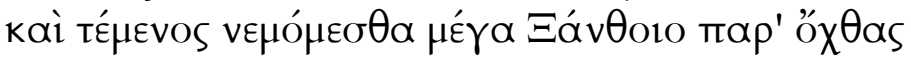

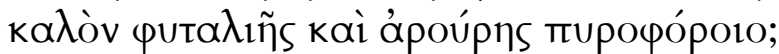

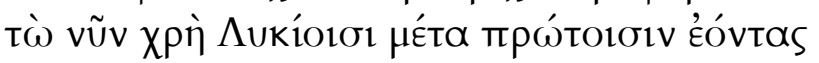

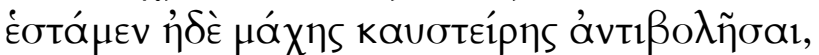

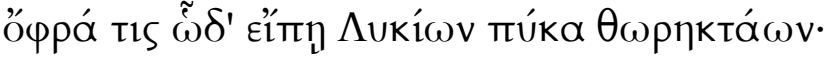

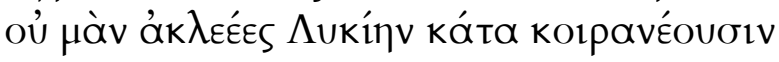

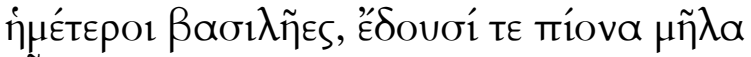

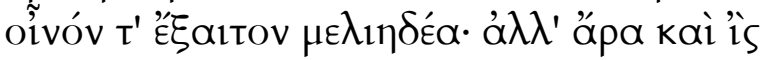

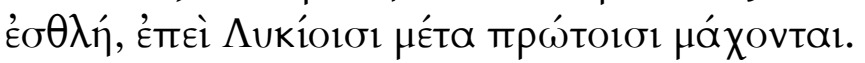

Glauco, por que nós dois somos honrados ao máximo com trono, carnes e cálices repletos na Lícia? 
Por que todos nos admiram como Deuses

e ocupamos vasto domínio às margens do Xanto,

belo em videira e de seara dotada de trigo?

Ora cabe a nós, estando entre os dianteiros dos lícios,

ficar firmes e encarar a batalha ardente, para que nenhum dos lícios de espessa couraça diga:

"Não sem glória na Lícia governam

nossos reis, eles que comem gordas ovelhas

e bebem vinho distinto e doce-mel; a sua força

também é boa, pois lutam entre os dianteiros dos lícios!

A glória de Sarpédon é definida em bens essencialmente materiais; é nesse mesmo sentido que Tirteu retrata a perda de bens do seu exilado: o guerreiro errante não tem posses que justifiquem a sua honra, diferente dos ancestrais

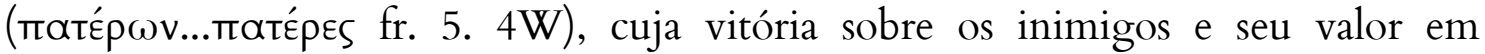

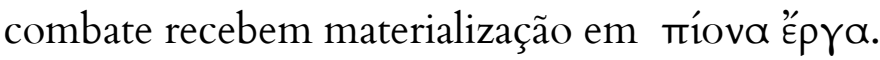

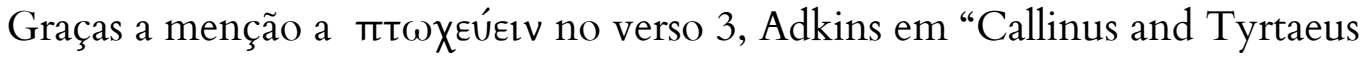
10 as poetry" (1977, p. 85) viu aqui uma alusão deliberada a Odisseia. Mesmo que não se trate de uma alusão direta, a ficção criada por Odisseu é muito similar à figura elaborada por Tirteu nos versos 3-10: o personagem se declara como um escravo fenício, um ex-nobre destituído duas vezes de seus bens, que recusou a morte e fugiu da escravidão ao longo de sua jornada. Os versos 18-19 do canto 17,

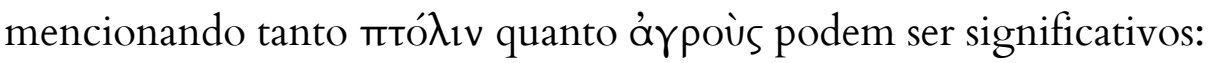

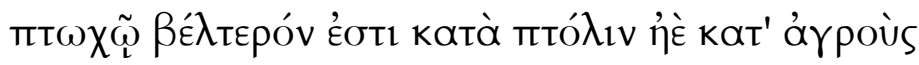

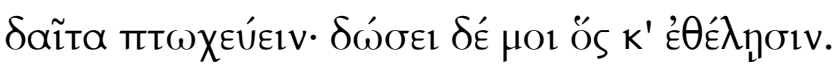

Ao mendigo, melhor coisa é pela cidade e pelos campos mendigar a refeição: Alguém, se quiser, me dará algo.

O superlativo óvinpótatov (anierótaton, "mais penoso") é raro, e além dessa ocorrência em Tirteu, todas as outras na poesia grega arcaica se encontram apenas na Teognideia e sempre na mesma posição, ocupando quase todo o segundo hemistíquio do pentâmetro elegíaco. 
Para Teógnis é óvinpótatov reconhecer alguém desonesto ou algo adulterado (vv.123-124); em um poema em que o eu-elegíaco é um "Iтாо к $\alpha \lambda \grave{\eta}$ kaì à $\varepsilon \theta \lambda i ́ n$ (belo e competidor corcel), carregar um homem kákıбтov (kákiston, "extremamente mau”, "pior") é óvınpótatov (vv.257-258); em outro dístico que

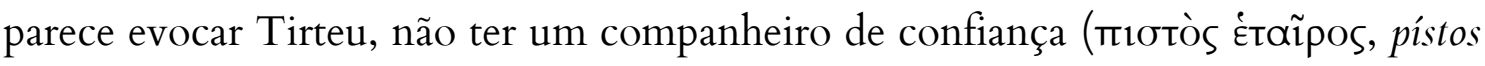
hetaîros) é que torna o exílio óvinpótatov (vv. 209-210); no verso 811-812 da Teognideia, ávinpótatov ressurge em contraponto com kákıv (kákion, "pior"). Segundo Teógnis, a traição de um amigo (

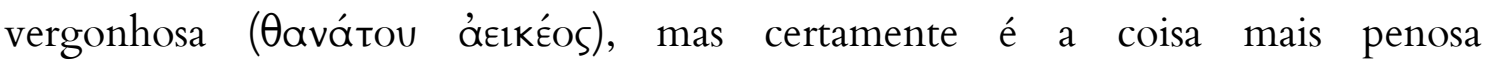
(åvinрótatov). A última ocorrência (vv. 1355-1356) diz ser ávinpótatov o amor não correspondido.

Quase todos os poemas acima, dada a importância que dão à ideia de heteria (vv.209-210, vv. 811-812), ao Eros (vv.1355-1356) e à ficcionalização de papéis (vv. 257-258), permitem-nos associar ávinpótatov como um vocábulo próprio dos jogos verbais do simpósio $^{70}$ e carregado de uma forte ética aristocrática.

O termo óvinpóv, por outro lado, já aparece em Homero, em conjunto com

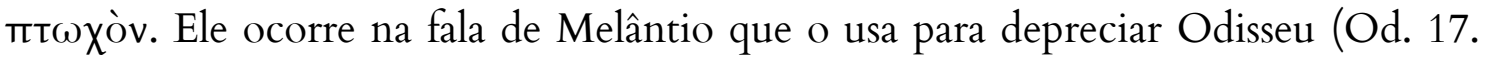

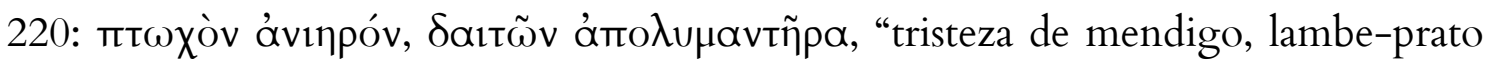
de banquetes"), o que leva a sugerir dois sentidos para o adjetivo: um, usado para qualificar um estado de sofrimento ("penoso") e outro, para depreciar alguém ("triste", ou "horrível").

Um dístico repleto de expressões convencionais (vv. 5-6) se segue, em que a ênfase recai em $\pi \lambda \alpha \zeta o ́ \mu \varepsilon v o v$, assinalando a condição do exilado. As outras expressões são todas convencionais, mas Tirteu tenta empreender certa variação nos adjetivos: como mostram De Martino e Vox (1996, p.561), pí $\lambda$ nı sugere

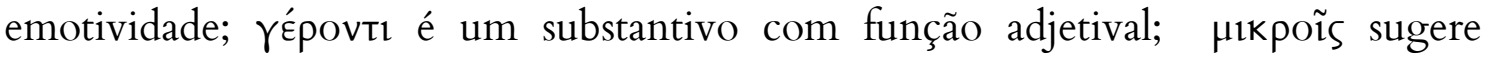
afetividade, diferente de ỏ $\lambda \hat{\gamma}$ os, que é usualmente empregado apenas para designar

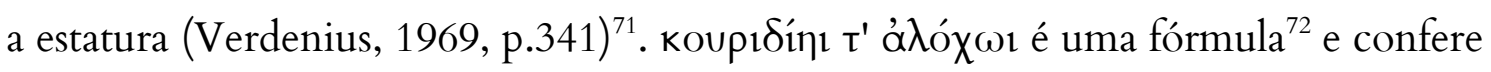

\footnotetext{
${ }^{70}$ Ver comentários ao fragmento $12 \mathrm{~W}, \mathrm{pp} .124-125$.

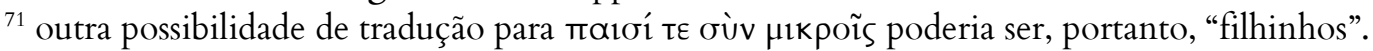


ao dístico certa tonalidade épica e própria ao universo bélico: define a esposa legítima, isto é, aquela que não é obtida como espólio de guerra.

Se nos versos 3 - 6 é o dano material que Tirteu relata, no próximo dístico ele relatará o dano moral, isto é, a perda da estima pública ${ }^{73}$. Èxy $\theta$ os (ékhtros, "odioso"), a palavra que abre o verso 7, cuida de descentralizar a imagem do herói

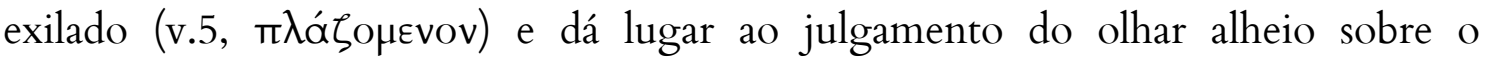
combatente que cede à pobreza e à necessidade de trabalhar (sentido sugerido por

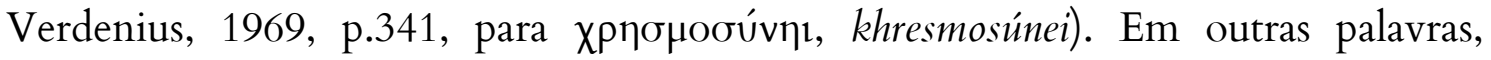
Tirteu realiza nesse dístico um apelo ao aíós (aidós, "pudor", "respeito").

Como mostra Douglas L. Cairns em Aidôs, The Psychology of Honor and Shame in Ancient Greek Literature (1993, p. 160-161), um dos principais motivadores para a ação na elegia marcial é a opinião pública. Já no fragmento $1 \mathrm{~W}$ de Calino (v.4) um dos argumentos para o véos lançar-se à guerra é o aỉó́s em relação aos

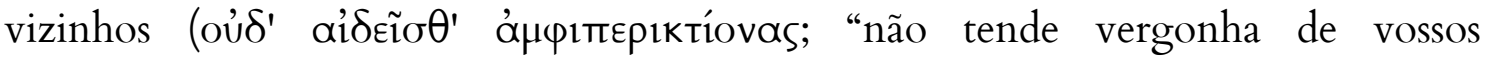
convizinhos?"). O mesmo ideário já ocorre na Ilíada, e um exemplo pode estar no discurso de Fênix no canto 9, vv.459-461; o único impedimento para que o

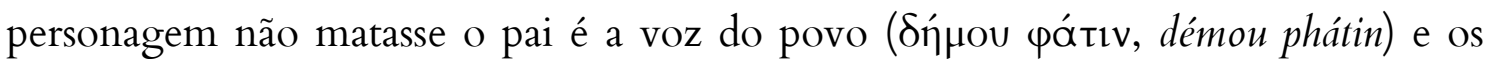
muitos insultos (ỏveídea, oneídea) que receberia:

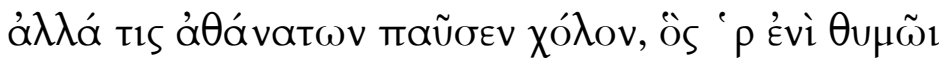

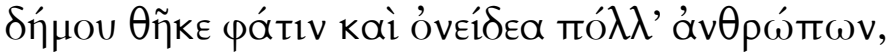

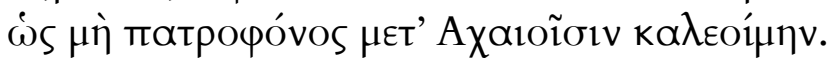

Mas um dos imortais cessou-me a cólera, no meu ânimo infundiu a voz do povo e os muitos insultos dos homens, que entre os aqueus me chamariam de parricida.

Em correlação com a partícula $\mu$ Év no verso 7 , a partícula $\tau \varepsilon$ no verso 9 prolonga o apelo ao aí $\delta \omega ́ s$ por mais um dístico, adicionando um verbo fundamental

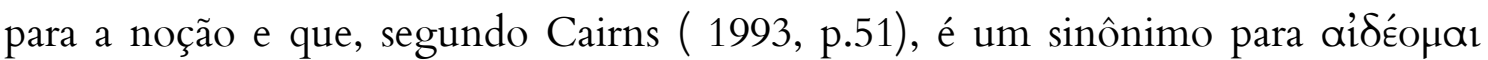

\footnotetext{
${ }^{72}$ Que ocorre também em outra elegia marcial, Calino $1.7 \mathrm{~W}$.

${ }^{73}$ Procedimento similar se dá nos fragmentos 6 e $7 \mathrm{~W}$, em que primeiro $(6 \mathrm{~W})$ Tirteu enfatiza a escravidão dos Messênios, e depois $(7 \mathrm{~W})$ a pena moral de lamentarem pelos seus senhores.
} 


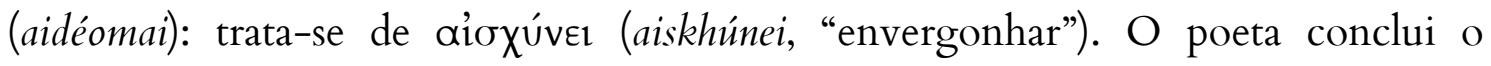
pequeno quadro do exilado recorrendo a parâmetros de excelência social

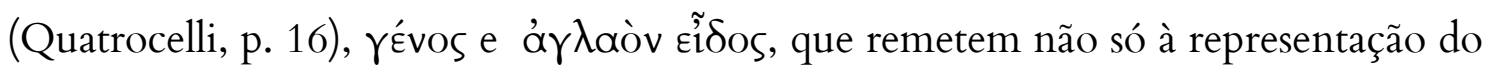
herói épico, mas também do aristocrata (Irwin, 2005, p. 36-40).

Adkins (1977, p.88) viu aqui uma alusão deliberada a um famoso discurso da Ilíada, o de Glauco para Diomedes acerca de suas origens (6.206-210):

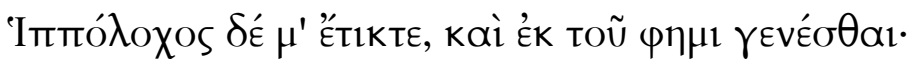

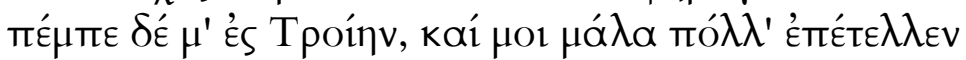

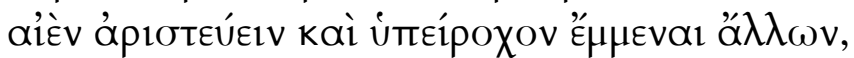

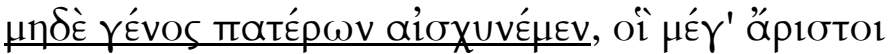

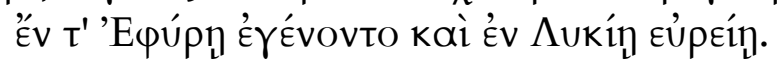

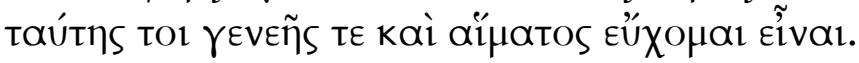

Hipóloco gerou-me, e filho dele afirmo ser: enviou-me à Troia, e muitas coisas prescreveu-me: ser sempre o mais valoroso, superar os outros, e não envergonhar a estirpe dos pais, que são de longe os melhores em Efira e na Lícia vasta.

Desta estirpe e deste sangue eu garanto ser.

A expressão, no entanto, talvez não seja uma alusão direta - já que a ideia era muito comum a uma moralidade heroica e ocorre, como demonstraram De Martino e Vox (1996, p.560) em outro passo da epopeia homérica, como em Odisseia 24.508509:

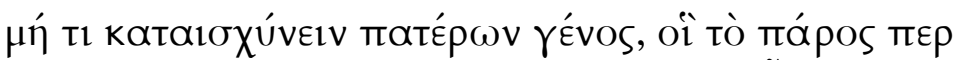

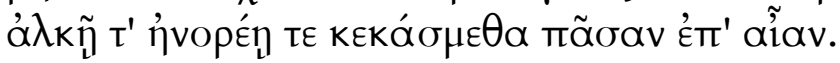

... Não envergonhar a estirpe dos pais, que até hoje Com bravura e força nos tem distinguido pela terra toda.

O que notamos é que estes versos já delineiam uma visão estética que Tirteu

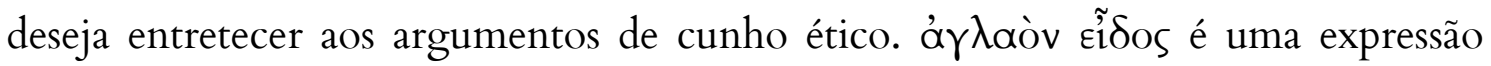
que não ocorre na épica, embora os vocábulos que a formam apareçam com frequência separadamente. Seu sentido está relacionado à beleza física e 
provavelmente aqui já indicam o vigor da juventude, como será desenvolvido no

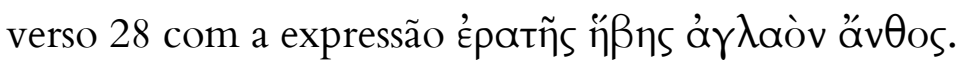

O termo incomodou aos estudiosos que viam nos poemas de Tirteu um retrato de uma Esparta austera, similar à do período clássico (Gentili e Perrota, 2007, p. 28; Fränkel, 1975, p.154), já que tal valor parece mais adequado à aristocracia arcaica de outras cidades gregas: Píndaro, por exemplo, exprime a correlação entre beleza e habilidade física na Olímpica 8, v.19, afirmando que Alcimedonte de Egina,

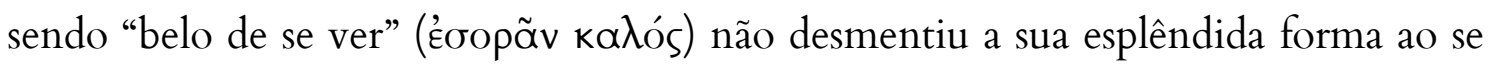

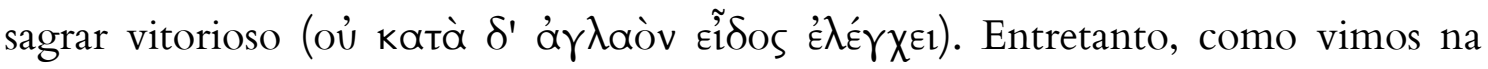
Introdução deste trabalho (pp. 31-33), tal valor não deve surpreender em Tirteu, pois revela como a sua Esparta, assim como a de Álcman, em pouco se distanciaria de outras cidades gregas.

$\mathrm{O}$ último verso dessa primeira dezena encerra a imagem, afirmando que "toda a desonra (ớrtนín) e vileza (kakótns) seguem [o exilado]", usando duas palavras-chave para resumir a condição desenhada pelo poeta: a ớtılín abrevia o que está expresso nos versos 7 e 8 , e tem a ver com a perda da estima pública demarcada pelo olhar do outro. É essa a análise de Verdenius (1969, p.341), que encontra seus argumentos em uma leitura de Heródoto (2.41). Prato (1968, p.90), Gentilli e Perrota (2007, p. 28), porém, discordam, e creem tratar-se das perdas materiais sofridas pelo exilado.

Os sentidos não são excludentes: ớtıín pode significar tanto a perda dos bens materiais quanto da estima moral. E um exemplo foi citado acima, quando

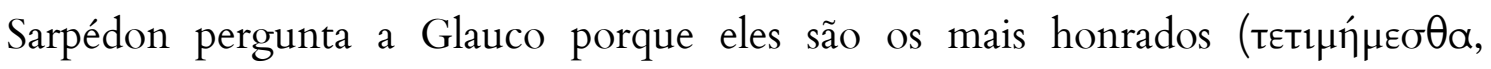
Il.12.310), e enumera uma lista de riquezas e privilégios que são concedidos levando em conta o crivo do olhar alheio. kakótns, por sua vez, é a "vileza", que pode ter aqui um duplo sentido: tanto a necessidade sofrida pelo que deixa sua terra, como a covardia, princípio determinante e que motiva a fuga.

Para prevenir-se desse destino, portanto, a única alternativa para o guerreiro é lutar com coragem, dando a sua vida se necessário (vv. 11-14). 
Nota-se aí um traço estilístico de Tirteu, que perpassará todos os seus fragmentos exortativos: o jogo simétrico de oposições e conceitos antitéticos a partir da elaboração de imagens vívidas e concretas. Tirteu não se preocupa em esclarecer

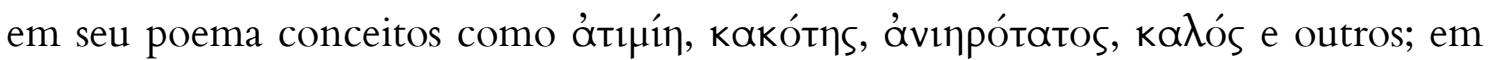
primeiro lugar, porque tais conceitos já estão fincados na cultura de sua audiência; em segundo, porque as suas imagens falam por ele.

\section{O papel do poeta e a exortação marcial (vv. 15-18)}

Os versos 11 a 14 resumem a imagem dos versos 3-10, extraindo dela uma máxima que será o fulcro para a exortação dos versos 15 e 16. Se o exilado não recebe aíós nem qualquer auxílio (v.11-12), é melhor perder a vida lutando de maneira nobre, defendendo os filhos e a pátria (v.13-14). O poema então se torna uma exortação de fato, e o poeta deixa de lado a descrição do quadro do derrotado para criar uma imagem de dentro do campo de batalha. å $\lambda \lambda \alpha_{\alpha}$ (v.15) marca a transição do argumento para a ação propriamente dita. O poeta então usará uma série de frases que encontra paralelos em outros seus poemas.

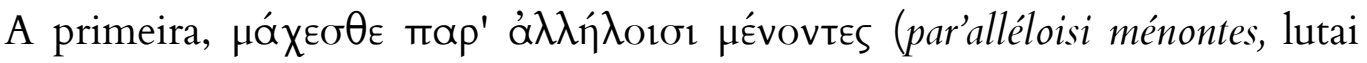
lado a lado, v.15) não corresponde a uma alusão ao confronto hoplítico, mas à

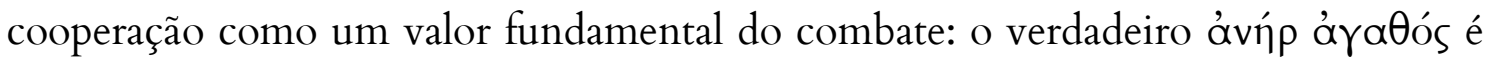
aquele que "encoraja o varão ao seu lado com palavras" (12. 19-20 W), e os que se mantêm lado a lado na linha de frente do combate salvam os que permanecem na retaguarda $(11.11-14 \mathrm{~W}) .^{74}$

No verso 16, o poeta exorta que os véoı não fujam nem fiquem paralisados

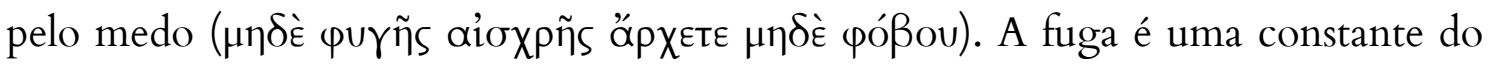
combate retratado por Tirteu e nem sempre vista como algo ruim: no fragmento 11 W, o poeta apela para a validade de sua exortação ao combate explorando a experiência de seus interlocutores na guerra: eles já conhecem as "proezas destrutoras de Ares", vivenciaram tanto a fuga quanto a perseguição (vv.9-10) e

\footnotetext{
${ }^{74}$ Essa questão será melhor desenvolvida nos comentários ao fr.11W.
} 
sabem empiricamente que lutar é melhor. O fragmento $10 \mathrm{~W}$, porém, apenas qualifica a fuga com um termo ético, aíoxpñs, ("feio e vergonhoso") - do qual trataremos mais tarde - e continua no dístico seguinte (vv.17-18) com o relato das disposições anímicas que um guerreiro deve ter em combate. Nesse sentido, os dois dísticos se contrapõem: o primeiro (vv. 15-16) traz ações tangíveis no campo de batalha, enquanto o segundo (vv.17-18) refere às qualidades internas que um véos deve apresentar. Que qualidades seriam essas?

Respectivamente, "tornar o ânimo no peito enorme e valente" (’’ $\lambda \lambda \grave{\alpha} \mu \dot{\varepsilon} \gamma \alpha v$

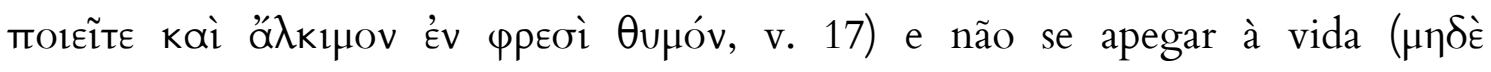

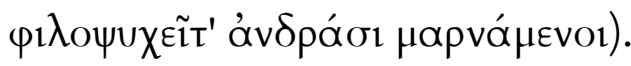

Quanto à primeira exigência, ela é fortemente calcada numa ideia básica da poesia marcial: a ò $\lambda_{\kappa}$ é a principal qualidade exigida pelos guerreiros, seja na exortação elegíaca, seja na exortação épica. ${ }^{75}$ Calino inquire a seus interlocutores

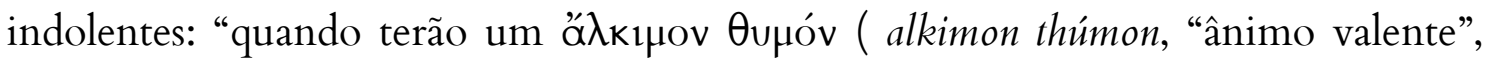
1.1 W) ?", uma expressão que não encontra paralelos em Homero e poderia muito

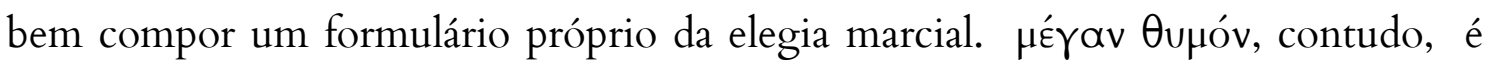
uma expressão frequente na Ilíada e na Odisseia, parecendo uma decomposição do

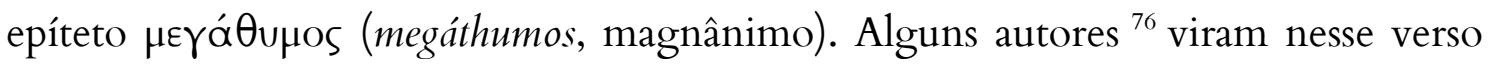
uma evolução da ideia de $\theta$ upós, que passa a ser retratado como uma parte controlável do espírito humano, e não mais um órgão que depende de estímulos externos. Mas algumas passagens em Homero já contrariam essa visão, citam-se

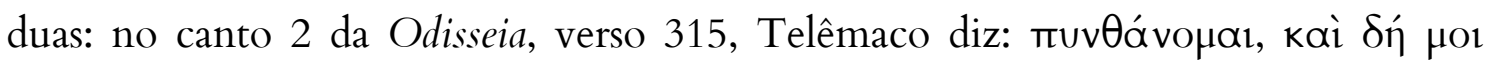

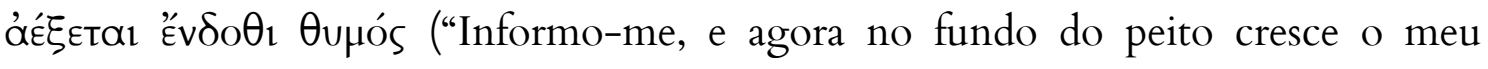
ânimo") e em Ilíada, 9.496, Fênix pede a Aquiles que dome o seu grande ânimo

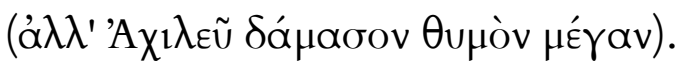

A segunda exigência feita pelo poeta constitui um paradoxo bastante original

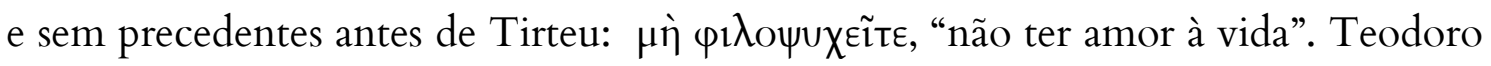
Assunção em "A Morte Política de Tirteu" recorda, citando Hannah Arendt

\footnotetext{
${ }^{75}$ Ver os comentários ao fr. $11 \mathrm{~W}$, p. $82-105$.

${ }^{76}$ Ver Introdução, "Tirteu e Homero".
} 
(Condition de l'homme moderne, 1983, p.46, n.1), que o amor à vida será associado por Platão (República, 386 a) à covardia: o servilismo do escravo seria natural devido à sua propensão a não optar pela morte. Se é assim também nesse fragmento, então Tirteu estará remetendo aos versos 3-10 aqui. Todavia, a ocorrência desse composto apenas no período clássico levou Wilamowitz (apud De Martino e Vox, p. 563) a julgar espúria esta elegia.

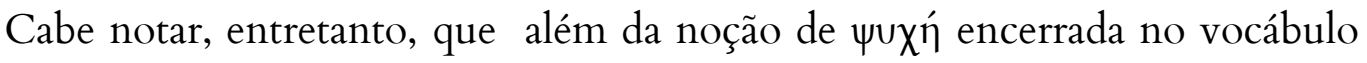
ser predominantemente arcaica, construções paradoxais desse tipo não são estranhas

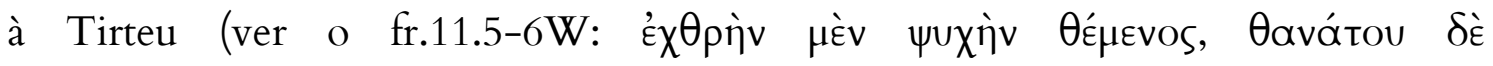

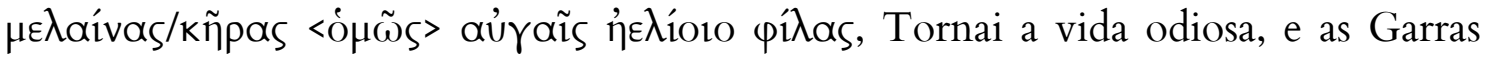
negras da Morte/ tão amadas quanto os raios de sol). Pensando assim, poderíamos até mesmo supor que $\varphi 1 \lambda o \psi v \chi \varepsilon \tilde{\varepsilon} \tau \varepsilon$ seja uma criação tirtaica.

No verso 16, Tirteu insere outro julgamento de valor: se no verso 1 a morte será bela, a fuga será então aioxpós (aiskhrós, "feia e vergonhosa"). E do mesmo modo que faz com kódós no verso 1, Tirteu elaborará a seguir outra imagem para explicar o conceito, que não só recuperará a expressão que abre o poema

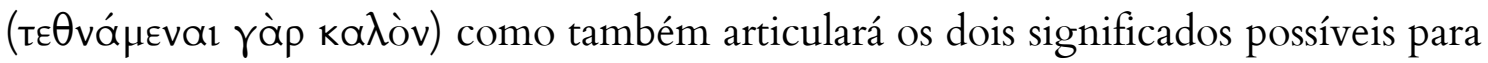
aioxpós.

\section{aíoxpòs Өávatos e valores éticos e estéticos no fragmento $10 \mathrm{~W}$}

Com uma imagem extremamente bem construída, Tirteu agora relata a morte aviltante que recai a um guerreiro mais velho, que assume o lugar daquele que recua do combate. Se nos primeiros 10 versos vemos o destino do jovem que foge à morte e temos um vislumbre de quão horrível será seu exílio, agora temos uma nova perspectiva, interna ao combate: o jovem que abandona a luta também abandona os mais velhos, que embora sejam dotados de coragem ( $\theta u \mu \grave{v}$...

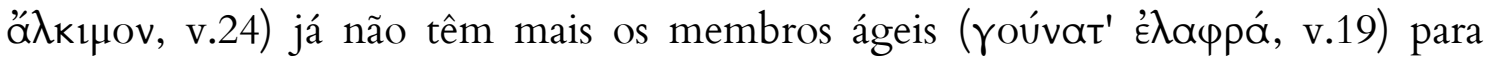

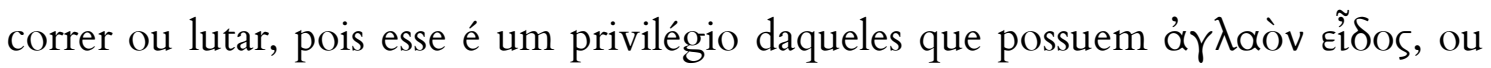




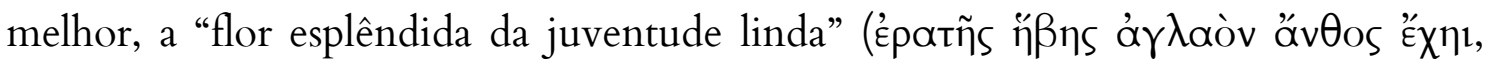

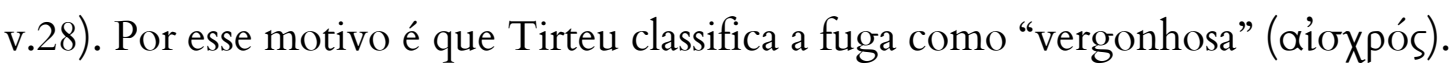

A passagem é fortemente reminiscente da epopeia homérica. Os versos 21-30 de Tirteu se relacionam, tanto na linguagem quanto na temática, com o pedido de Príamo a Heitor em Ilíada, 22. 71-76:

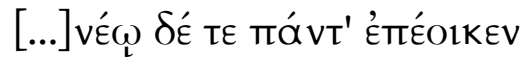

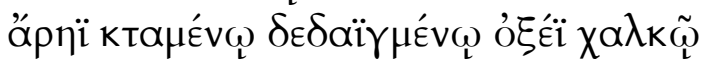

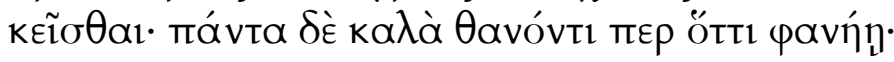

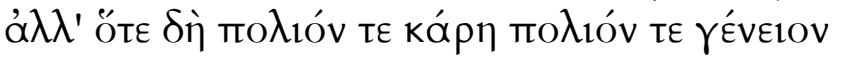

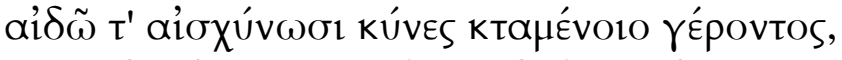

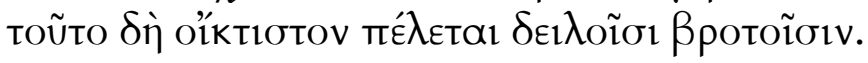

[...] Mas tudo convém ao jovem: na guerra assassinado, trucidado por agudo bronze, jazer. Nele, morto embora, é belo tudo que se mostra: mas quando a cabeça grisalha e a barba grisalha e as genitais de um ancião assassinado os cães desfiguram, isso sim vem a ser o mais deplorável para os pobres mortais.

Apesar das passagens apresentarem suas particularidades, aceitamos que há uma conexão entre elas por causa de duas referências específicas que recorrem em ambas: a visão brutal e reprovável do ancião dilacerado em suas partes intímas, e o espetáculo, sempre belo, do jovem que é morto em combate no viço da juventude. Não é possível, porém, identificar qual das passagens tem prioridade. Mülder (1906, apud Scott, J. A. 1908, p.123) foi o primeiro a considerar a possibilidade de que a passagem pertencesse originalmente a Tirteu e tivesse sido imitada posteriormente pelo aedo iliádico, tendo seu propósito inicial alterado, e essa teoria parece ser retomada por West em The Making of Iliad (p. 385). Os versos 71-73 da Ilíada seriam em princípio um encorajamento ao jovem para morrer na guerra, de maneira similar a uma exortação elegíaca - um dos escólios ao verso explica que tudo que se 
apresenta no jovem que morre é belo (v.73), "porque belo é morrer pela pátria e pela propriedade, em benefício dos presentes"77.

A Ilíada, contudo, transformaria a exortação em um quadro cruel do destino de Príamo - que diferente de seu par tirtaico, não é um guerreiro - e em um apelo à fuga feito a Heitor (vv. 73 - 76), enquanto Tirteu manteria a intenção original ao oferecer o contraponto perfeito entre a desgraça brutal do velho e a morte do jovem. O jovem morto é belo tanto do ponto de vista moral, pois assumiu o lugar seu devido no combate e protegeu "pai, filhos e esposa" (10.6W) bem como é belo do ponto de vista estético, suscitando desejo nas mulheres e admiração nos homens (10.29). A morte de um velho, porém, é vergonhosa, feia moralmente (um dos

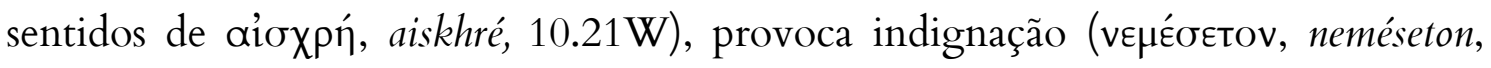
10.26W), e é horrível de se ver (outro sentido de aíoxpí, 10.26W). A imagem do do velho segurando as suas partes íntimas cheias de sangue,por exemplo, é rara e peculiar à Ilíada.

Nas diversas cenas de combate do épico, este tipo de ferimento é raramente retratado, mas há motivos para acreditar que fosse muito comum na guerra arcaica, pois a conformação da armadura deixava exposta e vulnerável a área entre o umbigo e a virilha ${ }^{78}$. Mas dentre todas as narrativas iliádicas, apenas na morte de um guerreiro chamado Adamante é que se pode entrever algo similar (Il. 13. 566-568):

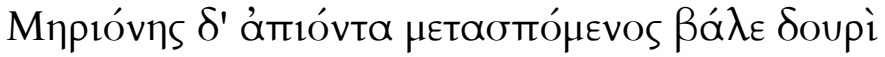

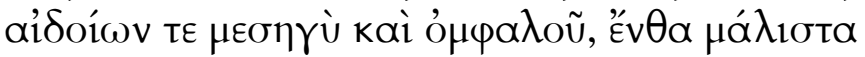

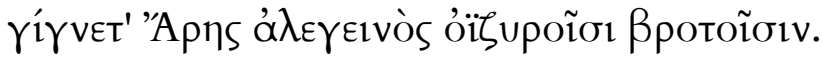
Meríones seguia, em seu encalço, e atirou com a lança entre os genitais e o umbigo, lá onde Ares é doloroso demais para os miseráveis mortais.

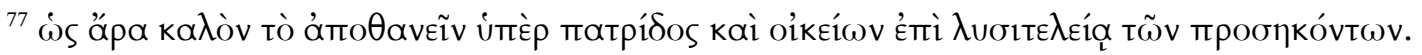

${ }^{78}$ Van Wees (1994, pp.135-136) informa que a couraça geralmente deixava desprotegida o baixo ventre e é justamente por isso que alguns guerreiros a reforçavam com um cinturão (zôster). Ver Martino e Vox, 1996, p. 563.
} 
É interessante notar esse detalhe não só para enfatizar como Tirteu costumava traçar retratos mais realísticos da guerra, mas também porque o realismo

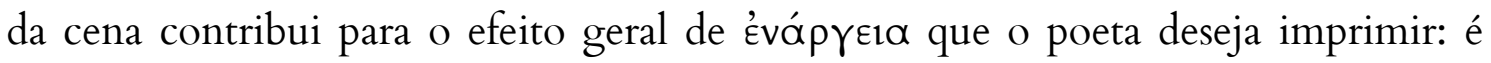

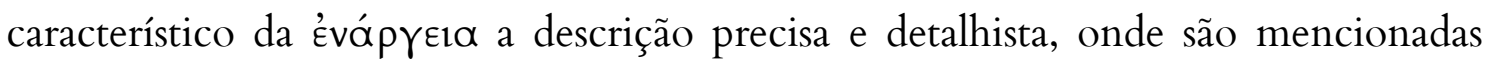
todas as circunstâncias de um fato e nada se omite (Ver Demétrio, Eloc., 209).

Nesse sentido, o que se conclui, contrapondo ambas as passagens é que ocorre uma diferença de ênfase. Na cena homérica o enfoque está na triste condição de Príamo: lá, a morte de um velho é considerada deplorável ou digna de piedade (ớktıбтov, oíktiston), enquanto em Tirteu, a antinomia entre velhice e juventude é posta para suscitar a ação guerreira, e portanto a narração da morte de um velho guerreiro não deve soar como triste, mas antes como abjeta e vergonhosa. A similaridade vocabular entre as duas passagens (Il. 22.71 e fr. $10.27 \mathrm{~W}$; Il. 22.73 e fr. 10.30 W; Il. 22.74 e fr.10.23 W) poderia, sim, como quer West, sugerir uma relação mais direta entre as duas passagens, mas sugerir que a passagem de Tirteu fosse prioritária apenas porque ali se desenvolve uma antítese completa entre jovem e velho parece ser exagero se antes consideramos a função de cada passagem, o sentimento que cada uma aspira alcançar, e o estilo particular de cada poeta.

Notemos ainda outros recursos presentes em Tirteu e não em Homero: o anacoluto do verso 26, interrompendo a descrição do velho lacerado, explicita uma força alocutória inexistente no discurso de Príamo na Ilíada: o poeta volta-se diretamente para os seus interlocutores, e o uso do vocábulo i $\delta \varepsilon \tilde{i v}$ (v.26) parece sugerir que a audiência visualize a cena, como se pudesse estar lá de fato. Esse expediente, aparentemente singular na poesia tirtaica ${ }^{79}$, ressalta a presença dos interlocutores do poeta e e os confunde, por meio de évápreia, com soldados atuando no campo de batalha. O uso de mais de um termo para a cor da barba e dos cabelos do ancião, que não julgamos tratar-se de sinônimos como propôs Prato (1968, p. 53), mas de tonalidades distintas de uma mesma cor, sugere também uma

${ }^{79}$ Ver Noussia, 2010. 
presentificação por évá $p \gamma \varepsilon ı \alpha$, que aviva na imaginação o espetáculo horrível que é a morte do guerreiro veterano ${ }^{80}$.

Como já notamos, a évápreıa, isto é, a representação icástica de um cenário distante, é um traço da poesia de simpósio. De certo modo, então, a poesia de Tirteu, rica na elaboração de imagens, poderia favorecer uma apropriação simpótica ou identificar o simpósio como ocasião de performance principal para esse poema.

Em um apelo final (vv.27-30) que anuncia a beleza do jovem, Tirteu evoca argumentos que são próprios de uma poesia amatória de simpósio: o guerreiro morto é detentor da "flor da juventude linda", expressão de conotação erótica encontrada também em Mimnermo (1. $5 \mathrm{~W})$. E esse mesmo guerreiro, durante a vida, é alvo de admiração dos homens e de desejos das mulheres, o que, como mostra Mimnermo, é um ideal no horizonte de todo o simposiasta :

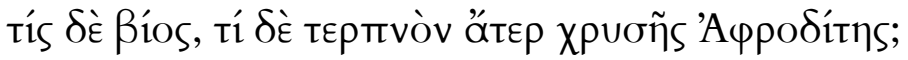

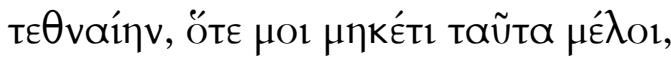

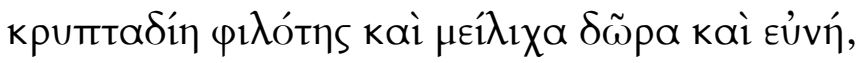

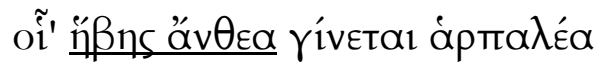

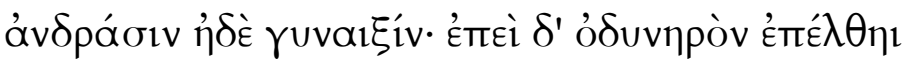

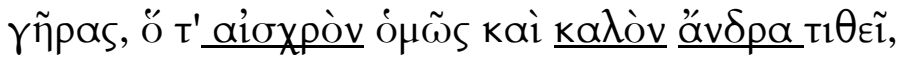

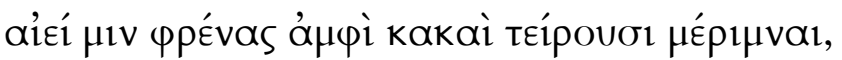

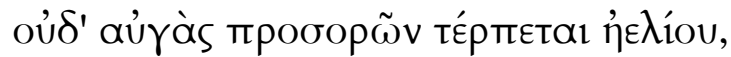

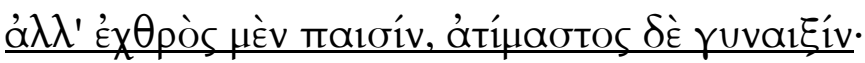

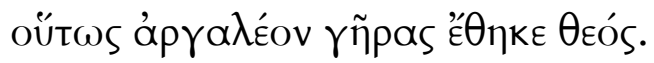

Que vida, que prazer, sem a Afrodite de ouro?

Esteja eu morto, quando isso não mais me interessar:

um amor furtivo, e melífluos presentes, e o leito:

essas são as agradáveis flores da juventude

para homens e mulheres: mas quando advém a odiosa

velhice, que deixa feio até mesmo um homem $\underline{\text { belo, }}$

\footnotetext{
${ }^{80}$ Dawson,1966 (apud Noussia, 2010, p.31): "Tyrtaeus may well have felt that silver and gray offered na interesting contrast to red blood in the grimmy dust, and all of them against bared flesh".
} 
toda a vez más preocupações consomem o seu espírito, não se alegra vendo os raios do sol,

mas é odioso aos meninos e desprezado pelas mulheres: assim Deus fez atroz a velhice.

A audiência exerce um papel central na recepção e interpretação da mensagem e a ocasião de performance é também importante para a apreensão do significado.

Se essa é inequivocamente o simpósio, Tirteu pode ter deliberadamente trabalhado uma ambiguidade que seria reforçada nesse ambiente: na primeira parte, o uso de termos específicos de uma ética afim à tradição épica constrói uma moralidade guerreira e assim torna presente a guerra no ambiente do simpósio, ao passo que na segunda o uso de um sentido privilegiadamente estético expõe a ocasião de performance desta poesia e denuncia o próprio jogo da poesia tirtaica, revelando que seus interlocutores não são como heróis homéricos, mas sim jovens aristocratas que fazem parte do ambiente simposial e que emulam os heróis da épica. ${ }^{81}$

Nesse sentido, a atribuição ao longo do poema de características épicas aos interlocutores do poeta opera a criação de uma identidade: ao afirmar que são

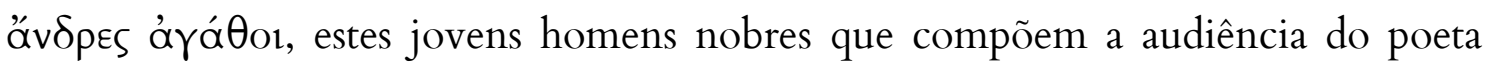
assumem, no espaço da ficção poética, a posição de baluartes para seu povo - aqueles

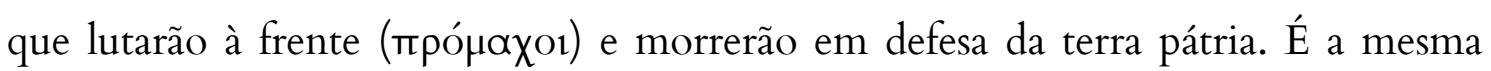
posição de um herói épico, porém, no contexto da pólis, o que força estes aristocratas a justificarem sua posição neste novo ambiente.

Fazem-no por meio da poesia, em um jogo de interpretação de papéis que os equalizará a heróis épicos e que o poeta torna vivo na realidade do simpósio, na medida em que ressalta a ambivalência de um vocabulário de cunho estético, tão comum ao simpósio e também à moralidade guerreira.

\footnotetext{
${ }^{81}$ Ver Irwin, 2005, pp.48-62.
} 


\section{Capítulo 2}

\section{O fragmento $11 \mathrm{~W}$ e o modo de guerra}

O fragmento 11 West constitui-se como mais uma elegia exortativa do corpus de poemas tirtaicos conservada na Antologia de João Estobeu, provavelmente

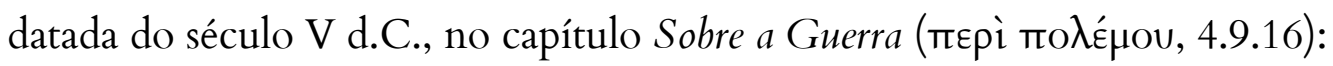

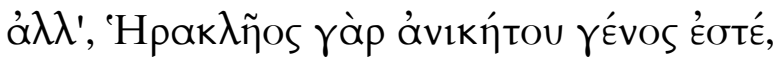

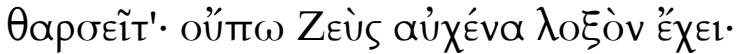

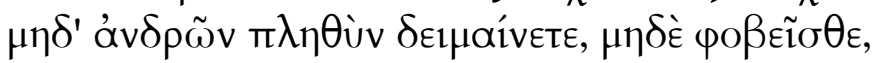

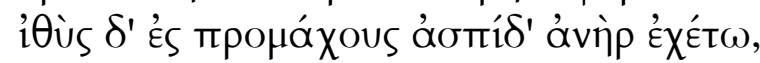

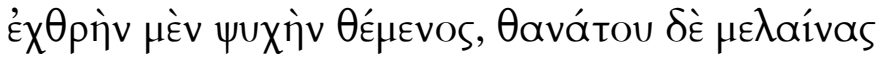

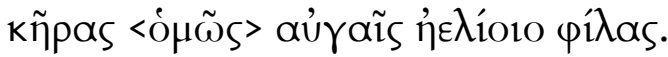

'ot

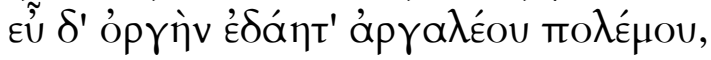

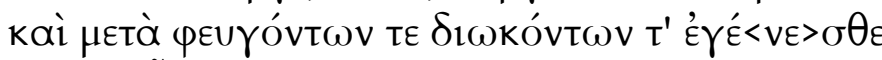

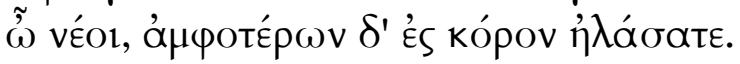

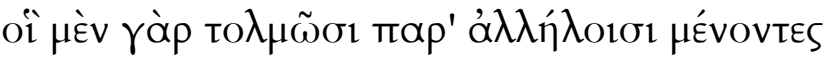

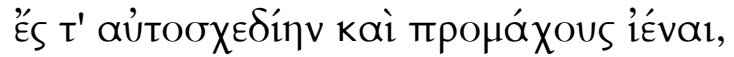

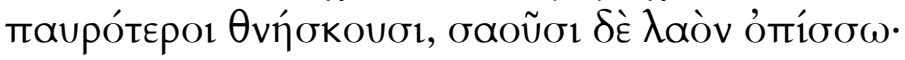

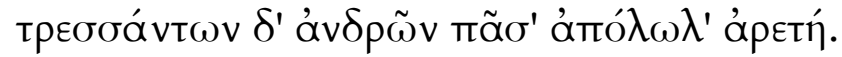

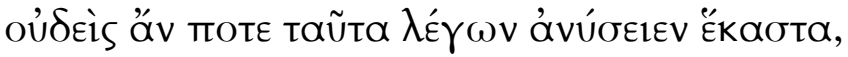

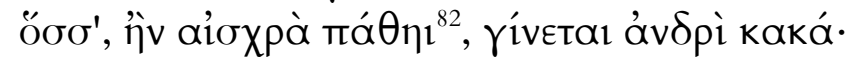

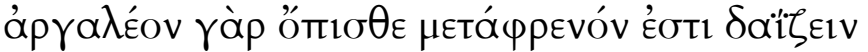

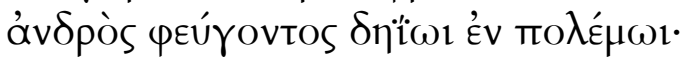

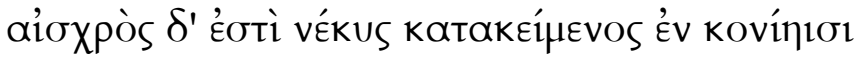

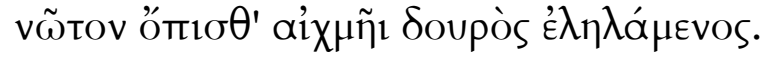

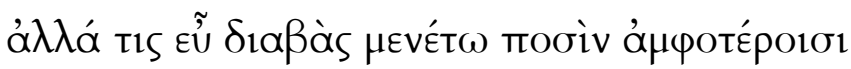

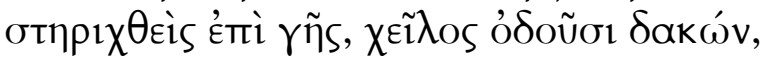

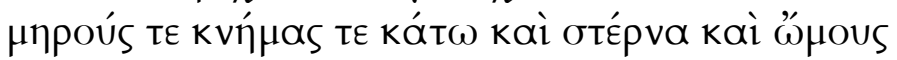

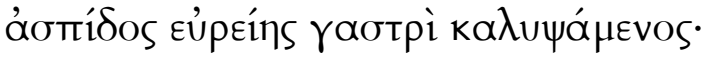

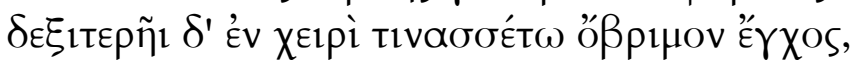

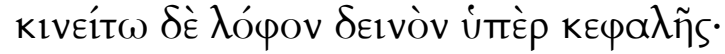

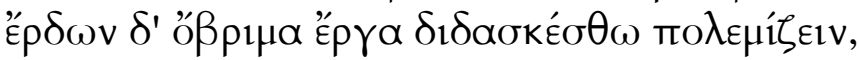

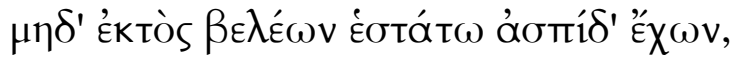

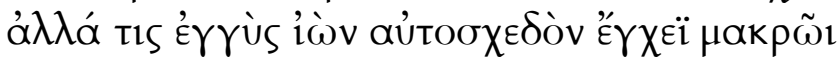

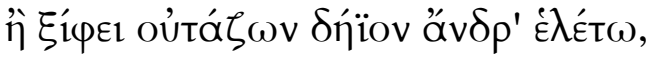

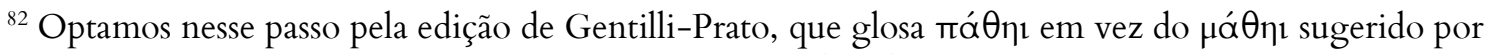
West, por motivos que explicitaremos nos comentários (p.99).
} 


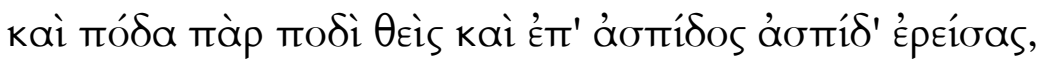

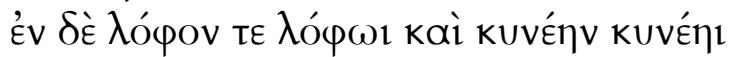

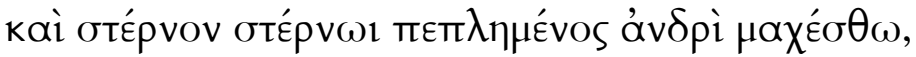

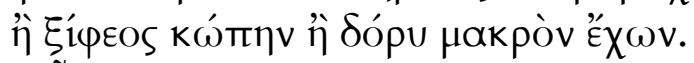

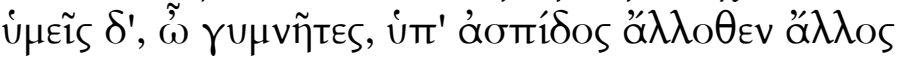

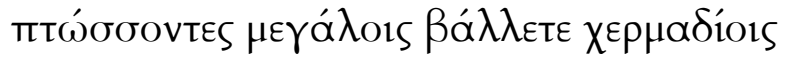

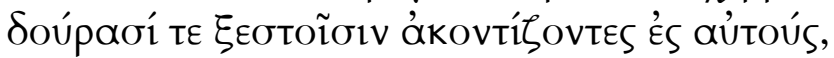

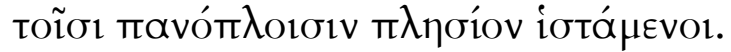

Mas porque sois da linhagem do invicto Héracles, coragem! Zeus ainda não virou as costas!

Não temais, não fujais da turba de guerreiros; que o varão avante contra os da vanguarda sustenha o escudo, tornando odiosa a vida e as Garras negras da morte tão amadas quanto os raios do sol;

pois sabeis que as proezas de Ares de muito pranto são destrutivas, bem conhecestes o furor da guerra atroz; estivestes entre os que fogem e os que perseguem, ó jovens, e de ambas as coisas vos fartastes.

Pois dos que se mantêm lado a lado e ousam ir à luta corpo a corpo e à vanguarda, menos morrem e salvam a tropa atrás; dos varões que tremem, toda a virtude perece.

Ninguém jamais terminaria de contar cada mal de quantos vêm ao varão que sofre ignonímia;

Pois é atroz trespassar as costas de um varão que foge na aterradora peleja

E é torpe um morto estirado na poeira, seu dorso ferido por trás com ponta de lança.

Mas que cada um fique bem firme, ambos os pés fixos ao chão, mordendo os lábios com os dentes!

As coxas e as canelas em baixo, o peito e os ombros cobrindo com o ventre do largo escudo, empunhe na mão destra a forte lança e temível a crina agite sobre a cabeça:

Fazendo fortes façanhas, aprenda a lutar e, sustendo o escudo, não fique longe dos dardos!

Que cada um avance ao corpo a corpo e mate o inimigo ferindo-o com longa haste ou gládio,

pé colocado junto a pé, escudo apoiando 
escudo, crina à crina, elmo a elmo

e peito a peito, lute perto de um varão

com cabo de espada ou grande lança em mãos.

E vós, de armadura leve, que se agacham aqui e ali

sob os escudos, lançai grandes pedras,

arremessando polidas lanças contra eles

e postando-vos perto dos que têm armadura completa.

O vocabulário é típico e há um dístico (vv.21-22) idêntico a outro do fragmento $10 \mathrm{~W} \cdot{ }^{83}$ Seu interesse particular reside em uma extensiva descrição do combate desempenhado pelos guerreiros que são incitados à guerra pelo poeta (vv. 12 -38), uma vez que a principal exortação do poema incide sobre as virtudes do combate corpo-a-corpo, um argumento sempre aludido em outros fragmentos ${ }^{84}$, mas que aqui recebe maior relevo. Nesse sentido, o fragmento $11 \mathrm{~W}$ pode trazer uma contextualização da maneira como a guerra era travada na poesia de Tirteu, e desse modo, elucidar questões concernentes ao modo de guerra no período arcaico.

Assim, durante a análise de elementos intrínsecos ao contexto do poema, pretende-se examinar também de que maneira as exortações feitas pelo poeta, as táticas e os equipamentos descritos podem contribuir para o delineamento da figura do guerreiro arcaico e do combate na poesia de Tirteu. ${ }^{85}$.

Por fim, consideraremos em que medida a descrição dos guerreiros e de suas

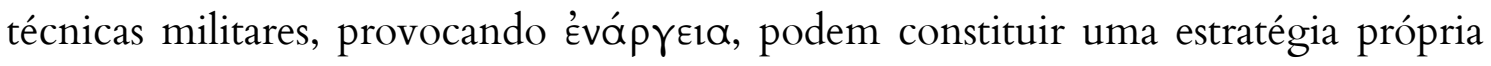
da elegia exortativa marcial para colocar seus interlocutores em posição de destaque.

\footnotetext{
${ }^{83}$ Bowra (1938, p. 51) observa que os três fragmentos exortativos de Tirteu (10, 11 e 12 W) apresentam diversas similaridades verbais entre si: o fragmento $12 \mathrm{~W}$ tem cinco frases que reaparecem de modo igual ou muito similar no fragmento $11 \mathrm{~W}$ e seis que reaparecem no fragmento $10 \mathrm{~W}$.

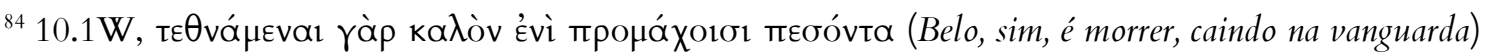

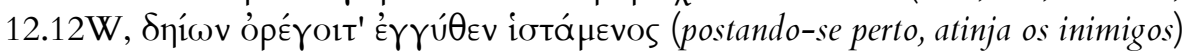

${ }^{85}$ Como se poderá notar pelo título, o escopo e recorte teórico empreendidos na análise desse fragmento têm em mente o estudo de Paula da Cunha Corrêa, Armas e varões, a guerra na lírica de Arquíloco, sobretudo o Capítulo 5: O modo de guerra heróico, onde a questão das táticas de guerra no período arcaico é observada minuciosamente, sobretudo no contexto do fragmento $3 \mathrm{~W}$ de Arquíloco.
} 


\section{Os filhos de Héracles vão à guerra (vv.01-02)}

Devido ao tom do poema, se considera que ele teria sido composto após um revés na Segunda Guerra da Messênia, de modo a encorajar os espartanos a não desistirem da luta e exortá-los a lutar sem temor. Bowra (1938, p. 56) chega até mesmo a imaginar um cenário em que os soldados, derrotados, põem-se a acreditar que os Deuses estariam contra eles, levando o poeta a afirmar-lhes uma ascendência divina no dístico inicial, como recurso para levá-los de volta à guerra.

A alusão mítica do início compõe, de fato, o alicerce da exortação dos dois primeiros versos. Recebem destaque no verso, por conta da sequência de sílabas

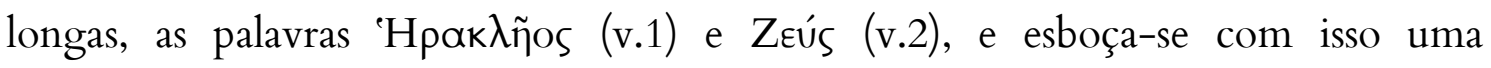
associação entre elas.

Tirteu parece, assim, realçar também na forma do poema a continuidade da linhagem divina de seus guerreiros usando as figuras de Héracles e Zeus. É a ascendência divina que garante a vitória: sendo descendentes de Héracles, os guerreiros espartanos compartilham também da mesma invencibilidade em combate, relembrada pelo epíteto óvikítos (v.1). A ascendência a partir desse herói também confere o amparo de Zeus, que dá a vitória como certa e determina a segurança do grupo.

O tema da intervenção divina - a imagem do Deus que, com um gesto, favorece ou prejudica os mortais - é largamente encontrado na poesia épica. A atuação dos Deuses e sua relação com os homens no decurso da guerra é matéria que concerne a toda a Ilíada (Assunção, 2001, p.63), e Tirteu poderia estar remetendo a

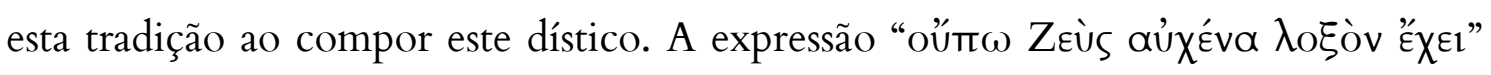
significa literalmente que Zeus “ainda não inclinou o pescoço", e o seu sentido é de que Zeus ainda não afastou os olhos dos espartanos (De Falco, 1941, p.172). Nesse sentido, alguns exemplos homéricos podem ser aduzidos por sua similaridade com o poema de Tirteu.

No canto 13 da Ilíada, Zeus, imaginando que nenhum outro imortal fosse contrariá-lo indo ao auxílio dos dânaos, permite-se voltar os olhos para longe de 
Tróia, e assim dá margem para um equilíbrio momentâneo de forças entre as tropas adversárias (Il. 13, 1-8):

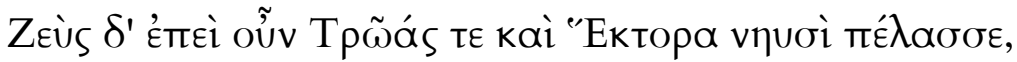

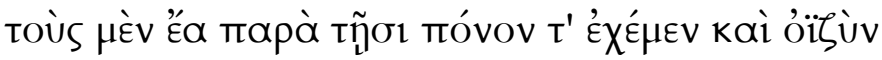

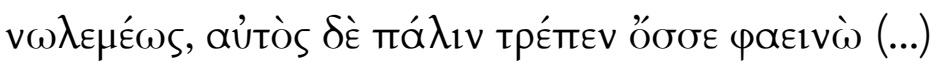

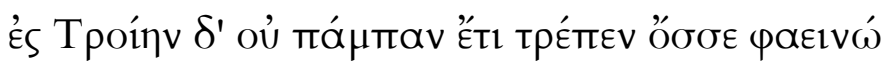

Depois que Zeus aproximou os Troianos e Heitor dos navios, deixou-os por lá para labutarem e sofrerem penas sem trégua, enquanto ele mesmo desviou os dois luzentes olhos (...) Para Troia de todo não mais voltou os dois luzentes olhos.

Deve-se lembrar, entretanto, que Zeus desempenha um forte papel em outros fragmentos da obra de Tirteu, além de a linhagem nobre dos espartanos já ser mencionada em um fragmento considerado parte da Eunomia, que a crítica tradicionalmente julga ter sido composta durante a crise que sucedeu à revolta messênica e exigira uma obra que ressaltasse a necessidade de seguir as leis estabelecidas ${ }^{86}$.

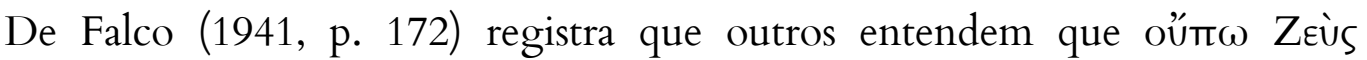

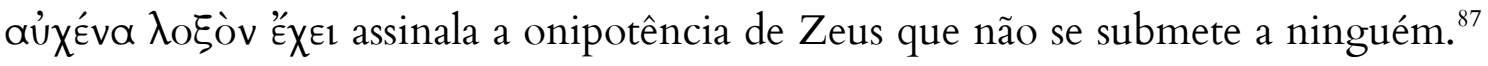
Tal argumento toma Teógnis (535-536) como exemplo :

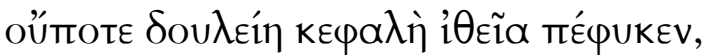

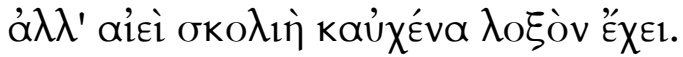

Nunca escrava cerviz nasce reta, mas sempre

\footnotetext{
${ }^{86}$ Ver os comentários ao fragmento $2 \mathrm{~W}, \mathrm{pp} .159-167$.

87 "Dizendo o poeta que Zeus não tem ainda o pescoço inclinado, quer significar, segundo alguns, que o deus é ainda onipotente" (De Falco, 1941). A leitura de Luginbill (2002, p.411), que verte a expressão por "Zeus não está com medo" parece seguir viés semelhante, influenciada sobretudo pelo trabalho de J.A.S. Evans (1962, p. 182-183). Fränkel (1975, p.156) lê do mesmo modo; a tradução inglesa para a passagem traz:"neither Zeus stand with his neck held awry".
} 
curva, e mantém o pescoço inclinado;

Fränkel (1975, p.156) acrescenta outra passagem do poeta da Teognideia (529530), para provar que é uma marca do escravo abandonar os amigos e ser indigno de confiança, justamente o oposto do que faz Zeus em relação aos espartanos :

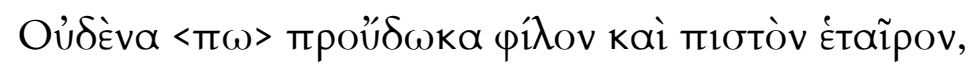

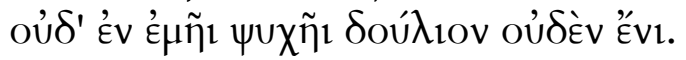

Nunca traí um amado e fiel companheiro nem escravidão alguma há em minha alma.

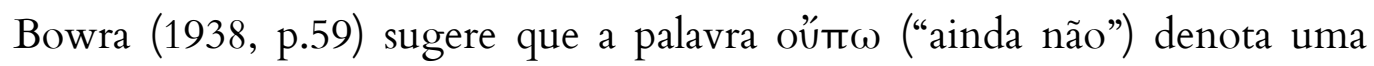
ocasião singular para o poema: sua performance se daria em momentos "em que as coisas não iam tão bem". ${ }^{88}$ Como procuramos demonstrar anteriormente, um recurso retórico comum na poesia elegíaca marcial, cuja ocasião principal e

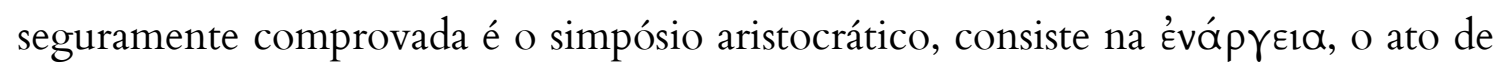
presentificar uma situação de guerra por meio de descrição vívida. Nesse sentido, o emprego de oúț $\omega$ poderia ter a mesma função que o advérbio vũv teria no último dístico do fragmento 12 de Tirteu ${ }^{89}$ : sugerir urgência ao colocar o cenário apresentado no poema diante dos olhos da audiência - uma audiência certamente em guerra, mas não necessariamente a caminho do combate (Ver Bowie, 1990, p. 223).

\section{A fuga e as virtudes do bom combate (vv. 03 -20)}

Tirteu desdobra o clamor por coragem do dístico inicial em uma exortação a manter o escudo nas linhas de frente do combate (трона́xous), armado com o escudo, em vez de temer o exército inimigo (vv.3-4). Em contraposição à coragem

\footnotetext{
${ }^{88}$ Bowra (1938, p.59) já assinala, contudo, o caráter genérico da elegia exortativa ao mencionar que Tirteu valia-se de procedimentos - como a utilização do imperativo presente, por exemplo - de modo a manter suas exortações sempre úteis para outras audiências.

${ }^{89}$ Ver os comentários ao fragmento $12 \mathrm{~W}, \mathrm{pp} .113-146$.
} 
evocada no segundo verso (Өápoєıт') há dois verbos que se referem ao medo:

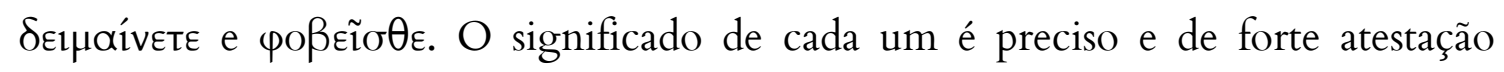
épica. Enquanto aquele, cuja raiz é confim ao verbo $\delta \varepsilon i ́ \delta \omega$ e ao substantivo $\delta \varepsilon ́ o \zeta$,

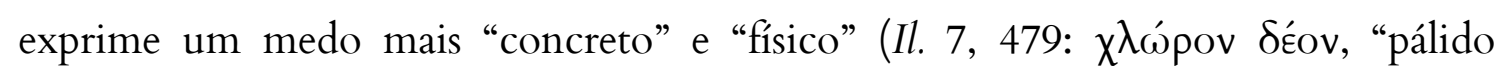
pavor"), $ф о \beta \varepsilon \tilde{\sigma} \sigma \varepsilon$ corresponde ao pânico que provoca a fuga desordenada e precipitada (Chantraine, 1968). Utilizados nesse sentido, ambos estão associados diretamente ao combate, e sugerem um vocabulário específico da guerra.

Desse modo, estes versos dão início a um discurso fundado nos aspectos mais realistas, pragmáticos e sombrios da guerra, como é comum em outros fragmentos de Tirteu (Luginbill, 2002, p.414). Trata-se de um cenário em que a fuga parece ser

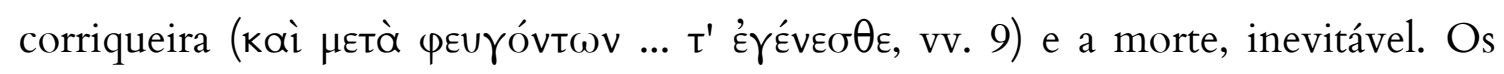
argumentos do poeta concentram-se nos versos 3 a 10, e introduzem uma tópica da elegia marcial, a da inevitabilidade da morte, cujo exemplo mais bem acabado talvez encontre-se em Calino de Éfeso (fr.1W, vv. 14-15) ${ }^{90}$.

Como faz alhures, Tirteu equaciona o pavor e a fuga ao apego à vida, afecção incompatível com a guerra, onde a morte é frequente ${ }^{91}$. Para se ter coragem de ir à frente do combate, não se pode temer perder a vida (Fr.10 W, 15-18):

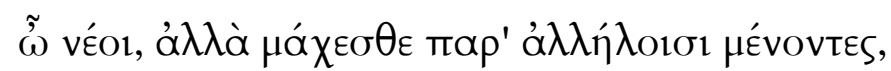

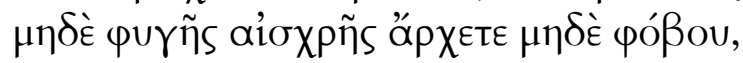

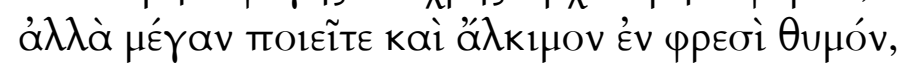

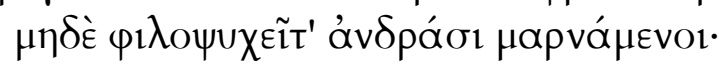

Ó jovens, eia, lutai, mantendo-se lado a lado, não inicieis a torpe fuga ou o pavor mas fazei grande e valente o ânimo no peito; não amai a vida, em luta com varões!

Para ilustrar essa tópica, Tirteu elabora uma construção em quiasmo

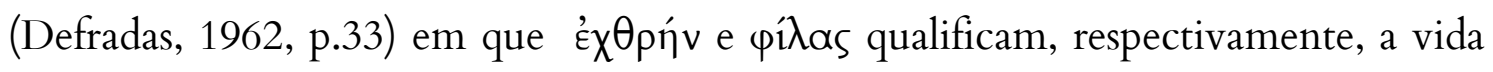

\footnotetext{
${ }^{90}$ Ver comentários ao fragmento 10W (pp.63-64) para outros exemplos dessa tópica na elegia grega arcaica.

${ }^{91}$ Ver Assunção 1997, p. 36.
} 


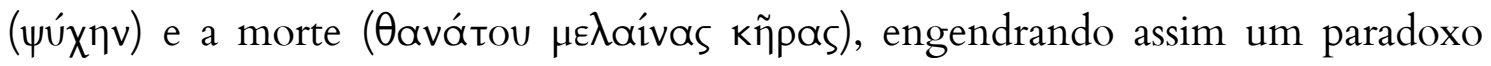
(Martino e Vox, 1996, p. 565). ${ }^{92}$ Tal paradoxo é posto em evidência, pois, como mostra Defradas (1962, p.34), o dístico é enquadrado pelas duas palavras que se

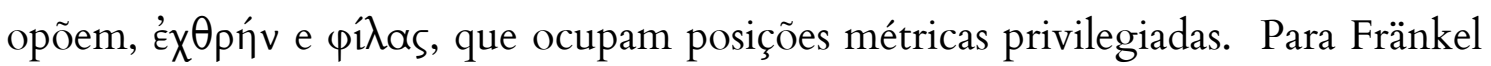
(1975, p.157) o paradoxo se resolve nos versos seguintes: O homem que vai à frente e luta corpo a corpo tem mais chances de sobreviver ${ }^{93}$. Nesse sentido, nota-se que o paradoxo se dissolve porque o poeta tem em vista neste poema a coletividade, e não o guerreiro singular- "menos morrem, e salvam a tropa atrás".

De Martino e Onnofrio Vox (1996, p. 565) assinalam que estes versos trazem certas reminiscências da poesia amatória, conforme praticada por Mimnermo; "A negra Kíp assedia tanto ao militar quanto ao amante" (Mimnermo, Fr. 2 W, 1 - 7 :

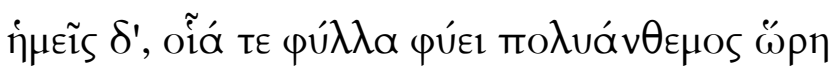

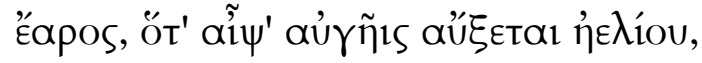

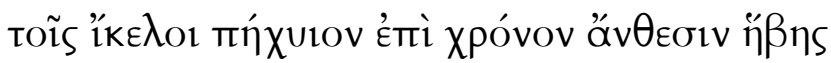

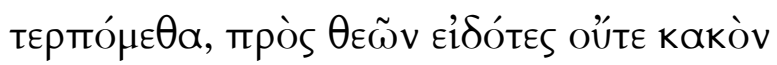

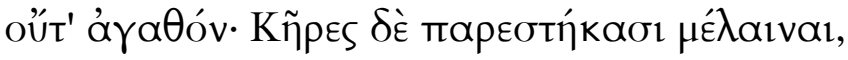

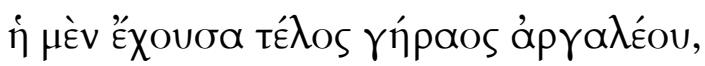

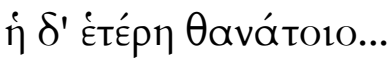

"Nós, quais as folhas da multiflórea estação da primavera quando aos raios de sol de pronto viçam, iguais à elas em breve tempo fruímos das flores

\footnotetext{
${ }_{92}$ Pois Defradas (1962, p.34) observa que a cor negra e a obscuridade estão frequentemente ligadas à noção de morte (Ver Il.11.332) e a noção de sol e luminosidade, à vida (Ver Il.18.442), e o homem por natureza ama a vida e odeia a morte ( Ver Il.12.231). Ver também Mimnermo $1 \mathrm{~W}$.

${ }_{93}^{93}$ De Martino e Vox (1996, p.585) relembram nesse verso uma passagem de Arquíloco, que traz, também, uma contagem dos mortos (Fr.101 W):

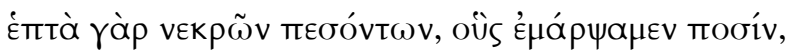

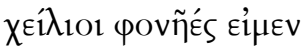

Dos sete corpos caídos, contra os quais investimos à pé, somos em mil os assassinos.
} 
da juventude, inscientes do bem e do mal

que vêm dos Deuses. Mas Sinas negras se aproximam:

uma, trazendo o termo da dura velhice;

outra, da morte. (...)"

Se pensarmos dessa maneira, a riqueza de detalhes na descrição do corpo do guerreiro nos versos 23-24 também relembraria aquela de fragmentos eróticos como os de Arquíloco ou Anacreonte. (Martino e Vox, 1996, p. 565). Tal identidade entre as imagens dos poemas de Tirteu e Mimnermo pode remeter ao contexto de performance da elegia - o simpósio - que identifica seus interlocutores como jovens na plenitude guerreira e sexual (Slings, 2000, p.433).

$\mathrm{O} \tilde{\eta} \theta$ os dos interlocutores de Tirteu é o do guerreiro experiente: homens que não só conhecem as "obras destrutoras de Ares de muito pranto" e o "furor da guerra atroz" (vv. 6-7), mas que vivenciaram a fuga e a perseguição e sabem que a guerra e a morte são inescapáveis (Bowra, 1960, p.56).

O poeta demarca a experiência de seus interlocutores na guerra por meio da

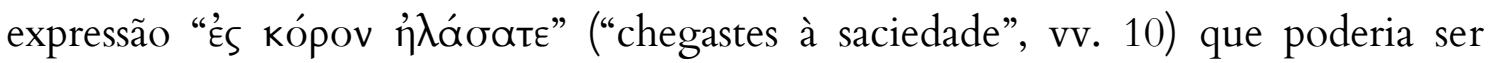
corrente e proverbial (De Falco, 1941, p.175). O termo kópos, como em Homero, indica um limite natural e absoluto de uma atividade que, quando cumprida, causa seu fim (Irwin, 2005, p.212). A palavra não é necessariamente vista de modo negativo na tradição poética arcaica, tendo recebido as primeiras conotações pejorativas apenas na poesia de Sólon (Irwin, 2005, pp. 216-217).

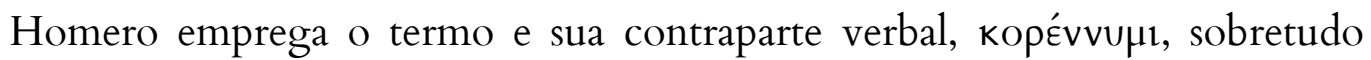
para a comida ou a bebida; mas esse sentido de satisfação alimentar facilmente acaba se estendendo a outros desejos humanos - como o amor, o canto e a dança (Il.13.636-639) - e mesmo experiências desagradáveis, como o lamento, a guerra e a batalha (Ver Helm, "Koros: from satisfaction to greed", 1993, p.5-6). Nesse sentido, kópos pode relacionar-se tanto ao cumprimento de um desejo, do qual decorre um sentimento benéfico, como a uma experiência desagradável, que apenas cessará 
quando se chegar ao seu limite que, portanto, deve ser alcançado o quanto antes (Helm, 1993, p.7).

Desse modo, alcançar o kópos da fuga e da perseguição acena não só para uma situação comum na guerra e para a experiência desses combatentes, como também pode significar que a única alternativa para eles é o combate homem a homem - situação oposta tanto à fuga quanto à perseguição, cujo "limite" já foi alcançado.

Os próximos versos ocupam-se de descrever as implicações morais (vv.11-16) e físicas (vv. 16- 20) da fuga (Martino e Vox, 1996, p.565). Notaremos que o poeta não condenará a fuga por esta representar a quebra de uma formação tática rígida, uma vez que as exortações dirigidas aos seus interlocutores parecem assinalar um tipo de combate que admite certa mobilidade. Segundo Snodgrass (1965, p. 115116), os poemas de Tirteu retratam um estágio rudimentar da falange hoplítica: embora a panóplia tenha sido adotada em larga medida, isso não necessariamente correspondeu a uma uniformização das técnicas. Tal ausência de uniformização é também patente nos poemas de Homero, onde coexiste a luta em formações compactas, reunidas para ataque ou defesa, e duelos em que predominam a livre movimentação de guerreiros pelo campo de batalha (Corrêa, 2009, p. 78). Van Wees (2004, p. 166) ainda acrescenta que o combate de infantaria arcaico era, em muitos aspectos, mais próximo dos embates retratados por Homero do que às lutas em formação hoplítica do período clássico.

Dessa maneira é pertinente pensar em aproximações entre o fragmento 11 de Tirteu e o modo de batalha descrito nos poemas homéricos: as exortações para

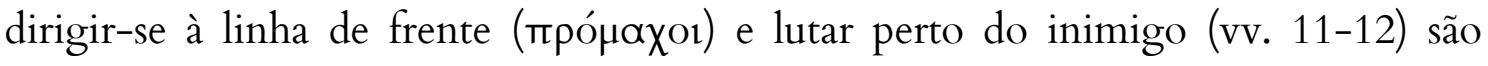
indícios de que os hoplitas que tomam parte desse combate são mais móveis de que seus sucessores, pois não tinham um lugar determinado em uma formação compacta (Van Wees, 2004, p. 172). Há também a valorização do combate corpo a corpo

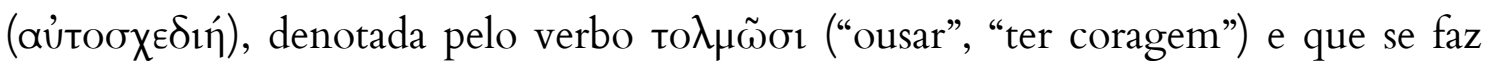

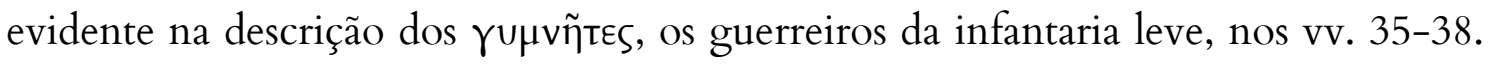


A mesma mobilidade é aludida por Mimnermo, contemporâneo de Tirteu (Van Wees, 2004, p.173), em um fragmento da Esmirneida (Fr.14 W):

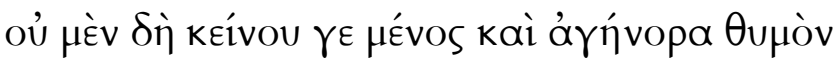

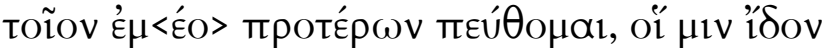

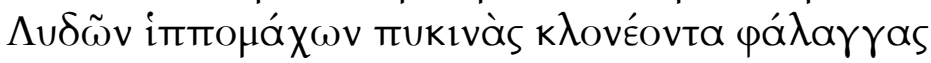

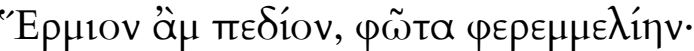

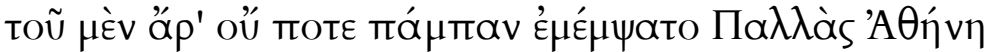

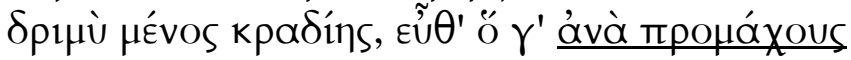

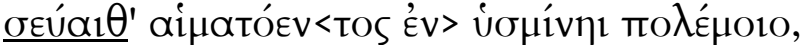

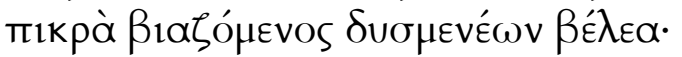

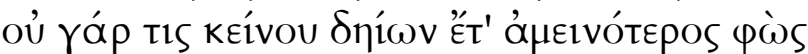

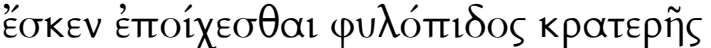

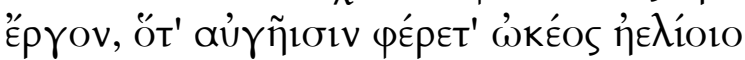

não é o ardor daquele homem e seu heroico ânimo

o qual de meus ancestrais aprendi, que o viram

romper dos cavaleiros lídios as sólidas falanges

na planície do Hermo, homem porta-lança.

A ele nunca de todo reprovou Palas Atena

o pungente ardor do peito, enquanto à frente

ele avançava no combate da sangrenta guerra

repelindo afiados dardos de inimigos.

Nunca os inimigos eram melhores do que ele

ao atacar, na tarefa da violenta guerra,

enquanto ele lançava-se com os raios do rápido sol.

Assumindo que Tirteu se refere a uma falange sem a mesma unidade estratégica que a caracterizará no período clássico, que sentido pode haver em пар'

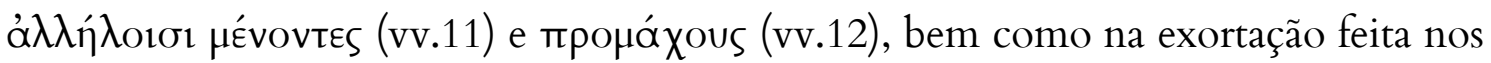
versos 21-22 (“Mas que cada um fique bem firme, ambos os pés /fixos ao chão, mordendo os lábios com os dentes"), que parecem ser admoestações aos guerreiros na falange? A hipótese de Van Wees (1994, pp.142-143) é de que estas ordens, embora adequadas ao hoplita por conclamarem as virtudes da formação cerrada e do corpo a corpo, também não são estranhas no campo de batalha homérico. 
O termo про́ $а \propto \chi 01$ pode ser utilizado para designar a primeira fileira da falange hoplítica ${ }^{94}$, não correspondendo exclusivamente a um modo de luta homérico. Em sua visão sobre o combate na Ilíada, Latacz (1977, apud Van Wees, 1994, pp. 5, 6) demonstra que Homero sempre sugere a presença de combatentes

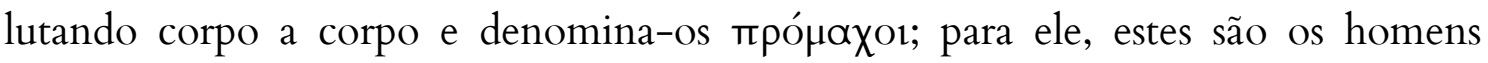
posicionados na primeira fila da formação, que dão um passo para fora da fila para engalfinhar-se com os campeões adversários e depois retornam às suas posições iniciais, quando por fim exortam suas tropas a começar os ataques em massa.

Van Wees (1994, p.7-9) e Corrêa (2009, p. 78) argumentam não haver uma sequência determinada no combate arcaico: a luta em massa e a luta individual retratam uma mesma coisa sob perspectivas distintas. Isso leva a pensar que os трóнахо1, em Homero, representam uma formação fluída: não passam de guerreiros que em dado momento da guerra engajam-se no combate corpo a corpo e retornam à turba ( $\pi \lambda \tilde{\eta}$ Toऽ) que está atrás quando bem entendem, para descansar ou recuperar-se de ferimentos (Van Wees, 1994, p.7).

Assumindo que por трó $а \propto \chi 01$ Tirteu está se referindo aos seus próprios guerreiros e não à linha de frente adversária, pode-se concluir que o modo de luta descrito pelo poeta de fato é similar ao de Homero, caracterizado pela mobilidade individual e a heterogeneidade de técnicas, que se pode verificar também na variedade de usos para os equipamentos: na guerra - descrita por Homero e Calino como um "estridor de dardos" - é comum a utilização de lanças tanto para o arremesso (vv. 28, 37) quanto para investidas. A advertência para lutar na frente, então, também sublinha o emprego de armas de luta corpo a corpo como a lança ou espada (vv.29-30, 34) em detrimento das armas a distância.

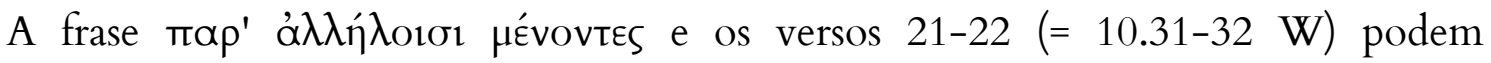
significar uma advertência aos guerreiros para permanecerem em suas posições nas fileiras, em vista de maior eficácia tática. Para Snodgrass (1965, p.115) as exortações de Tirteu para manter uma formação cerrada eram necessárias justamente por não

\footnotetext{
${ }^{94}$ Anderson (1984, p.152) sugere que o termo pode ser simplesmente um "substituto poético" para o técnico protostates, o hoplita que luta na primeira fila.
} 
haver a unicidade de táticas e equipamentos do período clássico. Van Wees (1994, p. 141), sendo da opinião de que Tirteu retrata um combate caracterizado pela mobilidade do mesmo modo que Homero, apresenta um exemplo da Ilíada para

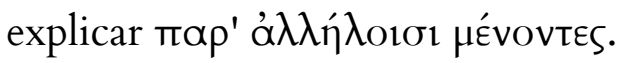

No Canto 5, Eneias, embora valente, recua diante de Menelau e Antíloco, que se

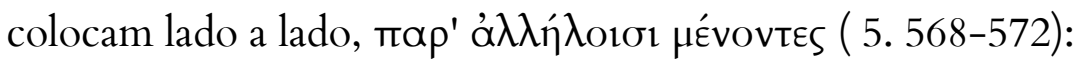

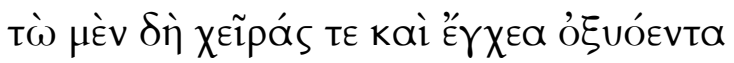

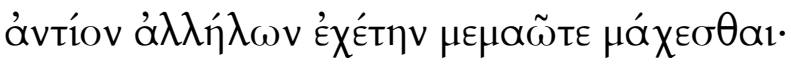

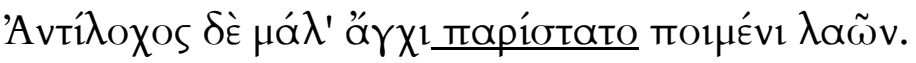

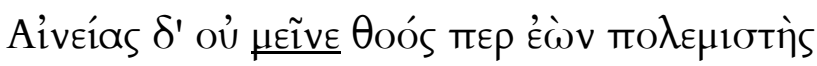

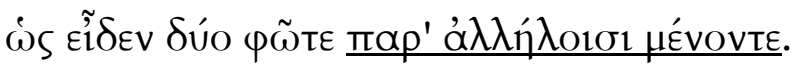

Os dois tinham os braços e as lanças pontiagudas um contra o outro, com o propósito de lutar:

Mas Antíloco postou-se muito próximo ao pastor de tropas,

e Eneas não permaneceu, embora fosse um ágil guerreiro, quando viu os dois homens lado a lado.

O autor postula que o valor do auxílio mútuo não é uma característica exclusiva da falange hoplítica, mas já está presente na Ilíada: Homero

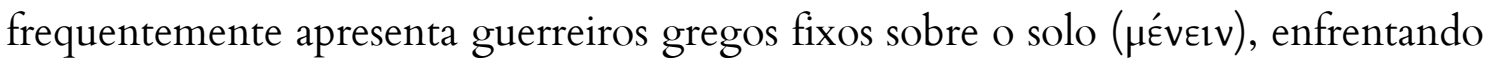
uma investida adversária, e realça a prontidão com que os heróis gregos assistem uns aos outros na batalha, habilidade ausente nos troianos (c.f. Il. 5, 497-498; 11.348; 13.150-151; 835-836; 16.312; 367-369; 405-407). ${ }^{95}$

Assim, de acordo com Van Wees, o contexto do fragmento 11 parece revelar antes um contraste: as exortações para permanecer lado a lado (v.11), ir ao combate corpo a corpo (vv.12) e manter-se fixo sobre o solo (vv.28-29 = 10.31-32) opõem-se

\footnotetext{
${ }^{95}$ Opinião com a qual não estamos plenamente de acordo. Ver, por exemplo, a organização das tropas troianas em Il.12. $80-107$.
} 
à situação da fuga e pavor descritos e condenados nos versos 1 a 10 , e não contradizem necessariamente a mobilidade de cada guerreiro que o combate aberto propicia. Destarte, Tirteu não alude categoricamente a nenhuma forma de combate nestes versos: tudo que ele está dizendo é que não se deve agir covardemente e sim, permanecer na luta. (Van Wees, 1994, p.142). Nota-se que oposição similar se desenvolve na segunda parte do fragmento $10 \mathrm{~W}$ (vv.19-32).

Os versos 19-20 do fragmento $10 \mathrm{~W}$ remetem diretamente a $10.31-32 \mathrm{~W}$, sendo intercalados por um juízo moral (aíoxpòv, “é torpe”,vv.21-22) que decorre da consequência da fuga dos jovens (nesse poema, a morte hedionda dos guerreiros veteranos), uma descrição vívida da situação dos guerreiros mais velhos abandonados no campo de batalha (vv.23-27) e a prerrogativa dos jovens na guerra (vv.27-30).

As visões de Van Wees e Snodgrass, porém, não são excludentes, mas se complementam: mesmo Homero dá mostras de reconhecer uma formação tática que se assemelha às falanges, bem como retrata os combates singulares em momentos cruciais da batalha (Corrêa, 2009, p. 78). Tirteu retrataria esse mesmo universo guerreiro de Homero, somando-lhe alterações que ocorreram gradualmente, como a introdução do escudo hoplítico, em vista de uma tática de combate mais orientada para a luta corpo a corpo. As diferenças aparentes são decorrências da estrutura de cada poema: uma vez que os poemas de Tirteu são exortações à luta que estão condensadas na forma mais breve da elegia, é natural que sejam realçados apenas os elementos que interessam ao contexto do poema - a luta corpo a corpo e a imobilidade em combate, opondo-se à fuga, enquanto a narrativa homérica pode empreender um quadro mais completo das táticas de batalha (Van Wees, 1994, p.142).

As consequências da fuga são expostas nos versos 14 a 20 e suas implicações estão de acordo com o pensamento grego tradicional (Luginbill,2002,p.411) e o vocabulário ético de outros fragmentos de Tirteu. $\mathrm{O}$ verso 14 conclui a oração iniciada em 11, desenhando outro contraste, reforçado pela construção $\mu \mu^{\varepsilon} v(. ..) \delta$,́,

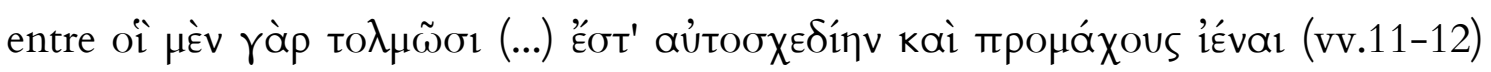

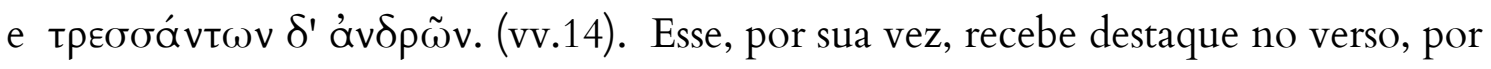


conta da pausa no final de 13 e pela sequência de sílabas longas que

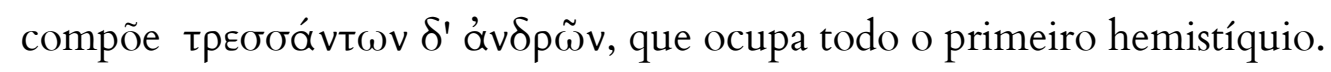

Tal recurso - enfatizar certas palavras com sílabas longas e colocá-las em posição inicial - é um mecanismo poético frequentemente utilizado por Tirteu (Adkins, 1977, p. 84). O procedimento parece conferir impacto à sentença e realçar ainda mais a oposição que o poeta desenvolve nos versos, sublinhando o aspecto negativo que é argumento central do poema, a fuga. O mesmo se dá com ávópòs peúrovtos no verso 18.

O homem que foge perde a sua ópєtí. A afirmação tem tom de máxima e faz parte de uma filosofia de vida que tem papel considerável no pensamento grego (Bowra, 1938, p.60). Tirteu utiliza uma concepção de ápєtń comum aos poemas homéricos: o poeta não se refere a uma qualidade abstrata ou uma virtude aplicável a todas as atividades humanas, mas a qualidades excepcionais inatas (Finkelberg, 1998, p.20), como a força ou a beleza. Nesse sentido, a ápєtí que Tirteu observa nesse verso é unicamente o valor militar.

Campbell (1982, p.173) observa no verso 14 um paralelo da Odisseia onde

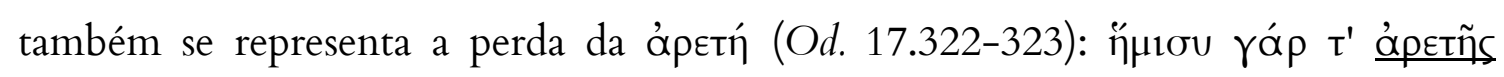

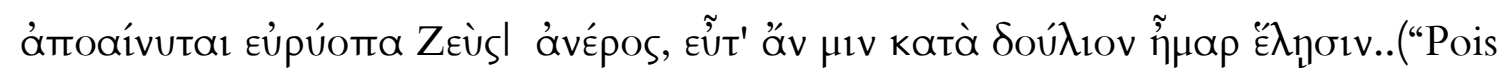
Zeus amplividente extrai metade da virtude/ de um varão, quando o dia da escravidão o submete"). A ápєtí, entretanto, não possui o sentido de valor marcial nesta passagem da Odisseia: para Finkelberg (1998, p.19), segundo o Lexicon Homericum de Ebeling, a passagem tem uma clara conotação moral e designa virtude, embora esse sentido seja raro em Homero. De acordo com o contexto do poema de Tirteu, esta ápєtí militar consiste justamente na luta corpo a corpo nas primeiras linhas; De Falco (1941, p.176) conta-nos uma anedota de Estobeu (4.9.11) sobre

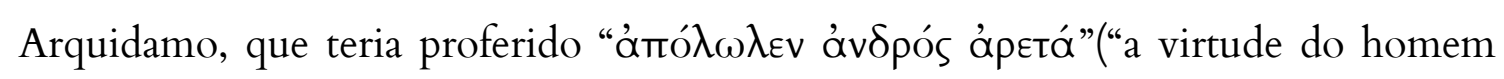
está morta”) ao ter visto armas de longo alcance trazidas da Sicília, que significariam o fim dos combates corpo a corpo.

O autor ainda se vale de outro dístico de Teógnis que traz ideia similar aos dos versos 13 e 14 (v.867-868): 


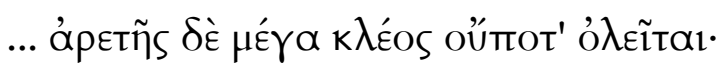

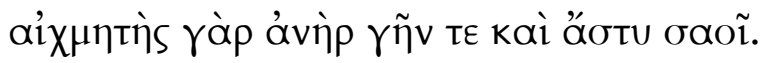

...Da virtude a grande glória nunca perece:

um varão lanceiro salva terra e cidade.

Em outras palavras, a noção de ỏpetí no poema em questão prende-se antes a uma idéia de mérito (Defradas, 1962, p.34) que advém das habilidades na guerra, justamente aquelas que Tirteu retratará no fragmento $12 \mathrm{~W}$. E essa habilidade não é outra senão a $\theta$ oũpıs á $\lambda_{k} \eta ́$ mencionada em $12.9 \mathrm{~W}$, qualidade que na Ilíada define o bom guerreiro ${ }^{96}$ e que muitas vezes aparece como um antônimo para a fuga ${ }^{97}$, mas que apenas na poesia de Tirteu é mencionada explicitamente como uma virtude. ${ }^{98}$

Para Adrados (1990, p.136) os versos 10 a 14 trazem outra alusão homérica, ou ao menos um argumento confim que é reutilizado no discurso de Tirteu. Tratase do momento em que Ájax Telamônio dirige-se ao exército grego, exortando (Il. 15.561-4):

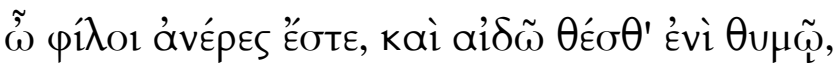

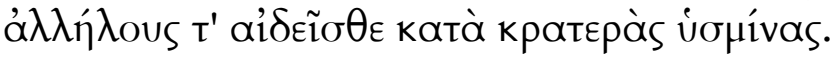

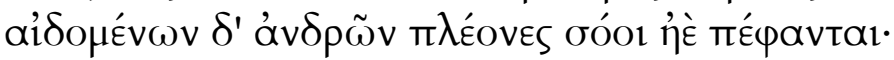

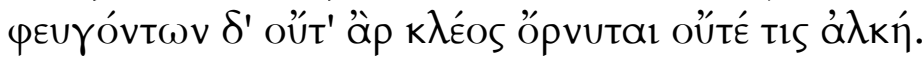

Amigos, sede homens e um bravo coração retende, mostrai respeito uns aos outros nos possantes prélios: De varões que se respeitam, mais se salvam do que morrem! Dos que fogem, não advêm nem glória nem bravura!

West (2011, p.165) também cita essa passagem, definindo-a como "um lugar-comum exortativo" e menciona outras passagens da Ilíada que parecem

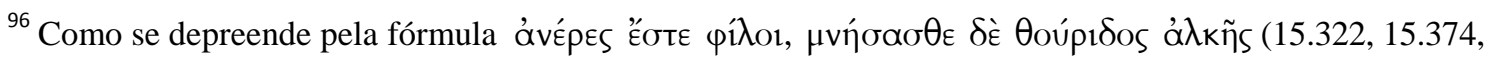
17.185 , etc.).

${ }^{97}$ Ver pp.130-131.

${ }^{98}$ Pretende-se uma análise mais detalhada do conceito de ápєtí no capítulo seguinte.
} 
delimitar um contraste entre avançar para as primeiras linhas do combate ou recuar. Assim, Diomedes, em um momento desfavorável da batalha, em face de um Heitor completamente tomado pelo furor da luta - incita Odisseu a resgatar Nestor em apuros, argumentando que ir às linhas de frente é melhor do que a vergonha de ser golpeado pelas costas (Il. $8.93-100)^{99}$ :

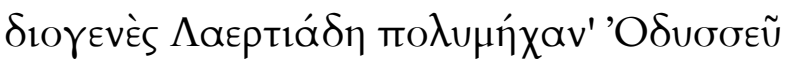

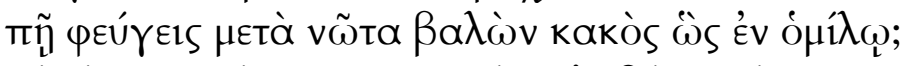

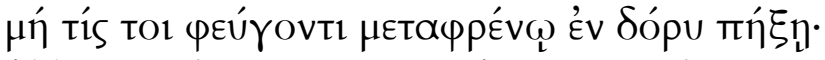

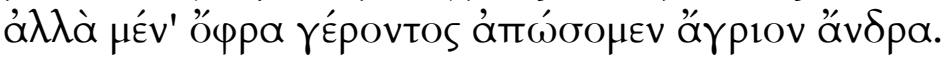

' $\Omega \varsigma$ '̌́

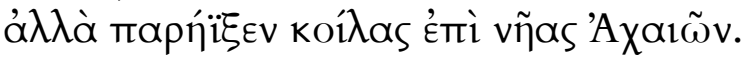

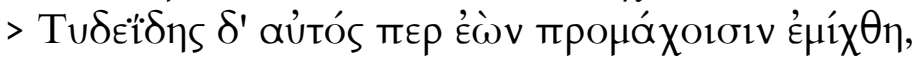

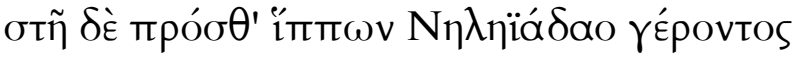

Laercíade divino, Odisseu de muitos engenhos,

P'ra onde foges, virando as costas como um covarde, em meio à turba !?

Que uma lança não te pegue nas costas, enquanto foges!

Mas vamos, a fim de afastar do ancião o guerreiro feroz!

Assim falou; e não lhe deu atenção Odisseu divino e pertinaz,

mas se apressou até os navios côncavos dos Aqueus.

E o Tidida, mesmo estando sozinho, misturou-se aos da vanguarda,

postou-se na frente dos corcéis do Nelida ancião.

A ligação entre os versos da Ilíada e os versos 11-14 do fragmento 11 W está em como o guerreiro se porta nas linhas de frente do combate. Nenhum paralelo verbal é identificado, exceto por oóor e бaoṽol. Nesses termos, pode ser que o paralelo seja apenas fortuito, e sua similaridade se deva ao andamento da argumentação, uma vez que o tema é o mesmo: uma exortação para lutar na frente em vez de fugir.

É interessante notar ainda o uso de ópetí em Tirteu no lugar de $\kappa \lambda$ éos e à $\lambda_{k}$ d́ do verso 564 do canto 15 da Ilíada. Tal uso porém não deve surpreender: na poesia de Tirteu (12.9 W) à $\lambda k \eta ́$ é quase um sinônimo para à como uma virtude indispensável para o guerreiro.

\footnotetext{
${ }^{99}$ Ver também Tirteu 11.17-20 W, abaixo.
} 
Os versos 15-16 aludem às incontáveis desgraças que acometem o homem que foge, mas o poeta não se detém sobre elas tal qual faz no fragmento 10 (vv.310). Em vez disso, se ocupará de descrever uma cena de combate (Fränkel, 1975, p. 158).

A maioria das edições e comentários (Klotz 1767, Francke 1816, Bach 1831, Diehl 1952, Prato 1968, Adrados 1990) traz no verso 16 a expressão “ìv aíoxpà

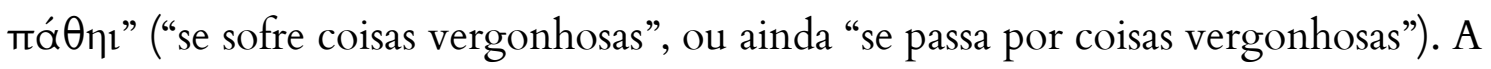
expressão é um eufemismo para uma conduta vergonhosa, isto é, a própria fuga, já mencionada nos versos anteriores (Campbell, 1982, p.173). O uso de rá $\theta \eta 1$ nesse contexto, porém, é incomum na lírica grega arcaica (Prato, 1968, p. 107) e talvez

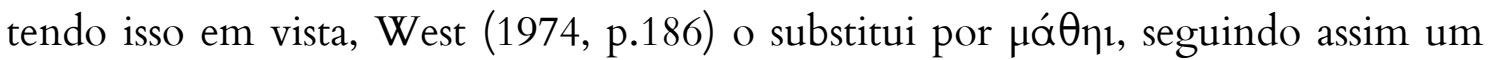
antigo questionamento de Page (1951, p.13): "Há alguém ainda satisfeito com

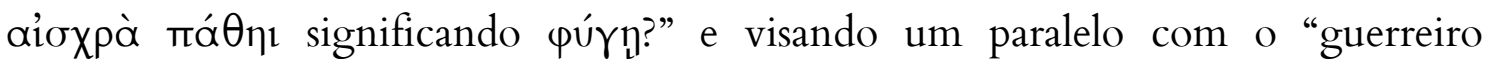
aprendiz de fortes façanhas" do verso 27.

Para o editor, o verso 444 do Canto 6 da Ilíada justificaria a sua opção por

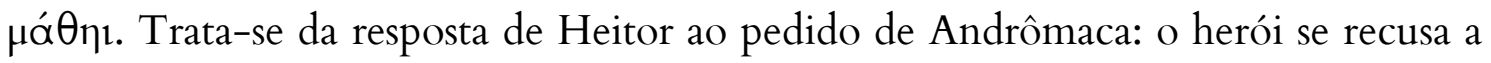
permanecer na cidade e opta pela luta entre os dianteiros, uma vez que "aprendeu a

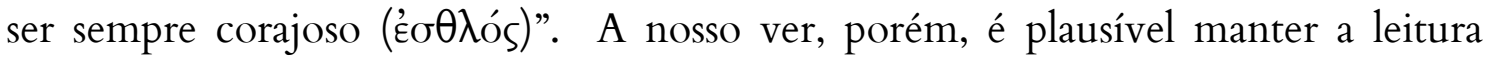

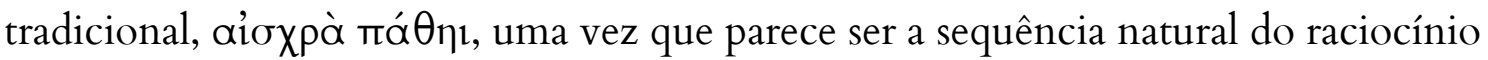
exposto no verso 14: não é estranho supor que o homem que "passa por coisas vergonhosas" é aquele mesmo que "fugiu do combate e perdeu toda a sua virtude".

Os versos 15-20 compõem uma unidade: enquanto os vv.15-16 fazem uma constatação geral e ostentam uma construção análoga aos catálogos épicos ${ }^{100}$ (De Martino e Vox, 1996, p.565), os vv.17-20 desenvolvem-no (observe-se, nesse sentido, a partícula explicativa rá $\rho$ conectando os dísticos), revelando alguns desses

\footnotetext{
${ }^{100}$ Nesse sentido, Álcman parece se utilizar de um recurso retórico similar no seu Partênio (1 PMG):a beleza de Hagesícora não pode ser reproduzida em palavras. No poema em análise, são os males incontáveis que Tirteu se furta de contar. Mesmo assim,ambos fazem suas descrições: $\tilde{\eta}$ oủx ópñı; ó

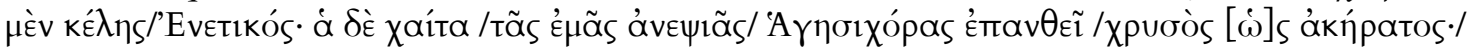

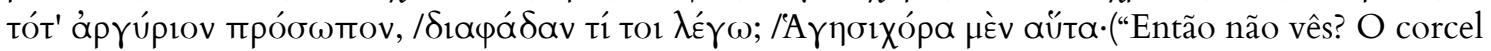
él enético; mas a sedosa melenal da minha primal Hagesícora brilhiflorescel [c] omo ouro imaculado; e a argêntea face - I por que abertamente te falo? I Hagesícora: é esta." - Tradução de Giuliana Ragusa, 2010)
} 
males inescapáveis numa espécie de preterição. Um, é de ordem prática: quem dá as costas para o combate pode ser atingido. O outro, de ordem moral: é vergonhosa a visão de um guerreiro morto pelas costas, pois tal tipo de morte revela covardia e é oposta à ápєtí do guerreiro, que granjeia renome e é representada por Tirteu no

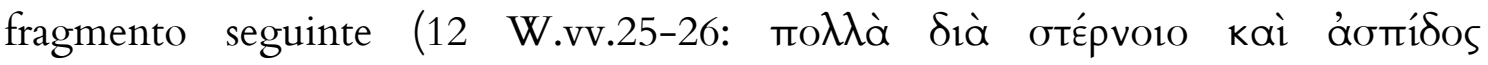

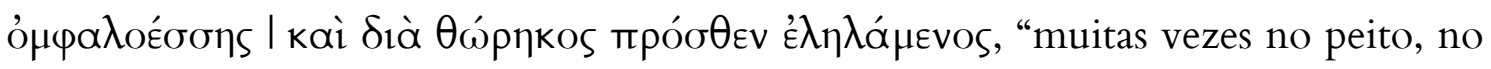
escudo umbilicado/ e na couraça golpeado de frente.").

As palavras utilizadas são comuns ao vocabulário ético de Tirteu: o termo usado aqui é novamente aioxpós, palavra ambivalente que sugere tanto a torpeza moral quanto física. Nesse sentido, Tirteu apela para uma motivação negativa - o sentimento de vergonha, aíó́s - para que seus interlocutores partam para a luta, como é frequente em outros de seus fragmentos (Luginbill, 2002, p.410).

A dificuldade da passagem está no termo åpra $\alpha$ Éov (vv. 17). O termo é comum nas exortações de Tirteu, e utilizado para designar as vicissitudes da guerra (11.8 W, 12. $28 \mathrm{~W})$, mas se crê em corrupção do manuscrito original, já que o uso

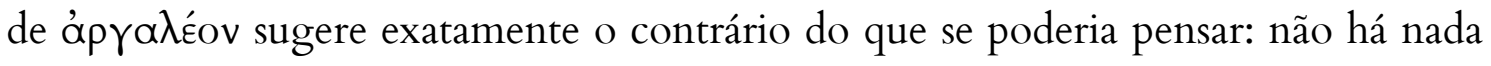
de difícil ou grave em atingir um inimigo pelas costas. Assim Diehl conjectura

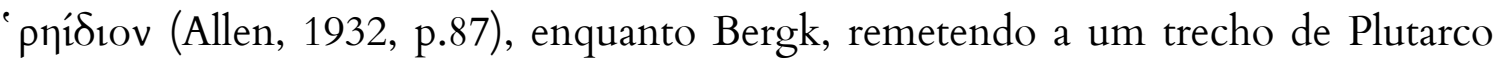
(Vida de Licurgo, 22) sugere a lição 'píra $\lambda$ Eov (desprezível), uma vez que os gregos não consideravam um ato nobre ferir alguém que foge (apud De Falco, 1941, p.177). Allen (1932, p.87),por outro lado, opta por á $\varepsilon \rho \gamma \eta \lambda \varepsilon ́ o v($ não trabalhoso) em sinízise. Campbell (1982, p.174) refuta a correção de Allen, alegando que a palavra é atestada apenas na poesia alexandrina e em um poema mélico anônimo (PMG 996).

Ahrens (1848, pp. 223-237) propõe åpra $\lambda$ Éov (“é agradável”), e essa é a leitura mais aceita, tanto do ponto de vista paleográfico quanto do contexto do poema, por deixar mais evidente o nexo entre os versos 15-16 e 17-20. Para Page (1951, p.13), a correção não é considerada satisfatória e West (1974), da mesma opinião, mantém a leitura contida no manuscrito original, embora julgue que “certamente Tirteu não tinha aversão de ferir nas costas um adversário que foge" (2000, p.403). Defradas (1962, p.35) observa que, caso seja conservado o termo 
original, deve-se entendê-lo no sentido de "lamentável", ou "doloroso". ${ }^{101} \mathrm{O}$ sentido, porém, não é habitual. ${ }^{102}$

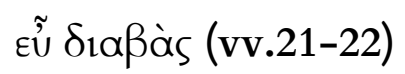

Os versos 21-22 constituem um dos dísticos mais bem construídos de Tirteu.

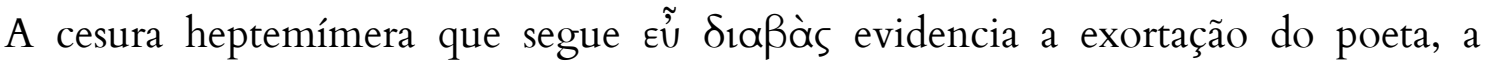
palavra $\mu$ Évet $\omega$, que ocupa o centro do verso. No início do verso seguinte,

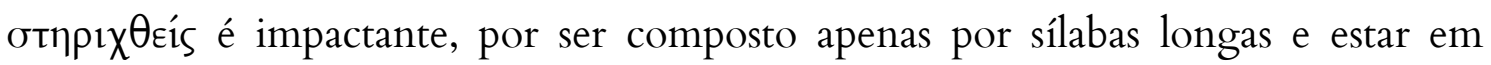
início de verso (Adkins, 1977, p.83-84). Dessa maneira, Tirteu parece salientar a necessidade de os guerreiros se manterem em uma posição fixa, contrapondo-a ao

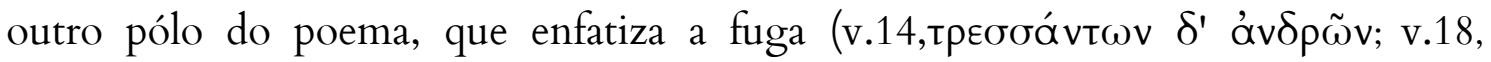

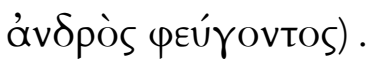

A maioria das palavras utilizadas nesses versos é incomum em Homero;

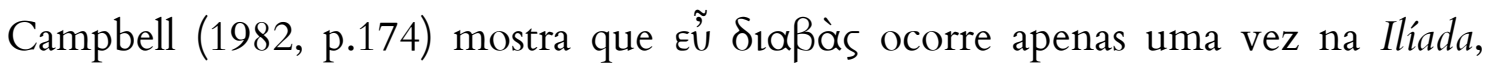
quando se relata o feito mais sobre-humano de Heitor, romper a muralha grega

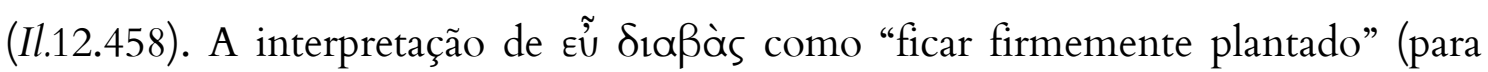

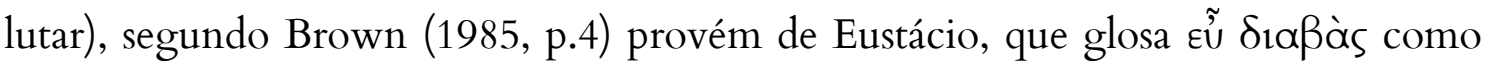

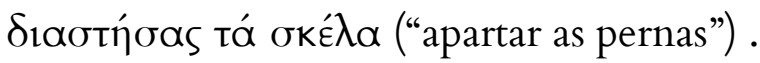

MacQueen (1984, p.473), contudo, visando uma tradução aproximada do

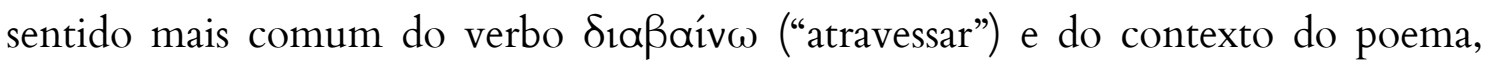
verte a expressão por "dar um passo largo (ou um salto)". Sua opção apoia-se no argumento de Camerarius (1550), relegado pela tradição, e também em uma inconsistência do sentido tradicional: embora o autor note que a posição é razoável em Tirteu - manter-se em posição lateral, com o ombro esquerdo e o escudo voltado para o inimigo, o pé esquerdo à frente e o direito atrás, de modo a obter

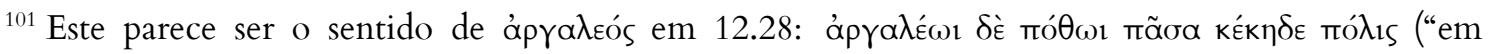
saudade atroz a cidade toda se enluta").

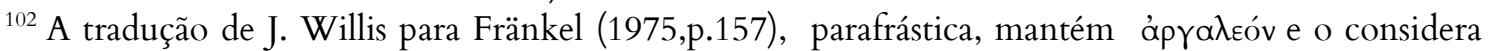
uma menção à guerra, como no verso 8: "Keenly the enemy grasps at chance: in turning and fleeing I Men are struck down from behind: bitter and ruthless is war”.
} 
equilíbrio e proteção máxima com o escudo - este sentido seria inaceitável na passagem da Ilíada, em que Heitor arremessa uma grande pedra contra a muralha

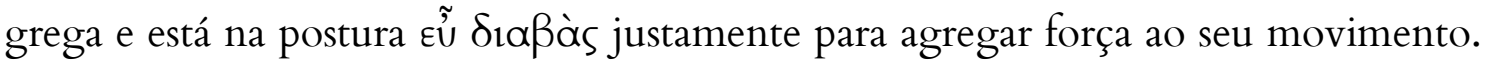
Assim, MacQueen conclui que a expressão significa, também na Ilíada, que o herói está tomando impulso antes de atirar. Para comprovar seu argumento, cita outras passagens de Álcman, Aristófanes e Plutarco em que termos similares sugerem esse movimento e a estende para o poema de Tirteu, alegando que "a verdadeira ópetí marcial consiste em atacar, e não esperar a investida inimiga” (1984, p. 457). MacQueen parece, no entanto, se esquecer do caráter especial e sobre-humano da cena na Ilíada (ver West, 2011, p.275).

Brown (1985, p.357) observa que a visão de MacQueen é inconciliável com

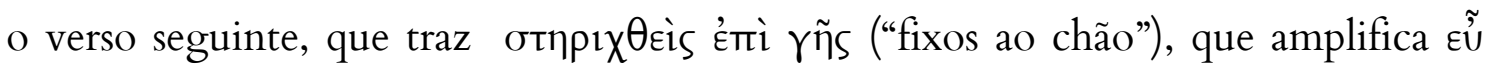

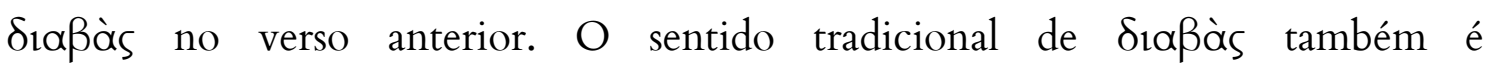
etimologicamente preciso, pois ßaívw significa, literalmente, "dar um passo", enquanto o prefixo $\delta ı \alpha ́$ traz a ideia de separação (p.358).

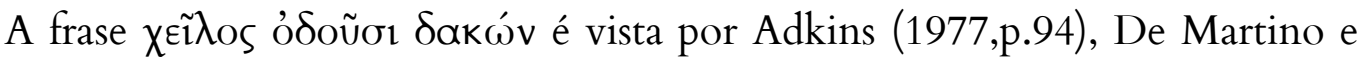
Vox (1996, p.564) como uma inovação em relação ao modelo homérico. Homero utiliza três vezes na Odisseia uma expressão formular para demonstrar a surpresa dos pretendentes diante de algum discurso de Telêmaco $(\mathrm{Od}$. 1.381-382 $=18.410-411$

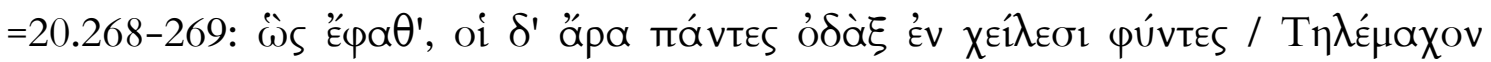

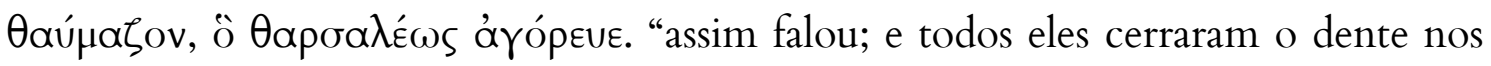
lábios/ surpresos com Telêmaco, que audaz arengava"). Em Tirteu, porém, a expressão tem o sentido de resistir com coragem ao impulso da fuga e ao perigo da morte (Adkins, 1977, p.94; De Martino e Vox, 1996, p.564). ${ }^{103}$

\footnotetext{
${ }^{103}$ É provavelmente com essa noção em mente que Aluízio Faria de Coimbra (1941) verteu essa passagem: "As plantas, pois, cada um firme no solo, I morda os lábios e, impávido, resista" .
} 


\section{Uma lição de guerra e uma cena de batalha (vv.23-34)}

Um retrato vívido da batalha ocupa a terceira parte do poema (vv. 23-34) representando, de acordo com Easterling e Knox (1985,p.132), o confronto entre fileiras hoplitas adversárias.

Wilamowitz observou uma interpolação nos versos 29-34, por pensar que o modo de guerra hoplítico não existia à época de Tirteu. Lorimer (1947, p.122), por outro lado, considerou os versos 21-28 como interpolações - provavelmente do século quarto ou quinto, por conta das armas descritas: o escudo que cobre "coxas e canelas em baixo, peito e ombros" (vv.23) não corresponde ao escudo hoplítico, utilizado no século VII a.C. Lorimer explica que o único período da história grega onde um escudo desse estilo foi utilizado remonta ao século XV e XVI. Desse modo, conclui que "a exortação, independente de sua data, não poderia ser uma convocação real a soldados contemporâneos". Da mesma maneira, elimina os versos 24 e 25 a 28, por considerar o elmo com penacho (v. 26) equipamento antiquado e ÉkTós $\beta \varepsilon \lambda \lambda_{\varepsilon} \omega v$ ("perto de dardos") inadequado para o modo de guerra hoplítico (Campbell, 1982, p.174).

Para solucionar a questão, Campbell (1982, p.175) foi da mesma opinião de Hammond (1950, p.51): embora os espartanos já conhecessem a luta em formação hoplítica, teriam adotado na Segunda Guerra Messênica uma organização tática mais aberta, uma vez que os adversários desconheciam o modo de guerra dos hoplitas. Isso implicara uma alteração nos equipamentos.

A análise de Van Wees sobre o modo de luta dos hoplitas à época de Tirteu (2004, p. 166-183) fornece respostas interessantes: uma das técnicas dos hoplitas era correr com o escudo hoplítico agachados, com o ombro esquerdo voltado para frente. Desse modo, o escudo permanecia reclinado contra o ombro e sua extremidade inferior mantinha-se um pouco à frente do portador, fornecendo uma proteção bem similar àquela que Tirteu descreve nos versos 23-24. 
Os versos 25-30 seguem na descrição dos equipamentos deste guerreiro, e

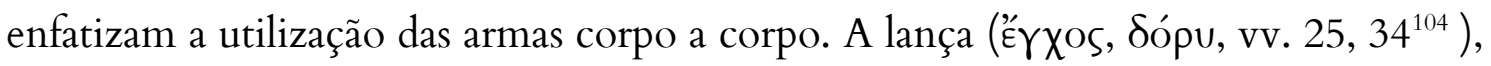
juntamente com o escudo, compunha o equipamento característico do hoplita (Cartledge, 1977, p.14) ${ }^{105}$, mas também era a principal arma do guerreiro homérico (Van Wees, 1994). A diferença central consiste em sua utilização: enquanto o hoplita usa sua lança apenas em investidas corpo a corpo, o herói homérico pode optar por usar a lança também como uma arma de arremesso. O fragmento exortativo de Calino, por exemplo, apresenta a lança como uma arma de arremesso

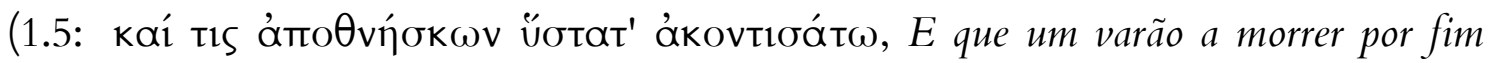
atire a lança) mas traz também uma provável alusão ao combate corpo a corpo, em um verso similar ao que Tirteu utiliza nesse passo (Calino, 1.9-11 (...) à $\lambda \lambda \alpha$ á tıs ïن̀ s

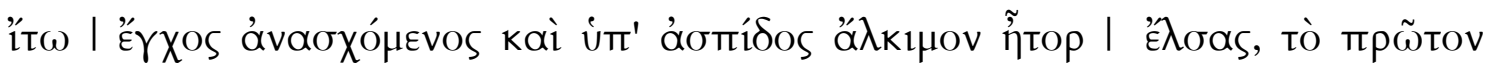

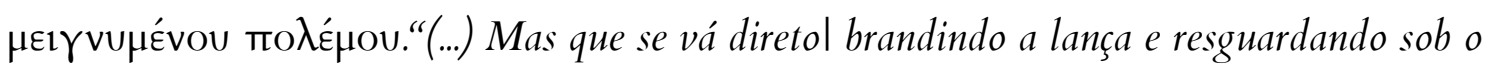
escudol um valente peito, assim que a luta se mesclar"). ${ }^{106}$ A espada ( por outro lado, era pouco utilizada em Homero e uma opção secundária para o hoplita, caso a lança se quebrasse durante o choque de combatentes.

Tirteu, porém, não parece dar preferência a nenhuma das duas armas nem se ocupa de descrever a falange hoplítica nesse trecho (Bowra, 1938, p. 58), mas antes insiste no argumento de que os hoplitas devem lutar homem a homem (v.29) em

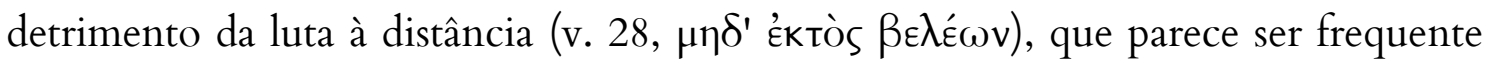
na guerra e é a prerrogativa das tropas ligeiras (vv.35-38). Tal mescla na descrição das armas e técnicas comprova, como afirma Snodgrass, que Tirteu está de fato em um período de transição de equipamentos e técnicas e retrata a preferência por uma modalidade de combate mais moderna, que privilegia o corpo a corpo. Nesse

\footnotetext{
${ }^{104} \mathrm{O}$ poeta parece buscar variedade na utilização das palavras, mas não há nenhuma diferença significativa nas armas descritas (Cartledge, 1977, p.14).

${ }^{105}$ Cartledge (1977, p.15) mostra que as lanças eram armas tão características para o guerreiro, que

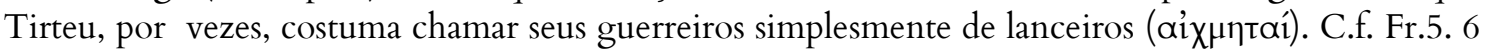
W.

${ }^{106}$ Tirteu também se refere à lança como arma de arremesso no fr.23 a W. v.12, mas não é possível dizer se esta menção está incluída em uma exortação ou mesmo se o poeta se refere a uma

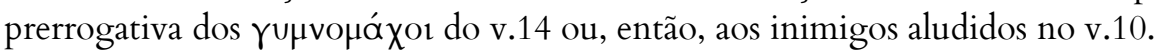


sentido, Arquíloco, poeta anterior a Tirteu, faz uma constatação análoga (Fr.3 W, c.f. Corrêa, 2009, p.96):

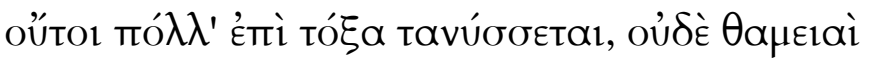

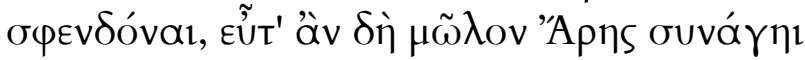

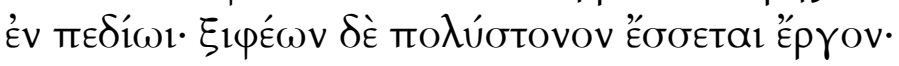

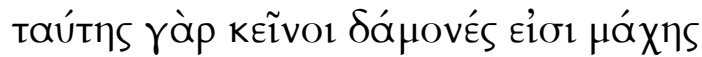

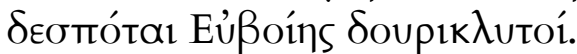

Não muitos arcos serão tendidos, nem frequentes fundas, quando Ares reunir a luta na planície: de espadas será a obra de muitos gemidos, pois eles são peritos nesse combate, os senhores de Eubeia, afamados lanceiros. ${ }^{107}$

O poeta intercala as suas descrições do combate (vv.21-26 e vv.29-34) com o que, segundo De Martino e Vox (1996, p.565), é um ensinamento de guerra. Isso se

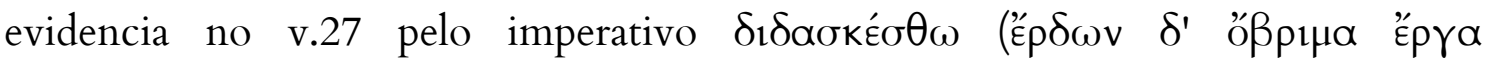

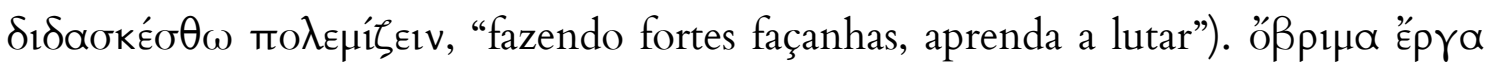

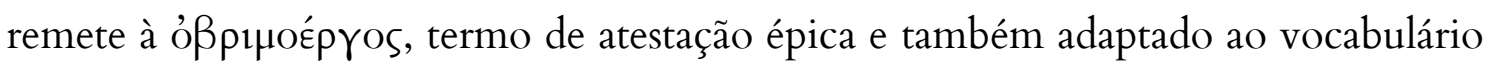

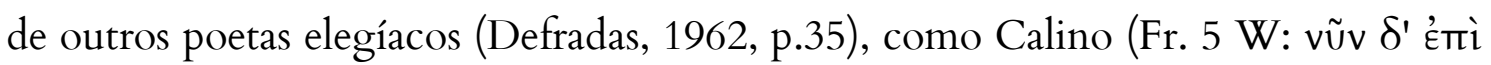

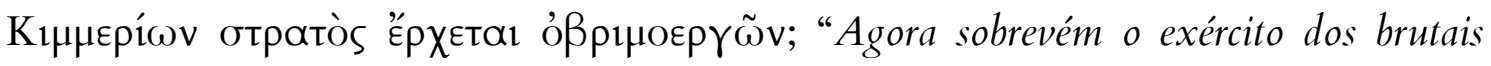

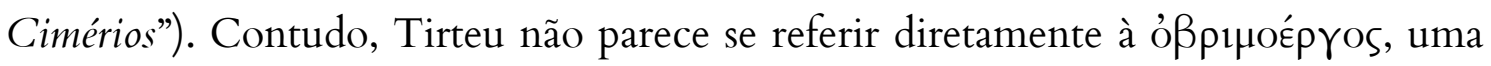
vez que em Homero e Calino a palavra assume tons negativos, seja para qualificar atos violentos contra homens ou Deuses ou caracterizar o inimigo. Se há aqui algum paralelo a um verso homérico, seria mais factível pensar em um passo da

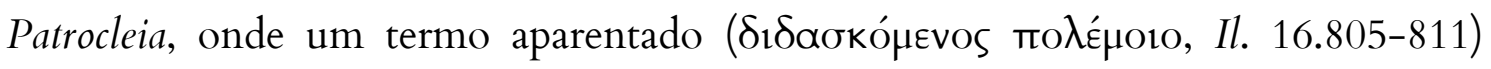
qualifica o jovem herói Euforbo, que fere Pátroclo e o deixa a mercê da morte (Defradas, 1962, p.35) :

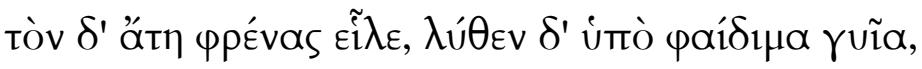

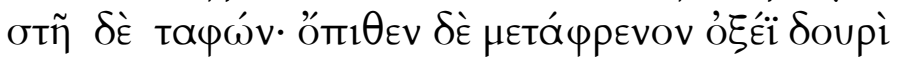

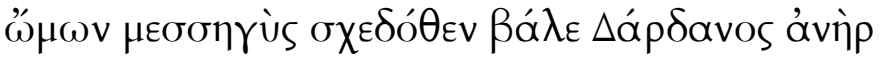

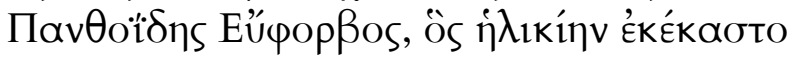

${ }^{107}$ Tradução de Paula da Cunha Corrêa (2009). 


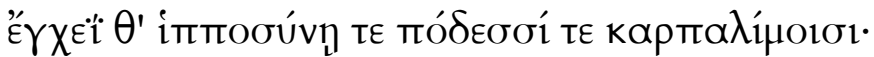

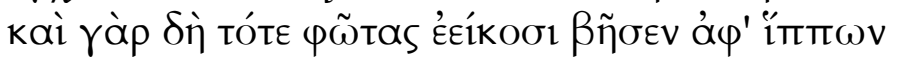

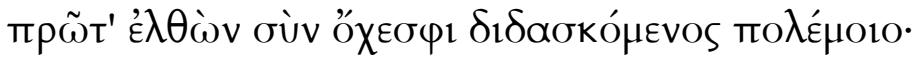

A cegueira arrebatou-lhe a mente, afrouxou-lhe os radiantes membros:

Estava parado, pasmo. E com uma lança afiada nas costas,

entre os ombros, de perto, atingiu-lhe um guerreiro dardânio,

Euforbo Pantoide, que superava os de sua idade

na lança, na cavalaria e nas velozes corridas:

até então já vinte homens derrubara de seus corcéis,

tão logo chegou com seu carro, aprendiz da guerra.

Fränkel (1975, p.138) observou que esta "lição de guerra" a princípio parece se opor às exortações descritas nos vv. 7-10, onde o poeta se dirige a guerreiros experientes. Nota-se, porém, um espelhamento, já que a conclusão é a mesma: o contraponto para o temor destes e para a inexperiência daqueles é o mesmo: enfrentar o inimigo de perto (vv. 11-12, vv. 29-30) - seja porque assim menos guerreiros morrerão (vv.13) ou porque fazê-lo é uma "forte façanha" (vv.27). Assim sendo, e como Fränkel já nota, tais diferenças se diluem - uma vez que estes véô

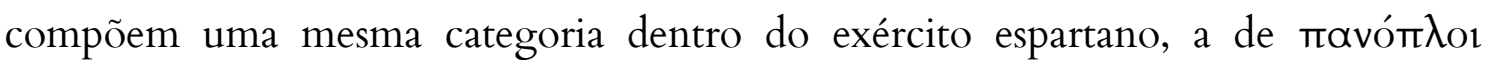
("hoplitas", vv. 38). Pode-se pensar, por outro lado, que em ambos os momentos Tirteu refere-se a uma mesma e única categoria de guerreiros - homens experientes cujo medo impediria a prática de tais façanhas do corpo a corpo, que o poeta ordena que sejam aprendidas.

Tradicionalmente, toma-se como paradigma para os versos 31-34 uma passagem de Homero (Il. 13.131ss. = 16.216ss.):

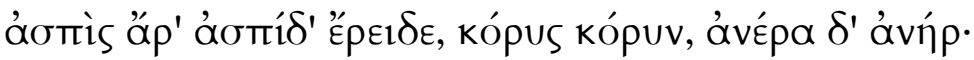

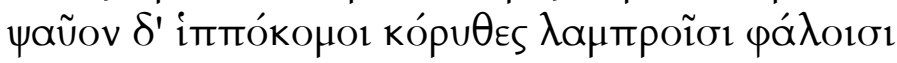

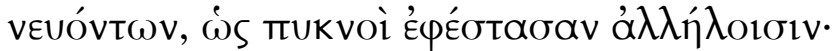

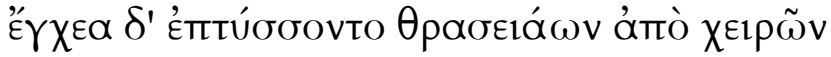

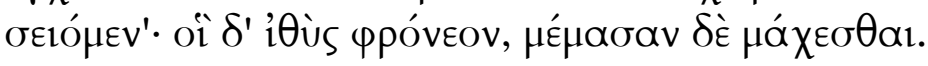

Escudo apoiava escudo, elmo a elmo, homem a homem; os elmos equicrines com brilhantes cimeiras tocavam-se, inclinados, tão perto posicionaram-se uns dos outros: 
As lanças vibravam nas corajosas mãos,

brandidas. Pensavam em lutar, ansiavam o combate.

A leitura mais comum é que Tirteu impõe nestes versos um sentido que está ausente na descrição da Ilíada. Para Bowra (1938, p.158) e Fränkel (1975, p.158) Tirteu manipula a linguagem tradicional da épica para representar o avanço das tropas em formação cerrada, enquanto na Ilíada a cena seria apenas uma representação do contato próximo entre os guerreiros na linha de frente, ávidos pelo combate. Fowler (1987, p.24), contudo, observa que expressões como "homem a homem, escudo contra escudo" podem ter sido tradicionais em exortações marciais. A repetição formular desta passagem em dois momentos distintos da epopeia homérica (Il. 13.130ss. = 16.216ss.) sugere que a expressão já fosse tradicional na poesia épica.

Campbell (1982, p.175), pelo contrário, observa que em Homero já está retratado o avanço em formação fechada, mas Tirteu emprega os mesmos versos para descrever o confronto dos lados adversários da falange hoplítica. Como argumento para esta visão, aduz otépvov otépv $\omega_{\mathbf{L}}$ como prova do novo estilo de combate, desconhecido por Homero.

Van Wees (1994, pp.1-14) faz uma leitura detalhada das duas passagens da Ilíada que trazem reminiscências da falange, e argumenta que os vv. 130-135 do Canto 13 representam agrupamentos momentâneos de tropas, que facilmente se rompiam ao despontar da batalha, e depois precisavam ser reagrupadas. É o caso desta passagem da Ilíada, onde os guerreiros são convocados à reunir-se à volta dos dois Ajantes, em vista de conter o avanço das forças troianas (Il. 13. 83-135). Os homens, então, ávidos pela luta e animados pela exortação do comandante, empurram-se para chegar às linhas de frente. Van Wees ainda explica que no modo de guerra clássico, em que manter a formação compacta é essencial - uma dispersão poderia significar o fim da batalha, pois seria impossível reagrupar uma formação tão fechada. Os exércitos homéricos, porém, passam por constantes reagrupamentos ao longo de uma batalha. 
Todavia, como já foi observado acima, é evidente que Homero não poderia se referir a uma falange similar à do período clássico, mas pode demonstrar, nessas passagens, uma espécie de falange hoplítica arcaica (Corrêa, 2009, p. 78), assinalando assim um processo gradual de alteração de técnicas (e equipamento), um processo também retratado nos versos de Tirteu. Em Homero, verifica-se que este tipo de formação, similar à falange hoplítica, parece ser adotado quando as tropas estão sob pressão inimiga (Il. 12.105). Por que não poderíamos pensar em condições similares para os versos de Tirteu?

Van Wees (2004, p.168) infere que Tirteu retrata aqui ${ }^{108}$ o escudo como uma arma ofensiva: nesses termos, não são os guerreiros aliados em agrupamento que Tirteu está representando, mas o esbatimento de combatentes adversários, que projetam seus escudos contra o inimigo, visando desequilibrá-los.

A descrição do combate apresentada nos vv.23-2 e vv.28-34 expande em imagens vivas e concretas o curso de ação que o poeta deseja ver em seus interlocutores. Tais descrições enfatizam as armas desses hoplitas, orientados para o combate corpo a corpo, com as quais eles empreenderão suas fortes obras: o escudo, que confronta os projéteis (vv.28), a lança longa e a espada. Uma pausa na descrição (vv.27), em tom sentencioso, mantém o caráter didático do poema.

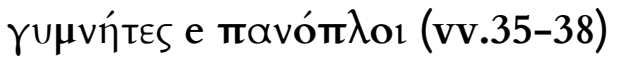

Tão desconectados de seu contexto original pareceram ser os versos 35-38 para a crítica, que Fränkel (1975, p.138) postulou que se tratasse de um excurso que aplicaria a conduta desenvolvida nos vv.1-34 às tropas ligeiras. Nota-se, assim, a

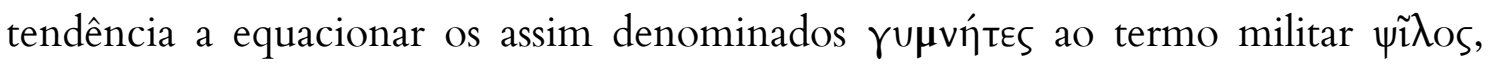
utilizado primeiramente por Heródoto (7.158) e amiúde por Tucídides (3.27, 4.125, etc.) para denominar os soldados desprovidos de armaduras pesadas, notadamente, os arqueiros, e que tinham uma função destacada dos hoplitas na falange clássica.

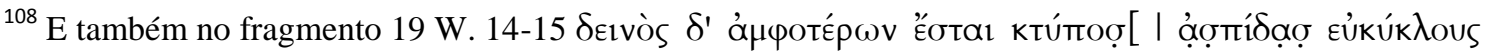

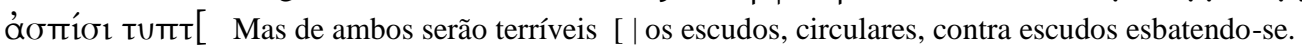


Irwin (2005, p.291), porém, questionou se é válida essa relação, uma vez que pode induzir a uma leitura teleológica que se pautaria no ideário da falange clássica e assim ficaria distante de contexto apresentado no poema. Segundo sua leitura, a observação do contexto parece remeter a uma representação que revela a estratificação na elegia marcial e engendra um aparato heróico de modo a caracterizar e distinguir uma elite (Irwin, 2005, p.35-39).

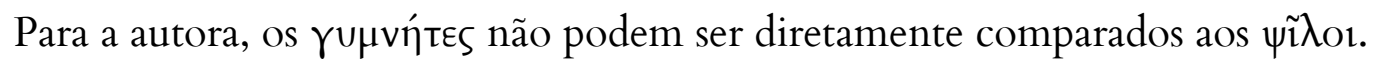
Embora a atuação destes seja muito similar a das tropas leves do período clássico,

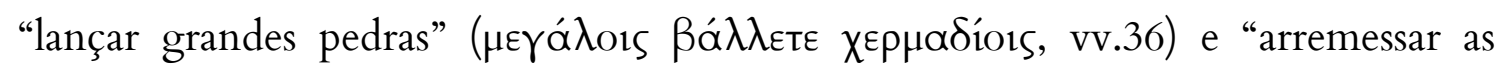

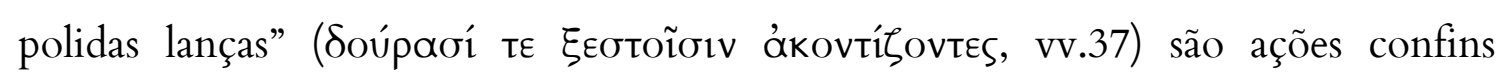
também ao herói homérico e não qualificam ação reprochável nem mesmo no gênero elegíaco (Calino $1.5 \mathrm{~W})$.

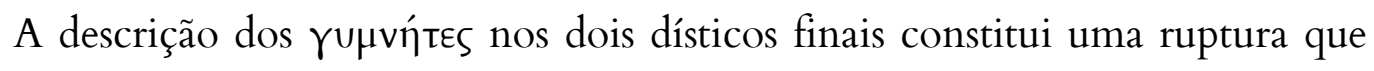
tem por função principal oferecer um contraponto aos guerreiros descritos nos versos anteriores, "a estirpe do invicto Héracles" (v.2), e assim elevar o estatuto destes últimos. De que maneira o poeta faz isso?

O vocabulário utilizado é fundamental para operar a separação entre as duas classes de combatentes: de acordo com Irwin (2005, p.38), que aduz como argumento Sólon $4 \mathrm{~W}$, ù $\mu$ ĩs $\delta^{\prime}$ (v. 35) não demarca na poesia elegíaca apenas a segunda pessoa do plural, mas parece também impor uma nítida separação do enunciador em relação aos seus interlocutores.

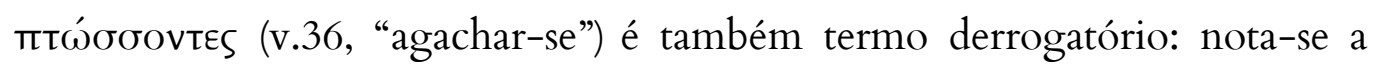
cuidadosa escolha do poeta por esta palavra em vez do correlato $\varepsilon \hat{\imath} \lambda \omega$, presente em Calino de Éfeso para designar postura similar (1. 10-11 W). Embora seja uma imagem homérica, $\pi \tau \omega ́ \sigma \sigma \omega$ é usado com frequência nas epopeias para sugerir uma ação covarde (Il. 4.371, 5.634, 7.129, 20.427), ou um comportamento humilde (Od. 17.227, 18.363). Tirteu coloca ainda o termo em início de verso e composto por sílabas longas, recurso tradicional de sua poesia quando se deseja chamar a atenção para um vocábulo específico. Irwin $(2005$, p.293) observa ainda que o uso de $\pi \tau \omega ́ \sigma \sigma \omega$ com preposição é raro em Homero, o que induz a pensar que Tirteu quer 
dar força à expressão ím' áoríßos (vv.35). Seguido desse termo, uma sentença de força meramente descritiva ( $\alpha \lambda_{\lambda} \lambda_{0} \theta \varepsilon v$ ó $\left.\lambda \lambda_{o \varsigma}\right)$ torna ainda mais impactante o verbo no início do verso $36 .^{109}$

No entanto, embora exista o tom derrogatório da passagem, as tropas ligeiras não são desprezadas pelo poeta (Corrêa, 2009, p.178) e também participavam da luta. Tirteu pode clamar pelos valores do combate corpo a corpo, mas como se vê, tais técnicas ainda estavam indiscriminadamente mescladas a outras, como o combate à distância ${ }^{110}$.

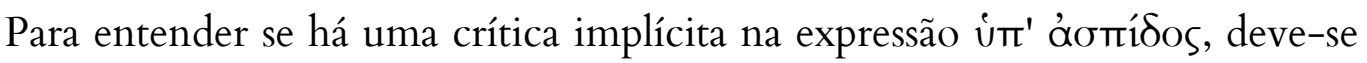
primeiro observar outras questões que norteiam a prática de guerra das tropas ligeiras, e assim, determinar o sentido dos escudos nessa passagem.

A crítica divide-se entre questionar se os escudos são uma propriedade dos Үuнvĩtєৎ ou não, e que implicações isso teria. Defradas (1962, p.53) assinala que os

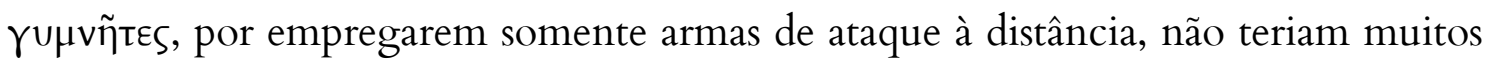
equipamentos defensivos (pois talvez assim obtivessem maior mobilidade) exceto o escudo leve que Tirteu menciona. Irwin (2005, p.293), desenvolvendo esta leitura, conclui que a menção ao escudo é uma ênfase no elemento que marcou a transição das técnicas militares no período arcaico. As consequências da adoção do escudo hoplítico foram a redução do emprego de armaduras mais pesadas e uma valorização

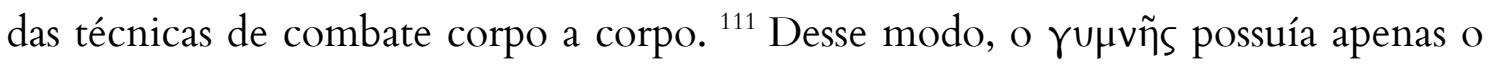
escudo, única arma realmente necessária para o ofício de hoplita na falange arcaica (Osborne, 1996, p.83) e a ausência de armaduras pesadas ou armas mais elaboradas seria um indício de status que os distinguiria dos $\pi \alpha v o ́ \pi \lambda o$, os aristocratas que podiam pagar pela panóplia completa.

Van Wees (2004, p.170), por outro lado, observa a iconografia a partir do século VII, que passa a representar os guerreiros de armamento leve não como

\footnotetext{
${ }^{109}$ À maneira do que parece acontecer em 11.21-22 W $=10.31-32 \mathrm{~W}$, conforme sugere Adkins (1977,p.85).

${ }^{110}$ Tirteu fala do uso de projéteis e pedras na guerra em outros momentos $(19.2 \mathrm{~W}, 19.19-20 \mathrm{~W}, 23 \mathrm{a}$ 10-14 W). Alceu menciona que "as grevas são anteparo ao dardo" (357 PMG, v.10). Ver Van Wees, 2004, p.170.

${ }^{111}$ Que já se nota neste mesmo poema: “... sustendo o escudo, não fique longe dos dardos” (vv.28).
} 
guerreiros individuais, mas homens desarmados agachados atrás de hoplitas. Van Wees explica a cooperação entre estes guerreiros e os hoplitas recorrendo à Ilíada: é comum arqueiros permanecerem sob os escudos de outros heróis, saindo apenas para atirar, depois de observar se podiam ferir alguém na multidão. Logo em seguida, voltavam para debaixo do escudo "como uma criança à sua mãe" (Il. 8.271). Assim, Van Wees de certo modo recupera a leitura de Wilamowitz (1900, apud Irwin,

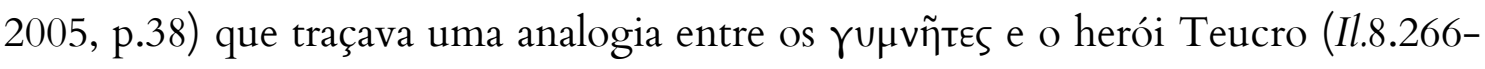
272):

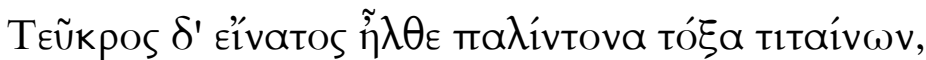

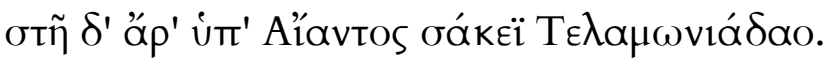

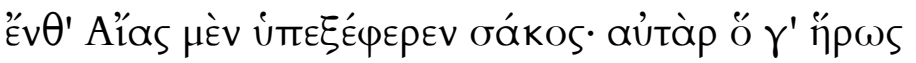

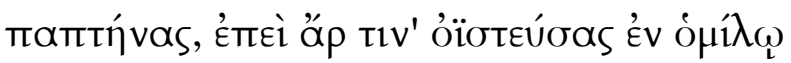

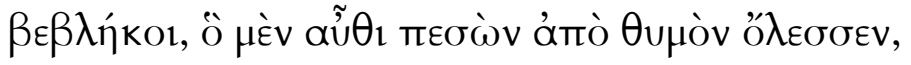
(270)

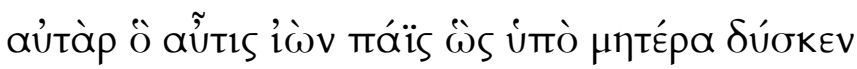

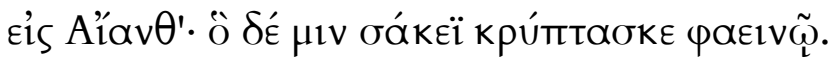

Teucro foi o nono, e retesando o fléxil arco, Posicionou-se sob o escudo de Ájax Telamônio. Daí Ájax pôs de lado o seu escudo, e o herói, mirando, assim que asseteasse um alvo na turba, o feriria. Quando o inimigo cai e perde a vida,

Teucro então de pronto voltava, como criança junto à mãe, para Ájax: escondia-se sob o reluzente escudo.

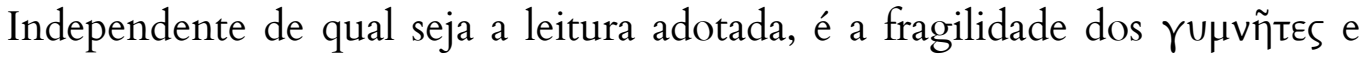
sua dependência dos hoplitas no combate que está sublinhada nesses versos. A descrição das atividades das tropas ligeiras eleva o já magnificente estatuto dos

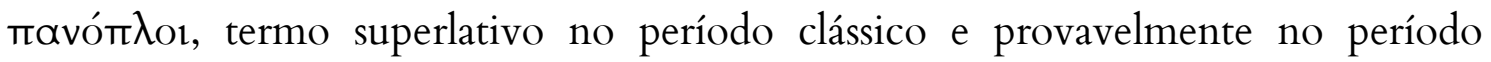
arcaico para designar circunstâncias elevadas (Irwin, 2005, p.294, n.6). A conduta 


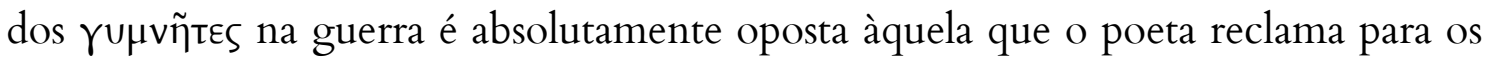
filhos de Héracles dos versos anteriores: em vez de avançar contra o inimigo e ficar

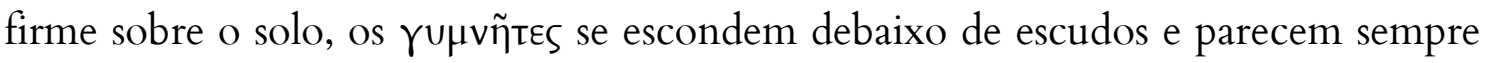
estar em movimento pelo campo de batalha, "aqui e ali" (ă $\lambda \lambda_{\circ} \theta \varepsilon v$ ŏ $\left.\lambda \lambda_{o \varsigma}\right)$, buscando talvez uma proteção que não têm, ou uma melhor posição para atacar de longe.

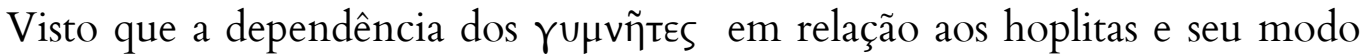
próprio de luta - oposto àquele que Tirteu exige nos versos anteriores - está condicionada à questão da panóplia, Irwin (2005, p.293) conclui que o poeta engendra uma representação que tende a interligar a ópєtí marcial, apresentada como as virtudes do "homem bom na guerra" e verificada principalmente em sua coragem de ir à frente e não ter medo, à aristocracia, que possuía de fato os melhores armamentos e compunha a audiência principal deste tipo de poesia que se realizava no ambiente do simpósio. 


\section{Capítulo 3}

\section{O fragmento 12 W: simpósio e ápєtń em Tirteu}

O fragmento $12 \mathrm{~W}$ é considerado pela crítica como único no corpus tirtaico sobrevivente (Luginbill, 2002, p. 405). Esta afirmação apoia-se na estrutura empregada por Tirteu na composição do poema, que enfatiza a exposição e desenvolvimento de uma ideia - a saber, a virtude (ápєtí) que um bom guerreiro deve ter na guerra - e relega a exortação propriamente dita aos últimos versos (Luginbill, 2002, p. 406):

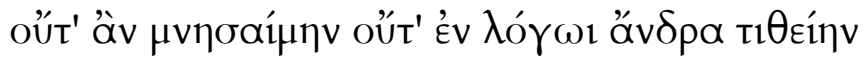

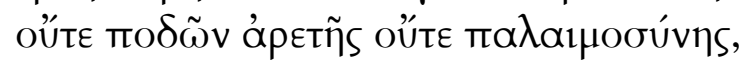

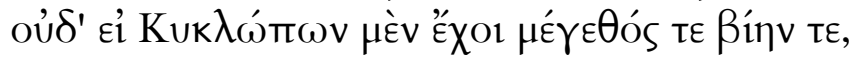

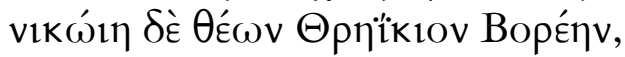

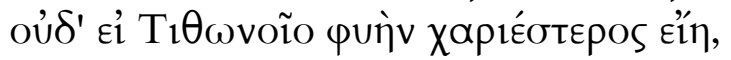

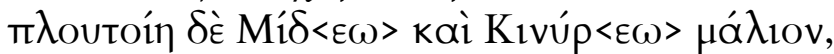

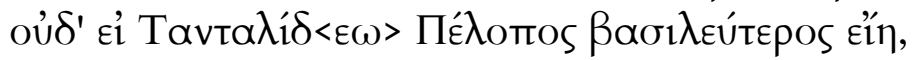

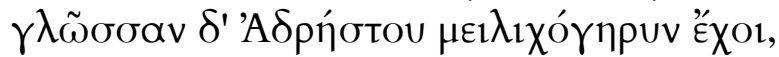

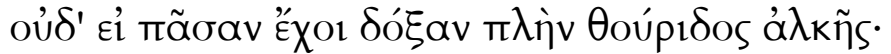

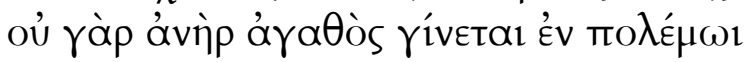

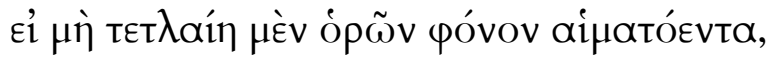

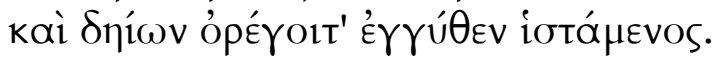

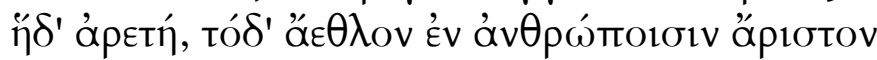

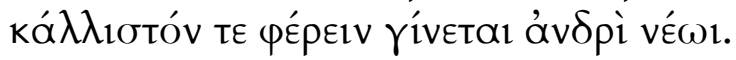

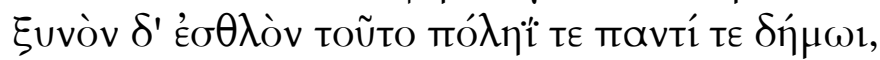

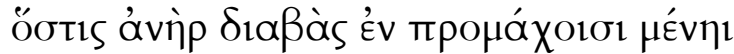

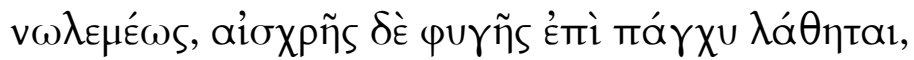

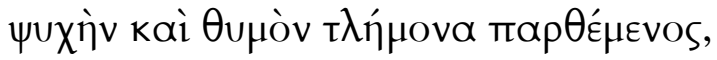

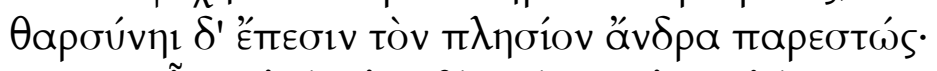

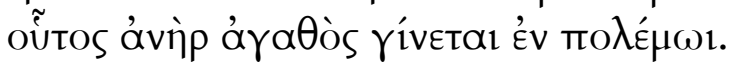

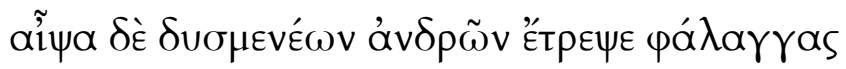

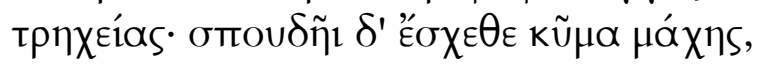

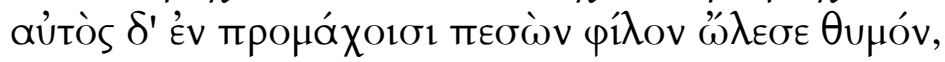

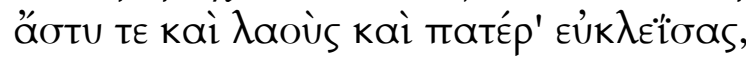

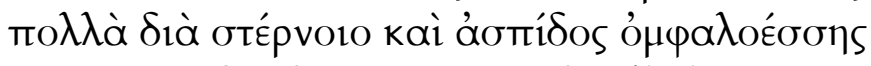

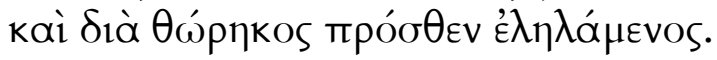

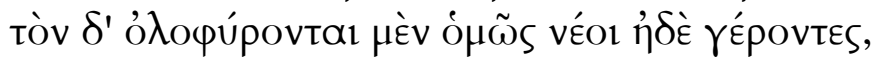




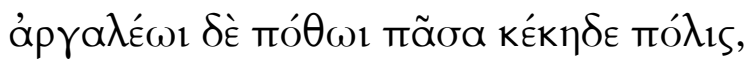

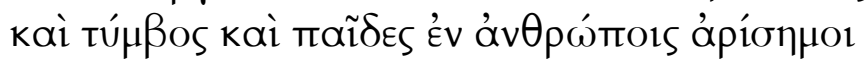

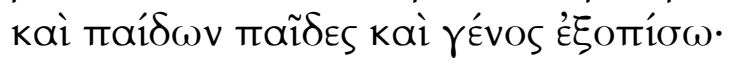

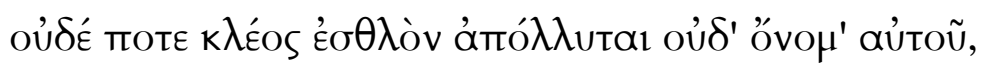

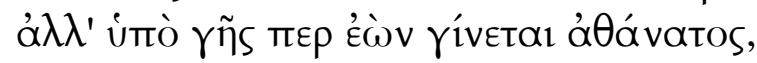

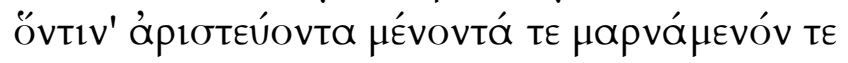

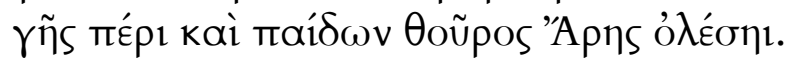

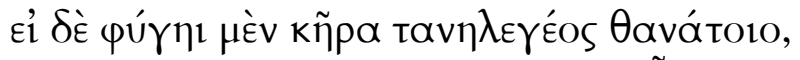

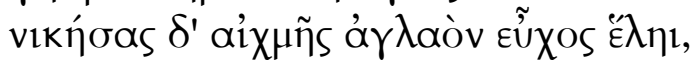

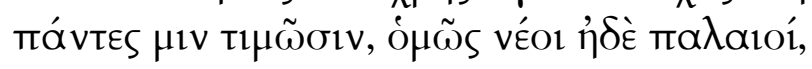

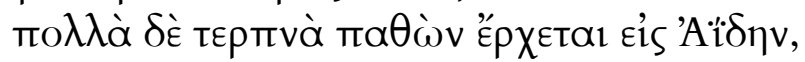

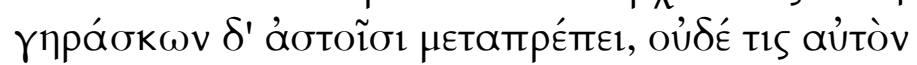

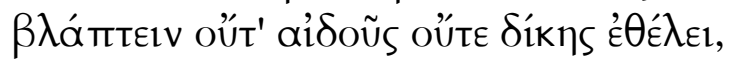

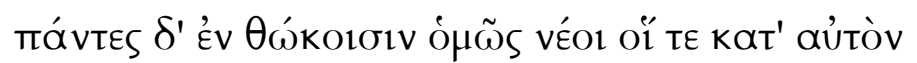

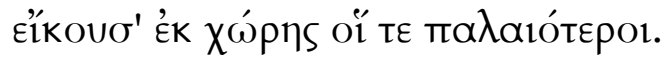

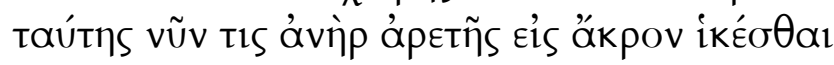

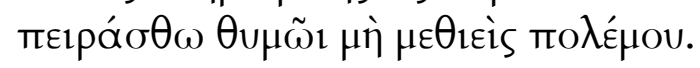

Não me lembraria e em verbo um varão não poria, pela virtude de seus pés ou de sua luta,

nem se tivesse altura e força de Ciclopes

e em corrida vencesse o trácio Bóreas,

nem se tivesse porte mais grácil que Títono,

e mais riquezas do que Midas e Ciniras,

nem se fosse mais rei que Pélope Tantálida,

e tivesse a língua de mel de Adrasto,

ou toda a fama, senão a bravura impetuosa;

pois um varão não se torna valoroso na guerra

se não ousar olhar a matança sanguinária,

e postando-se perto, atingir inimigos.

Tal virtude, tal prêmio, entre homens é o melhor

e mais belo que há para um jovem varão receber.

É esse um bem comum à cidade e ao povo todo,

que um varão firme na vanguarda se mantenha,

sem trégua, de todo se esqueça da torpe fuga

arriscando a vida e o coração audaz,

e próximo encoraje o varão ao seu lado com palavras :

eis o varão que se torna valoroso na guerra.

Súbito, dispersa de varões hostis as falanges 
brutais, com zelo detém a onda da luta.

Caído na vanguarda, ele próprio perde a sua vida, mas glorifica a cidade, as tropas e seu pai, muitas vezes no peito, no escudo umbilicado e na couraça golpeado de frente.

A ele pranteiam por igual jovens e anciãos, e em saudade atroz, a cidade toda se enluta.

Seu túmulo e filhos são insignes entre os homens e os filhos dos filhos, e a geração no porvir,

e jamais nobre glória ou o nome dele perecem, mas, mesmo sob a terra, se torna imortal aquele que, primando por manter-se em combate pela terra e pelos filhos, o impetuoso Ares mata.

Mas se escapa à sina da morte que aflige longamente

e, ao vencer, conquista o triunfo ilustre da lança,

todos o honram, por igual os jovens e os velhos, e depois de viver muitas alegrias, vai ao Hades.

Envelhecendo, distingue-se entre os cidadãos e ninguém quer faltar-lhe com respeito e justiça;

todos, os jovens e seus coetâneos, cedem-lhe lugar em conselho, e também os mais velhos.

Tente hoje cada varão ao ápice dessa virtude chegar, com coragem, sem descuidar da guerra!

Embora o desfecho do poema ainda contenha a admoestação aos concidadãos, este fragmento apresenta um tom aparentemente mais reflexivo, que o difere dos demais onde reflexões sobre a guerra alternam-se com instrução e exortação para dirigir-se à linha de frente do combate.

Assim, ao analisar a estrutura singular do fragmento 12, pretende-se verificar nesse texto de que modo se dão as reflexões ali contidas, o emprego da ideia de ápєtń e em que medida esta se adequa ao universo ético grego e ao contexto marcial apresentado na poesia de Tirteu. 


\section{As fontes e a fortuna crítica}

Deve-se a sobrevivência deste fragmento a Estobeu, que o inseriu em sua

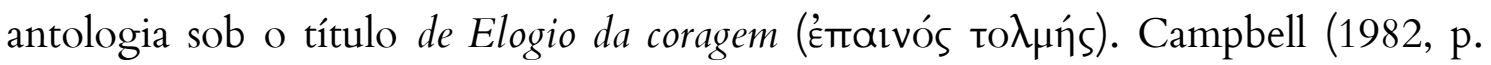
176) salienta que o poema, já na antologia de Estobeu, aparece dividido em duas seções: a primeira dos versos 01-14 e a segunda parte dos versos 15-44, estes últimos atribuídos pela primeira vez a Tirteu apenas à época da edição princeps de Estobeu em 1535.

Todavia, o fragmento deve ter adquirido certa popularidade já no período clássico, e é referido por Platão, que o conhecia e atribuía a sua autoria a Tirteu. Para Jäger (1995, p.121), Platão trata a produção poética de Tirteu como representativa do espírito marcial e político da Esparta arcaica, estabelecendo assim o lugar que esta ocuparia em toda a cultura posterior (1995, p. 117). Nas Leis (629a), o Ateniense cita passagens e faz paráfrases do fr. $12 \mathrm{~W}$ visando questionar se as instituições são orientadas para a guerra ou para a paz, a partir do estabelecimento do contraponto entre os conflitos externos e os civis:

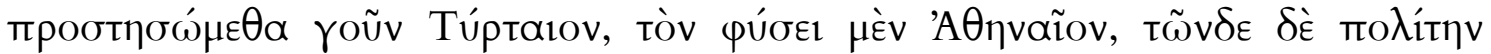

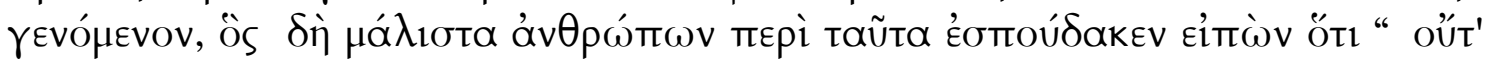

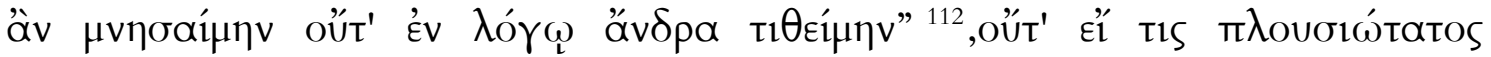

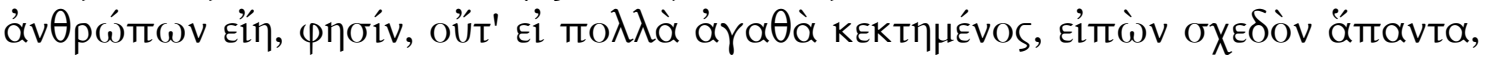

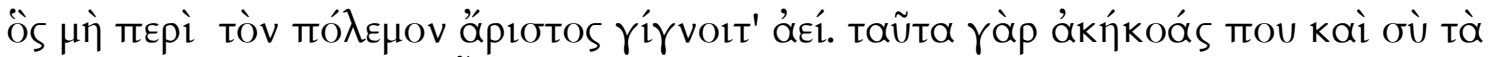

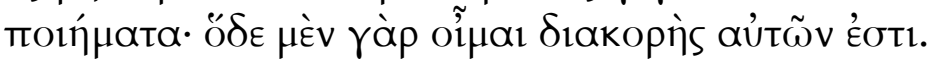

"Apresentemos, por exemplo, Tirteu: embora de natureza ateniense, ao ter se tornado cidadão destes (scil. dos lacedemônios), [foi] quem melhor do que [todos] os homens se empenhou em tais questões, ao dizer: "Não me lembraria e em verbo um varão não poria", "nem se um desses homens fosse o mais rico" - disse - "nem se obtivesse muitas virtudes" - e depois de dizer quase todas, [diz]: "se ele não for sempre o melhor da guerra". Você também ouviu por aí esses poemas, e ele aqui [scil. Megilo, de Esparta], imagino, já está farto deles”.

\footnotetext{
${ }^{112}$ A citação de Estobeu para este verso dá tı $\theta$ eínv, presente optativo ativo, ao passo que Platão tem,

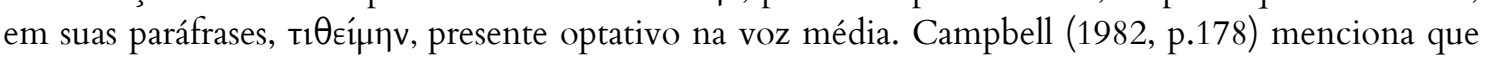
Heródoto utiliza a voz média em expressões similares (3.32: év тı тı$\theta$ Eínv, por ser a tradição direta mais confiável do que uma citação, especialmente de Platão (1974, p. 187).
} 
O poeta da Teognideia repete os versos 13-16 desta elegia com pouca

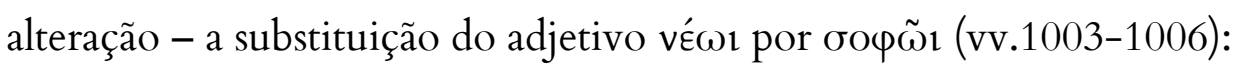

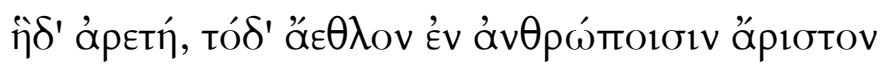

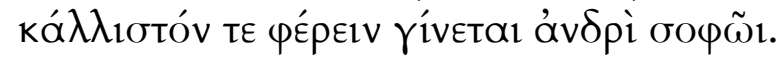

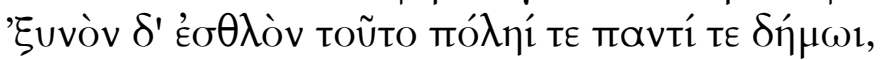

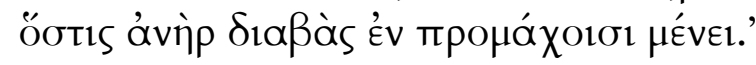

Tal virtude, tal prêmio, entre homens é o melhor e mais belo que há para um sábio varão receber É este um bem comum à cidade e ao povo todo: que um varão firme na vanguarda se mantenha.

Smyth (1903, p. 354) já salientava nessas passagens um traço da composição oral, onde se substitui um termo por outro equivalente em metro.

Highbarger (1929, p. 344), por outro lado, indica que a Teognideia frequentemente se apropriava de excertos de poetas que o precederam e adaptava-os para uma ocasião particular que estivesse em voga no momento, dando assim um novo ambiente para os versos de seus antecessores. Desse modo, o poema de seu predecessor era trazido para as necessidades do momento atual e assim - talvez se possa considerar - o adequaria a um momento de performance específica.

A hipótese de Highbager (1929, p. 352) é a de que Teógnis amplia o conceito de virtude que está delineado em Tirteu: em outro passo (865-868) o poeta

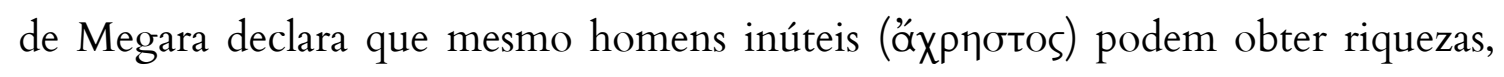
mas a "grande glória da virtude" pertence apenas ao homem que salva sua terra e cidade. ${ }^{113}$ Nesse sentido, todo o homem, seja um jovem (véos) ou não, será sábio, conquanto lute por sua terra natal. Highbarger (1929, p.353) ainda equaliza o óvíp

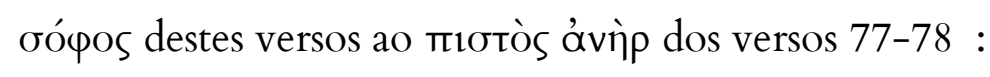

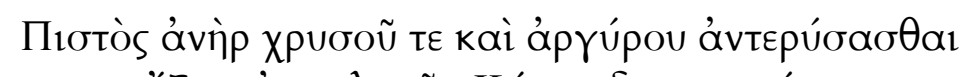

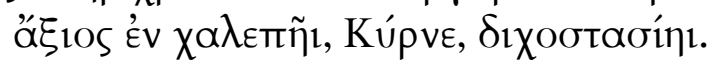

${ }^{113}$ Ver análise do fragmento $11 \mathrm{~W}$. 
Em dura sedição, Cirno, o homem fiel equivale seu peso a ouro e prata.

Nesse sentido, esses fragmentos da Teognideia são comparados com excertos do fragmento $12 \mathrm{~W}$ de Tirteu por Platão: o filósofo argumenta que o homem que

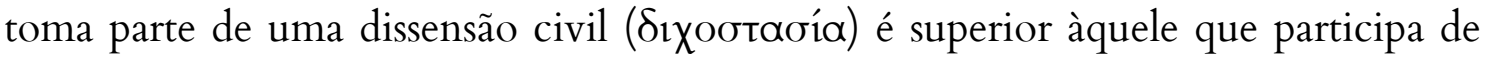
conflitos externos ( $\left.\pi \lambda^{\lambda} \varepsilon \mu \circ \zeta\right)$, e o faz estabelecendo um contraste entre as noções de virtude apresentadas pelos dois poetas. Para o estrangeiro ateniense das Leis $(627 \mathrm{e}-$

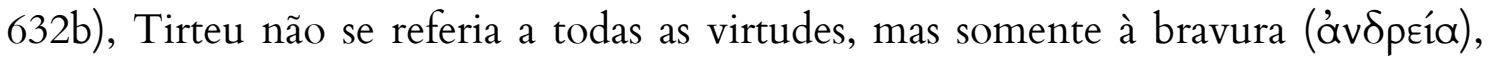
que é a menos importante dentre quatro virtudes que Platão delineia, que consistem

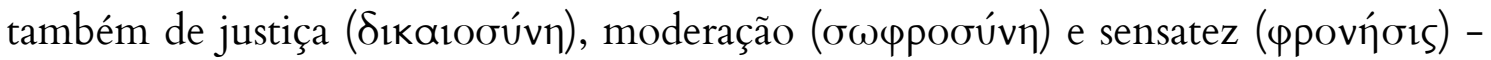
todas elas possuídas pelo "homem fiel" (e sábio, como quer Highbarger) de Teógnis, enquanto os guerreiros de Tirteu - grande parte deles mercenários -embora

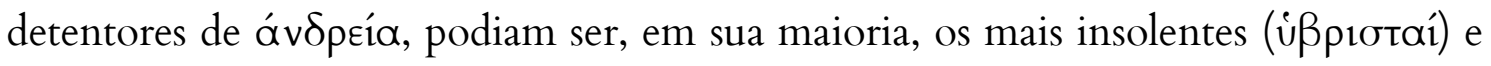
insensatos (åppovéotato1) dos homens (Leg.630b).

Platão faz outra paráfrase do mesmo fragmento (vv.1-12) no Livro II das Leis, adaptando-o às circunstâncias do seu diálogo. Ao tratar das qualidades necessárias para o "homem justo", o filósofo traça um paralelo com as ápetaí descritas por Tirteu no início do fr. 12W. Platão trata a única qualidade que merece o canto de Tirteu - a impetuosa coragem que faz o guerreiro postar-se perto do inimigo como uma qualidade do homem justo (Leg. 660e-661b) :

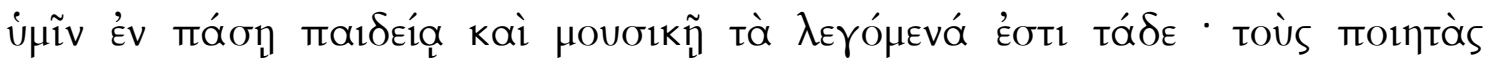

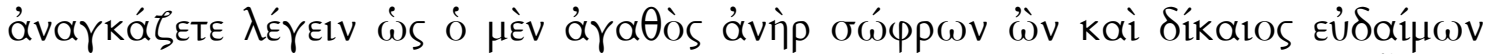

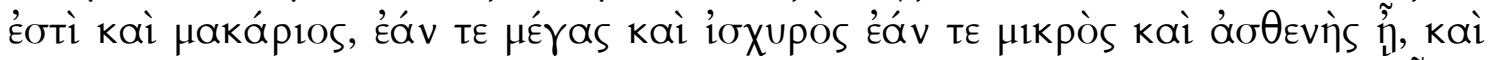

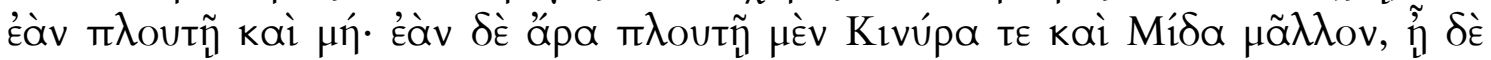

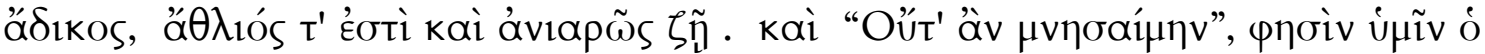

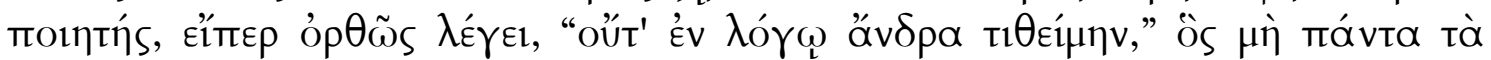

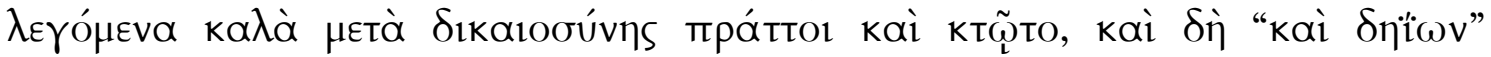

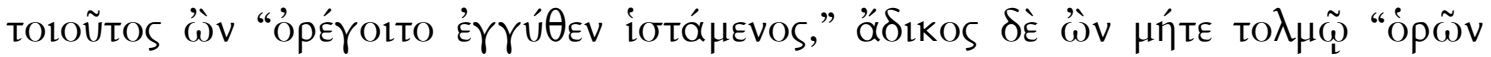

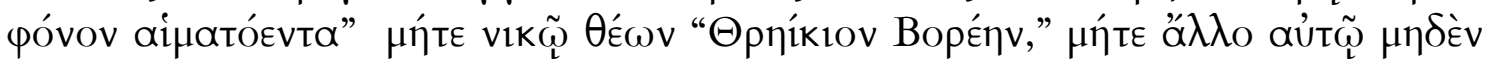

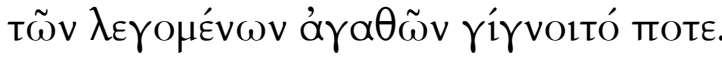

"Em todo o ensino e música de vocês, o que se diz é o seguinte: vocês compelem os poetas a dizer que o varão de valor, por ser prudente e justo, é feliz e bem- 
aventurado, seja ele rico e poderoso, seja pobre e fraco, ainda que não tenha qualquer riqueza. Mesmo se tivesse mais riquezas do que Midas e Ciniras, caso seja injusto, é um homem miserável e vai viver em desgraça. Diz o poeta de vocês (se é que ele fala corretamente): "Não me lembraria e em verbo um varão não poria", o qual não pratica ou obtém com justiça todas as coisas consideradas belas, e, além disso, como tal, posta-se perto e atinge o inimigo. Mas o homem que é injusto não ousaria nem olhar o sanguinário massacre nem venceria na corrida o Trácio Bóreas, e jamais poderia ter para si qualquer outra coisa das que são chamadas de "boas".

Jäger (1966) chega a supor que essa elegia fora conhecida por Sólon e Píndaro, e que Xenófanes a imitara. Para este, não é mais a coragem na guerra a mais importante das virtudes para a polis, mas a oopía (sophía, a sabedoria, ou a poesia), que "enche os cofres da cidade" (Fr.2 W, vv. 1-12) :

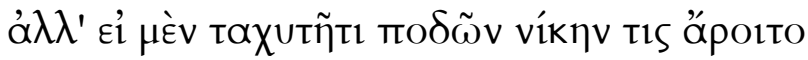

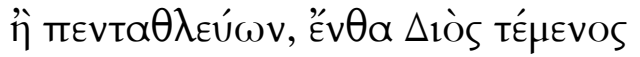

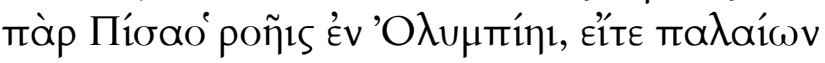

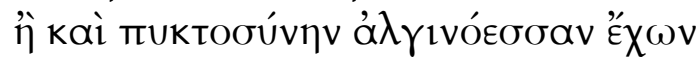

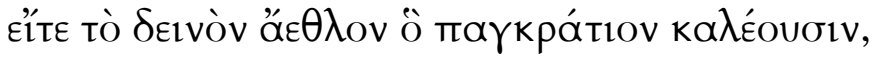

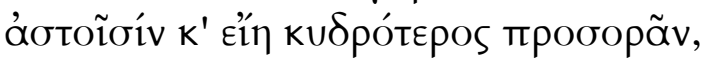

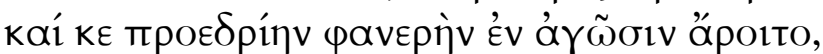

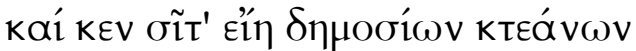

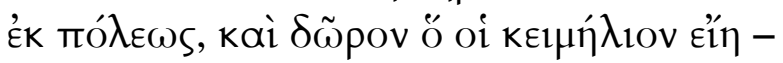

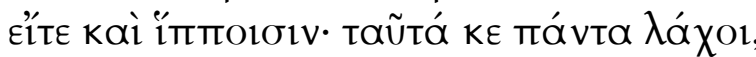

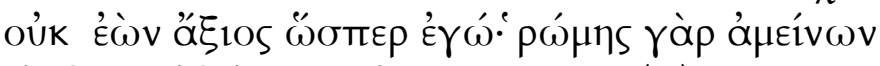

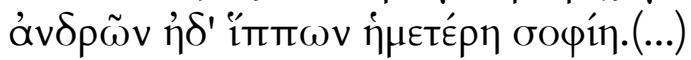

Mas se alguém vencesse por presteza nos pés ou no pentatlo, onde está o templo de Zeus, às margens do Pisa, em Olímpia, ou na luta, ou por dominar a dolorosa arte do pugilato, ou aquele torneio terrível que chamam de o pancrácio, seria visto pelos cidadãos como mais renomado, teria um ilustre primeiro assento nos concursos, alimentos vindos dos bens públicos

da cidade, e dádiva que lhe serviria de herança; mesmo se [vencesse] com seus corcéis, obteria tudo isso sem ser digno, como eu: Pois melhor que a força de homens e corcéis é minha sabedoria. (...) 
Assim como Tirteu, Xenófanes arrola em sua elegia uma série de virtudes ('̊́pєtaí) atléticas que são louvadas pelo povo, mas coloca acima de todas elas uma virtude política, a sua própria sabedoria (бopía) $)^{114}$. Nesse sentido, de acordo com Adkins (1960, p. 74), ambos os poetas estão preocupados com a घúvopía, isto é, o bom governo da pólis: enquanto Tirteu busca louvar a ópetń necessária para conter as ameaças externas, Xenófanes ocupa-se de realçar o atributo necessário para o bem estar de sua cidade.

Desse modo, a preocupação com a Eủvoría poderia antes constituir um motivo frequente nos poemas elegíacos gregos arcaicos, como parece demonstrar a obra posterior de Sólon e Teógnis (Adkins, 1960, p. 75), do que uma emulação de Xenófanes ao fragmento $12 \mathrm{~W}$.

Wilamowitz (apud De Falco, 1941, pp.179-180) foi o primeiro a julgar duvidosa a autenticidade deste fragmento. O autor situa a autoria do poema no início do século $\mathrm{V}$, levando em conta questões estilísticas, como a ausência de uma fraseologia tipicamente arcaica e o tom fortemente retórico dos doze primeiros versos (Fowler, 1987, p. 82; Luginbill, 2002, p.405). O modo de guerra retratado no fragmento também foi motivo para dúvidas acerca da autoria de Tirteu. Wilamowitz (apud Luginbill, 2002, p.406) julgou que a menção à falange (12.21) remete a práticas de combate inexistentes no tempo do poeta.

Fränkel (1975,p.337) considerou que o poema pertencesse à época de Xenófanes. Diferente do que se poderia esperar de Tirteu, não ocorre aqui uma vívida descrição da batalha e não há a preocupação em condenar o medo ou a covardia (1975, p.338). A longa introdução (vv. 1-12) que se assemelha ao início de Xenófanes $2 \mathrm{~W}$ (vv. 1-11) e o equilíbrio entre as partes do poema ${ }^{115}$ colocariam o poema no final da era arcaica, segundo Fränkel (1975, p.338, n.8).

Jäger (1966,p.112) rebateu estas considerações a respeito da inautenticidade do poema: o tom oratório dos primeiros versos é uma característica tipicamente

\footnotetext{
${ }^{114}$ Adkins (1960, p.74) lança a hipótese de que Xenófanes não menciona explicitamente a sabedoria como a mais importante das virtudes porque, assim como nos tempos homéricos, a ápetŕ do guerreiro é ainda de fundamental importância para o bem estar de uma comunidade.

${ }^{115}$ Ver à frente comentários sobre a estruturação do poema.
} 
elegíaca e comum nas composições arcaicas. Ainda, o uso do pronome trs em sentido impessoal juntamente com a terceira pessoa do imperativo (vv.43-44) é comum na elegia exortativa, já empregado pelo próprio Tirteu $(10.31 \mathrm{~W})$ e também por Calino $(1.5,1.9)$, e pode ser um indício para a datação do poema ainda no período arcaico (Luginbill, 2002, p. 406, n.8). Jäger também demonstrou que as táticas e os equipamentos apresentados em $12 \mathrm{~W}$ estão de acordo com aqueles descritos em outras elegias tirtaicas (1966, pp.108 -111).

Fowler (1987, p.82) atesta que muitos dos artifícios verbais utilizados por oradores antigos já podiam ser encontrados na poesia. A conclusão do fragmento 4 W de Sólon, por exemplo, embora se utilize de procedimentos notadamente retóricos, não tem sua autoria contestada.

Em relação à autenticidade $\mathrm{d}$ fragmento $12 \mathrm{~W}$ colocada em questão pela crítica, Luginbill (2002, p.406) conclui que as diferenças de temática devem-se antes ao fato de Tirteu utilizar-se de um estilo diferenciado do apresentado nos outros excertos (que talvez, diga-se, pudesse estar presente em outras de suas elegias que foram perdidas) e que nenhum dos argumentos contrários é conclusivo, revelando antes certa relutância em conferir a autenticidade da elegia à Tirteu (2002, p.407).

\section{A glória do canto e a maior virtude (vv. 1-12)}

Como afirma Nagy (1999, p.16), o poeta grego é um mestre do $k \lambda$ Éoک, capaz de eternizar aquele que é celebrado em seu canto e garantir-lhe glória eterna sobre o poder anulador da morte. É esse privilégio, "lugar comuníssimo" (Ver Achcar, 1994, p. 153) da literatura grega, que Tirteu promete para aquele que detém a virtude necessária para a guerra.

No âmbito essencialmente discursivo e circunstancial da poesia arcaica, onde uma audiência - um "tu" ou um "vós" - algumas vezes configura-se explicitamente (Goldhill, 1991, p.110), há também espaço para a manifestação de um "eu" cuja personalidade poética por vezes se mostra com clareza (Martino e Vox, 1996, p.568) 
e, distante de convenções genéricas como as da poesia épica, arroga somente para si

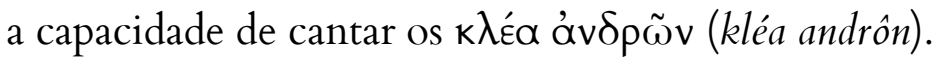

O que impediria o canto deste Eu elegíaco é, assim, a insuficiência de seu próprio repertório e a ausência da virtude heróica nos seus interlocutores, não a incapacidade de relembrar os grandes nomes sem o auxílio dos Deuses (Martino e Vox, 1996, p. 569). A dependência do poeta ante a Musa, propiciada pela sua distância dos grandes acontecimentos ou por sua própria incapacidade mental, constitui um traço do gênero épico que Homero evidencia no canto 2 da Ilíada (vv.484-494). O aedo, incapaz de relembrar todos os guerreiros que assediaram Tróia, pede auxílio às Deusas para enunciar os comandantes e a quantidade de naus de cada segmento do exército:

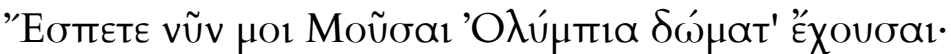

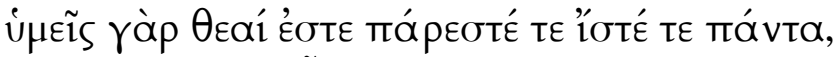

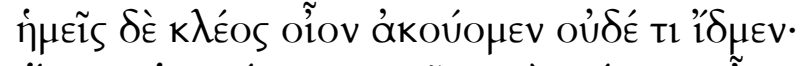

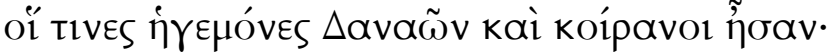

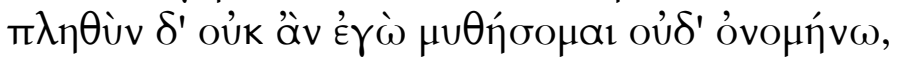

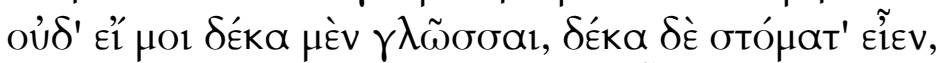

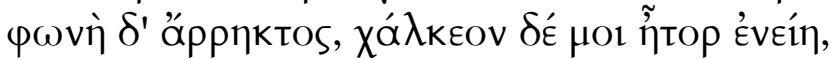

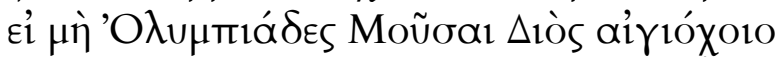

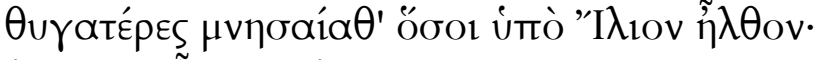

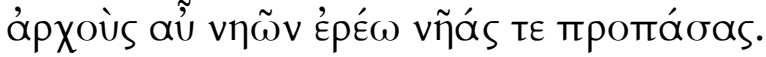

Dizei-me agora, Musas que habitam a Olímpia morada, Pois vós sois Deusas, vós estais presentes e tudo sabeis, mas nós, ouvimos apenas a fama e nada sabemos: quais eram os líderes dos Dânaos e os seus senhores. A multidão eu não conseguiria narrar ou nomear nem mesmo se dez línguas, dez bocas eu tivesse, uma voz inquebrável e um peito brônzeo em mim, se vós, Olímpiades Musas filhas de Zeus egífero não lembrásseis quantos chegaram ao pé de Ílion. Em seguida, direi o número de navios e seus comandantes.

De Martino e Vox (1996, p. 569) creem que o início deste poema de Tirteu (vv.1-12) alude à estrutura dos versos de Homero citados acima: a sequência anafórica da expressão "oư $\delta$ ' eì" no início de cada dístico (vv. 3, 5, 7, 9) e a 
condicional " $\varepsilon \grave{\imath} \mu \grave{\eta}$ ” no verso 11 remetem ao apelo feito pelo poeta da Ilíada às musas, no entanto reforçam a autonomia do poeta elegíaco - se o aedo compõe apenas se as musas derem ajuda à memória, Tirteu depende exclusivamente de seu repertório poético. No caso, o homem não é digno de canto "se não ousar olhar o sanguinário massacre" (vv.11) e "enfrentar o inimigo de perto" (vv.12). É disso que se constitui a coragem, a åpetí militar louvada pelo poeta.

Entretanto em vez de uma alusão direta, estaremos mais de acordo com a leitura de R.L. Fowler em The Nature of Greek Lyric: Three Preliminary Studies (1987, p.82), que já havia notado que a repetição de negativas é um recurso comumente utilizado na poesia arcaica quando se deseja obter ênfase. Os versos 112 trazem somente esse procedimento tradicional levado ao extremo.

Faraone (2008, p.31), indo além, observa o que pode ser um traço característico da elegia arcaica. $\mathrm{O}$ autor demonstra que poetas elegíacos frequentemente utilizam-se de uma unidade de cinco dísticos como recurso formal para a composição de catálogos, que são característicos nos fragmentos mais extensos da elegia arcaica. Tais unidades seriam delimitadas por meio de repetições de sintagmas a cada verso. ${ }^{116}$

A partir de Race (1982, p.30) e Faraone (2008, p.34) pode-se dizer que os versos 1 - 10 de Tirteu constituem uma forma denominada priamel, que consiste de uma enumeração de itens em sequência paratática, de modo a adicionar expectativa quanto à revelação do último item e colocá-lo em posição superior aos arrolados anteriormente, que são refutados pelo poeta. A principal característica do priamel é, portanto, a multiplicidade de itens apresentada utilizada para realçar aquele que é considerado mais importante ou para introduzir alguma reflexão ou posicionamento moral.

O recurso é frequente também em Píndaro (Pítica. 1.75-80, 99-100, Ístmicas .5.30-35, ver Race, 1982, p.02). Por se tratar de uma prática discursiva comum entre

\footnotetext{
${ }^{116}$ Faraone (2008, p.31-43) cita como exemplo dos catálogos elegíacos Sólon 13 W, o priamel em Sólon $27 \mathrm{~W}$ e Tirteu $12 \mathrm{~W}$.
} 
os sofistas, também empregada pelo Sócrates platônico ${ }^{117}$, julgou-se que o poema pertencesse a essa época ou ao início do século IV (Willamowitz 1908, apud De Falco, 1941). No entanto, Safo 16.1-4 V, um exemplo clássico de priamel, já atesta a antiguidade da forma:

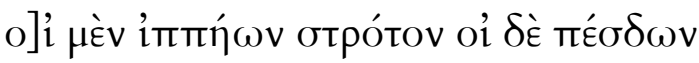

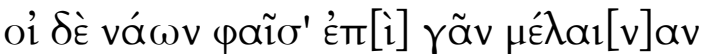

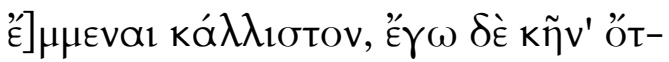

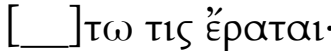

U]ns, renque de cavalos, outros, de soldados,

outros, de naus, dizem ser sobre a terra neg[r]a

a coisa mais bela, mas eu (digo): o que quer

que se ame. ${ }^{118}$

Pietro Pucci em "Il testo de Tirteo nel tessuto homerico" (2006, p. 35) observou que a recusatio e a propositio, a conferir aos versos 1- 12 uma natureza retórica, e a riqueza de exemplos míticos dados pelo poeta configuram o poema como adequado à ocasião de performance do simpósio. Ainda nesse sentido, não seria estranho imaginar que um poema que menciona diversas virtudes de modo a eleger uma única, seja apropriado a um simpósio onde outras formas de virtude já tivessem sido louvadas.

De fato, o fragmento $12 \mathrm{~W}$ de Tirteu aponta para um jogo verbal e filosófico

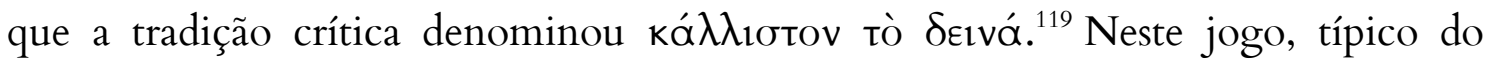
simpósio, cada participante é convidado a declarar, sucessivamente, aquilo que

\footnotetext{
${ }^{117}$ Kirby (1984, p.142) refere-se ao priamel como uma forma essencialmente retórica. Apoiando-se na teoria clássica da retórica aristotélica, Kirby verifica que o priamel consiste de uma função retórica que pode corresponder ao exemplo (o aspecto indutivo da argumentação)e cujo par oposto é o topos do maior e do menor, - exemplo de argumento dedutivo (entimema). Kirby ainda salienta que o uso priamel em lugar do argumento entimemático é forma apropriada para inícios de poemas e gera efeitos mais adequados à poesia do que à prosa (1984, p.143).

${ }^{118}$ Tradução de Giuliana Ragusa (2005).

${ }^{119}$ Ver Ford (1999, p. 116)
} 


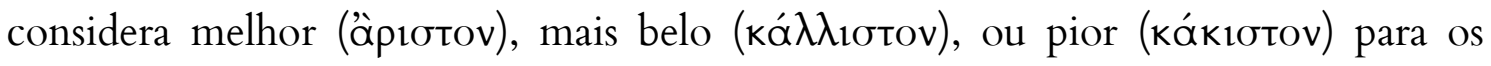
mortais. A Teognideia possui um dístico (255-256) que demonstra exemplarmente o mecanismo que constituía o ká $\lambda \lambda_{1 \sigma \tau}$ tov tò $\delta \varepsilon 1 v a ́$; os versos apresentam um simposiasta, que, ao mesmo tempo em que se mostra justo, também aprecia o prazer (e parece pô-lo em primeiro plano - dando destaque a ele no segundo verso):

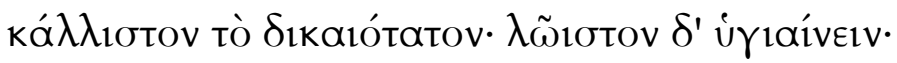

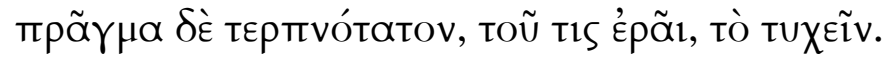

O mais belo é o mais justo; o melhor, ter saúde;

E a coisa mais doce, conquistar quem se ama.

Tirteu também se vale deste jogo: para o poeta espartano a melhor virtude não é a excelência nos jogos atléticos, beleza, riquezas, a realeza, a eloquência ou uma boa reputação (vv.1-9). Acima de todas essas virtudes, Tirteu coloca a coragem de olhar a chacina no campo de batalha e enfrentar seus inimigos em combate corpo-a-corpo (vv.9-12).

O verso 1 constitui um início impactante, frequente em Tirteu. Os pés do

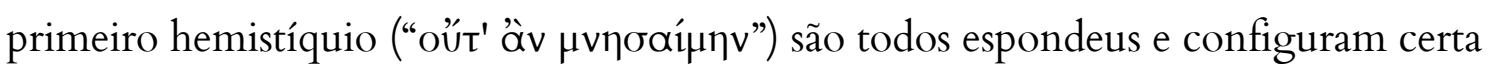
solenidade ao começo ${ }^{120}$. Ambos os termos que indicam o ofício poético recebem

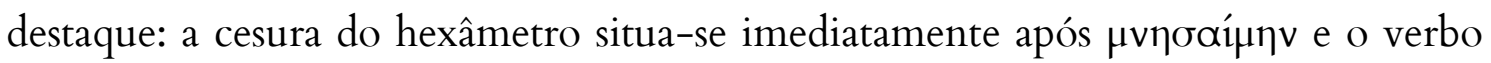

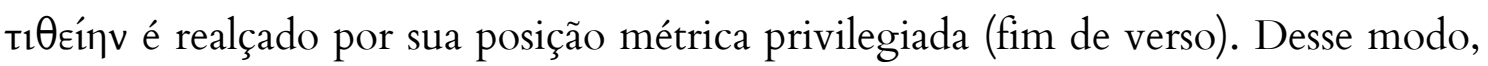
o poeta coloca-se em evidência e confere gravidade à sua própria atividade poética.

Para De Martino e Vox (1996, p. 568) os versos 1-9 apresentam o programa poético de Tirteu: nesse sentido, o fr.12 W de Tirteu poderia configurar-se como uma introdução aos temas que Tirteu trata em sua poesia, isto é, apresentam aquilo que o poeta se propõe ou se recusa a cantar. ${ }^{121}$

\footnotetext{
${ }^{120}$ Pode-se pensar, tomando como modelo o estudo de Adkins (1977, p. 63-64) para o Fr.1W de Calino, que o verso 1 do Fr.12 W de Tirteu corresponderia provavelmente ao começo do poema, por conta da ausência de partículas conectivas e da eficácia de um verso como este em início de poema, o qual anuncia uma espécie de "programa poético".

${ }^{121}$ Ver também Prato, 1968, pp.119-126.
} 
O modo como Tirteu denomina os seus versos, $\lambda o \gamma \omega$ (vv.01), é fundamentalmente técnico; A expressão já é empregada por Hesíodo para qualificar

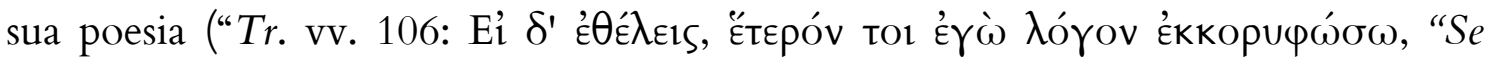
queres, com outra história esta encimarei”122), mas é o Fragmento S 151 de Íbico (vv.2326) que atesta um uso em contexto similar ao de Tirteu (Martino \& Vox, 1996, p.573). O poeta interrompe a narração de episódios concernentes ao ciclo troiano e diz-se incapaz de colocá-los em discurso, engendrando uma preterição:

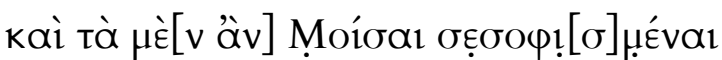

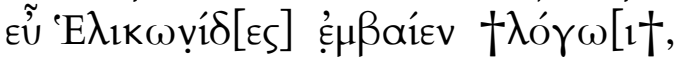

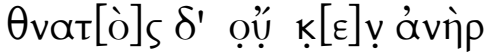

_-

Mesmo essas coisas [as] Musas habil[i]dosas

Heliconíad[es] bem poderiam perfazer em narrativa, mas um $\mathrm{m}[\mathrm{o}] \mathrm{rtal}$, um homem vivo, não poderia

dizê-las cada uma - (...) $)^{123}$

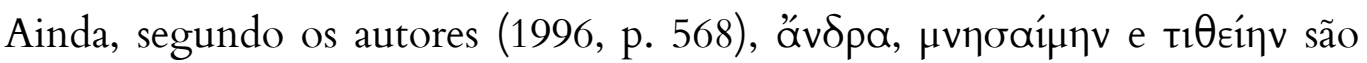
todos termos técnicos significativos: o primeiro delimita a matéria do canto e tem como exemplo célebre o verso inicial da Odisseia. Os outros dois são verbos por excelência do fazer poético. O primeiro é típico da poesia épica e denota a relação entre o cantor e o seu repertório, como o demonstram os versos iliádicos mencionados acima. O segundo é menos comum, mas adequado ao contexto programático, como demonstram outros fragmentos elegíacos (Sólon, Fr. 1W,

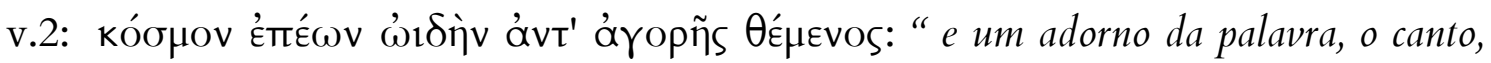
anteponho à fala")

O pentâmetro que sucede o verso inicial (v.2) contrapõe com a ágil e constante dicção do metro datílico a forte sequência de espondeus do verso anterior. O dístico forma uma unidade de sentido completa ${ }^{124}$, à qual se seguirá uma série de

\footnotetext{
${ }^{122}$ Tradução de Mary de Camargo Neves Lafer (1989).

${ }^{123}$ Tradução de Giuliana Ragusa (2010)

${ }^{124}$ Embora a correspondência entre o dístico elegíaco e uma oração de sentido completo de modo a formar uma unidade seja uma regra de composição tradicional para a poesia elegíaca latina, o mesmo nem sempre era válido na produção elegíaca grega (Adkins, 1985, p.07).
} 


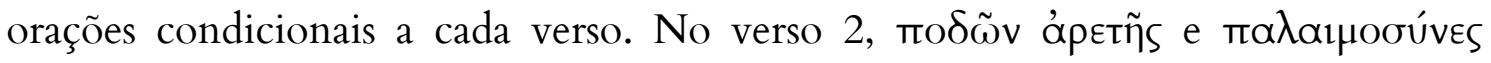
atuam como genitivos causais que limitam a oração anterior: o poeta especifica qual é o homem que ele não lembrará nem colocará em seu discurso (Defradas, 1962, p.37).

Nesse sentido, os dois termos já fornecem a primeira instância que o poeta recusará no verso 9. Ambos tratam de atividades do mundo atlético (Bowra, 1938,

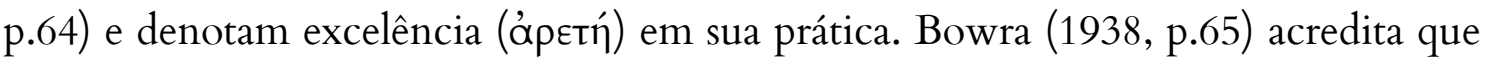
as vitórias espartanas em Olímpia no século anterior foram provavelmente importantes para a menção de Tirteu às aptidões atléticas. De Martino e Vox (1996, p.568), contudo, remetem a uma passagem da Odisseia em que ocorre uma reflexão sobre o esporte em termos similares aos de Tirteu, que induz pensar que se tratam de referências comuns na poesia grega $(\mathrm{Od} .8 .145-148)^{125}$ :

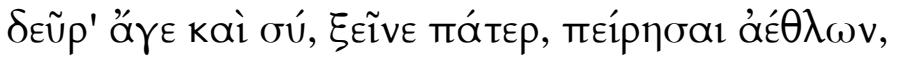

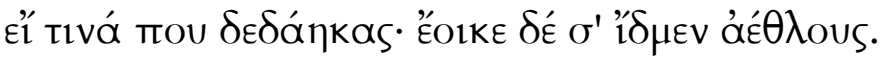

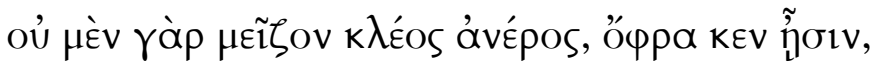

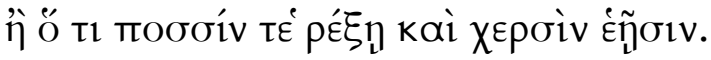

Eia, tu também, senhor hóspede, vem pôr-te à prova nos jogos, se é que aprendeste algum... pois parece que os conhece! Pois não há maior glória para um varão, enquanto vive, do que a que se realiza com os seus pés e as suas próprias mãos.

Nesse sentido, há de se notar o uso particularizante de àpetŕ, associado à

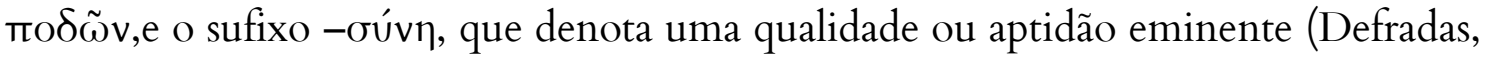
1962, p. 37).

Seguindo-se à formulação geral do verso 1 e ampliando o contexto apresentado no início, os versos 3-9 expõem em sequência cinco exemplos míticos

\footnotetext{
${ }^{125}$ É significativo também o fato de que Odisseu, ele mesmo um ơvíp, tecerá reflexões similares à frente Ver Od.8.167, 172, 206.
} 
de outras virtudes inferiores ao ímpeto na guerra: força física (v.3), agilidade (v.4), essas duas estreitamente relacionados às aptidões citadas no verso 2 - beleza (v.5), riqueza (v.6), poder (v.7) e eloquência (v.8). O acúmulo de virtudes e o caráter hiperbólico das comparações, que recorre a heróis ou a divindades, reforçará a grandiosidade da virtude enunciada no verso 9.

Uma sequência de orações coordenadas em que cada verso corresponde a uma unidade de sentido completa (Adkins, 1985, p. 7), e a anáfora de oủ ¿' cí (vv.3, $5,7)$ no início de cada dístico imprimem uma ordem regular e uniforme (Faraone, 2008, p. 33). Do mesmo modo, Faraone também observou regularidade na organização de cada verso, que oferece sempre uma virtude natural e um exemplo mitológico correspondente $(2008$, p.33). Não raro o poeta se vale da estruturação do hexâmetro e do pentâmetro para enfatizar a regularidade: é o caso do terceiro dístico (vv. 5-6), por exemplo, onde os elementos da comparação situam-se cada qual em um hemistíquio, separados pela cesura.

O último dístico que compõe o priamel, embora seja introduzido por oủ $\delta^{\prime}$ z', rompe o padrão regular dos versos anteriores. Faraone (2008, p.34) observa que no verso 9 o poeta muda o tom ao fazer uma declaração sumária, que resume todas as

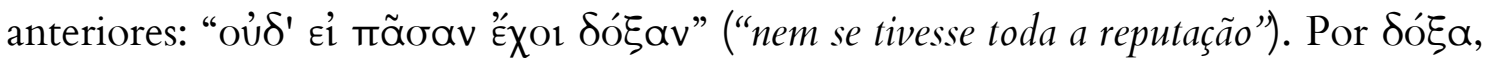
entende-se a expressão objetiva da ópєtí diante da sociedade e da pólis, um termo que, para Jäger (1966, p.119) é virtualmente um sinônimo de ápetŕ. ${ }^{126} \mathrm{O}$ aspecto de síntese é reforçado pelo uso de Tãoav $\delta o ́ \xi \alpha v$, que se refere de maneira breve, a todas as ả petái anteriormente descritas.

$\mathrm{O}$ recurso é enfático e acrescenta à enumeração constante dos versos anteriores um índice de multiplicidade ( $\pi \tilde{\alpha} \sigma a v)$, que sugere serem diversas as virtudes que são superadas pela virtude guerreira exaltada por Tirteu.

Race (1982, p.16) observa que dois são os modos para sugerir quantidade/diversidade no priamel: por meio de exemplos particulares ou por meio de uma forma sumária, que indica a multiplicidade, com um termo que de certa

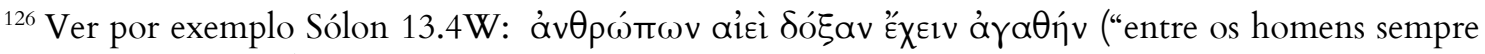
ter a boa reputação")
} 


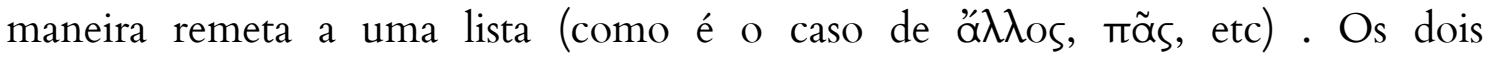
procedimentos são empregados por Tirteu no fragmento 12, de modo a colocar em posição de destaque a última das virtudes relatada. A enunciação dessa virtude conclui o priamel e abre o poema para uma declaração dos talentos e habilidades do

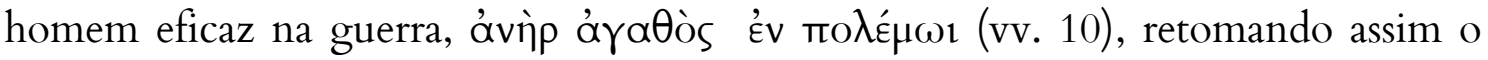

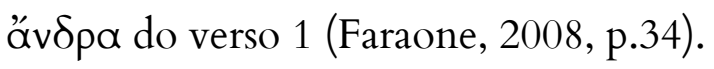

Contra virtudes atléticas, plutocráticas e estéticas Tirteu anuncia a primazia da virtude guerreira, isto é, "a bravura impetuosa" (v. 10). Mas de que é constituída esta maior virtude? Tirteu descreve o homem detentor da ápєtŕ marcial como capaz de suportar olhar o sanguinário massacre (póvov áuıatoévta, phónon haimatoénta, v.11) e enfrentar os inimigos de perto (v. 12). É essa, de certo modo, também a maior exigência do poeta aos soldados em outros de seus fragmentos exortatórios ${ }^{127}$. No entanto, o valor marcial que ele afirma que os jovens podem conquistar, caso fiquem firmes na guerra, é o mesmo valor que em outros fragmentos é perdido pelos guerreiros que ousam fugir (ver fr.11.14 W).

Nesses termos, Luginbill (2002, p.407) observou que a ópєtí exigida por Tirteu apenas pode ser conquistada na guerra, obtida no esforço do combate. A virtude conquistada por esforço é retratada por Hesíodo nos Trabalhos e Dias (vv. 286-92). Segundo a concepção hesiódica, reminiscente nos versos 43-44 do fragmento, os Deuses interpõem uma íngreme e difícil via para a obtenção da virtude, mas uma vez que se alcança o topo dessa via, tudo se torna fácil (vv. 286292):

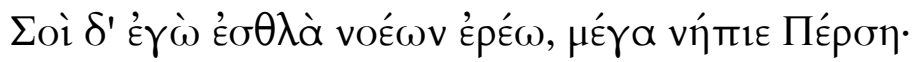

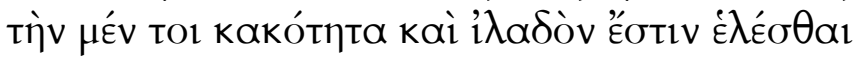

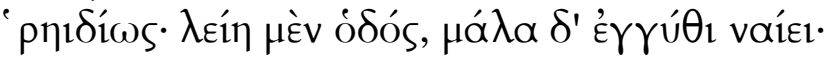

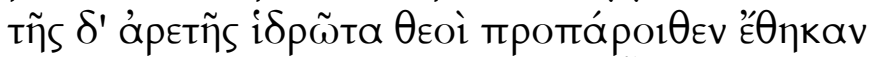

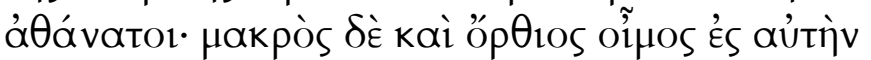

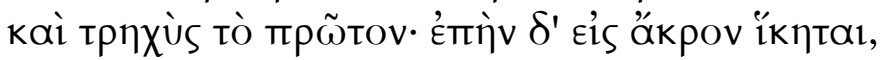

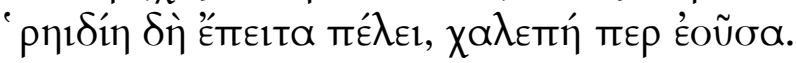

${ }^{127}$ Ver 10. 15-18 W, 10. 31-32 W, 11.7-8 W, 11.11-12 W, 11.21-22 W. 
A ti boas coisas falarei, ó Perses, grande tolo!

Adquirir a miséria, mesmo que seja em abundância

é fácil: plana é a rota e perto ela reside.

Mas diante da excelência, suor puseram os deuses

imortais, longa e íngreme é a via até ela,

áspera de início, mas depois que atinges o topo

fácil desde então é, embora difícil seja. ${ }^{128}$

Hesíodo, porém, não elege uma virtude específica como faz Tirteu, e claramente não se refere a um contexto marcial como ele: o homem excelente (mavápıotos, vv. 293) é aquele que pensa todas as coisas por si mesmo e bom

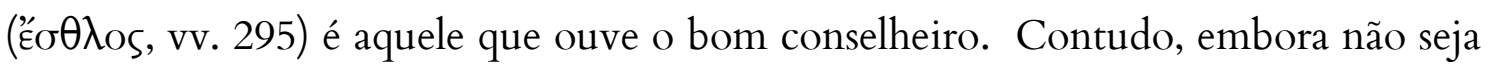
o valor militar que esteja em jogo para Hesíodo, como é para Homero e Tirteu, a ideia de virtude como habilidades e conhecimentos necessários para se obter o sucesso é compartilhada pelos três autores. Nesse sentido, a única virtude que pode ser eleita por Tirteu é a coragem, visto que é essa que pode garantir o sucesso na guerra.

No verso 9, Өoũpı ${ }^{\alpha} \lambda k \dot{n}$ é colocada acima das virtudes atléticas mencionadas anteriormente. Esta expressão é recorrente na Ilíada, e como já observamos antes ${ }^{129}$, é utilizada em exortações como uma característica definidora do varão: clamar para que um guerreiro seja um åvíp equivale a pedir que ele demonstre $\theta$ oũpıs á $\lambda_{k} \tilde{\eta}$.

Em muitas passagens $\theta$ oũpıs å $\lambda_{k} \tilde{~ c o n f i g u r a-s e ~ c o m o ~ u m ~ a n t o ̂ n i m o ~ p a r a ~ a ~}$ fuga ou o medo, como se pode depreender em 11.566-568, onde uma oposição

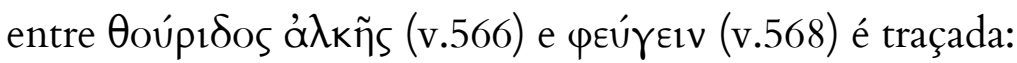

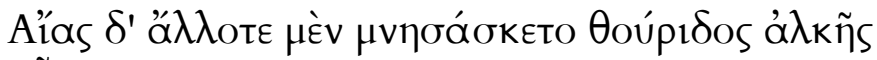

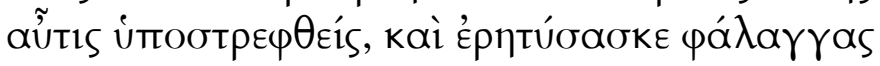

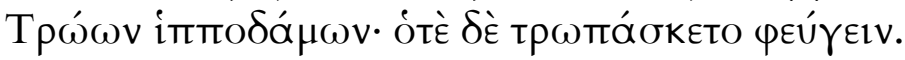

Ájax ora se lembrava de sua impetuosa bravura, e ao se virar para trás tentava refrear as falanges

\footnotetext{
${ }^{128}$ Tradução de Mary de Camargo Macedo Lafer.

${ }^{129}$ Ver comentários ao fragmento $11, \mathrm{p}$. .
} 
dos Troianos domadores de corcéis. Ora, virava-se para fugir. ${ }^{130}$

Apenas no fragmento 12 esta qualidade do guerreiro supera as outras virtudes atléticas: desse modo, Tirteu coloca no lugar do atleta dos jogos o jovem guerreiro que, assim, obterá prêmios similares aos que seriam destinados a este. (Luginbill, 2002, p. 411).

De fato, assim como no fragmento $2 \mathrm{~W}$ de Xenófanes acima citado, o guerreiro de Tirteu obtém status eminente em sua sociedade $(12.41 \mathrm{~W})$ do mesmo modo que o atleta vencedor de Xenófanes $(2.7 \mathrm{~W})$. O oferecimento de um prêmio (12.13 W: ă $\varepsilon \theta \lambda o v$, termo frequentemente utilizado para designar o prêmio obtido com a vitória nos jogos) e o alto apreço dado a ele $(12.14 \mathrm{~W})$ podem também remeter a esse contexto.

A relação entre os jogos atléticos e a atividade militar pode ter sido frequente na poesia de Tirteu. Além do símile da corrida de cavalos no fragmento $20 \mathbf{W}^{131}$, o fragmento $14 \mathrm{~W}$ pode trazer uma associação similar:

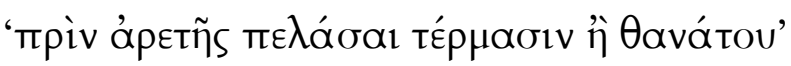

Antes de alcançar os limites da virtude ou da morte.

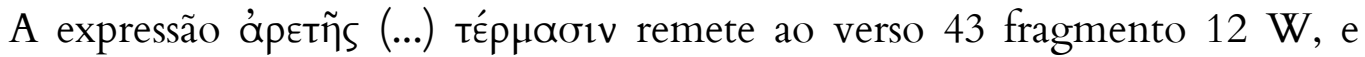
ambas parecem tratar de um contexto atlético: para Jäger (1966, p.116) a palavra

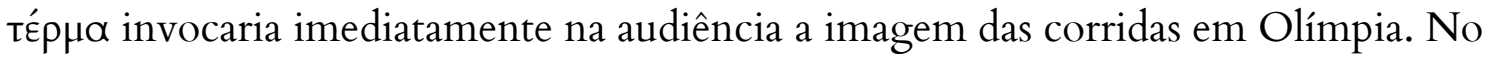
entanto, o termo da corrida de Tirteu apenas se encontra em batalha. E no fim desta corrida, restam apenas duas opções: ou a virtude, ou a morte.

Pucci (2006, p. 36), contrário às leituras tradicionais do poema, considerou que o priamel refere-se não às virtudes celebradas nos jogos, mas alude diretamente àquelas louvadas na Ilíada. Assim, Tirteu configura uma polêmica com o texto

\footnotetext{
${ }^{130}$ Outros exemplos: em Il.15. 318-327, o agitar da égide de Apolo "enfeitiçava o peito" dos Dânaos

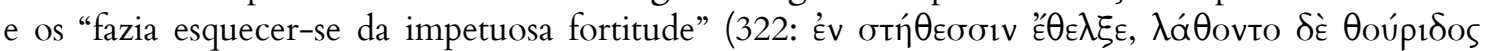

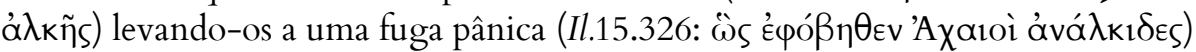

${ }^{131}$ Ver comentários aos fragmentos 6 e 7, pp.211-216.
} 
homérico: o poeta recusa as virtudes próprias dos heróis homéricos, de modo a gloriar não o nobre de ascendência divina, mas o soldado comum.

Por outro lado, caso se pense na ocasião de performance do poema como o simpósio, espaço eminentemente aristocrático, verifica-se que a identificação dos participantes nesse ambiente com heróis de investidura épica é corriqueiro e um dos traços característicos da elegia marcial (Irwin, 2005, p. 36).

Jäger pensou que o poema engendrava uma transvaloração (umwertung) da palavra ápєtí em relação aos poemas homéricos (1966, p.120). Para ele, o ideal heróico da ápetí homérica transforma-se no heroísmo do amor à pátria, recebendo expressão artística pela primeira vez neste poema em termos absolutos (1995, p.119).

Campbell (1982, p. 177) ofereceu outro ponto de vista para a compreensão da ápetŕ no poema, e foi seguido por Luginbill (2002, pp.407-409): segundo o

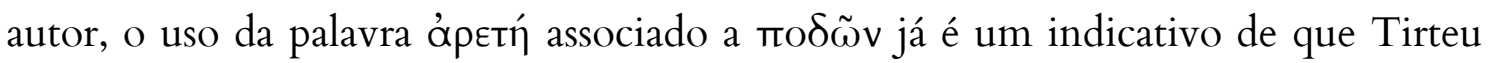
trata a noção de virtude nos mesmos termos que Homero, como diversas formas particulares de excelência. Há outras virtudes, mas para o poeta, todas são inferiores à coragem.

O uso de ij $\delta$ ' åpetŕ no verso 13 é outro indicativo da especificidade deste termo na poesia de Tirteu. A expressão consagra a ỏpetń marcial como suprema, em vez de propor uma definição geral sobre o que é a virtude, como pretendera Bowra (1938, p.70).

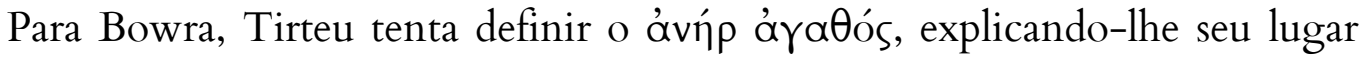
na sociedade a partir de uma definição geral de sua ápєtí. Gerber (1970, apud Luginbill, p.407, n. 21) nota o paralelismo nas posições dos pronomes em $\dot{\eta} \delta$ ' ’’ $\rho \in t \tilde{~}$ e tó $\delta{ }^{\prime}{ }^{\prime} \varepsilon \theta \lambda_{o v}$, de maneira a pensar que as duas expressões devem ser sintaticamente entendidas da mesma forma. Sendo assim, Gerber observa que tanto "Isso é ápєtŕn" quanto "esta ảpєtín" são interpretações possíveis, no entanto o contexto do poema favorece a segunda. ${ }^{132}$

\footnotetext{
${ }^{132}$ A tradução de Aluízio Faria de Coimbra (1941) mantém a correlação sintática vertendo a passagem por "Mais alta esta é dos homens a virtude/ e florão (...)
} 
Observando este contexto, mantém-se aqui posição similar a de Luginbill (2002, pp.407-409): o poeta refere-se às diversas ápetaí - todas afins ao universo ético e aristocrático grego - de modo a eleger aquela que lhe é mais conveniente em seus poemas: a coragem que deve ser demonstrada em guerra. Elegendo esta virtude, o poeta agora define o homem que a possui, o herói que participa da guerra por sua terra e seus familiares.

\section{O homem bom na guerra (vv. 15-22)}

O ideal do soldado valente, o homem bom (ávíp åräós) na guerra, engendra boa parte das reflexões morais da obra poética de Tirteu. (Bowra, 1960, p. 59). Questão que recebe uma de suas maiores expressões no fragmento 10. 1- 2 W (Bowra, 1960, p.60) ${ }^{133}$.

Também no fragmento $12 \mathrm{~W}$, o valor marcial é associado à defesa da terra pátria: o homem bom é considerado um bem comum a toda a cidade e ao seu

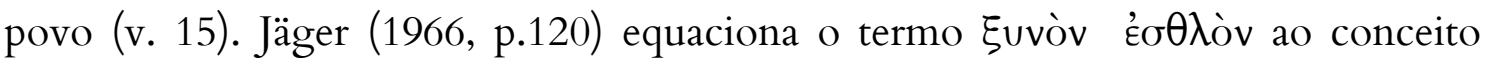
tardio de koıvóv årađóv, e assinala que o único valor que define o herói no tempo de Tirteu é o seu zelo em lutar pela terra pátria, ao passo que o herói homérico tem unicamente propósitos pessoais.

Bowra (1960, p.65), seguindo leitura similar, pontua que não há no poema de Homero um homem que possa ser chamado de åräós no sentido dado por Tirteu, entretanto reconhece em Heitor um homem próximo desse ideal.

Já foi visto anteriormente que o sentimento patriótico ou de coletividade existe tanto na poesia de Homero quanto na de Tirteu, e as diferenças existentes restringem-se ao gênero e as circunstâncias de cada poema, não sinalizando propriamente um desenvolvimento histórico ${ }^{134}$.

Adkins (1960, p. 33) sugeriu que os heróis homéricos são caracterizados como áraӨoí não somente pela nobreza de seu nascimento, mas também por

\footnotetext{
${ }^{133}$ Ver os comentários ao fr. $10 \mathrm{~W}$, pp.63-73.

${ }^{134}$ Ver Introdução.
} 
(deverem) apresentar as qualidades que permitem o bom regimento de uma sociedade, seja na guerra ou na paz. Assim, aquele que possui a ápetŕ é também tido como capaz de defender a coletividade, e deve conjugar atributos como força e coragem. Uma vez que estes atributos são os que uma sociedade em tempo de guerra mais necessita, é natural que aqueles que os possuem sejam denominados åräós (Adkins, 1971, p.13).

Desse modo, a ápєtŕ considerada um bem comum a todo o grupo não é ideia exclusiva da elegia de Tirteu. Luginbill (2002, p. 408) relembra o fragmento 2 W de Xenófanes que define a sabedoria como ópetŕ mais importante em vista do

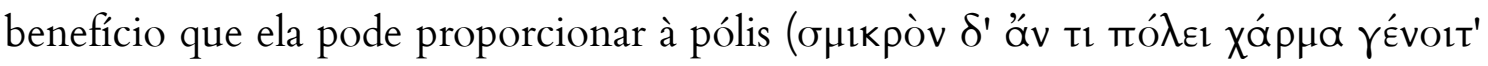

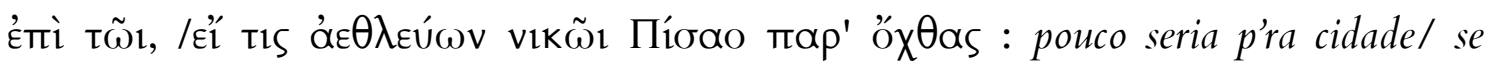
conquistassem vitória às margens do Pisa) No canto 19 da Odisseia (vv. 106- 114) compartilha-se de um ideal similar quando Odisseu menciona que o povo prospera (’’ątãv) quando está sob o governo de um rei excelente:

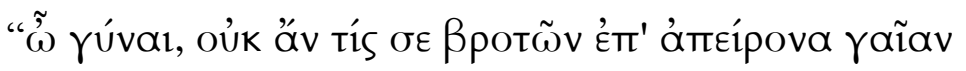

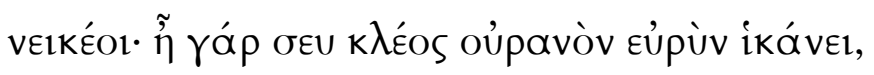

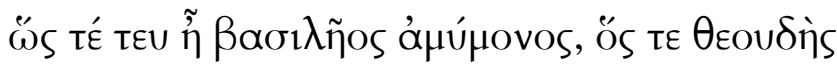

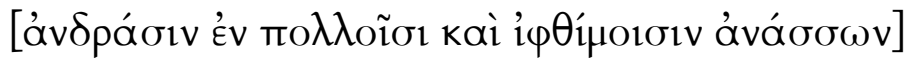

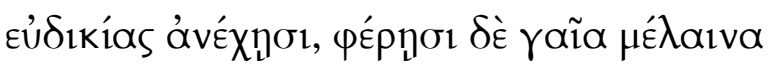

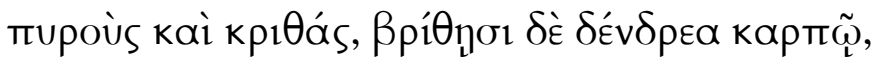

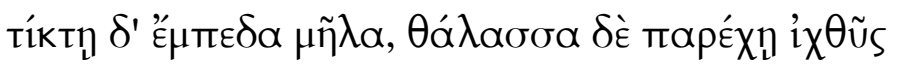

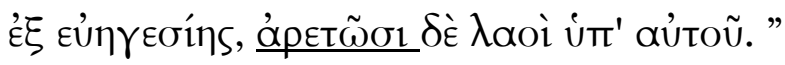

Mulher, nenhum mortal sobre a terra infinita poderia repreendê-la, pois a glória tua alcançou o céu vasto, como se fosses um rei irreprochável, que piedoso [entre muitos e poderosos varões reinando] sustenta boas decisões. e a terra negra produz-lhe trigo e cevada, as árvores se vergam de fruto, as ovelhas parem sempre e o mar fornece peixe, graças ao bom governo. Sob ele o povo prima. 


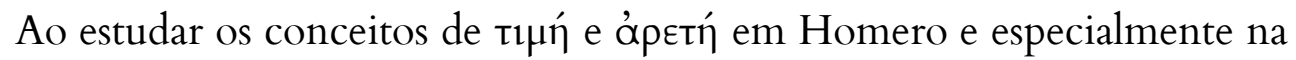
Ilíada, Margalit Filkenberg em "Time and Arete in Homer" (1998, p. 21) nota que a ápєtŕ deixa de existir quando não colocada a serviço de propósitos públicos.

Nesse sentido, Heitor não seria o único que serviria como exemplo de algo próximo ao ideal de ávíp áräós de Tirteu, mas conforme o exemplo de Finkelberg, também em menor evidência, Aquiles, visto que fica implícito que a ápєtí do herói grego deixará de existir se ele continuar abstendo-se da guerra (Finkelberg, 1998 p. 21-23) e permitir a morte dos seus aliados aqueus. No canto 11 da Ilíada, Nestor conta a Pátroclo como, ainda jovem, tomou parte do confronto contra os Epeios em favor de Pilos e sobressaiu-se no combate. Em seguida, compara-se a Aquiles (Il. 11. 762-764):

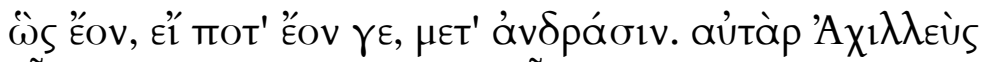

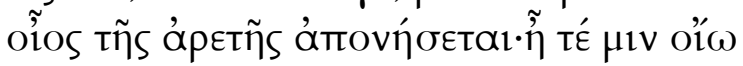

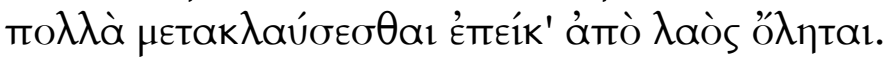

Assim eu fui, se o fui um dia, entre os varões.

Mas apenas Aquiles aproveitará seu valor; Sim, creio que ele muito chorará, depois que a tropa for destruída.

A cena continua no Canto XVI, quando Pátroclo dirige-se a Aquiles, reproduzindo a reprimenda de Nestor (16. 29-33):

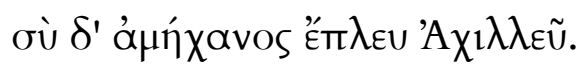

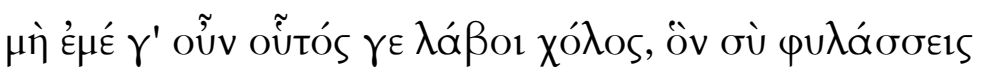

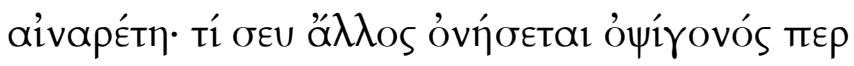

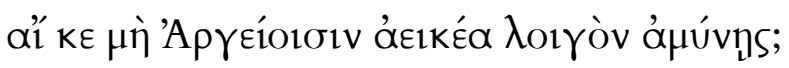

Tu és impossível, Aquiles.

Que não se apodere de mim essa cólera que tu guardas, 
terrível virtude! Quem no futuro se beneficiará de ti, se não repelires a vexatória ruína dos Argivos?

Segundo Finkelberg (1998, p.22), embora a expressão ápєtí não conste nas palavras ditas por Pátroclo, ele reproduz quase que fielmente o que diz Nestor no canto 11, insinuando que se abster da luta implica perder a sua virtude, e por extensão, a sua própria razão de ser, uma vez que tal atitude nada lega aos outros homens (pósteros ou não).

Deste mesmo modo é que pode se dar na poesia de Tirteu a associação entre ápєtń individual possuída pelo guerreiro e a sua comunidade: o guerreiro receberá os benefícios de sua ápєtń apenas quando esta for significativa para seu

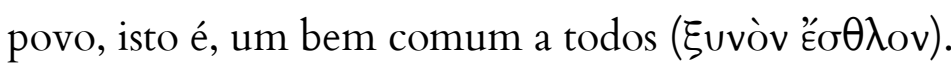

Os versos 16-20 compõem o caráter do ávíp åräós que garante o sucesso na guerra. Há de se notar que o verso 20 termina com a mesma declaração

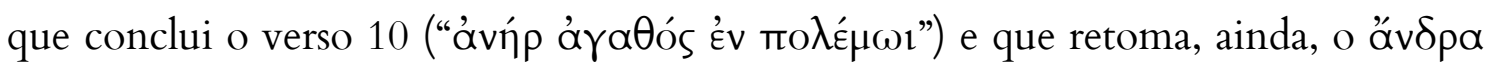
mencionado no verso 1. Deste modo, Tirteu separa seu poema em duas partes distintas cujas estruturas são equivalentes: os primeiros cinco dísticos expõem aquilo que não tem lugar na elegia marcial e os cinco dísticos que se seguem apresentam a matéria digna de canto: a virtude guerreira (vv. 11-12), os benefícios que dela provêm (vv. 13-15) e os principais elementos que caracterizam seu detentor (vv. 1620).

Tirteu engendra assim dois pólos opostos, um negativo nos vv. 1-10, e outro positivo em 11-20, mas correspondentes em estrutura, visto que são enquadrados claramente por uma mesma oração ao término de cada um dos cinco dísticos (Fränkel, 1975, p.339, n. 8). Fränkel considerou, por outro lado, que este equilíbrio entre as partes do poema denunciava-o como próprio do período clássico.

Entretanto, considera-se que este tipo de construção pode ser um traço comum na poesia elegíaca: a teoria de Faraone (2008, pp.49-50) é a de que este tipo de construção em blocos é recorrente na elegia grega arcaica, e pode até mesmo ser rastreada em outros fragmentos de Tirteu. 
No fragmento $10 \mathrm{~W}$ de Tirteu, por exemplo, o verso 21 ecoa o primeiro verso do poema e há um padrão retórico alternado, que conjuga reflexão e exortação: a cada cinco dísticos de reflexão, marcados pelo emprego de uma terceira pessoa do singular, seguem-se outros cinco de exortação, denotados pela segunda pessoa do plural e pelo subjuntivo exortativo.

Coincidentemente, o fragmento $11 \mathrm{~W}$ também se inicia com uma exortação (vv. 1-10) e parte para a reflexão (vv. 11-20) antes de seguir para a descrição da batalha (vv. 21 ss.).

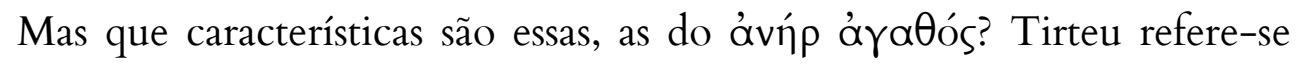
novamente ${ }^{135}$ à necessidade do homem permanecer em uma posição fixa ( $\delta$ ıßßás)

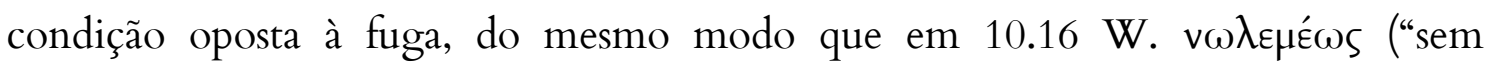
trégua”, vv. 17) segue em enjambement, recebendo destaque por estar em início de verso e ser o único termo que antecede à cesura. $\mathrm{O}$ procedimento reforça todo o

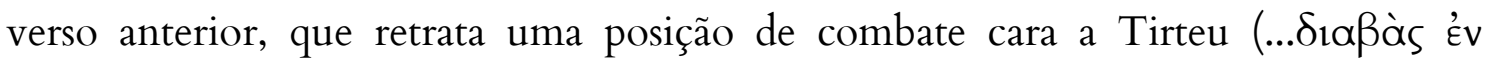

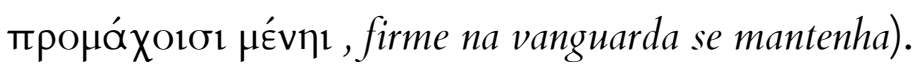

Nesse trecho, a menção à fuga serve apenas para recrudescer o valor do herói objeto de louvor: o homem bom elimina por completo de sua mente o desejo de fuga. Situação bem diferente se lê em outros fragmentos: no fragmento $10 \mathrm{~W}$ supramencionado, também há a condenação da fuga em termos similares (Fr.10.16 W), mas esta é condenável sobretudo porque acarreta um destino funesto para os anciãos $(10.21-30 \mathrm{~W})^{136}$; no fragmento $11 \mathrm{~W}$, a fuga e a derrota são situações

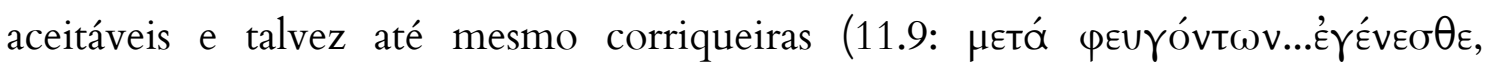
"estivestes entre os que fogem...”).

Para lutar firme nas primeiras linhas do combate, o guerreiro deve

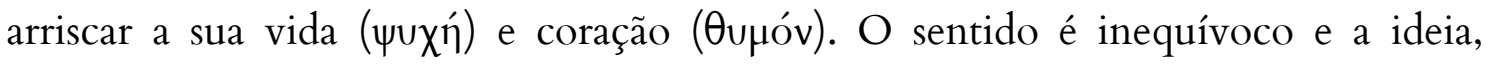
recorrente $^{137}$. Os dois termos são representativos de princípios vitais humanos. Postos lado a lado e ocupando todo o primeiro hemistíquio do verso 18 na forma de

\footnotetext{
${ }^{135}$ Ver Tirteu 10 W. 31-32; Tirteu $11 \mathrm{~W} 21$-22. c.f. análise do fragmento $11 \mathrm{~W}$.

${ }^{136} \mathrm{O}$ guerreiro enquanto um objeto de louvor é mencionado apenas brevemente (10.29-30), não ocupando o argumento central do poeta como no fragmento $12 \mathrm{~W}$.

${ }^{137}$ Ver Tirteu 10.18 W, 11. 5-6 W
} 
espondeus, o poeta destaca a oposição marcante entre a vida e a necessidade eminente do combate, que a põe em jogo ( $\pi \alpha \rho \theta \varepsilon ́ \mu \varepsilon v o \varsigma)$.

A representação de Tirteu para cada um destes elementos é comum, também, a Homero. ${ }^{138} \mathrm{O}$ Gupós pode ser entendido como um princípio vital, uma vez que ao abandonar o corpo faz cessar a respiração e a consciência. É, no entanto, ativo durante a vida e considerado sede dos pensamentos e sentimentos (Corrêa, 2009, p.36), dentre os quais a coragem e a cólera. A $\psi v \chi \chi$, , por outro lado, diz respeito frequentemente a último sopro vital, que abandona o corpo do individuo juntamente com o $\theta$ urós. Difere do $\theta$ unós por não ter nenhuma participação ativa na consciência ou pensamento (Corrêa, 2009, p.36), e por poder designar, portanto, a alma dos mortos. Por extensão, Homero, como Tirteu, já representa a భuxý como a própria vida que é colocada em jogo no combate (Corrêa, 2009, p.38).

Por fim, Tirteu salienta o valor da cooperação como uma característica essencial na guerra. Assim como em outros poemas ele admoesta os guerreiros a

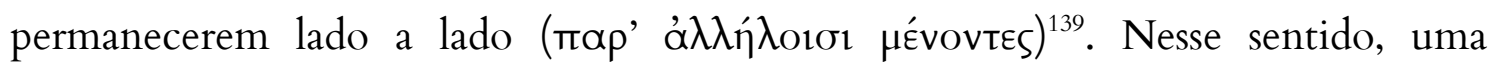
característica do bom guerreiro é manter-se ao lado de outro homem e o encorajálo à luta, não só com exemplos, mas também com o discurso (Pucci, 2006, p. 31). O poeta reforça a noção de cooperação empregando dois termos que indicam esta proximidade: $\pi \lambda \dot{\sigma} \sigma ı v$ e $\pi \alpha \rho \varepsilon \sigma \tau \omega ́ s$.

Pucci (2006, p.31) viu neste verso um elemento metapoético: para o autor, o discurso que o guerreiro faz para outro no ambiente da guerra se identifica com o próprio discurso que a elegia realiza. Em outras palavras, a própria elegia torna-se uma ação bélica. A hipótese é interessante, pois, se considerarmos dessa maneira, a elegia exortativa marcial realiza-se antes em performance, mimetizando em forma poética o discurso guerreiro que o poeta espera de seus interlocutores. Nesse sentido, ao emular um contexto bélico, podemos supor que essa performance

\footnotetext{
${ }^{138}$ Defradas (1962, p. 38) observa que o verso é composto a partir da junção de duas fórmulas

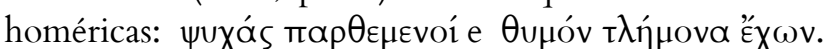

${ }^{139}$ Ver estudo do fragmento 11 para uma análise mais detalhada do valor do auxílio mútuo na poesia de Tirteu.
} 
provavelmente se inseriria num ambiente propício à ficcionalização de papéis como o simpósio.

Os versos 20-21 descrevem as habilidades físicas do herói de Tirteu, e demonstram que a ópetí do homem bom provoca efeitos tangíveis no campo de batalha (Luginbill, 2002, p. 408). Do mesmo modo que a caracterização do guerreiro privilegia o indivíduo, e não o yévos (como em $11.1 \mathrm{~W}$ ) e tampouco há referências ao coletivo, como há no uso da primeira e segunda pessoa do plural nos fragmentos 10, 11 e 19, também pode se pensar que os feitos de força descritos nos versos 20-21 são estritamente individuais (Luginbill, 2002, p.411) e aludem a um mundo tipicamente iliádico - onde um herói destaca-se da massa por suas habilidades sobre-humanas.

Contudo, tal visão idealizada (Luginbill, 2002, p. 410) não é exclusiva da épica, mas também recorre no mais extenso fragmento militar de Calino, onde surge, enfatizada, a individualidade do guerreiro (roũvos éćv, v. 21). Cabe lembrar, ainda, que a recompensa do interlocutor de Calino por seus feitos épicos, a lembrança de todos, será a mesma que Tirteu concederá ao seu véos nos versos 2742 (Calino, 1.18-21 W):

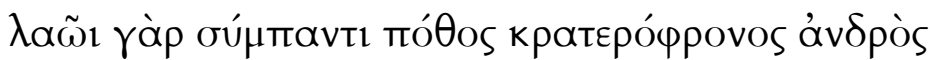

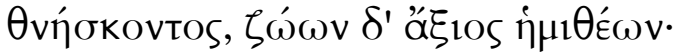

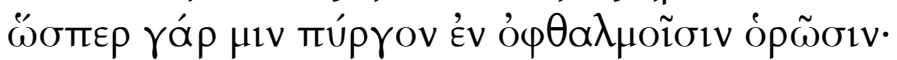

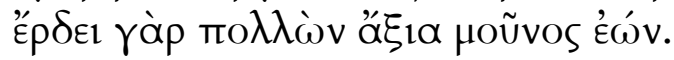

Toda a tropa tem saudade de um varão de coração forte que morre, e em vida era digno de semideuses.

Com os seus olhos veem-no qual uma torre, pois, embora só, faz atos dignos de muitos.

$\mathrm{O}$ feito do guerreiro tirtaico consiste em desfazer as falanges ${ }^{140}$ inimigas (vv.21) e deter o fluxo da guerra (vv. 22). O caráter heróico de cada ação ainda é

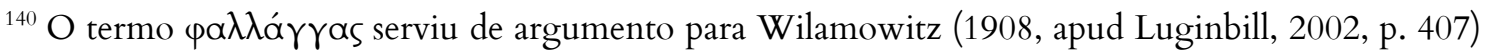
destituir do poema a autoria de Tirteu, uma vez que, segundo ele, esta tática de guerra ainda era desconhecida no tempo de Tirteu. Mas o termo poderia ser usado em um sentido menos específico,
} 
realçado pelo advérbio å̌ $\psi$, ("prontamente"), em início de verso, e pelo dativo

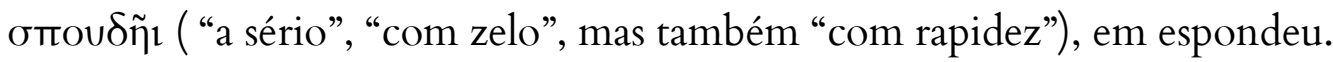

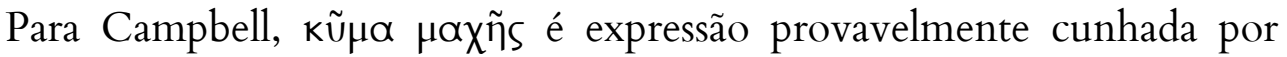
Tirteu (1982, p. 181). No entanto, a imagem é recorrente desde Homero. Fenno (2005) em A great wave against the stream: water imagery in Iliadic battle scenes, assinala ser tradicional comparar o ruidoso avanço de tropas gregas ao mar em movimento, em símiles que podem ser amplificações poéticas de ações denotadas

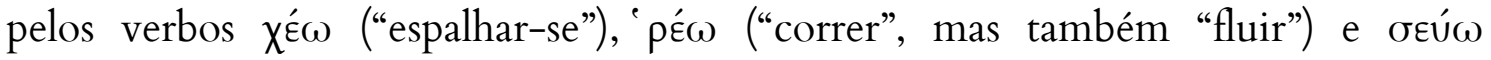
("lançar-se"), verbos que podem ser utilizados tanto para referir o movimento das águas quanto, em sentido estendido, o movimento de agrupamentos humanos (2005, p. 479). Assim, não raro o poeta épico compara a investida das falanges gregas ao acampamento troiano com ondas do mar pulsando nas praias (Il. 4. 422428):

' $\Omega \varsigma \delta^{\prime}$ 'öт' Ėv aỉ

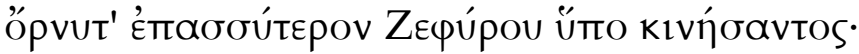

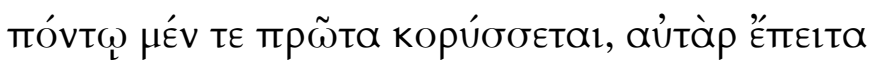

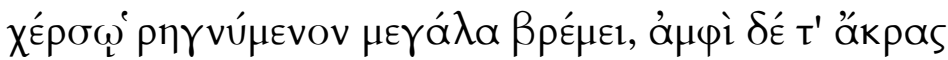

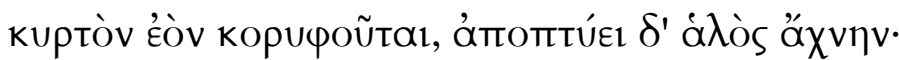

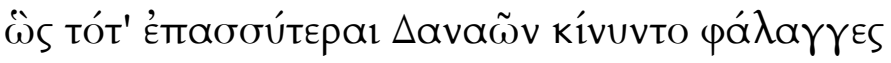

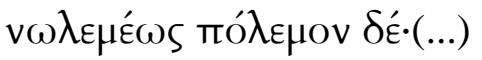

Como as ondas do mar quando na praia undíssona avançam, ininterruptas por Zéfiro lançando-se: em alto mar elas primeiro se encristam, aí depois rugem forte rebentando contra a terra, e em volta dos promontórios se ergue inchada e vomita a salsa escuma; assim, ininterruptas as falanges dos Dânaos lançavam-se

como é frequente na Ilíada (ver, por exemplo, 19. 158), onde designa simplesmente as fileiras do exército. 
sem trégua à guerra.

Desse modo, Tirteu faz uso de uma imagem tradicional - não confim à Homero mas frequente em outros contextos ${ }^{141}$ - para evocar a estrondosa investida

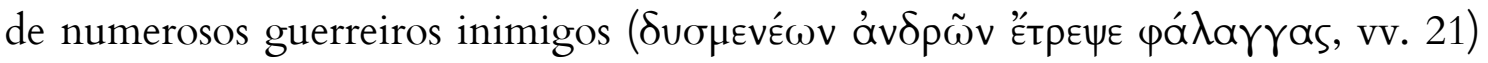
- que o guerreiro ideal detém, mantendo-se firme em seu posto ( $\delta$ ißßás, v. 16) à maneira, por exemplo, dos dois Ajantes na Ilíada (17.746-753) que, imóveis diante dos troianos que avançavam em linha reta, se assemelham a uma barragem dividindo a água dos rios (Fenno, 2005, p.487, n. 27):

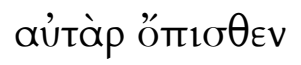

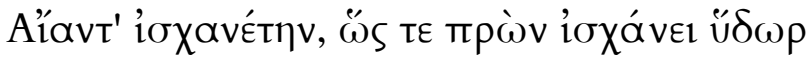

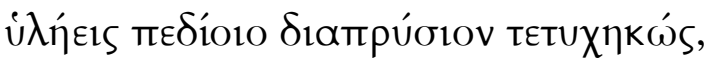

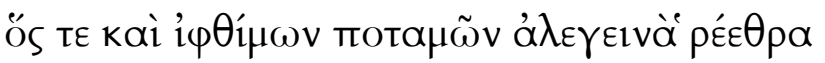

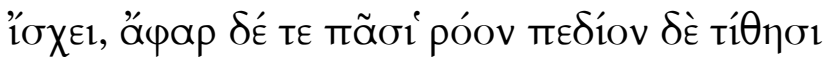

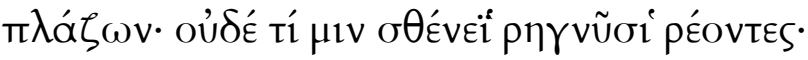

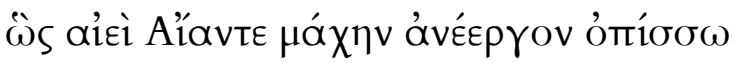

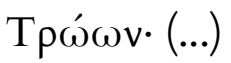

\section{E atrás deles}

os Ajantes refreavam o inimigo, qual barranco frondoso da planície, que refreia a água violenta, que até mesmo as intensas correntezas dos fortes rios retém; prestes a planície põe a correnteza a vagar por toda a parte, e nem fluindo com força ela a rompe; Assim sem cessar os Ajantes faziam retroceder a investida

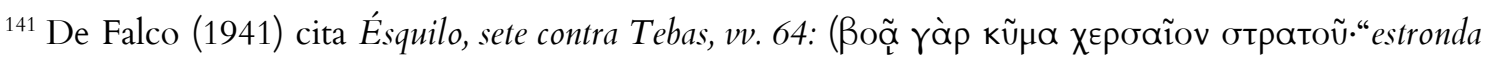
a sólida onda do exército", Tradução de Jaa Torrano, 2009). Fenno (2005, p.478) menciona que na poesia mélica, Anacreonte utilizará à imagem não para aludir ao estrondo provocado pelas tropas,

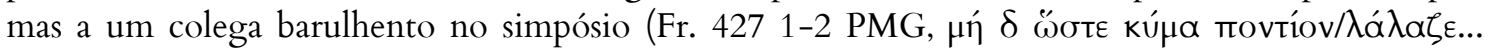
"Como a onda marítima/não tagarele...").
} 
troiana (...).

\section{O herói tirtaico e suas recompensas (vv.27-43)}

Tirteu relata nos versos 23 - 34 as recompensas que aguardam o óvíp áräós na morte, enquanto nos versos 35 - 42 descreve as suas prerrogativas caso sobreviva à guerra. Bowra (1938, p.66) observa que esta ordem não deve causar estranhamento: decerto a morte em batalha soaria mais satisfatória do que a vida após a vitória. Por outro lado, essa maior importância pode se dar simplesmente porque a morte na guerra é o maior objeto de preocupação do poema (De Martino e Vox, 1996, p. 576). Fränkel (1975, p.339, n.8) nota que os versos 23-34 são enquadrados por dois dísticos que apresentam ideias similares (23-24 e 33-34), formando assim uma unidade.

Tanto as epopeias homéricas quanto a elegia marcial exortativa compartilham da ideia de que o valor marcial é o meio para conferir a glória ( $\mathrm{k} \lambda$ ćos,$k l e ́ o s)$ para um individuo em meio ao seu povo e cidade (Irwin, 2005, p. 55).

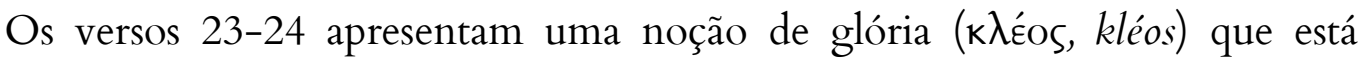
diretamente relacionada à morte. A morte em pleno campo de batalha é bela, pois

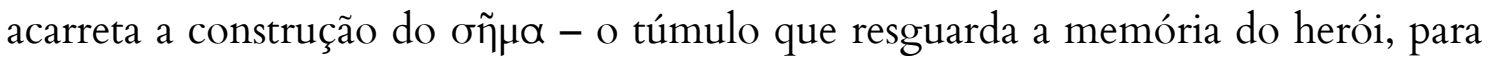
que "as gerações futuras perguntem a respeito" (Od.11.76), em contraponto à obscuridade de uma morte anônima (Goldhill, 1991, p. 71). Nesses termos, a glória ( $\mathrm{k} \lambda$ Éos) de um homem que perece no combate transfere-se também à sua cidade e a

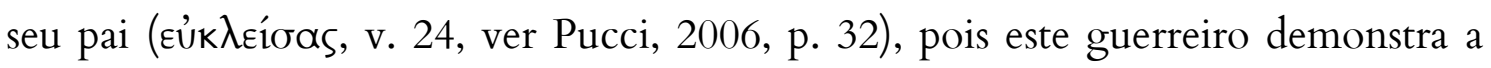
excelência militar essencial para a salvação da cidade, que o poeta retoma novamente

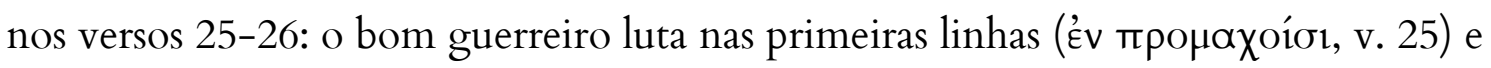
morre ao receber os golpes pela frente ( $\left.\pi \rho o_{\sigma} \theta \varepsilon v, v v .26\right)$ situação contrária à morte vergonhosa descrita nos versos 17-21 do fragmento 11, onde o prófugo é atingido

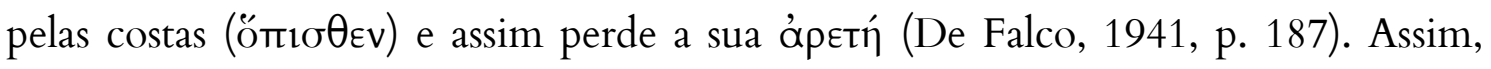
segundo Assunção (1989, p.32) “a disposição para o risco máximo é o único meio de 
acesso à glória”. Desse modo, apenas “arriscando sua vida e coração audaz” (v. 18) há a possibilidade do $\mathrm{k} \lambda$ Éos: seja por meio de uma morte que consagre a existência heróica do guerreiro (vv.23-24) seja por meio do triunfo da vitória (vv.35-36)

As distinções recebidas pelo guerreiro morto visam transpor o problema da mortalidade. A morte é fonte de reconhecimento. Este reconhecimento é sobretudo afetivo: пóӨos (póthos, "saudade"), no verso 28, corresponde ao desejo

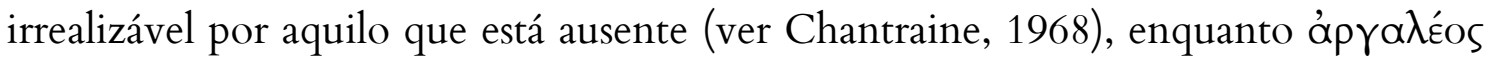

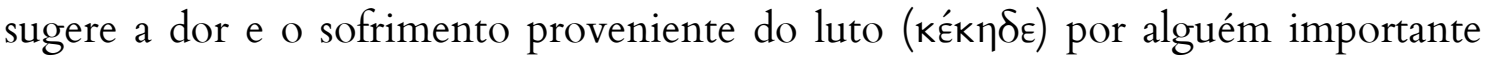
para a cidade. A importância do guerreiro é reforçada pela ideia da totalidade

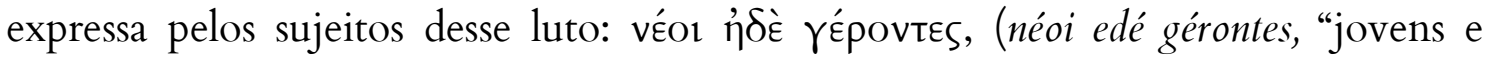

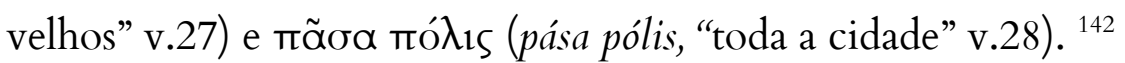

As recompensas expostas nestes versos demonstram que a imortalidade não provém apenas da poesia, ideia explícita no priamel, mas também do túmulo: se os feitos são consagrados pelo canto poético, a tumba do herói é o símbolo de sua permanência no mundo - "o anúncio visual de sua existência, a tentativa plástica de resposta ao problema insolúvel da morte” (Assunção, 1989, p. 9). E, nesse sentido, aquele que demonstra valor marcial ao permanecer no combate e morrer pela sua terra e por seus filhos (vv. 33-34) adquire renome eterno para si e todos os seus (vv. 30-31).

Pucci (2006, p. 32) imagina que este passo realiza performativamente a imortalidade poética prometida nos versos 1-9 ao homem corajoso. Nesses termos, o poeta parece revelar o contexto cívico e a ocasião simpótica de seus versos, uma vez que projeta as afecções civis em seu canto e assim torna-o nóӨos, e não mais somente exortação à luta - ato circunscrito ao espaço bélico (2006, p.32).

Os últimos dísticos do poema (vv. 35-42) dedicam-se a apresentar a honra que o guerreiro corajoso recebe caso sobreviva à batalha, em versos assimilados pelo poeta da Teognideia (933-938):

\footnotetext{
${ }^{142}$ Do mesmo modo que ocorre em Calino 1W: o guerreiro morto é deplorado tanto pelo humilde

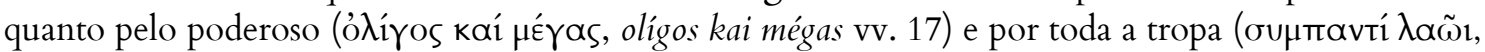
v.18). Ver Assunção, 1989, p. 165.
} 


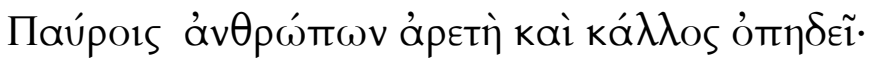

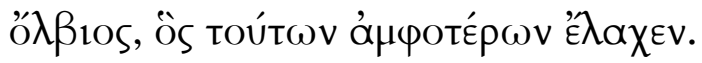

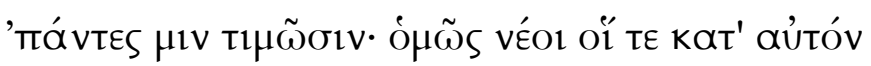

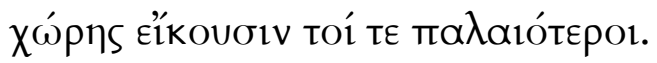

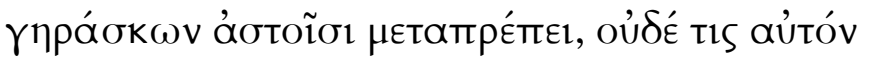

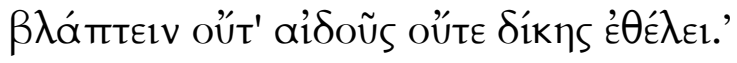

"Virtude e beleza acompanham poucos homens:

venturoso, aquele que dispõe de ambas.

Todos o honram: jovens e seus coetâneos

cedem-lhe lugar no conselho, e também os mais velhos.

Envelhecendo, distingue-se entre os cidadãos e ninguém

quer faltar-lhe com o respeito e a justiça.”

Assim, pode-se supor, como Irwin (2005,p.79) que há aparentemente uma forte associação dessa poesia ao seu contexto cívico: a pólis é o meio e o espaço para a aquisição de glória que transcende a duração da vida humana (vv. 23-34) e estima de uma comunidade (vv. 35-42).

O último dístico (vv. 43-44) realiza a exortação, clamando que os véor aspirem pela virtude mais alta, a coragem. Cabe ressaltar o uso de vũv, que

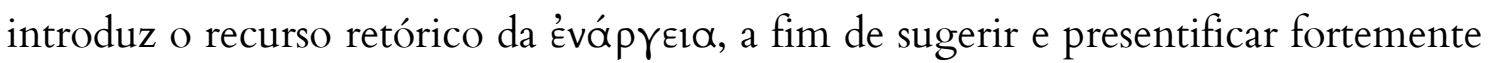
no ambiente de performance uma situação de guerra (Bowie, 1990, p.222).

Para Luginbill (2002, p.413) a exortação final é puramente fantasiosa: o jovem deve buscar a coragem, pois assim garantirá glória perene a si mesmo e a sua progênie. Quadro bem diferente será encontrado em outros fragmentos, onde os benefícios da vitória não são assim tão realçados. Em geral, os guerreiros dos poemas de Tirteu lutam porque não têm alternativa: deve-se lutar não para obter a imortalidade, mas para evitar a vergonha advinda de um exílio vergonhoso, considerado pior do que a morte (10.1-14 W). 
Assim, Luginbill conclui (2002, p. 413)que as diferenças entre o fragmento $12 \mathrm{~W}$ e outros residiam em suas circunstâncias particulares de performance: enquanto os demais poemas eram dirigidos a guerreiros experientes, que conviviam com a brutalidade da guerra, o temor e a possibilidade iminente da desgraça - os versos do fragmento 12 tinham como alvo um público jovem, inexperiente na guerra, e dessa forma as promessas de recompensas expostas nestes versos, típicas de heróis épicos, soariam mais atraentes.

Observamos, a partir dos traços aduzidos acima por Bowie (1990, p. 222, p.228), Luginbill (2002, p.413) e Pucci (2006,p.32) a possibilidade de adequar esta poesia a um cenário de performance para além da campanha militar e dotado de certa conotação civil: o simpósio aristocrático no interior da pólis.

Caso se pense, ainda, como Irwin (2005, p.104), que a pólis aparece subordinada à perspectiva do herói possuidor da excelência marcial, que ocupa o ponto central do poema, e que as recompensas obtidas por ele são estritamente pessoais e familiares (glória eterna para si mesmo, família e a progênie, vv. 23-34; estima entre o povo, vv. 35-42), pode-se concluir que a leitura desse fragmento não só se restringe a uma audiência jovem e inexperiente na guerra, mas também constitui um forte exemplo da emulação e ficcionalização de papéis heroicos que, segundo Irwin, se assume no ambiente do simpósio como um meio de afirmação e justificativa de uma aristocracia ante o espaço iminente da polis. 
II. As Elegias Narrativas e o Festival Público 


\section{Capítulo 1}

\section{A Poética da Eunomia}

\section{A Eunomia e a miragem espartana}

A Eunomia ocupa um lugar peculiar no corpus de elegias de Tirteu e talvez sem paralelo em outros poemas elegíacos gregos arcaicos, porquanto seus versos parecem aludir ao mais importante registro da história de Esparta, a assim chamada Grande Retra. De acordo com Plutarco, o documento foi outorgado pelo legislador lendário Licurgo, que o trouxe de Delfos na forma de profecia (Vida de Licurgo, 6).

Acredita-se que a citação de Plutarco não seja uma transcrição exata do oráculo recebido por Licurgo, e sim o próprio texto da lei, que teria sido registrado

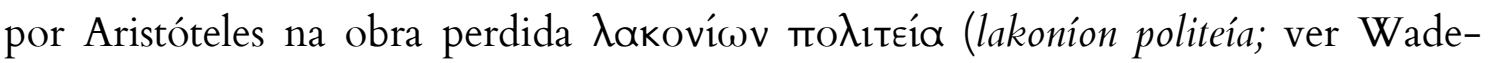
Gery, 1944b, p.115). O texto contém informações religiosas e administrativas, que demarcam o papel do povo $(\delta a ́ \mu \omega)$ no processo de decisão política - a ele, relata Plutarco, apenas cabia aprovar ou reprovar as propostas oferecidas pelo conselho (Ver Raaflaub, 2006, p. 395):

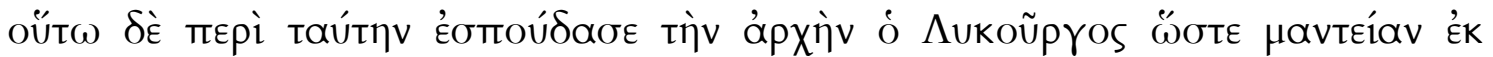

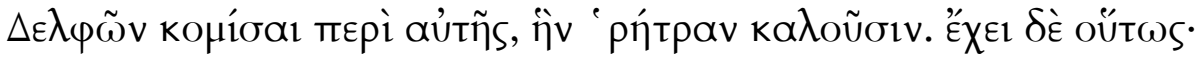

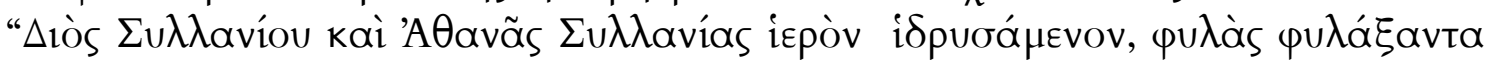

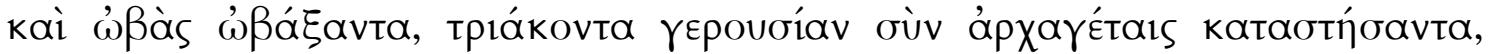

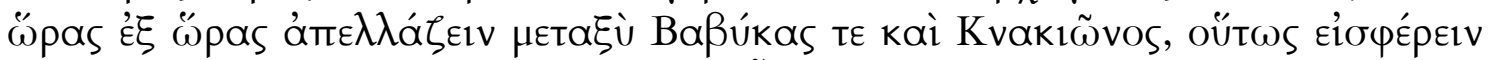

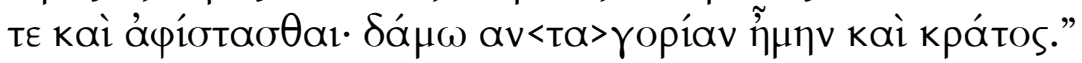

Licurgo zelou tanto pelo poder que trouxe de Delfos uma profecia sobre isso, a qual denominam Retra. Diz o seguinte: "Depois de fundar um templo de Zeus Silânio e Atena Silânia ${ }^{143}$, as tribos distribuir ${ }^{144}$, as obes ${ }^{145}$ organizar e instalar um conselho de

\footnotetext{
${ }^{143}$ Ogden (1994, p.102) propõe para este epíteto a etimologia ouv - $\lambda \alpha v-10 \varsigma$, sendo ouv o prefixo,

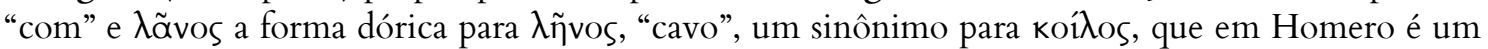
epíteto para a região da Lacedemônia (Il.2. 581). - los é o sufixo formador de adjetivo. Assim, segundo o autor, Zeus e Atena recebem este epíteto porque seriam os protetores do vale entre Bábica e Cinácion.

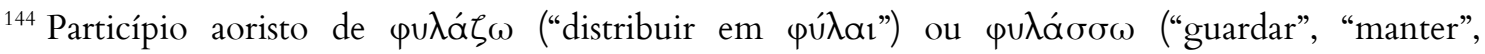
"vigiar")? A primeira opção parece mais apropriada, tendo em vista um possível espelhamento entre

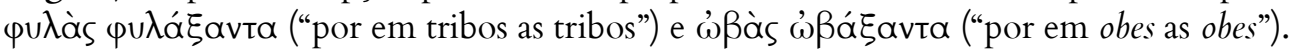


trinta anciãos com os seus príncipes, realizar a apela ${ }^{146}$ de tempos em tempos entre Bábica e Cinácion. Dessarte, propõe e depõe, mas o poder e a respon<sa $>$ bilidade serão do povo. [Plutarco, Licurgo, 6.1-3]

No poema, Tirteu justificaria a autoridade do poder real e a validade das leis, afirmando que ambas estavam assentadas em estatutos divinos: os reis são descendentes de Héracles; a região do Peloponeso, uma dádiva de Zeus para eles; e a constituição, prescrita por Apolo.

Segundo Jäger (1932 apud De Falco; Coimbra 1941, p. 158), provavelmente influenciado pela leitura plutarquiana ${ }^{147}$, Tirteu defendia uma constituição na qual o povo ocupava posição secundária, e os reis e anciãos detinham grande poder de decisão. O contexto encontrado pelo erudito é que, com o término da Segunda guerra da Messênia, o povo toma conta de sua força e passa a reinvidicar maiores privilégios políticos de seus líderes; Tirteu, assumindo o papel de mentor e educador do estado, compõe a Eunomia com o intuito de relembrar o caráter sagrado da constituição e da origem espartana, e assim evitar um conflito.

Tal entendimento dos fragmentos de Tirteu incorrem em um problema que os historiadores têm chamado de "Miragem Espartana"148. Quanto daquilo que sabemos da história espartana não é fruto de uma visão equivocada de autores estrangeiros, provocada pela distância, preconceito ou fascínio? Quanto não é parte de uma reinvenção tardia da tradição, operada no período Clássico e Helenístico (Nafissi, 2009, p. 128)?

Nesse contexto de testemunhos escassos ou pouco confiáveis da história espartana, o poema de Tirteu ocupa um lugar maior do que poderia ter tido originalmente, cercando-se desde a Antiguidade de narrativas que o colocam como um registro importante da figura de Licurgo, das leis atribuídas a ele e da fundação

\footnotetext{
${ }^{145}$ As obes eram subdivisões das $\varphi \underline{u} \lambda \alpha_{1}$ espartanas. (LSJ)

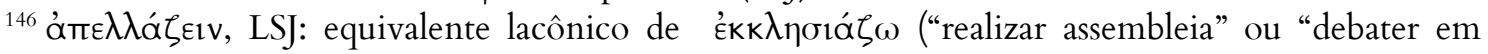
assembleia"). A apela, dessarte, é o nome dado à assembleia popular espartana.

${ }^{147}$ Ver Plutarco, Licurgo 6. 4 infra.

${ }^{148}$ Termo que ficou convencionado depois da publicação da obra de François Ollier, La Mirage Spartiate em 1933.
} 
da Esparta Clássica. Todavia, tais narrativas têm peso e devem ser levadas em conta na medida em que influem no próprio estabelecimento do texto ${ }^{149}$.

Mas quanto do poema de Tirteu refere-se explicitamente a um período particular da história espartana, e quanto não é uma utilização de lugares-comuns da tradição poética grega arcaica?

Aristóteles $($ Política, $5.130667=$ Fr. $1 \mathrm{~W})$ é o primeiro a mencionar que a Eunomia fazia referências a um período de dissonância política que atingira Esparta no século VII a.C. Aristóteles apresenta a Esparta de Tirteu como exemplo para sua teoria de que conflitos no interior da polis estão atrelados à disparidade de riquezas entre os cidadãos.

Embora não fale nada sobre os pedidos do povo por maiores direitos políticos, Aristóteles menciona que Esparta encontrava-se à beira de uma guerra civil por posse de terras:

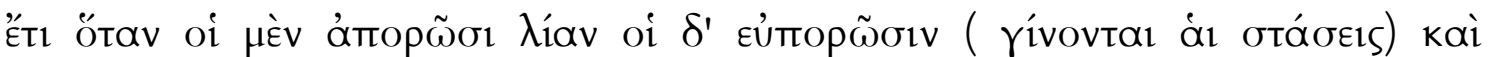

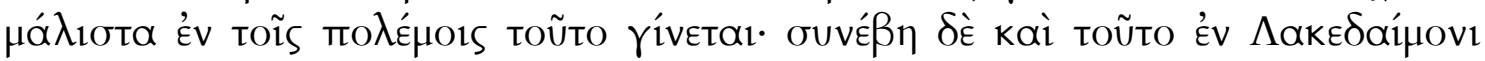

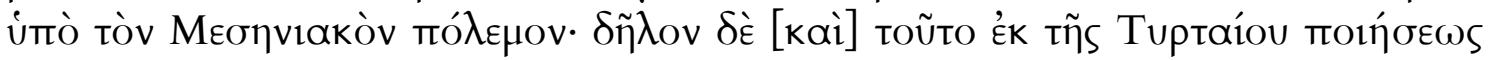

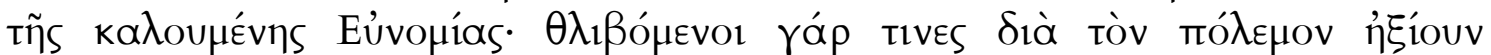

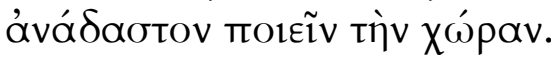

"Ainda quando alguns estão demasiadamente sem recursos e outros prosperam (acontecem as sedições). Isso acontece, sobretudo, nas guerras: ocorreu também na Lacedemônia, durante a guerra messênica. Isso[ também] faz-se manifesto pelo poema de Tirteu, denominado Eunomia. Pois alguns, oprimidos por causa da guerra, achavam digno fazer uma redistribuição de terras".

A Descrição da Grécia de Pausânias informa com maiores detalhes do que Aristóteles o teor dos confrontos em Esparta. Durante a Guerra da Messênia, os espartanos teriam deixado inúmeras porções de terra sem cultivo, para que os messênios que habitavam a região do Ira não pudessem usufruir de seus campos. Com o fim da guerra, a escassez de alimentos levou à revolta da população e a ameaça de uma sedição interna $(4.18=$ Fragmento 1 Bergk $)$ :

${ }^{149}$ Ver fr.4 W p.169-191. 


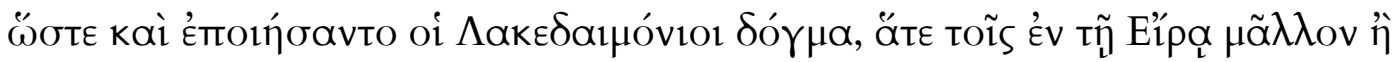

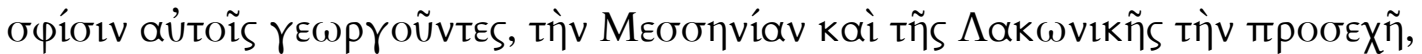

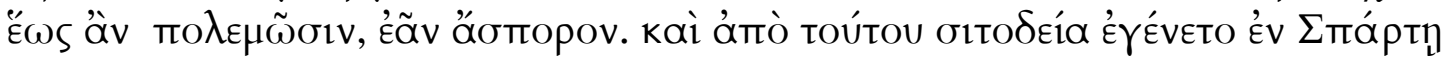
kaì ó

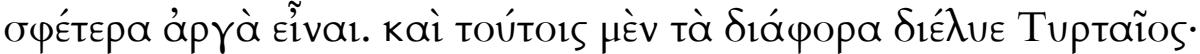

E desse modo os Lacedemônios, porque cultivavam a terra mais para os habitantes de Ira do que para eles próprios, tomaram a decisão de deixar Messênia e vizinhanças da Lacônia sem semeadura, enquanto guerreassem. Por isso houve carestia em Esparta, e juntamente com a carestia, a sedição: Pois os que tinham propriedades ali não suportavam que suas terras não fossem cultivadas. Tirteu resolveu a desavença entre eles.

Se Van Wees (1999, p. 2) está certo em suas hipóteses, o relato de Pausânias é uma invenção tardia, que tenta conciliar o mito de Licurgo - cujas leis transformaram Esparta em uma sociedade de iguais, bem antes do tempo de Tirteu $^{150}$ - com a evidência fornecida por Aristóteles de uma desigualdade predominante na sociedade espartana. As considerações de Pausânias refletem uma situação particular e sem paralelo na História de guerra da Grécia Antiga, podendo ser resultado de uma especulação posterior que visou adequar tanto a lenda de Licurgo como o poema de Tirteu na história espartana.

Para Van Wees $(1999$, p.2) é mais provável que Tirteu não tivesse referido explicitamente os eventos posteriores à guerra, mas somente feito uma ou outra alusão à necessidade de redistribuição de terras, do mesmo modo que Sólon em seus fragmentos. O Fragmento $34 \mathrm{~W}$ de Sólon, por exemplo, trata de um evento similar. Embora seja patente nos versos abaixo o desejo do Eu poético em direcionar a recepção de sua figura no poema (Ver Irwin, 2005, p.133), o poeta também alude nesse fragmento à necessidade de reformas (vv. 8 -9) sem tecer narrativas de alguma crise política específica:

\footnotetext{
${ }^{150}$ Tirteu teria vivido duas gerações depois da diarquia dos reis Polidoro e Teopompo (Ver Fr.5.1.W) - que possivelmente combateram na Primeira Guerra da Messênia em tempos da $50^{\circ}$ Olimpíada, no último quartel do século VIII a.C.. Segundo Aristóteles, o oráculo recebido por Licurgo data de 776 a.C., época da $1^{\circ}$ Olimpíada. (Ver Wade-Gery, 1944, p.115)
} 


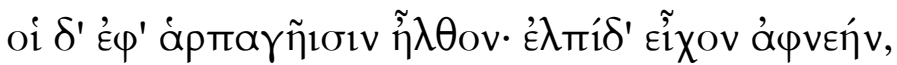

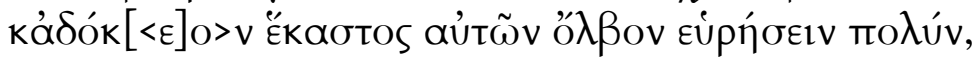

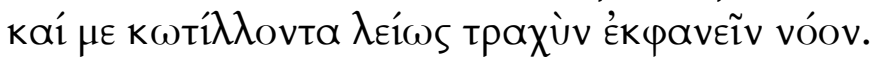

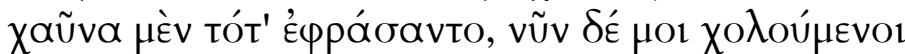

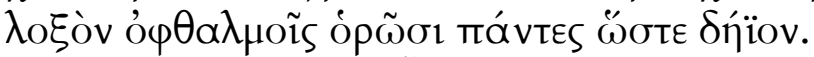

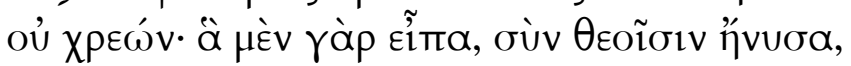

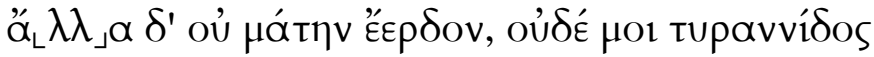

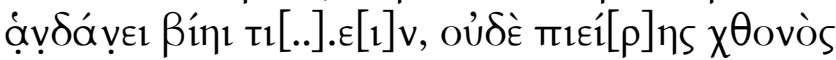

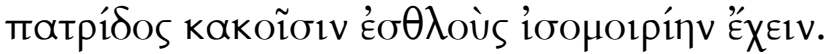

...Outros, vieram pela rapinagem, tinham esperança de riqueza e acreditavam - cada um deles - que encontrariam muita fortuna e que eu, lisonjeando com brandura, revelaria um espírito rude. Aquela vez, ponderavam coisas frívolas; agora, irritados comigo, de soslaio olham-me todos, como a um inimigo, sem necessidade: Pois as coisas que eu disse, com Deuses cumpri; as demais, não realizei em vão, e com a violência da tirania não me apraz (?)... [. .], [i]r, nem que do pingue solo pátrio os nobres tenham igual quinhão que os vis.

Ademais, este procedimento antes alusivo do que descritivo pode constituir um traço do gênero: como trata de um momento contemporâneo à sua performance, ${ }^{151}$ poderia parecer redundante ao poeta descrever os pormenores da situação política.

Da leitura das fontes pode-se aduzir apenas que Tirteu certamente teria mencionado em seus poemas a ameaça da otáorı que pairava então na sociedade espartana ${ }^{152}$, filiando-se assim a um tema tradicional da poesia elegíaca grega arcaica. ${ }^{153}$

\footnotetext{
${ }^{151} \mathrm{Ou}$, supostamente, não tão recuado como de grandes epopeias como a Ilíada e a Odisseia. (Ver West 1974).

${ }^{152}$ Segundo Platão (Leis, 629 b-e), contudo, Tirteu louvara apenas os homens que se destacavam em guerra externa, e nada nos informa sobre como Tirteu poderia ter trabalhado o tema da otóơı:

ATENIENSE: "Vem, agora vamos perguntar todos juntos ao poeta aqui, desta maneira: "Ó Tirteu, mais divino dos poetas (pois para nós você parece sábio e nobre, porque louvou com distinção os distintos na guerra), acontece agora que eu, o Clínias e o Cnósios aqui concordamos bastante com você nisso, conforme nosso parecer; mas o que queremos saber com certeza é se estamos falando dos mesmos homens ou não. Conte-nos, pois: você também considera que há, com certeza, dois tipos de guerra, como nós? Ou outra coisa?" Em relação a essa pergunta, penso que até mesmo um homem mais simples do que Tirteu diria a verdade, que há dois tipos, uma que todos chamamos "civil" que de todas as guerras é a mais dura, como dizíamos agora há pouco; a outra espécie de guerra - todos
} 
Um adágio espartano outrora atribuído a Tirteu ${ }^{154}$, se considerado legitimamente arcaico, coloca Esparta no mesmo patamar de outras poleis arcaicas virtualmente contemporâneas (como a Atenas de Sólon ou Mégara dos poemas teognídeos) e introduz uma tópica comum a esta tradição poética: a ganância e a desmedida do povo são responsáveis por levar uma cidade à ruína. O provérbio encontra-se na Biblioteca Histórica de Diodoro da Sićlia e seria um oráculo délfico proferido (também) a Licurgo:

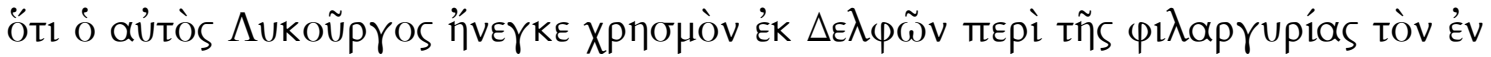

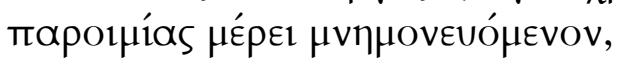

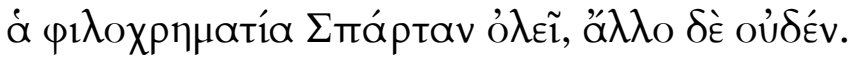

A lembrança de que o próprio Licurgo trouxe de Delfos um oráculo a respeito da avidez por dinheiro está no trecho do adágio:

A ganância arruinará Esparta, e nada mais.

A tendência entre os estudiosos é situar este provérbio no quinto século, seguindo proposta de Willamowitz (1900, p.108, n.1 apud Van Wees, 1999 p. 27, n.6). Cartledge (1987, 403), por outro lado, acredita que sua origem é posterior à Guerra do Peloponeso. Van Wees (1999) voltou a propor uma ascendência arcaica

ficaremos de acordo, creio - [é aquela em que] conduzimos contra estrangeiros e outros povos, muito mais suave do que a outra."

CLÍNIAS: Sim, como não?

AT. Então vamos lá: "Que homens, diante de qual das duas guerras, em louvor você elogiou assim além da conta, enquanto censurou outros? Ao que parece, os [que lutaram] fora. Ao menos, você disse em seus poemas o seguinte, que jamais poderia suportar homens que não ousassem olhar uma matança sangrenta, e que "postando-se perto não atingem os inimigos." Em vista disso, portanto, nós diríamos: você, ó Tirteu, conforme nosso parecer, elogia sobretudo os homens que se tornam ilustres em guerra externa e estrangeira". Ele, talvez, afirmaria e consentiria com isso?

CL. É claro.

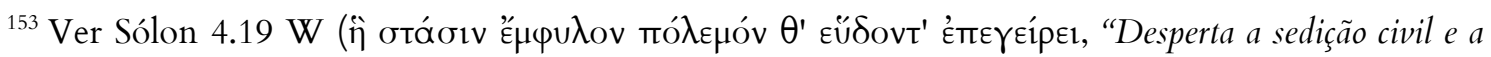
dormente guerra"). Xenófanes 1.20-23 W rejeita como comportamento adequado ao simpósio a

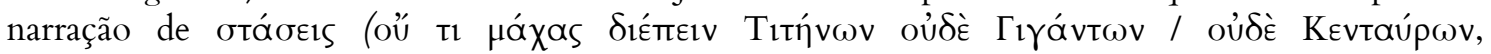

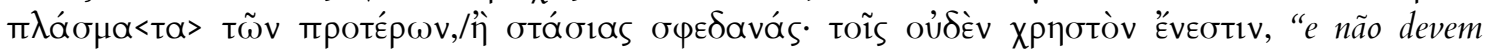
narrar combates de Titãs, de Gigantes, /de Centauros, fiç̧ôes dos antigos,/ou ardentes sedições, nelas não há o que preste")

${ }^{154}$ Na edição de Bergk (1882) é o fragmento 3. 
para o provérbio. $\mathrm{O}$ autor verifica que o adágio é um verso hexamétrico perfeito ${ }^{155}$ em dialeto dórico, e, como tal, dificilmente seria um produto da sabedoria popular, mas teria sido recolhido dos versos de algum poeta que compôs neste gênero. ${ }^{156}$ Quais seriam os candidatos? Para Van Wees, Terpandro seria o autor deste verso poeta que teria usufruído de fama na Esparta do século VII a.C. e cujos poemas em hexâmetro seriam uma mescla entre dórico e jônico.

Por conta do dialeto, notadamente dórico por causa do uso de $\alpha$ longo, Van Wees prontamente descarta que os versos possam ter vindo de um oráculo, como afirma Diodoro, ou que sejam provenientes da obra de um poeta elegíaco, uma vez que ambos são compostos em dialeto jônico. Há possibilidade de contrapor essa hipótese: um oráculo poderia ser alterado no processo de sua transmissão (Ver Maurizio, 1997, p. 313); a poesia elegíaca também, embora o emprego do jônico seja um elemento da composição genérica, pode apresentar registros em outros dialetos, como demonstra a própria poesia de Tirteu, com alguns doricismos ocasionais, e Sólon, que apresenta alguns resquícios do ático ${ }^{157}$. Alguns explicam tais resquícios como inépcia dos poetas (Ver De Martino e Vox, 1996); Gentili (1988, p.230) chega a supor que os poemas de Tirteu foram compostos originalmente em dórico, e sua redação posterior em jônico, mantendo os doricismos apenas nos passos em que a métrica poderia ser comprometida. Noussia (2001, p. 349-50, apud Irwin 2005, p.85, n.1) propõe que os aticismos encontrados nas elegias de Sólon

\footnotetext{
${ }^{155}$ Embora ele fosse conhecido de outras maneiras. Ver Plutarco, Moralia, 239 f ( $\dot{\alpha}$ pı $\lambda$ oxp $\eta \mu \alpha t i ́ \alpha$

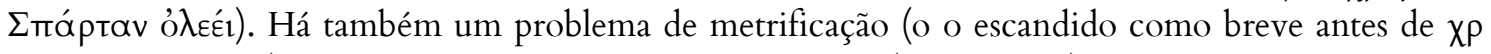

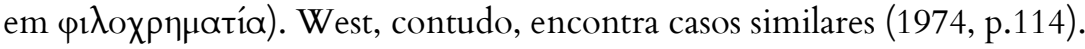

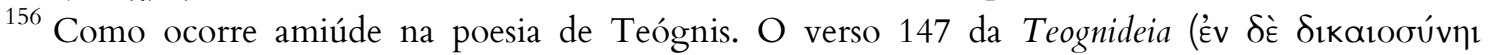

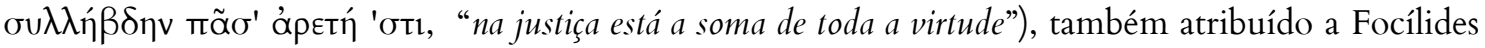
(fr.10 W), é um provérbio no tempo de Aristóteles, e também os hexâmetros (vv.425 e 427) que compõem os versos 425-428. O oposto também parece ser verdadeiro, e Teógnis entrelaça a seus pentâmetros versos que poderiam ser provenientes de outras tradições (vv.15-18): Moũoaı kaì

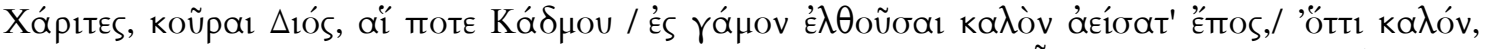

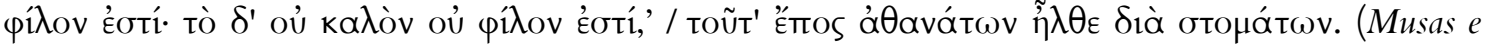
Graças, filhas de Zeus, indo outrora / às núpcias de Cadmo o verso cantaram:/ "o belo é amável, o não belo não é”/ este verso partiu de imortais lábios.)

${ }^{157}$ Os manuscritos do fr.4 W de Sólon apresentam Euvopía, o a longo alterado para $\eta$ na edição de West (1974, ver p.77)
} 
poderiam ser um meio desenvolvido pelos poetas elegíacos a fim de estabelecer um diálogo entre o local e o pan-helênico.

Nesse caso, não seria lícito supor que estes versos pudessem pertencer a Tirteu? A edição de Bergk (1882, p.316) é a primeira a apresentar a citação como um fragmento de Tirteu. Para o editor, a sua autoria é "verossímil" e o verso

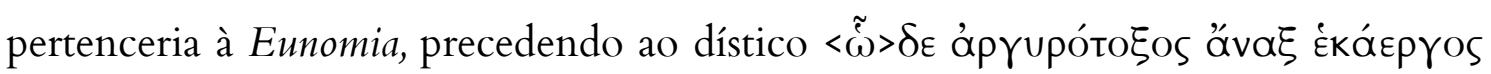

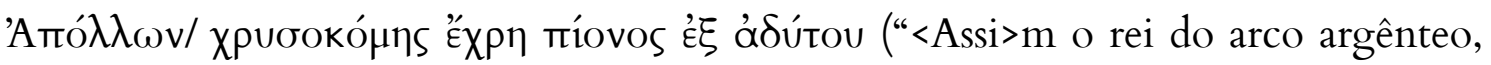
Apolo que age à distância,/ de áurea coma, predisse do pingue santuário"), que é a versão de Diodoro para o início do fragmento $4 \mathrm{~W}$ (7.12.6).

Bach (1831, p.83) já registra o provérbio em sua obra e também supõe que Diodoro possa ter reunido dois oráculos de diferente procedência como um só, mas é reticente quanto à sua atribuição por causa do uso do dórico em companhia de versos de composição predominantemente jônica. West (1974) prefere omiti-lo de sua edição, não vendo motivo para atribuí-lo a Tirteu (Ver Gerber, 1999, p. 43, n.3).

$\mathrm{O}$ argumento de Bergk em prol da autoria de Tirteu é que Diodoro misturou inadvertidamente dois oráculos diferentes registrados na obra do poeta. $\mathrm{O}$ primeiro, sobre a ganância espartana, trazido por Licurgo, e outro, que corresponde ao Fragmento $4 \mathrm{~W}$, recebido pelos reis Teopompo e Polidoro e cuja autoria de Tirteu é assegurada pelo testemunho de Plutarco.

Se o verso fosse comprovadamente de Tirteu, não se estaria diante apenas de uma sociedade espartana idêntica a outras cidades gregas do período arcaico, como também de um poeta que se serve de argumentos semelhantes aos de outros elegíacos gregos arcaicos ao tratar das causas das revoltas civis. Em sua Eunomia, Sólon (fr.4.1-6 W) defende que a causa da ruína de uma cidade não se deve às deliberações divinas, e sim à ganância e ausência de moderação dos líderes que nela habitam, caracterizada como üßpıs (hybris):

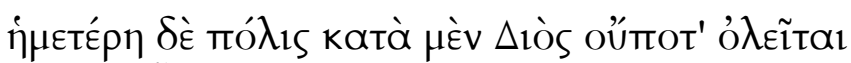

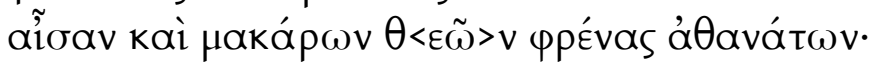

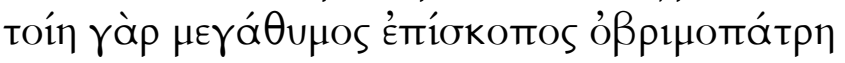




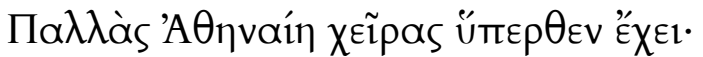

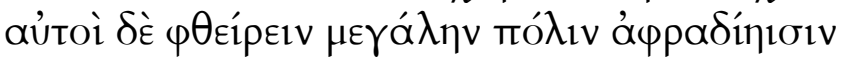

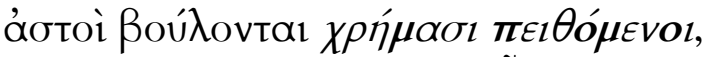

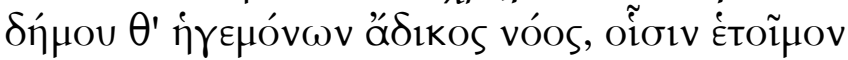

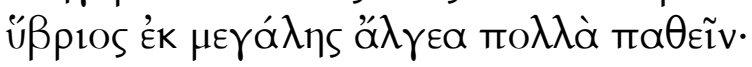

Nossa cidade jamais se perderá, por desígnios de Zeus

e vontade dos ditosos Deuses imortais.

Uma guardiã tão magnânima, de um poderoso pai,

Palas Atena, sua mão tem sobre ela.

Mas, eles próprios, os cidadãos, querem com tolices

destruir a grande cidade, persuadidos por riquezas.

Dos líderes do povo injusta é a mente; a eles muitas dores está reservado sofrer por seu grande excesso.

Para Teógnis, a üßpıs (Hýbris, "desmesura” ou "excesso") é a única causa

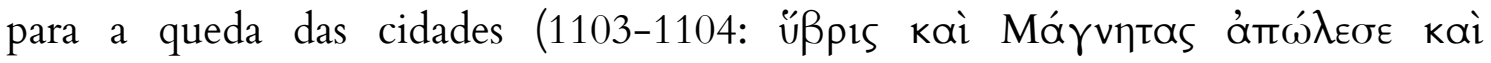

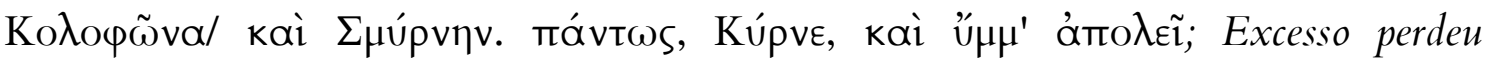
Magnésia e Colofon,/e Esmirna: Decerto, Cirno, vos perderá também). Esta üßpı, em outros passos da Teognideia, está associada às injustiças cometidas pelos líderes em

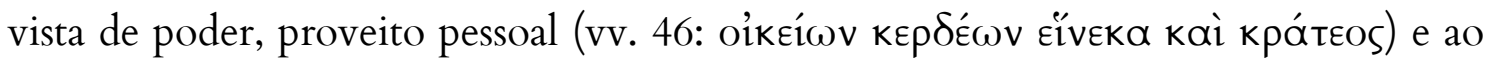

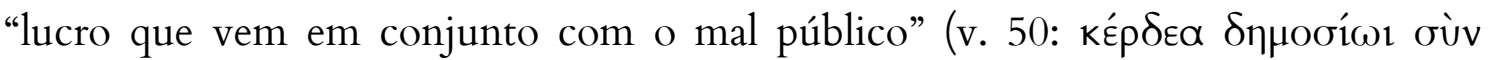

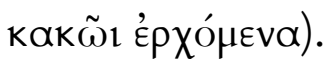

Esse tema constitui uma tradição comum à elegia grega arcaica, devido a seu tom frequentemente moralizante, pondo em causa uma antinomia entre Síkn e üßpis - uma vez que a üßpis é um "comportamento excessivo que transpõe os limites do que é correto e provoca voluntariamente a injustiça” (Ver Del Grande, 1947, p.01 apud Ragusa, 2010, p.123). Não é incomum, portanto, que üßpis apareça

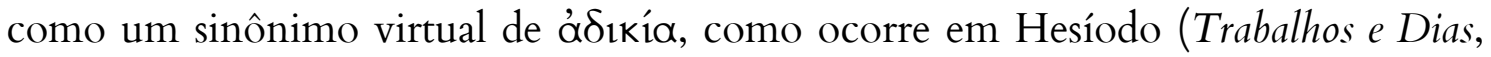
vv.215-286). ${ }^{158}$

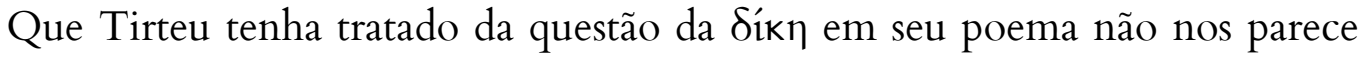
surpreendente, dado o título pelo qual a sua obra ficou conhecida na posteridade. A Eunomia é um ideal oligárquico de justiça (Ver Raaflaub, 2006, p. 392), uma

${ }^{158}$ Ver McGlew, 1993, p.59. 
condição em que o estado é obediente às leis que já foram estabelecidas (Andrewes, 1938, p.91).

Se este é o caso, como veremos, a única discrepância do argumento de Tirteu em comparação com o de outros poetas da tradição é sobre quem recai a responsabilidade destes excessos: enquanto Sólon e estes versos de Teógnis atribuem-no à falta de juízo das oligarquias, Tirteu deve ter mencionado a

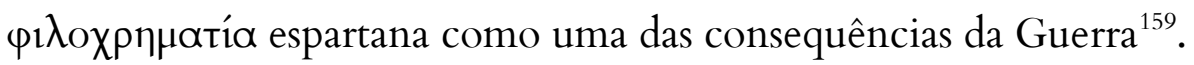

\section{A Eunomia de Tirteu}

Ao que consta, o primeiro autor a intitular assim o poema de Tirteu é Aristóteles. Segundo Andrewes (1938, p.91),nos tempos do filósofo Eúvopía seria palavra de uso popular, com o sentido de "obediência às boas leis" e Aristóteles detém-se em uma definição mais estrita do termo, que teria para ele apenas o sentido de “obediência a lei”, sejam estas boas ou más (Política, 1294a) :

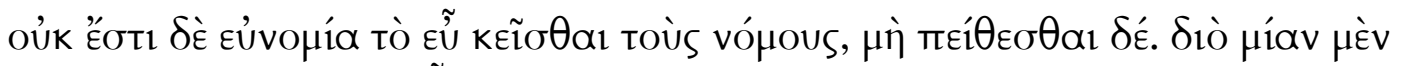

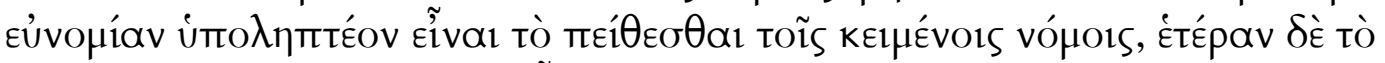

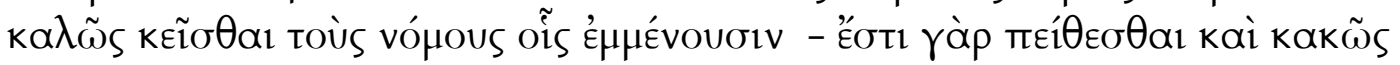
KE1นદ́vols.

"Eunomia não é o bom estabelecimento de leis, nem a obediência a isso. Porque, deve-se supor que uma Eunomia é obedecer às leis estabelecidas, e outra coisa é estabelecer bem as leis para que as respeitem - Pois também é Eunomia obedecer a leis que foram mal estabelecidas."

\footnotetext{
${ }^{159} \mathrm{O}$ que também não deveria constituir nenhuma inovação: na própria Teognideia já se pode notar

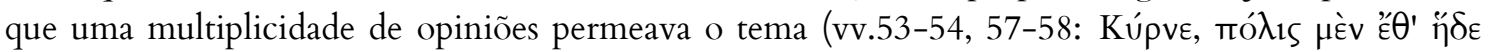

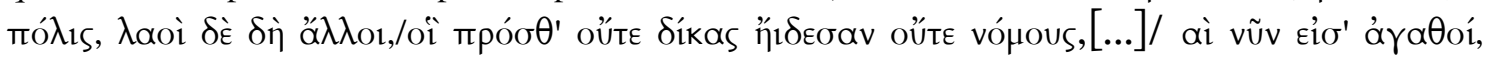

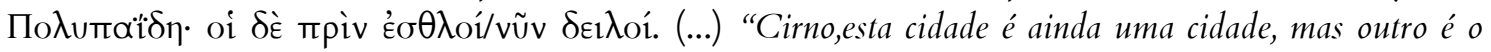
povo./ Os que antes não conheciam nem as leis, nem os costumes[...]/agora são os bons, Polipaides, enquanto os que antes eram nobres/ agora são desprezíveis". Tradução de Viviane M. Ishizuka, 2002). A aparente contradição na Teognideia pode ser entendida, como quer Faraone (2008, p.79), como produto da catena simposiale que fazia parte do ambiente dos poemas elegíacos.
} 
Diógenes Laércio (Vida e Opinião dos filósofos, III.103), ao tratar da obra de Aristóteles, já aponta o sentido multívoco da palavra:

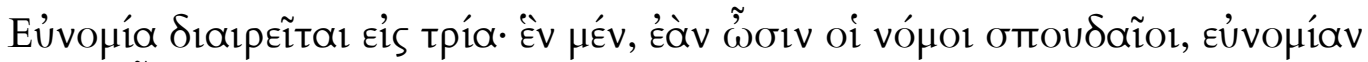

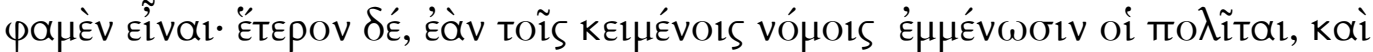

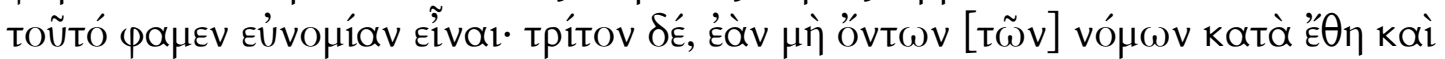

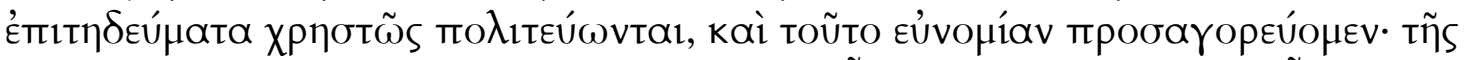

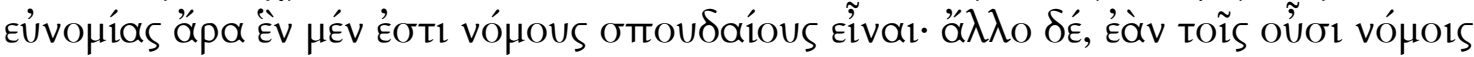

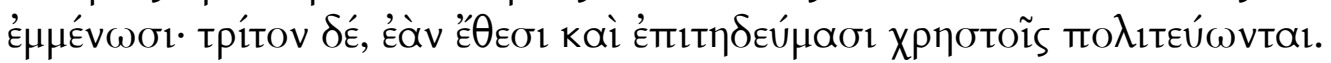

"Eunomia é dividida em três partes. Primeira: se as leis forem sérias, afirmamos ser Eunomia; segunda: se os cidadãos respeitam as leis estabelecidas, afirmamos ser isso também Eunomia, e terceira: se, não havendo leis, exercem bem a cidadania conforme a tradição e os costumes, alegamos ser isso também Eunomia. Assim, Eunomia pode ser: primeiro, leis sérias; segundo, se respeitam as leis que existem; terceiro, se exercem a cidadania por meio de boas tradições e costumes.”

É provável que Tirteu não desconhecesse o termo, já que ele é atestado na

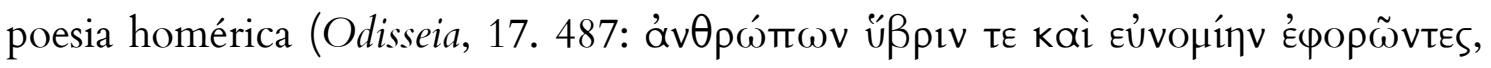
"a violência humana e a equidade observando"): Homero refere-se à Eunomia como um tipo de comportamento que se opõe à üßpıs, e é essa a mesma utilização que Sólon parece conferir à palavra no célebre fragmento $4 \mathrm{~W}$ (vv.30-35):

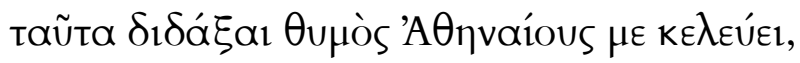

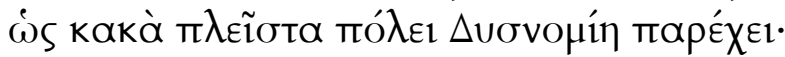

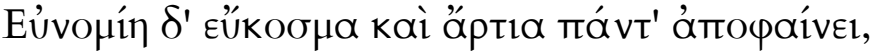

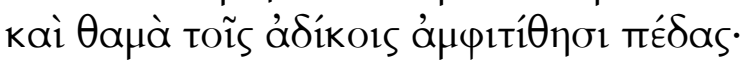

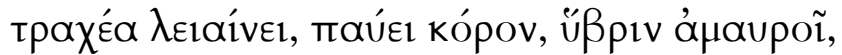

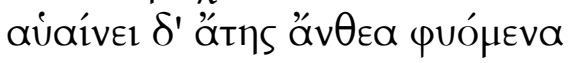

Isto o ânimo ordena-me ensinar aos atenienses:

Disnomia oferece males máximos à cidade,

mas Eunomia revela tudo bem disposto e adequado,

e muita vez encadeia os injustos:

aplana o áspero, cessa a saciedade, turva a violência faz murchar a viçosa flor da perdição 
Hesíodo a apresenta como uma Hora, filha de Zeus e Têmis (Teogonia, 901902: “Após desposou Têmis luzente que gerou as horas,/Equidade, Justiça e Paz

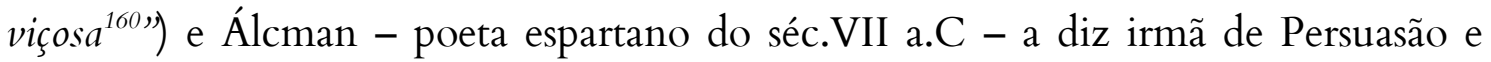

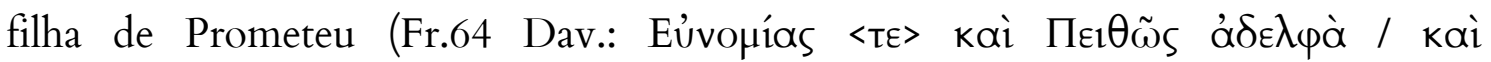

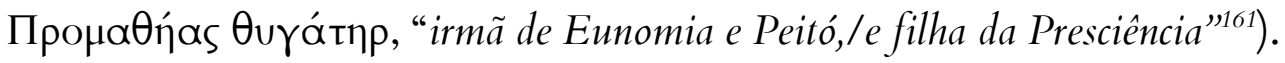

Além disso, autores que trataram do período de dissensão política da Esparta arcaica recorrem frequentemente ao termo. Todos parecem registrar um período de guerras civis e anomia que permeava a antiga civilização espartana: Heródoto (Histórias I.64-65) menciona que Esparta tinha as piores leis de toda a Grécia, mas que passaram a ter Eunomia graças ao legislador Licurgo. Plutarco (Licurgo, 30.2) também informa que Licurgo conferira Eunomia e justiça à cidade ${ }^{162}$. Tucídides (História da Guerra do Peloponeso, I. 18.1) resume a história de Esparta em um parágrafo: embora a região da Lacedemônia tivesse sofrido com as mais longas

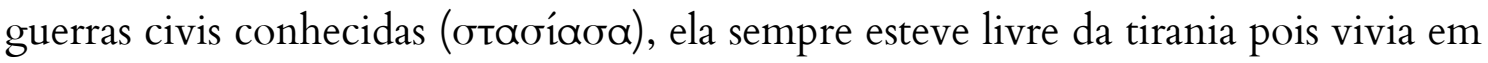
boa ordem $(\varepsilon \dot{u} v o \mu \varepsilon \tilde{i} \sigma \theta \alpha \imath)$.

É interessante notar aqui que Tucídides contrapõe Eunomia à tirania: o governo garantido pela lei é oposto àquele no qual um só homem governa. A sugestão de Andrewes (1938, pp.93-95) é que essa contraposição é fortuita: deve-se antes ao fato de que o surgimento da tirania significaria a interrupção da constituição estabelecida. Nesses termos, não há razão para desacreditar que já no século VII a.C. houvesse um poema de Tirteu conhecido como Eunomia, mas se o próprio poeta empregou o termo, ele ainda não devia conter todos os sentidos atestados por Diógenes Laércio e Aristóteles, mas simplesmente "boa ordem”, “equidade” ou ainda “amor à ordem” - à mesma maneira de Homero e Hesíodo. ${ }^{163}$

\footnotetext{
${ }^{160}$ Tradução de Jaa Torrano (2006).

${ }^{161}$ Tradução de Giuliana Ragusa (2010).

${ }^{162}$ Curiosamente, ao discutir uma possível genealogia de Licurgo, Plutarco o associa a uma figura de nome Êunomo (Eüvouss).

${ }^{163}$ Ver Prato, 1968, p.06.
} 


\section{O Fragmento $2 \mathrm{~W}$}

Antes de 1971, apenas quatro versos deste fragmento da Eunomia eram conhecidos, tendo sido conservados por Estrabão (Geografia, 8.4.10). O autor recorre aos versos de Tirteu com o fito de comprovar a nacionalidade espartana do poeta, verificando o uso da primeira pessoa do plural (ápıкó $\mu € \propto$, aphikómetha, "chegamos", v.12) nos dísticos em questão:

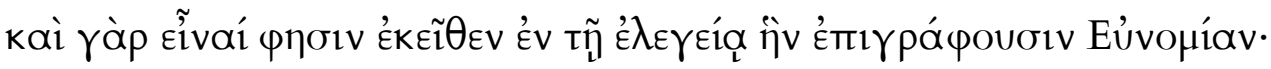

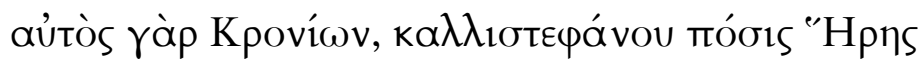

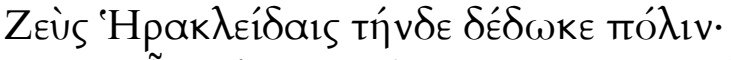

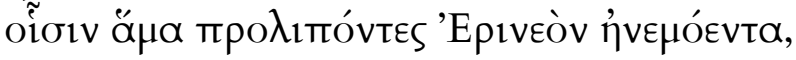

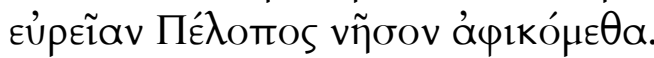

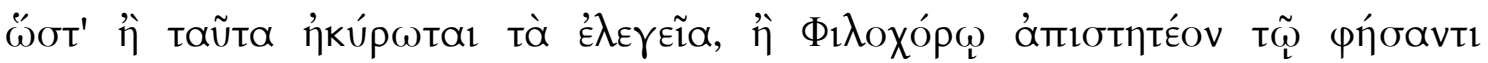

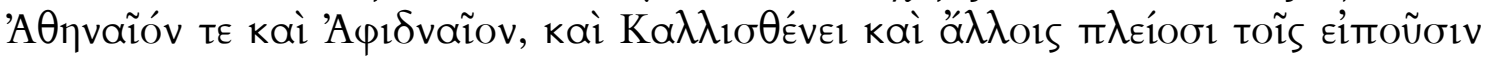

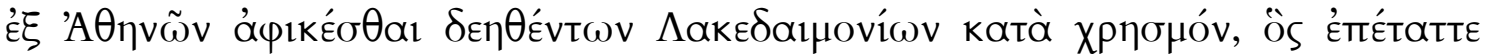

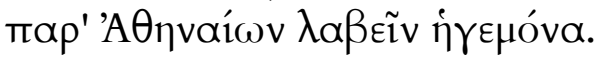

De fato, dizem que ele é dali (sc. da Lacedemônia), na elegia que intitularam como Eunomia:

Pois o Crônida em pessoa, esposo de Hera bem-coroada

Zeus, deu aos Heraclidas esta cidade:

junto deles, deixando Eríneo batida pelos ventos, à vasta ilha de Pélope chegamos.

De maneira que, ou esta elegia é espúria, ou deve-se desacreditar Filocoro (328 F 215), que o declara ateniense e de Afidna, e também Calístenes (124 F 24) e a maioria restante, que dizem que ele veio de Atenas porque os Lacedemônios precisavam dele, segundo o oráculo que lhes ordenou obter um comandante junto aos atenienses.

Analisando estes versos, Francke (1816, p.134 apud Bach p.82) julgou que eles faziam parte de uma exortação, mais precisamente após o dístico inicial do fragmento $11 \mathrm{~W}$ ("Mas porque sois da estirpe do invicto Héracles,/ coragem, Zeus ainda 
] mais próximos da linh[agem

Pois o Crônida em pessoa, esposo de Hera bem-coroada,

Zeus, deu aos Heraclidas esta cidade:

junto deles, deixando Eríneo batida pelos ventos,

à vasta ilha de Pélope chegamos

]de olhos glaucos [

Embora muito lacunares, os novos versos possibilitaram a formulação de hipóteses mais consistentes sobre o poema. A primeira palavra inteligível é

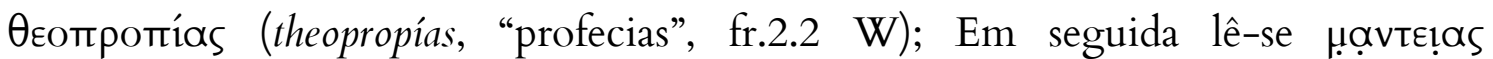

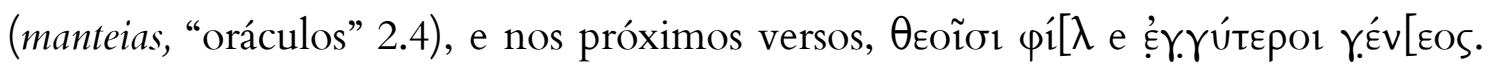
Para West (1974, p.184), estas lacunas pareceram suficientes para afirmar que o poeta alude aqui a oráculos e aos reis de Esparta - eles próprios "amados por Deuses" e também os mais próximos da raça dos imortais.

Além disso, a menção a oráculos e profecias talvez ligasse esse fragmento ao 4 $\mathrm{W}$, sugerindo que ambos pudessem fazer parte de um mesmo poema, como já se supunha anteriormente devido à temática cívica comum a ambas as elegias, em oposição às outras de conteúdo bélico (Ver Prato, 1968, p.61.). O que restou do verso 10 foi um subjuntivo exortativo na primeira pessoa do plural, $\pi \varepsilon 1 \theta \omega ́ \mu \varepsilon \theta \alpha$ (peithometha, "obedeçamos"), que encontra paralelos em outras elegias marciais (10.13-14 W, e 19.11-12, onde se utiliza o futuro indicativo) e pode indicar tanto um discurso feito por uma personagem como a voz do próprio Eu elegíaco.

A interpretação proposta por West (1974, p.184) para estes versos é a mais aceita: no poema, Tirteu exortaria seus interlocutores a obedecerem aos reis (v.10), cuja autoridade deve-se à estima dos Deuses (v.9) e ao seu parentesco divino (v.11). Uma prova dessa ancestralidade é que a região do Peloponeso, para onde os reis conduziram o povo (vv.14-15), é um presente de próprio Zeus (vv.12-13). ${ }^{165}$

Pela sequência dos versos 2-7, não seria estranho supor que o poeta estivesse na verdade exortando guerreiros a uma ação bélica anunciada por um oráculo ou

\footnotetext{
${ }^{165}$ West (1974, p. 184): "Os versos [do fr.4 W] poderiam situar-se logo após o fr.2 W, onde a referência aos oráculos é seguida depois de alguns versos pela exortação: "Obedeçamos [aos reis; pois eles] estão próximos [dos Deuses], uma vez que Zeus em pessoa concedeu esta cidade aos filhos de Héracles”. Ver Osborne (1996, p.36) para o contexto histórico.
} 
então mencionando brevemente alguma batalha antiga dos Heraclidas. O verso 7

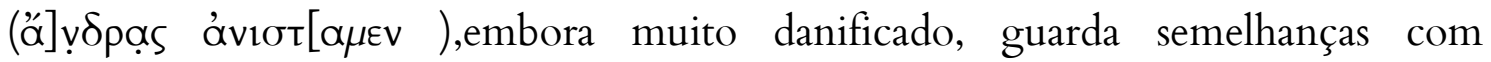
passagens de elegias exortativas de Tirteu, nas quais um verbo de mesma raiz,

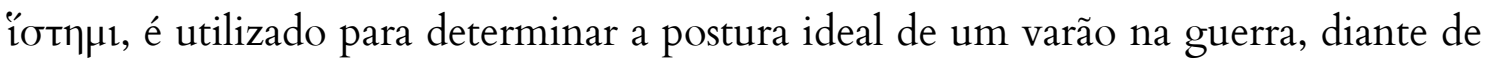
seu inimigo. Quase sempre a ideia é complementada por verbos que indicam movimento (11.29 W, îv; em 12.12 W, óṕ́routo). Nesses termos, a ideia de que

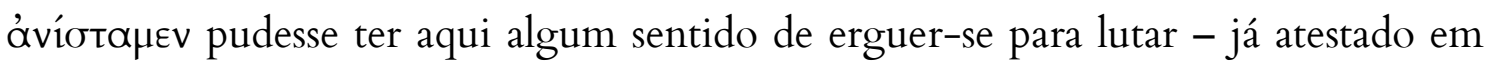
outros textos $^{166}$ - torna-se mais atraente e pode ser reforçada pelo uso de á] termo que significa na poesia de Tirteu exclusivamente o homem envolvido em ação militar, i.é, o guerreiro. ${ }^{167}$

Os versos citados por Estrabão (vv.12-15) deviam tratar de um episódio da pré-história de Esparta, o chamado "Retorno dos Heraclidas" (ver Prato, 1968). A história começa com a luta entre Héracles e os filhos de Hipocoonte, que usurparam o trono de Esparta. Vitorioso, o primeiro retorna a cidade ao seu legítimo rei, Tíndaro. Com a morte deste o trono deveria passar aos descendentes de Héracles, mas em vez disso quem o herda é Menelau, e em seguida Orestes, que reinaria sobre as duas coroas Atridas. Os Heraclidas retornariam em conjunto com os Dórios, povo que habitava a Grécia Central, para reclamar seu direito real apenas durante o reinado de Tisâmeno, filho de Orestes (Ver Nafissi, 2009, p.118). ${ }^{168}$

A relação com o mito é comprovada pela menção à "Eríneo batida por ventos"169 no verso 14. Trata-se de uma das quatro cidades da tetrápole dórica, na Grécia Central, e não uma comunidade ática próxima a Elêusis, como postularam

\footnotetext{
${ }^{166}$ LSJ "stand up [to fight against]: Il.23.635; Od.18.334.

${ }^{167}$ Por exemplo, 10. $18 \mathrm{~W}$, onde este sentido parece bem marcado: "não amai vida, em luta com

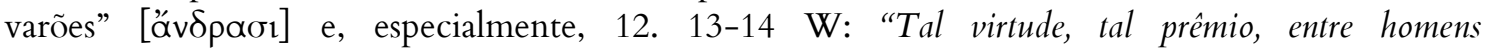

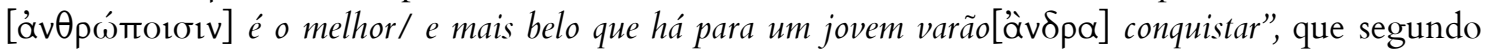
Prato $(1968, p, 130)$ constitui o primeiro registro em nossa literatura supérstite de uma distinção claramente marcada entre ôv $\theta \rho \omega \pi$ (ánthropos), "humano" e ỏví $\rho$, (anér) "varão".

${ }^{168}$ Para detalhes do mito dos Hipocoontidas (e a tradução das fontes donde o mito foi extraído) ver Ragusa, 2010, p. 105-111.

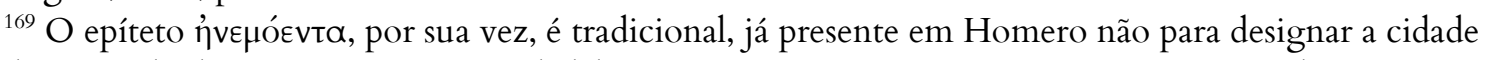
da tetrápole dórica mas a própria cidadela troiana e, curiosamente, uma árvore que recebe o mesmo nome (Il.22.145: "passaram as guaritas e a figueira ['́pıvéov] ao vento", tradução de Haroldo de Campos (2002).
} 
alguns estudiosos que defendiam a procedência ática de Tirteu (Como, por exemplo, Thiersch, 1826, p. 593 apud Bach, 1831, p.80). Estrabão (Geografia, 9.4.10) é quem dá a localização exata da cidade e informa sobre o mito do Retorno:

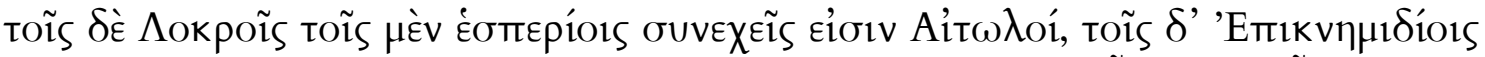

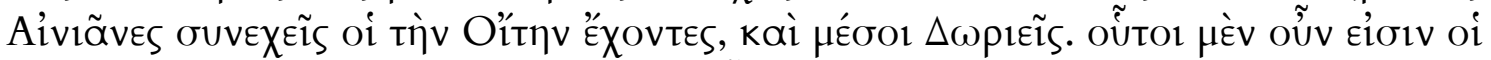

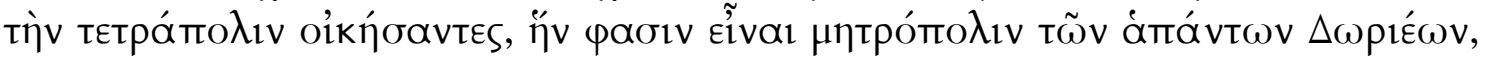

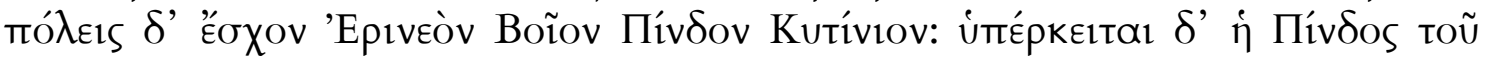

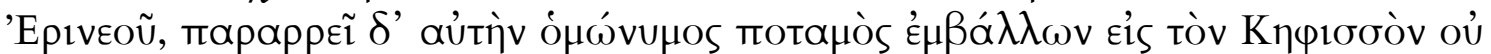

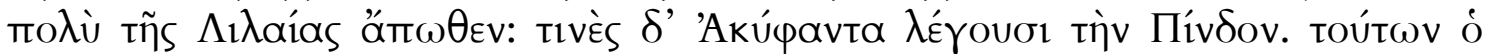

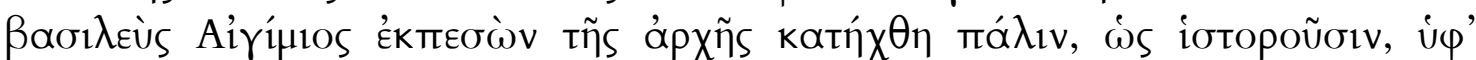

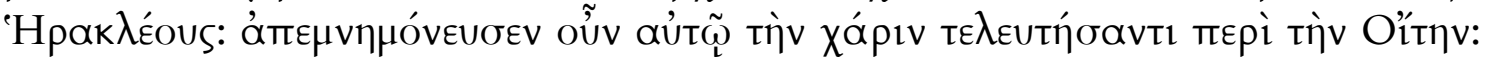

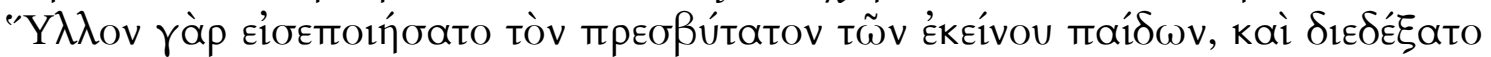

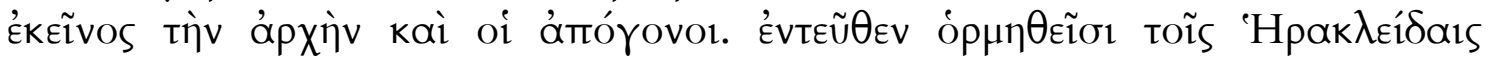

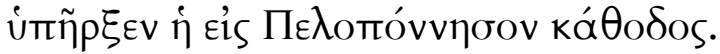

Contíguos aos Lócrios ocidentais estão os Etólios, enquanto os Enianos, que habitam o Eta, [são] contíguos aos [Lócrios] Epicnemídios; no meio [estão] os Dórios. Esses Dórios são os que habitam a Tetrápole, a qual afirmam ser a capital de todos os Dórios. Suas cidades eram Eríneo, Beos, Pindo e Citínio. Pindo estava localizada acima de Eríneo, e ao seu lado corre o rio homônimo, que deságua no Cefiso, não muito longe de Lileia. Alguns chamam o rio Pindo de Acifante. O rei desses [Dórios], Egímio, foi derrubado e depois reconduzido novamente ao poder, como informam, por Héracles. [Egímio] relembrou o favor quando da morte de Héracles no Eta: pois adotou Hilo, o mais velho dos filhos de Héracles, e ele e seus descendentes o sucederam no poder. A partir dá, teve início o retorno dos Heraclidas, que partiram para o Peloponeso.

Prato (1968, p.61) parece estar certo quando diz que o verso 12 marcaria o início de uma nova composição, uma transição para algo novo que será narrado.

Marca este novo início a ênfase na figura de Zeus: o verso inicia-se com um molosso (aủiòs rà̀), um dos recursos preferidos de Tirteu (Adkins, 1977, p.185) que imprime não apenas solenidade como também, nesse caso, chama a atenção dos ouvintes para o novo tema que virá.

Após a cesura, Zeus é qualificado por sua associação com Hera pelo uso do

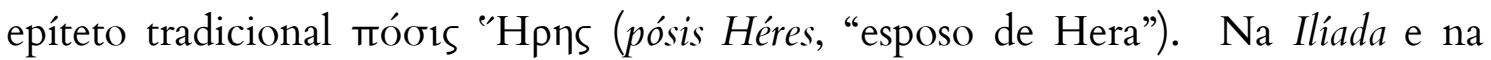

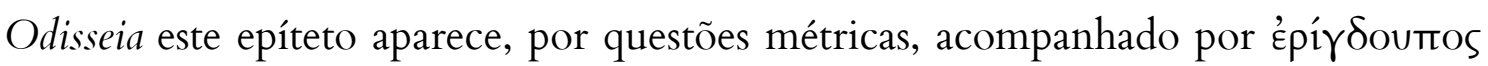
(erígdoupos, "trovejante"), referindo-se a Zeus (Il. 10.329, 13.154, 16.88; Od.8,465, 


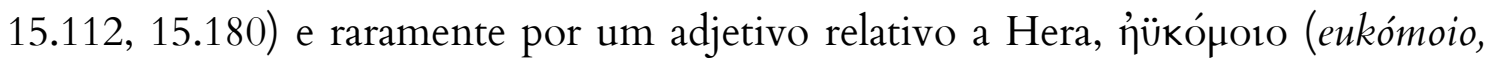
“de lindos cabelos”, Il.10.5) ${ }^{170}$. Tirteu opta por realçar a representação da Deusa referindo-se a ela com um epíteto mais incomum e vívido, ausente na Ilíada e na Odisseia, mas presente na tradição épica para designar Afrodite (na célebre inscrição da Taça de Nestor) e Deméter (Hino a Deméter, v.251).

Contudo, mesmo que na tradição épica ser referido como "Esposo de Hera" seja um motivo de honra para Zeus, poderia soar estranho à primeira vista que o poeta tenha enfatizado e escolhido justamente este epíteto para designar Zeus em um poema que menciona os descendentes de Héracles, como já notou antes a maioria dos comentadores, como Defradas (1962, p.16), Prato (1968, p.61), Vox e De Martino (1996, p. 548).

Todos também informam sobre a amplitude do culto à Hera na Lacônia. Desde a antiguidade, Esparta estava entre as três cidades mais caras à Deusa (Il. 4.51-

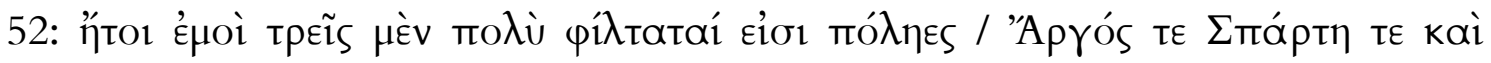

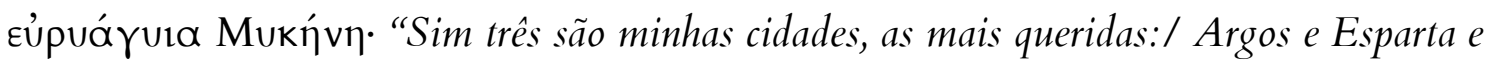
Micenas de amplas vias"). Na própria poesia de Tirteu, Hera é denominada aióoíns (aidoiés, "respeitável”, 23. $17 \mathrm{~W})$; Pausânias já informa sobre várias localidades dedicadas a Hera na antiga Lacônia (Descrição da Grécia, 3.18 ss.) e que o próprio Héracles teria fundado um templo a ela, em virtude de sua não intervenção durante a luta contra os Hipocoontidas (Descrição da Grécia, 3.15.9):

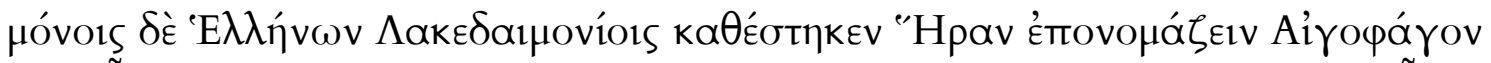

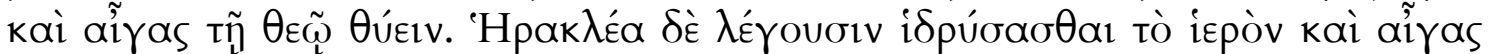

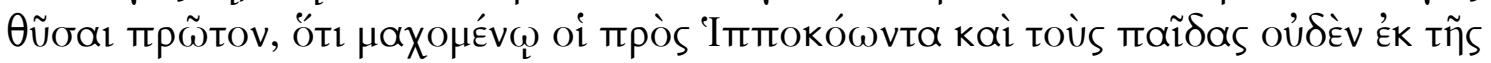

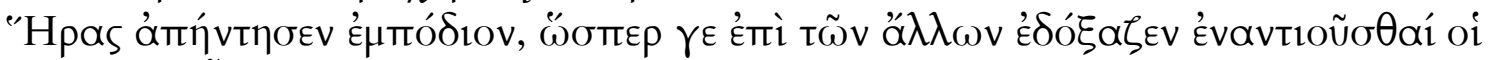

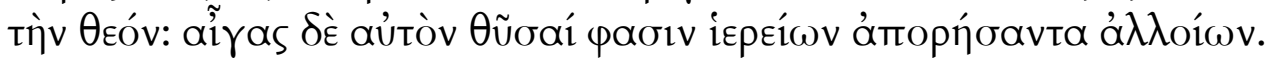

Dos Helenos, apenas entre os Lacedemônios atribui-se à Hera o epônimo "Comecabra" e sacrificam cabras à Deusa. Conta-se que Héracles fundou um templo e foi o primeiro a sacrificar cabras, porque, enquanto lutava contra Hipocoonte e seus filhos, não encontrou nenhum obstáculo de Hera, mesmo que em outras ocasiões

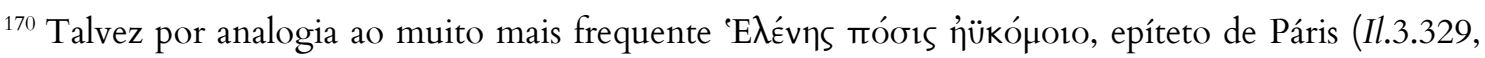
$7.355,8.82,11.369,11.505)$. 
pensasse que a Deusa se lhe opunha. Diz-se que ele sacrificou cabras, por carecer de outras opções de sacrifício.

Se no verso 12 era Hera quem recebia o maior destaque do poeta, no

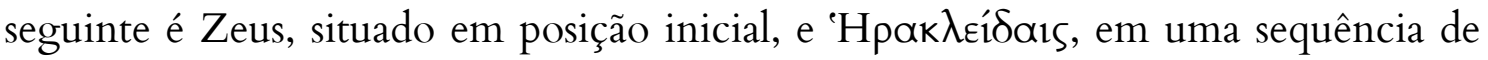
longas que ocupa todo o primeiro hemistíquio do pentâmetro, em procedimento similar ao do verso anterior. Nesse sentido, é curioso notar que o poeta parece interessado em assinalar, iniciando cada verso com espondeus, uma marcha descendente que parte do meio divino para a realidade dos mortais; no verso 12 ,

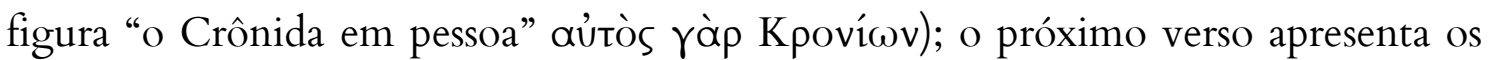
reis semideuses ('Hpak $\left.\lambda \varepsilon \varepsilon^{\prime} \delta \alpha_{1 \varsigma}\right)$ ); por fim, os mortais são prenunciados no verso 14

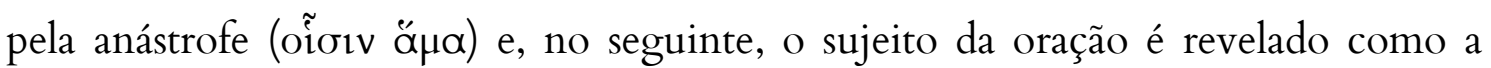
própria audiência do poema, personificada na realidade da performance (á $\varphi$ ıкó $\mu € \theta \alpha$ ).

Este recurso que confunde um passado mítico distante a uma realidade atual da performance é também verificável em outros registros e constitui-se como um elemento tradicional de toda a literatura grega arcaica e clássica. ${ }^{171}$ Efeitos parecidos ao engendrado por Tirteu parecem especialmente recorrentes em hinos literários gregos; Ver, como exemplo, a leitura do Ditirambo 17 de Baquílides em Macedo (2010, p. 265-266), onde se mostra que o clamor da jovem tripulação de Teseu subitamente transforma-se no Peã entoado pelo coro em seu contexto de performance. No caso da elegia de Tirteu, o poeta preocupa-se em forjar uma conexão entre passado, presente e futuro, e definir "um grupo coeso de todos os espartanos, vivos ou mortos" (Stehle, 1997, p. 52).

Em um passo surpreendentemente similar ao poema de Tirteu - que poderia apontar para uma tópica comum ao período - Mimnermo (fr.9W) também correlaciona a si mesmo e sua audiência aos colonizadores de Cólofon, provenientes de Pilos ${ }^{172}$ :

\footnotetext{
${ }^{171}$ São exemplos na elegia grega arcaica Calino 2, 2a, o novo fragmento de Arquíloco ("Télefo"), Mimnermo 11-14 W, Simônides $11 \mathrm{~W}$.

${ }^{172}$ Embora a temática do poema pareça mais adequada à Esmirneida, a fonte (Estrabão, Geografia, 14.1.4: Por fim, expulsos pelos Eólios, fugiram para Cólofon. Depois disso, atacaram daquela região e reconquistaram a sua terra. Exatamente como Mimnermo declara em Nannó, depois de mencionar que
} 


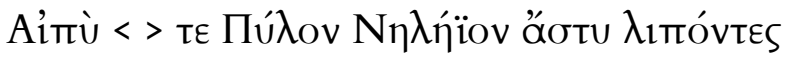

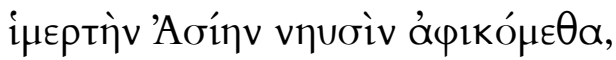

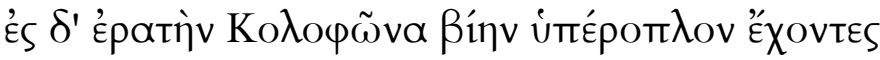

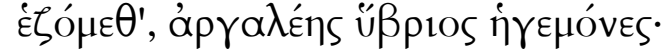

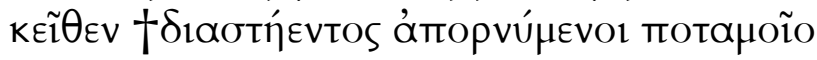

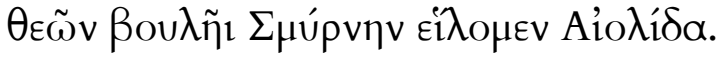

(?)...deixando Pilos, a cidade de Neleu,

à Ásia adorável em navios chegamos

e na amável Cólofon com soberba força

nos assentamos, condutores da dura violência:

Daí, atacando desde o rio [?]

Por querer dos Deuses conquistamos Esmirna Eólia.

Bowie (1986, p.31) considerou que o $\pi \varepsilon 1 \theta \omega ́ \mu \varepsilon \theta \alpha$ do verso 10 vem do discurso de um personagem, e admitiu a possibilidade de o á também ser parte deste mesmo discurso, mas, visto que o próprio Estrabão provavelmente não lia o poema dessa maneira, Bowie (2001, p.47) reformula a sua hipótese e afirma que a Eunomia poderia ter sido um poema predominantemente exortativo com breves passagens narrativas, de modo "funcionalmente similar aos elementos narrativos nos discursos de personagens na Ilíada". Se Faraone (2008, p.156) está certo em suas hipóteses sobre a estrutura da poesia elegíaca grega arcaica, poderíamos estar de fato diante de um poema exortativo com partes narrativas, em que passagens exortativas (como provavelmente seriam os vv.2-11) alternam-se com trechos narrativos (vv. 12 ss.).

Note-se que sugestão parecida à de Bowie já está no Studies in Elegy and Iambus de Martin West (1974, p.14), que alude a uma possível identidade entre a Eunomia e outros poemas comprovadamente exortativos, como a Salamina de Sólon

Esmirna sempre foi objeto de conflito) atribui os versos à Nannó, poemas menores, que, por consequência, eram apresentados no ambiente do simpósio. Seria um erro cometido por Estrabão, ou a passagem, originária da Esmirneida, teria sido reformulada para uma performance simpótica? (Bowie, 2009, p.113 n.11). A segunda opção é interessante, caso se considere que o poeta trabalha aqui com termos do universo erótico para definir Cólofon e Esmirna (Bowie, op.cit.). O mesmo uso é verificado em Tirteu $4 \mathrm{~W}$, infra. 
(fr.1-3 W) - uma identidade que não é só de tema, mas também de ocasião de performance ${ }^{173}$.

\section{Estratégias comunicativas no fr. $2 \mathrm{~W}$}

Poderíamos, assim, entender o simpósio como um ambiente adequado para a apresentação deste canto? Uma vez que não é possível precisar a extensão exata da Eunomia $^{174}$, é profícuo verificar se as estratégias comunicativas presentes no poema podem fornecer algum indício das circunstâncias em que o fragmento $2 \mathrm{~W}$ poderia ter sido apresentado.

D’ Alessio (2009, p.151-156) assinala que esta estratégia consiste no emprego da primeira pessoa do plural: ao empregá-la, o poeta torna possível que qualquer indivíduo da comunidade espartana possa se identificar na voz poética. Tirteu estaria, assim, na contramão de outros poetas gregos arcaicos que tinham o simpósio como horizonte, visto que estes se ocupavam de, muitas vezes, enfatizar o seu próprio $\mathrm{Eu}$ poético ${ }^{175}$ e retratar uma visão de mundo que era compartilhada apenas pelo grupo que participava do simpósio. ${ }^{176}$ Portanto, segundo o autor, não haveria a necessidade que alguém incorporasse a voz de "Tirteu" em suas performances ${ }^{177}$, pois o próprio poeta já personifica a comunidade espartana em suas elegias; $\mathrm{O}$ autor justifica que o uso de 'Hpak $\lambda \varepsilon^{\prime} \delta \alpha_{1}$ (vv.13) remete a esta coletividade, que diz respeito a todos os espartanos, e não apenas a um grupo que clama ancestralidade divina. Assim, a poesia de Tirteu está em oposição à poesia simpótica aristocrática,

\footnotetext{
173 "Se foi assim, [a elegia narrativa] é semelhante à elegia marcial ou político-exortativa e pode ser imaginada cantada em circunstâncias semelhantes" (1974, p.14).

${ }^{174}$ Embora a presença de um título - que já era conhecido por Aristóteles - possa indicar que se tratava de um poema razoavelmente longo.

${ }^{175}$ Arquíloco, fr. $1 \mathrm{~W}$ ( "sou servo do senhor Eniálio el das musas o amável dom conheço", Tradução de Paula da Cunha Corrêa, 2009) Teógnis (vv. 19-23, "Cirno, que o selo de minha habilidade poética seja colocado sobre/ estes versos, e o roubo deles sempre será notado./ Ninguém trocará o pior pelo bom, que está à mão/ Assim, todo homem dirá: "São os versos de Teógnis/ de Megara", célebre entre todos os homens". tradução de Viviane M. Ishizuka,2002), Sólon (fr.1W: "Eu mesmo, um arauto, vim da adorável Salamina/ e um adorno da palavra, o canto, anteponho à fala")

${ }^{176} \mathrm{Um}$ exemplo pode ser o fragmento $69 \mathrm{~V}$ de Alceu.

${ }^{177}$ Com em alguns poemas de Safo (1.19-20 “Quem, ó Safo, te maltrata?" - trad. Giuliana Ragusa, 2005, grifos meus), Hipônax (34: Pluto, Deus da riqueza (porque é cego demais)/nunca me veio em casa e disse: "Hipônax,/dou-te trinta minas de prata/ e muitas outras coisas." - pois é um desgraçado no coração") e Alceu (fr. 129 e $130 \mathrm{~V}$ )
} 
pois não apresenta a linguagem sectária das heterias, mas antes coloca em cena todo o povo de Esparta. As divisões que a elegia tirtaica engendra são apenas de funções militares que devem ser desempenhadas por cada grupo. Desse modo, D’Alessio conclui que os poemas de Tirteu encontrariam seu espaço ideal no peculiar banquete comum espartano, a syssitia.

Há espaço para discordâncias da hipótese de D’Alessio: uma delas é que a maioria dos estudiosos estabelece que o início desta instituição espartana se deu em meados do século VI a.C., anos depois do período de atividade poética de Tirteu, e que antes disso, os simpósios em Esparta não apresentavam grandes diferenças com os de outras poleis gregas (Irwin, 2005, p.32 n.40). Ainda que se possa considerar a syssitia como espaço de reperformance privilegiado para a poesia de Tirteu (como de fato deve ter sido), não se pode afirmar com exatidão que o poema difundia um ideal de comunidade, uma vez que mesmo no interior da comunidade de homoioi que integrava a syssitia havia distinções que se baseavam em ideais aristocráticos como riqueza, nascimento, mérito e idade (Hodkinson, 2002, p.108). É correta a sugestão de que a única divisão encontrada em Tirteu é de grupos militares, mas esta divisão na verdade promove um componente aristocrático: apenas os mais abastados podiam pagar pela panóplia, restando a outros o uso de armas mais rudimentares ${ }^{178}$.

Nesse sentido, de maneira similar a Andrew D. Morrison (2007, p.57), que analisou os narradores na poesia grega arcaica, pode-se chegar à conclusão de que o uso de uma voz poética bem delimitada, e, por assim dizer, autorreferencial (como ocorre em elegistas como Sólon ou Teógnis) ou o uso de um Eu coletivo como aqueles dos poemas de Tirteu é uma questão de estilo ou preferência particular de cada poeta - e não necessariamente de diferentes circunstâncias de performance. É comum, também, como observa Rösler (1990, p. 234), que uma rememoração no espaço do simpósio esteja relacionada à comunidade, tornando nebulosos os limites do "eu" e do "nós" - uma vez que esta é uma festividade que define identidades de um grupo que se reúne por afinidades comuns (Rösler, 1990, p.233). E, como é comum no restante da poesia de Tirteu, tais afinidades se manifestam a partir da

${ }^{178}$ Ver Van Wees 1999, Irwin, 2005, e os comentários ao fr.11.34-38 à frente. 
subordinação do povo às figuras aristocráticas - aqui representadas por Heraclidas que assumem o papel de mantenedores da polis. Os versos 15 e 16 sugerem esta leitura: neles, o poeta deixa implícito que o povo (no qual ele se inclui, talvez por intenções retóricas) obteve a cidade graças aos Heraclidas, que para lá o conduziu.

\section{O Fragmento $4 \mathrm{~W}$}

O texto definitivo desta elegia provém da reunião de duas passagens, presentes no Licurgo de Plutarco e na Excerpta Vaticana da obra de Diodoro da Sicília.

O primeiro atribui os versos à Tirteu, e informa um artifício político utilizado pelos reis Teopompo e Polidoro para conter o povo e garantir a supremacia de suas decisões. Segundo Plutarco, os dois reis fizeram um acréscimo à Retra original - o oráculo recebido por Licurgo - que lhes garantia o poder de vetar decisões e evitava que o povo alterasse as leis propostas por eles (Plutarco, Vida de Licurgo, 6.4):

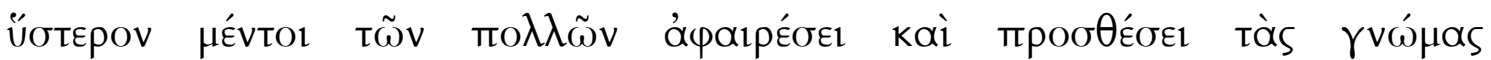

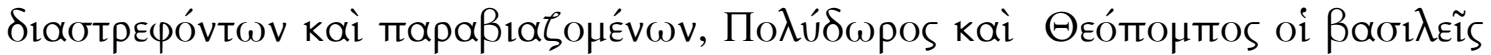

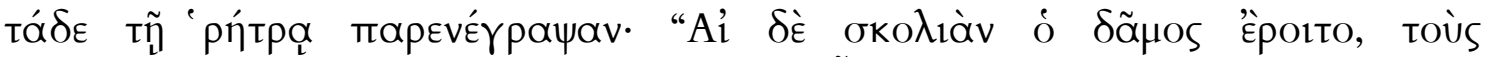

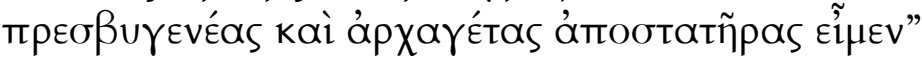

Depois, no entanto, porque muitos distorciam e forçavam as máximas, com subtrações e acréscimos, os reis Polidoro e Teopompo adicionaram à Retra o seguinte: "Se o povo falar de modo oblíquo, nós - anciãos e príncipes - seremos divergentes.

Ainda de acordo com Plutarco, os mesmos reis fizeram o povo crer que esse acréscimo fora uma prescrição divina, proferida pelo oráculo de Delfos e que desde sempre pertenceu à Retra. O testemunho de Plutarco para o fato são os versos de Tirteu correspondentes aos versos 1-6 do fragmento $4 \mathrm{~W}$ : 


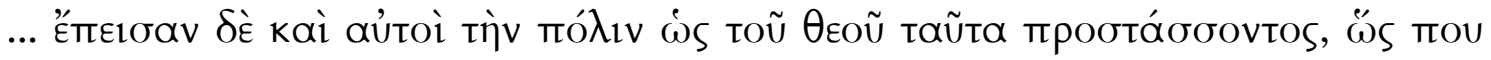

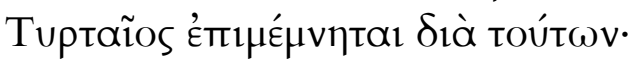

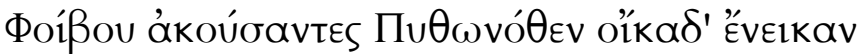

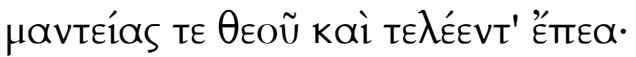

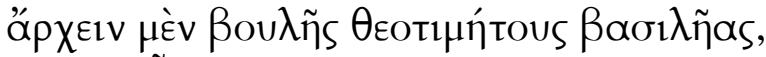

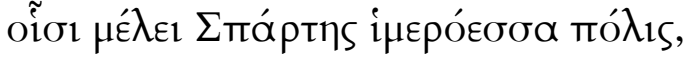

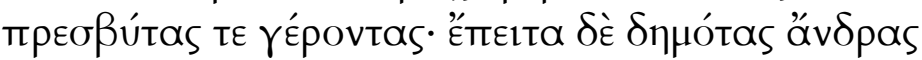

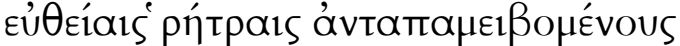

Eles próprios também persuadiram a cidade de que era o Deus quem prescrevia estas palavras, como Tirteu aparentemente relembra por meio destes versos:

Febo escutaram, e de Pito ao lar levaram

as profecias do Deus e as palavras certas:

que dirijam o concílio os reis honrados por Deuses, a quem importa a linda cidade de Esparta, e os veneráveis anciãos: depois homens do povo, por sua vez, respondendo às retas sentenças

Plutarco informa que os versos mencionados por Tirteu são parte de um oráculo trazido de Delfos por Polidoro e Teopompo, mas ao mesmo tempo parece creditar a um oráculo mais antigo, trazido por Licurgo (6.1-3, supra), a formulação inicial da Grande Retra. Nesse sentido, os dois reis teriam acrescentado à Retra

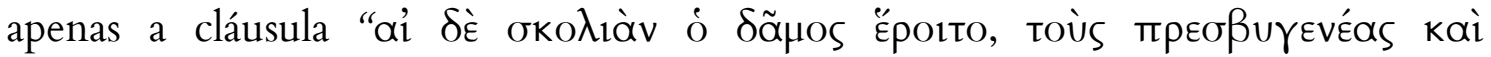

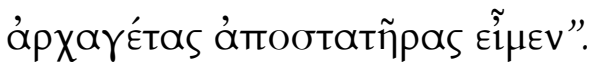

Para West (1974, p.185), a leitura de Plutarco não parece satisfatória: o editor considera difícil que um acréscimo posterior pudesse ser registrado e relembrado posteriormente como parte do oráculo original. Sua hipótese é de que Tirteu cita o oráculo original de modo a justificar a nova cláusula inserida pelos reis.

Já Diodoro da Sícilia oferece uma redação ampliada, entretanto divergente. O manuscrito que traz a citação apresenta o oráculo em scripta continua, com cada dístico ocupando cinco linhas do manuscrito original. Uma nota lateral acrescenta que se trata do oráculo recebido por Licurgo em Delfos, e não menciona o nome de Tirteu ${ }^{179}$.

${ }^{179}$ Ver Wade-Gery, 1944, p.3. 
Os versos 3 a 6 citados por Plutarco reaparecem com pequenas variações ${ }^{180}$ na versão de Diodoro, mas antes e depois são citados trechos ausentes em Plutarco. Os versos 1-2 de Diodoro falam de Apolo, atribuindo-lhe uma profusão de epítetos que levou muitos estudiosos a desacreditar a autenticidade desses versos. Os versos 7 a 9 dão sequência aos ordenamentos do oráculo e o último verso conclui o poema com uma composição anelar que retoma o nome do Deus de Delfos. Poucos duvidaram da autenticidade destes dísticos finais, por verem neles certa discrepância de estilo e língua típicos do período arcaico e do ambiente lacônico (Prato, 1968, p. 69) ou uma contradição explícita do conteúdo apresentado nos versos citados por Plutarco: enquanto nos versos 1 a 6 retratar-se-ia o povo submisso às ordens dos reis e dos anciãos, nos versos 7 a 10 ele é retratado com autoridade sobre estes (Andrewes, 1938, p. 98).

Citamos abaixo a versão de Diodoro (= Fr. 14 G-P), editada por Boissevain (1906) com as correções e alterações propostas por Wade-Gery (1944a):

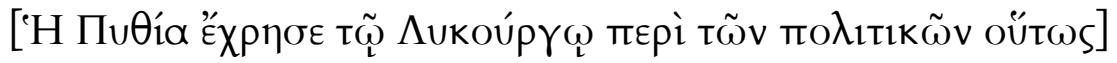

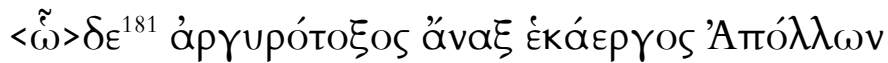

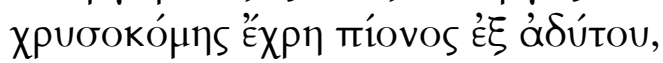

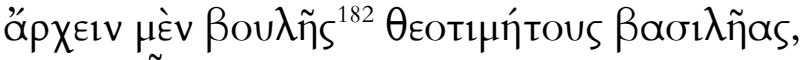

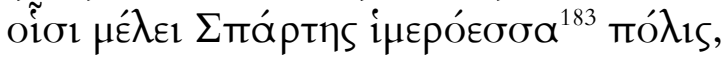

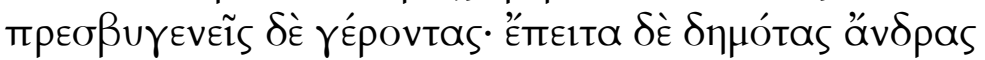

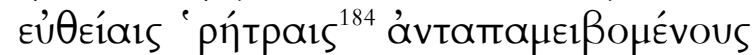

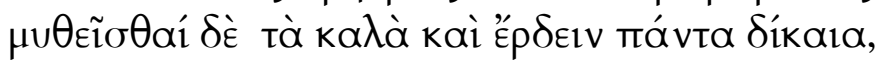

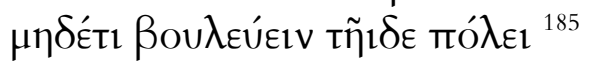

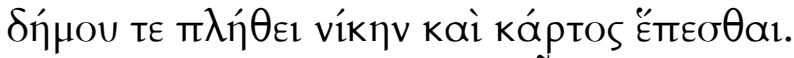

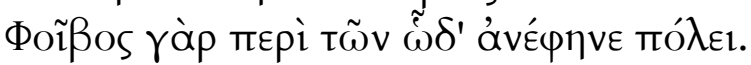

[A Pítia deu o seguinte oráculo a Licurgo, sobre questões políticas:]

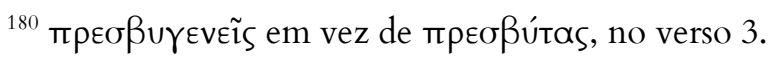

${ }^{181}$ Dindorf (1828): $\delta \grave{\eta}$ Boissevain (1906): $\delta \grave{\varepsilon}$

${ }^{182}$ Dindorf (1828): Bou $\lambda \tilde{\eta}$ Boissevain (1906): $\beta$ ou $\lambda \eta$

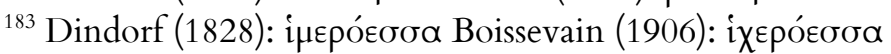

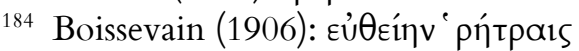

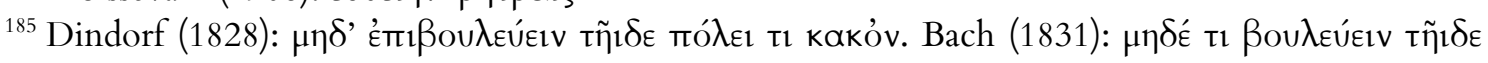

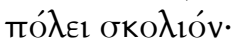


Assim o rei do arco argênteo, Apolo que age à distância,

de áurea coma, predisse do pingue santuário:

que dirijam o concílio os reis honrados por Deuses

a quem importa a linda cidade de Esparta, e os primevos anciãos: depois homens do povo,

por sua vez, respondendo a retas sentenças

pronunciem ditos belos e ajam com justiça em tudo

(?) e ainda não deem à cidade conselho (?)

para que vitória e poder sigam as massas.

Sobre isso, eis o que Febo revelou à cidade.

Desde as primeiras edições do texto questiona-se se é possível conciliar ambas as versões, na tentativa de aceder à composição legítima de Tirteu. A tendência vigente desde Bergk (1882, p.317) é tomar a versão de Plutarco como a mais próxima do poema original. $\mathrm{O}$ argumento usado por Bergk e quase todos os editores que o seguiram (Prato 1968, West 1974) para rejeitar a autenticidade da versão de Diodoro é o acúmulo de epítetos ornamentais atribuídos a Apolo no primeiro dístico, considerado como um arranjo desajeitado ou convencional demais para Tirteu ${ }^{186}$, e provavelmente elaborado por um compilador tardio que visava conciliar o fragmento com a lenda de que Licurgo trouxera o oráculo. Para isso, este

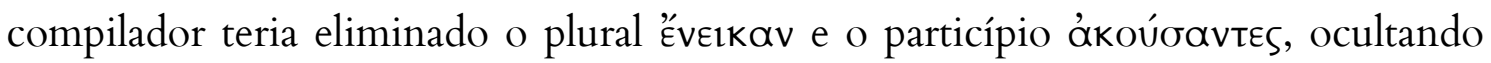
assim uma possível menção a Polidoro e Teopompo.

West (1974, p.185), por sua vez, não viu motivos para que a citação de Plutarco fosse falsa. Segundo o editor, seria muito mais simples se Plutarco também possuísse uma versão do poema que não trouxesse os verbos no plural, uma vez que ele próprio já atribui o estabelecimento da Retra a um oráculo anterior recebido por Licurgo (Vida de Licurgo 6). O que West conclui, portanto, é que a fonte em que Plutarco baseou seu relato ${ }^{187}$ não conhecia outra versão para a elegia.

\footnotetext{
${ }^{186}$ Hipótese também defendida por Jacoby (1918, p. 11) Wade-Gery (1944, p.3) e Treu (1955, p.268).

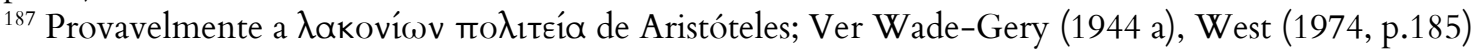


Essas hipóteses são discutíveis: o uso de epítetos convencionais não é estranho à poesia elegíaca grega arcaica ${ }^{188}$, e o próprio Tirteu, no fragmento $2 \mathrm{~W}$ - que pertenceria à Eunomia -, compõe um verso formado exclusivamente por epítetos de

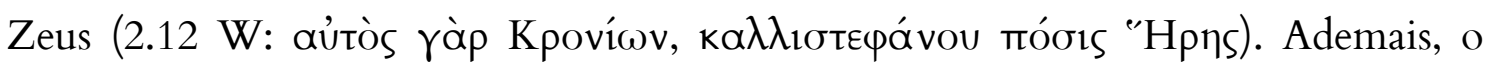
emprego exacerbado de epítetos poderia ter como finalidade ressaltar o poder e a influência de Apolo diante da comunidade espartana, em um procedimento muito similar ao dos hinos homéricos. Poucos estudiosos creram na originalidade dos versos 1-2 citados por Diodoro. De Falco (1941, p.159) julga a referência de Diodoro mais segura e admite, embora sem muita convicção, que ambos os dísticos pudessem ser autênticos, aqueles de Plutarco precedendo imediatamente aos de Diodoro:

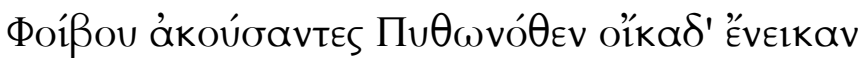

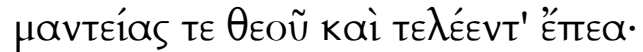

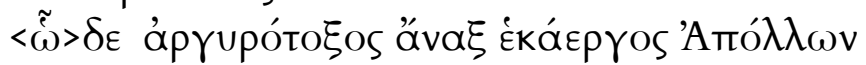

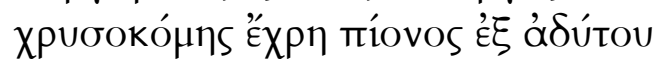

Febo escutaram, e de Pito ao lar levaram profecias do Deus e as palavras certas;

Assim, o rei do arco argênteo, Apolo que age à distância, de áurea coma, predisse do pingue santuário...

Van Wees (1999, pp.7-8) retomou parcialmente esta visão, demonstrando que uma análise minuciosa de ambas as fontes leva à conclusão de que ambas são igualmente confiáveis.

Para o estudioso, se um compilador hipotético quisesse apagar os verbos no plural para atribuir o oráculo a um único legislador, Licurgo, seria plausível que ele compusesse um dístico que de fato nomeasse Licurgo. A versão de Plutarco, por outro lado, está em pleno acordo com seu argumento de que a profecia foi dada aos

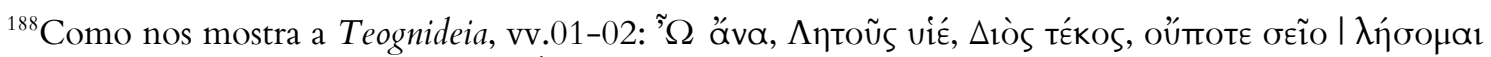

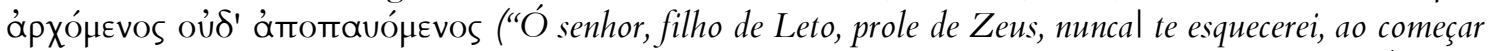

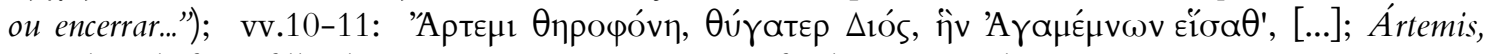
matadora de feras, filha de Zeus, para quem Agamênon/fundou um templo...
} 
reis Teopompo e Polidoro, e seria, segundo Van Wees, uma transição abrupta da afirmação de que os reis voltaram de Delfos para o oráculo propriamente dito.

Desse modo, Van Wees conclui que se trata de uma citação seletiva, isto é, Plutarco menciona alguns versos que teriam the parecido uma evidência satisfatória de que os dois reis eram os receptores do oráculo, e depois passaria diretamente ao texto oracular, omitindo assim todos os versos que não lhe interessavam - inclusive a fórmula introdutória que menciona Apolo. A hipótese de Van Wees é interessante, porém indemonstrável. Limitemo-nos a questionar se os versos 1-2 da versão plutarquiana de fato soariam abruptos aos ouvidos da audiência do poema, lembrando, com Nagy (2009, p.19), que a palavra Ětrea no verso 2 é frequentemente empregada na poesia elegíaca para referir versos hexamétricos que se seguem a ela, e que portanto poderiam muito bem introduzir um oráculo. ${ }^{189}$

Em termos gerais, seguiremos a edição proposta por West - que colige os versos 01-06 da versão de Plutarco e os versos 07-10 da versão de Diodoro, e trabalharemos a hipótese de que esses versos fossem um poema completo - ou, nos termos de Cristopher A.Faraone (2008), uma estrofe com sentido completo. Esse julgamento que é fortalecido pela composição em anel dos versos 1 e 10 (Фoíßou Фoīßos), que também já fora notada por Adkins (1985, p.69) ${ }^{190}$.

O verso 1 do manuscrito de Plutarco está corrompido, e não traz

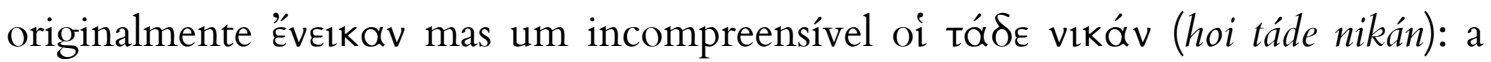
lição adotada por todas as edições modernas foi proposta primeiramente por Jacques Amyot, em sua tradução de 1559 de Plutarco (Ver Prato, 1968, p. 70). Wade-Gery

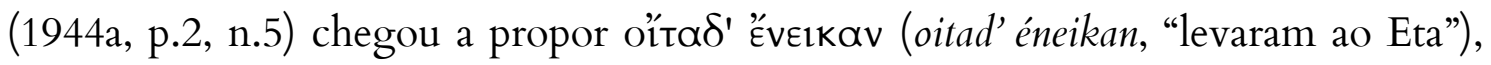
uma leitura que relacionaria o oráculo a Egímio e ao mito do Retorno dos Heraclidas ao Peloponeso. ${ }^{191}$ Embora seja paleograficamente possível, esta leitura entraria em contradição com o verbo $\mu$ ć $\lambda \epsilon ı$ no verso 4 do poema.

\footnotetext{
${ }^{189}$ Como em Teognideia, vv.15-18 (ver p.156, n.159).

${ }^{190}$ Embora na versão de Diodoro também se forme uma espécie de anel temático, referindo-se à Febo nas duas extremidades do poema. Ver Jäger (1966, p.126) e Faraone (2008, p.26).

${ }^{191}$ Ver a passagem de Estrabão (Geografia, 9.4.10), p. 163., acima.
} 


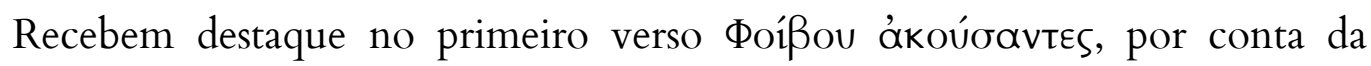
sequência de espondeus tão frequentemente utilizada por Tirteu para causar impacto

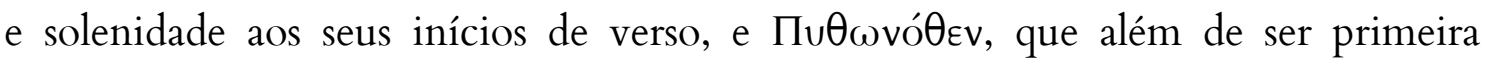
palavra após a cesura, é um termo raro e eminentemente poético. ${ }^{192}$ Importa ao poeta, neste dístico inicial, afirmar a origem divina da informação que ele relatará.

Uma questão longamente discutida entre os estudiosos deste fragmento é a

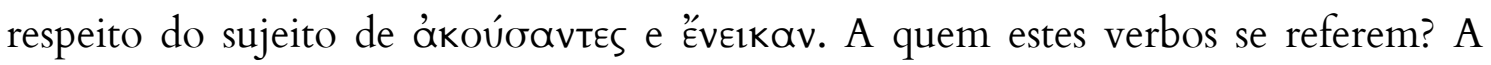
leitura mais comum entre os estudiosos é de que os versos tratam dos reis Teopompo e Polidoro. Plutarco relata que o poema de Tirteu menciona o acréscimo feito pelos dois reis à Grande Retra, fazendo o povo acreditar que aquelas eram palavras divinas (vv.05-06). Segundo alguns, como Forrest (1963, p.160), a referência a estes reis só é possível porque Tirteu os teria mencionado em outro trecho do poema que se perdeu.

Nafissi (2009, p. 126), porém, lança a teoria de que Plutarco tenta explicar a origem do acréscimo relacionando-a a uma teoria em voga nos séculos IV-III a.C., de que o rei Teopompo teria sido responsável pela instituição do eforato em Esparta,

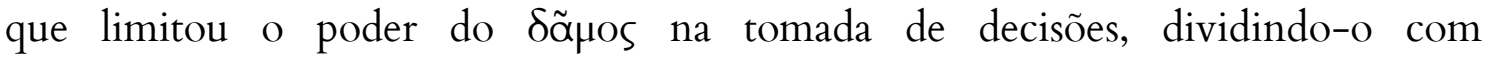

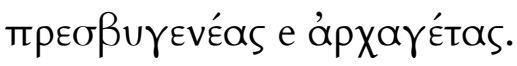

Nesse sentido, o único elo entre estes dois acontecimentos seria o poema de Tirteu, que supostamente teria citado que Teopompo foi quem recebeu o oráculo que originou a Retra. Entretanto, nota-se que o próprio Plutarco não parecia muito convicto de que Tirteu mencionara de fato estes reis ou mesmo o acréscimo à Retra, fato que se observa no uso do advérbio nou, "talvez", que antecede a citação do fragmento.

Outros estudiosos chegaram a propor leituras alternativas: Andrewes (1938, p.99) sugere que o fragmento $2 \mathrm{~W}$ e o fragmento $4 \mathrm{~W}$ estavam muito próximos, e que os Heraclidas (fr.2.13 W) citados naquele fragmento são retomados aqui. Para

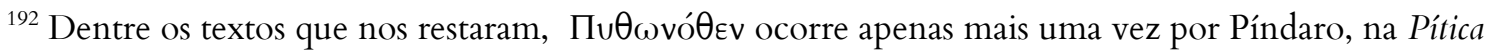
5, v.105; Mas na poesia grega arcaica, $\Pi u \bar{\theta} \theta \omega ́ v$ é um termo frequentemente utilizado para referir-se à cidade do oráculo. Ver Ilíada 2, 519; Hino Homérico a Hermes, vv.178 e um verso de Teógnis (v.807).
} 
ele, estes Heraclidas eram os primeiros reis espartanos, Eurístenes e Procles desconsiderando, como a maioria dos estudiosos, que Tirteu tivesse feito qualquer menção explícita a Licurgo. A sugestão de Andrewes encontra respaldo em uma tradição, atribuída ao historiador Helânico de Lesbos, que confere aos primeiros reis a fundação da constituição espartana. ${ }^{193}$

Wade-Gery (1944, p. 3), considerando o trabalho de Andrewes, concorda com o argumento de que Heraclidas é sujeito da oração, mas não descarta a possibilidade de que Licurgo pudesse estar incluído entre eles, como menciona Xenofonte, que situa Licurgo historicamente no tempo dos primeiros Heraclidas ${ }^{194}$. Van Wees (1999,p.12) é da mesma opinião, observando que, se Tirteu tivesse de fato mencionado Teopompo e Polidoro na Eunomia, Plutarco provavelmente teria citado estes versos de maneira a reforçar o seu argumento.

Caminho um pouco distinto seguiu Prato (1968, p. 70), ao relembrar da intensa relação entre Esparta e o oráculo de Delfos, consolidada na figura dos Pítios, quatro oficiais espartanos designados pelos reis para consultar o oráculo de Delfos ${ }^{195}$.

Prato chega a evocar o testemunho de Marcello Gigante, que em seu artigo Tyrtaeus poeta non felix (1961, p.237) afirma que Tirteu era conhecido como O Pítio

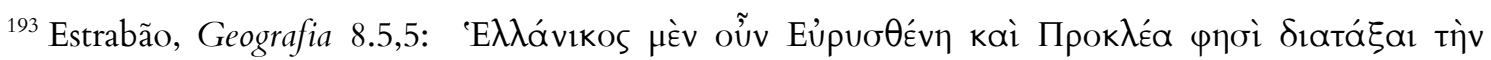

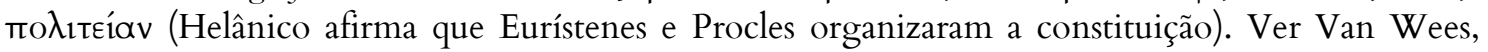
1999, p.13.

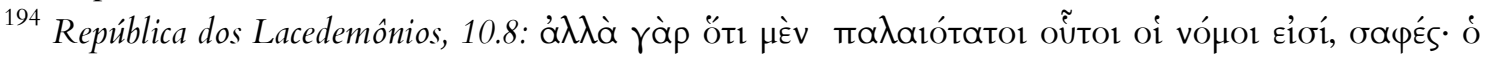

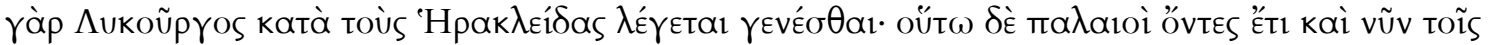
ă $\lambda \lambda$ ols kaıvótatoí eỉor (...) "Todavia, é evidente que essas leis são antiquíssimas: Pois conta-se que Licurgo viveu entre os Heraclidas. Assim, embora sejam antigas, ainda [são], até hoje, novíssimas entre eles [sc. os Espartanos]". Gray (2007, p.171) observa que Xenofonte é propositalmente vago ao referir-se às datas em que estas leis "antiquíssimas" foram estabelecidas, pois deseja criar um paradoxo que estimule os gregos à imitação: embora as leis sejam muito antigas, como ninguém imitou os espartanos, elas permaneceram como se fossem novas. Por esse motivo, ele não cita o sujeito de

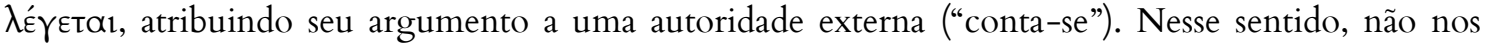
parece lícito supor, como Van Wees (1999, p.13) que situar Licurgo no tempo dos primeiros Heraclidas pudesse ser uma leitura incorreta de Xenofonte ao poema de Tirteu, mas antes, uma observação que visa fortalecer o seu paradoxo.

${ }^{195}$ Ver Heródoto Histórias 6.57, Xenofonte, República dos Lacedêmonios, 15.5. 
- não no sentido técnico do termo, mas como o "poeta do oráculo délfico", i.é, o responsável por transmitir as profecias emitidas pelo Deus. ${ }^{196}$

A nosso ver, as diversas possibilidades de receptores propostos para o oráculo, sugeridas tanto por estudiosos modernos quanto antigos, informam que a própria Eunomia talvez tivesse expressado o sujeito desta oração de maneira deliberadamente vaga. Esta leitura que não atribui nenhum nome ao recipiente do oráculo nos parece mais adequada à proposta de interpretação que fazemos para a Eunomia, na qual se daria uma mescla entre passado mítico e realidade atual de performance de maneira a criar uma identidade coesa para todos os cidadãos espartanos.

No contexto do fragmento $4 \mathrm{~W}$, essa mescla parece-nos ainda mais importante, pois demonstra um ideário político aristocrático: a conexão entre passado e presente não se dá apenas pela continuidade da linhagem dos Heraclidas (Fr.2 W) mas também pela continuidade e manutenção de leis que regem a sociedade espartana e foram sancionadas por um Deus.

A oração participial encerra-se com a cesura heptemímera, dando lugar à oração principal cujo objeto, ravteías, revela-se apenas no início do segundo verso, em espondeus - recurso abundante na poesia de Tirteu quando o poeta deseja enfatizar algo, como já nota Adkins (1977, p.76). Nesse caso, Tirteu inicia o verso com a palavra mais importante da oração. Havteías também ocorreria possivelmente no verso 4 do fragmento $2 \mathrm{~W}$, o que levou West (1974, p.184) a considerar que os dois fragmentos faziam parte de um mesmo poema. Plutarco (Licurgo 6.1) emprega

\footnotetext{
${ }^{196}$ Gigante (1967) menciona um escólio à Arte Gramática de Dionísio Trácio que por muito tempo intrigou os estudiosos de Tirteu. Fortemente influenciado pela Poética de Aristóteles, o escoliasta parece classificar Tirteu no mesmo grupo de escritores que se utilizam de verso, mas que não podem ser considerados poetas. Gigante (1961, p.237) deu a última palavra neste debate, ao emendar a menção a Tuptaıv por ПuӨıv: Os poetas são organizados em quatro [tipos]: pelo metro, pela fábula, pela história, e pelo modo de execução; todo o poema que não compartilha destes quatro, não é um poema. Carecem disso Empédocles e o Pítio [Tirteu], e também não são chamados poetas os que falam sobre astrologia, porque eles não se utilizam das características dos poetas, embora também se sirvam do metro." (Schol. In Dionys.Thrac.Art.Gramm.p.168, 8 Hilgard = Gentilli Test.37). Desse modo, o autor sugere assim que o escoliasta se referia à poesia oracular de Tirteu. Entretanto, podemos ainda nos perguntar: por que não podemos considerar estes versos como poesia, assim como outros versos oraculares que abundam na poesia grega arcaica e clássica?
} 
Havteía como um sinônimo para a Grande Retra que Licurgo trouxe de Delfos ${ }^{197}$. Enquanto o primeiro dístico expressa a origem divina dos decretos proferidos, o verso 3 se encarrega de ressaltar a proximidade destes mesmos reis com os Deuses. Os reis são chamados $\theta \varepsilon$ cotı́ńtous e a raridade deste epíteto - encontrado em textos poéticos pela primeira vez em Tirteu e apenas mais tarde no Agamênon de Ésquilo (v.1337) - levou Prato a considerá-lo um neologismo tirtaico, ou um adjetivo especificamente dórico. A ideia, porém, não é inédita, mas um lugar comum encontrado com frequência em Homero ${ }^{198}$.

O verso é predominantemente espondaico, raro para os padrões de Tirteu (Ver Adkins, 1985, p. 71); caso se trate de fato de um poema tirtaico, seria um traço incomum de seu estilo, porém apropriado para a métrica oracular. A ação dos reis

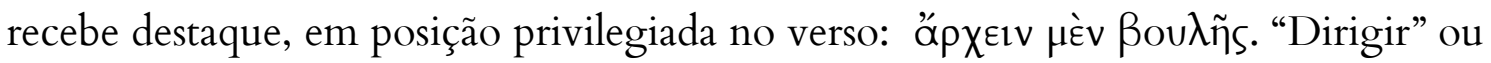
"iniciar" o conselho? A segunda opção nos parece mais adequada, tendo em vista

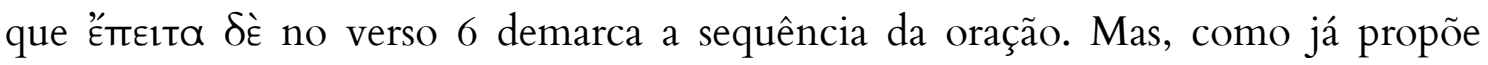
Adkins (1985, p. 71), até o verso 6, ambas as informações são possíveis. Terá o poeta manipulado retoricamente os versos originais do oráculo em vista de enfatizar a proeminência dos reis, como sugere Adkins (1985, p. 74) ? É uma possibilidade, embora se possa considerar que seja apenas Tirteu emulando o estilo oracular, ambíguo por definição.

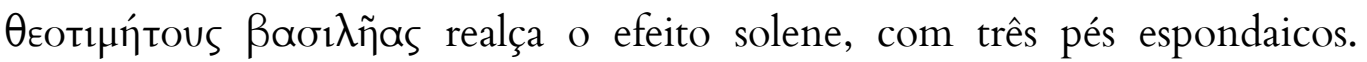
Todo este verso parece assinalar um contraste com o verso 5, datílico, que refere os

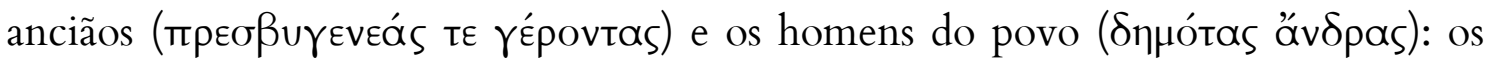
reis estão sempre em primeiro plano, e até mesmo o ritmo do poema encarrega-se de mostrar isso.

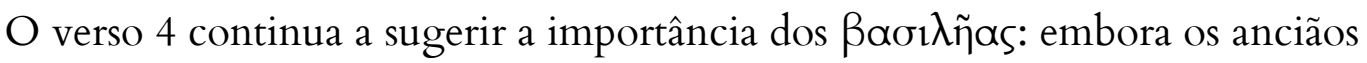

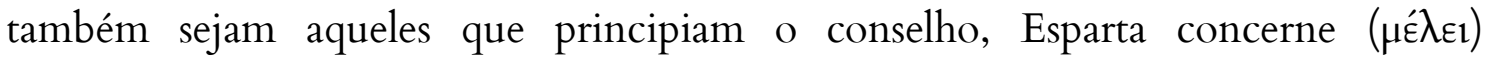

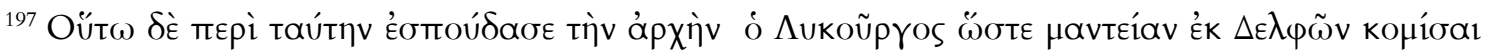

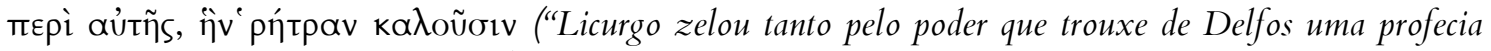
sobre isso, a qual denominam Retra."). Ver acima.

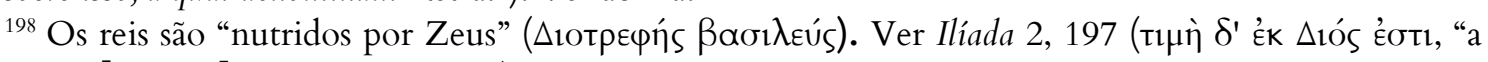
honra [dos reis] provém de Zeus")
} 
especialmente aos reis. $\mathrm{O}$ verso, que à primeira vista parece não acrescentar nada ao sentido geral do poema (West, 1974, p.184) revela-se eficaz por adiar ainda mais

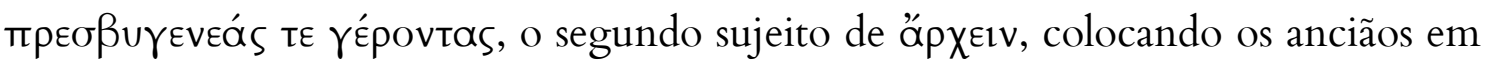
segundo plano. Segundo Adkins (1985, p. 72), a "mente de um ouvinte não está preparada para um segundo sujeito”. Assim, embora ambos sejam sujeitos de áp $\chi £ £ v$, é notória a ênfase que Tirteu dá aos reis, atribuindo-lhes um adjetivo mais

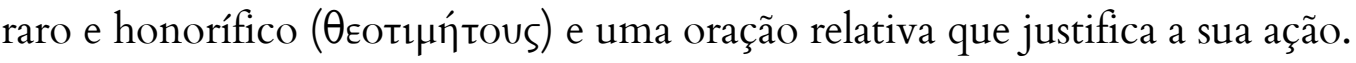

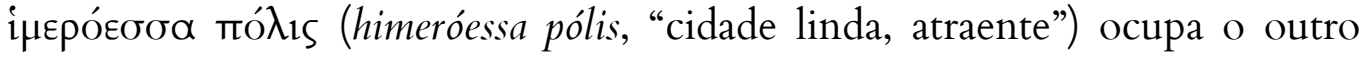
hemistíquio do pentâmetro e desde cedo chamou a atenção dos helenistas. Tsopanakis (1954, apud Prato, 1968, p. 70) julgou estranho o uso deste epíteto para

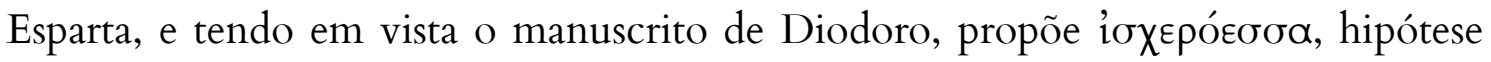
logo descartada por Adrados (1954, p. 272) que considerou improvável a formação de um adjetivo como esse. Segundo o estudioso, o sufixo - $\varepsilon v \tau$ raramente se une a adjetivos como íoxepos. Defradas (1962, p. 4) e Prato (1968, p. 70) associaram-na ao esplendor da atividade musical e poética da Esparta arcaica. Em Homero, o termo está sempre associado a atividades ou objetos que suscitem desejo e amabilidade, ${ }^{199}$ assim como na poesia elegíaca ${ }^{200}$.

$\mathrm{Na}$ poesia grega arcaica, nota-se que a amabilidade é um adjetivo frequentemente atribuído a cidades ou localidades, embora os epítetos mais

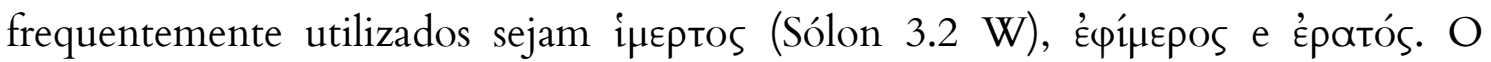
exemplo mais notável talvez seja o fragmento $22 \mathrm{~W}$ de Arquíloco $^{201}$ :

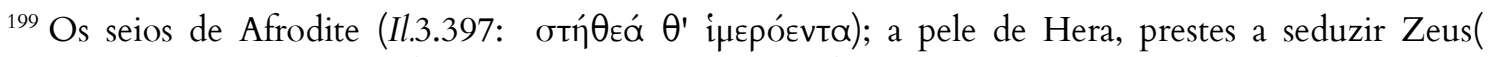

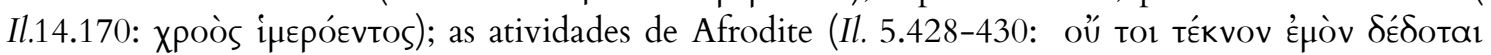

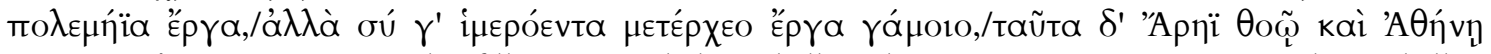

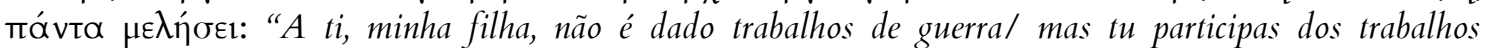
atraentes do casamento/ Que todas aquelas coisas interessem a Ares célere e Atena") a dança $(I l .18,603)$ e o canto (Od.1.421).

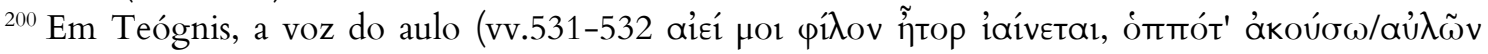

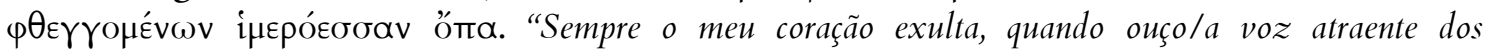

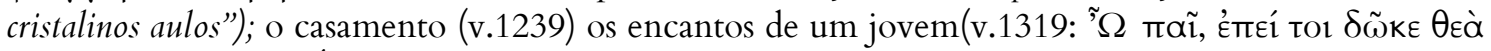

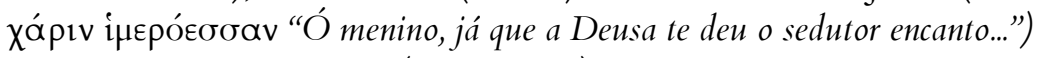

${ }^{201}$ Ver De Martino \& Vox (1996, p.545)
} 


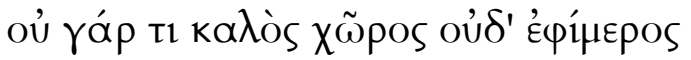

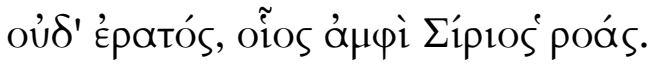

Pois não há terra bela, nem desejável,

Nem amável, como às margens das correntes de Síris ${ }^{202}$

Alguns estudiosos entendem que estes epítetos geralmente são atribuídos a cidades ou regiões a serem colonizadas, em um topos que geralmente confere a uma região epítetos próprios do discurso erótico. ${ }^{203}$ Talvez pensando neste topos que Tirteu emprega este epíteto, uma vez que a Eunomia era também um poema que narrava a fundação e a retomada de Esparta pelos Heraclidas.

O verso 5 introduz os anciãos que compartilham a legislação de Esparta com os reis. Eles são os sujeitos de ópxєıv. A maioria dos estudiosos, julgando que este poema

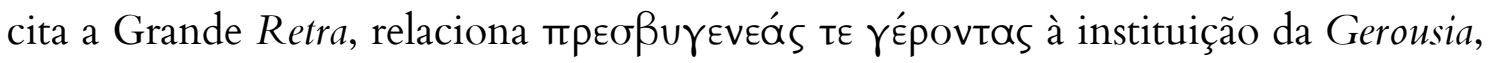
que viria a se tornar o órgão político mais importante da Esparta clássica. A possível menção a Teopompo no verso 1 reforça a tese, uma vez que este rei teria sido o responsável pela fundação do eforato. Van Wees (1999, p. 24) e Nafissi (2009, p.128), negando a conexão com o contexto da Retra, anotam que a estrutura política delineada por Tirteu pouco difere daquela apresentada nos poemas homéricos: assim como na poesia épica, são os reis e os anciãos que dirigem as assembleias cujas decisões o povo deve acatar. Note-se que na poesia homérica o termo yépovtas pode ser empregado também para designar os chefes do exército ou guerreiros mais proeminentes que tomavam parte do conselho. ${ }^{204}$ Isso poderia ajudar a dirimir uma

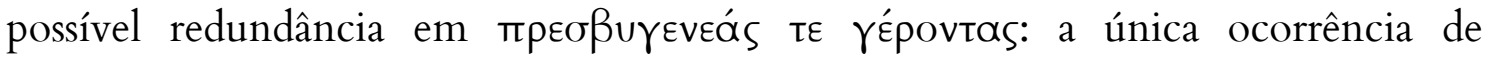

\footnotetext{
${ }^{202}$ Tradução de Paula da Cunha Corrêa (2010)

${ }^{203}$ Como afirma Chris Eckerman, na conferência "Pindar's Olympia: landscape, rhetoric and ideology" proferida em setembro de 2011 na Universidade de São Paulo.

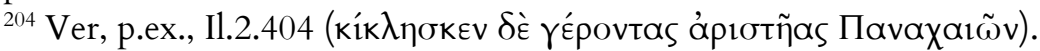


$\pi \rho \varepsilon \sigma \beta u \gamma \varepsilon v \varepsilon i \tilde{s}$ em Homero tem o sentido de "ancião" 205 e o mesmo se dá na poesia trágica clássica ${ }^{206}$.

Após a cesura, inicia-se uma nova oração com દ̌T€ııta $\delta \dot{\varepsilon}$, colocando-a

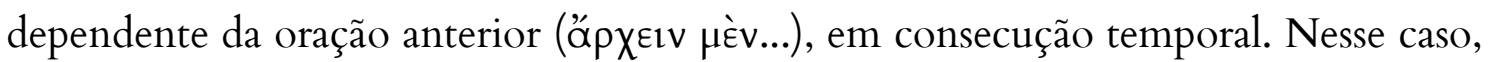
a primeira sentença cria a circunstância em que a ocorre a oração com $\delta \grave{\varepsilon}$ (Denniston, 1954, p. 370): apenas depois de iniciado o conselho pelos reis e anciãos, é a vez do povo agir. Assim, embora alguns estudiosos tenham considerado que estes dísticos eram incompatíveis com o restante do poema por conferir poder demasiado ao povo, nota-se que na própria estrutura frasal o poeta já situa o povo em uma situação de subordinação aos reis. Agora o poeta ocupa-se de descrever os deveres

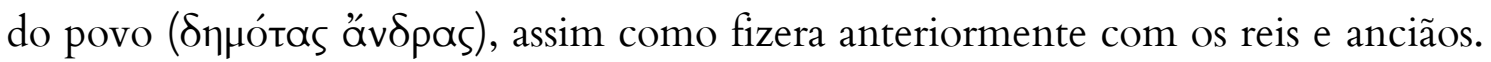
Mas, segundo Adkins (1985, p. 73), a estruturação desta nova oração é diferente: enquanto na anterior tanto os $\beta \alpha \sigma i \lambda \tilde{\eta} \alpha \varsigma$ quanto $\gamma$ Épovtas recebem adjetivos que os

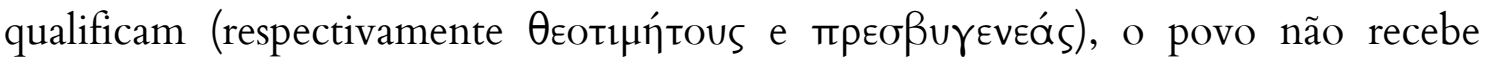
nenhum atributo que o caracterize. A sua ação ( $\mu v \theta \varepsilon \tilde{\imath} \sigma \theta \alpha i ́$, v.7), porém, é qualificada por uma oração relativa adjetiva, que é apresentada com grande destaque no verso 6: o povo deve proferir suas decisões tendo em vista às retas sentenças

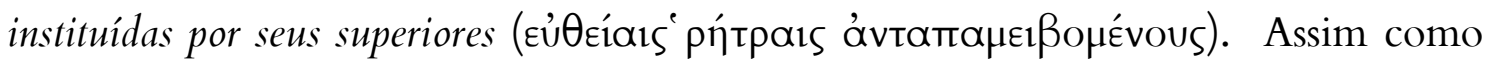

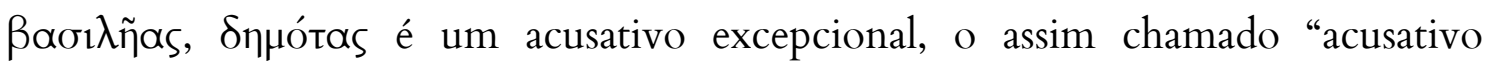
dórico". Seria apenas um traço da linguagem épica continental (Onofrio \& Vox, p. 568) ou uma intenção de Tirteu em realçar a identidade espartana de seu poema? ${ }^{207}$

O verso 6 guarda duas ambiguidades importantes: o poema abre

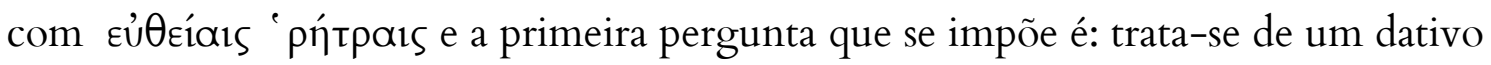

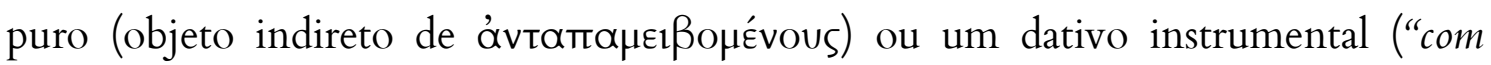

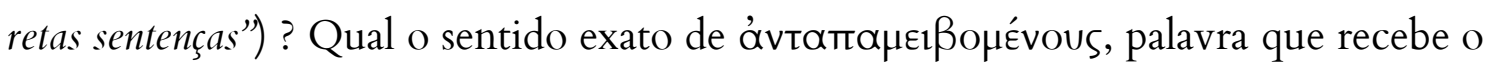

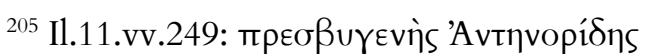

${ }^{206}$ Eurípides, Troianas, vv.593, referindo-se à Príamo.

${ }^{207}$ É digno de nota, nesse sentido, que ao citar o poema Plutarco empregue a forma dórica $\Sigma \pi \alpha ́ p t a \varsigma$ (v.4) ao passo que em outros de seus fragmentos Tirteu sempre se refere à Messênia pela forma

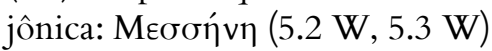


maior destaque no verso e cuja ocorrência em toda a literatura grega supérstite se dá apenas neste poema de Tirteu?

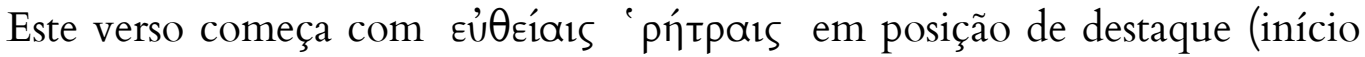
de verso) e espondeus, chamando mais a atenção da audiência do que o sujeito

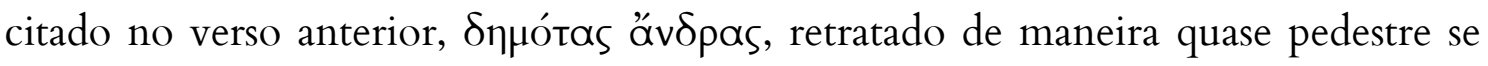
comparado ao modo grandiloquente com que o poeta referira-se aos reis e anciãos.

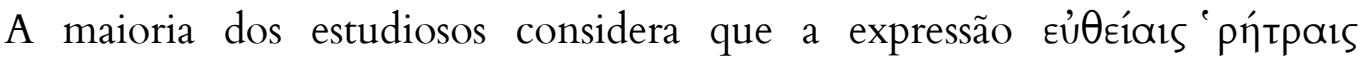

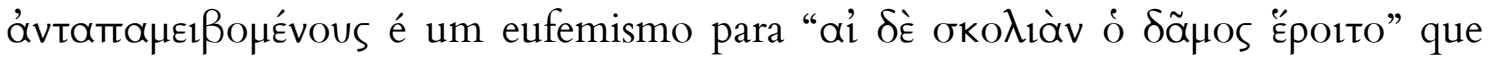
consta no texto da Grande Retra oferecido por Plutarco (Ver Prato, 1968). O sentido mais comum deste termo é encontrado, por exemplo, na poesia homérica, onde é empregado para designar um acordo verbal, como aquele empreendido entre Odisseu e Eumeu no Canto XIV, vv.390-394, da Odisseia. Odisseu disfarçado relata a Eumeu que ele próprio está vivo e regressará. Incrédulo destas palavras, o estrangeiro então propõe um pacto sob a observância dos Deuses do Céu: se estas palavras forem falsas, que ele fosse castigado; caso contrário, que Eumeu arrumasselhe roupas e transporte:

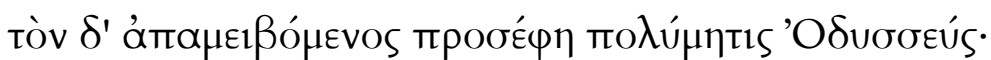

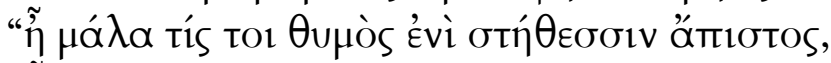

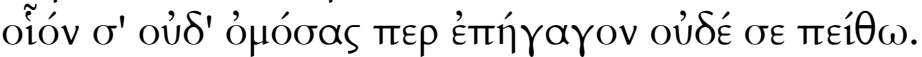

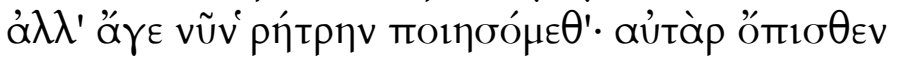

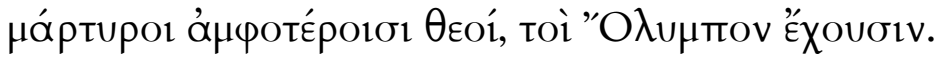

Em resposta disse-lhe Odisseu de mil astúcias: de fato [tens] um coração desconfiado aí em teu peito, tal que nem mesmo com juras influenciei-te, nem estou persuadindo-te. Então, vamos, ora façamos um trato [ [serão] nossas testemunhas os Deuses que habitam o Olimpo.

Segundo Defradas (1962, p.15), contudo, o sentido do termo entre os espartanos diferia do uso comum. Para este e outros autores, em Esparta ' $p$ í p significaria lei, e geralmente referiria-se às próprias leis estabelecidas por Licurgo. Simônides de Céos também emprega uma expressão afim, ’́ń 


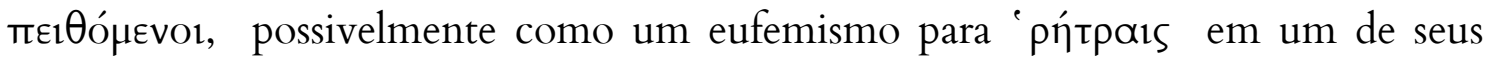
epigramas :

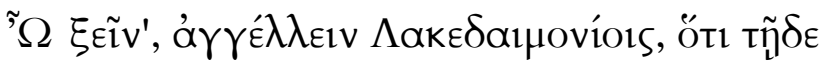

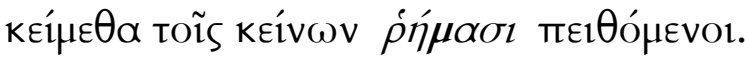

Viajante, avise aos lacedemônios que aqui

jazemos, às palavras deles obedientes;

Esta versão consta na Antologia Palatina (7.249) e Heródoto (Histórias, 7.228). Mas o orador Licurgo (Contra Leócrates, 109) conhecia outra versão para o fragmento, com

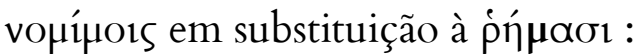

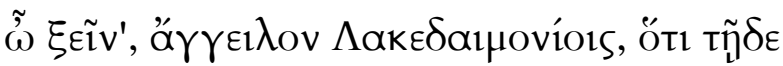

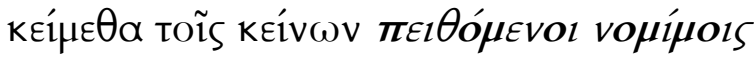

Estrangeiro, avise aos Lacedemônios que aqui

jazemos, obedientes às suas leis.

Esta também era a versão conhecida por Diodoro da Sicília (11.33). Do mesmo modo, Cícero, na tradução deste fragmento notório (Tusculanas, I 101):

"Dic, hospes, Spartae nos te hic vidisse iacentes

dum sanctis patriae legibus obsequimur”

Diz em Esparta, viajante, que nos viu aqui jacentes, às sacras leis da pátria obedientes.

Em contrapartida, o adjetivo ev่Acíaıs nunca é empregado em Homero para qualificar 'ṕ́tpas, mas se levarmos em conta o sentido dado em Esparta para esta 


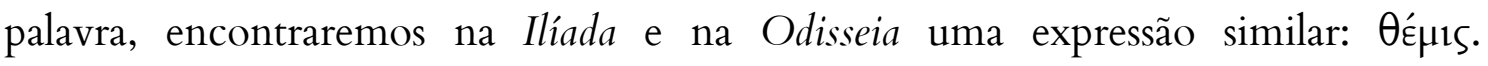
Segundo Lloyd-Jones (1983, p.06), na Ilíada a palavra ocorre sempre com um sentido concreto, de "legislação" ou "sentença" e que o sentido de "costume" ou "direito" é menos frequente, visto na poesia épica apenas na Odisseia. Comó pítpas,

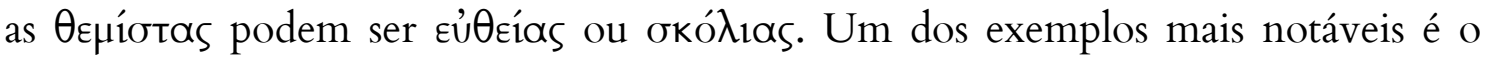
proêmio de Trabalhos e Dias, que coloca Zeus como o responsável por endireitar

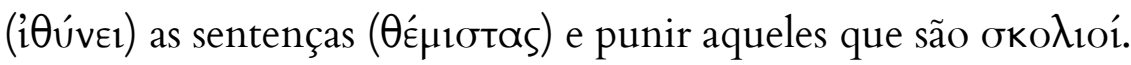

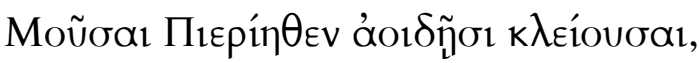

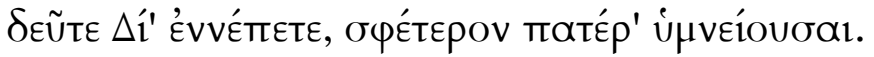

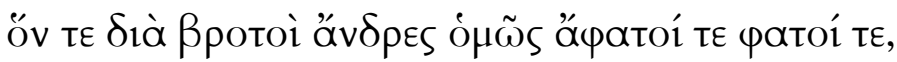

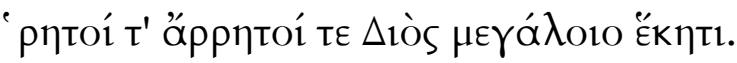

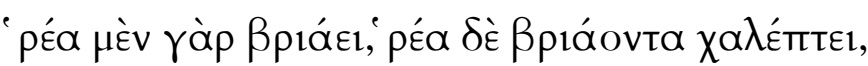

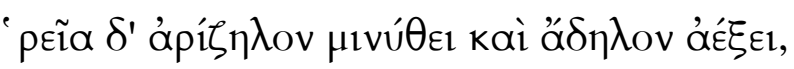

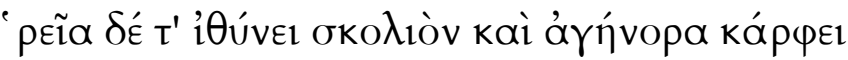

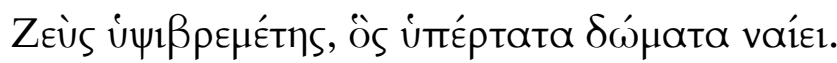

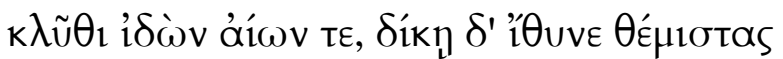

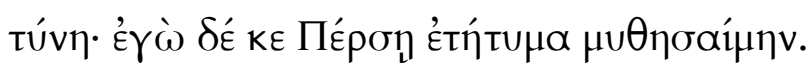

Musas da Piéria, por canções glorificando, vinde, falai de Zeus o vosso pai hineando.

Por ele, os mortais são notos ou ignotos,

famosos ou infames, por querer de Zeus grande.

Fácil ele faz forte, fácil o forte ele enfraquece,

facilmente o amplo amaina e o inviso acresce;

facilmente aplaina o torto, o altivo esvaece

Zeus que no alto freme e habita a sublime sede.

atende-me, porque vês e ouves; apruma as sentenças,

tu! E eu, a Perses verdades gostaria de enunciar. 


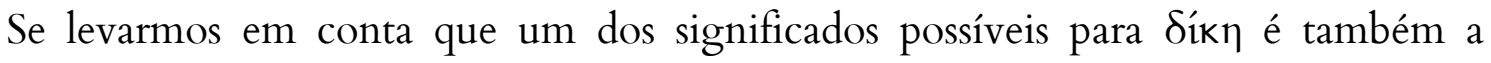
preservação da ordem pré-estabelecida e que o suposto título atribuído para estes fragmentos de Tirteu seria Eunomia - cujo sentido, conforme atestava Aristóteles,

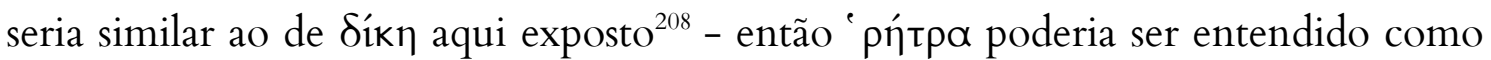

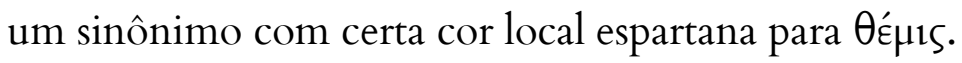

Plutarco, no Licurgo - uma das fontes para o fragmento - parece entender

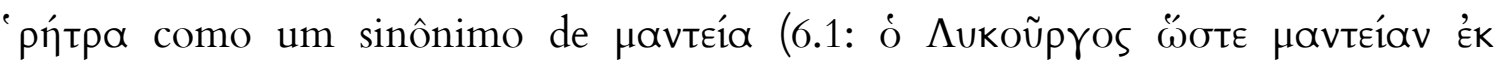

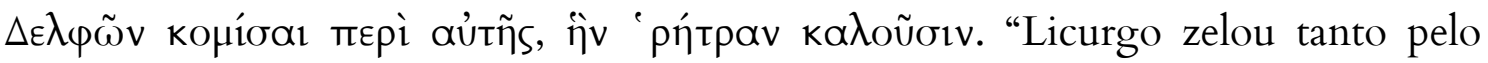
poder que trouxe de Delfos uma profecia sobre isso, a qual denominam Retra.", ver supra.). Mas em outras passagens de sua obra, ele utiliza a palavra com o sentido de uma proposta que é colocada para votação para uma assembleia, um significado que mais tarde teria se tornado o mais comum em Esparta. ${ }^{209}$ Talvez essa definição tardia de 'pп́tpa possa ajudar a dissipar a ambiguidade observada acima e oferecer um

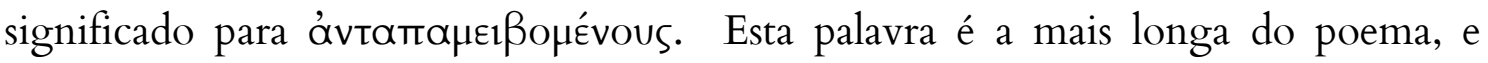
ocupa todo o segundo hemistíquio do pentâmetro - conferindo assim certo peso à ação do povo. ${ }^{210}$ O dicionário Liddell-Scott dá a definição de "obedecer em resposta", enquanto o Bailly oferece o sentido de "responder de modo equivalente". Este sentido dá conta da preposição óvtı- presente na composição da palavra, e se levarmos em

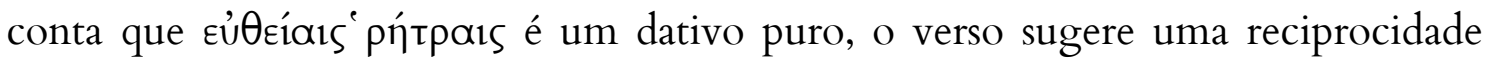
entre a atitude do povo e as propostas dos reis: as sentenças ("pítpaıs) proferidas

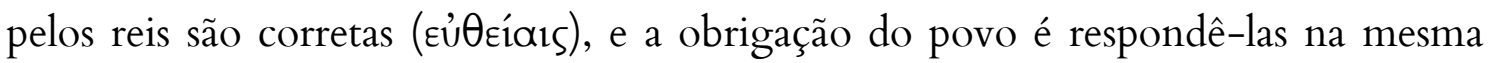

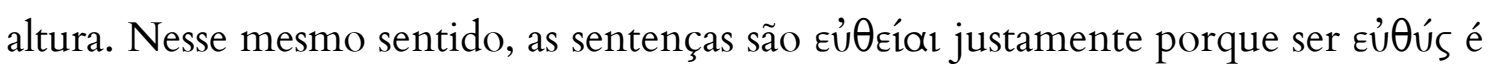
uma qualidade dos indivíduos que as proferem - ver como exemplo a Teognideia, que apresenta esta como uma das características do homem que recebe um oráculo (vv.805-810) :

\footnotetext{
${ }^{208}$ Ver “A Eunomia de Tirteu”, p. 156-158.

${ }^{209}$ Plutarco, Agis 5.3; 8.2; 9.1.

${ }^{210}$ Este recurso enfático aparece em outros poetas gregos arcaicos: ver á $\mu \varphi \imath \pi \varepsilon p \imath k т i ́ o v a s ~ e m ~ C a l i n o$ $1.2 \mathrm{~W}$; Tirteu também utiliza-se disso em $10.4 \mathrm{~W}$, onde o superlativo ávinpótatov ocupa quase toda a extensão do segundo hemiepes.
} 


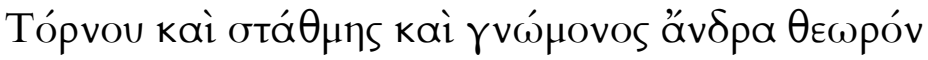

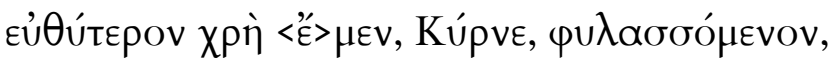

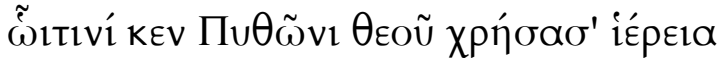

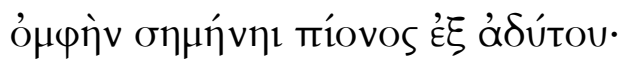

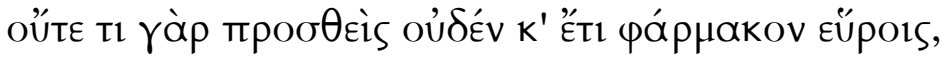

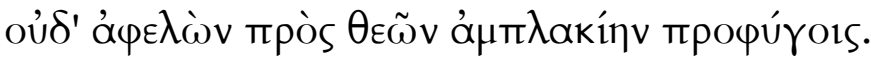

Mais reto do que torno ou régua um teoro

precavido deve ser em discernimento, Cirno,

Aquele a quem a sacerdotisa do Deus em Pito,

De seu pingue santuário, assignar a voz divina:

Pois jamais encontrarias remédio, se lhe acrescentasses

Ou retirasses algo, nem escaparias da punição que vem dos Deuses. ${ }^{211}$ (810)

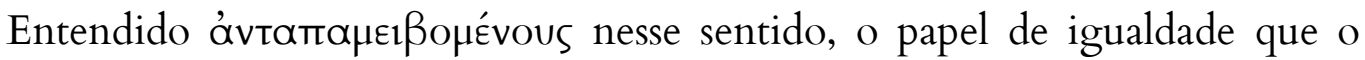
poema parece promover fica ainda mais reduzido: cabe ao povo apenas ratificar as

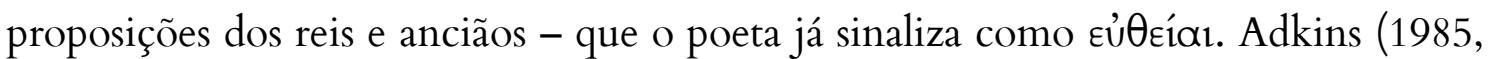
p.71) vê Tirteu novamente manipulando versos oraculares em vista de beneficiar a autoridade dos reis - como faz com áp $\chi^{\varepsilon 1 v}$ no verso 3; Uma hipótese interessante,

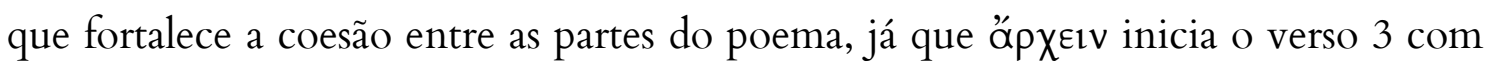

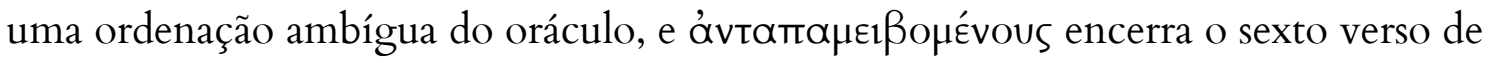
maneira também ambígua.

O dístico seguinte desenvolve o verso anterior e é construído a partir de uma polaridade bem cara ao estilo elegíaco ${ }^{212}$ : enquanto o hexâmetro (v.7) expressa em

\footnotetext{
${ }^{211}$ Olhando sob essa perspectiva, essa elegia de Teógnis poderia colocar em questão a própria conduta moral dos reis espartanos, pois, se Tirteu de fato refere-se à Grande Retra, verificamos que Teopompo e Polidoro fizeram um acréscimo ao oráculo, e, portanto, não seriam homens "retos". De modo algum nos parece que Tirteu queira sugerir esta via de pensamento em seu poema, e isso talvez possa ser mais um indício de que a Eunomia não tivesse nenhuma relação com a Retra Licurgeana. Ver Wade-Gery (1944, p.2, n.1)

${ }^{212}$ Segundo Fowler (1987, p. 76-77) a antítese é uma das maneiras favoritas para um poeta arcaico de organizar o seu material, e poderia até mesmo constituir um traço genérico da elegia. Ver o fragmento 10.1-4 W de Tirteu.
} 
termos laudatórios a ação do povo, o pentâmetro (v.8) ressalta o que não deve ser feito. Embora alguns autores considerem estes quatro versos finais, que constam apenas na versão de Diodoro, como espúrios, não há nenhum argumento concreto para isso.

Prato (1968, p.71) observa que o termo tà ka入à é uma expressão tipicamente dórica, cujo sentido seria "honraria". Seu argumento baseia-se em uma passagem da República dos Lacedemônios de Xenofonte. A passagem concerne à educação dos

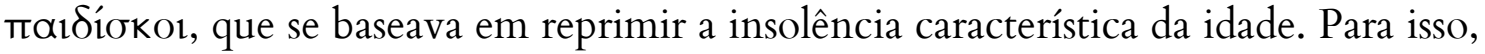
Licurgo teria instituído um regime de ocupações e deveres constantes, que se não cumpridos, excluiriam o jovem de todas as honras, tò ka $\lambda \grave{\alpha}$ :

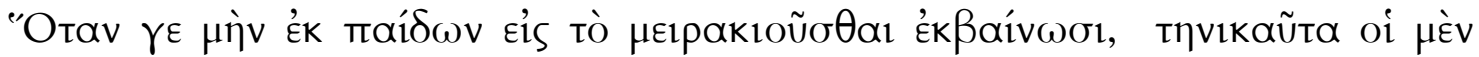

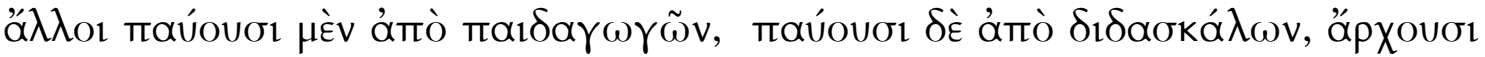

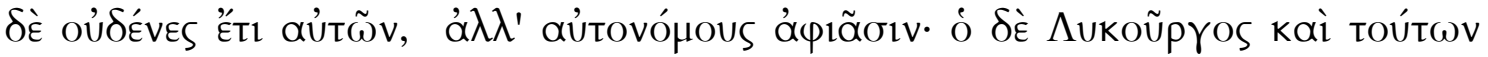

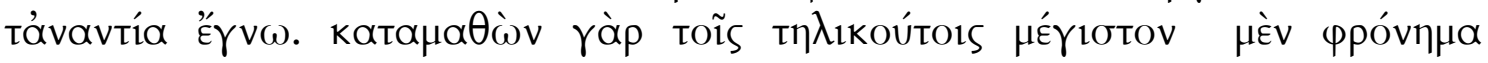

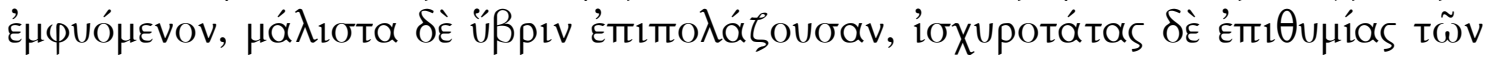

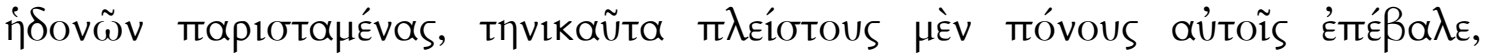

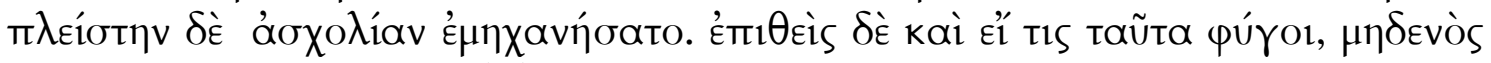

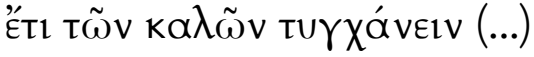

"Quando passam da infância à adolescência, então os outros os liberam dos preceptores, e liberam-nos dos professores, e nenhum deles os guia mais, mas os deixam independentes. Licurgo, porém, também determinou o contrário disso. Compreendendo que nos jovens dessa idade a presunção enraíza-se com muita força, que a insolência vem à tona, e que se interpõem os mais fortes desejos por prazer, [Licurgo] então lhes impôs inúmeros trabalhos penosos e planejou a maior parte de suas ocupações, acrescentando que nunca obteriam honrarias, se fugissem destes deveres (...)."

No contexto desta obra de Xenofonte ainda vemos que estas "coisas belas" estão relacionadas à atribuição de cargos públicos: Em certas passagens (2.9; 13; 4.4), por exemplo, entre as “coisas belas" está ser um inmeús (hyppeús, “cavaleiro"). Mas o que se observa é que antes de significar estritamente "honrarias", tà kaגà só se dá quando ocorre o cumprimento das leis estabelecidas: um sentido que corresponde exatamente ao princípio de Eunomia que Tirteu teria preconizado em seu poema. 


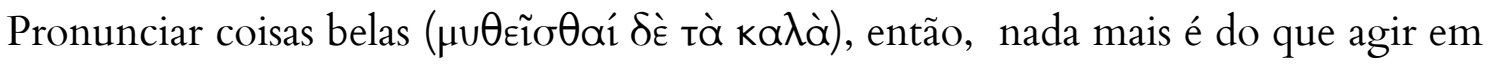
consonância com as decisões lançadas pelos reis e pelos anciãos, que são eư

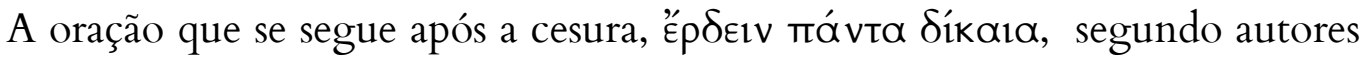
como Treu (1941, p. 37), remeteria a um imaginário "decididamente ático"; West (1970, p.151) considera que a ideia de algo não espartano nesta frase "não pode ser levada a sério"; de fato, Hammond (1950, p.48, n.34) já observara a dicção perfeitamente homérica desta sentença, e o uso de um mesmo vocabulário em outras passagens de Tirteu ${ }^{213}$. O próprio sentido de Síkaı está em conformidade com o restante do poema, porquanto seu sentido seria o de ação praticada de acordo com um regulamento ou costume; assim, este verso não contradiz o restante do poema,

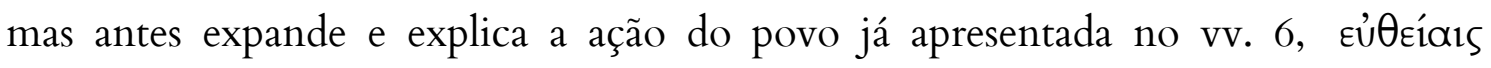
'ри́траıs åvтатанє1ßоне́vous.

O verso 8 é o mais problemático do ponto de vista textual: o manuscrito de

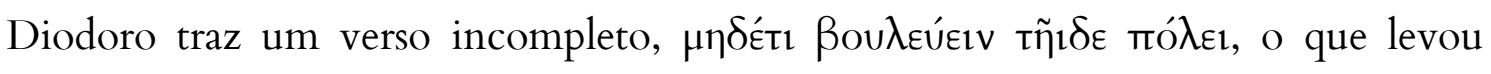
alguns helenistas (Wilamowitz 1884, p.286, Meyer 1892, p.227, apud Van Wees, p.30, n.31) a considerarem que não se tratava de um poema e o texto fora composto em prosa $^{214}$. Dindorf (apud Bach, 1831, p.86) foi o primeiro a propor uma emenda para este verso, sugerindo:

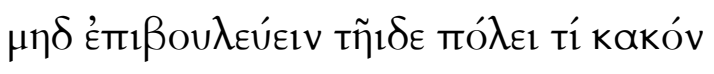

(e nem tramem contra à cidade um mal)

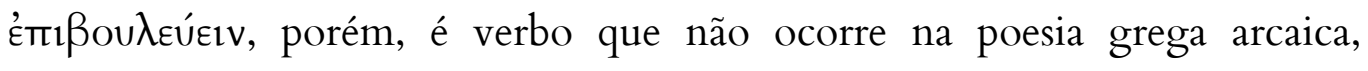
tornando-se comum apenas a partir do século V a.C. (Van Wees, 1999, p.31, n.38, West, 1970, p.151), o que levou alguns autores (Prato, 1968,p.152) a comprovarem que estas linhas seriam tardias, e fez outros (Musti, 1996 apud. Van Wees, 1999,

\footnotetext{
${ }^{213}$ Tirteu fr. 11.27 W

${ }^{214} \mathrm{O}$ que estaria de acordo com a própria configuração do manuscrito de Diodoro, que, diferente de Plutarco, cita estes versos em scripta continua.
} 
p.31) sugerirem um sentido propriamente arcaico para o verbo em questão ${ }^{215}$. A sugestão mais aceita hoje foi proposta por West (1974) e já remonta a Bach (1831) e Bergk (1882):

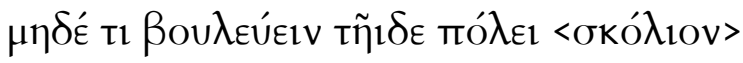

(E não deem à cidade conselho <oblíquo>)

A adoção de okódıov para completar a extensão do verso baseia-se na adição à Retra feito por Teopompo e Polidoro e mencionada por Plutarco ${ }^{216}$. Van Wees (1999, p.10) conjectura que se Tirteu tivesse utilizado esta palavra, Plutarco certamente a teria citado, uma vez que a intenção deste ao citar o fragmento era ratificar a hipótese de que os reis persuadiram o povo a crer que o acréscimo desde sempre pertencera à Retra. Este argumento, embora possível, é indemonstrável. Eliminá-lo apenas porque poderia constituir uma referência à Retra que escapou a Plutarco não é um argumento válido se considerarmos outros poemas gregos

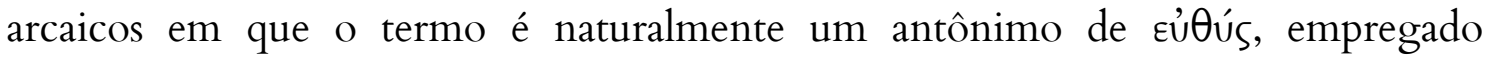
frequentemente em admoestações sobre a justiça:

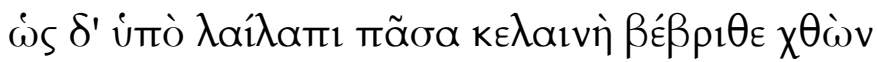

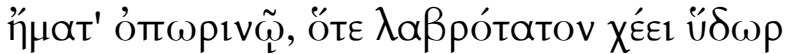

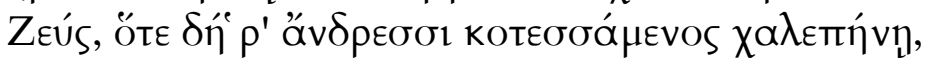

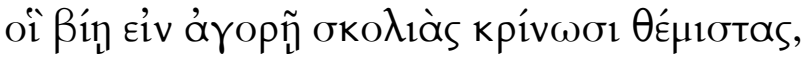

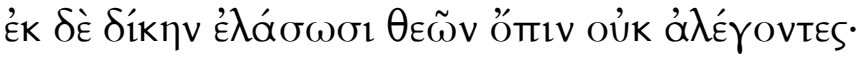

(Ilíada, 16, 384-388) $)^{217}$

Como a tenebrosa tormenta preenche toda a terra

em dia outonal, quando a água verte violentíssima,

como Zeus, quando guarda rancor e desgosto com homens

que à força na assembleia preferem as oblíquas sentenças

e rebaixam à justiça, desatentos da punição divina...

\footnotetext{
215 "aconselhar em acréscimo"

${ }^{216}$ Ver p.169.

${ }^{217}$ Segundo West (2011, p.320) a imagem é atípica da Ilíada e de extração hesiódica.
} 


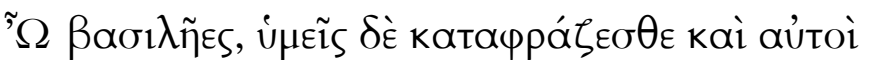

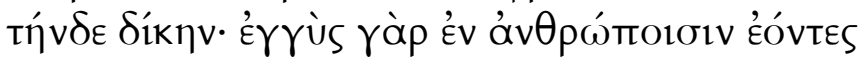

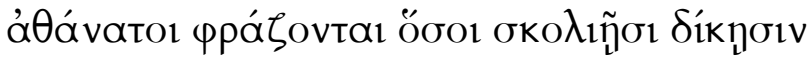

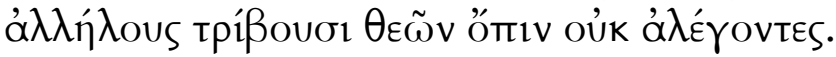

(Hesíodo, Trabalhos e Dias, vv. 251-253)

"E também vós, ó reis, considerai vós mesmos esta Justiça, pois muito próximos estão os imortais e entre os homens observam quanto lesam uns aos outros Com tortas sentenças, negligenciando o olhar divino" ${ }^{218}$

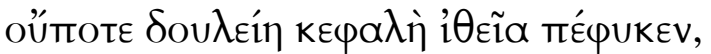

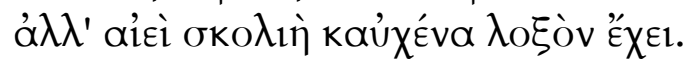

(Teognideia, vv.535-536)

"Nunca escrava cerviz nasce reta, mas sempre torta, e mantém o pescoço inclinado"

Nesse sentido, estivesse okó $\lambda_{10 v}$ relacionado ou não à Retra, Tirteu poderia perfeitamente empregar o termo, uma vez que a palavra é frequentemente utilizada em discursos similares que tratem da justiça.

Recentemente, Van Wees (1999, p.11-12) sugeriu uma alternativa interessante: para ele, o $\tau \tilde{\imath} 1 \delta \varepsilon$ тó $\lambda_{\varepsilon 1}$ do verso 8 deve ser entendido em conexão com

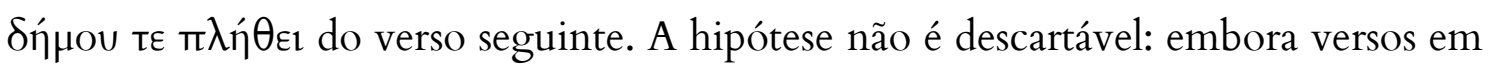
enjambement sejam raros na poesia grega arcaica (West, 1974, p.116) eles existem e são inclusive utilizados por Tirteu ${ }^{219}$. Além disso, Tirteu emprega uma estrutura similar a essa no fragmento $12 \mathrm{~W}$ (v.15).

No entanto, as sugestões de Van Wees para o que deveria anteceder $\tau \tilde{\eta} 1 \delta \varepsilon$ тó $\lambda_{\varepsilon 1}$ não parecem convincentes, tanto por gerar um torneio sintático incomum em Tirteu e na poesia elegíaca arcaica, como por parecer paleograficamente difícil tendo em vista as leituras do manuscrito: o autor sugere $\dddot{\omega} \sigma \theta$ ” ă $^{\circ}$ ( "não deem mais conselho, para que assim, ao mesmo tempo, a esta cidadel e às massas, sigam poder e vitória") ou ó $\lambda \lambda \alpha ́$ ákì ("não deem mais conselho, e então sempre à esta cidade...")

\footnotetext{
${ }^{218}$ Tradução de Mary de Camargo Neves Lafer.

${ }^{219}$ Fr.5.4-5 W
} 
Um verso pesado (com quatro espondeus) conclui o registro do oráculo apolíneo, garantindo aos que seguirem estas palavras "vitória e poder" (víknv kaì

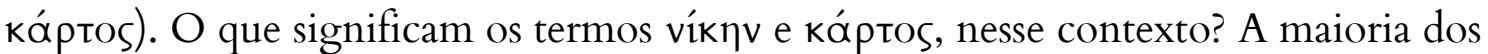
estudiosos a relaciona com uma passagem da Retra, também corrompida: " $\delta \alpha ́ \alpha \omega$

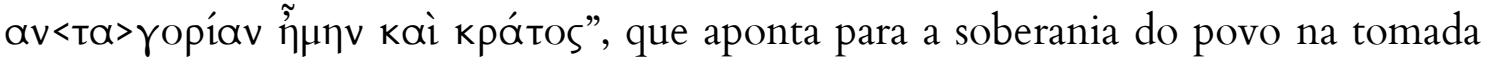
de decisões. No entanto, como já observa Van Wees (1999, p.11) o sentido exato da combinação "vitória e poder" está antes associado ao sucesso militar do que à soberania política. Assim é na Teogonia de Hesíodo, quando, durante o confronto com os Titãs, Zeus afirma (vv. 647-648):

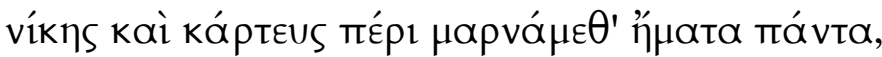

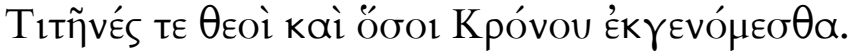

"todo dia combatemos pela vitória e poder os Deuses Titãs e quantos nascemos de Crono" ${ }^{220}$

Em seu último verso o poema cita novamente o nome do Deus responsável pelo oráculo (Фоĩßos), que já abrira o poema, constituindo assim um exemplo clássico de composição em anel. ${ }^{221}$ Para Faraone (2008, p.31) este fechamento em anel é um sinal da composição da elegia grega arcaica: se o poeta estivesse de fato citando hexâmetro oraculares, seria lógico se ele tentasse emoldurá-los em uma única estrofe elegíaca.

\section{Ocasião de Performance e estrutura do Fragmento $4 \mathrm{~W}$ de Tirteu}

Tradicionalmente, por sua temática cívica, costuma-se classificar estes versos como parte da Eunomia. Versos do fragmento $2 \mathrm{~W}$ com possíveis menções a oráculos, auxiliam a introdução deste fragmento na Eunomia, e consequentemente, em um espaço de performance público que é típico do festival.

\footnotetext{
${ }^{220}$ Tradução de Jaa Torrano.

${ }^{221}$ Ver Jaeger 1960 (p.106), Adkins, 1985 (p. 69), Fowler, 1987 (p.81) e Faraone, 2008 (p.31).
} 
Recentemente, depois do estudo de Rösler (1990, pp.230-237), essa aproximação tornou-se mais frágil. Segundo o autor, o simpósio também se revelava como um espaço propício à rememoração de ditos célebres, seja como demonstração de um sinal de erudição, seja como um meio para propiciar um diálogo que ratifica ou contesta alguma máxima do passado. Um exemplo é o fragmento $21 \mathrm{~W}$ atribuído a Simônides, no qual um verso da Ilíada (Il. 6. 146) serve de preâmbulo para a reflexão tecida pelo poeta:

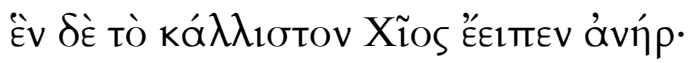

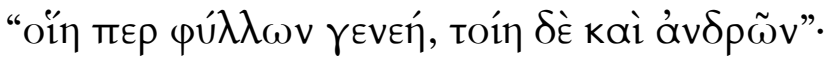

Uma coisa, a mais bela, disse o homem de Quios:

"Tal qual a geração das folhas, assim a dos homens."

Nesse sentido, se os editores do fragmento $4 \mathrm{~W}$ de Tirteu estiverem corretos na proposta de que Tirteu teria sido responsável apenas pela composição do primeiro dístico e dos pentâmetros (vv. 1-2, 4, 6, 8 e 10) e os versos 3, 5, 7 e 9 pertenceriam ao próprio oráculo de Delfos (Ver West, 1974, p.184) não seria lícito supor que Tirteu estivesse fazendo o mesmo? Embora sejam escassos os relatos, a prática não parecia ser estranha aos antigos: Teógnis (vv.425-428) menciona hexâmetros que a Antiguidade atribuía a Homero ${ }^{222}$, ou ao menos à tradição épica, acrescendo-lhes pentâmetros:

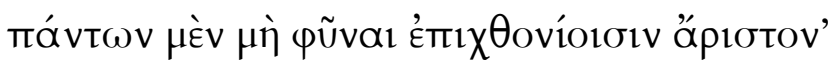

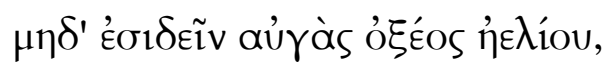

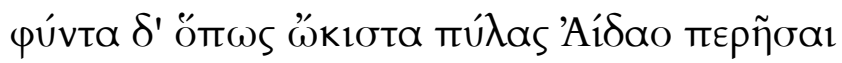

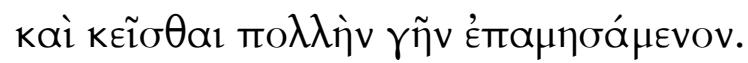

De tudo, não nascer é o melhor para os sobre a terra

${ }^{222}$ Certame de Homero e Hesiodo, 7-8. 
e não contemplar os raios do aguçado sol

mas, nascido, cruzar o mais rápido os portais do Hades

e jazer, enterrado por muita terra.

Um poeta obscuro de nome Pigres - mencionado na $S u d a^{223}$ como autor do Margites e da Batracomiomaquia - teria sido conhecido também por ter introduzido um pentâmetro após cada hexâmetro da Ilíada:

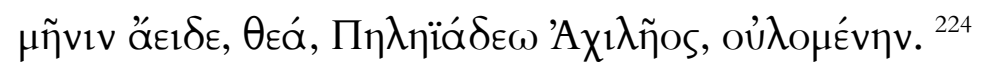

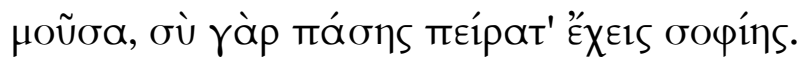

A cólera canta, Musa, de Aquiles Pelida, a destrutiva.

Pois tu, Musa, tens os limites de todo o saber.

Nesse sentido, é possível que Tirteu também tenha introduzido pentâmetros a um oráculo anterior, talvez porque a passagem já estivesse entretecida a uma narrativa maior em dísticos elegíacos, mas também porque seria interessante ao poeta engendrar um jogo expressivo que favorecesse os aristocratas que lideravam a pólis. Afinal, a atribuição de hexâmetros ao Deus de Delfos é o ápice da estratégia retórica da Eunomia: a partir deles, o poeta pode admoestar e rememorar valores comuns ao seu público eminentemente aristocrático, revestindo-os com a sanção divina de Apolo e com elementos comuns ao passado e à tradição espartana.

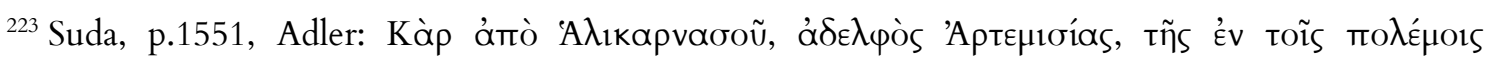

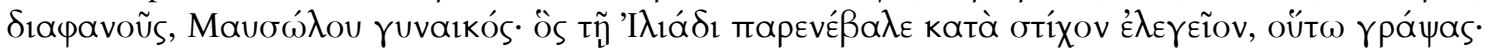

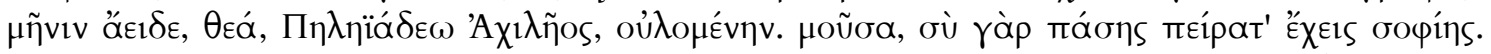

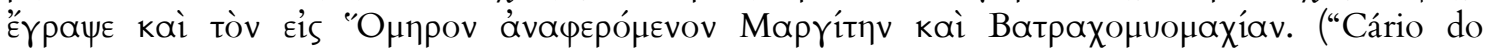
Halicarnasso, irmão de Artemísia, a que foi ilustre nas guerras, esposa de Maúsolo. Ele acrescentou um verso elegíaco a cada verso na Íliada. Escreveu assim: "A cólera canta, Musa, de Aquiles Pelida, a destrutiva/Pois, Musa, tu tens os limites de todo o saber". Escreveu também o Margites atribuído à Homero e a Batracomiomaquia.")

${ }^{224}$ Note-se, contudo, que a citação do verso da Ilíada não é precisa: o poeta traz o adjetivo oủ $\lambda$ opév $\eta v$, originalmente no verso 2 , para o primeiro verso, o que aparentemente arruína o seu esquema e também o efeito poético da passagem na Ilíada.
} 
A transição de um canto como este para um simpósio, se é que de fato tivera pertencido originalmente a um contexto público, seria natural, uma vez que tanto a reinterpretação de passagens célebres como a reafirmação de laços aristocráticos por meio da recriação ou rememoração de um passado comum eram prerrogativas da poesia composta para este cenário. Ao mesmo tempo, a composição anelar favoreceria este processo, uma vez que isolaria a passagem em uma unidade breve e autocontida.

\section{O fragmento $5 \mathrm{~W}$}

Três fontes distintas compõem este fragmento. O primeiro dístico encontrase na Descrição da Grécia (4.6.5). Embora muito distante cronologicamente, Pausânias produz a fonte mais extensa sobre as duas Guerras da Messênia. Seu relato baseia-se em outros dois, também tardios, datados do período helenístico: o do prosador Míron de Priene e o do poeta épico Riano de Creta.

As elegias de Tirteu, a fonte mais antiga sobre esta guerra, são evocadas apenas em três passagens, o que poderia levar a pensar que o poeta não teria narrado integralmente os dois conflitos entre Messênia e Esparta, ou ao menos que Pausânias não tinha acesso a todo o material do poeta.

Nos três momentos, Tirteu é relembrado por ocasião da primeira guerra: dois fragmentos tratam das consequências da guerra para os messênios (fr. 6 e 7 W), e o fragmento em questão (5.1-2 W) cita o elegista arcaico como autoridade para determinar a participação do rei Teopompo durante toda a Primeira Guerra da Messênia e assim contestar o registro de Míron, que teria informado erroneamente em sua obra que Teopompo havia sido assassinado antes do término da Primeira Guerra pelo herói messênio Aristômenes:

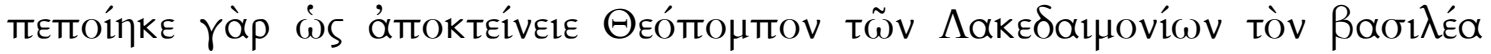

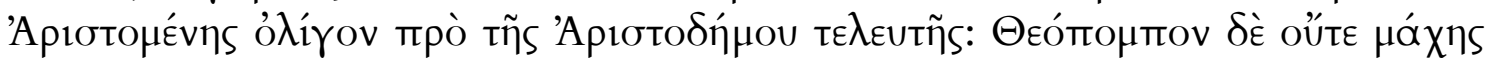

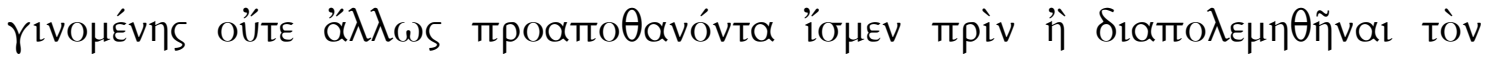




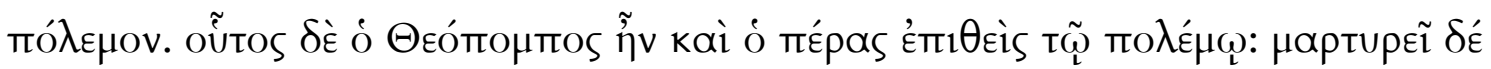

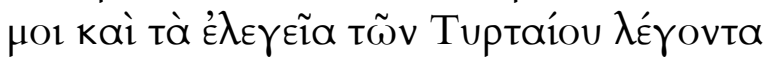

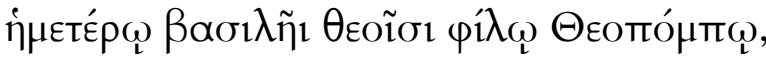

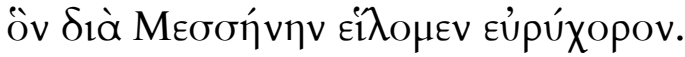

Pois ele fez com que Aristômenes assassinasse Teopompo, o rei dos lacedemônios, pouco antes da morte de Aristodemo; Mas sabemos que Teopompo não foi assassinado, nem em combate e nem de outro modo, antes da guerra ser concluída. Este Teopompo foi, na verdade, quem pôs fim à guerra; meu testemunho é a elegia de Tirteu, que diz:

Ao nosso rei Teopompo, dileto dos Deuses,

graças ao qual conquistamos vasta Messênia.

O verso 3 é citado pelo escoliasta às Leis de Platão, visando esclarecer as origens do poeta marcial. Lá, ele menciona que o verso obteve destaque (tò фєрópєvov...Е̌nos, tó pherómenon épos, "verso notório") e que foi citado como uma maneira de insuflar os ânimos espartanos para o conflito contra os messênios:

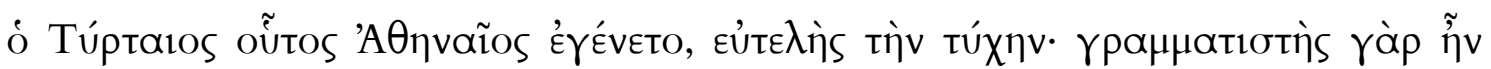

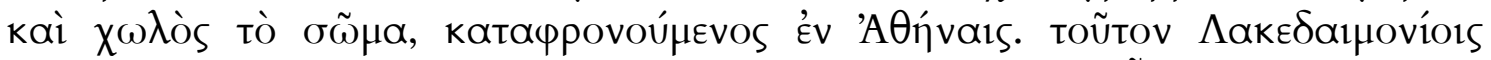

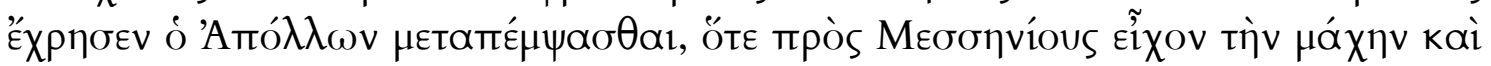

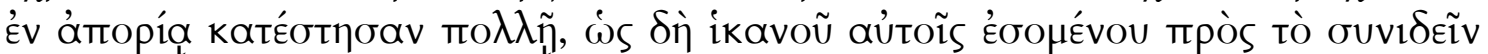

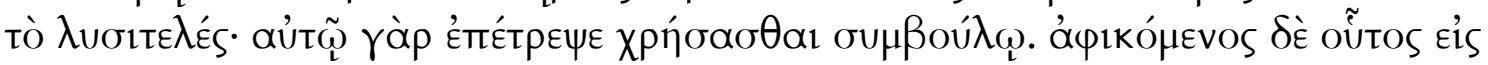

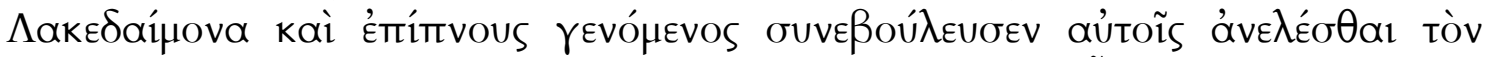

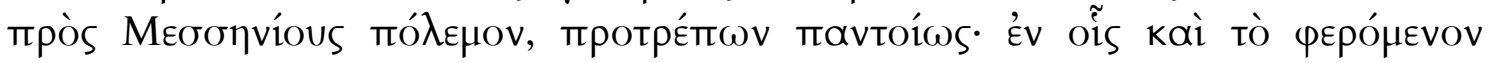

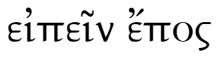

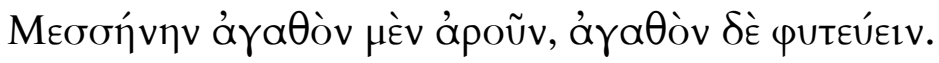

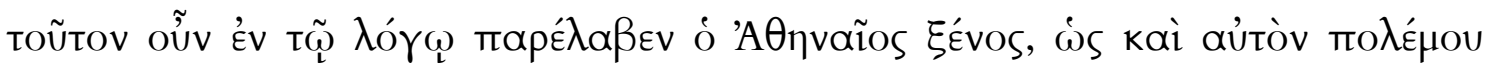

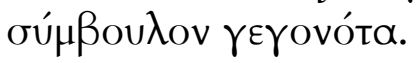

Este Tirteu era um Ateniense de pouca sorte: pois ele era um mestre-escola, coxo, subestimado em Atenas. Apolo vaticinou aos Lacedemônios que mandassem buscálo, enquanto guerreavam contra os messênios e se encontravam em grande dificuldade, porque [ele] bastaria para fazê-los compreender o que era vantajoso; de fato, o oráculo ordenou que confiassem a ele o cargo de conselheiro. E quando ele chegou a Esparta, ficou inspirado e aconselhou-lhes a empreender a guerra contra os 
Messênios, encorajando-os de todas as maneiras - entre as quais, pela récita do notório verso:

Messênia, boa p'ra arar, boa p'ra plantar.

Portanto, o Estrangeiro Ateniense o refere em seu discurso, porque ele (sc. Tirteu) também havia sido um conselheiro de guerra.

Os dois últimos dísticos (vv. 4- 8) foram conservados na Geografia de Estrabão ${ }^{225}$, e são evocados como um testemunho de que a guerra durou vinte anos:

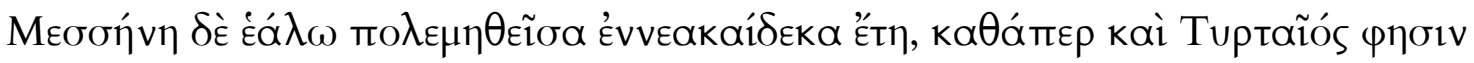

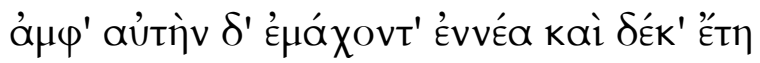

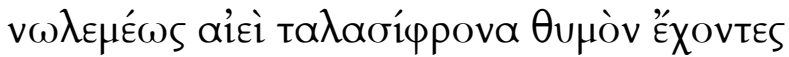

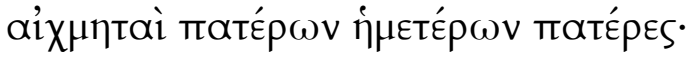

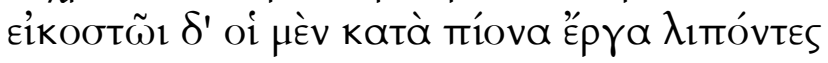

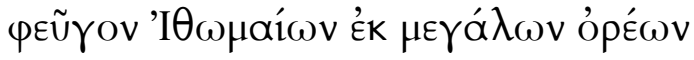

Messênia foi conquistada após dezenove anos de guerra, como diz Tirteu:

Por ela lutavam dezenove anos,

sem trégua, sempre de coração animoso

os lanceiros pais de nossos pais;

ao vigésimo, os messênios deixaram as férteis lavouras

e fugiram dos altos montes de Itome.

O Iambi et elegi Graeci de Martin L. West (1992) adota a reunião proposta primeiramente por Bergk em 1882. Os fragmentos se combinam tão perfeitamente que a maioria dos editores que o seguiram não viu objeções quanto à orientação de Bergk e imprime os fragmentos deste modo desde então.

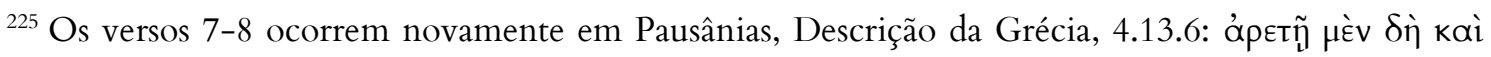

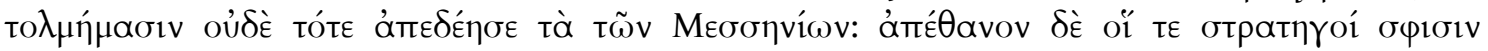

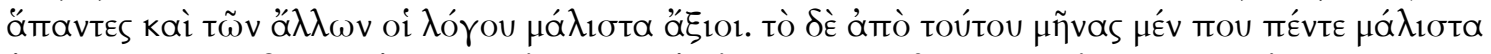

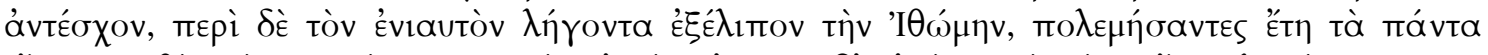

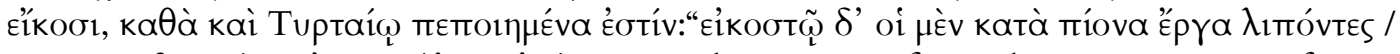

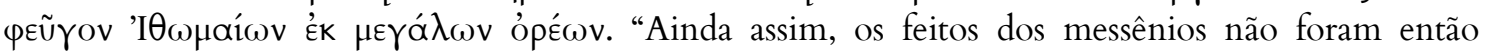
desprovidos de valor ou coragem. Porém, todos os seus generais morreram e a maior parte dos outros homens dignos de nota. Depois disso, resistiram ao máximo por aproximadamente cinco meses, mas, quando o ano estava terminando, desertaram Itome, depois de guerrearem ao todo vinte anos, segundo o que Tirteu compôs: "no vigésimo [ano], os Messênios deixaram as férteis lavouras/ e fugiram dos altos montes de Itome."
} 
Entre alguns, contudo, ainda há alguma nota de discordância: Prato (1968, p.73), por exemplo, embora admita que estes versos pudessem ter sido parte do mesmo poema, a longa elegia denominada Eunomia, não concorda na disposição

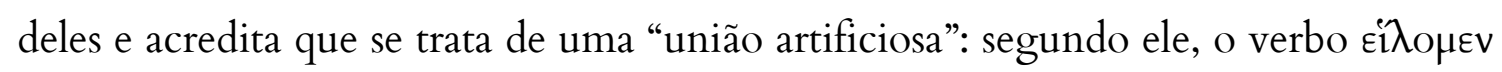
(heílomen, “tomamos”, v.2) na primeira pessoa do plural e દ́ráxovt(o) (emákhonto "lutaram", v.4) na terceira pessoa, sugerem duas situações distintas ou pelo menos certa distância entre os dois versos.

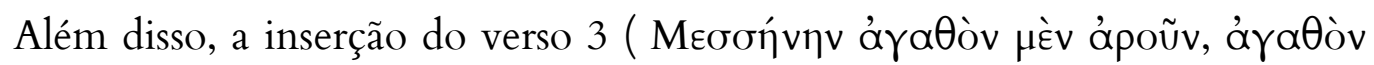

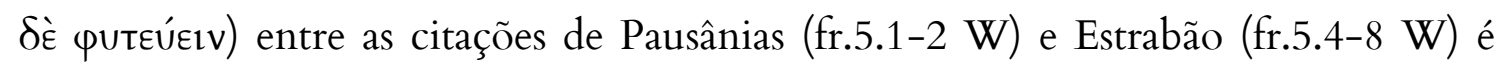
problemática para Prato, que adota para o verso 4 a leitura pouco convencional e

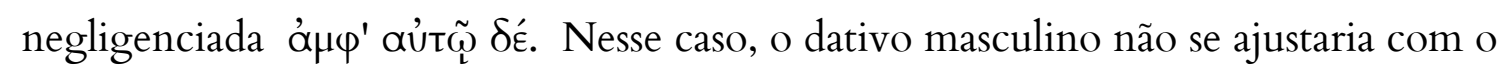

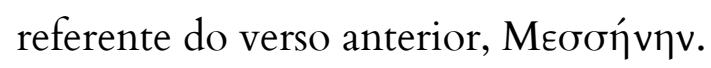

E.Schwartz (1889, p.428, n.5 apud Prato, 1968,p.73) também prefere esta leitura, observando que á $\mu \varphi$ í no sentido de "lutar por" geralmente é regido por dativo, ao passo que a preposição em conjunto com acusativo possuía sentido mais estrito de “lutar ao redor de”. Mas West (1974, p. 186) entende simplesmente que um sentido poderia contaminar o outro, e é impossível saber com certeza porque Tirteu teria empregado o acusativo ${ }^{226}$.

Uma vez que todos os versos retratam a tomada da Messênia, é verossímil crer que eles provavelmente teriam feito parte do mesmo poema, mas parece prudente considerá-los como fragmentos separados e que os versos não estivessem dispostos em sequência direta.

\footnotetext{
${ }^{226}$ A Ilíada de Homero já demonstra como estes sentidos são normalmente intercambiáveis. O poeta utiliza mais frequentemente a construção ó $\mu \varphi \hat{i}$ + dativo para indicar o sentido de "ter por alvo" (por

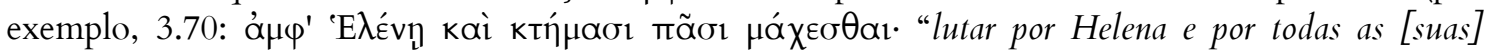

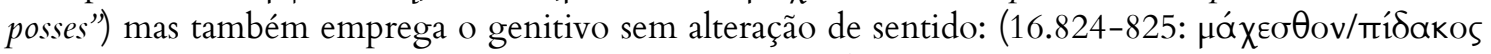

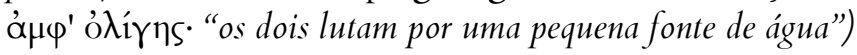




\section{A conquista da Messênia (vv.01-03)}

Estes versos registram pela primeira vez e de maneira laudatória a história da Primeira Guerra da Messênia. Nesse sentido, o poema é frequentemente utilizado por historiadores para comprovar a autenticidade das Guerras da Messênia e já foi lembrado pelos estudiosos de literatura grega como um exemplo de narrativa historiográfica arcaica, tendo em vista a preocupação do poeta com referências e datas cronológicas (Ver Bowie 1986, pp. 29-34; 2001, pp.45-47). Seria este poema de fato um registro apurado deste conflito?

O interesse dos editores em colocar este fragmento como parte da Eunomia é antigo: Giuseppe Fraccaroli (1889, apud De Falco e Coimbra, 1941, p. 160) aceita uma leitura pouco comum do último verso do fr. $4 \mathrm{~W}$, que escreve потє em vez de тó $\lambda \varepsilon 1$, e supõe assim que o fr. $5 \mathrm{~W}$ continuaria a elegia a partir daí:

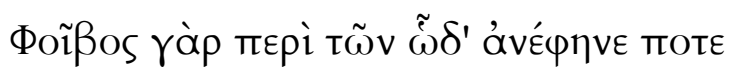

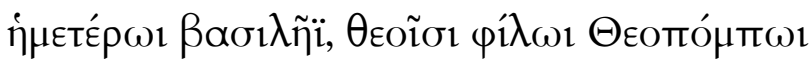

Sobre isso, eis o que Febo revelou então ao nosso rei Teopompo, dileto dos deuses

Contudo, esta hipótese teve pouca adesão. Prato (1968, p.75) observa que

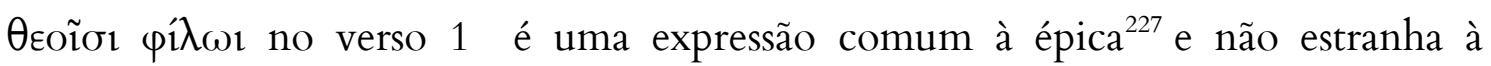
elegia $^{228}$, mas salienta o que ele chama de "dicção délfica", consagrada por expressões como Z qvì pí̀os, presente por exemplo no oráculo que teria sido proferido a

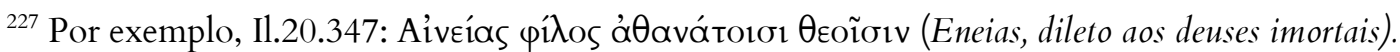

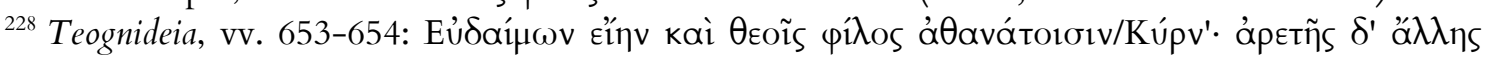

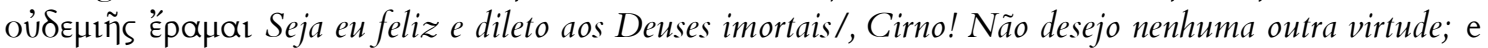

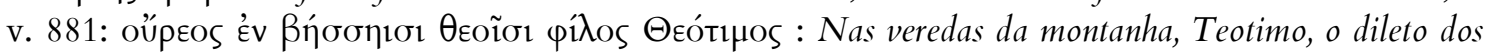
deuses.
} 


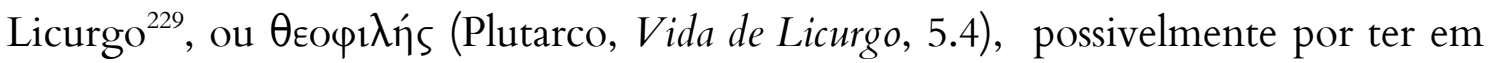
vista também uma relação entre esse verso e o fragmento $4 \mathrm{~W}$. Mas a associação entre Deuses e heróis é tão corriqueira na tradição épica que nos parece impossível assegurar se o poeta visava de fato introduzir neste verso algum elemento particular da linguagem oracular.

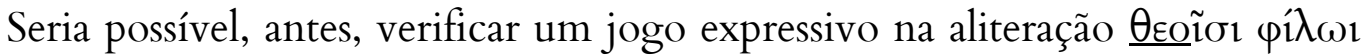

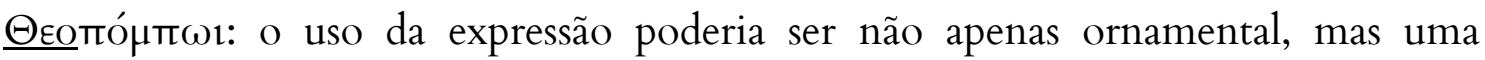
aliteração criada propositalmente para reforçar o elo entre os Deuses e a figura da autoridade lacedemônia, procedimento que já ocorre em ambos os fragmentos da Eunomia: no fragmento $2 \mathrm{~W}$, pela menção aos reis ${ }^{\top} H \rho \alpha k \lambda \varepsilon i ́ \delta \alpha ı s$, e no fragmento 4 $\mathrm{W}$, pelo oráculo proferido aos reis.

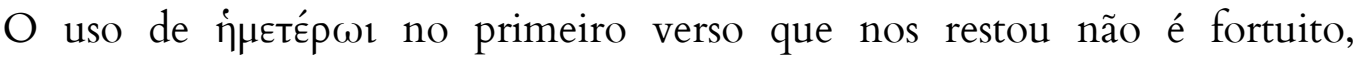
tampouco a "tentativa de associar, em um momento de desunião espiritual, a força de toda a nação em nome do velho rei vitorioso" (Prato, 1968, p. 75), mas de uma estratégia narrativa particular da Eunomia: ao longo de todo o fragmento, Tirteu cuida de rememorar os ideais e eventos históricos compartilhados por uma elite ${ }^{230}$, a fim de apresentar como contínuo um ideário que a mantém no centro do universo político em um momento de crise, ao mesmo tempo em que reforça, entre seus pares, a coesão do grupo aristocrático a que pertence (Ver Quatroccelli, 2008, p. 16).

A oração relativa do verso 2 desenvolve a identidade deste Teopompo: tratase do rei que conquistou a região da Messênia. Pode-se supor aqui, com Bowie (2010, p.147), que a necessidade de uma oração relativa para descrever o rei espartano já indicaria se tratar de um poema breve, que realizava apenas uma narração sumária do conflito: talvez apenas uma rememoração da guerra passada, com o intuito de servir de exemplo para uma situação atual.

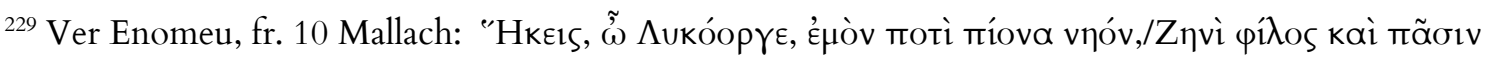

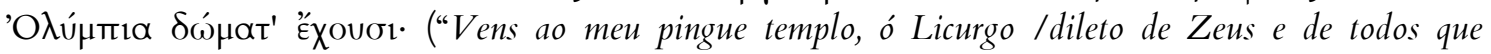
habitam a morada olimpia").

${ }^{230}$ No fragmento $2 \mathrm{~W}$, a menção às origens míticas e à fundação da cidade como um presente de Zeus aos descendentes de Héracles; no fragmento $4 \mathrm{~W}$, o oráculo recebido pela cidade adquire força admonitória. 
Mas esta hipótese também não é concludente, uma vez que não sabemos ao certo em que ponto do poema estaria o fragmento citado; tudo o que se sabe é que não se trata do início, por causa do dativo no primeiro verso. O fato de Tirteu servir-se aparentemente de narrativas mais extensas em outros fragmentos (18-23 W e 23a W) que poderiam ter feito parte da Eunomia reforça a dúvida.

Se o primeiro verso encarrega-se de justificar e demonstrar a adesão de Tirteu à aristocracia, os versos seguintes (vv.2-3) justificam o valor da terra pela qual se luta. O escoliasta das Leis já anunciava que o terceiro verso gozava de prestígio em seu tempo, chamando-o de pepófєvov - isto é, um verso muito citado, ou que estava em circulação na época - mas, sobretudo, informa que o verso teria sido recitado em um contexto de exortação, como uma das muitas maneiras encontradas

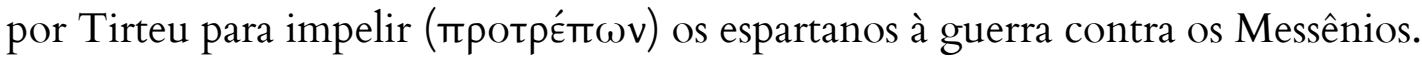

Se o escoliasta teve acesso a outros trechos do poema para basear a sua afirmação, e se a ordenação dos versos proposta pelos editores modernos para o fragmento $5 \mathrm{~W}$ procede, seria possível imaginar um poema em princípio exortativo em que a narração do passado não seria predominante, mas serviria antes para pautar a ação presente, como West (1974,p.14) já sugere como um traço constitutivo da elegia narrativa.

A descrição da terra natal ou de colônias adjacentes poderia constituir um lugar comum na poesia grega arcaica. Como demonstram De Martino e Vox (1996, p. 550), o tema já é comum desde a Odisseia, e em chave negativa, aparece em Hesíodo $^{231}$ e Arquíloco ${ }^{232}$.

O expediente encontraria facilmente lugar na argumentação de Tirteu: determinar para a sua audiência aquilo que é ợaӨós ou kakós não é algo incomum em suas elegias, e, segundo Noussia (2010, p. 74), procedimentos como esses evocam na memória da audiência as tradições compartilhadas entre todos os espartanos.

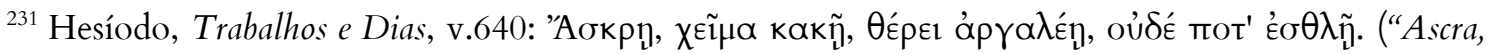
má no inverno, ruim no verão, nunca boa" - Tradução de Jaa Torrano, 2005)

${ }^{232}$ Ver Arquíloco fr.22 W, p.179.
} 


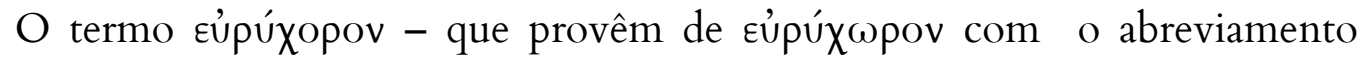
métrico, e cujo sentido seria "vasto, amplo para o cultivo" e não "com amplos chãos de dança” (West 1994) - também evoca o principal epíteto para Esparta em Homero (Ver Od. 13.414, 15.1).

åraӨóv, por outro lado, é epíteto normalmente atribuído à cidades (como o é para a Ítaca de Odisseu em Od. 9.27, onde Ítaca é áraӨì koupotpópos, agathé kourotróphos, "boa nutriz de jovens"). Alguns editores corrigem o texto com

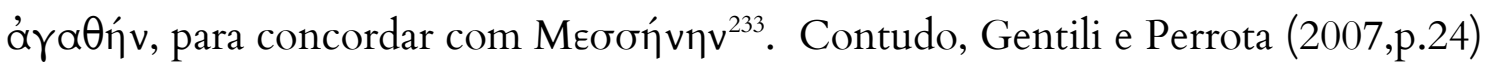
advertem que não se conheciam os versos precedentes e que seria possível

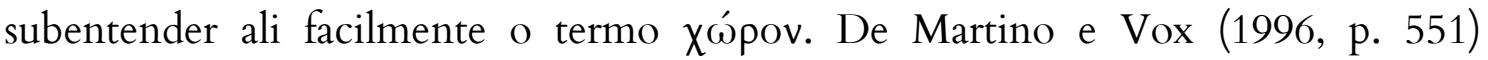
informam que poderia se tratar da construção de neutro ở $a \theta$ óv + infinitivo, como vemos em Homero (Il. 7.282, 24.130-1).

A fertilidade da região da Messênia - que na época de Tirteu designava toda a região entre vales próxima à Esparta, e não a cidade de mesmo nome, fundada apenas após 369 a.C. - já era proverbial na literatura grega clássica. Eurípides também a celebraria em verso (fr.1083 Nauck) :

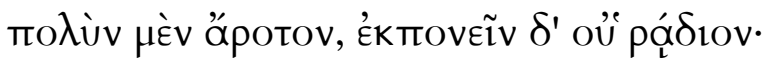

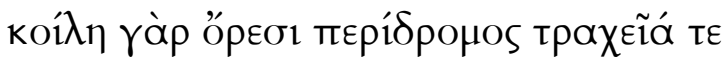

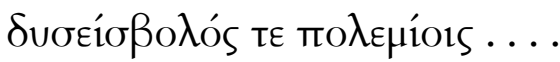

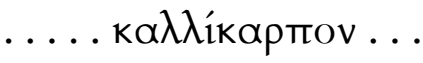

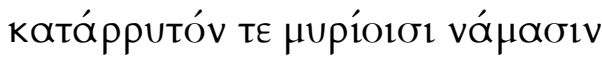

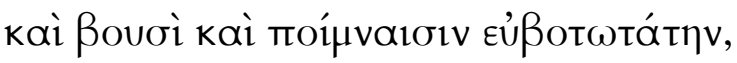

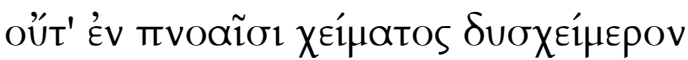

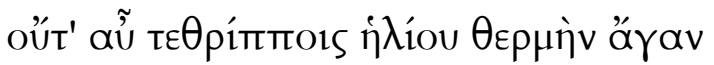

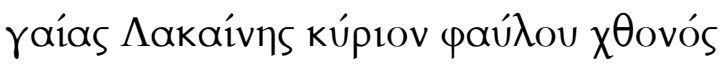

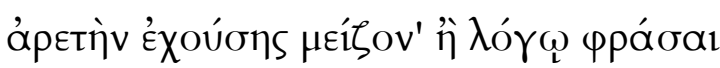

${ }^{233}$ Como faz Buttmann (apud Gentilli e Perrota, 2007, p.24) 


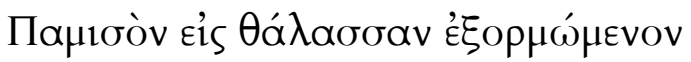

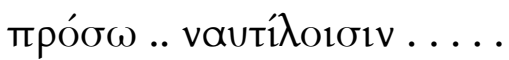

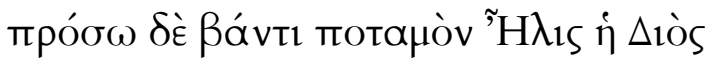

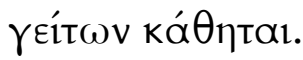

Muita lavoura, a lavrar não facilmente:

pois vale selvagem entre montanhas

para guerreiros duro de invadir...

....frutífera....

irrigada por incontáveis nascentes

ótimo pasto para bois e carneiros,

não rigorosa pelos sopros do inverno

nem quente demais pelas quadrigas do Sol

Da fraca terra lacônia um forte solo

da qual a excelência é maior do que dizem,

lançando-se ao mar Pamiso,

à frente.....nautas......

ao que à frente andando pelo rio Élis a vizinha

de Zeus lançou-se....

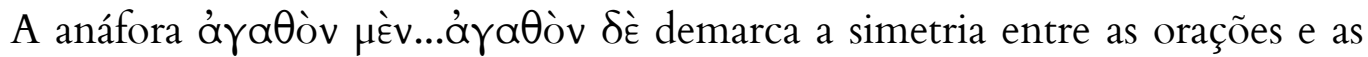

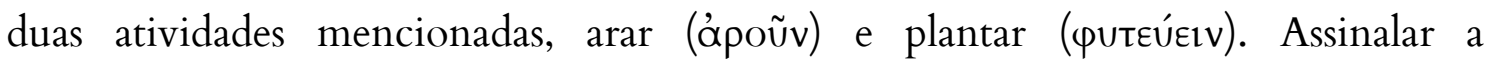
fertilidade do solo por meio desses termos constitui lugar recorrente na poesia grega. São essas as duas principais atividades do agrícola e também uma fonte de riqueza (Trabalhos e Dias vv. 21-22): 


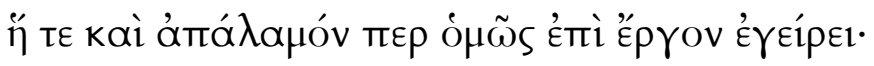

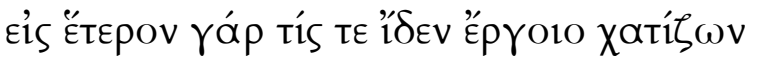

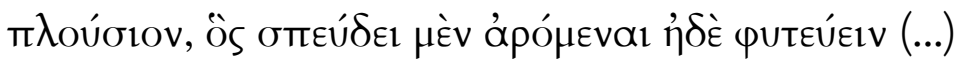

Esta (sc. "Boa Éris") desperta até o indolente para o trabalho:

pois um sente desejo de trabalho tendo visto

o outro rico, apressado em plantar, semear (... $)^{234}$

Ao passo que a sua ausência denota um sinal de barbárie (Prato, 1968, p.76), como se lê na Odisseia (9.106-108) :

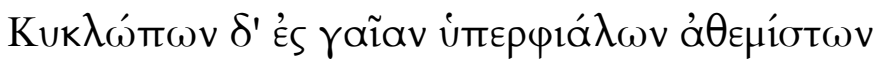

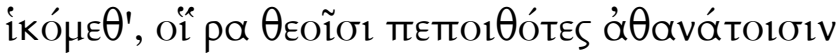

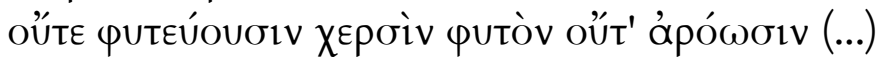

À terra dos Ciclopes arrogantes e sem lei chegamos. Eles, confiados nos Deuses imortais não plantam nem aram com as próprias mãos (...)

Se este verso constituía ou não uma exortação que trabalhava a imagem proverbial da fertilidade da terra messênia como estímulo para que os espartanos combatessem ou se fazia parte de uma narrativa, parece impossível saber dada a escassez dos fragmentos. O que podemos sugerir, entretanto, é que a exaltação de valores da terra que se deseja conquistar é uma tópica exortativa, que Sólon poderia ter também explorado em seu poema Salamina (Ver fr. 1.1W, iнєрті̃ $\Sigma \alpha \lambda \alpha \mu \tilde{v} v o \varsigma)$.

Entretanto, a hipótese de que se trataria de uma elegia narrativa é reforçada por estudiosos que tendem a ver uma ligação entre os elementos deste poema e procedimentos formais típicos da vindoura prosa historiográfica. Em que medida é viável traçar essa relação?

${ }^{234}$ Tradução de Mary de Camargo Neves Lafer (1989). 


\section{Elegia e Historiografia? A Primeira Guerra da Messênia (vv.4-8)}

Os versos 4 a 8 do fragmento $5 \mathrm{~W}$ apresentam tons épicos e apontam para um procedimento típico da Eunomia: a fusão entre um passado lendário e a realidade atual de performance. Essa estratégia já é clara no fragmento $2 \mathrm{~W}$, demarcando a continuidade da linhagem dos fundadores da pólis, descendentes de Heraclidas, e da audiência do poema, através do uso do verbo ápı́kó $\mu € \theta \alpha$; já nos versos 1 e 2 do fragmento $5 \mathrm{~W}$, Tirteu serve-se novamente do mesmo recurso: com o aoristo na primeira pessoa do plural, عí $\lambda_{\mathrm{o}} \mu \varepsilon v$ (vv.2) o poeta torna atemporal o ato de conquistar Messênia e assim suprime a distinção entre passado e presente, criando um grupo coeso que reúne todos os espartanos.

Este passado se reveste de autoridade nos outros fragmentos porque geralmente menciona Deuses e semideuses (fr. $2 \mathrm{~W}$ ), ou as ordens que eles pronunciaram (o oráculo do fr. $4 \mathrm{~W}$ ). Mas, diferentemente destes, no fragmento 5 W a autoridade se dá por meio da heroicização do passado recente, que é retratado com uma dicção épica que remeterá não só à Ilíada, mas sobretudo à Odisseia.

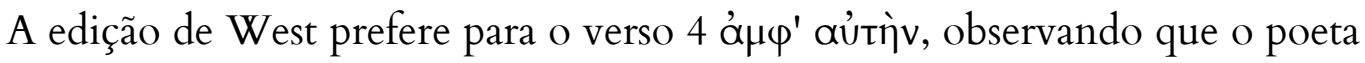

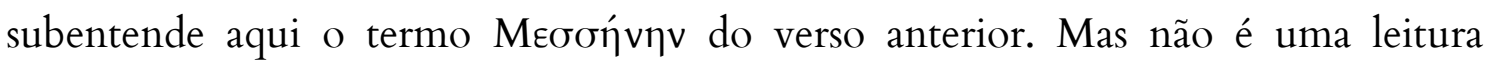

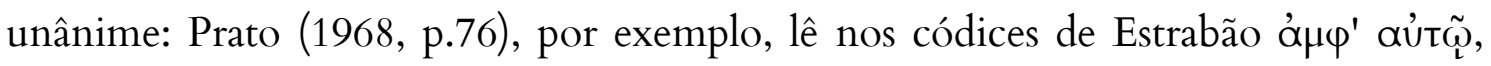
sugerindo uma descontinuidade entre este verso e o anterior e subentendendo que o

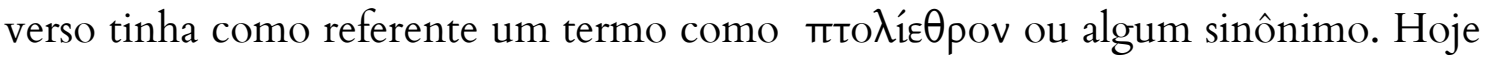
a questão parece ter se resolvido e as opiniões parecem pender para á $\mu \varphi^{\prime}$ aútìv, com o registro de casos similares na poesia homérica com o sentido de "em volta de"

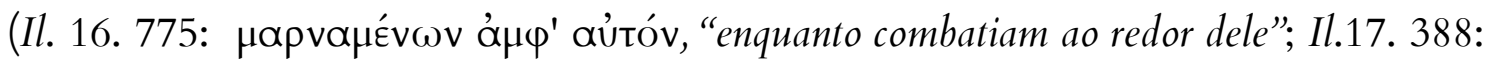

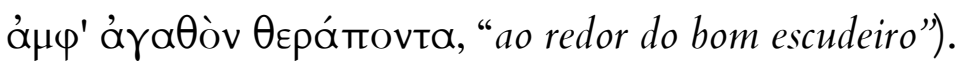

A meticulosidade cronológica com que Tirteu descreve os acontecimentos da

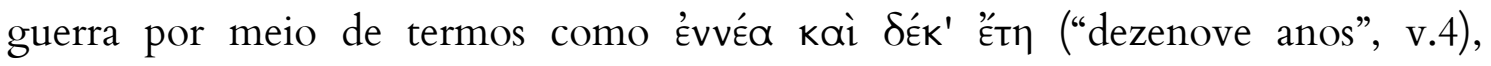

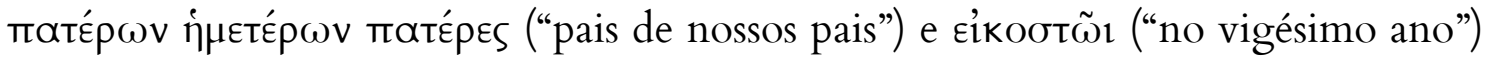


poderia, segundo alguns autores ${ }^{235}$, sinalizar para um cuidado que apenas mais tarde se tornaria praxe com a prosa historiográfica. Entretanto, é mais provável que a demarcação temporal feita pelo poeta não ocorra por uma necessidade de delimitar com precisão os eventos, como na historiografia, mas antes seja um recurso tópico para anotar uma duração vaga de tempo, como já se verifica em Homero (Ver West, 2011, p.84). Na Ilíada, o período de nove dias ou nove anos (com algo de novo ocorrendo no décimo) é típico ${ }^{236}$, como por exemplo, nota-se em Il. 1. 53-54:

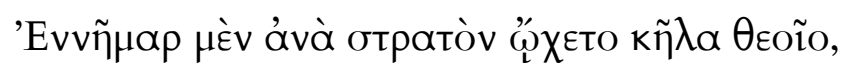

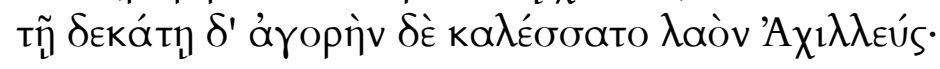

"Por nove dias as flechas do Deus percorriam o exército, mas no décimo, Aquiles convocou a tropa à assembleia”.

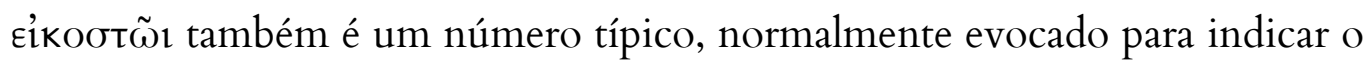
ano do regresso de Odisseu à Ítaca contado a partir do início da guerra de Troia ${ }^{237}$. Que seu uso também era tradicional é demonstrado por uma passagem da Ilíada (24.765-766), na qual Helena declara que se passaram vinte anos desde a sua partida de Esparta para Troia (Ver West, 2011, p.427) ${ }^{238}$ :

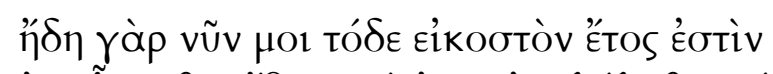

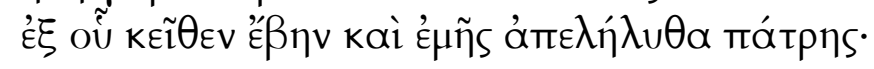

Sim, pois este já é o meu vigésimo ano desde que saí de lá e deixei a minha pátria.

\footnotetext{
${ }^{235}$ Ver Bowie, 1986, p.30, mas com as ressalvas feitas em Bowie, 2010, p.147.

${ }^{236}$ Em Odisseia,22.v.228, por exemplo, Atena diz que "Odisseu lutou contra os Troianos por nove

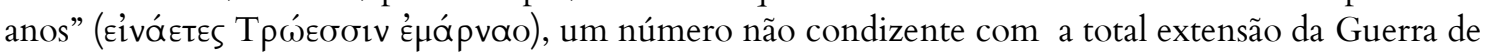
Troia, mas que é condizente com a diç̧ão épica.

${ }^{237}$ Od.2.175; 5,34; 16,206; 17, 327; 19, 222; 21,208; 23, 102; 170; 24,321

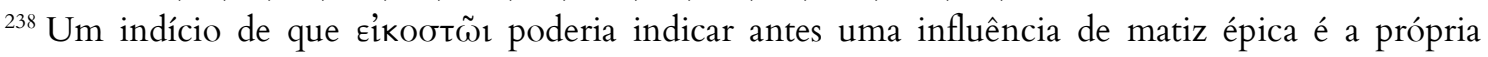
incerteza quanto à duração da Segunda Guerra da Messênia nas fontes. Pseudo-Longino (Do sublime,

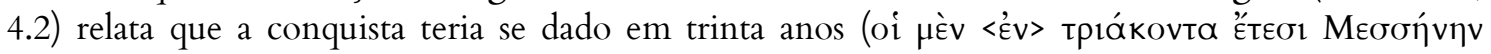

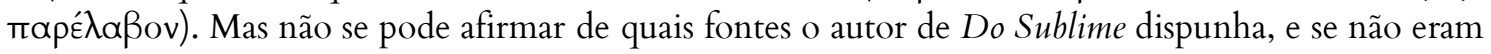
tão tardias quanto as de Pausânias ou Estrabão.
} 
O verso quinto inicia-se com $v \omega \lambda \varepsilon \mu \varepsilon ́ \omega \varsigma$ ("incessantemente", "sem trégua"), advérbio comum na Ilíada sempre em início de verso, e frequentemente acompanhado por aỉeì. Na Ilíada, seu uso em geral está associado à persistência em combate e, por extensão, designará na Odisseia a resistência de seu protagonista não só na guerra, mas nas diversas provas que lhe são impostas em sua jornada (um

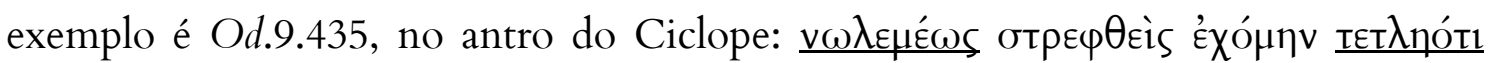
$\theta$ vน $\left.)_{1}\right)$. É inevitável associar este termo com a virtude que Tirteu incita em seus interlocutores, a capacidade de se manter imóveis ante à investida do inimigo (Ver, por exemplo, fr.11. 21-22 W = 10.31-32 W). Em outro fragmento, o guerreiro que permanece firme e sem interrupção no combate é considerado um bem comum

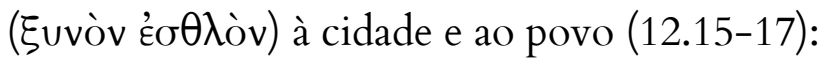

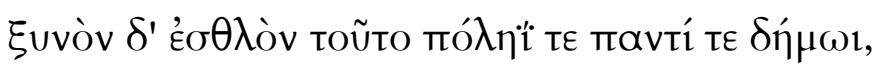

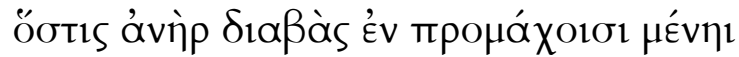

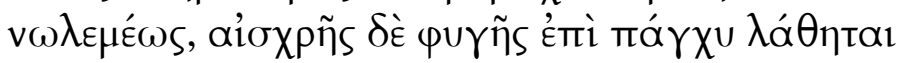

É esse um bem comum à cidade e ao povo todo,

que um varão firme na vanguarda se mantenha, sem trégua, de todo se esqueça da torpe fuga

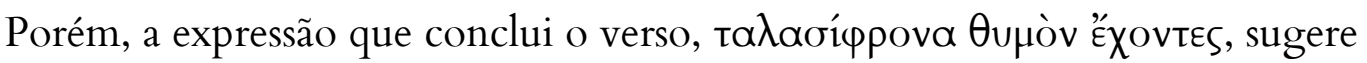
que o poeta deseja realçar aqui uma associação com um personagem da tradição

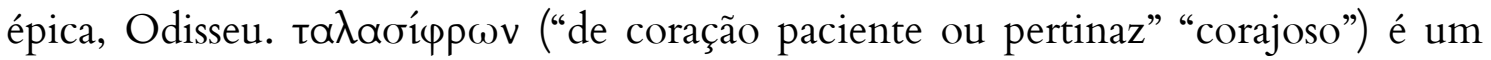
epíteto fixo de Odisseu, e para alguns autores (Prato, 1968, p.77; Grethlein, 2010, p. $56^{239}$ ) uma alusão direta ao próprio herói. De fato, analisando a presença do epíteto na literatura grega supérstite, nota-se que ele é utilizado predominantemente para

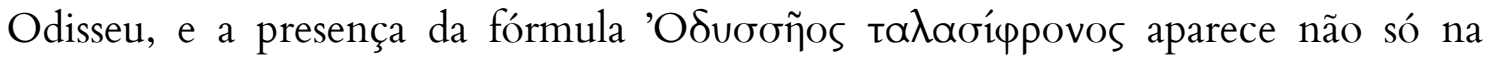
Ilíada, mas também na mélica do espartano Álcman, que se refere ao personagem da Odisseia da mesma maneira, o que poderia denotar o seu conhecimento da tradição

239 "A conquista da Messênia é então equiparada a uma empresa digna de um Odisseu" 
épica e de mitos não tradicionalmente espartanos, mas pan-helênicos (Álcman, fr.80 PMG $)^{240}$ :

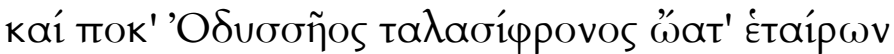

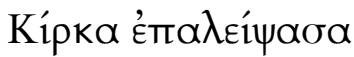

E os ouvidos dos companheiros do pertinaz Odisseu, Circe, tendo ungido...

Não é difícil imaginar que Tirteu, quase contemporâneo de Álcman, também

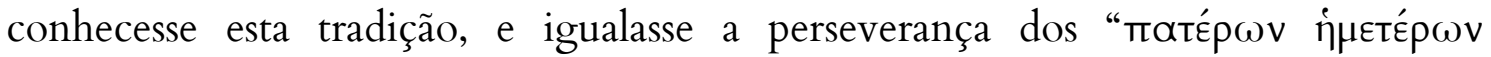
татє́pєs" durante os vinte anos de guerra com a imagem de Odisseu e sua resistência lendária durante os vinte anos de périplos no mar e de cerco a Troia. $\mathrm{O}$ passado é retratado heroicamente, e com isso torna-se modelo de autoridade para o presente.

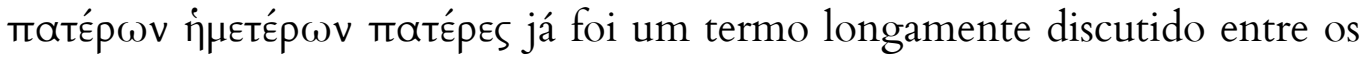
estudiosos desse poema; Pausânias (4.15) o interpreta como a terceira geração anterior à do poeta (трі́tᄁ $\gamma \varepsilon v \varepsilon \tilde{\alpha}$, trítei genéai), um período que os estudiosos interessados em datar a primeira guerra da Messênia ${ }^{241}$ julgam ser de setenta anos. Mas a expressão também tem tonalidades épicas e está presente em elegias narrativas como a de Simônides ${ }^{242}$ : a menção à linhagem aristocrática e ao nome são as formas padrões encontradas pela tradição épica para conferir identidade e prestígio aos seus heróis $^{243}$. Assim, no Canto 14 da Ilíada, Diomedes cita seu pai Tideu e avô Eneu,

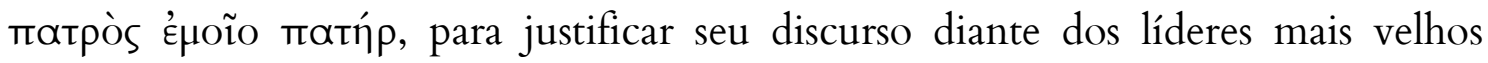
(Il.14.113-118):

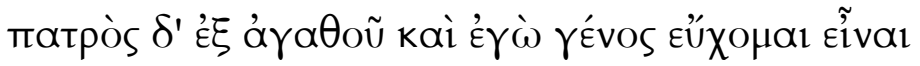

\footnotetext{
${ }^{240}$ Ver Carey, 2010, p.443, n.21 em ATHANASSAKI, L; BOWIE, E. (org) Archaic and Classical Choral Song, De Gruyter, 2010.

${ }^{241}$ Ver Schwartz, E. p.438, em Prato, C; p. 30*, n.112.

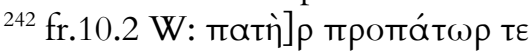

${ }^{243}$ Por exemplo, quando Agamêmnon recomenda que Menelau exorte as tropas, chamando cada guerreiro pelo nome e pelo patronímico, "honrando a todos": $\varphi \theta \varepsilon \varepsilon_{\gamma} \gamma \in O$

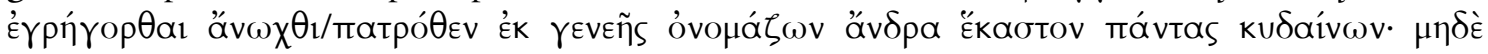
$\mu \varepsilon \gamma \alpha \lambda i \zeta_{\varepsilon o} \theta u \mu \tilde{\omega}$. "Convoca-os, onde quer que vás, e ordena que se reúnam,/Chamando cada guerreiro pela estirpe e pelo nome do pai;/Honra a todos! Não tenha coração soberbo."
} 


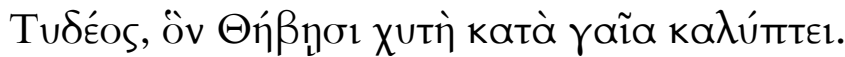

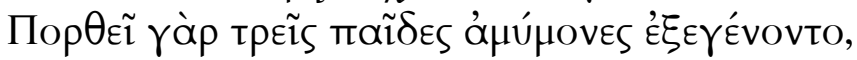

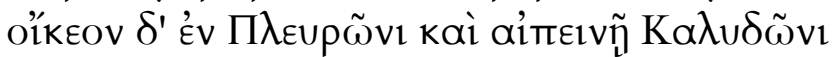

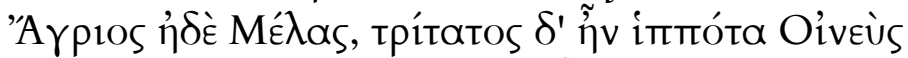

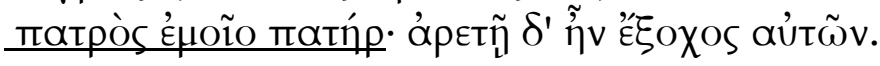

De um bom pai eu garanto que sou filho,

Tideu, a quem vela a terra de Tebas.

Pois para Porteu vieram à luz três filhos irrepreensíveis,

que habitam em Plêuron e íngreme Calidônia,

Agrio e Mela. O terceiro era o cavaleiro Eneu,

pai do meu pai: Dentre eles, era exímio em virtude.

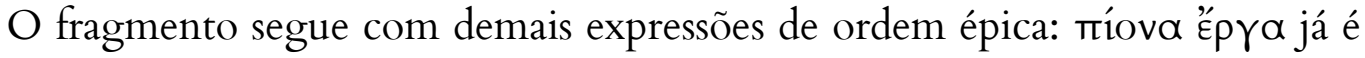
empregado desde a Ilíada e Odisseia para designar a rica propriedade (Ver Od.4, 318:

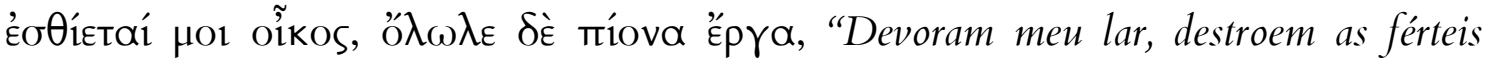
lavouras"). Expressão afim é retomada também no fr. $10.3 \mathrm{~W}$ de Tirteu - lá os espartanos derrotados devem abandonar sua cidade e seus férteis campos ( árpoùs), os mesmos que os pais dos pais conquistaram durante a primeira guerra.

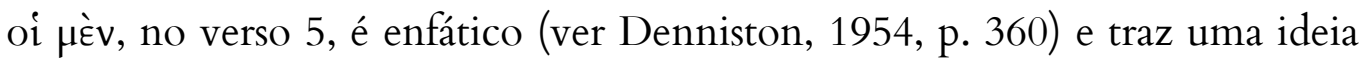
de progressão do argumento, tirando o foco dos espartanos e colocando-o sobre os seus inimigos. ${ }^{244}$ Há ênfase também por causa da primeira metade do hexâmetro, que assinala a transição por meio do metro predominante espondaico. Entretanto, o poeta não se detém em uma narrativa longa do conflito, mas brevemente pontua a fuga dos messênios do monte Itome (v.5, peũyov). Tendo em vista o retrato que a fuga tem na poesia de Tirteu, no fragmento provavelmente não haveria a preocupação de retratar com detalhes a última batalha pela posse da Messênia (alguns autores sugerem que isso é narrado no fr. $23 \mathrm{~W}$, que poderia ser um outro poema) mas antes procederia na construção de um éthos para os messênios oposto àquele que o poeta deseja exaltar nos lacedemônios em suas elegias exortativas. A construção deste éthos poderia continuar nos fragmentos 6 e 7 , nos quais o poeta relata um

${ }^{244}$ Ver um exemplo similar em Od.6. 7-12. 
estado de penúria tão extremo que os Messênios são retratados chorando por seus próprios algozes). ${ }^{245}$

Com base no fragmento, não se pode afirmar que a elegia grega arcaica prevê elementos da historiografia ao registrar a data de eventos cronológicos, mas é certo que, retomando este passado, Tirteu realiza uma epicização do mesmo, preenchendo-o com aspectos de um mundo heroico e aristocrático.

Além disso, a concisão do relato ${ }^{246}$ torna mais atraentes as hipóteses ${ }^{247}$ de que se trataria antes de um modelo de conduta para fins parenéticos do que um acurado registro histórico, embora nem o fragmento em si ou a sua fonte permitam conclusões sólidas.

\section{Os Fragmento 6 e 7}

Os fragmentos 6 e 7 W foram registrados por Pausânias (Descrição da Grécia, 4.14.4-5) como um testemunho das penas impostas aos Messênios ao término da Primeira Guerra da Messênia. Pausânias relata que diante da ausência de

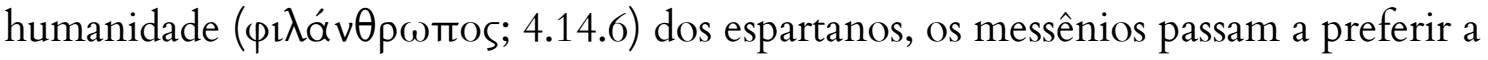
morte em combate às suas atuais condições, levando assim ao levante liderado pelo herói Aristômenes. Estas penas incluíam um juramento que os impedia de causar novas revoltas, o pagamento de metade dos víveres que cultivassem em suas terras e a ida aos funerais de reis e autoridades espartanas (4.14.5):

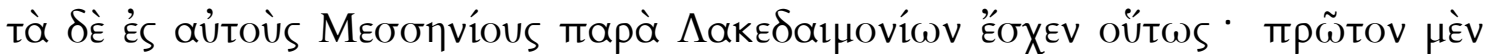

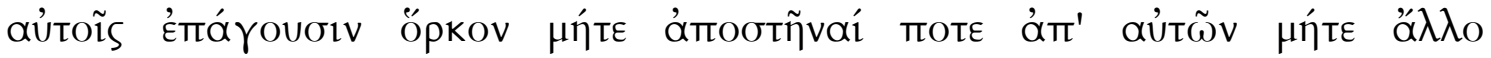

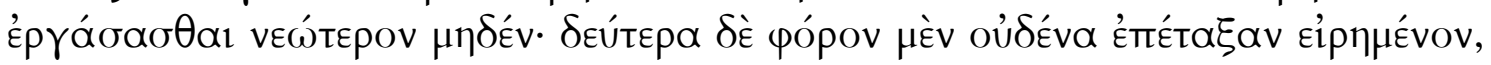

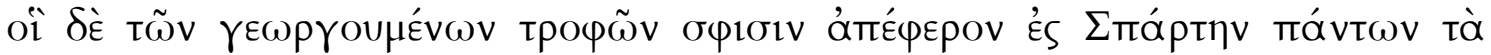

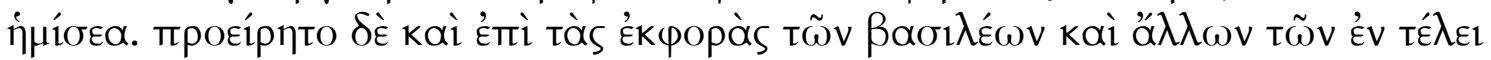

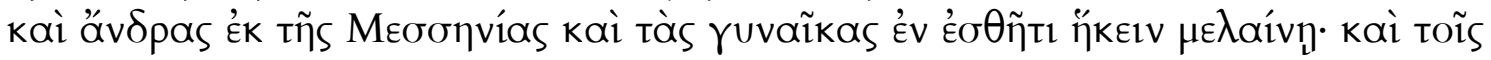

\footnotetext{
${ }^{245} \mathrm{O}$ monte Itome circundava todos os vales adjacentes, e foi a sede natural da resistência dos Messênios, sob o comando do rei Aristodemo (ver De Martino e Vox, 1996, p. 552). Segundo o relato de Pausânias (IV, 14.1), porém, a maior parte dos Messênios não fugiu, mas permaneceu na região como escravos dos espartanos (Ver Fragmentos 6-7, infra).

${ }^{246}$ Pausânias (4.14) chega a informar que Tirteu não teria mencionado quem eram os reis em seu tempo, durante a segunda guerra messênica. A ausência do nome de Polidoro no fragmento que nos restou também perturbou aos estudiosos ao longo do tempo (Ver, por exemplo, Bach 1831,p.86) ${ }^{247}$ Ver Prato, 1968, p. 75; Grethlein, 2010, p.57.
} 


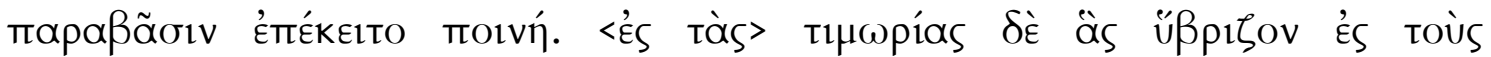

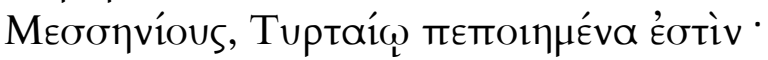

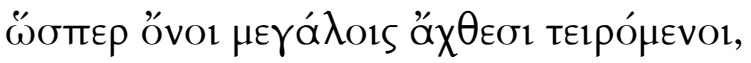

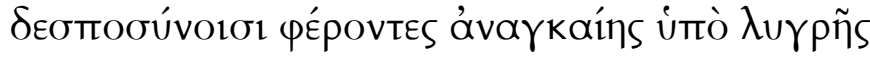

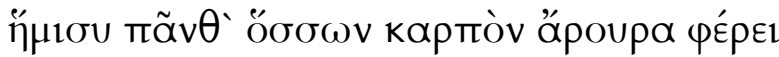

No que concerne aos próprios Messênios, [a situação] junto aos espartanos era a seguinte: primeiro, atribuem-lhes um juramento para que não se revoltassem no futuro por conta destas coisas mesmas, tampouco empreendessem qualquer outra sedição novamente. Segundo, não impuseram qualquer tributo específico, no entanto, levavam para Esparta metade do total de alimentos que eram cultivados. Prescrevia-se também que tanto homens quanto mulheres da Messênia fossem com vestes negras aos funerais de reis e de outras autoridades, e uma pena era aplicada aos transgressores. <Para as> punições que ultrajavam os Messênios, há o que o que foi composto por Tirteu:

Como asnos oprimidos por ingentes fardos levando aos senhores, sob triste necessidade, metade de todo o fruto que a terra produz

Alguns estudiosos ${ }^{248}$ rejeitaram a conexão deste fragmento com a Primeira Guerra Messênica, devido a uma aparente contradição no discurso de Pausânias: o periegeta conta em outro trecho (4.15.1) que a Messênia detinha certa liberdade política e lhe era permitido manter contato com outras cidades e mesmo tomar decisões autônomas. Esta seria, aliás, a única explicação para os Messênios terem conseguido causar uma rebelião tão violenta e infligido importantes derrotas aos Lacedemônios mais tarde (4.14.8).

Segundo Prato (1968, p.31) e Wilamowitz (1900, p.98, apud Prato 1968, p.31) a contradição de Pausânias explica-se porque os lacedemônios não ocuparam todo o território da Messênia durante o primeiro confronto, mas teriam se limitado apenas à costa meridional, ao fim da cadeia de montanhas de Itome. São aduzidos

${ }^{248}$ Kahrstedt, U. 1919; Chrimes 1952 apud Prato 1968, p. 74. 
testemunhos históricos, como a participação de um messênio de nome Fanas nos jogos olímpicos anteriores à primeira guerra ${ }^{249}$, comprovando assim a liberdade de uma parte da Messênia e que a conquista de toda a região apenas se daria com o fim do segundo conflito, já no tempo de Tirteu.

Eliano (Várias Histórias, 6.1) relata os mesmos fatos atestados pelos fragmentos de Tirteu e Pausânias:

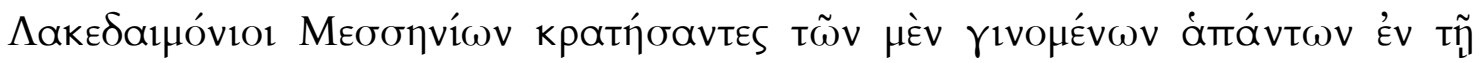

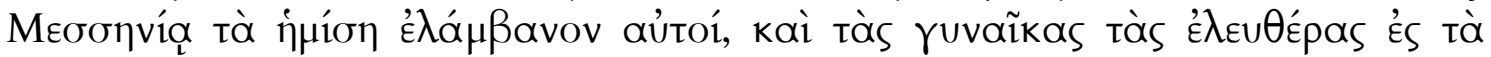

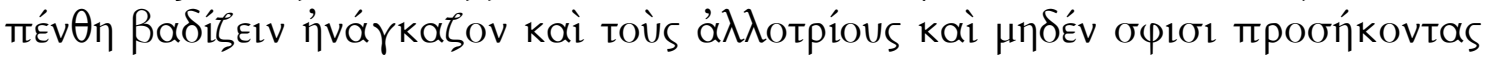

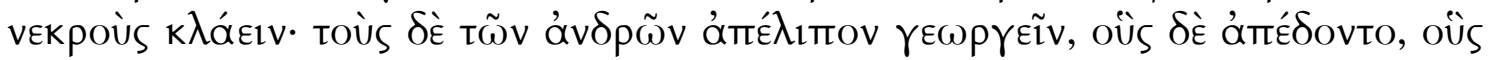

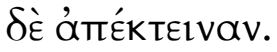

Por terem vencido os Messênios, os Lacedemônios recebiam a metade de tudo o que era produzido na Messênia; compeliam as mulheres livres a irem aos funerais, e a chorar por mortos alheios e nada familiares a elas. Dos homens, deixaram alguns para cultivarem os campos, venderam uns e mataram outros.

Muito se questionou sobre o sentido dos fragmentos 6 e $7 \mathrm{~W}$ : por que Tirteu teria retratado de maneira patética e humilhante a condição dos inimigos? Em que contexto estes versos poderiam ter sido recitados?

\section{O Símile Homérico e o Símile Tirtaico (Fr. 6.1 W e Fr. 13 W)}

Pomtow (1881, apud De Falco \& Coimbra 1941, p.163) foi o primeiro a sugerir que os dois fragmentos estavam em sequência e também ligados ao fragmento $5 \mathrm{~W}$. Segundo o estudioso, entre os fragmentos 5 e $6 \mathrm{~W}$ perdera-se apenas um hexâmetro, no qual constava uma oração com oi $\delta$ é, traçando uma simetria com oi $\mu \grave{v} v$ de 5.7 W. O sentido, para Pomtow, seria algo como: "Uns deixaram as férteis lavouras de Itome e fugiram; os outros foram escravizados e,

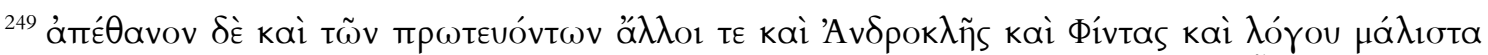

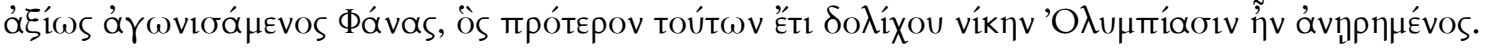
(Também morreram outros líderes: Andrôcles, Fintas, e Fanas, depois de um confronto muito digno de nota. Antes disso, este ainda havia levado nas Olimpíadas o prêmio na corrida de longa extensão.).
} 
como asnos...”. De Falco e Coimbra (1941, p.163) aceitam esta hipótese, conjecturando que tanto o fragmento $5 \mathrm{~W}$ quanto os fragmentos 6 e $7 \mathrm{~W}$ tinham a mesma função: relembrar aos espartanos as vantagens da conquista da Messênia e as duras condições da escravidão às quais os vencidos são submetidos.

A maioria dos editores e comentadores não concorda com esta ligação entre os fragmentos, mas julga possível que tanto $6 \mathrm{~W}$ quanto $7 \mathrm{~W}$ fizessem parte de um mesmo poema ${ }^{250}$, uma vez que o tema de ambos é o mesmo, retratar a punição recebida pelos messênios depois da primeira guerra: enquanto $6 \mathrm{~W}$ trata da exploração econômica que sofreram, $7 \mathrm{~W}$ retrata a sua degradação moral.

As interpretações acerca do poema divergem: Bergk (1882) sugeriu primeiro que o poema é uma demonstração de piedade do poeta para com os vencidos. Jacoby (1918, p.2), Prato (1968, p.79), Gentilli e Perrota (2007, p. 24), por sua vez, acreditavam que o poema tinha uma função exortatória e paradigmática: mais do que apenas uma descrição da sorte reservada aos escravos, o poeta também projetaria, implicitamente, uma advertência ao destino reservado para os próprios espartanos, caso fossem subjugados pelos adversários.

Luginbill (2002, p.410) crê que o poeta relembra a condição degradante dos Messênios com o intuito de incutir em seus interlocutores o sentimento de humilhação com a possibilidade de serem derrotados por inimigos que já foram vencidos antes e encontram-se em situação tão aviltante.

A leitura dos fragmentos de Tirteu pode tornar plausível a hipótese de Luginbill. Na maior parte de seus fragmentos exortativos, Tirteu não exalta apenas a glória da guerra e os benefícios para o soldado que participa dela, mas também sublinha aspectos sombrios e pragmáticos, um traço inexistente na poesia épica (Luginbill 2002, p.410): se o poeta afirma que "Morrer, caído na linha de frente é belo" $(10.1 \mathrm{~W})$ é porque está pensando na conduta oposta, a fuga, que gera pobreza, humilhação e vergonha (vv.3-10):

\footnotetext{
${ }^{250}$ Chegando a editá-los como um único fragmento, como é o caso da edição de Gentilli-Prato (Fr. 5 G-P)
} 


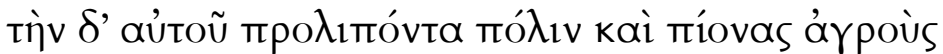

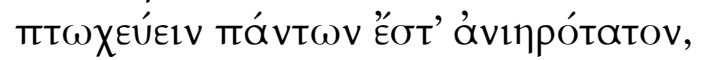

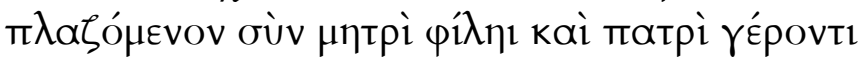

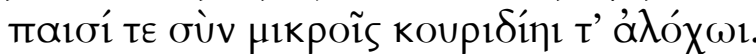
Ė $\chi$ Ө

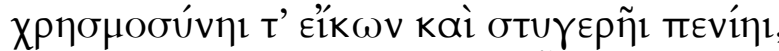

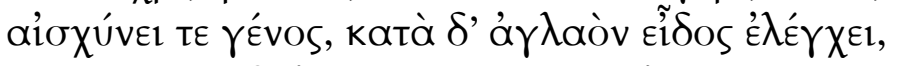

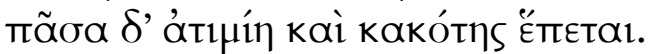

Mas mendigar, deixando sua cidade e férteis campos, de tudo é o mais penoso, vagando com a cara mãe e o velho pai, filhos pequenos e esposa legítima.

Será odioso entre aqueles a quem chegar, pois cede à carência e à pobreza horrível, envergonha a linhagem, vexa a forma esplêndida, e toda a desonra e vileza o seguem.

Não é estranho à poética de Tirteu que uma imagem expressiva seja construída logo em seguida a um argumento para realçá-lo e avivá-lo para a sua audiência. No caso do poema em questão, Tirteu constrói um símile que enfatiza a condição degradante de seus inimigos. A capacidade de criação destas imagens

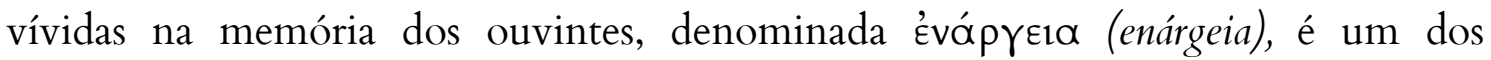
recursos mais profícuos da poesia de Tirteu ${ }^{251}$ : por exemplo, no fragmento $11 \mathrm{~W}$, como já anota Noussia (2010, p. 18), o poeta intercala as suas exortações com descrições vívidas de um guerreiro em plena luta, coberto com seu escudo, agitando a lança e lutando em combate corpo a corpo contra o seu adversário (vv.21-34) ${ }^{252}$. O mesmo se repete em outros fragmentos: em 10.19-20 W a exortação para não fugir da luta e abandonar os anciãos é seguida por uma descrição detalhada da morte vergonhosa sofrida por eles (10.21-26 W).

Segundo Kenneth Sniepes em Literary Interpretations in the Homeric Scholia: the similes of the Iliad (1988, p.208-209), provocar Évápүદia era considerada pelos

\footnotetext{
${ }^{251}$ Ver os comentários ao fr. $10 \mathrm{~W}$

${ }^{252}$ Ver comentários ao fr. $11 \mathrm{~W}$.
} 
antigos ${ }^{253}$ como um dos principais objetivos do símile homérico ${ }^{254}$, e é provavelmente com esse objetivo que Tirteu também o emprega aqui.

Edwards (1991, p.25) distingue duas formas de símile na poesia homérica: uma, breve, que se comporta tal qual um epíteto formular, e outra, estendida - cujo uso é uma especialidade da poesia épica e é raro em Hesíodo e nos Hinos.

O símile estendido consiste em desenvolver um símile breve com uma oração relativa, especificando um ou mais elementos daquela comparação e criando uma espécie de parábola. ${ }^{255}$ Estes símiles longos podem ser de dois tipos: Os símiles pospostos são aqueles que exemplificam algo já exposto pela narrativa, isto é, ocorrem após o referente (Edwards, p.26, aduz o exemplo de Il.17, 262-266). Os símiles prepostos são aqueles em que o símile é introduzido antes do referente, como em Il. 23. 222-224 (Edwards, 1991, p.28).

Nas elegias de Tirteu, há a ocorrência de três símiles, o que, em um corpus escasso como este, poderia sugerir um uso frequente. $\mathrm{O}$ relato de uma corrida de cavalos no fragmento 20. 6-14 W é muito fragmentário, mas provavelmente trata-se de uma comparação entre o universo dos jogos atléticos e o da guerra, uma associação que já se verifica em outros fragmentos (como por exemplo, 12 e 14 W) e que poderia ser comum na poesia de Tirteu. Tratar-se-ia, provavelmente, de um símile posposto inserido em uma narrativa bélica:

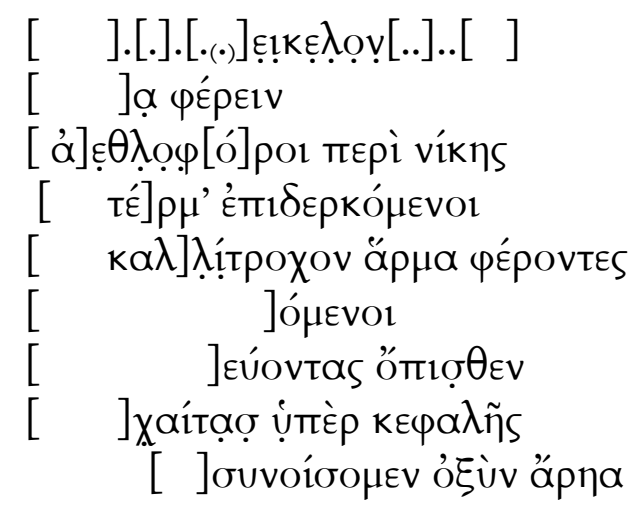

\footnotetext{
${ }^{253}$ Ver Eustácio, I, 270.23-30; Demétrio, Da Elocução, 209.

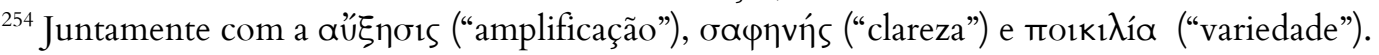

255 Utilizo os termos empregados por Nünlist e De Jong, em Latacz, Ilias Gesamtkommentar:Prolegomena, 2009, que dão o nome de "Gleichnis" ("Parábola") para o símile estendido.
} 
].[.] [. (.)] semelhante [..]..[ ]

](?) levar

[p]rem[i]ados pela vitória

contemplando a [me]ta

conduzindo carro de $[$ bel $]$ as rodas

]$(?)$

] (?) para trás

]as melenas sobre a cabeça

]suportaremos a pungente guerra

Uma metáfora também é registrada por Galeno, na obra Das Doutrinas de Hipócrates e Platão $(3.209$ = fr. $13 \mathrm{~W})$ :

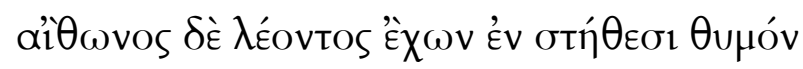

Tendo no peito o ânimo de árdego leão

Apesar de muito exíguo (não sabemos se o verso fez parte de uma narrativa ou de um poema exortativo), o símile do leão é um dos mais comuns na poesia épica militar e usado frequentemente para enfatizar as principais virtudes do guerreiro: a

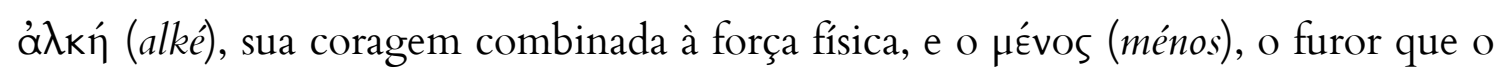
impulsiona ao combate (Ver Clarke, 1995, p. 149). O raro epíteto $\theta u \mu o \lambda \varepsilon ́ o v t \alpha$ é empregado na épica para os combatentes que apresentam o ápice deste vigor combativo, como é o caso de Aquiles e Héracles. ${ }^{256}$ É nesses mesmos termos que o próprio Galeno - que decerto tinha acesso a outras partes do poema - explica o símile (3.309):

\footnotetext{
${ }^{256} \mathrm{Em}$ todas as passagens em que $\theta$ uнo $\lambda$ Éovta ocorre sempre é enfatizada a capacidade destes guerreiros de dizimar sozinhos grandes porções do exército: existe a fórmula de Aquiles, 'A $\chi \imath \lambda \lambda \eta ̃ a$

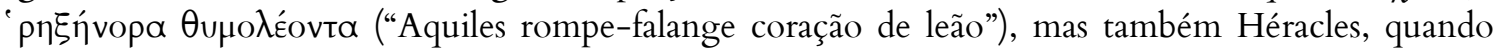
Tlepolemo menciona a desolação provocada pelo filho de Zeus sozinho, na Troia de outrora (Il.5.638-642).
} 


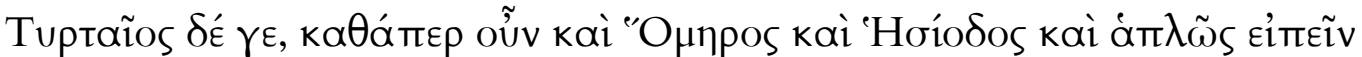

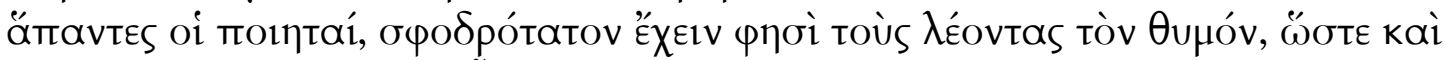

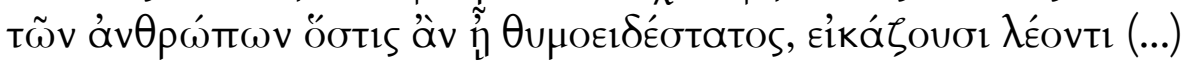

Tirteu, assim como Homero e Hesíodo, e, para dizer de modo simples, todos os poetas, afirmam que leões têm o ânimo mais violento (sphodrótaton), de modo que comparam a um leão o homem que seja extremamente corajoso (thumoeidéstatos).

Nesse sentido, a metáfora do leão no fragmento $13 \mathrm{~W}$ significaria, em termos mais vívidos, o mesmo á $\lambda_{k} ı$ ov $\theta$ unóv que o poeta conclama aos seus interlocutores em outros fragmentos $(10.17 \mathrm{~W}, 10.24 \mathrm{~W})$ e que é uma expressão típica da elegia

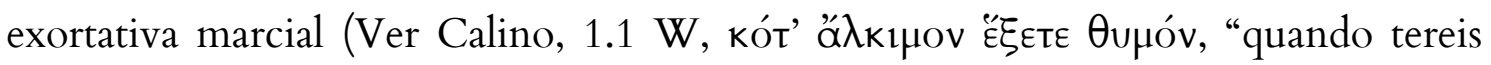
um valente ânimo?").

Bem distinta parece ser a imagem que Tirteu quer evocar no fragmento 6 W. O primeiro verso que temos, um pentâmetro, já introduz o símile:

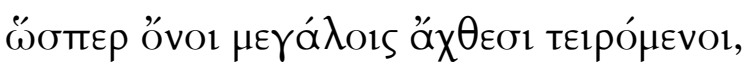

Como asnos, oprimidos por ingentes fardos

Não se sabe o que viria antes deste verso, mas Pausânias informa que o símile

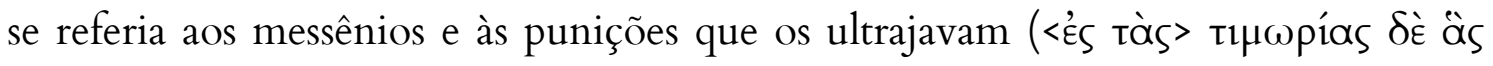

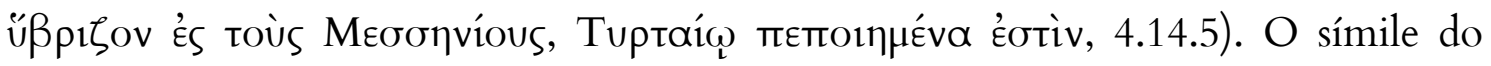
asno é raro na poesia épica e elegíaca do período $\operatorname{arcaico}^{257}$, sendo ele apresentado apenas como um animal de carga resistente a maus tratos, uma característica que compartilha com as mulas (íníovos), cujo epíteto principal na epopeia homérica é

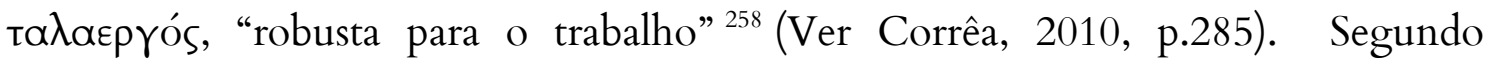
Corrêa (2010, p.288) os textos mais tardios de Pseudo- Luciano (Asinus), Apuleio (Metamorfoses, 7-11) e Artemidoro (1.37) enfatizam o aspecto miserável da vida do asno no campo, que sofre todo o tipo de injustiças como escravo. Essa parece ser

${ }^{257}$ Apenas uma menção em Homero (Il.11.558-566) e uma no corpus elegíaco (Teognideia, 183-185). ${ }^{258}$ Il 23.654, 23.662, 23.666, Od .4.636, 21,23. 
característica que Tirteu quer atribuir aos messênios ao fazer a comparação, e nem tanto a tenacidade e resistência dos asnos, atributos de que Homero se serve para tecer um símile entre Ájax e o animal no Canto XI da Ilíada, vv. 558 - 566. (Ver Corrêa, 2010, p.282-284).

\section{A punição dos messênios (fr.6.2-3 e fr.7)}

A vida de trabalhos incessantes dos Messênios é descrita brevemente nos versos seguintes (vv.2-3), onde o poeta informa que os Messênios eram constrangidos a levar metade do alimento que produziam para seus senhores espartanos. No entanto, a punição aos Messênios não era apenas econômica, mas também moral.

Se os fragmentos 6 e $7 \mathrm{~W}$ fazem parte de um mesmo poema, o que é bem provável, a exploração física sofrida pelos messênios no fragmento 6 serve para realçar o páthos do fragmento $7 \mathrm{~W}$, onde os vencidos são obrigados a prantear publicamente aqueles que os castigam, perdendo assim o restante de sua honra.

Os dois versos restantes conservados por Pausânias relatam esta pena destinada aos escravos, obrigados a comparecer nos funerais de reis e outras autoridades :

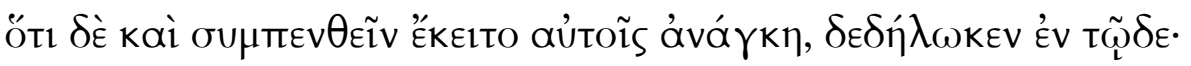

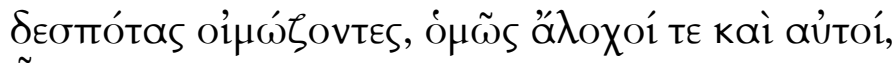

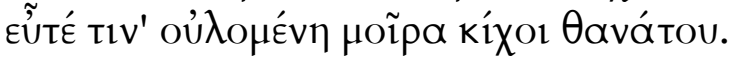

Que a necessidade punha-os a prantear juntos está evidente neste [dístico]:

pelos seus senhores, os homens e as mulheres lamentavam,

Sempre que o destino destrutivo da morte encontrava algum.

Em Esparta, de fato, havia no século V a.C. o costume de que toda uma cidade, tanto seus cidadãos quanto os hilotas, deveriam comparecer aos funerais e guardar luto de seus reis. Heródoto disserta a respeito da cerimônia (6.58. 2-3): 


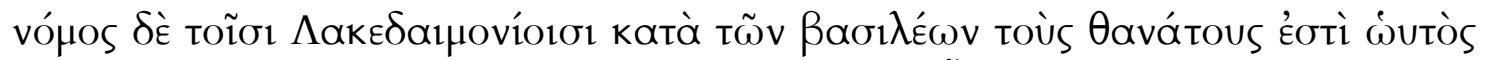

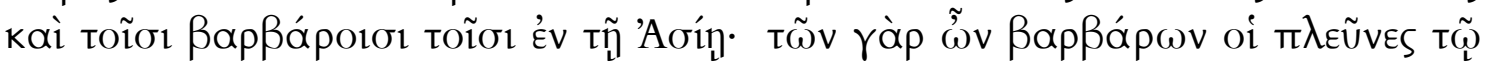

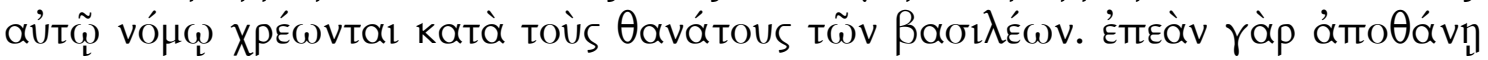

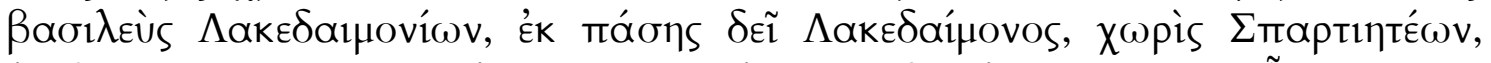

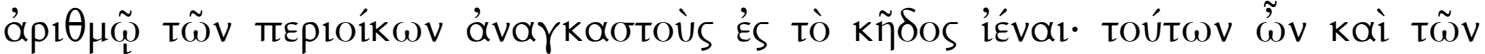

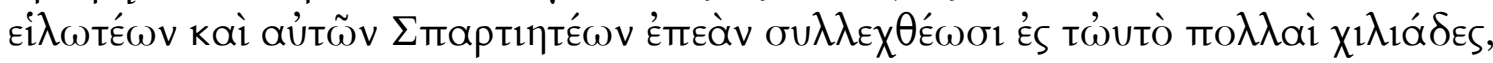

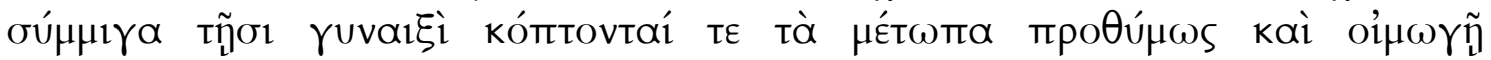

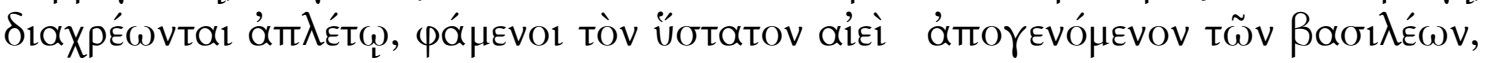

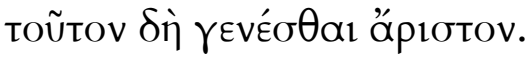

Há um costume (nomos) entre os Lacedemônios com relação à morte de seus reis que é igual ao dos bárbaros da Ásia. De fato, a maioria dos bárbaros utiliza-se deste mesmo costume para com a morte de seus reis. Quando morre o rei dos Lacedemônios, é obrigatório a um número de periecos, provenientes de toda a Lacedemônia, irem ao funeral, além dos espartanos. Quando então milhares desses [periecos], de Hilotas e dos próprios Espartanos estão reunidos no mesmo local, misturados com as mulheres golpeiam a fronte violentamente e se valem de lamentos imensuráveis, falando a cada instante que o falecido último rei havia sido o melhor.

Cecilia Nobili, no artigo "Threnodic Elegies in Sparta" (2011, p. 42), acredita que o depoimento de Heródoto sinaliza para uma prática comum de cantos lamentosos na Esparta arcaica, associados pela autora a uma possível escola de elegias trenódicas. Talvez o próprio Tirteu já tivesse conhecido esta prática, e o verso 28 do

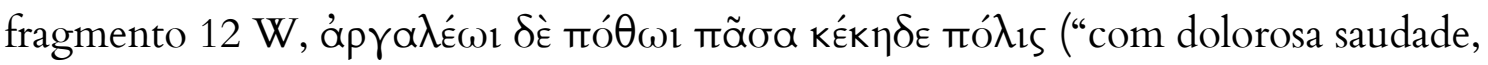
toda a cidade se enluta") não seja somente uma amplificação retórica, mas também um registro deste costume espartano.

Se considerarmos que a Eunomia poderia introduzir discursos em meio a narrações e exortações, não seria estranho supor que o fragmento $7 \mathrm{~W}$ pudesse incluir um lamento aos reis, da mesma maneira que ocorre com o oráculo citado no fr. $4 \mathrm{~W}$.

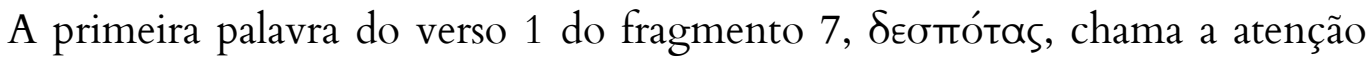
não só por estar em início de verso, mas também por conta do acusativo plural em $\alpha$ 
breve, considerado pela maioria dos estudiosos como dórico. ${ }^{259}$ Como ocorre em outros fragmentos de Tirteu, talvez o uso do dórico seja um efeito estilístico já pretendido pelo poeta, a fim de assinalar a sua poesia como um produto propriamente espartano em um cenário de reperformances pan-helênicas. Não parece ser fortuita a escolha em enfatizar esta palavra, pois outra similar, do fragmento $6 \mathrm{~W}$,

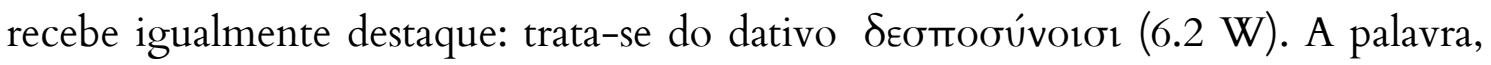
normalmente um adjetivo ("o que pertence aos senhores", "senhorial") exerce neste verso a rara função de substantivo e ocupa toda a parte inicial do hexâmetro até o final do segundo troqueu.

Segue-se um verso pesado, que encerra abruptamente o poema com um tom escuro, graças a assonância de vogais fechadas e à combinação incomum de três

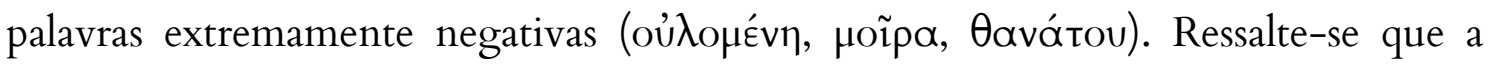

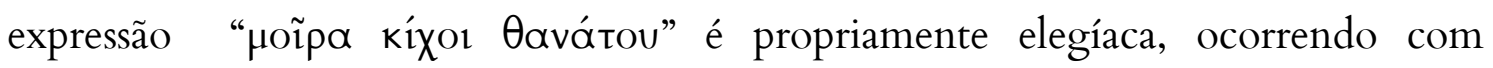
frequência em outros poetas elegíacos: no fragmento 1. $15 \mathrm{~W}$, Calino usa $\mu$ oĩpa Kíxev Aavátou para descrever o soldado que sobrevive à guerra apenas para encontrar a morte em sua casa. Este uso aparenta ser formular, como demonstra o

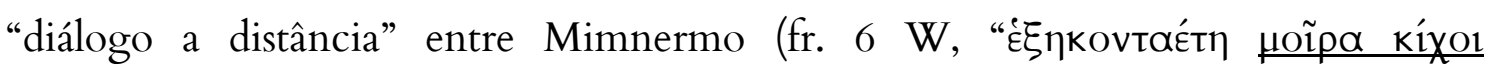

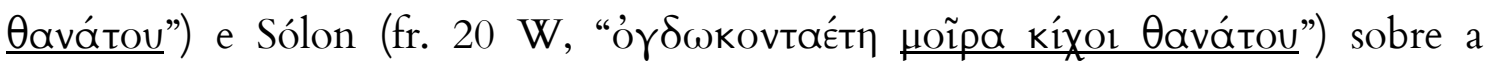

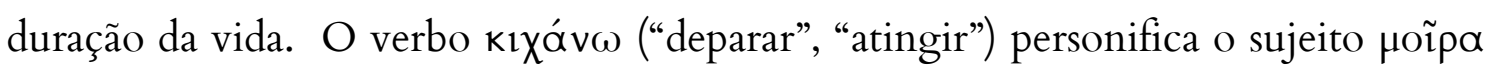
Өavótov, em um processo comum à elegia política e marcial (ver, por exemplo, Sólon, fr.4. 26-28 W).

Destarte, o fato de Tirteu representar nestes versos a violência do domínio espartano sobre os Messênios não seria uma demonstração de piedade para com os vencidos, como pretendeu Bergk, mas antes se insere em um registro do pensamento grego, o de "violência justa" (Ver De Martino e Vox, 1996, p. 553-554, Lloyd-Jones, 1972, p. 55 - 56). A ideia, uma espécie de oximoro moral, é rara na poesia arcaica, mas encontra paralelos: essa seria a explicação mais plausível para a

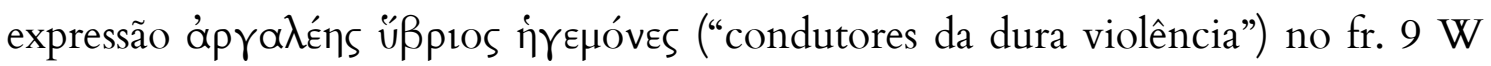

${ }^{259}$ Schwyzer, Grieschische Grammatik I, p. 559 apud Defradas, 1962, p. 28; Gentilli, 2007, p. 25; De Martino \& Vox, p. 554. 
de Mimnermo, utilizada para caracterizar os colonizadores de Cólofon; no fragmento 36 W, Sólon equaciona termos díspares como ßín ("força, violência") e Síkn (vv. 15-17), e os versos 39 a 52 da Teognideia mencionam o tirano como uma punição para a üßpıs da cidade. ${ }^{260}$

Mas talvez a referência mais significativa esteja em Píndaro, que em um de seus fragmentos, alude a esse conceito ao tratar dos trabalhos de Héracles (fr. 169a, vv. $1-5$, Sn $-M)$ :

\begin{tabular}{|c|}
\hline 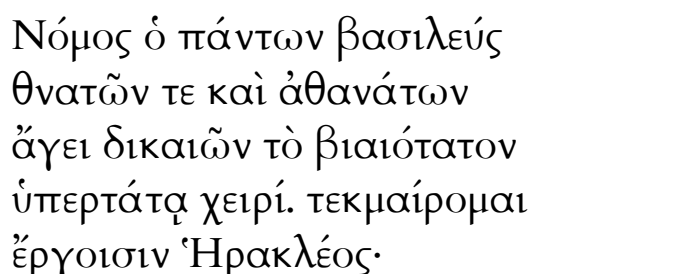 \\
\hline $\begin{array}{l}\text { Nomos, rei de todos, } \\
\text { De mortais e imortais, } \\
\text { rege tornando justa a maior violência } \\
\text { com mão suprema. Comprovo-o } \\
\text { com as proezas de Héracles... }\end{array}$ \\
\hline
\end{tabular}

Outras passagens sobre Héracles parecem frequentemente retratá-lo como um “justiceiro violento": é o caso de Pisandro (Heracleia fr.10 Bernabé: Sikaıotótou Sè povños, "assassino justíssimo") e talvez o Hino Homérico 15, que define os atos

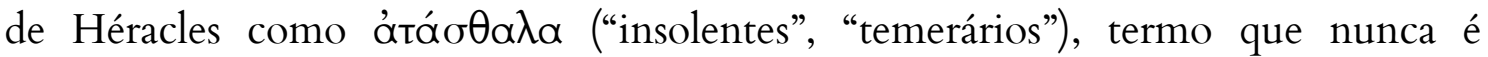
empregado positivamente na poesia hexamétrica grega arcaica. Nesse contexto, a punição infligida aos Messênios adquire tons universais: aos olhos de Tirteu, esta é a consequência justa para todos aqueles que são vencidos na guerra: o exemplo, ao mesmo tempo em que rebaixa o inimigo, serve como alerta para que os próprios espartanos jamais sejam derrotados e caiam em situação igual. É nesses termos que os fragmentos 6 e 7 poderiam inserir-se na Eunomia, pois oferecem um colapso do sistema político delineado no restante do poema (sobretudo no fragmento $4 \mathrm{~W}$ ).

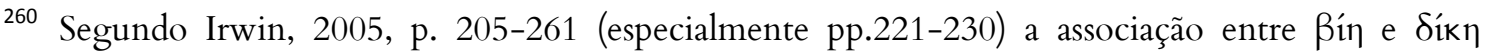
corresponde a uma peculiaridade própria do discurso da tirania.
} 
III . As Elegias Fragmentárias 


\section{Descrições de guerra:}

\section{Os fragmentos $18-23$ a W}

O texto visa a uma consideração sobre os fragmentos $18-23 \mathrm{~W}$ e 23 a W de Tirteu. Em um primeiro momento, a análise ocupa-se de uma consideração acerca da fonte e de sua possível conexão com os demais fragmentos que a constituíam.

Um segundo movimento busca estudar a relação entre o fragmento $19 \mathrm{~W}$ e os fragmentos parenéticos $10 \mathrm{~W}, 11 \mathrm{~W}$ e $12 \mathrm{~W}$, de modo a encontrar similaridades ou diferenças temáticas que contribuam para a compreensão do poema.

\section{O papiro de Berlim e os fragmentos 18-23 W}

Diferente dos demais fragmentos que compõem o corpus de elegias tirtaicas, os fragmentos aqui estudados provém de fontes de transmissão direta. O papiro editado por Martin L. West em Iambi et Elegi Graeci ante Alexandrum Cantati (1991) é oriundo do período ptolomaico, de meados do século III a.C.

West (1974, p.187) explica que restaram três partes do papiro, que apresentam duas colunas de texto - redigidas, como de praxe, em scriptio continua e de extensão desconhecida. Segundo De Falco (1941, p. 150) o assim chamado Papyrus Berolinensis 1175 foi primeiro publicado por Wilamowitz em 1918, que prontamente o atribuiu a Tirteu.

A edição de West distingue seis fragmentos nas duas colunas, que não necessariamente pertenciam a um mesmo poema. A primeira coluna, praticamente ilegível, compõem os fragmentos classificados como $18 \mathrm{~W}, 20 \mathrm{~W}$ e $22 \mathrm{~W}$. Segundo De Falco (1941, p.151), revelam unicamente a forte adesão de Tirteu a um vocabulário comum à tradição épica, aspecto de sua obra já denotado em outros de seus fragmentos: 


\section{Fragmento $18 \mathrm{~W}$}

$[\quad \alpha]_{\gamma} \alpha \lambda \lambda \lambda_{0} \mu \varepsilon^{\prime} \vee \eta$

[ ] ] [a kọ̣ Kpokóevta

desunt versus tres

[ ] $] \underline{u} \underline{u}[. . \cdot \cdot \cdot] .[.] \underline{\underline{y}}$

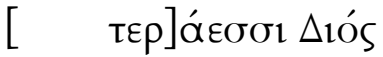

[u]fanando-se (ela) ...

](?) e cróceo...

Faltam três versos

](?)[..(.).] [ ] (?)

aos pre]sságios de Zeus

Fragmento 20 W (= P.Berol, 11675, fr. B col.i)

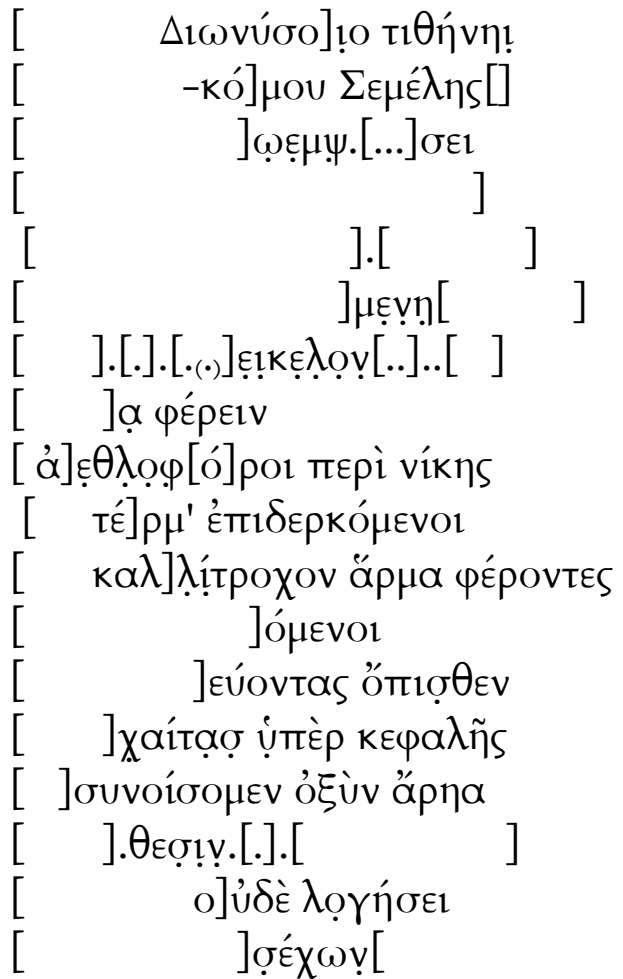

À nutriz de Dioniso,

Sêmele de [ca]belos [

] (?) [...] (?) 
] (?)[

]

].[.] [. (.)] semelhante [..]..[ ]

](?) levar

p]rem[i]ados pela vitória

contemplando a [me]ta

conduzindo carro de [bel] as rodas

](?)

] (?) para trás

]as melenas sobre a cabeça

]suportaremos a pungente guerra

]. (?)[.] [

E n]ão levará em conta (?)

Fragmento 22 (P.Berol 11675. Fr.C. col.i)

[].tov

[]

[]

[]

[ọ!

Os fragmentos $19 \mathrm{~W}, 21 \mathrm{~W}$ e $23 \mathrm{~W}$ pertencem à segunda coluna, mais conservada e com alguns versos mutilados nas extremidades:

\section{Fragmento $19 \mathrm{~W}$ :}

[ ] ].[... ].oo[

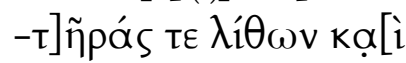

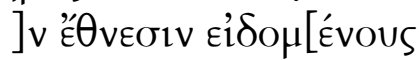

- $\quad \beta p]$ otoגoryòs 'Apпs ak[

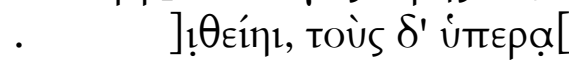

].[.]v Éo1kótes $\eta[$

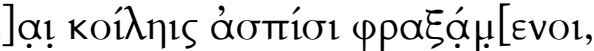

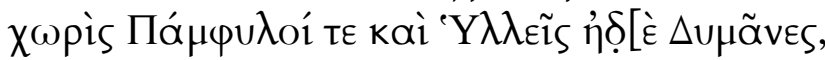

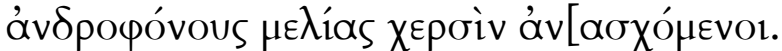

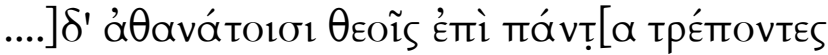

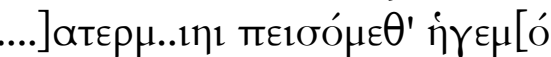

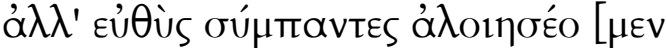


ả]

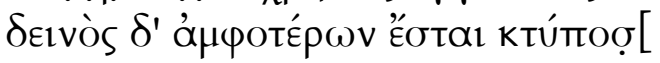

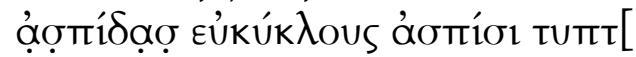

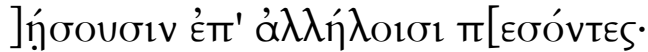

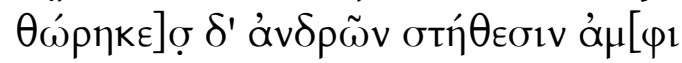

$\lambda$ 入orò]

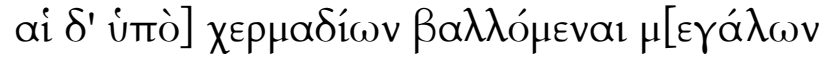

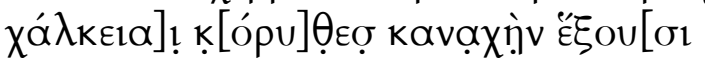

] [.(.).] (?)[

](?), pedras e...

...às tribos semelh[ando-se...]

[ho]micida Ares (?)[

]em linha reta, e aos de cima[

](?) semelhantes à[?]

](?) com os côncavos escudos defende[ndo-se]

à parte Panfílios, Hileos e[Dímanes]

sust[endo] em suas mãos as lanças as[sassinas],

...] a aos imortais Deuses sobretud[o voltando-nos,]

...] sem saída...obedeçamos (aos líderes?)

Mas todos nós diretamente avance [mos

ma[ntendo] próximos aos lanceiros,

... e de ambos serão terríveis...

os escudos, circulares, contra escudos esbaten[do-se]

(?) ...ca[indo] uns sobre os outros:

[as couraça $]_{s}$ em volt [a] do peito dos varões

rompidas, mas escapam com ímpeto da $\mathrm{m}$ [orte

[e os] e[lm] os brônze[os], abatidos [por] gr[andes

pedras, provocar[ão] o estrondo.

Fragmento 21 W (P.Berol 11675, fr. B col.ii)

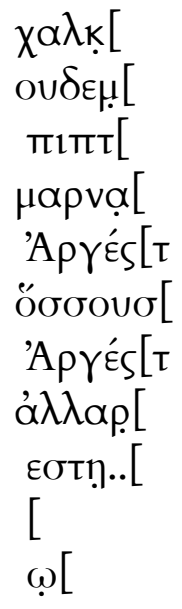




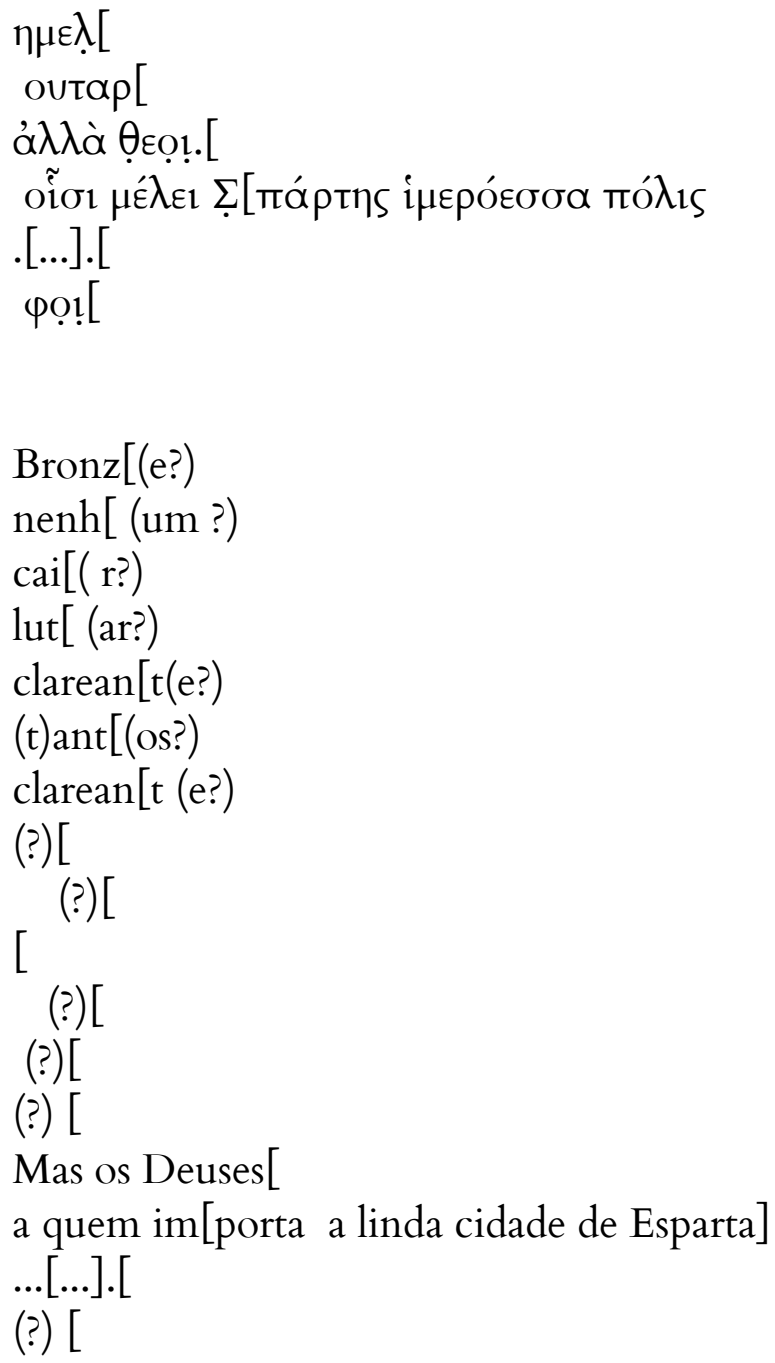

Fragmento 23 (P.Berol 11675, fr.C. col ii)

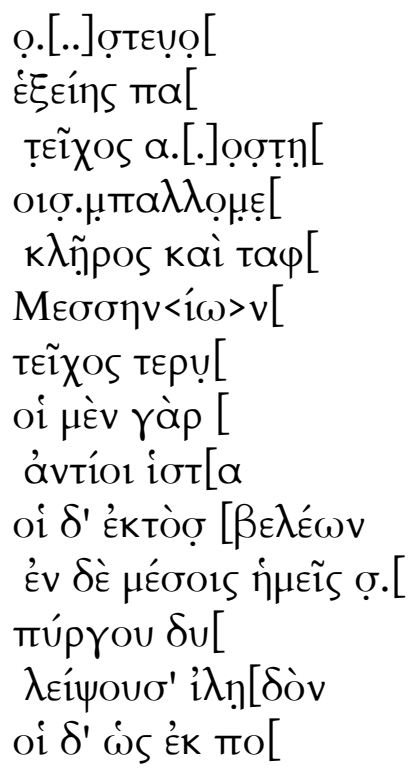


$\mathrm{kU}[.] \mathrm{\alpha} \underline{\mathrm{C}}[$

toĩ 'ike

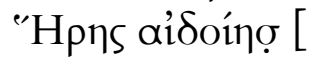

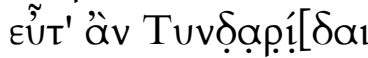

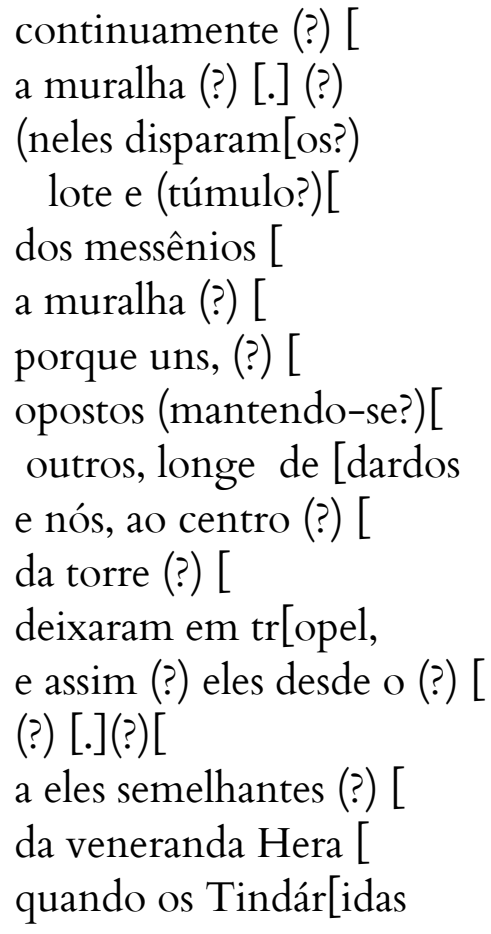

Edições anteriores à de West tendem a restituir estes fragmentos em uma só sequência: é o caso das edições de Gercke (1921), Sitzler (1925) e De Falco (1926), que dispõem o fragmento em seis colunas. Diehl (1949, apud Page, 1951, p. 12) rearranjou os fragmentos de modo a constituir duas colunas de 32 e 31 versos, mesclando resquícios de versos dos atuais fragmentos 18 W e 20 W. Page (1951, p.

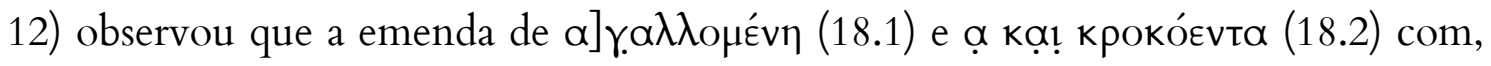

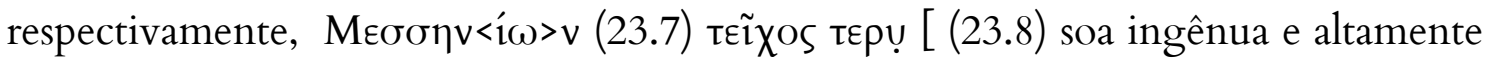
improvável. Nota também que certos versos encaixados como pentâmetros são mais encontrados em inícios de hexâmetros.

West (1974, p. 187), por sua vez, observa que o fr.23 W descreve uma situação de guerra distinta daquela do Fr. $19 \mathrm{~W}$ e $20 \mathrm{~W}$. Enquanto o fragmento 23

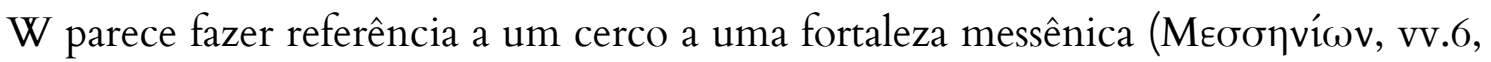

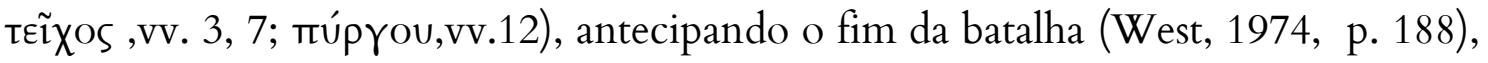


os outros dois narram o combate em pleno andamento. Ademais, se 19 e 20 fizessem parte do mesmo poema, deve-se então inferir uma quantidade excessiva e inadequada de repetições (West, 1974, p.187).

De Falco e Coimbra (1941, p. 154), tomando os seis fragmentos como uma única elegia, consideraram que talvez esta pudesse ser a mais recente das exortações do corpus tirtaico, porque narra as batalhas derradeiras que culminaram na queda e posse de Ira, a fortaleza messênica, o que, como já sugere West (1974, p.187), não se pode concluir devido à exiguidade dos fragmentos.

\section{O Papiro de Oxirrinco 3316 e o fragmento $23 \mathrm{aW}$}

O fragmento 23 a W provém de outra fonte, o Papiro de Oxirrinco 3316, descoberto em 1980. Data provavelmente do século III a.C., e seria uma elegia exortativa que trazia referências a um momento particular da Segunda Guerra da Messênia, a aliança entre Argivos e Arcádios já mencionada no fragmento 8. Sua atribuição a Tirteu - e não a outro poeta elegíaco marcial como Calino, por exemplo - se deve a uma possível referência aos espartanos no verso 21:

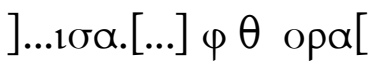

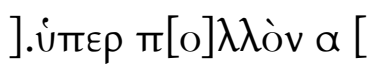

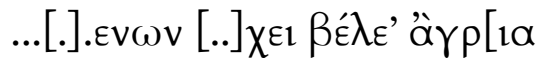

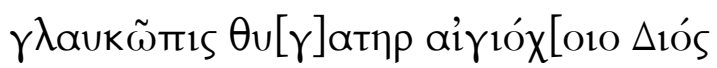

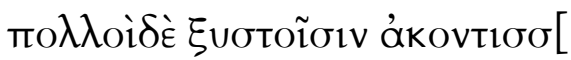

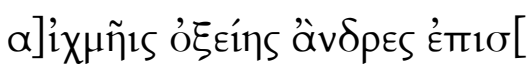

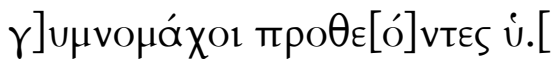

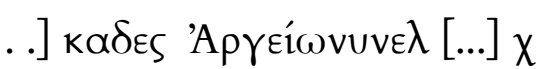

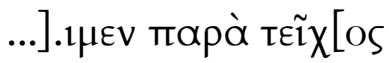

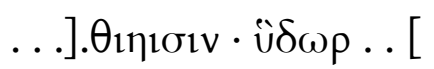

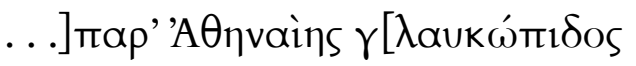

$$
\begin{aligned}
& \text {... ] i }
\end{aligned}
$$




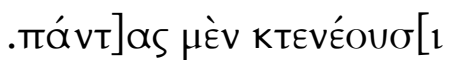

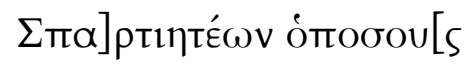

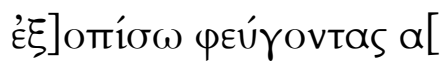

]...(?) [...] (?) [

]. acima $\mathrm{m}[\mathrm{u}]$ ito (?) [

]...[ ] (?) [de]ter(?) os dardos fero[zes...

A fi[l]ha de olhos glaucos de [Zeus porta-égi]de

Muitos com as lanças atir[arão, (?)

varões com [l] anças pontiagudas (?)[

gu] erreiros desarmados corren[do] à frente sob (?)[

](?) Argivos(?) [ ] (?) [

] (?) junto à mur[alha

](?) : água [

]ao lado de Atena de o[lhos glaucos]

](?)[ ] trinche[ira

Matarã $[\mathrm{o}]$ a [tod]os

os espar] tanos quanto[s,

para a retaguarda fugindo, [

O primeiro verso legível menciona "a filha de olhos glaucos de Zeus portaégide"(v.11). Atena é referida em alguns fragmentos de batalha de Arquíloco ( como

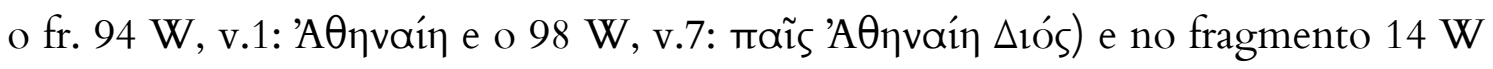
de Mimnermo, uma elegia que poderia ter integrado uma narrativa de batalha e que rememorava um guerreiro valoroso auxiliado pela Deusa ${ }^{261}$. O fragmento também

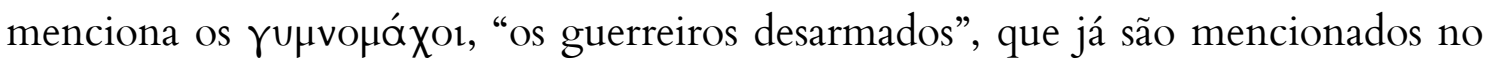
fragmento 11. $35 \mathrm{~W}$. No fr. $23 \mathrm{aW}$, eles são retratados "correndo à frente" (dos Argivos?) e atirando lanças pontiagudas. Sua função parece a mesma desempenhada no fragmento $11 \mathrm{~W}$, mas o texto está muito mutilado para encontrar outras

${ }^{261}$ Ver p.92, para uma tradução deste fragmento. 
informações. Seguem ainda menções a "Argivos”; "muralhas', “água”, e "trincheiras”. Todas essas leituras, porém, são muito incertas. O que é provável supor é que este fragmento, diferente de 18-23 W, não narrava um evento da Primeira Guerra; se dermos crédito à Pausânias (Descrição da Grécia, 4.15-16 = fr.8W), veremos que ele conheceu versos que relatavam uma aliança entre Argivos, Eleios e Pisanos e que o próprio Tirteu teria se retratado nesses versos como general:

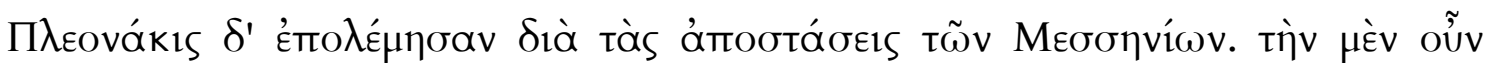

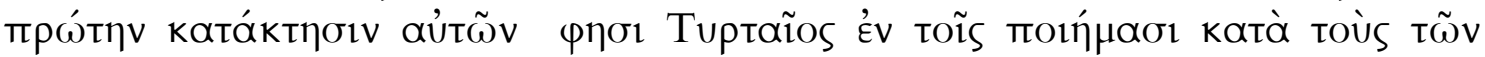

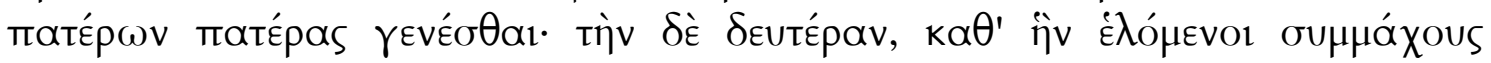

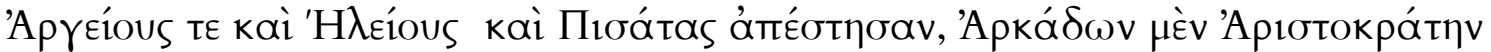

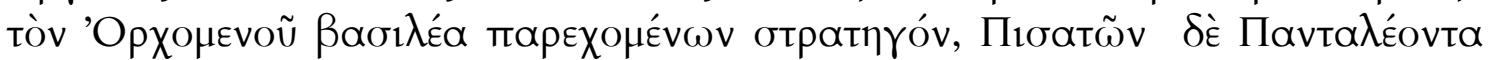

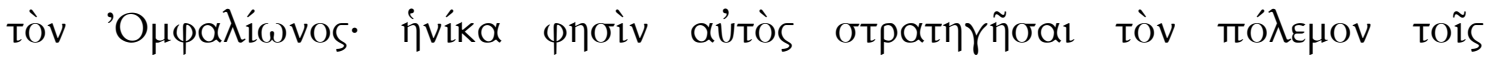

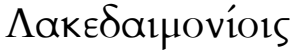

Amiúde fizeram guerra por causa das insurreições dos Messênios. Tirteu diz em seus poemas que a primeira conquista deles ocorreu no tempo dos pais dos pais (fr. 5.6.) A segunda, no tempo em que se revoltaram, tendo escolhido aliados Argivos, Eleios e Pisanos. Os árcades ofereceram Aristócrates, rei dos Orcômenos, como general e os Pisanos [ofereceram] Pantaleão de Onfalion, enquanto pelos espartanos [Tirteu] diz que ele próprio foi o general.

Poderíamos pensar que Tirteu de fato estivesse narrando aqui uma batalha contemporânea, da qual ele próprio participou - o poema, porém, está muito fragmentado para permitir qualquer conclusão. Vale salientar, porém, que uma menção à Atena também ocorre na Eunomia (fr. 2.16W) logo após a menção a Zeus e aos Heraclidas (fr.2 .12-15W), o que torna as hipóteses a respeito da guerra que Tirteu se referiu ainda mais difíceis.

\section{O fragmento $19 \mathrm{~W}$ : uma elegia exortativa?}

Como o fragmento $19 \mathrm{~W}$ se mostra o mais completo dentre os seis (Bowra, 1933, p. 63) pretende-se focar os comentários neste fragmento, fazendo breves alusões aos demais apenas quando necessário. 
O fragmento $19 \mathrm{~W}$ retrata um Eu vislumbrando, em entonação mais ou menos heróica (Irwin, 2005, p. 60), um combate a se travar em um futuro próximo, do mesmo modo que o fragmento 3 W de Arquíloco (West, 1974, p. 187).

Para Bowra (1933, p. 63) pareceu que o poema não era tanto uma exortação ao combate, mas uma exortação à organização das tropas, o que o diferenciava das demais elegias de Tirteu. Tal consideração pode se depreender pelo verso 11, onde o poeta clama por obediência aos líderes. Mas a mistura de exortação ao combate e à organização das tropas em uma mesma elegia apresenta paralelos em outro fragmento de Tirteu. No fragmento 11. 35-38 W, ao concluir a descrição da batalha, o poeta dirige-se às tropas leves e indica-lhes sua posição no campo de batalha, de modo a definir, por contraste, a eminência dos soldados que possuíam a panóplia:

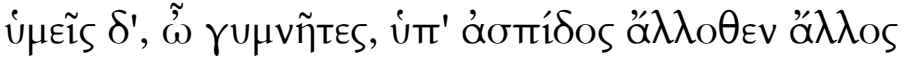

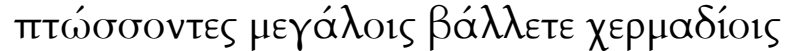

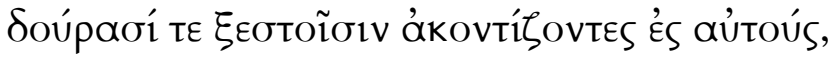

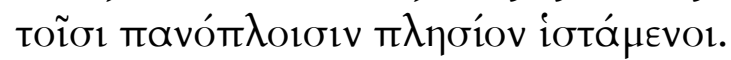

Vós, de armaduras leves, que se agacham aqui e ali sob os escudos, lançai grandes pedras

arremessando polidas lanças contra eles e mantendo-vos perto dos de armadura completa.

Nesse sentido, a partir do que se pode depreender pelos versos que restaram, não parece haver grandes distinções entre o fragmento $19 \mathrm{~W}$ e os demais do corpus elegíaco exortativo de Tirteu.

O que de fato parece ocorrer no contexto do poema é primeiro uma exortação à organização das tropas que enfatiza a marcha destemida dos guerreiros em direção ao combate, avançando em linha reta (v.5) enquanto se defendem com o escudo (v.7) e agitam suas lanças (v. 9). Para Hammond (1950, p. 51) a restituição óv[aoxónєvoı no verso 9 (sugerida primeiro por Diehl 1952, ver Hammond, 1950, p. 50) é "quase obrigatória”, levando-se em conta as palavras que a precedem

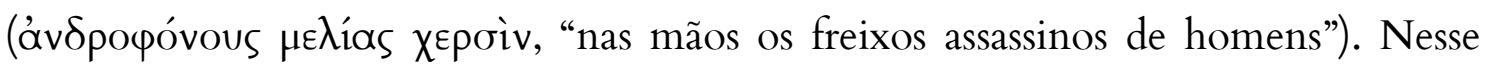
contexto, o verbo ávaơxó $\alpha_{\mathfrak{r}}$ sugere o ato de erguer a lança no momento 
imediatamente anterior ao conflito, de modo a preparar uma investida ou arremessála. O particípio $\varphi p a \xi ̧ a ̣$ ب̣ [Evol (vv.7) sugere também uma ação preliminar à luta, a de defender-se sob o escudo enquanto se vai à frente (Hammond, 1950, p.51), provavelmente para se proteger de projéteis (Ver Tirteu 11. 28-30 W). É evidente que o poeta apresenta uma cena de combate.

Esta imagem é quase tópica na elegia marcial para descrever a ação do guerreiro valoroso no momento inicial do combate. É a ação de se dirigir às linhas de frente do combate, que oferece contraste à fuga. Desse modo também se configuram os versos de Calino 1. 9-11 W:

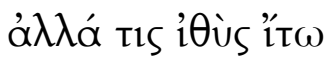

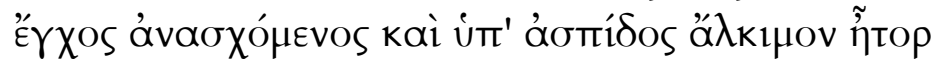

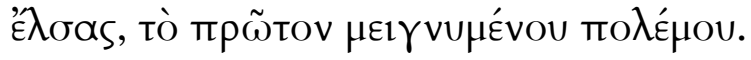

.... Mas que se vá direto

brandindo a lança e resguardando sob o escudo

um valente peito, assim que a luta se mesclar"

E Tirteu 11. $4 \mathrm{~W}$ :

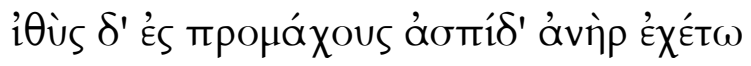

Que o varão, direto contra os dianteiros, sustenha o escudo

Em seguida, o verso 12 introduz a partícula ơ $\lambda \lambda \alpha$ ú um marcador forte na poesia elegíaca marcial, que assinala a passagem entre um argumento e outro, geralmente expressando a transição de uma exortação para a ação para a ação propriamente requerida (Campbell, 1982, p. 171). Assim, com essa partícula, o poeta parece empreender também no fragmento 19 uma transição, e essa transição é a da exortação à marcha e organização das tropas para a exortação e descrição da batalha, que se estende até o verso 20, como já observara West (1974, p. 187).

É cabível sugerir, ainda observando as possíveis similaridades entre

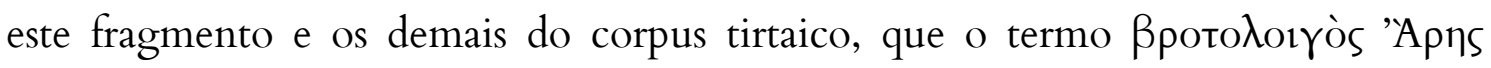
("Ares homicida") no verso 2 parece introduzir um eufemismo comum tanto ao 
gênero épico quanto à elegia marcial, que (geralmente) eleva o objeto de canto a um estatuto superior : o guerreiro que é morto na guerra perece pelas mãos do próprio Deus Ares (Irwin, 2005, p. 68), e torna-se eterno aos olhos de sua cidade, como mostra Tirteu fr. 12.31-34 W:

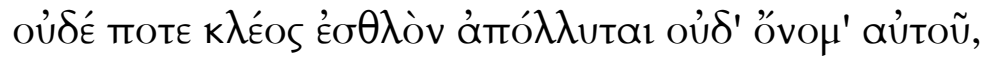

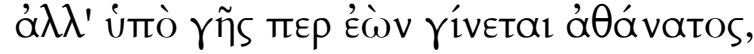

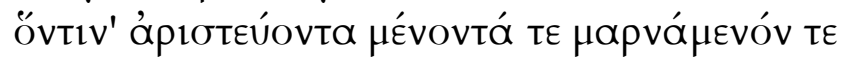

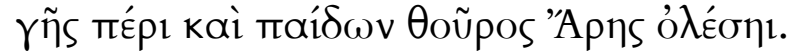

e jamais nobre glória ou o nome dele perecem, mas, mesmo sob a terra, se torna imortal aquele que, primando por manter-se em combate pela terra e pelos filhos, o impetuoso Ares mata.

Segundo West (1974, p.187), os versos 6 ss. constituem uma menção aos hoplitas. Nesse sentido, é possível pensar que o poeta tivesse tratado de segmentos específicos do exército, visando algum efeito expressivo, tal como ocorre também no fragmento $11 \mathrm{~W}$ ?

Se for aceita a restituição ao verso 2 sugerida por Diehl (apud West, 1974,

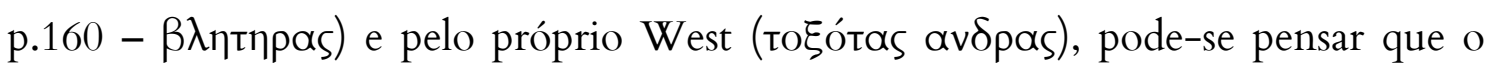
poeta fala a respeito ou se dirige a diferentes grupos do exército, pois antecedendo à descrição dos versos 6-8, que provavelmente aludem ao combate corpo-a-corpo, teríamos o seguinte pentâmetro:

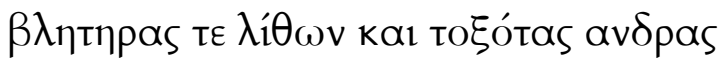

“atiradores de pedras e arqueiros"

A menção da tropa em diversos agrupamentos distintos é, de certo modo, evidente no poema e engendra um recurso que será analisado à frente e já foi observado por Tarditi (1998, p. 173). No verso 8, diz-se que os espartanos lutam 
“à parte Panfílios, Hilíos e Dímanes”. Segundo Wade-Gery (1944 b, p.119-120) o poema é uma prova de que, ainda à época de Tirteu, durante a segunda guerra da Messênia, as unidades do exército espartano eram equivalentes a cada uma das três tribos que constituíam todo o povo dório, cuja descendência provinha de um dos três filhos de Héracles: Pânfilo, Hilo ou Dimas. Hammond (1950, p. 52) aventou a possibilidade de que estes versos fizessem referência a um combate anterior provavelmente à primeira guerra da Messênia e ao modo de luta da geração anterior à de Tirteu - e serviriam assim de exemplo à batalha iminente que se pode entrever nos versos 10 ss. (apud Tarditi, 1998, p.171). Chega a esta conclusão observando que o verbo que integra a oração principal (os versos 6-8) perdeu-se e que estes versos não dependem do futuro $\pi \varepsilon 1 \sigma o ́ \mu \varepsilon \theta \alpha$ (v.11). Tarditi (1983, p. 171) não vê, por outro lado, qualquer impedimento em considerar que os versos se referem a um momento

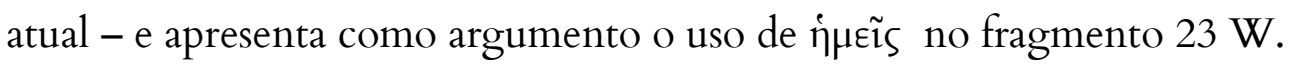

Afora essas considerações, do ponto de vista textual parece haver um recurso expressivo ao partir da descrição do individual (vv. 1-8) para o conjunto unido no

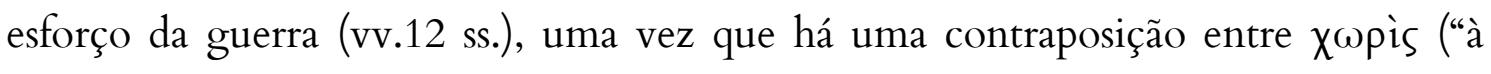
parte”, vv. 8) е бúptravtєs (“todos”, vv. 12) - conforme observa Tarditi (1998, p. 173) - que é evidenciada por ambos serem termos em destaque (escandidos com sílabas longas). Levando em conta que o v.12 poderia marcar uma transição do argumento e adotando as emendas feitas por West, pode-se pensar que o poeta deliberadamente trabalha esta oposição de modo a agregar maior eficiência retórica em sua exortação: os exércitos que lutavam separadamente agora unem forças na iminência da batalha que se avizinha. Tarditi acrescenta, ainda, que o agrupamento do exército em tribos é uma característica do modo de guerra aristocrático (Tarditi, 1998, p.172).

Outro procedimento digno de nota é que todos os verbos que restaram

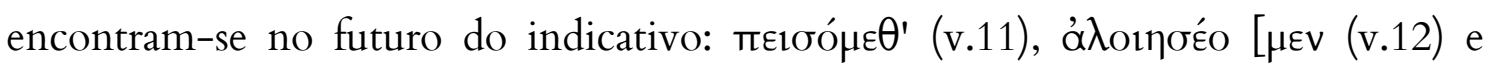

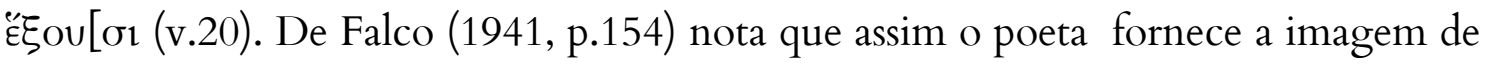
uma batalha aparentemente favorável aos espartanos, aumentando a eficácia de seu discurso. Se pensarmos em termos do simpósio aristocrático, novamente se pode 


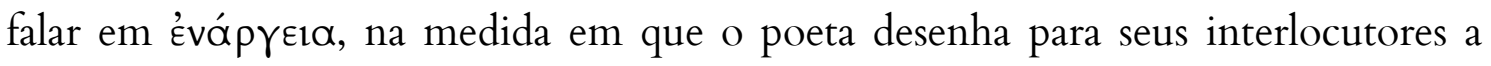
imagem de uma batalha prestes a acontecer.

West (1974, p.187) observa ainda mais similaridades com os demais

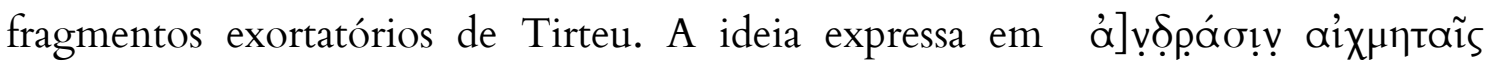

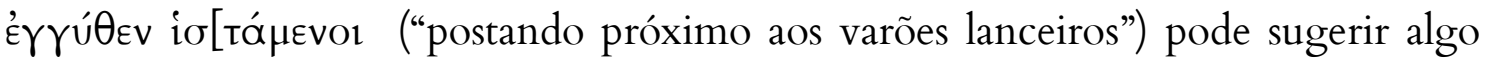
similar ao que ocorre no fragmento $11.38 \mathrm{~W}$ : os guerreiros leves se agrupam sob a guarda dos escudos de seus aliados melhor equipados; ou, em outra chave, poderia sugerir algo semelhante ao fragmento 12. $12 \mathrm{~W}$ : o guerreiro posta-se diante do inimigo e o enfrenta em distância corporal. O fragmento $19 \mathrm{~W}$ poderia, ainda, trazer uma argumentação similar àquela apresentada em 11. $2 \mathrm{~W}$ (que sinaliza a importância dos Deuses no desenrolar de eventos do combate ), caso seja adotada a restituição de West para o verso 10:

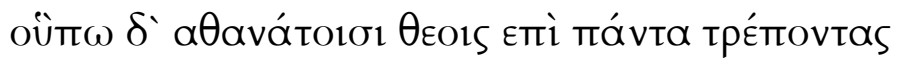

"ainda não confiando tudo aos Deuses imortais"

Conclui-se que, exceto pela utilização do futuro do indicativo (que pode constituir um traço poético interessante), o fragmento $19 \mathrm{~W}$ em nada difere dos demais fragmentos exortativos da obra de Tirteu: há uma vívida descrição da batalha, como em 11.29-35 W ; elementos temáticos da poesia exortativa, como a exortação para avançar à linha de frente (vv. 5-8), permanecer "lado a lado" - seja do amigode-armas, seja do inimigo (v.13) e cenas que parecem enfatizar a morte em combate (vv. 14-20, o epíteto de Ares em 19.2 W).

Pode-se considerar que o uso do futuro constitui mesmo um traço interessante da poética exortativa sob o ponto de vista da prática simposial, embora não haja elementos suficientes para pensar em um tipo de "estratificação heróica", afeita ao simpósio aristocrático (Ver Irwin, 2005, p.29-35), do mesmo modo que parece ocorrer no fragmento $11 \mathrm{~W}$, apenas a partir da divisão do exército e da (aparente) divisão das classes de combatentes. 


\section{CONSIDERAÇÕES FINAIS}

Este trabalho ocupou-se, sobretudo, da tradução e dos comentários dos fragmentos de Tirteu que apresentam exortações ao combate $(10,11,12 \mathrm{~W})$ e dos versos fragmentários que teriam feito parte de um único e longo poema destinado à ocasião pública, denominado Eunomia. Esteve em nosso horizonte sempre contemplar essa poesia do ponto de vista de sua ocasião de performance, um critério fundamental no período arcaico para a definição de um gênero poético (ou tendência composicional, como anota Chris Carey em "Genre, Occasion and Performance", 2009, p. 9).

Como observamos, o caso da poesia de Tirteu ainda é problemático; pois, se por um lado, o simpósio aparece como único espaço para a performance da elegia seguramente atestado, a poesia de Tirteu é frequentemente retratada como um ato de guerra, um discurso proferido diante das tropas com o intuito de exortá-las.

Ao articular a relação entre elegia, simpósio e tradição épica, Elizabeth Irwin em Solon and Early Greek Poetry, The Politics of Exhortation (2005, p 30) apresentou uma proposta interessante: notando que é "claramente impossível” não reconhecer algum tipo de relação entre a poesia épica como representada por Homero, notadamente pela Ilíada, e os versos da elegia marcial, a autora propõe como elo e ligação entre eles a instância de exortação.

Irwin (2005, p.33) sugere uma mudança de foco em relação às correntes anteriores (que julgaram haver um desenvolvimento de conceitos na elegia exortativa em relação à épica) para compreender a dinâmica entre tradição épica, poesia elegíaca militar e o seu contexto histórico-social. Nesse sentido, é necessário enfatizar não as diferenças, mas as similaridades óbvias que norteiam ambas as poesias, e, assim, explorar o que significaria ter apresentado tais similaridades no contexto social demarcado pela ocasião de performance do simpósio.

Observamos que a autora encontra o elo entre ocasião de performance da elegia grega arcaica e a poesia épica nas cenas de banquetes apresentadas na Ilíada e na Odisseia, nas quais são revelados os privilégios e honras heróicas. A audiência do 
simpósio era composta unicamente por indivíduos detentores de privilégios, a saber, os membros da aristocracia. Nesse sentido, o simpósio se identifica com os banquetes da poesia épica, uma vez que os indivíduos que participam de ambos recebem privilégios por conta de seu status.

Estaríamos diante, portanto, de uma audiência exclusiva: não se trata, por exemplo, do espaço público da ágora, onde noções políticas e menções a obrigações civis eram moduladas conforme a ocasião que se apresentava (Irwin, 2005, p.11).

Assim, ao apresentar uma exortação afim à poesia épica no ambiente simposial, o poeta grego, também ele um aristocrata, revela índices de estratificação social que demarcam os privilégios recebidos por essa elite que toma parte do simpósio, visando assim uma identificação entre os bens aristocráticos que eles partilham e os lugares de honra recebidos pelos heróis da epopeia. (Irwin, 2005, p. 29-35). Uma vez que os heróis épicos recebem seus privilégios por serem os melhores dentre os seus e distintos por sua proeminência no combate, Irwin teoriza que ocorre, no âmbito do simpósio, uma ficcionalização de papéis heróicos: são os interlocutores de Tirteu que assumem o lugar dos aristocráticos heróis épicos. Portanto, uma das funções da elegia marcial praticada em âmbito simposial seria, a de asseverar uma identidade heróica aos participantes do simpósio, por meio de uma linguagem em comum com a tradição épica.

Em que medida se verifica tal leitura a partir dos comentários aos fragmentos bélicos de Tirteu?

No fragmento $10 \mathrm{~W}$, se pôde observar uma prescrição de conduta e um juízo valorativo por parte do poeta, de modo a construir um éthos de guerreiros avessos à fuga. Os valores lá apresentados condizem com o mundo da tradição épica, no entanto o cenário onde se desenvolvem era provavelmente o simpósio, como demonstra o vocabulário ambivalente, ético e estético, dos versos 19-30, que em nada deve a poetas elegíacos simposiais :

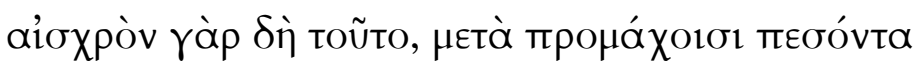

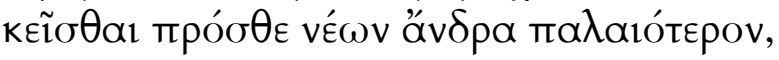




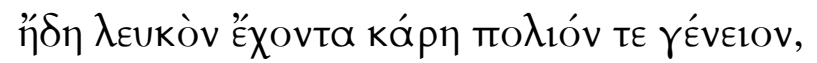

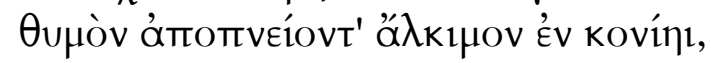

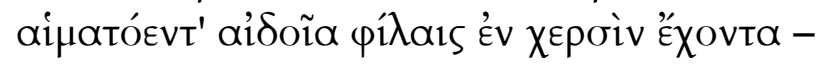

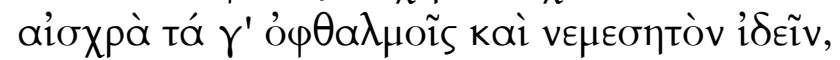

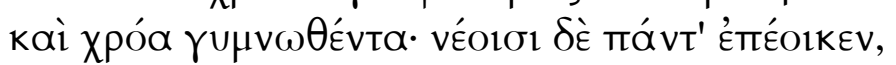

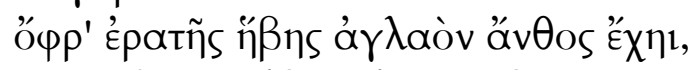

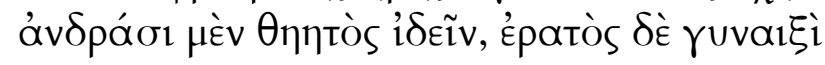

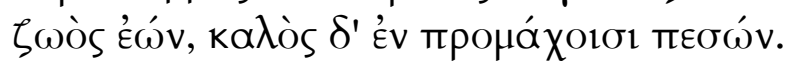

Pois, sim, isto é torpe: na vanguarda caindo, jazer ante aos jovens um varão mais velho, já de cabeça branca e barba grisalha, expirando o valente fôlego na poeira, os ensanguentados genitais nas próprias mãos que espetáculo feio, que visão revoltante! e o corpo despido: mas tudo convém aos jovens enquanto tiverem a flor brilhante da linda juventude: é admirado por homens, por mulheres amado, quando vivo; e belo, se na vanguarda cai.

No fragmento $11 \mathrm{~W}$ examinamos a figura do guerreiro na poesia de Tirteu e pôde-se notar no poema que, independente do estilo ou tática de guerra à qual o poeta alude, há uma exaltação do estatuto guerreiro magnificente de seus interlocutores, chamados "os filhos de Héracles invencível".

Esta exaltação é clara nos versos 35-38, onde uma oposição entre guerreiros

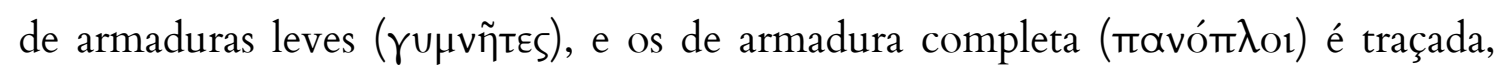
favorecendo os últimos. Nesse sentido, concluímos, que também o fragmento $11 \mathrm{~W}$ poderia trazer uma representação que alude diretamente ao espaço exclusivo do simpósio: Tirteu não trata de qualquer guerreiro em seu poema, mas abre seu poema com uma argumentação calcada na noção aristocrática de $\gamma^{\prime}$ v́os, dirigindo-se a um público aristocrático e exclusivo comum ao simpósio.

É o fragmento $12 \mathrm{~W}$, contudo, que apresenta esse ideário heroico e aristocrático em seu ápice. Observamos, depois de uma breve consideração às fontes e à fortuna crítica, que o louvor à coragem e ao varão valoroso na guerra se dá sobre bases puramente míticas: o guerreiro de Tirteu é retratado quase como um herói de 
estatura épica. Que esse retrato possa estar ligado ao simpósio, sugere-o o modo

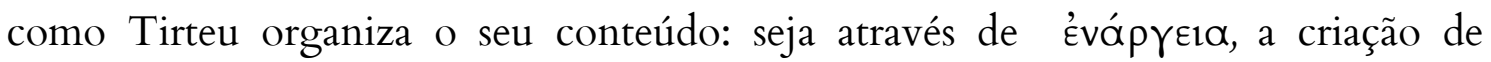
imagens vívidas que presentificam e põem diante dos olhos o guerreiro ideal que o poeta imagina (como demonstram outros exemplos no fragmento 10 e $11 \mathrm{~W}$ ) seja através de uma forma poética típica, o priamel, que revela jogos verbais e agonísticos próprios do simpósio:

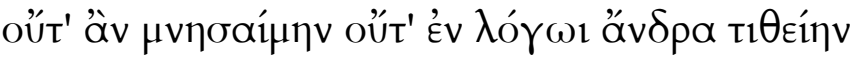

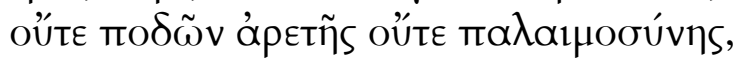

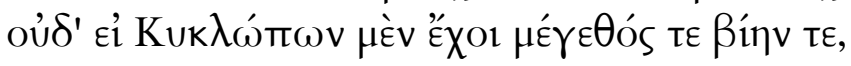

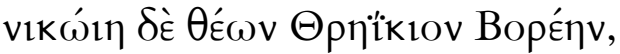

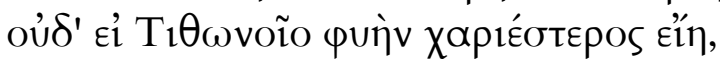

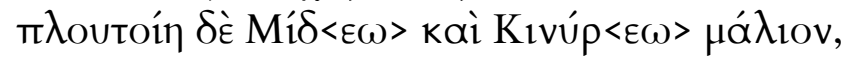

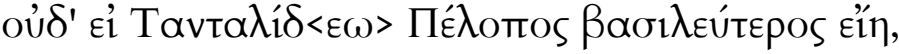

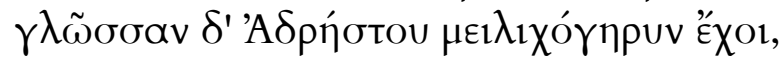

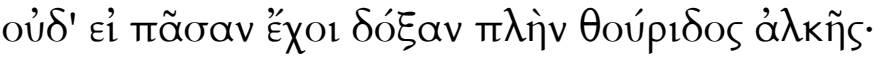

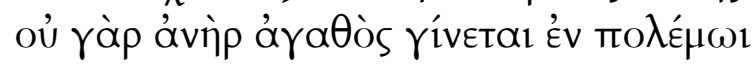

Não me lembraria e em verbo um varão não poria, pela virtude de seus pés ou de sua luta, nem se tivesse altura e força de Ciclopes e em corrida vencesse o trácio Bóreas, nem se tivesse porte mais grácil que Títono, e mais riquezas do que Midas e Ciniras, nem se fosse mais rei que Pélops Tantálida, e tivesse a língua de mel de Adrasto, ou toda a fama, senão a bravura impetuosa; pois um varão não se torna valoroso na guerra

Quanto aos fragmentos atribuídos à Eunomia, analisados na Parte II desse trabalho, a questão é ainda mais complexa. Como foi notado, muitos estudiosos atribuem a esses poemas um caráter cívico e adequado aos festivais públicos da cidade, onde se reforçavam laços de identidade comum entre a população. Tais elegias, segundo E. L. Bowie em "Early Greek Elegy, Symposium and Public Festival" (1986, p. 29-35), seriam de longa extensão e totalmente narrativas. O aspecto 
fragmentário dos versos que nos restaram impede que saibamos sua real extensão ou se entremeavam, às narrações, exortações.

$\mathrm{O}$ fragmento $2 \mathrm{~W}$ parece narrar uma história da fundação de Esparta, tipo de narrativa propício ao festival público e praticado por Mimnermo (ver fr. 9W). Mas notamos aqui que o poeta, do mesmo modo como faz em seus fragmentos exortativos, coloca a aristocracia - representada por Heraclidas - em primeiro plano.

Similarmente, o fragmento $4 \mathrm{~W}$ apresenta, por meio da ficção de um oráculo, os valores norteadores de uma aristocracia vigente e levam em conta por meio de expressões como víknv kaì káptos um forte componente bélico. Sugerimos a hipótese de que se esse fragmento de fato levava em conta um oráculo verdadeiro, um contexto simpótico para ele seria esperado, uma vez que o simpósio constitui-se como lugar de reelaboração, confronto ou ratificação de ditos célebres.

$\mathrm{Na}$ leitura do fragmento $5 \mathrm{~W}$ observamos que Tirteu procede em outra heroicização: dessa vez, não dos guerreiros de seu tempo, como faz no fragmento 12 W, mas de seus ancestrais que venceram a primeira guerra contra os Messênios: louvados por sua resistência, há muitos paralelos que permitem dizer que o poeta os compara a um herói já conhecido via tradição épica, Odisseu.

Os fragmentos 6-7 retratam a servidão dos messênios com uma imagem sombria, que em muito relembra aquela do fr.10. 3-10 W. Na medida em que se opõe ao ideal de Eunomia exposto no fr. $4 \mathrm{~W}$ - onde obediência aos reis confere vitória e poder - a imagem poderia ganhar tons admonitórios.

Pelos temas expostos acima, similares ao dos fragmentos $10-12 \mathrm{~W}$, não é estranho acreditar que os fragmentos da Eunomia poderiam ter sido apresentados em uma mesma ocasião de performance que os fragmentos exortativos. Ambos os grupos de fragmentos exaltam valores aristocráticos, e o principal ambiente para veicular tais valores era o simpósio. Se a Eunomia recebeu, porém, um espaço de performance público, tratar-se-ia de um caso de duplo uso da elegia, que depois teria sofrido reperformances de trechos nos simpósios das póleis. 


\section{REFERÊNCIAS BIBLIOGRÁFICAS}

ACHCAR, F. Lírica e lugar comum, alguns temas de Horácio e sua presença em português. São Paulo: Edusp, 1999.

ADKINS, A,W.H. "Callinus 1 and Tyrtaeus 10 as Poetry" CPh 81, 1977. pp.59-97. . "Homeric Values and Homeric Society" in JHS 91, 1971. pp.1-

14.

- Merit and Responsibility. A Study on Greek Values. Oxford:

Clarendon Press, 1960.

- Poetic craft in the Early Greek Elegists. Chicago and London: University of Chicago Press, 1985.

ADRADOS, F.R. "Sobre la retra de Licurgo, con uma nueva conjetura", in: Emerita 22, 1954, pp. 271-277.

- Liricos Griegos I: Elegiacos y Yambografos arcaicos. Madrid:

Alianza Editorial. 1990.

AHRENS, H.L. "De Hiatu apud Elegiacos Graecorum Poetas Antiquiores” in: Philol. 1848. pp. $223-277$.

ALONI, A. "Elegy: Forms, Function and Meaning" in BUDELMANN, F. (org.) in The Cambridge companion to greek lyric. Cambridge: Cambridge University Press, 2009. pp.168-188. 
ALLEN, T.W. Miscellanea - IX. in: CQ 26, 1932.p.87.

ANDREWES, A. Eunomia in: CQ 32, no.2, 1938, pp.89-102.

ANDERSON, J.K. Hoplites and Heresies: a note. in JHS 104, 1984, p.152.

ANÉE, M. “La mémoire oubliée: perspectives poétiques de l'élégie chez Tyrtée.” In Camenulae 1, Paris/Sorbonne: Université Paris-Sorbonne. 2006.

ARISTOTLE. Athenian Constitution, Eudemian Ethics,Virtues and Vices. Trad. H.Rackham. Cambridge: Harvard University Press, 1935.

, LONGINUS, DEMETRIUS. Aristotle: Poetics, Longinus:On the Sublime, Demetrius: On Style. Trad. W.R.Roberts. Cambridge: Harvard University Press. 1995.

ASSUNÇÃO, T.R. Morte nas elegias de Arquíloco, Calino e Mimnermo (comentários a Arquíloco Fr.5W e $13 W$, Calino $1 W$ e Mimnermo $1 W$ e $2 W$ ). São Paulo: 1989. Dissertação (DLCV/FFLCH/USP).

"A morte política em Tirteu" in: Kleos 1. Rio de Janeiro: Editora da UFRJ. 1997. p.33-46.

. "Ação divina e construção da trama nos Cantos I e II da Ilíada" in: Letras Clássicas 5. São Paulo: FFLCH/USP, 2001. pp.63-77.

ATHENAEUS. The Deipnosophists I. Books 1 - 3.106e. Trad. C.B.Gulick. Cambridge: Harvard University Press. 1927. . The Deipnosophists VI. Books 13-14.653b. Trad. C.B.Gulick. 
Cambridge: Harvard University Press. 2009.

BACH, N. Callini Ephesi, Tyrtaei Aphidnae, Asii Samii, carminum quae supersunt. Leipzig: 1831.

BAILLY.Dictionnaire grec-français. Paris:Hachette, 2000.

BERGK, T. Poetae Lyric Graeci - II. Leipzig: Teubner, 1882.

BLOK, J.H; LARDINOIS, A.P.M.H. Solon of Athens, new historical and philological approaches. Leiden/Boston: Brill, 2006.

BOWIE, E.L. "Ancestors of Historiography in Greek Elegiac and Iambic Poetry?" in: LURAGHI, N (org.) The Historian Craft in the Age of Herodotos. Oxford: Oxford University Press. 2001. pp. 45-66.

. "Early Greek Elegy, Symposium and Public Festival" in JHS 106, p.13-35, 1986.

. "Greek Table-talk before Plato" In: Rhetorica 11, 1993.

. "Historical Narrative in Archaic and Early Classical Greek Elegy" in KONSTAN, D, RAAFLAUB, K. (org) Epic and History. Chichester/Malden: Blackwell. 2010.

"Miles Ludens? The Problem of Martian Exhortation in Early Greek Elegy" in MURRAY, O. (org.) Sympotica. A Symposium on the symposium. Oxford: Oxford University Press, 1990, p. 220-229. 
. "Wandering poets, archaic style" in: HUNTER, R; RUTHERFORD,

I. Wandering Poets in Ancient Greek Culture: Travel, Locality and PanHellenism. Cambridge/New York: Cambridge University Press, 2009.

BOWRA, C.M. "Earlier Lyric and Elegiac Poetry” in: BARBER, E., POWELL, J.U.(org.). New Chapters In The History of Greek Literature - third series.,Oxford: Clarendon Press. 1933.

. Early Greek Elegists. Cambridge: Cambridge University Press, 1938.

BROWN,C. "On the 'correct' understand of eu diabas: a reply" in $A J P h$ 106, no.4 1985. pp. 453-457.

BUDELMANN, F. (org.) The Cambridge companion to greek lyric. Cambridge: Cambridge University Press, 2009.

BULLOCH, A. Callimachus, the Fifth Hymn. Cambridge: Cambridge University Press. 1985.

CAIRNS, D.L. Aidôs, The Psychology of Honor and Shame in Ancient Greek Literature. Oxford: Oxford University Press. 1993.

CAMPBELL, D.A. Greek Lyric Poetry: a selection of early greek lyric, elegiac and Iambic poetry. Bristol: Classical Press. 1982.

CAMPOS, H.(trad.) Ilíada. São Paulo: Arx. 2002. 2 vols.

CARTLEDGE, P.A. Agesilaos and the Crisis of Sparta. London: Duckworth, 1987. 
- "Hoplites and Heroes: Sparta's Contribution to the Technique of Ancient Warfare” in JHS, vol. 97, p.11-27. 1977.

- Sparta and Lakonia: a regional history 1300-362 BC. London,

New York: Routledge, 1979.

CAREY, C. "Alcman: from Laconia to Alexandria” in: ATHANASSAKI L, BOWIE, E. (org) Archaic and Classical Choral Song, De Gruyter, 2010.

- "Genre, Occasion and Performance" in: BUDELMANN, F. (org.)

The Cambridge companion to greek lyric. Cambridge: Cambridge University Press, 2009.

CHANTRAINE, P. Dictionaire étymologique de la langue grecque. Paris: Klincksieck, 1999.

CICERO. Tusculan Disputations. Trad. E.J.King. Cambridge: Harvard University Press, 1927.

CLARKE, M. "Between Lions and Men: Images of the hero in the Iliad" in GRBS 36.2, 1995, pp. 137-159.

COMBELLACK, F. (Review: kampfparanese, kampfdarstellung und kampfwirklickeit in der "illias" bei Kallinos und Tyrtaios by Joachim Latacz) in: CPh 77, 1982, pp. 62-65.

CORRÊA, P.C. Armas e Varões, A Guerra na Lírica de Arquíloco. São Paulo: Editora da UNESP. 2009. 2.ed.

. Um Bestiário Arcaico, Fábulas e Imagens de Animais na poesia de 
Arquíloco. São Paulo: Editora da Unicamp, 2010.

D’ALESSIO, G.B. "Defining local identities in greek lyric poetry" in: HUNTER, R; RUTHERFORD, I. Wandering Poets in Ancient Greek Culture: Travel, Locality and Pan-Hellenism. Cambridge/New York: Cambridge University Press, 2009. pp.137-167.

. "Sull'epigramma dal Polyandrion di Ambracia” in: ZPE 106. 1995.

pp.22-26.

DAVIES, M. (ed.). Poetarum Melicorum Graecorum Fragmenta. Oxford: Clarendon Press, 1991.

DE FALCO V., COIMBRA, A.(ed., trad. e comentários). Os elegíacos gregos: de Calino a Crates. São Paulo, 1941.

DEFRADAS, J. Les Élegiaques Grecs. Paris: Presses universitaires de France, 1962.

DE JONG, I, NÜNLIST R. Homerische Poetik in Stichwörtern in: LATACZ, J. Homers Ilias, Gesamtkommentar: Prolegomena. Berlin: De Gruyter. 2009. pp. 159-173.

DE MARTINO, F., VOX, O. Lirica greca II: lirica iônica. Bari: Levante, 1996.

DENNISTON, J.D. The Greek Particles. Oxford: Oxford University Press. 1934.

DIEHL, E. (ed.) Anthologia Lyrica Graeca. Leipzig: Teubner. 1952.

DIOGENES LAERTIUS. Lives of Eminent Philosophers - I. Books 1-5. Trad. R.D.Hicks. Cambridge: Cambridge University Press, 1925. 
DOVER, K.J. "The Poetry of Archilochus" in: Entretiens sur l'antiquité Classique, Fondation Hardt X. Genève, 1964, p.183-212.

EASTERLING, P. E. \& KNOX,B.M.W. (ed). The Cambridge History of Classical Literature. Cambridge : Cambridge University Press, 1985, p. 129-136.

EDWARDS, M. The Iliad, A commentary - $V$. Cambridge: Cambridge University Press. 2002.

FARAONE, C. The Stanzaic Architecture of Early Greek Elegy. Oxford: Oxford University Press, 2008.

FENNO, J. "A Great Wave Against the Stream: Water Imagery in Iliadic Battle Scenes" in: AJPh 126. 2005. pp.475-504.

FORD, A. "Odysseus after dinner: Od.9.2-11 and the traditions of sympotic song" in: KAZAZIS, J.N; RENGAKOS, A (org.) Euphrosyne: Studies in Ancient Epic and its Legacy in honor of Dimitris N. Maronitis, Stutgart: Verlag, 1999.

FORREST, W.G. "The Date of the Lykourgan Reforms in Sparta", in Phoenix 17, 1963. pp.157-179.

FOWLER, R. L. The Nature of Early Greek Lyric: Three Preliminary Studies. Toronto: University of Toronto Press, 1987.

FRÄNKEL, E. Early Greek Poetry and Philosophy. Trad. M.Hadas e J.Willis. Oxford: Blackwell, 1975. 
FRIEDLÄNDER, P. , HOFFLEIT, B.H, Epigrammata: Greek Inscriptions in Verse, From the Beginnings to the Persian Wars. Berkeley: University of California Press, 1948.

FRIEDLÄNDER, P. “A New Epigram by Damagetus” in AJPh. 1942. pp. 78-82.

GENTILI, B. Epigramma ed Elegia. In: Entretiens sur l'antiquité Classique, Fondation Hardt XIV. Genève, 1967, p.37-82.

, PRATO,C. (ed.). Poetae Elegiaci: Testimonia et Fragmenti. Leipzig: Teubner. 1988.

. Poetry and its public in ancient Greece: from Homer to the fifth century. Trad. A.Thomas Cole, Baltimore: The John Hopkins University Press, 1988. , Perrota, G. Polimnia, Poesia Greca Arcaica. Firenze: G D’Anna. 2007.

GERBER, D. A Companion to Greek Lyric Poets. Leiden: Brill, 1997. . (trad.). Greek Elegiac Poetry. Cambridge : Harvard University Press, 1999.

GIGANTE, M. “Tyrtaeus poeta non felix”. in: RFIC. 1961. pp.234-238.

GOLDHILL, S. "Intimations of immortality: fame and tradition from Homer to Pindar” in: Poet's Voice: Essays on Poetics and Greek Literature, Cambridge: Cambridge University Press. 1991. pp. 69-166. 
GRAY, V. (ed. e estudo). Xenophon, On Government. Cambridge: Cambridge University Press, 2007.

GREENHALGH, P. "Patriotism in the Homeric world" in Historia 21. 1972, pp.528-537.

GRETHLEIN,J. The Greeks and Their Past: Poetry, Oratory and History in the Fifth Century BCE. Cambridge/New York: Cambridge University Press, 2010.

HAINSWORTH, J.B. "Tyrtaeus and Homer" in: CR. Cambridge: Cambridge University Press, 1972.

HAMMOND, N.G.L. "The Lycurgean Reforms at Sparta." In: JHS 70, 1950 pp. $42-64$

HARVEY, A.E. “The Classification of Greek Lyric”. CQ 5, 1955. pp.157-75.

HEINRICH, C.H. (ed.) Lycurgi Oratio in Leocratem. Bonn: C.von Bruck, 1821.

HELM, J. "Koros: from satisfaction to greed" in: $C W$ 87, 1993. pp. 5-11

HERODOTUS. The Persian Wars III, Books V-VII. Trad. A.D.Goodley, Cambridge: Harvard University Press, 1999.

HESIOD. Theogony, Works and Days, Testimonia. Trad. G. Most. Cambridge: Harvard University Press, 2007.

HIGHBARGER, E.L. Literary imitation in the Theognidea. In: $A J P h, 50,1929$. pp. 341-359 
HODKINSON, S. "Social Order and Conflict of Values in the Classical Sparta" in WHITBY, M. Sparta. Edinburgh: Edinburgh University Press. 2002.

., POWELL, A. (org.) Sparta: new pespectives. Swansea: The Classical Press of Whales, 2009.

HOMER. The Iliad - I. Books I-XII. Trad. A.T.Murray. Cambridge: Harvard University Press. 1975.

. The Iliad - II. Books XIII-XXIV. Trad. A.T.Murray. Cambridge: Harvard University Press. 1975.

. The Odyssey - I. Books I-XII. Trad. A.T.Murray. Cambridge: Harvard University Press. 1975. . The Odyssey - II. Books XIV-XXIV. Trad. A.T.Murray. Cambridge: Harvard University Press. 1975.

HORACE. Satires, Epistles and Ars Poetica. Trad. R. Fairclough. Cambridge: Harvard University Press. 1929.

HUNTER, R; RUTHERFORD, I.Wandering Poets in Ancient Greek Culture: Travel, Locality and Pan-Hellenism. Cambridge/New York: Cambridge University Press, 2009.

IRWIN, E. Solon and Early Greek Poetry, The Politics of Exhortation. Cambridge: Cambridge University Press. 2005.

ISHIZUKA, V.M. Teógnis: a Voz de Megara. Kléos, Nêmesis e Phília. São Paulo: 2002. Dissertação (DLCV/FFLCH/USP). 
JACOBY, F. "Studien zu den älteren griech. Elegikern A. Zu Tyrtaios." In: Hermes 53, 1918. p.1-44.

JÄGER, W. Paidéia: a formação do homem grego. Trad.Artur M. Parreira. São Paulo: Martins Fontes, 1995.

. "Tyrtaeus on True Arete" in Five Essays. Trad. Adele Fisk. Montreal: Mario Casalini, 1966.

KIRBY, J.T."Toward a general theory of the Priamel" in: CJ 80, 1984. pp.142-144.

KLOTZ, Ch. A., $\quad$ Tyrtaei quae supersunt omnia, coll., commentario ilustr., edid. Altenburgi, 1767.

LAFER, M.de C.N. (trad. e estudo ) Hesíodo, Os trabalhos e os dias (primeira parte). São Paulo: Iluminuras, 1989.

LIDDEL,H.G; SCOTT, R., JONES,S. Greek-English Lexicon with a revised supplement. Oxford: Clarendon Press. 1996.

LINDO, L. "Tyrtaeus and Horace Odes 3.2" in AJPh 66. p.258-260.

LLOYD-JONES, H. The Justice of Zeus. Berkeley: University of California Press. 1983.

LORIMER, H. The Hoplite Phalanx, with Special Reference to the Poems of Archilochus and Tyrtaeus in ABSA, 1947, p.76-149.

LOURENÇO, F. (trad.) Ilíada. Lisboa: Livros Cotovia, 2006. 
LUGINBILL, R.D. Tyrtaeus 12 West: Come Join The Spartan Army. In: CQ 52.2,2002. 405-414.

MACEDO, J. A palavra ofertada, um estudo dos hinos gregos e indianos. São Paulo:Editora da Unicamp, 2010.

MACQUEEN, B.D. "On the correct understanding of Eu diabas" in: $A J P h$, Vol.105 nº 4. 1984. 453-457.

MARTIN, R. The Language of Heroes. Speech and Performance in the Iliad. Cornell: Cornell University Press, 1989.

MAURIZIO, L. "Delphic Oracles as Oral Performances: Authenticity and Historical Evidence" in ClAnt, 1997. p.308-334.

McGLEW, J.F. Tyranny and political culture in ancient Greece. Ithaca/ London: Cornell University Press, 1993.

MORRISON, A.D. The narrator in Archaic greek and Hellenistic poetry. Cambridge: Cambridge University Press. 2007.

MURRAY, O. (org.) Sympotica. A Symposium on the symposium. Oxford: Oxford University Press, 1990, p. 220-229.

NAFISSI, M. Sparta in: RAAFLAUB, K. Van Wees, H. (org.). A Companion to Archaic Greece. Oxford: Blackwell, 2009.

NAGY, G. "Ancient Elegy" in WEISSMAN, K. Oxford Handbook of Elegy. Oxford: Oxford University Press, 2009. 
. The best of the Achaeans: concepts of the hero in archaic greek poetry.

Baltimore: John Hopkins University Press. 1999.

. "Poetry and the Ideology of the Polis: The symbolism of Apportioning meat" in NAGY, G. Greek Mythology and poetics. Cambridge: Harvard University Press. 1990.

NAUCK, J.A. Tragicorum Graecorum Fragmenta. Leipzig: Teubner, 1892.

NOBILI, C. "Threnodic Elegy in Sparta" in GRBS 51. 2011. pp. 26-48.

NOUSSIA, M. Lo Stilo Semplice di Tirteo? In: CHIRON, P.; LEVY, C. (org.) Les noms du style dans l'antiquité gréco-latine. Louvain/Paris/Walpole: editions peeters, 2010. pp.11-24

OGDEN, D. "Crooked speech: the genesis of the Spartan Rhetra" in: JHS 114 (1994), pp. 85-102.

OSBORNE, R. Greece in the Making 1200 -479 B.C. London: Routledge. 1996.

PAGE, D.L. "The Elegiacs in Euripides" In: Greek Poetry and Life. Oxford: Clarendon Press, 1936, p. 206-230

(ed.) Poetae Melici Graeci. Oxford: Oxford University Press, 1962.

(Resenha de Diehl, E. Anthologia Graeca) in CR 3-4, 1951. pp.105-107. 
PARRY, H. (Resenha de Prato, Tirteo. Introduzione, texto critico, testimonianze e commento.). AJPh 91, 1970. p.498-500.

PLATO. Laws - I. Books 1 - 6. Trad. G.S.Bury. Cambridge: Harvard University Press. 1926.

PLUTARCH. Lives - I, Theseus and Romulus, Lycurgus and Numa, Solon and Publicola. Trad. B.Perrin. Cambridge: Harvard University Press.1967.

PRADO, A.A. (estudo e trad.) Tucídides. História da Guerra do Peloponeso. Livro I. São Paulo: Martins Fontes, 1999.

PRATO, C. (ed. e estudo). Tirteo. Introduzione, testo critico, testimonianze e commento. Roma:Edizioni dell' Ateneo. 1968.

PUCCI, P. "Il testo di Tirteo nel tessuto homerico". in: ROSCALLA, F. (ed.) L' autore e l'Opera: Attribuzioni, appropriazioni, apocrifi nella Grecia antica. Pisa, 2006.

QUATROCELLI, L. "Sparta Convivialità a Sparta Arcaica, Nuove Prospettive di studio" in Cahiers Du Centre Gustave Klotz, 13, 2002. pp.7-32.

. "Tirteo e la Retorica dell'elite" in AION XXX. 2008. pp.7-22.

QUINTILIAN. The Orator's Education - IV. Books 9-10. Trad. D.A.Russell. Cambridge: Harvard University Press. 2002.

RAAFLAUB, K. “Athenian and Spartan Eunomia or: what to do with Solon's timocracy?” in BLOK, J.H; LARDINOIS, A.P.M.H.(org.). Solon of Athens, new historical and philological approaches. Leiden/Boston: Brill, 2006. 
"Homer to Solon: the Rise of the Polis" in: HANSEN, M.H. (org.). The Ancient Greek City-State. Copenhagen: Munkssgaard, 1993. pp.41-105.

RACE, W.T. The Classical Priamel from Homer to Boethius. New York: Brill, 1982.

RAGUSA, G. Fragmentos de uma deusa: a representação de Afrodite na lírica de Safo.São Paulo: Editora da Unicamp, 2005.

Lira, mito e erotismo: Afrodite na poesia mélica grega arcaica. São

Paulo: Editora da Unicamp, 2010.

REITZENSTEIN, R. Epigramm und Skolion. Gissen: Rickersche Buchandlung, 1893.

ROCHA JR., R. A. O Perì Mousikês de Plutarco: tradução, introdução e notas. Campinas, 2007. (Tese IEL-UNICAMP).

RÖSLER, W. "Mnemosyne in the symposium" in: MURRAY, O. (org.) Sympotica. A symposium on the symposium. Oxford: Oxford University Press, 1990. pp.230-237.

RUTHERFORD, I. Wandering Poets in Ancient Greek Culture: Travel, Locality and Pan-Hellenism. Cambridge/New York: Cambridge University Press, 2009.

SCHWARTZ, E. “Tyrtaeos” in: Hermes 34, 1899. pp.428-468.

SCHULHOF, J.M. “Callinus and Tyrtaeus” in: CR 14, 1900. p. 103-106. 
SCOTT, J.A. (Review: Homer und die altionische elegie by Dietrich Muelder) In: CPh 3, 1908.

SLINGS, S.R. "Symposion and Interpretation: Elegy as group-song and the socalled awakening individual”, in: AantHung 40: 423-434, 2000. pp.423-434.

SMYTH, H.W. Review: Harrison on Theognis. in: CR 17, 1903. pp. 352-356.

SNELL, B. The Discovery of Mind. New York: Dover Publications. 1982. , MAEHLER, H. (eds.) Pindarus - pars altera: fragmenta. Leipzig: Teubner. 1964.

SNIEPES, K. Literary Interpretation in the Homeric Scholia: The Similes of the Iliad Kenneth Snipes. AJPh, 1998. pp. 196-222.

SNODGRASS, A.M. "The Hoplite Reform and History" in: JHS 85. 1965. p.110122.

SPIRO, F. (ed.), PAUSANIAS. Graecia Descriptio. Leipzig: Teubner. 1903.

STEVENS, P.T. Euripides. Andromache Edited with Introduction and Commentary. Oxford: Clarendon Press, 1971.

STEHLE, E. Performance and Gender in Ancient Greece. Princeton: Princeton University Press, 1997.

STRABO. Geography - IV. Books 8-9. Trad. H.L.Jones. Cambridge: Cambridge University Press, 1927.

TARDITI, G. Parenesi e areté nel corpus tirtaico. In: RFIC 1982. pp. 257-276. 
. "Tirteo: momenti di uma campagna di guerra" (1983) in: Tarditi, G.

(org.). Studi di poesia greca e latina . Milano: Vita e pensiero, 1998. pp.167-182.

TEDESCHI, G. L'elegia parenetica-guerriera a Il simposio. In: RSC 26, 1978. pp.203209.

THUCYDIDES. The History of Peloponnesian War - III. Books 5 - 6. Cambridge: Harvard University Press. 1921.

TORRANO, J.A.A. (trad.) “O Certame Homero- Hesíodo.” in: Letras Clássicas 9. São Paulo: FFLCH/USP, 2005. pp.215-224.

. (estudo e trad.) Hesíodo. Teogonia: a origem dos deuses. São

Paulo: Iluminuras, 2006. 6 ed.

.(estudo e trad.) Ésquilo. Tragédias. São Paulo: Iluminuras. 2009.

TREU, M. "Der Schlussatz der Grossen Rhetra” in: Hermes 76. 1941. pp. 22-42.

VAN WEES, H. Greek Warfare: Myths and realities. London: Duckworth, 2004

. "The homeric way of war and the hoplite phalanx (I)" in: G\&R 41.1, 1994. p.1-18.

. "The homeric way of war and the hoplite phalanx (II)" in: GER 41.2, 1994. p.135-155

. "Tyrtaeus Eunomia: Nothing to do with the Great Rhetra" in:

HODKINSON,S. \& POWELL, A. (org.) Sparta: new pespectives. Swansea: The 
Classical Press of Whales, 2009.

VERDENIUS, W.J. “Callinus 1: a Commentary.” in Mnemosyne 25, 1972. p.1-8. . Tyrtaeus 6-7 D: a Commentary. in Mnemosyne 22, 1969. p.337-355.

VERNANT, J-P. “A Bela Morte e o Cadáver Ultrajado” in: Discurso 9, 1979. p.3162.

VERRALL, A.W. “Tyrtaeus, a Graeco-Roman Tradition” in: CR 10, 1986. p.269277.

VETTA, M. "Il Simposio: la monodia e il giambo" in CAMBIANO, G., CANFORA, L. LANZA, D. Lo Spazio Letterario Della Grecia Antica I - La Polis. Roma: Salerno Editrice. p.177-218. . (ed.) Theognis: Elegiarum Liber Secundus. Roma: Edizioni dell'Ateneo. 1980.

VIRGÍLIO. A Eneida brasileira. Campinas : Editora da Unicamp, 2008.

WADE-GERY, H. “The Spartan Rhetra in Plutarch, Lycurgus VI.B" - The Eunomia of Tyrtaios. CQ 38, 1944a. pp.1-9.

- "The Spartan Rhetra in Plutarch, Lycurgus VI.C - What is Rhetra?" CQ 38, 1944b, pp.115-126.

WECOWSKI, M. "Homer and the Origins of Symposion" in MONTANARI F. (org) Omero tremila anni dopo. Atti del congress di Genova, Roma, 2002. pp.337-361. 
WEST, M.L. "Archilochus and Tyrtaeus” in CR 20 n.2. 1970. pp. 147-151. . (trad.) Greek Lyric Poetry. Oxford: Oxford University Press. 1994. . Greek Metre. Oxford: Clarendon Press. 1996. . “Greek poetry 2000-700 B.C” in CQ, 23 pp.179-92, 1974. . (ed). Iambi et Elegi Graeci ante Alexandrum Cantati. Oxford: Oxford University Press. 1992. v.2. . The Making of the Iliad. Oxford: Oxford University Press. 2011. - (Resenha a Gerber, D. Greek Iambic Poetry. From the Seventh to the Fifth Centuries BC; Greek Elegiac Poetry. From the Seventh to the Fifth Centuries BC ) in: CR 50, n.2 2000. p.402-403. Studies in Greek Elegy and Iambus. Berlin: Walter de Gruyter, 1974. 


\section{ANEXO}

Texto Grego e Tradução dos Fragmentos de Tirteu

\section{Fragmento 1 - 4 W “Eunomia”}

\section{Fragmento $1 \mathrm{~W}$ ( = Aristóteles, Política, 1306b7)}

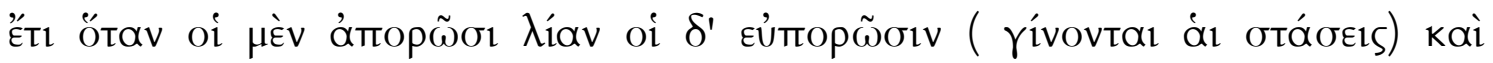

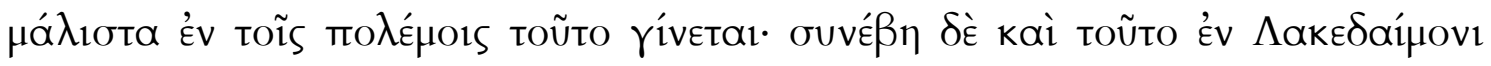

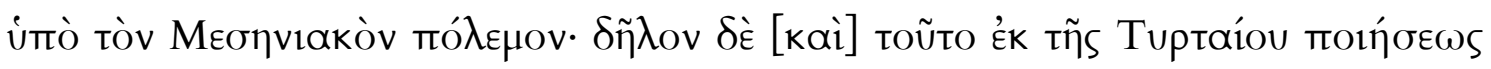

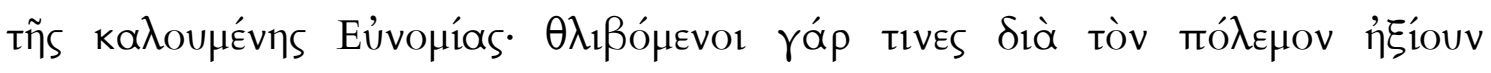

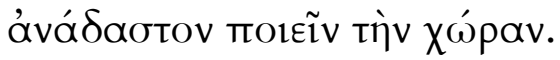

Ainda quando alguns estão demasiadamente sem recursos e outros prosperam (acontecem as sedições). Isso acontece, sobretudo, nas guerras: ocorreu também na Lacedemônia, durante a guerra messênica. Isso [ também] faz-se manifesto pelo poema de Tirteu, denominado Eunomia. Pois alguns, oprimidos por causa da guerra, achavam digno fazer uma redistribuição de terras.

Fragmento 2 W (Papiro Oxy.2824)

]...v!!...

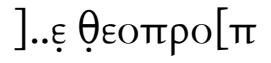

$$
\begin{aligned}
& \text { ]......vvak[ }
\end{aligned}
$$

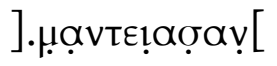

] 


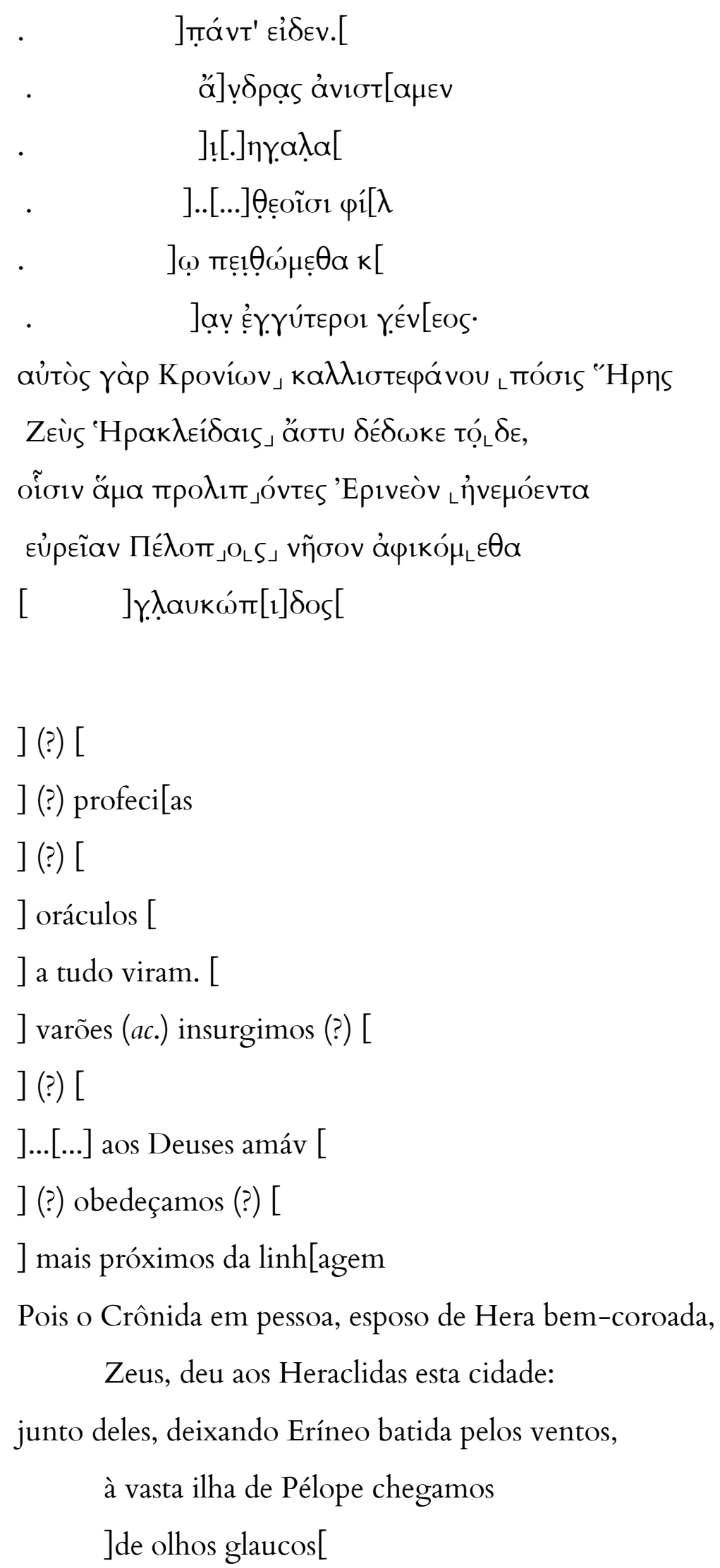

] (?) [

] (?) profeci[as

] (?) [

] oráculos [

] a tudo viram. [

] varões (ac.) insurgimos (?) [

] (?) [

]...[...] aos Deuses amáv [

] (?) obedeçamos (?) [

] mais próximos da linh[agem

Pois o Crônida em pessoa, esposo de Hera bem-coroada,

Zeus, deu aos Heraclidas esta cidade:

junto deles, deixando Eríneo batida pelos ventos,

à vasta ilha de Pélope chegamos

]de olhos glaucos[

12- 15 Estrabão, Geografia, 8.4.10 


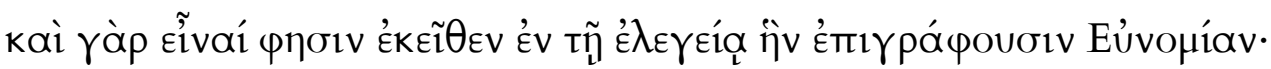

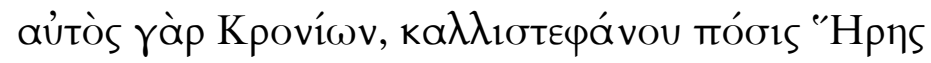

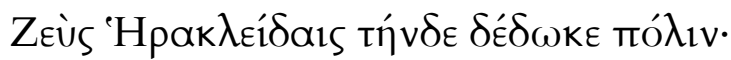

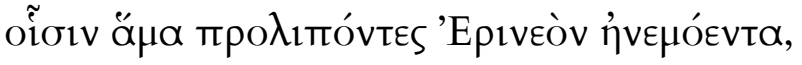

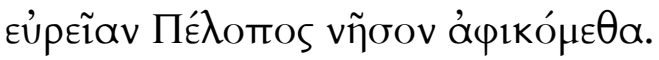

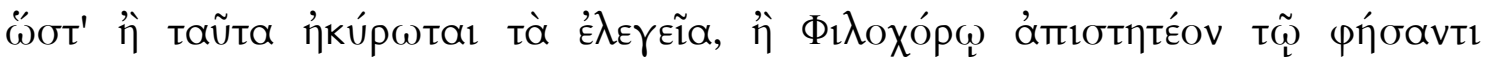

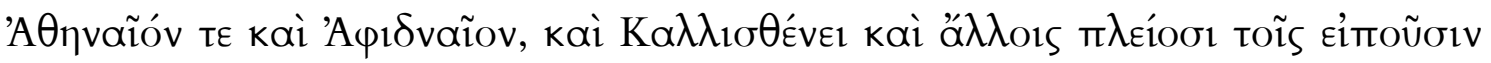

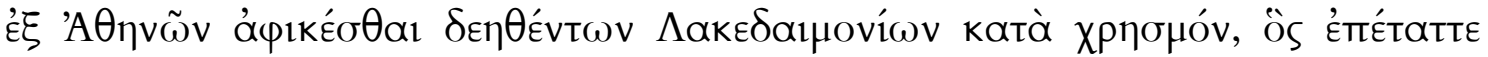

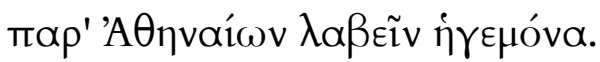

De fato, dizem que ele é dali (sc. da Lacedemônia), na elegia que intitularam como Eunomia:

Pois o Crônida em pessoa, esposo de Hera bem-coroada

Zeus,deu aos Heraclidas esta cidade:

junto deles, deixando Eríneo batida pelos ventos,

à vasta ilha de Pélope chegamos

De maneira que, ou esta elegia é espúria, ou deve-se desacreditar Filocoro (328 F 215), que o declara ateniense e de Afidna, e também Calístenes (124 F 24) e a maioria restante, que dizem que ele veio de Atenas porque os Lacedemônios precisavam dele, segundo o oráculo que lhes ordenou obter um comandante junto aos atenienses".

\section{Fragmento $4 \mathrm{~W}$}

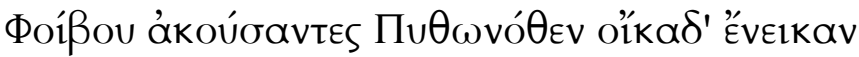

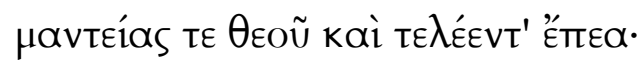




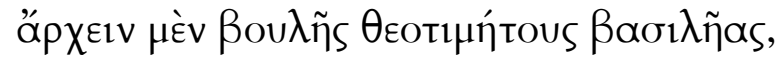

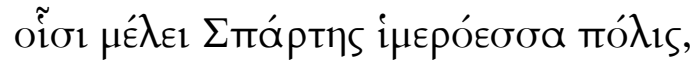

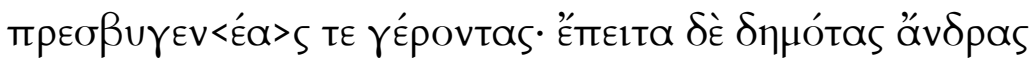

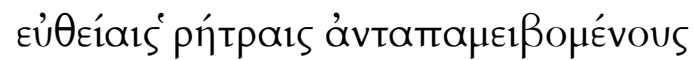

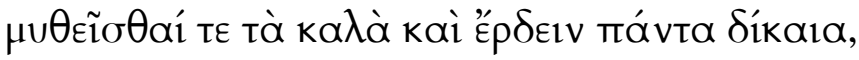

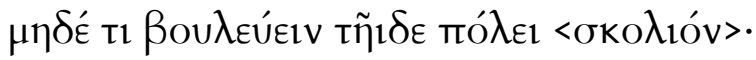

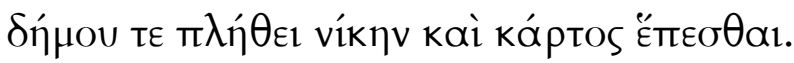

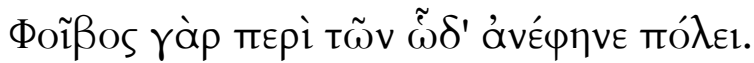

Febo escutaram, e de Pito ao lar levaram as profecias do Deus e as palavras certas: que dirijam o concílio os reis honrados por Deuses,

a quem importa a linda cidade de Esparta, e os primevos anciãos: depois homens do povo,

por sua vez, respondendo às retas sentenças pronunciem ditos belos e ajam com justiça em tudo e não deem a cidade conselho < oblíquo> para que vitória e poder sigam as massas.

Sobre isso, eis o que Febo revelou à cidade.

$$
\text { 1- } 6 \text { Plutarco, Licurgo } 6
$$

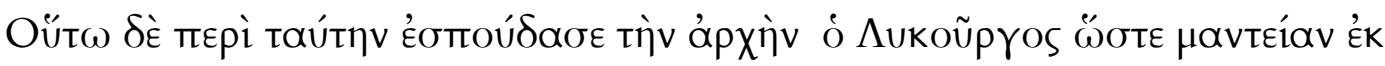

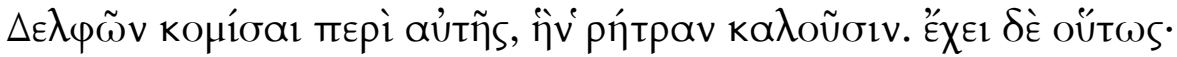

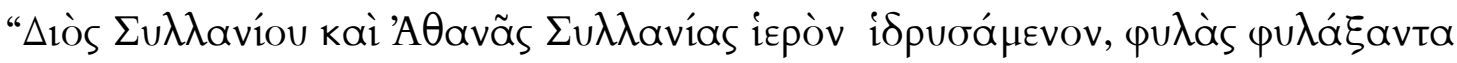

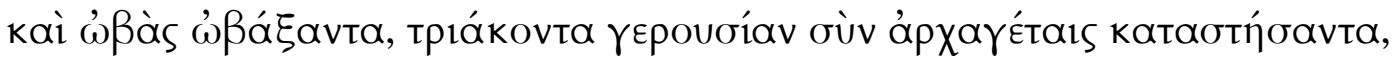

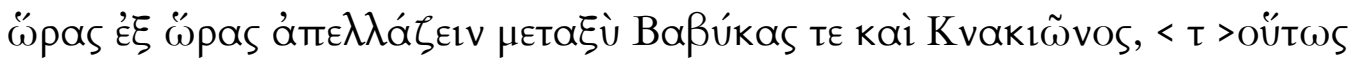

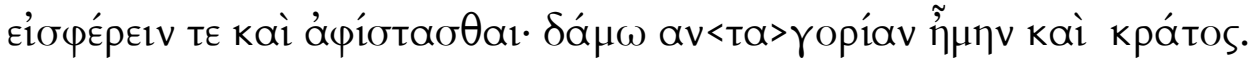




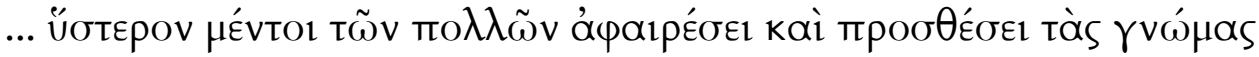

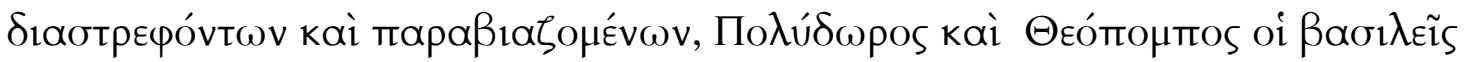

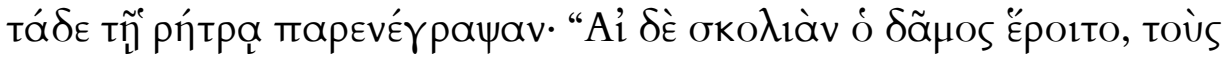

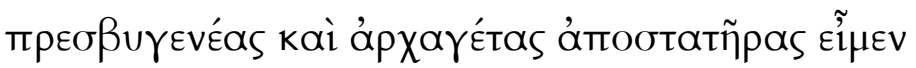

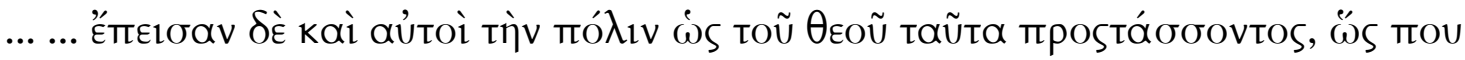

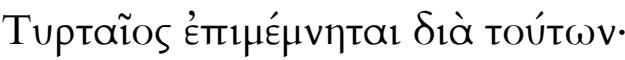

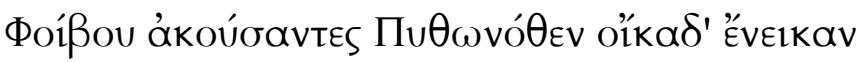

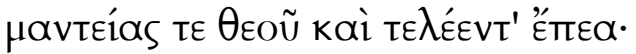

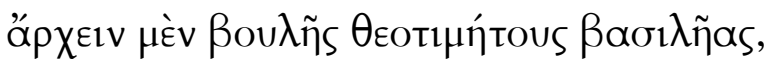

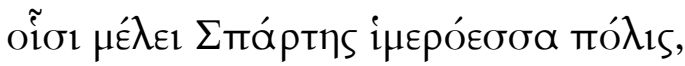

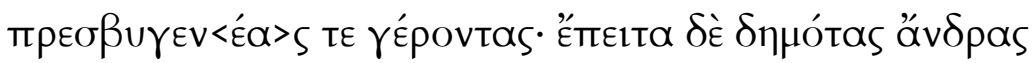

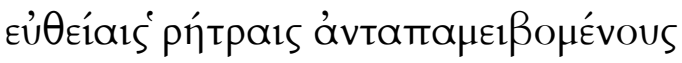

Licurgo zelou tanto pelo poder que trouxe de Delfos uma profecia sobre isso, a qual denominam Retra. Diz o seguinte: "Depois de fundar um templo de Zeus Silânio e Atena Silânia, as tribos distribuir, as obes organizar e instalar um conselho de trinta anciãos com os seus príncipes, realizar a apela de tempos em tempos entre Bábica e Cinácion. Dessarte, propõe e depõe, mas o poder e a respon<sa>bilidade serão do povo."

... Depois, no entanto, porque muitos distorciam e forçavam as máximas, com subtrações e acréscimos, os reis Polidoro e Teopompo adicionaram à Retra o seguinte: "Se o povo falar de modo oblíquo, nós - anciãos e príncipes - seremos divergentes".

... Eles próprios também persuadiram a cidade de que era o Deus quem prescrevia estas palavras, como Tirteu aparentemente relembra por meio destes versos: 
Febo escutaram, e de Pito ao lar levaram

as profecias do Deus e as palavras certas:

que dirijam o concílio os reis honrados por Deuses,

a quem importa a linda cidade de Esparta,

e os veneráveis anciãos: depois homens do povo,

por sua vez, respondendo às retas sentenças

(1) - 10 Excertos da Biblioteca Histórica de Diodoro da Sicília (7.12.6; iussu Const.

Porphyrogeniti confecta, ed. Boissevain etc, iv.273.14) de Oraculo Lycurgo datis):

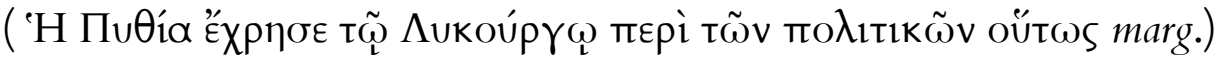

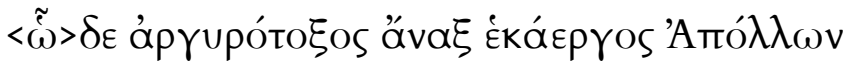

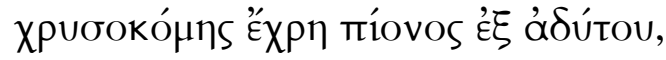

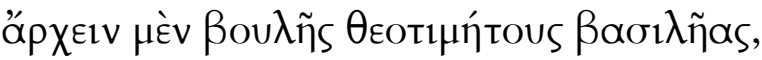

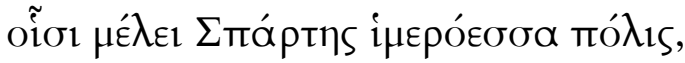

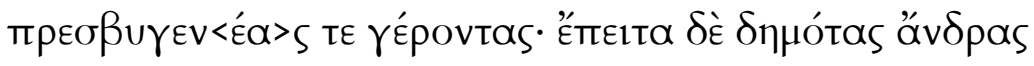

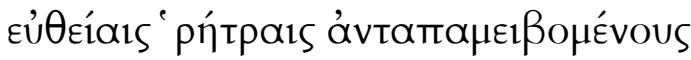

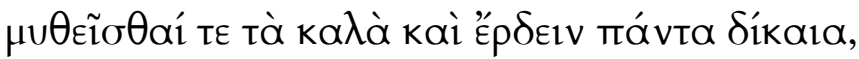

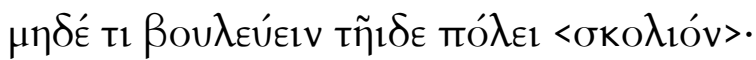

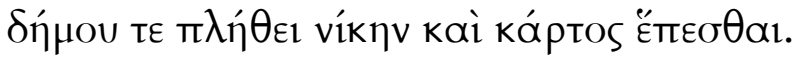

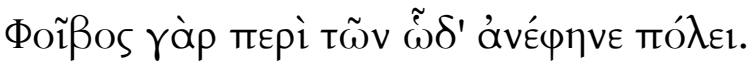

[A Pítia deu o seguinte oráculo a Licurgo, sobre questões políticas:] 
Assim o rei do arco argênteo, Apolo que age à distância,

de áurea coma, predisse do pingue santuário:

que dirijam o concílio os reis honrados por Deuses,

a quem importa a linda cidade de Esparta,

e os primevos anciãos: depois homens do povo,

por sua vez, respondendo às retas sentenças

pronunciem ditos belos e ajam com justiça em tudo

(?) e ainda não deem à cidade conselho (?)

para que vitória e poder sigam as massas.

Sobre isso, eis o que Febo revelou à cidade.

\section{Fragmento 5 W}

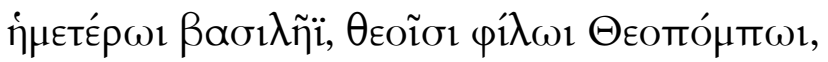

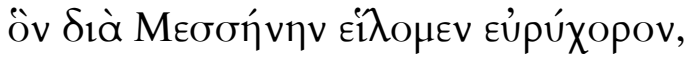

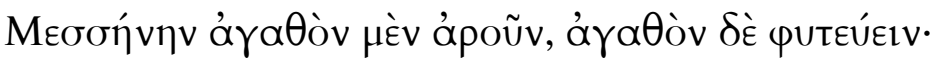

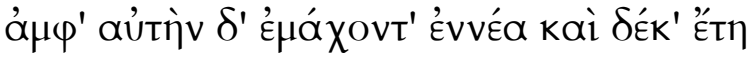

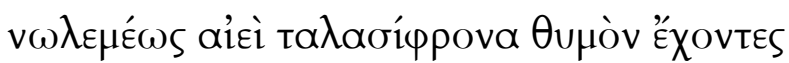

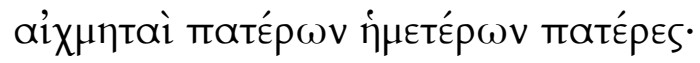

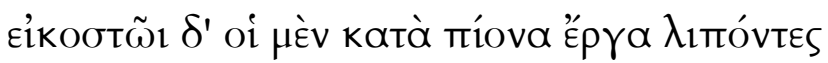

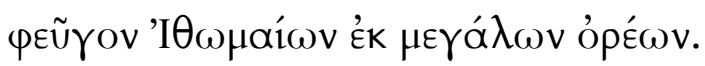

Ao nosso rei Teopompo, dileto dos Deuses,

graças ao qual conquistamos vasta Messênia,

Messênia boa p'ra arar, boa p'ra plantar;

por ela lutavam dezenove anos

sem trégua, sempre de coração animoso,

Os lanceiros pais de nossos pais;

ao vigésimo, os messênios deixaram as férteis lavouras 
e fugiram dos altos montes de Itome.

\section{1-2 Pausânias, Descrição da Grécia 4.6.5}

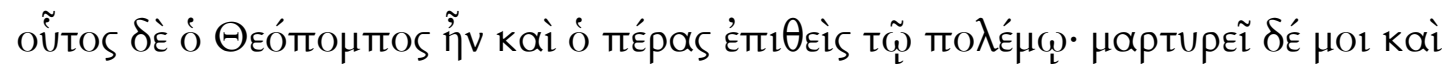

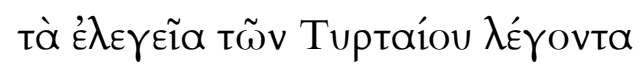

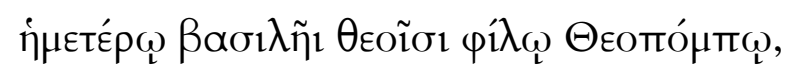

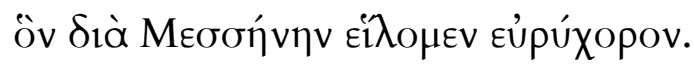

Este Teopompo foi, na verdade, quem pôs fim à guerra; meu testemunho é a elegia de Tirteu, que diz:

Ao nosso rei Teopompo, dileto dos Deuses

Graças ao qual conquistamos vasta Messênia.

3 Escólio às Leis de Platão, 629 a

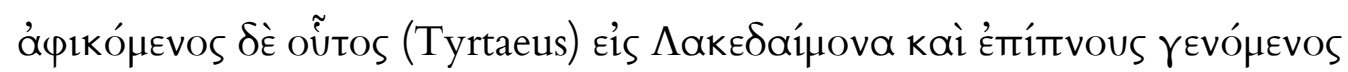

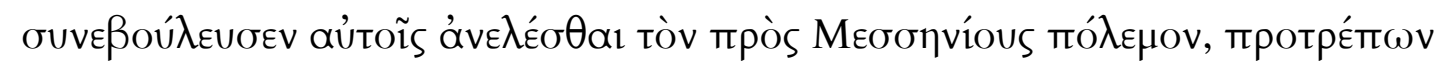

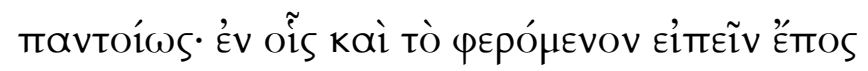

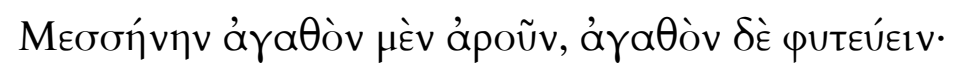

E quando ele (sc. Tirteu) chegou à Esparta, ficou inspirado, e aconselhou-lhes empreender a guerra contra os Messênios, encorajando-os de todas as maneiras entre as quais, pela récita do notório verso:

Messênia, boa p'ra arar, boa p'ra plantar 
4 - 8 Estrabão, Geografia, 6.3.3.

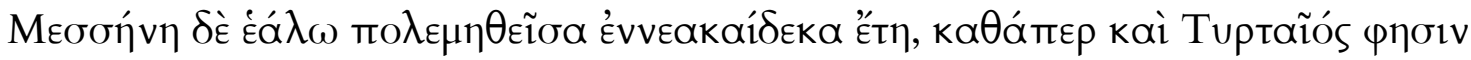

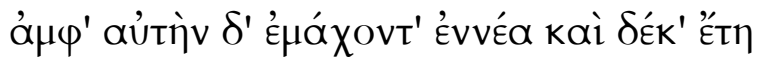

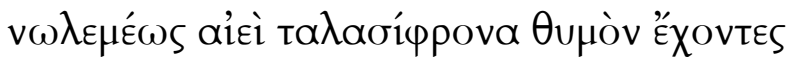

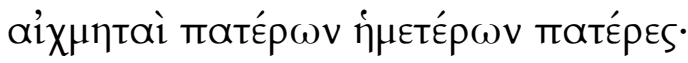

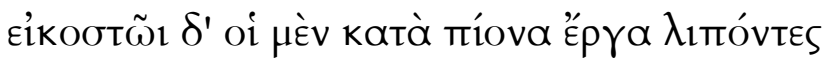

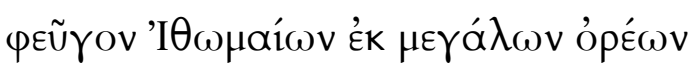

Messênia foi capturada após dezenove anos de guerra, como diz Tirteu:

por ela lutavam dezenove anos

sem trégua, sempre de coração animoso,

Os lanceiros pais de nossos pais;

ao vigésimo, os messênios deixaram as férteis lavouras

e fugiram dos altos montes de Itome

Fragmento 6 W (= Pausânias, Descrição da Grécia, 4. 14. 4-5)

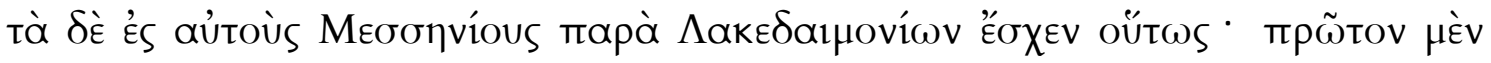

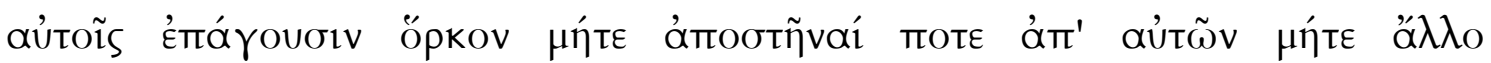

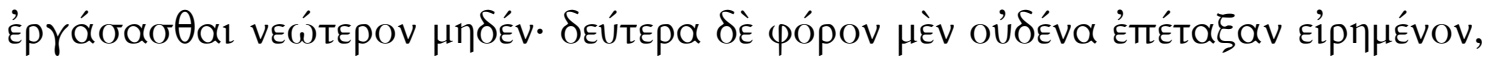

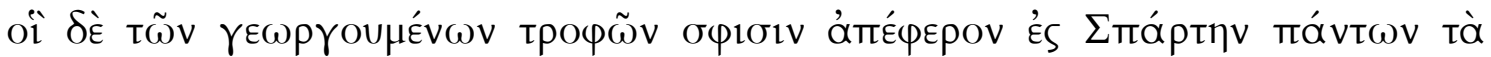

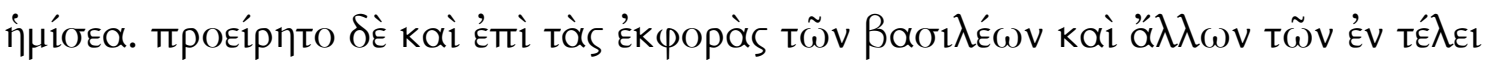

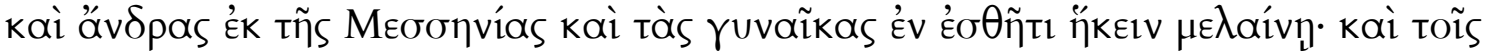




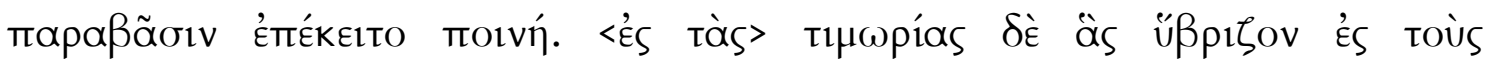

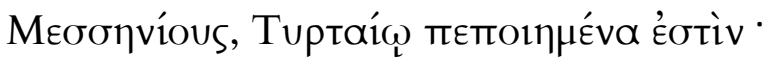

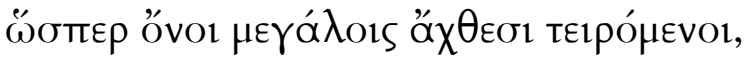

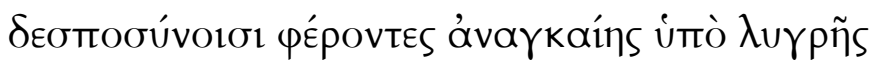

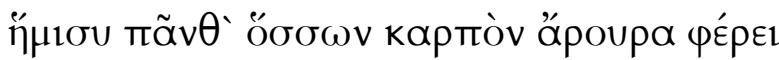

No que concerne aos próprios Messênios, [a situação] junto aos espartanos era a seguinte: primeiro, atribuem-lhes um juramento para que não se revoltassem no futuro por conta destas coisas mesmas, tampouco empreendessem qualquer outra sedição novamente. Segundo, não impuseram qualquer tributo específico, no entanto, levavam para Esparta metade do total de alimentos que eram cultivados. Prescrevia-se também que tanto homens quanto mulheres da Messênia fossem com vestes negras aos funerais de reis e de outras autoridades, e uma pena era aplicada aos transgressores. <Para as> punições que ultrajavam os Messênios, há o que o que foi composto por Tirteu:

Como asnos oprimidos por ingentes fardos levando aos senhores, sob triste necessidade, metade de todo o fruto que a terra produz

\section{Fragmento 7 W (Pergit Paus.)}

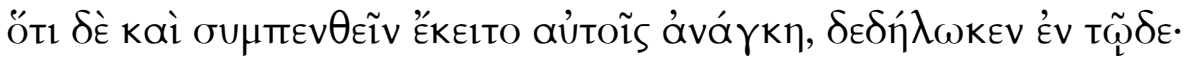

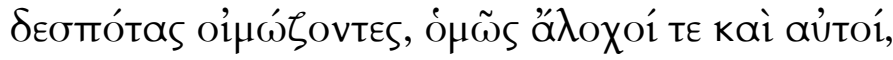

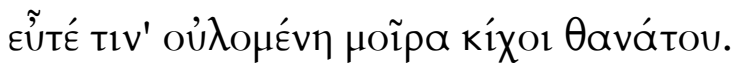


Que a necessidade punha-os a prantear juntos está evidente neste [dístico]:

pelos seus senhores, os homens e as mulheres lamentavam,

Sempre que o destino destrutivo da morte encontrava algum.

\section{Fragmento $8 W$ ( = Estrabão, Geografia, 8.4.10)}

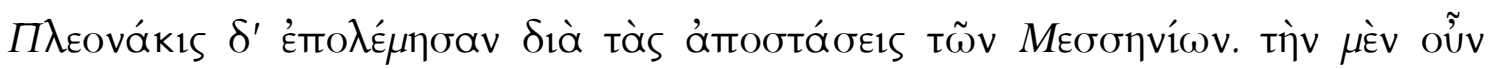

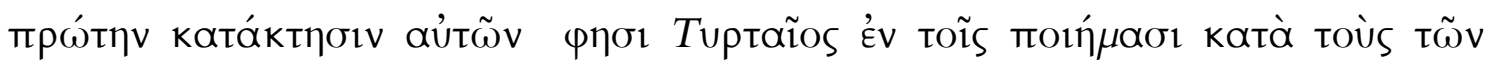

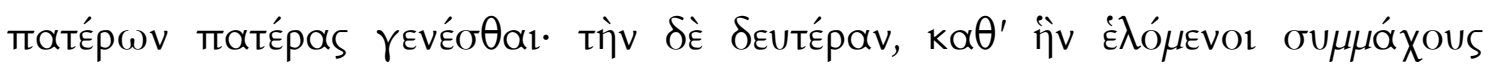

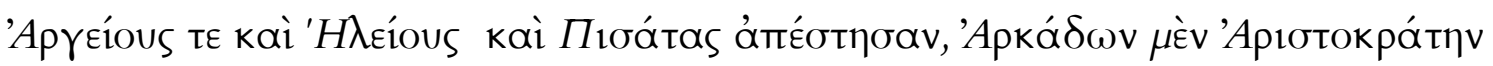

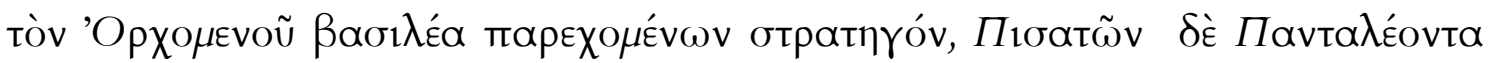

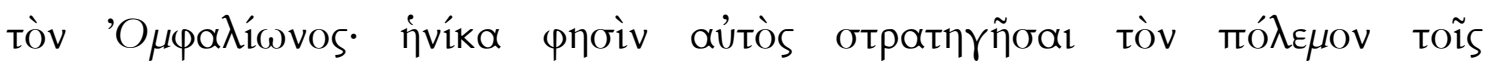

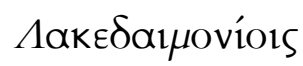

Amiúde fizeram guerra por causa das insurreições dos Messênios. Tirteu diz em seus poemas que a primeira conquista deles ocorreu no tempo dos pais dos pais (Fr. 5.6.) A segunda, no tempo em que se revoltaram, tendo escolhido aliados Argivos, Eleios e Pisanos. Os árcades ofereceram Aristócrates, rei dos Orcômenos, como general e os Pisanos [ofereceram] Pantaleão de Onfalion, enquanto pelos espartanos [Tirteu] diz que ele próprio foi o general.

\section{Fragmento 9 W ( = Aristóteles, Ética a Nicômaco, 1116a36)}

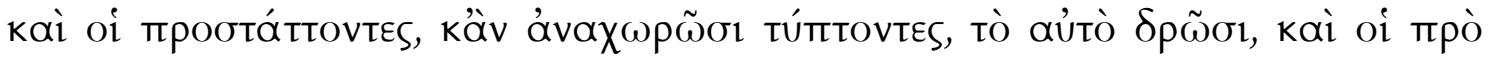

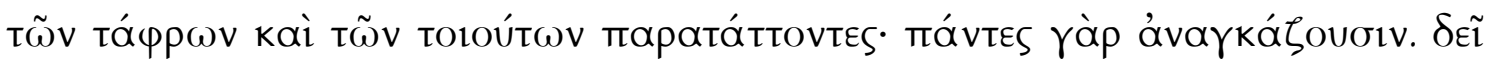

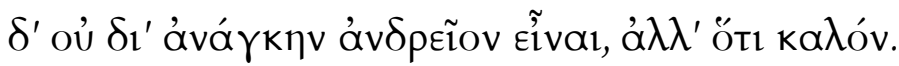


Aqueles que vão à frente e golpeiam os outros caso retrocedam, fazem o mesmo (e também aqueles que se põem diante de trincheiras e de outras coisas do tipo) porque são obrigados. Mas deve-se ser viril não por obrigação, e sim porque é belo.

\section{Eustrácio, Comentário a Aristóteles, 20, 165.1:}

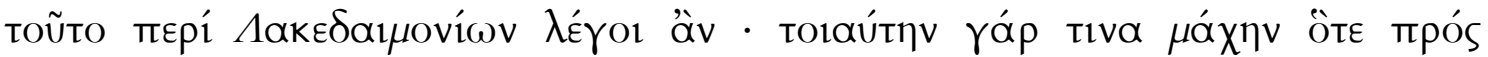

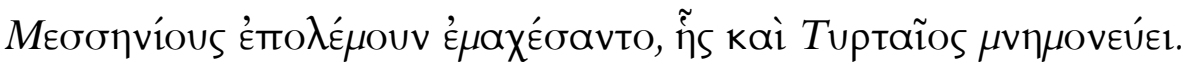

Poder-se-ia falar isso dos espartanos: Pois lutaram de tal modo quando travavam uma guerra contra os Messênios, aquela que Tirteu menciona.

\section{Fragmento 10 W ( = Licurgo em Contra Leócrates, 107)}

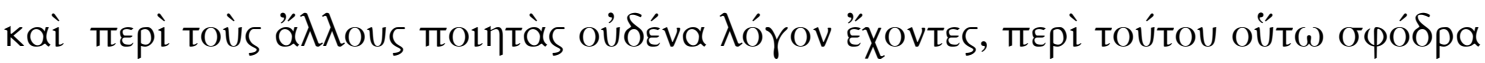

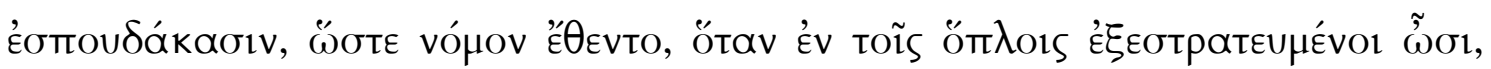

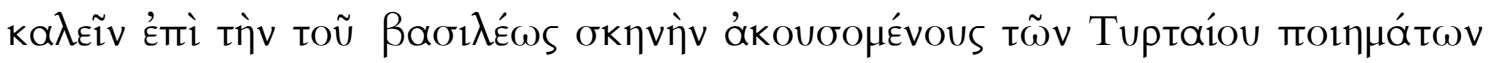

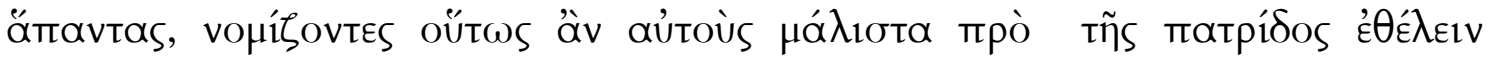

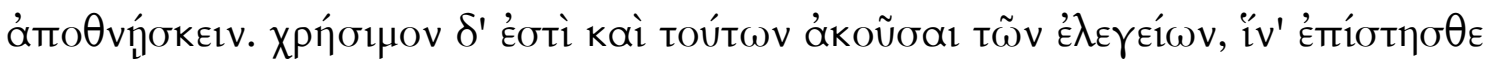

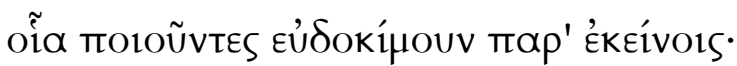

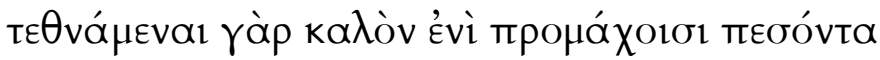

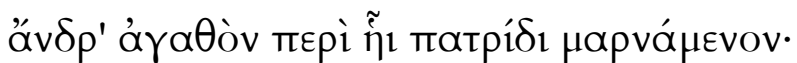

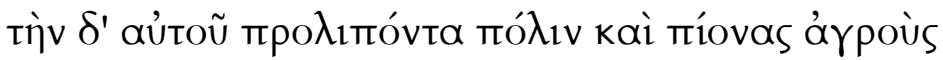

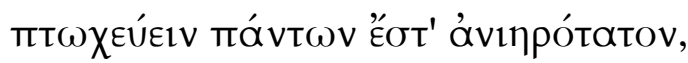

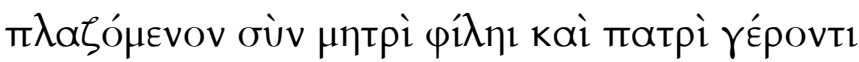

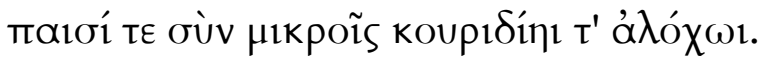

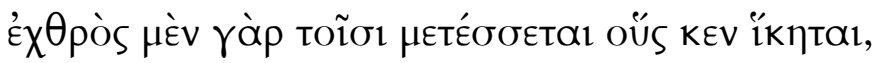

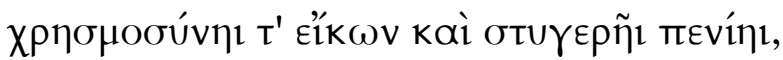

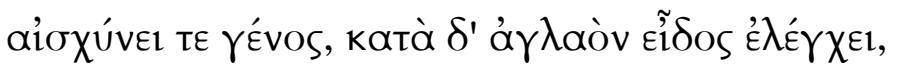




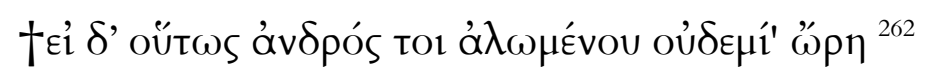

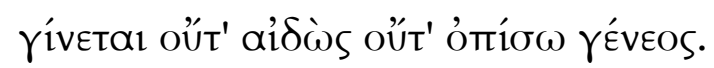

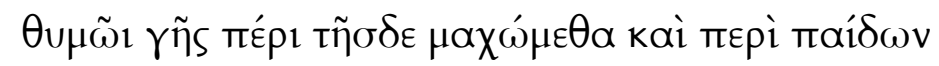

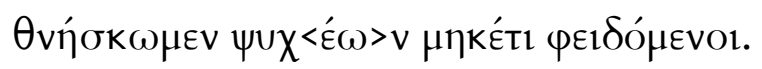

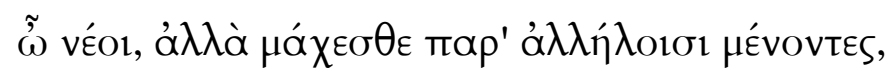

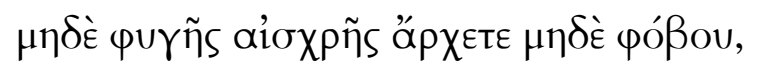

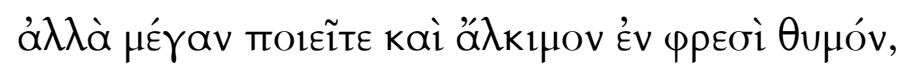

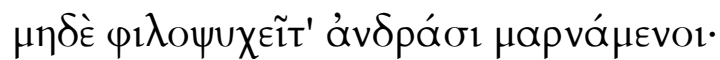

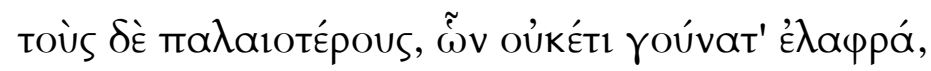

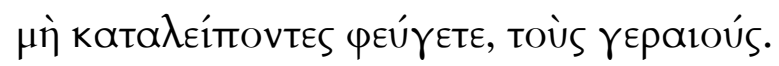

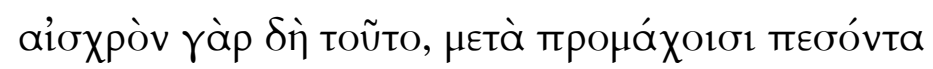

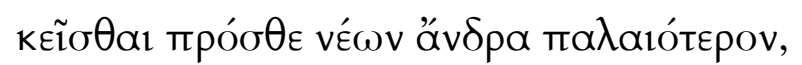

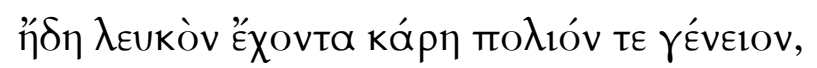

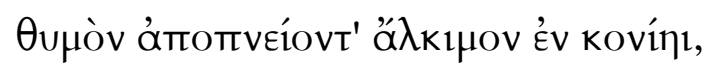

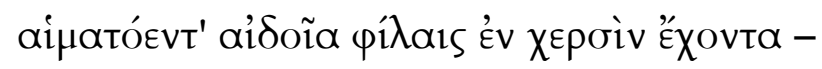

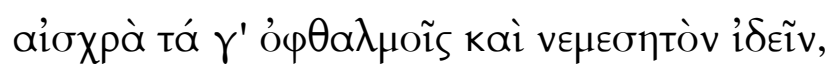

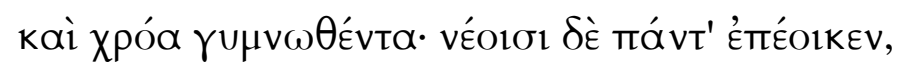

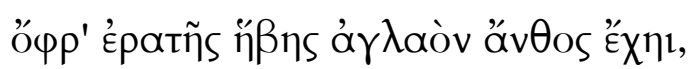

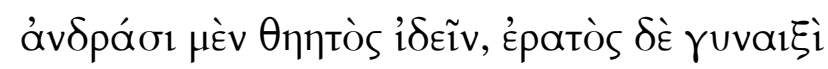

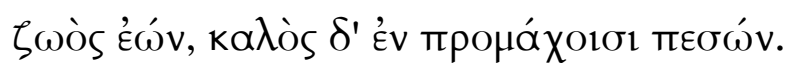

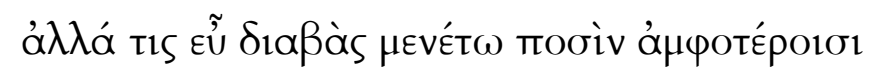

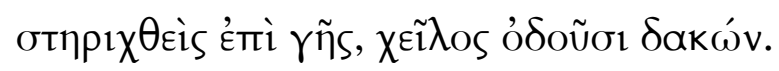

${ }^{262}$ Neste verso, adotamos a correção proposta por Francke (1816) 
"Embora não tivessem em conta alguma os outros poetas, por ele [scil. Tirteu] tiveram um interesse tão veemente que outorgaram uma lei que, quando estavam em armas,\{fazendo uma expedição militar, $\}$ convocava todos à tenda do rei para ouvirem os poemas de Tirteu, presumindo que assim eles desejariam ao máximo morrer pela terra pátria. É-vos útil ouvir destes dísticos elegíacos, de modo a vos persuadires quanto ao tipo de poesia que era apreciada entre eles [scil. espartanos]:

Belo, sim, é morrer, na vanguarda caindo um varão valoroso em luta pela pátria. Mas mendigar, deixando sua cidade e férteis campos, de tudo é o mais penoso, vagando com a cara mãe e o velho pai,

filhos pequenos e esposa legítima.

Será odioso entre aqueles a quem chegar, pois cede à carência e à pobreza horrível, envergonha a linhagem, vexa a forma esplêndida, e toda a desonra e vileza o seguem.

Se é assim, se ao varão errante não vêm préstimo ou respeito algum, nem à descendência, com ânimo por esta terra lutemos, e pelos filhos morramos, não mais poupando a vida! Ó jovens, eia, lutai, mantendo-se lado a lado, não inicieis a torpe fuga ou o pavor mas fazei grande e valente o ânimo no peito; não amai a vida, em luta com varões! 
E não fujais, aos mais velhos abandonando, aos anciãos, que não têm mais joelhos ágeis.

Pois, sim, isto é torpe: na vanguarda caindo, jazer ante aos jovens um varão mais velho,

já de cabeça branca e barba grisalha,

expirando o valente fôlego na poeira, os ensanguentados genitais nas próprias mãos -

que espetáculo torpe, que visão revoltante! -

e o corpo despido: Mas tudo convém aos jovens

enquanto tiverem a flor brilhante da linda juventude:

é admirado por homens, por mulheres amado,

quando vivo; e belo, se na vanguarda cai.

Mas que cada um fique bem firme, ambos os pés

Fixos ao chão, mordendo os lábios com os dentes !

\section{Fragmento $11 \mathrm{~W}$ (= Estobeu, 4.9.16)}

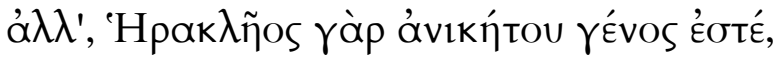

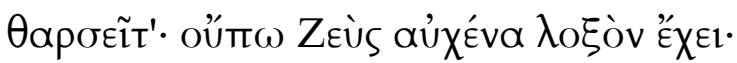

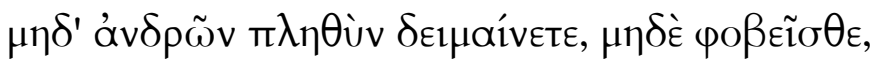

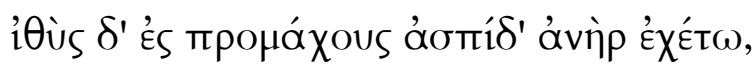

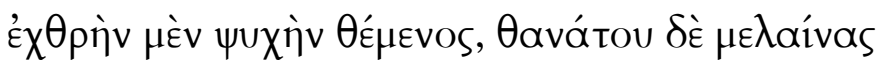

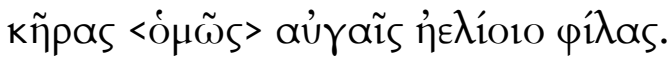

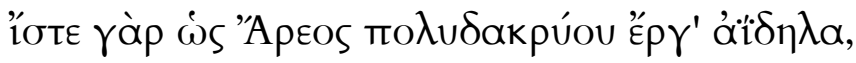

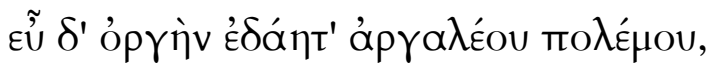




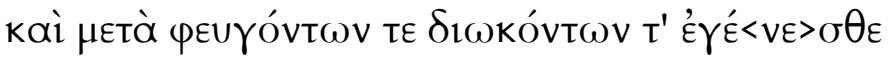

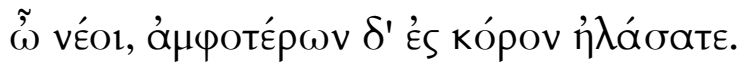

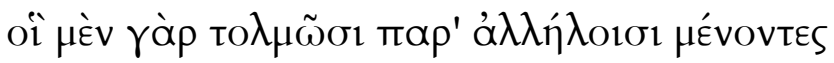

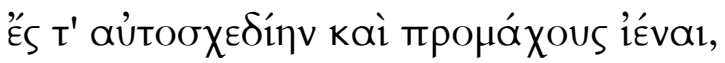

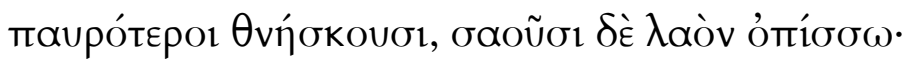

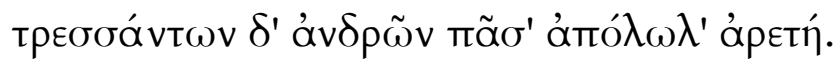

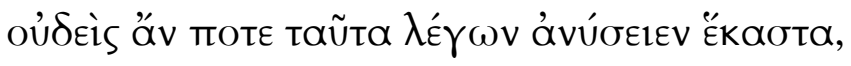

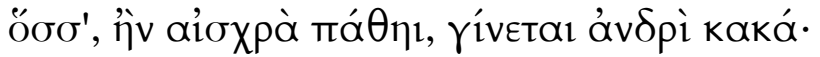

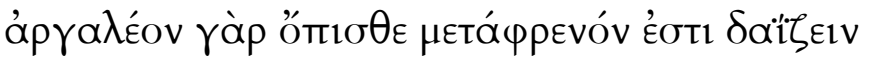

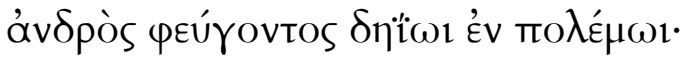

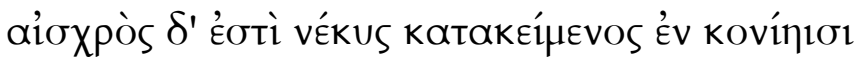

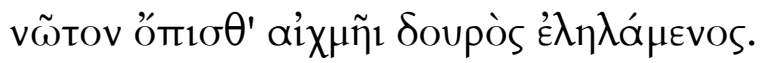

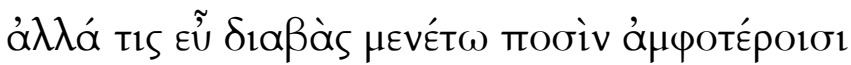

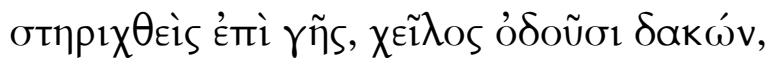

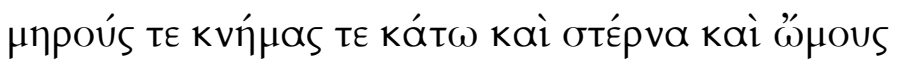

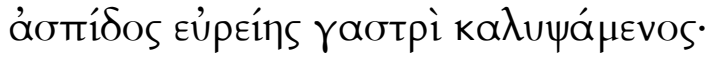

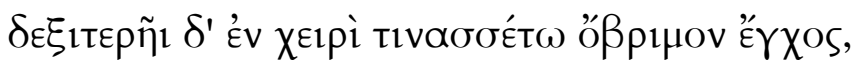

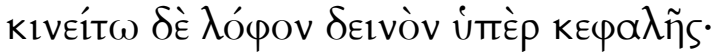

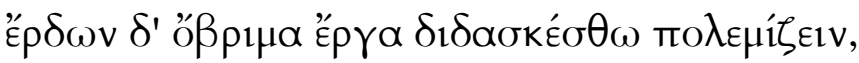

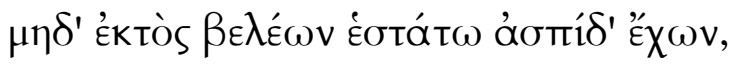

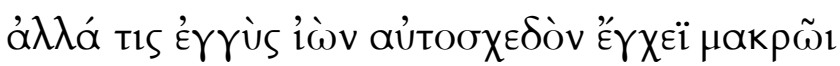

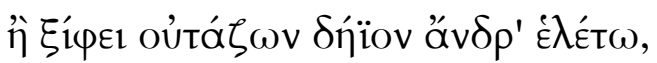

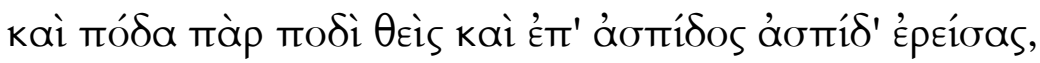

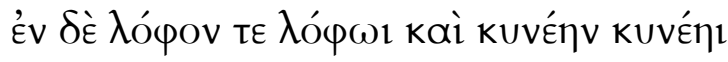




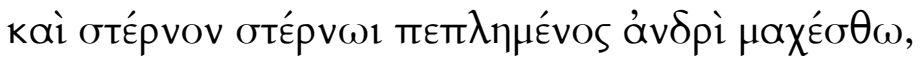

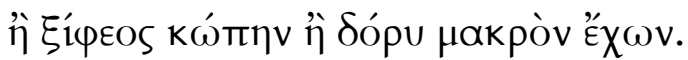

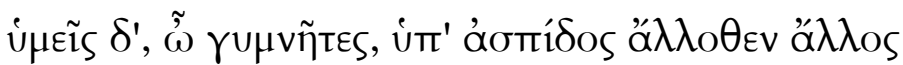

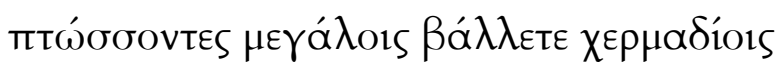

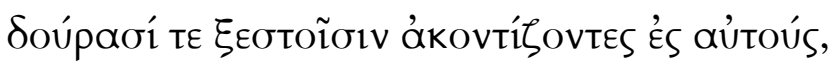

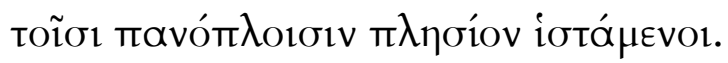

Mas porque sois da linhagem do invicto Héracles,

coragem! Zeus ainda não virou as costas!

Não temais, não fujais da turba de guerreiros;

que o varão avante contra os da vanguarda sustenha o escudo,

tornando odiosa a vida e as Garras negras da morte

tão amadas quanto os raios do sol;

pois sabeis que as proezas de Ares de muito pranto são destrutivas,

bem conhecestes o furor da guerra atroz;

estivestes entre os que fogem e os que perseguem,

ó jovens, e de ambas as coisas vos fartastes.

Pois dos que se mantêm lado a lado e ousam

ir à luta corpo a corpo e à vanguarda,

menos morrem e salvam a tropa atrás;

dos varões que tremem, toda a virtude perece.

Ninguém jamais terminaria de contar cada mal

de quantos vêm ao varão que sofre ignonímia;

Pois é atroz trespassar as costas de um varão

que foge na aterradora peleja

E é torpe um morto estirado na poeira, seu dorso 
ferido por trás com ponta de lança.

Mas que cada um fique bem firme, ambos os pés

fixos ao chão, mordendo os lábios com os dentes!

As coxas e as canelas em baixo, e o peito e os ombros

cobrindo com o ventre do largo escudo,

empunhe na mão destra a forte lança

e temível a crina agite sobre a cabeça:

Fazendo fortes façanhas, aprenda a lutar

e, sustendo o escudo, não fique longe dos dardos!

Que cada um avance ao corpo a corpo e mate

o inimigo ferindo-o com longa haste ou gládio,

pé colocado junto a pé, escudo apoiando

escudo, crina à crina, elmo a elmo

e peito a peito, lute perto de um varão

com cabo de espada ou grande lança em mãos.

E vós, de armadura leve, que se agacham aqui e ali

sob os escudos, lançai grandes pedras,

arremessando polidas lanças contra eles

e postando-vos perto dos que têm armadura completa.

Fragmento $12 \mathrm{~W}(=$ Estobeu 4.10.1 [vv.01-14] + 6 [vv.15-44])

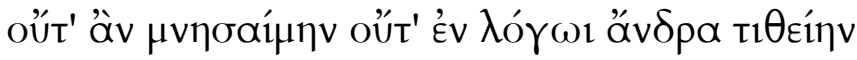

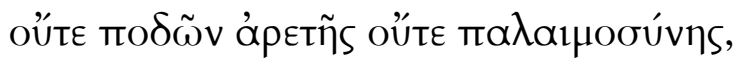

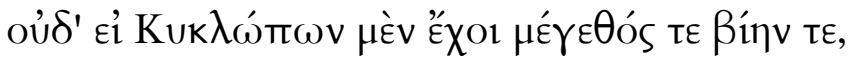




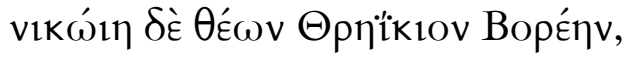

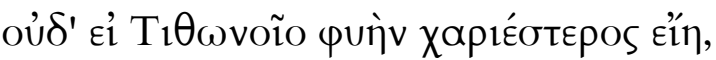

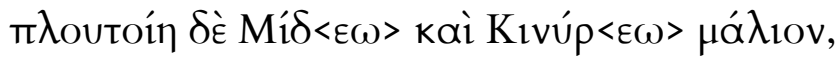

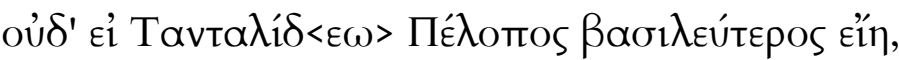

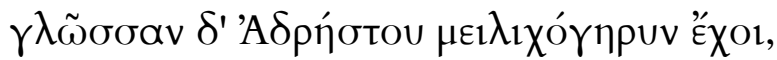

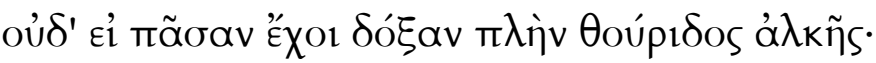

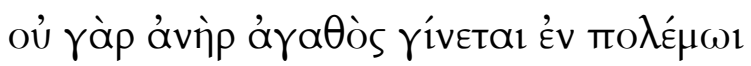

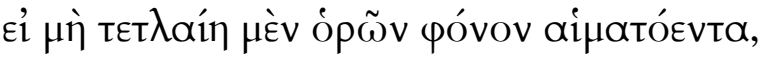

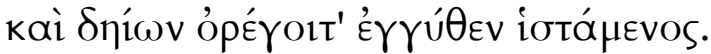

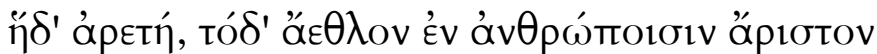

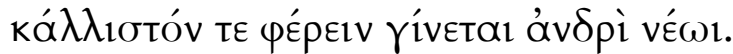

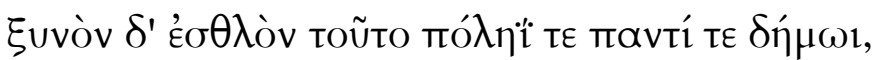

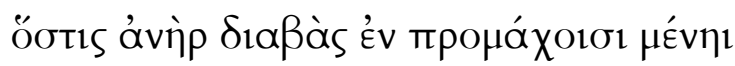

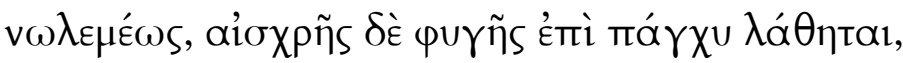

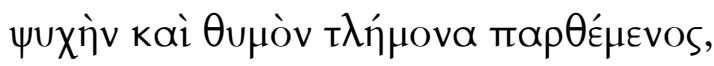

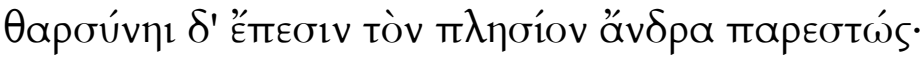

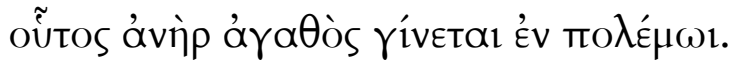

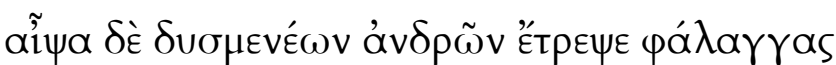

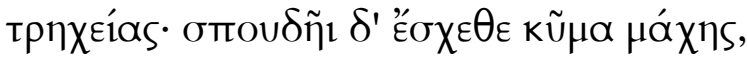

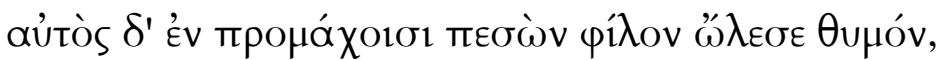

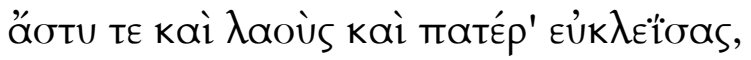

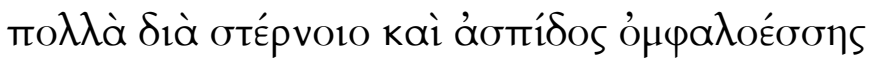

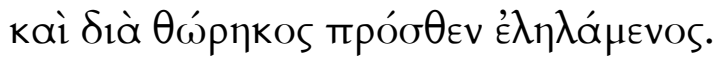

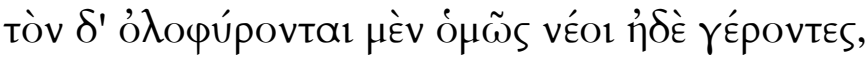




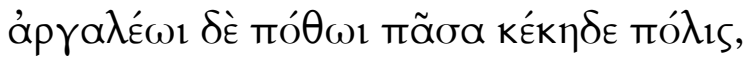

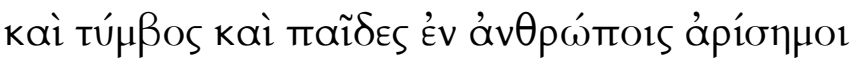

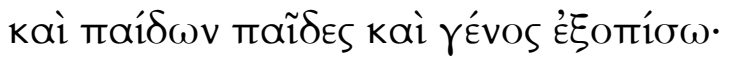

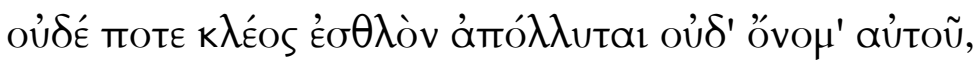

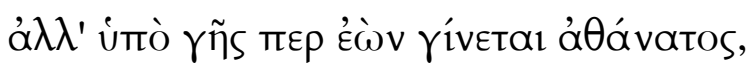

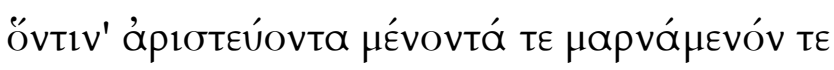

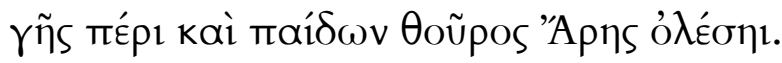

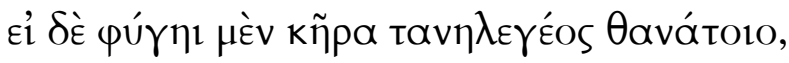

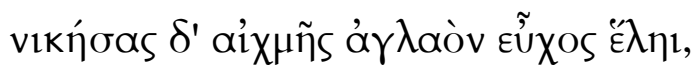

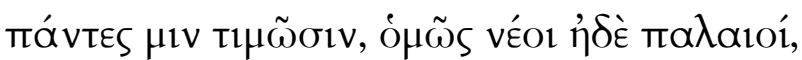

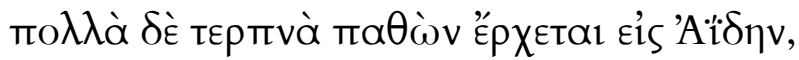

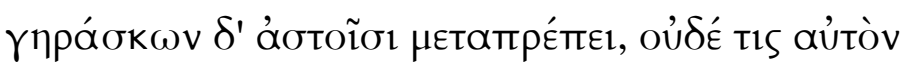

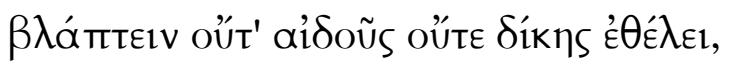

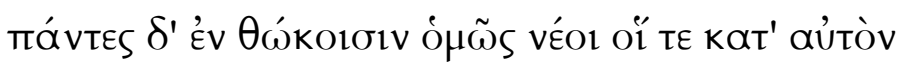

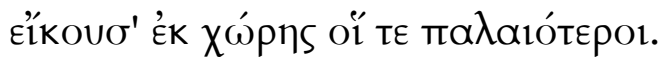

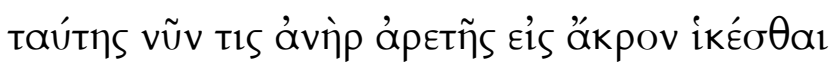

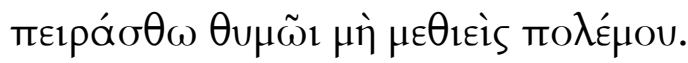

Não me lembraria e em verbo um varão não poria,

pela virtude de seus pés ou de sua luta,

nem se tivesse altura e força de Ciclopes

e em corrida vencesse o trácio Bóreas,

nem se tivesse porte mais grácil que Títono,

(5)

e mais riquezas do que Midas e Ciniras,

nem se fosse mais rei que Pélope Tantálida, 
e tivesse a língua de mel de Adrasto,

ou toda a fama, senão a bravura impetuosa;

pois um varão não se torna valoroso na guerra

se não ousar olhar a matança sanguinária,

e postando-se perto, atingir inimigos.

Tal virtude, tal prêmio, entre homens é o melhor

e mais belo que há para um jovem varão receber.

É esse um bem comum à cidade e ao povo todo,

que um varão firme na vanguarda se mantenha,

sem trégua, de todo se esqueça da torpe fuga

arriscando a vida e o coração audaz,

e próximo encoraje o varão ao seu lado com palavras :

eis o varão que se torna valoroso na guerra.

Súbito, dispersa de varões hostis as falanges

brutais, com zelo detém a onda da luta.

Caído na vanguarda, ele próprio perde a sua vida, mas glorifica a cidade, as tropas e seu pai,

muitas vezes no peito, no escudo umbilicado

E na couraça golpeado de frente.

A ele pranteiam por igual jovens e anciãos, e em saudade atroz, a cidade toda se enluta.

Seu túmulo e filhos são insignes entre os homens e os filhos dos filhos, e a geração no porvir,

e jamais nobre glória ou o nome dele perecem, 
mas, mesmo sob a terra, se torna imortal

aquele que, primando por manter-se em combate

Pela terra e pelos filhos, o impetuoso Ares mata.

Mas se escapa à sina da morte que aflige longamente

e, ao vencer, conquista o triunfo ilustre da lança,

todos o honram, por igual os jovens e os velhos,

e depois de viver muitas alegrias, vai ao Hades.

Envelhecendo, distingue-se entre os cidadãos e ninguém

quer faltar-lhe com respeito e justiça;

todos, os jovens e seus coetâneos, cedem-lhe

lugar em conselho, e também os mais velhos.

Tente hoje cada varão ao ápice dessa virtude

chegar, com coragem, sem descuidar da guerra!

Fragmento 13 W (= Galeno, Das Doutrinas de Hipócrates e Platão 3.309)

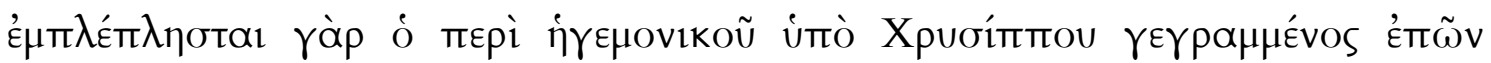

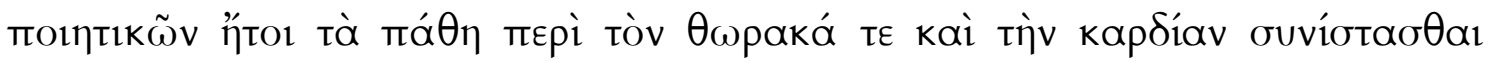

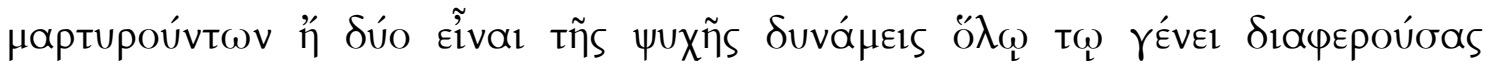

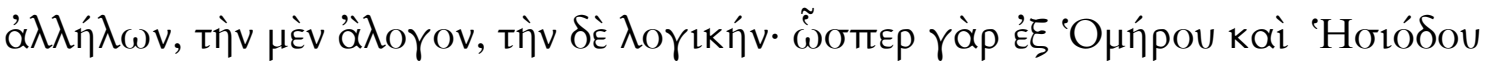
ßpax

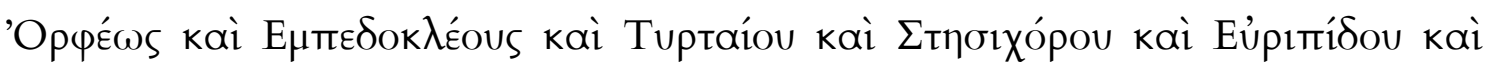

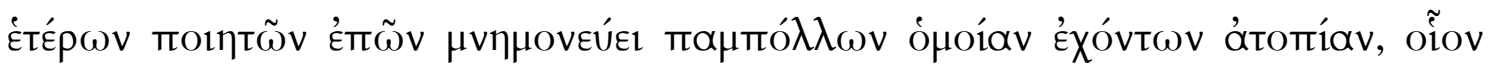
kaì ötav Eìṇ̃ Tuptaĩov $\lambda$ É Yovta

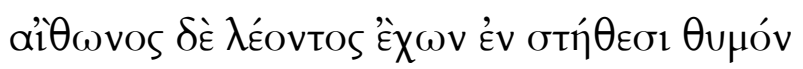


O tratado escrito por Crisipo acerca da parte hegemônica da alma está repleto de versos (epôn) poéticos que testemunham males associados ao peito e ao coração, ou que há duas faculdades da alma em toda a espécie, a irracional e a racional, que são mutuamente distintas: pois, tal qual apresentei um pouco antes [passagens] breves de Homero e Hesíodo que Crisipo anotara, assim ele menciona inúmeros versos de Orfeu, Empédocles, Tirteu, Estesícoro, Eurípides e de outros muitos poetas que detém igual estranheza, como quando cita Tirteu, que diz:

Tendo no peito o ânimo de árdego leão

\section{Fragmento 14 W (Plutarco, de Stoic.repugn. 14.1039e)}

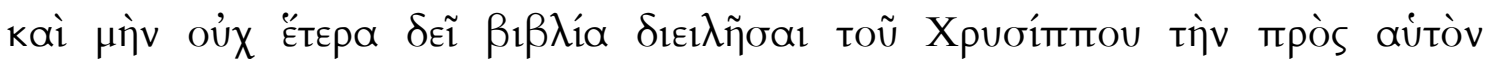

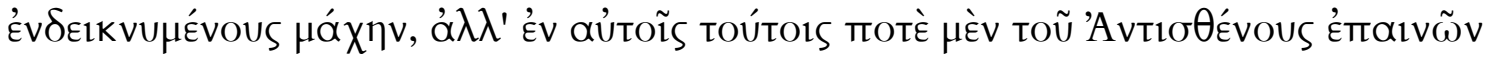

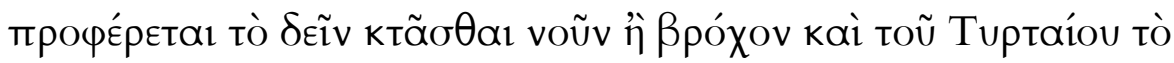

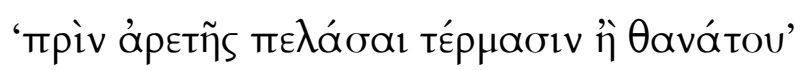

Não é preciso interpretar outros livros de Crisipo que o apontam em conflito consigo mesmo, mas nestes mesmos ele cita em algum momento as palavras de Antístenes sobre o dever de se adquirir o intelecto ou a corda, e [o verso] de Tirteu:

Antes de alcançar os limites da virtude ou da morte.

Fragmento $15-16 \mathrm{~W}$ (= PMG 856-7)

Fragmento $15 \mathrm{~W}$ 
ơץ

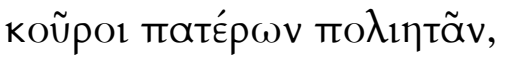

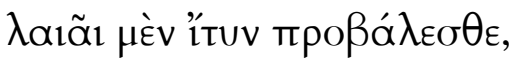

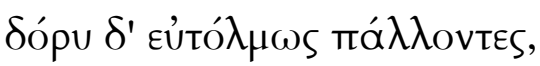

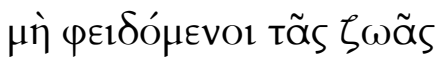

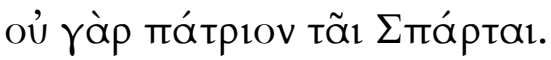

Vamos, valentes d' Esparta,

moços de pais livres!

À esquerda, anteponde o escudo,

e atirai a lança com coragem,

não poupando a vida:

este não é o costume de Esparta.

Fragmento $16 \mathrm{~W}$

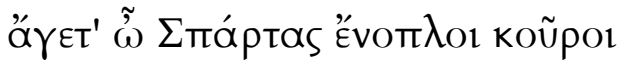

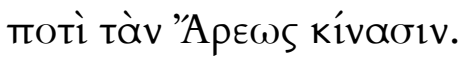

Vamos, moços de Esparta em armas,

para a marcha de Ares.

Fragmento 17 W (= Querobosco, Escólios a Heféstion p.196.6. Consbruch)

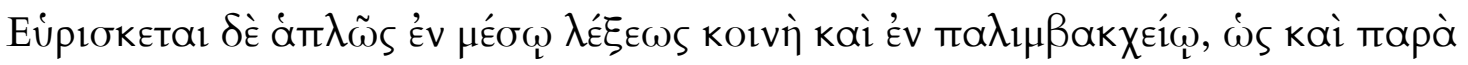
Tupraí $\omega$ 
īpwes

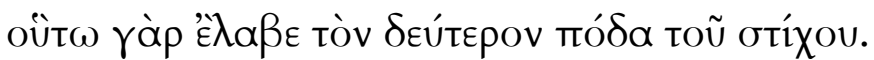

Encontra-se uma [sílaba] simples no meio de uma palavra e no palimbáquio, como em Tirteu:

Heróis

Pois assim ele escandiu o segundo pé do verso.

Fragmento $18 \mathrm{~W}(=$ P.Berol. 11675 fr.A.col.1)

$[\quad \alpha] \gamma \cdot \alpha \lambda \lambda$ [
$[\quad$ ]

desunt versus tres

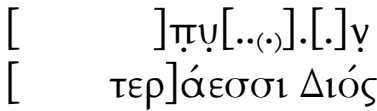

u]fanando-se (ela) ...

](?) e cróceo...

Faltam 3 versos

](?)[..(.).][] (?)

... pre]sságios de Zeus

Fragmento 19 W (=P.Berol. 11675 fr.A. col ii)

[ ] $] .[\cdot(\cdot)] \cdot . \circ[$ 


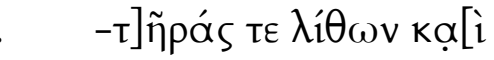

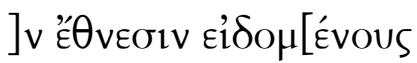

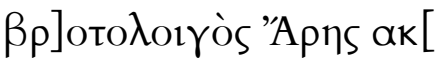

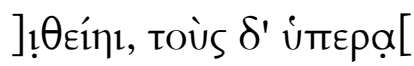

].[.]v Éorkótes ṇ[

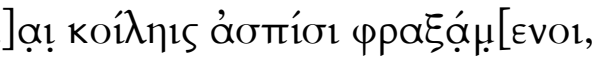

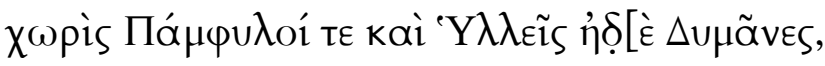

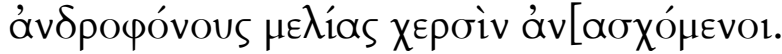

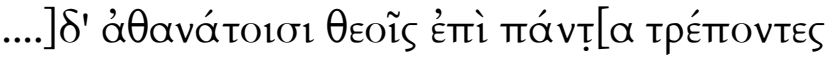

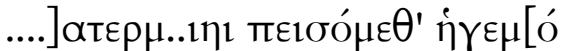

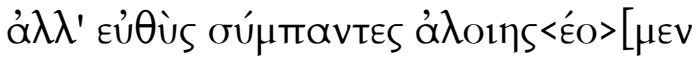

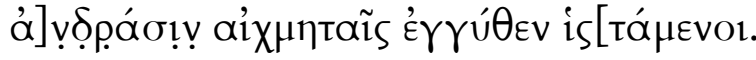

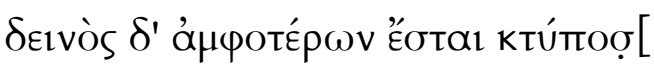

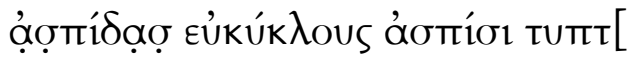

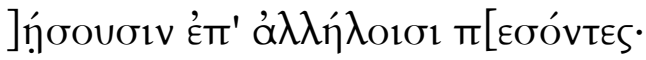

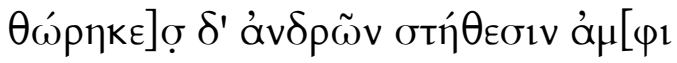

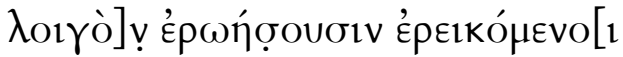

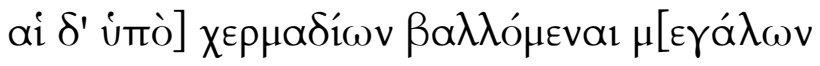

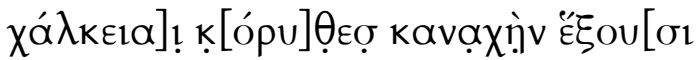

] [.(.).] (?)[

](?), pedras e...

...às tribos semelh[ando-se...]

[ho]micida Ares (?)[

]em linha reta, e aos de cima[

(5)

](?) semelhantes à[?]

](?) com os côncavos escudos defende[ndo-se]

à parte Panfílios, Hileos e[Dímanes]

sust[endo] em suas mãos as lanças as[sassinas],

...]e aos imortais Deuses sobretud[o voltando-nos,] 
...]sem saída...obedeçamos (aos líderes?)

Mas todos nós diretamente avance[mos

ma[ntendo] próximos aos lanceiros,

... e de ambos serão terríveis...

os escudos, circulares, contra escudos esbaten[do-se]

(?) ...ca[indo] uns sobre os outros :

[as couraça]s em volt[a] do peito dos varões

rompidas, mas escapam com ímpeto da $\mathrm{m}$ [orte

[e os] e [lm]os brônze[os], abatidos [por] gr[andes

pedras, provocar[ão] o estrondo.

Fragmento $20 \mathrm{~W}$ (= P.Berol, 11675, fr. B col.i)

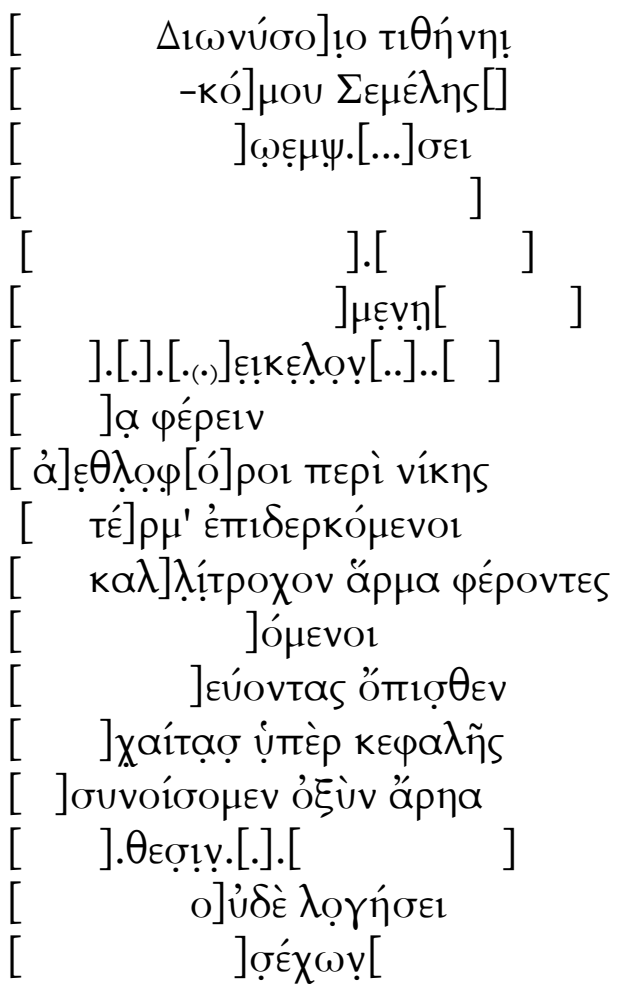

À nutriz de Dioniso,

Sêmele de [ca]belos [ 
] (?) [...] (?)

].[ $\quad$ ]
] ](?)[ [ ] [.] [. (.)] semelhante [..].[ ]

](?) levar

p]rem[i]ados pela vitória

contemplando a [me]ta

conduzindo carro de [bel]as rodas

](?)

] (?) para trás

]as melenas sobre a cabeça

]suportaremos a pungente guerra

]. (?)[.] [ ]

E n]ão levará em conta (?)

] (?)[

Fragmento 21 W (P.Berol 11675, fr. B col.ii)

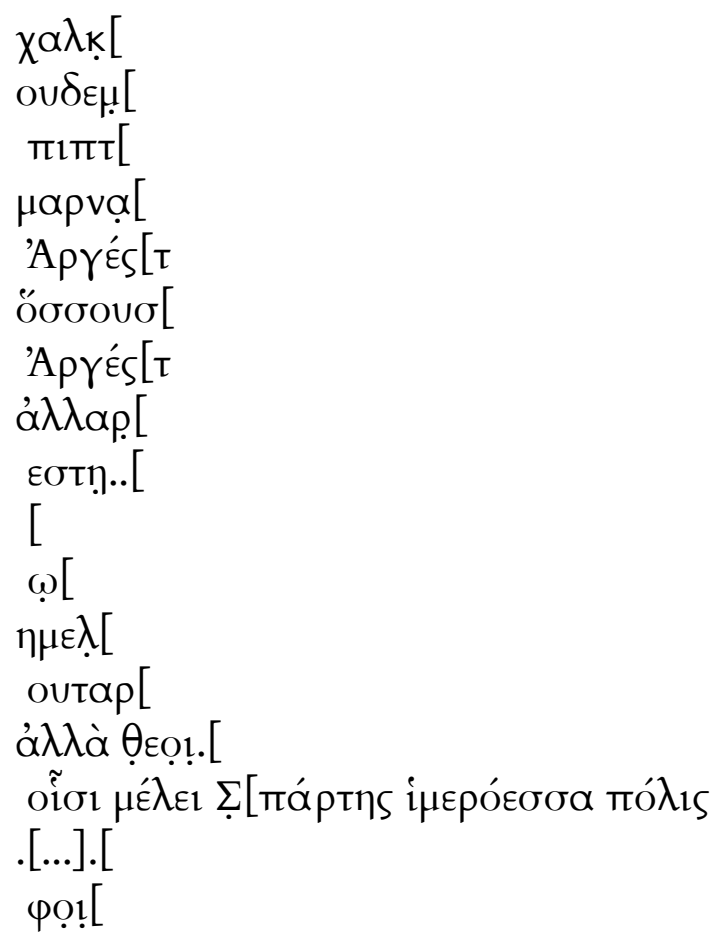




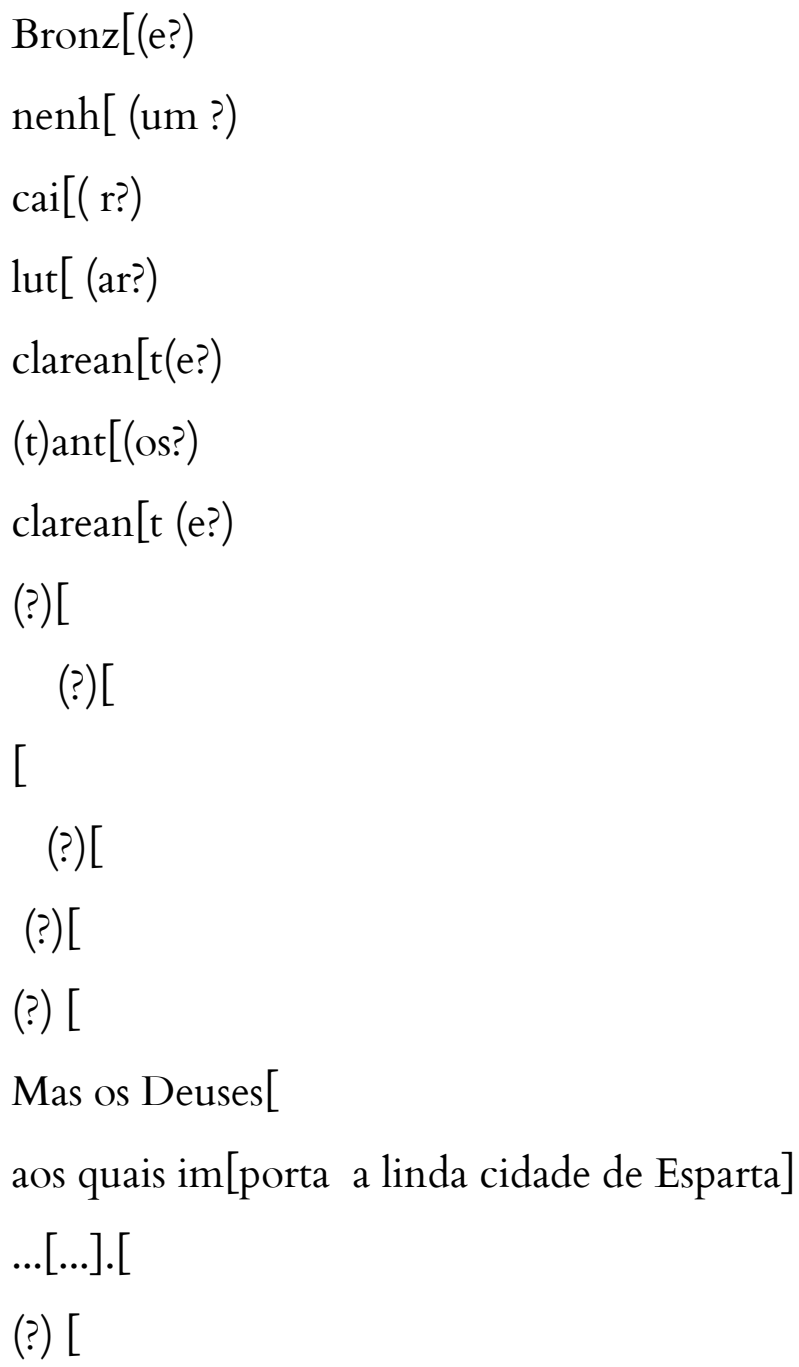

Fragmento 22 (P.Berol 11675. Fr.C. col.i)

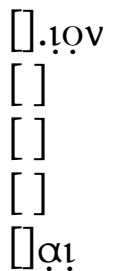

Fragmento 23 (P.Berol 11675, fr.C. col ii)
o..[..] ọтєụọ[
छ̇รEins $\pi \alpha[$ 


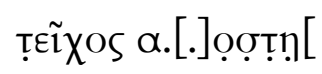

olọ.

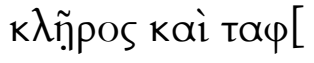

$M \varepsilon \sigma \sigma \eta v<i \omega>v[$

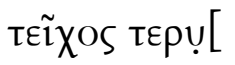

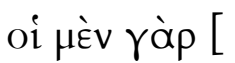

àvtíol iot $[\alpha$

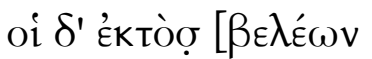

(10)

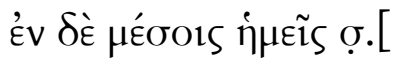

тúprou $\delta v[$

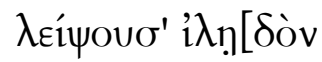

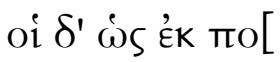

kv[.] $\alpha \delta ̣[$

Toĩs íke $\lambda \mathrm{Ol} \mu[$

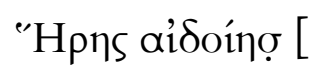

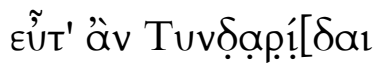

continuamente (?) [

a muralha (?) [.] (?)

(neles disparam[os?)

lote e (túmulo?)[

dos Messênios [

a muralha (?) [

porque uns, (?) [

opostos (mantendo-se?)[

outros, longe de [dardos

e nós, ao centro (?) [

da torre (?) [

deixaram em $\operatorname{tr}[o p e l$,

e assim (?) eles desde o (?) [ 
(?) $[].(?)[$

a eles semelhantes (?) [

da veneranda Hera [

quando os Tindár[idas

Fragmento 23 a W (P.Oxy, xlvii 3316)

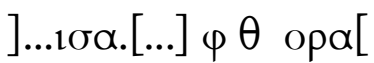

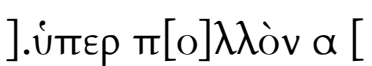

...[.]. $\varepsilon v \omega v[..] \chi £ \varepsilon 1 \beta \varepsilon \lambda^{\prime} \varepsilon^{\prime} \widehat{\alpha}_{\gamma} \rho[1 \alpha$

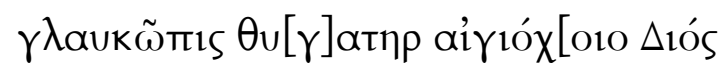

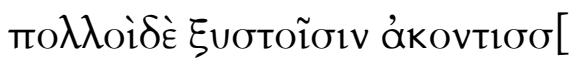

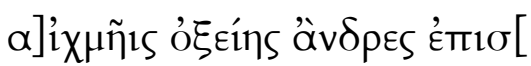

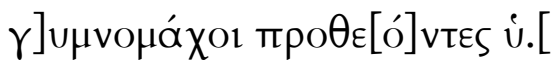

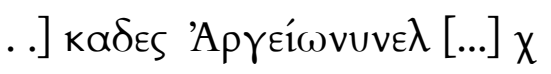

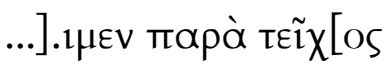

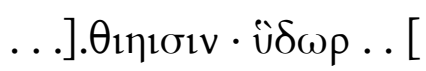

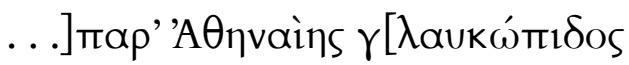

... ] i iүavt. [.] тарpo .[

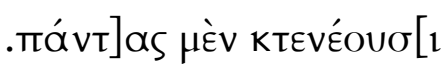

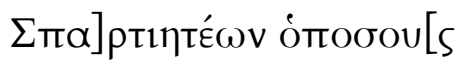

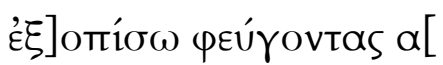

]...(?) [...] (?) [

]. acima $\mathrm{m}[\mathrm{u}]$ ito (?) [

]...[ ] (?) [de]ter(?) os dardos fero[zes...

A fi[1]ha de olhos glaucos de [Zeus porta-égi]de 
Muitos com as lanças atir[arão, (?)

varões com [l] anças pontiagudas (?)[

gu] erreiros desarmados corren[do] à frente sob (?)[

](?) Argivos(?) [ ] (?) [

] (?) junto à mur[alha

$$
\text { ](?) : água [ }
$$

]ao lado de Atena de o[lhos glaucos]

](?) [ ] trinche[ira

Matarã[o] a [tod]os

os espar] tanos quanto[s,

para a retaguarda fugindo, [

Fragmento 24 (Inscr. Acarn. Sarc. III-II a.C, vv.7-8)

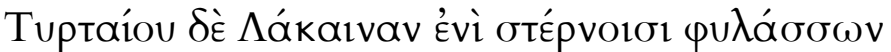
‘

Guardando no peito o lacônio verbo

de Tirteu, escolheu virtude em vez da vida. 